UNIVERSIDADE DE SÃO PAULO

FACULDADE DE FILOSOFIA, LETRAS E CIÊNCIAS HUMANAS

DEPARTAMENTO DE HISTÓRIA

PROGRAMA DE PÓS-GRADUAÇÃO EM HISTÓRIA SOCIAL

CARLOS EDUARDO MARTINS TORCATO

A história das drogas e sua proibição no Brasil: da Colônia à República

(VERSÃO CORRIGIDA)

SÃO PAULO

2016 
UNIVERSIDADE DE SÃO PAULO

FACULDADE DE FILOSOFIA, LETRAS E CIÊNCIAS HUMANAS

DEPARTAMENTO DE HISTÓRIA

PROGRAMA DE PÓS-GRADUAÇÃO EM HISTÓRIA SOCIAL

\section{A história das drogas e sua proibição no Brasil: da Colônia à República}

Tese apresentada ao Programa de PósGraduação em História Social da Faculdade de Filosofia, Letras e Ciências Humanas da Universidade de São Paulo para obtenção do título de Doutor em História.

Área de Concentração: História Social

ORIENTADOR: Dr. Henrique Soares Carneiro

(VERSÃO CORRIGIDA)

SÃO PAULO

2016 
Autorizo a reprodução e divulgação total ou parcial deste trabalho, por qualquer meio convencional ou eletrônico, para fins de estudo e pesquisa, desde que citada a fonte.

Catalogação na Publicação

Serviço de Biblioteca e Documentação

Faculdade de Filosofia, Letras e Ciências Humanas da Universidade de São Paulo

\begin{tabular}{|c|c|}
\hline \multirow[t]{3}{*}{$\mathrm{T} 676 \mathrm{~h}$} & $\begin{array}{l}\text { Torcato, Carlos Eduardo Martins } \\
\text { A história das drogas e sua proibição no Brasil: da } \\
\text { Colônia à República / Carlos Eduardo Martins Torcato ; } \\
\text { orientador Henrique Soares Carneiro. - São Paulo, } \\
2016 \text {. } \\
\quad 371 \text { f. }\end{array}$ \\
\hline & $\begin{array}{l}\text { Tese (Doutorado) - Faculdade de Filosofia, Letras } \\
\text { e Ciências Humanas da Universidade de São Paulo. } \\
\text { Departamento de História. Área de concentração: } \\
\text { História Social. }\end{array}$ \\
\hline & $\begin{array}{l}\text { 1. CB381.3X. 2. CB330.18.10. I. Carneiro, } \\
\text { Henrique Soares, orient. II. Título. }\end{array}$ \\
\hline
\end{tabular}


Nome: TORCATO, Carlos Eduardo Martins

Título: A história das drogas e sua proibição no Brasil: da Colônia à República

Tese apresentada ao Programa de PósGraduação em História Social da Faculdade de Filosofia, Letras e Ciências Humanas da Universidade de São Paulo para obtenção do título de Doutor em História.

Área de Concentração: História Social

ORIENTADOR: Dr. Henrique Soares Carneiro

Banca Examinadora:

$\operatorname{Prof}^{\circ} \operatorname{Dr}^{\circ}$

Instituição:

Assinatura:

$\operatorname{Prof}^{\mathrm{o}} \mathrm{Dr}^{\mathrm{o}}$

Instituição:

Assinatura:

$\operatorname{Prof}^{0} \operatorname{Dr}^{\circ}$

Instituição:

Assinatura:

$\operatorname{Prof}^{\mathrm{o}} \mathrm{Dr}^{\mathrm{o}}$

Instituição:

Assinatura: 


\section{AGRADECIMENTOS}

Gostaria de agradecer à Fundação de Amparo à Pesquisa do Estado de São Paulo (FAPESP) pela bolsa de estudos. E aos meus pais pela incansável ajuda.

Também agradeço ao Henrique Carneiro que, além de orientador, também foi colaborador. Ao Robson, Fábio e Berluscone por me cederem um pouso quando mais precisei. Ao meu incansável parceiro de arquivo Kleber Siqueira e aos colegas mais próximos, Luciano Thomé e Júlio Delmanto. E também a minha colega não tão próxima, mas sempre presente Thamires Sarti.

Pelas trocas de ideia são muitíssimas as pessoas que preciso agradecer. Todos e todas que ajudaram a construir o Grupo de Estudos Drogas e Sociedade (GEDS); o pessoal do Núcleo de Estudos Interdisciplinares Sobre Psicoativos (NEIP) e da Associação Brasileira de Estudos Sociais do Uso de Psicoativos (ABESUP); à Roberta Marcondes Costa por ter me colocado em contato mais direto com o Coletivo Desentorpecendo a Razão (DAR), que tem servido desde então como uma espécie de bússola política.

Gostaria de fazer uma menção ao Mario Luiz Gomes, que conheci pela internet, e que foi extremamente gentil ao me ceder fontes que foram muito úteis ao trabalho. Nesse mesmo sentido também agradeço a generosidade do Nauber, meu colega desde os tempos de UFRGS, e a Daniele Crespo De Morais.

Mais recentemente ao pessoal do Rio de Janeiro, Maria de Lourdes e Jonatas de Carvalho. Ao Marcos Bretas e todo o pessoal do GT em História do Crime, da Polícia e das Práticas de Justiça.

Aos vários amigos e amigas que estiveram comigo em São Paulo durante esse tempo, em especial a Ivis. Dedico esse trabalho ao meu amor e minha inspiração Ana Paula Koetz. 


\section{RESUMO}

O tema dessa Tese são as drogas que hoje são consideradas ilícitas e os processos sociais, culturais, políticos e econômicos que levaram ao proibicionismo. Partindo de uma revisão historiográfica e de um conjunto variado de fontes - médicas, jurídicas, jornalística, literária e iconográfica - foram reconstruídos os principais marcos da história da proibição das drogas no Brasil. A análise desse material mostrou que, mesmo estando em uma posição periférica do mercado mundial, o Brasil participou do fenômeno conhecido como revolução psicoativa. A maior disponibilidade de fármacos levou a uma difusão dos antálgicos, fato que foi combatido pela classe médica oficial. Ocorreram intercâmbios entre as concepções oficiais e as práticas populares graças à difusão das artes de formular e dos medicamentos de fórmula secretas. As drogas, apesar da crescente restrição, permaneceram como recursos terapêuticos utilizados durante toda a primeira metade do século XX. O Brasil apresentou uma política proibicionista autóctone, que dialogou com o contexto internacional plural de ascensão das políticas restritivas. A reconstituição das políticas sobre drogas mostrou as variações de objetivos existentes ao longo da história, questionando a visão unilateralista que percebe as leis sobre esse tema como uma única política que se perpetua ao longo de mais de cem anos em uma ascensão punitivista.

Palavras chave: Drogas; proibicionismo; história da medicina 


\begin{abstract}
The themes of this thesis are the illicit drugs and the social, cultural, political and economic factors that resulted in prohibition. From a historiographical review and a varied set of sources - medical, legal, journalistic, literary and iconographic - this work rebuilds the main boundaries in the history of drug prohibition in Brazil. The analysis of this material showed that this country participated in the phenomenon known as psychoactive revolution despite being in a peripheral position in the world market. The greater availability of drugs has led to diffusion of analgesics. The official medical profession was against the popularization. There have been exchanges between official conceptions and popular practices through the dissemination of the pharmaceutical formulation and Patent Medicine. The drugs remain as therapeutic resources used during the first half of the twentieth century despite growing restrictions. Brazil presented autochthonous prohibitionist policy that dialogue with the plural international context of the rise of restrictive policies. The reconstitution of the drug policy showed variations of existent objectives throughout history with questioning of the unilateralist vision about increasing punishment law.
\end{abstract}

Keywords: Drugs; prohibition; history of medicine 


\section{LISTA DE FIGURAS}

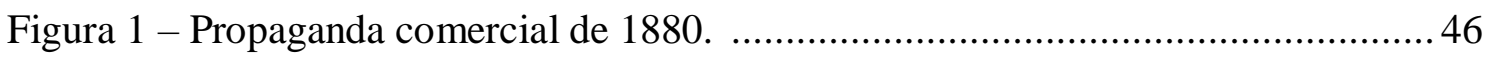

Figura 2 - Cigarretes Indiennes da Grimault \& Cia ....................................................50

Figura 3 - Propaganda do Vinho Mariani ............................................................. 54

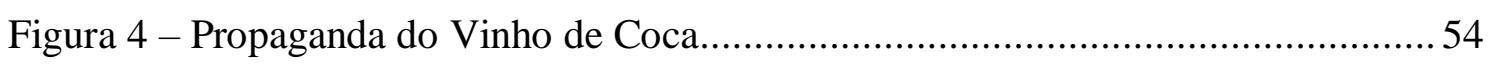

Figura 5 - Chineses no Rio de Janeiro por Johann Moritz Rugendas ........................ 126

Figura 6 - Miss Gordon na Associação Cristã Feminina do Rio de Janeiro (1921) .... 160

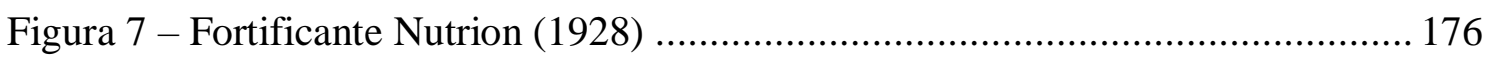

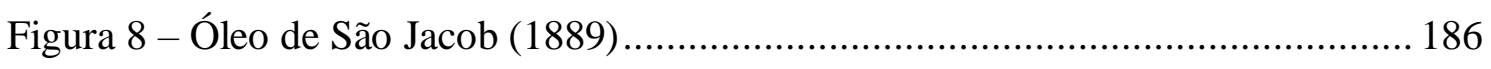

Figura 9 - Anestesia por clorofórmio com lenço ................................................... 217

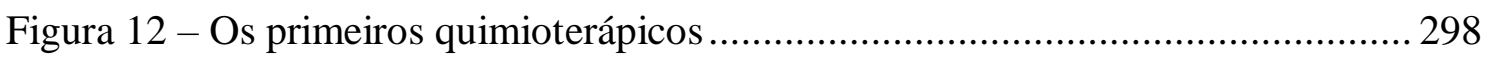

Figura 13 - Cartaz de divulgação do filme "Cais do Vício"...................................... 310

Figura 14 - Cartaz do documentário "Ilegal: a vida não espera" ................................ 330

\section{LISTA DE GRÁFICOS}

Gráfico 1 - Hipótese do continuísmo e da ascensão punitivista ..............................253

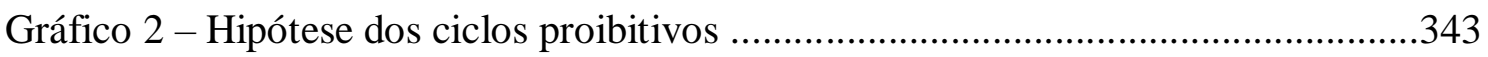




\section{LISTA DE ABREVIATURAS}

Academia Imperial de Medicina (AIM)

Agência Nacional de Vigilância Sanitária (ANVISA)

Annaes Paulistas de Medicina e Cirurgia (APMC)

Archivo da Sociedade de Medicina e Cirurgia de São Paulo (ASMCSP)

Archivo Medico Brasileiro (AMB)

Arquivos Rio Grandenses de Medicina (ARGM)

Boletim da Sociedade de Medicina e Cirurgia de São Paulo (BSMCSP)

Centro de Atenção Psicossocial (CAPS)

Centro de Atenção Psicossocial- Álcool e Drogas (CAPS-AD).

Comissão Interamericana para o Controle do Abuso de Drogas (CICAD)

Comissão Nacional de Ética em Pesquisa (CONEP)

Conselho Federal de Entorpecentes (CFE)

Comissão Nacional de Fiscalização de Entorpecentes (CNFE)

Comitê de Ética em Pesquisa (CEP)

Departamento de Nacional de Saúde Pública (DNSP)

Diretoria Geral de Saúde Pública (DGSP)

Drug Enforcement Administration (DEA)

Faculdade de Medicina do Rio de Janeiro (FMRJ)

Faculdade de Medicina de Porto Alegre (FMPA)

Food and Drug Administration (FDA)

Gazeta Clínica [SP] (GCSP)

Gazeta Médica do Rio de Janeiro (GMRJ)

Junta Central de Higiene Pública (JCHP)

Liga Nacional Contra o Alcoolismo (LNCA)

Ministério das Relações Exteriores (MRE)

Ministério da Educação e Saúde (MES)

O Propagador das Sciencias Medicas (OPCM)

Organização Mundial da Saúde (OMS)

Partido Comunista Chinês (PCC)

Partido Republicano Rio-Grandense (PRR)

Redução de Danos (RD)

Revista Médica Fluminense (RMF)

Sanatório Pinel de São Paulo (SPSP)

Serviço Nacional de Fiscalização da Medicina (SNFM)

Sistema Único de Saúde (SUS)

Termo de Consentimento Livre e Esclarecido (TCLE) 


\section{SUMÁRIO}

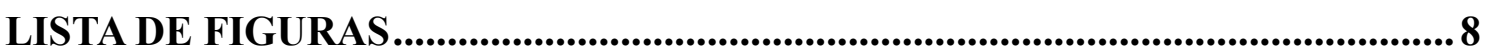

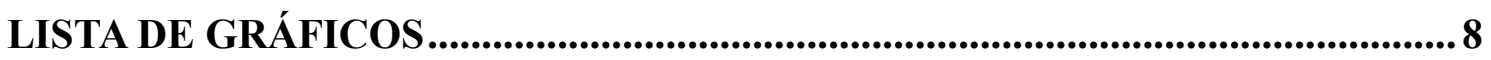

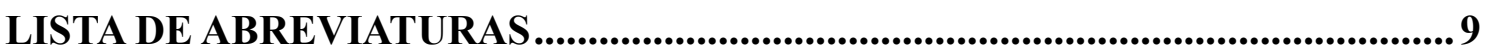

INTRODUÇÃ

CAPÍTULO 1 - AS DROGAS NA HISTÓRIA E A MODERNIDADE ..................... 21

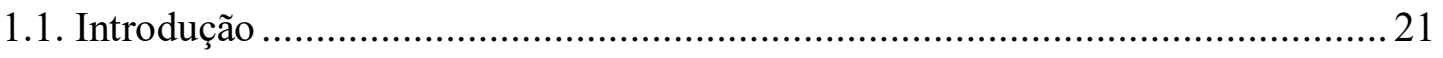

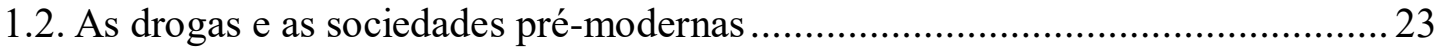

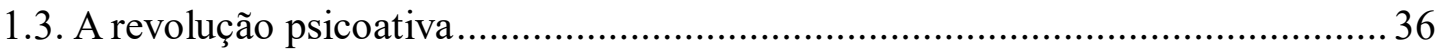

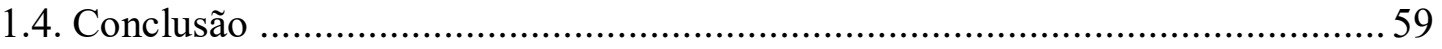

CAPÍTULO 2 - AS DROGAS E AS ARTES DE CURAR NO BRASIL ................ 62

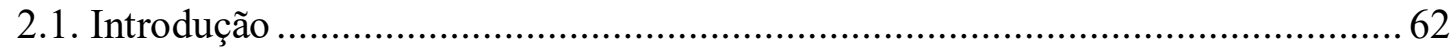

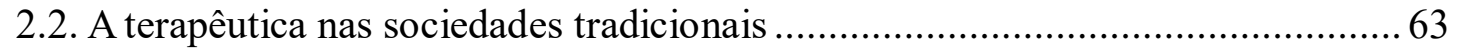

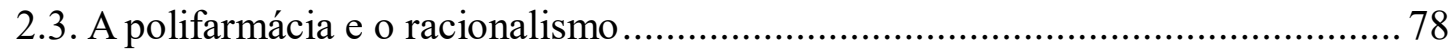

2.4. Os fármacos e a terapêutica oitocentista brasileira .......................................... 88

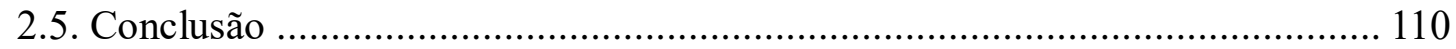

CAPÍTULO 3 - A EMERGÊNCIA DAS DROGAS COMO UM PROBLEMA

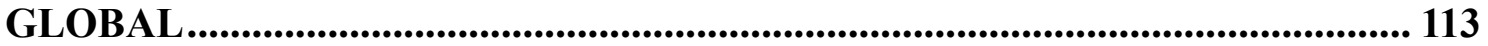

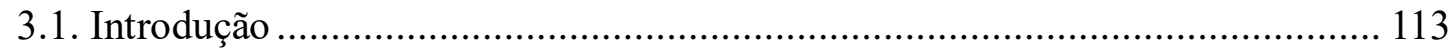

3.2. A ascensão do proibicionismo chinês e as disputas imperialistas no Oriente.... 117

3.3. A política de drogas na Liga das Nações ........................................................ 144

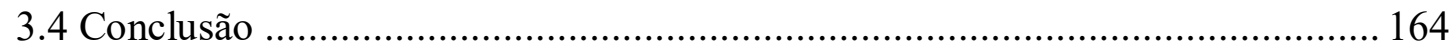

CAPÍTULO 4 - OS USOS TERAPÊUTICOS DE DROGAS ATÉ MEADOS DO

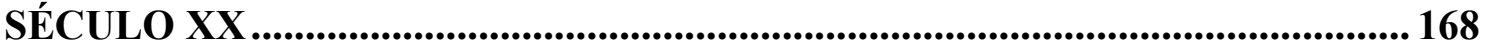

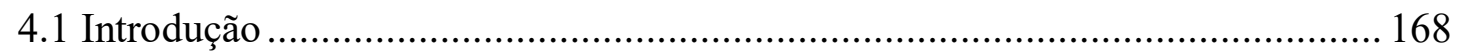

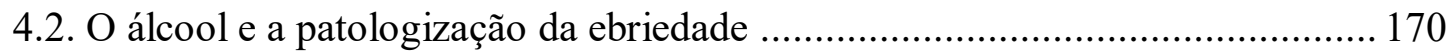

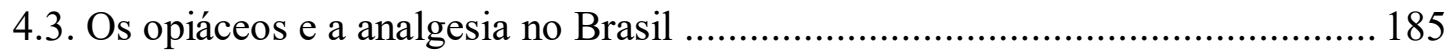

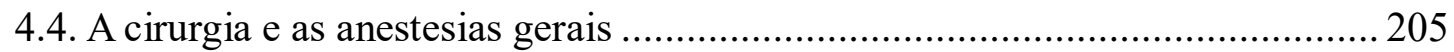

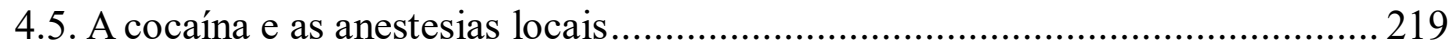

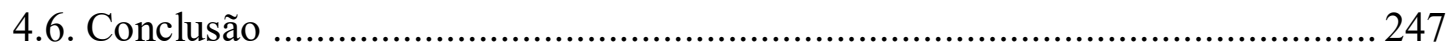

CAPÍTULO 5 - O PROIBICIONISMO COMO POLÍTICA HISTÓRICA: ou uma crítica à hipótese do continuísmo e da ascensão punitivista. ................................... 250

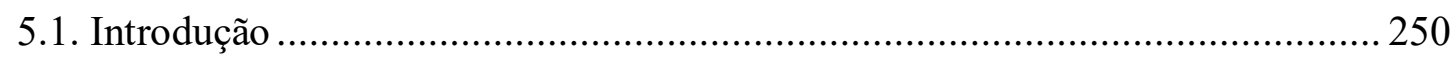

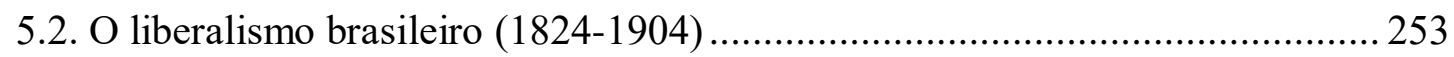

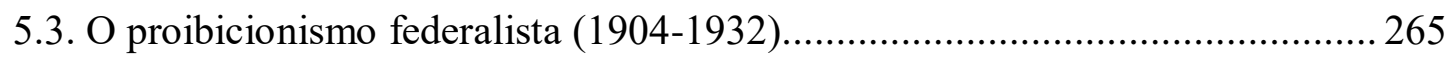


5.4. O proibicionismo centralista (1932-1964) 289

5.5. O proibicionismo punitivista (1964-1999). 312

5.6. A crise do proibicionismo (2006-hoje). 337

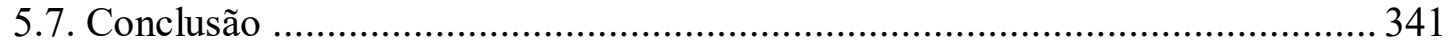

CONCLUSÃO

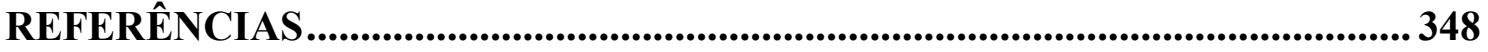

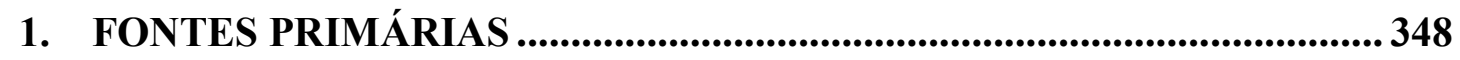

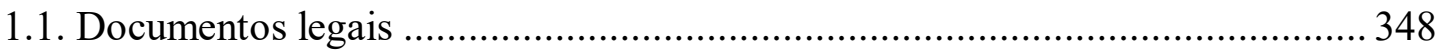

1.2. Teses, Livros e Artigos Médicos …............................................................. 351

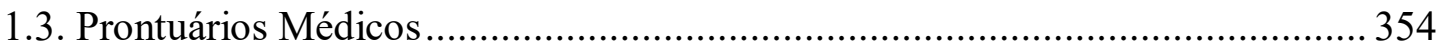

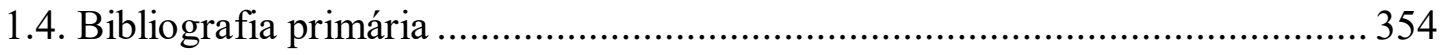

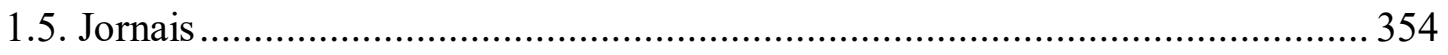

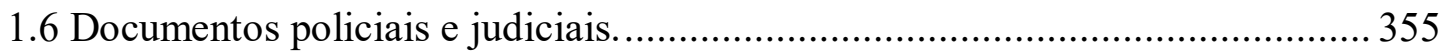

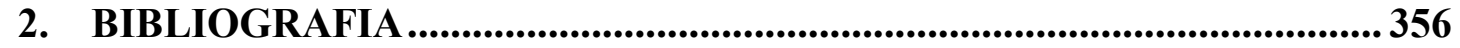




\section{INTRODUÇÃO}

O fenômeno da criminalidade associada ao tráfico ilícito de drogas é evidente em praticamente todas as grandes cidades do país - as notícias de mortes envolvendo disputas por pontos de venda ou por conflitos entre traficantes e a polícia são praticamente diárias. Esse fenômeno não é exclusividade do Brasil. Estimativas de 2009 apontam que esse gênero comercial movimento algo em torno de 870 bilhões de dólares naquele ano - o que equivaleria a 1,5\% do Produto Interno Bruto (PIB) global ou 7\% das exportações mundiais de mercadorias. ${ }^{1}$

A presente Tese tem como objetivo compreender esse fenômeno, entender como ocorriam os consumos de drogas no passado e as motivações que levaram as interdições - resultando nesse cenário atual. Buscou-se refletir sobre as relações que estabelecemos com o passado, visando compreender como os controles e as censuras se modificaram ao longo do tempo, elucidando as suas facetas e intensidades. A polêmica que envolve essa questão na contemporaneidade coloca vários desafios ao fazer historiográfico, pois os preconceitos são muitos, os debates carregados de pressupostos morais e pobres em informações críveis. Não raro, o simples fato de colocar questões sobre essa temática já é suficiente para que toda a pesquisa seja tratada como transgressora e ilegítima do ponto de vista científico.

As dificuldades começam na própria definição do que é uma droga. No senso comum essa expressão está carregada de sentido negativo por estar associada à adicção e ao vício. Porém, essa é uma perspectiva deturpada porque as drogas, sejam elas lícitas ou ilícitas, não necessariamente levam a usos problemáticos. Não é preciso ser um grande conhecedor de farmacologia para perceber que o uso crônico e abusivo de álcool traz mais problemas fisiológicos e sociais que algumas das drogas consideradas ilícitas. E nem por isso ele deixa de ser vendido ou até estimulado - como é o caso das propagandas de cerveja que associam o seu consumo à juventude e ao sucesso sexual, contribuindo ainda para a reificação da mulher. Existem vários estimulantes baseados na cafeína ou na taurina, vendidos no supermercado, que comumente são combinados com destilados alcoólicos - lembrando dos antigos tônicos alcoólicos que foram proibidos. As bebidas açucaradas, conhecidas como refrigerantes, são amplamente promovidas comercialmente, mesmo que tal consumo seja prejudicial à saúde da população. O

\footnotetext{
${ }^{1}$ Informações obtidas no sítio eletrônico da United Nations Office on Drugs and Crime. <https://www.unodc.org/toc/es/crimes/organized-crime.html > Último acesso: 05 de junho de 2016.
} 
cigarro pode ser considerado a droga mais letal e viciante de todas, porém é permitido. Até as bebidas estimulantes de origem vegetal, como o café, o chá e o mate, podem provocar dependência química e crises de abstinência. Percebe-se, portanto, que muitos produtos que compramos nos supermercados como alimento inócuo também são drogas. Pela perspectiva etimológica (CARNEIRO, 2005, p.11-12) sabemos que essa expressão derivou do holandês droog, significando produtos secos destinados à alimentação e à medicina - os mercados antigos eram conhecidos como Secos e Molhados em alusão a essa expressão.

Se a fronteira entre droga e alimento pode ser considerada difusa e problemática, o mesmo ocorre se focarmos a diferença entre as drogas e os remédios. Não é a toa que muitas farmácias ainda são conhecidas e denominadas como drogarias. O termo farmácia é derivado de fármaco, que pela perspectiva etimológica (ESCOHOTADO, 2008, p.21-22) remonta à expressão grega phármakon. No contexto da antiguidade esse termo poderia designar, tanto remédio, quanto veneno. Assim, fármaco é um termo neutro que enfatiza a dose e as condições de uso como fatores fundamentais para determinar se a substância faz bem ou mal às pessoas. Existe também a expressão "narcótico" que é derivada do grego narkon. No contexto original ela significa adormecer ou sedar. Em francês esse termo foi traduzido como estupéfiants, que acabou originando a expressão estupefaciente. Farmacologicamente os termos narcótico e estupefaciente são equivocados para designar as drogas em geral, porque algumas substâncias têm efeito diferente e até oposto ao de adormecer ou dormir. A cocaína, a taurina, a cafeína, a teobromina (do mate/chimarrão), as anfetaminas ou outras substâncias estimulantes. O mesmo raciocínio vale para aquelas substâncias que têm efeito sobre a percepção, denominadas de visionários, alucinógenos ou enteógenos.

Antes do estabelecimento dos controles políticos, a palavra "droga" não significava necessariamente algo ruim. Ela pode ter efeitos positivos a partir de aplicações alimentares, terapêuticas e lúdicas, contribuindo para controlar as dores, os desconfortos decorrentes das enfermidades e as emoções indesejadas. Podiam trazer paz, fortalecer a cognição e os limites da vontade. Elas eram usadas também como uma forma de exploração psíquica de caráter laico ou com fortes significados espirituais. Usos positivos que não excluem o risco de levarem à intoxicação crônica ou aguda, problemas fisiológicos ou psíquicos e não menos importante, o desenvolvimento de práticas sociais não adequadas às normas sociais hegemônicas. Em suma, as drogas podem ser boas ou ruins dependendo do contexto e das formas sociais de uso. 
As dificuldades de se trabalhar com o tema das drogas apenas iniciam com as imprecisões existentes entre drogas, alimentos e remédios. A complexidade da questão se amplia quando se percebe que ela é objeto privilegiado da antropologia, uma vez que praticamente todas as sociedades humanas fazem uso de substâncias capazes de alterar a consciência. Segundo Carneiro (2010, p.206-208), a questão do uso do álcool e sua influência sobre o suicídio foi importante na obra de Durkheim, um dos fundadores da sociologia - interesse que se renova constantemente. As leis proibitivas estão na base de formação de um sistema internacional, fato que faz ela objeto da diplomacia e do direito. Tema que pode ser abordado também da perspectiva da ciência política ou da filosofia. O uso de drogas é um tema essencialmente humano, propício como nenhum outro a uma abordagem interdisciplinar ou transdisciplinar.

As ciências sociais e humanas, entretanto, são em geral marginalizadas nesse debate. Hoje, com a crise social e o drama humanitário existente em torno do comércio ilícito elas são chamadas a dar resposta, mas é inegável que sobre esse tema o discurso hegemônico pertence às ciências da saúde. As interdições sobre os usos de fármacos na sociedade moderna estão fundamentadas na defesa da saúde pública e na racionalidade terapêutica que definem quais são os fármacos bons, denominados remédios, e os fármacos ruins, conhecidos pela alcunha de drogas. O diálogo necessário entre ciências humanas e da saúde geralmente são bloqueados em nome de uma ética biomédica que interdita certas questões. O que faz uma substância ser utilizada pela terapêutica e outra não? Por exemplo: Quais são as diferenças, sob o ponto de vista dos efeitos fisiológicos, entre a cocaína e as anfetaminas? Ou entre essas duas e o estimulante pediátrico vendido comercialmente com o nome de Ritalina ${ }^{\circledR}$ ? Quais as vantagens e desvantagens do ópio e seus derivados em relação aos seus similares sintéticos? Quais são os males efetivos que o ópio ou a cocaína fazem em pequenas doses ou quando consumidos na forma vegetal?

Esse tipo de perguntas, que poderiam se multiplicar, não são feitas ou pesquisadas pelas ciências da saúde na opinião de Escohotado (2008, p.968-969) porque a ideologia que sustenta as políticas atuais já estaria instalada na formação desses profissionais. A situação apontada por este autor pode ser percebida, claramente, na resistência da Agência Nacional de Vigilância Sanitária (ANVISA) em aceitar a importação de derivados de Cannabis, a despeito das inúmeras evidências de suas utilidades terapêuticas. Os regulamentos e protocolos necessários para pesquisas com 
substâncias proibidas praticamente inviabilizam investigações dentro das universidades brasileiras.

Essas interdições não são somente feitas com pesquisa com fármacos diretamente utilizados em seres humanos. Mesmo prontuários médicos escritos a mais de 100 anos são rejeitados para estudos históricos pelos controles diretos produzidos pela classe médica através dos Comitês de Ética em Pesquisa (CEP). Desde o renascimento europeu até as abomináveis práticas perpetuadas com inspiração política no nazismo, inúmeros são os exemplos de experimentos científicos que ignoram os preceitos mais básicos da ética e da dignidade humana. Esses acontecimentos geraram o imperativo político de controlar as práticas científicas que lidam com os seres humanos. Depois da II Guerra Mundial, vários foram os compromissos internacionais em Direitos Humanos assumidos pelo Brasil e, posteriormente, ratificados na Constituição de 1988. Os CEP foram instituídos para garantir aos participantes da pesquisa informação e autonomia no processo de construção do conhecimento - com objetivo principal de protegê-los de possíveis malefícios. Portanto, mais do que legítima, essa iniciativa é necessária. Entretanto, é preciso discutir abertamente e de forma interdisciplinar o sentido da ética de pesquisa para que os CEP não se transformem em uma forma de impor uma epistemologia sobre as demais. São pelo menos dois os limites mais evidentes da visão biomédica hegemônica nessas instituições.

Em primeiro lugar, a biomedicina compreende os sujeitos como "indivíduosorganismos" que estabelecem relações de causalidade entre o fator patogênico e a resposta do organismo, ou ainda, entre os fatores ambientais e as respostas cognitivocomportamentais. Essa lógica de pensamento faz sentido para as investigações epidemiológicas, porém não são adequadas para compreender os fenômenos sociais ou culturais complexos. Os Termos de Consentimento Livre e Esclarecidos (TCLE) pressupõem indivíduos plenamente autônomos e racionais - fato empiricamente insustentável e que traz problemas epistemológicos para às Ciências Humanas. Essa concepção acima destacada nos leva ao segundo ponto. A pesquisa com seres humanos é definida pelo Conselho Nacional de Ética em Pesquisa (CONEP) como "pesquisa que, individual ou coletivamente, tenha como participante o ser humano, em sua totalidade ou partes dele, e o envolva de forma direta ou indireta, incluindo o manejo de seus dados, informações ou materiais biológicos" ${ }^{2}$. Essa forma de pensar o ser humano

\footnotetext{
${ }^{2}$ RESOLUÇÃO No 466, DE 12 DE DEZEMBRO DE 2012, Parágrafo II-14.
} 
pressupõe um indivíduo passivo que será alvo de experimentos, o que contraria a perspectiva das ciências sociais e humanas - o pesquisador está inserido em um contexto de interlocução com os participantes da pesquisa, que são compreendidos como agentes capazes de estabelecer diálogo, ações e contribuir para o conhecimento que está sendo produzido (FARE et al, 2014, p.263-269).

No ano de 2015, foi realizada uma consulta pública por parte do CONEP para a preparação de uma Resolução Complementar para avaliação ética nas Ciências Sociais e Humanas. Sabendo que o peso da ética recai com mais força sobre as pesquisas que contestam a epistemologia biomédica dominante, como a que sustenta ideologicamente a proibição atual das drogas, o Núcleo de Estudos Interdisciplinares sobre Drogas (NEIP) enviou uma contribuição à consulta pública alertando sobre a impossibilidade de obter o TCLE em pesquisas que trabalham com populações ocultas. Esse termo é usado para caracterizar indivíduos ou grupos que estão envolvidos em atividades ilícitas ou estigmatizadas, como o caso de usuários ou traficantes de drogas. Nesses casos, o imperativo ético é a preservação do anonimato porque qualquer forma de registro pode colocar em risco o sujeito participante da pesquisa. Infelizmente o CONEP ignorou o apelo do NEIP e as pesquisas com essas populações terão que ser realizadas a margem da ética oficial - mais interessadas em defender o privilégio epistemológico da biomedicina do que os próprios agentes participantes da pesquisa.

É com todas essas dificuldades e enfrentando uma perspectiva biomédica - que se pretende eticamente superior e tecnicamente universal - que essa Tese foi construída. Essas contradições colocadas acima não são novidades. Durante grande parte do século XX, a proibição de dadas substâncias e a promoção de outras foi colocada nesses mesmos termos por uma classe médica ansiosa em transformar a saúde em reserva de mercado. Entretanto, desde 1963, a Divisão de Farmacologia e Toxicologia da Organização Mundial da Saúde (OMS) é categórica em afirmar que era impossível estabelecer uma correlação entre dados biológicos e medidas administrativas. Está claro desde então que essa divisão entre drogas lícitas e ilícitas responde a fatores outros que não técnicos. Essa divisão não foi decidida por químicos, médicos ou toxicologistas (SILVA, 2013, p.375).

Todas essas considerações procuraram mostrar que não existe uma explicação farmacológica capaz de sustentar racionalmente a opção atual pelas políticas de controle 
de drogas. A problemática de pesquisa que orientou o trabalho foi a seguinte: O que define o estatuto legal ou ilegal de uma substância? Quais foram os critérios adotados para essa definição? Como chegamos à crise atual?

Para responder essas perguntas foi feito um levantamento de fontes em instituições de São Paulo, Rio de Janeiro e Rio Grande do Sul. São elas: Academia de Polícia do Rio Grande do Sul; Academia de Polícia de São Paulo; Arquivo Nacional; Arquivo Público do Estado do Rio Grande do Sul; Arquivo Público do Estado de São Paulo; Biblioteca Central da PUCRS; Biblioteca Central da UFRGS; Biblioteca do Centro de Ciências da Saúde da UFRJ; Centro Brasileiro de Informações Sobre Drogas Psicotrópicas (CEBRID); Centro de Memória da Assembleia Legislativa do Rio Grande do Sul; Centro de Memória da Saúde Pública da USP; Cinemateca Brasileira; Biblioteca da Faculdade de Biblioteconomia e Comunicação da UFRGS; Fundação Biblioteca Nacional; Biblioteca da Faculdade de Direito da UFRGS; Biblioteca da Faculdade de Direito da USP; Biblioteca da Faculdade de Educação Física da UFRGS; Biblioteca da Faculdade de Farmácia da UFRGS; Biblioteca da Faculdade de Medicina da USP; Biblioteca da Faculdade de Medicina da UFRGS; Biblioteca da Faculdade de Psicologia da UFRGS; Biblioteca da Faculdade de Saúde Pública da USP; Biblioteca do Instituto de Filosofia e Ciências Humanas da UFRGS; Biblioteca do Instituto de Neurologia Deolindo Couto da UFRJ; Instituto de Psiquiatria da UFRJ.

Estamos vivendo nos dias atuais uma revolução na forma de fazer a pesquisa em história com a desvinculação dos documentos dos arquivos. A Hemeroteca Digital da Fundação Biblioteca Nacional é o símbolo máximo dessa mudança, colocando em outras bases os trabalhos realizados manualmente na década de 1990 em jornais. Iniciativas como as do Grupo de Estudos e Pesquisas em Higiene Mental e Eugenia (GEPHE), da Universidade Estadual de Maringá, também precisam ser elogiadas e multiplicadas. O material obtido na pesquisa de campo somado aos encontrados na internet colocou para essa pesquisa o desafio dos recortes, da escolha das fontes e dos dilemas trazidos pela abundância de informações.

Isso explica, em parte, o recorte temporal pouco usual para os trabalhos de história atuais - espremidos pelos prazos e as pressões por produtividade quantitativa. $\mathrm{O}$ projeto apresentado para ingresso no Programa de Pós-Graduação em História Social da Universidade de São Paulo (PPG-HS-USP) procurava compreender as bases sociais e políticas que inseriam o Brasil no fenômeno internacional do proibicionismo às drogas na primeira metade do século XX. A visão corrente sobre o tema da proibição às drogas 
no Brasil percebe a proibição de forma crescente e ascendente, que iniciou graças às pressões externas nascida das primeiras conferências internacionais e, posteriormente, ganhando força com as institucionalizações ocorridas no final dos anos de 1930. Pretendia-se mostrar que a configuração federalista levou a experiências diversas nesse campo, dependendo da capacidade da classe médica em se articular com os políticos. Seriam exploradas as diferenças do Rio Grande do Sul e o centro político (Rio de Janeiro) e econômico (São Paulo) do Brasil. Entendia-se que o entreguerras (19181939) era um período nevrálgico para compreender a dinâmica que levou a ascensão do proibicionismo em âmbito nacional.

Embora a limitação fosse o entreguerras, em nenhum momento se pretendeu restringir a análise aos documentos ou as práticas situadas nessa delimitação. Mais do que isso, objetivei compreender o que tem de específico nessa delimitação através da diferenciação do que vem antes e do que se criou depois. Nesse sentido, foi necessário mergulhar na história da medicina para compreender como o uso de fármacos foi pensado pela historiografia - onde foi percebida a necessidade de expor, sobre novas bases, como se constituiu um mercado mundial das drogas e a participação do Brasil nesse cenário. Esse será o tema do primeiro Capítulo.

A historiografia brasileira inspirada em Foucault procurou defender a hipótese que o poder médico penetrou em amplas esferas da sociedade desde o início do século XIX, reprimindo as práticas terapêuticas populares e se tornando imanente ao Estado. Central nessa perspectiva foi o conceito de medicalização da sociedade. Contra essa perspectiva se levantou a historiografia mais recente, inspirada nos preceitos da história social, opondo essa leitura estruturalista às práticas sociais de sujeitos concretos - com especial destaque àquelas ligadas às noções tradicionais de enfermidade e de cura. $\mathrm{O}$ problema é que essa cisão entre medicina oficial, de um lado, e práticas populares de cura, de outro, criou um obstáculo para compreendermos a real inserção dos fármacos clássicos na sociedade brasileira como um todo. Uma visão mais dialética será construída no Capítulo dois com a descrição das artes de formular remédios e a circularidade de conhecimentos propiciadas pelos manuais de medicina. As noções tradicionais do neohipocratismo brasileiro perduraram vários anos, justificando o uso de drogas na terapêutica até as primeiras décadas do século XX.

O Capítulo três procurou compreender a ascensão das drogas como um problema global através da discussão sobre a questão do ópio no Oriente e a problematização da ideologia da nação submetida pelo vício estrangeiro - as derrotas chinesas nas guerras 
do ópio do século XIX. O objetivo foi mostrar que a proibição, mais do que um fenômeno universal que inicia neste período, coexistiu com diversos tipos de controle instaurados pelo mundo. Os modelos mais repressivos (EUA, China) eram exceções, valendo na maioria dos países uma visão mais reticente ao controle público sobre os antálgicos e a ebriedade. É a época onde o monopólio médico é reconhecido, porém ele esbarra nas pequenas indústrias farmacêuticas que sustentavam uma cultura farmacológica que valorizava as práticas de automedicação. O Brasil e a América Latina, ao contrário do que defende a historiografia (SILVA, 2013), tiveram uma postura de defesa de seus interesses e de suas políticas nesse campo.

Depois de realizado o panorama global da emergência das políticas de restrição às drogas, buscou-se reconstituir as concepções da medicina oficial sobre o álcool e as drogas em seus múltiplos aspectos: revisitarei a discussão sobre a patologização da ebriedade, mostrando a coexistência de usos terapêuticos e visões patologizantes. A retórica triunfalista da biomedicina procurou apagar as utilidades terapêuticas das substâncias que hoje são proibidas. Esse Capítulo quatro procurou também reconstruir a história da cirurgia e da anestesia para evidenciar a persistência do uso terapêutico dos fármacos clássicos ao longo de toda a primeira metade do século XX.

O quinto e último Capítulo será feita uma reconstituição das políticas de drogas no Brasil ao longo de toda a sua história, evidenciando as suas várias fases constitutivas. Procurei reconstruir a tradição antialcoólica e a cultura farmacológica dos séculos XIX e $\mathrm{XX}$, mostrando os interesses profissionais e econômicos que estavam envolvidos na troca de uma farmacopeia por outra. $\mathrm{O}$ advento da quimioterapia será fundamental para a expropriação das práticas e dos saberes populares por parte da classe médica, que abandona o discurso da necessidade de reduzir o consumo para se tornar instrumento de acumulação de capital - graças à aliança com as indústrias estrangeiras. Mostrar-se-á que por trás do discurso técnico existiam inúmeros interesses econômicos envolvidos. $\mathrm{O}$ tráfico ilícito, restrito a pequenos desvios de estabelecimentos legais na primeira metade do século XX, será outra consequência da expropriação da saúde da população. Por último, destacarei as mudanças atuais, políticas, econômicas e epistemológicas, que vêm forçando uma racionalização do debate público.

Percebe-se, portanto, que apesar da ênfase no período de formação do proibicionismo, a delimitação temporal desse trabalho vai literalmente da antiguidade aos dias atuais. Da mesma forma, a delimitação espacial foca no Brasil, porém o fenômeno da proibição é global - o que nos leva a necessidade de comparar a realidade 
brasileira com a de outros países. Nenhuma história global como a proposta poderá dar conta de todos os aspectos em questão, porém certamente traz consigo uma visão de conjunto que pode ser bastante útil às pesquisas posteriores e ao entendimento sobre essa questão tão cara na contemporaneidade.

Uma última observação é sobre a grafia: buscou-se, dentro do possível, atualizar as grafias mais antigas para a forma moderna de modo a facilitar a leitura. Da mesma forma, sugeriram-se traduções dos excertos dos autores estrangeiros de modo manter o texto todo em português. 


\section{CAPÍTULO 1 - AS DROGAS NA HISTÓRIA E A MODERNIDADE}

\subsection{Introdução}

A presente pesquisa buscou compreender como ocorreu o processo de criminalização das drogas no Brasil, principalmente durante a primeira metade do século XX. Um dos primeiros desafios encontrado foi tentar entender as particularidades do consumo de drogas dentro de um contexto de afirmação da sociedade moderna burguesa. Somente a partir desse entendimento foi possível ponderar sobre as dinâmicas sociais, econômicas, políticas e culturais que levaram aos primeiros movimentos proibitivos. Em suma, se buscou compreender quais as especificidades do consumo moderno em relação aos tradicionais.

Interessante perceber que essa questão está presente, de uma forma ou de outra, em grande parte da historiografia da proibição das drogas no Brasil. Uma abordagem clássica se dá através da oposição entre liberalismo e antiliberalismo. O liberalismo seria tributário da laicização da sociedade europeia, que se opunha a interferência estatal ou da igreja no campo da consciência. As substâncias psicoativas, durante largo período, teriam sido identificadas à ação de espíritos e a idolatria. $\mathrm{O}$ desenvolvimento do conhecimento herbário e, depois, a identificação dos princípios ativos derrubaram a associação das plantas com a magia. A alteração da consciência passou a ser uma forma de autoconhecimento, inspirando literatos. A partir de meados do século XIX, o liberalismo começou a ser fortemente criticado pelo discurso médico, que se consolidava como saber legítimo. A patologização do consumo de álcool e outras drogas estariam ligadas a emergência da medicina ao lugar anteriormente ocupado pela religião (CARVALHO, 2013, p.36-48; CARNEIRO, 2010, p.226-235).

O proibicionismo às drogas, ligados ao antiliberalismo, geralmente é associado a um processo social ocorrido nos EUA e exportado para outros países. Silva (2013, p.91), por exemplo, defende que o Brasil ficou em grande medida incólume ao problema das drogas na primeira metade do XX. Em geral (CARVALHO, 2013; DELMANTO, 2013, p.53-63; RODRIGUES, 2004), o proibicionismo é caracterizado como uma política que se desenvolve em território estadunidense e que influencia outras regiões do mundo, incluindo o Brasil, através das convenções e acordos internacionais.

Outra perspectiva sobre a relação das drogas com a sociedade moderna destaca o duplo papel que o consumo de substâncias psicoativas exerce: de um lado, provoca desregramento das condutas sociais necessárias ao correto funcionamento do 
capitalismo; de outro, isola os indivíduos dentro de si mesmo provocando alienação (SILVA, 2015, p.23-25). A regulação do homo faber (Hannah Arendt) teria sido feita pela medicina quando ela conseguiu "acomodar seus interesses corporativos nos dispositivos de controle instaurados pelo Estado" (SILVA, 2015, p.63). O resultado desse processo foi transposição da vida laborativa e outras dimensões da vida para a esfera pública, submetendo-as a normatização. O controle sobre o uso de drogas, portanto, faria parte do autoritário processo que é denominado de medicalização da sociedade.

Em todas essas hipóteses acima destacadas a emergência da proibição aparece associada à consolidação da medicina enquanto ciência. De todos os autores da historiografia brasileira, quem leva mais adiante esse argumento é Adiala (2011, p.0815) ao focar o processo de patologização do uso de drogas no Brasil. Apesar do foco ser a classe médica, ele também procurou apresentar um breve panorama moderno do consumo de psicoativos, destacando que as drogas foram objetos privilegiados no comércio transatlântico (Braudel), principalmente as estimulantes que exerceram papel relevante na sociabilidade burguesa (Wolfgang Schivelbusch). Igual aos demais, aponta a oposição entre o liberalismo, como o defendido por Escohotado - que assume uma "posição militante, polêmica e antiproibicionista [...] em relação ao tema das drogas" (ADIALA, 2011, p.13) - e outra posição mais ponderada, representada por Courtwright - ao apontar que o aumento do consumo e as preocupações com a saúde se constituíram no "maior problema político e moral que percorreu a história do comércio de drogas" (ADIALA, 2011, p.18).

Essa breve revisão bibliográfica apresentada deixa clara que a caracterização do consumo moderno ainda está bastante atrelada à visão dualista que põe, de um lado, o liberalismo em matéria de alteração da consciência, e de outro lado, as críticas morais ou o papel autoritário e/ou moral do saber médico como normalizador da sociedade. Complementando essa visão, esse Capítulo procurará apresentar as especificidades do consumo moderno, comparando com o antigo, mostrando que as dinâmicas sociais envoltas nesses usos se alteraram significativamente com a maior disponibilidade de fármacos criadas pelo comércio transatlântico. O Brasil foi parte integrante desse fenômeno, seja como consumidor, seja como exportador de drogas. 


\subsection{As drogas e as sociedades pré-modernas}

Espalhadas pelo planeta existem mais de 200 compostos orgânicos capazes de alterar as sensações ordinárias e modificar os ânimos. Ao longo de todo o mundo se percebe a exploração sistemática das zonas fitogeográficas em busca de plantas com qualidades inebriantes. A capacidade de alterar o funcionamento natural do corpo - seja potencializando a serenidade, a energia ou a percepção, seja reduzindo a aflição, a dor ou a rotina psíquica - faz dessas substâncias alvos privilegiados de controle político, social, cultural e religioso em todos os agrupamentos humanos.

As observações em animais e crianças apontam que a busca por estados alterados de consciência são uma necessidade básica. Porém, o sentido dessa procura é alvo de controvérsia. Courtwright (2001, p.91-94) defende, por exemplo, que tal busca é um paradoxo, pois a alteração da consciência provocada por elementos externos ao corpo invariavelmente altera a química cerebral de tal forma que a pessoa se torna dependente de tais elementos. A natureza é parcimoniosa com o prazer. A euforia induzida por neurotransmissores do cérebro é frágil e frugal, sendo acionadas somente nos momentos ligados à sobrevivência ou à reprodução. Drogas enganariam o sistema, incrementando temporariamente o prazer através desses neurotransmissores. Um dos fatores que explicaria o paradoxo da construção da dependência seriam as circunstâncias sociais. Pessoas chateadas ou em situações de miserabilidade tem maior tendência para buscar estados alterados de consciência. Animais em cativeiro, por exemplo, gostam mais de se intoxicar que os que estão livres. É possível pensar que a própria civilização é uma espécie de cativeiro. Depois da revolução neolítica, a maioria das pessoas passou a se inserir em sociedades opressivas. As drogas seriam armas contra a condição humana, ferramentas contra a prisão do cotidiano.

Essa interpretação é baseada em uma concepção bastante pessimista da natureza humana. As escolhas por dada substância e as funções sociais que elas exercem em dados grupos sociais não são definidas por critérios neurológicos. Da mesma forma que a escolha por dado alimento em detrimento de outro não pode se reduzir aos critérios nutritivos. O homem pré-histórico pode ser considerado onívoro, porém o protohistórico e o contemporâneo não se enquadram nessa classe generalizadora. As formas de ingestão (de comida, bebidas e psicoativos) são elementos fundamentais da cultura material. Servir e distribuir esses elementos são atividades centrais nos grupos humanos e, portanto, atividades essencialmente antropológicas. São elas que apontam quem 
proporciona sustento e prazer para quem, quais as circunstâncias, dando as relações familiares e as classificações sociais o seu conteúdo específico.

Nesse debate fica latente a tentativa de enquadramento de determinadas atitudes sociais dentro do campo da ordem natural. Se a busca por substâncias capazes de alterar os estados de consciência pode ser considerada uma faceta universal das sociedades humanas, os usos somente podem ser interpretados a partir das concepções de mundo vigentes nos contextos sociais em que eles são realizados. Uma análise de história social precisa considerar, portanto, mais as particularidades e as mudanças nos padrões de consumo realizadas em dada sociedade do que a universalidade da busca pelos estados alterados de consciência.

Uma das formas de alterar a consciência mais difundida é através das bebidas fermentadas. Mesmo estando presente em vários continentes e sociedades humanas, as técnicas de preparo variam bastante.

As técnicas de elaboração dos fermentados primitivos [...] oferecem elementos peculiares a diferentes estágios da evolução da tecnologia rudimentar, configurando quadros culturais correspondentes às mais diversas fases de preparo do mosto final, desde a mais primitiva utilização de seivas selvagens como líquidos dessedentadores [...] até os vinhos de sumo de frutas silvestres obtidos por mera atuação de leveduras ocorrentes na natureza, e as cervejas mais primitivas, em que a sacarificação do amilo se realiza pela técnica da insalivação e esputo. Apresentando um degrau cultural mais avançado, estão as cervejas maltadas, de remotíssima origem, entre os povos que constituem as grandes civilizações da zona mesopotâmica [...] e os egípcios (LIMA, 1974, p.IX-X).

Importante ressaltar que, embora essas bebidas tenham uma ação psicoativa sobre o corpo, seu uso não pode ser reduzido a isso. Elas também possuem qualidades nutritivas, o que levaria a expressão alimento-droga como a mais correta para expressála.

\footnotetext{
"As vantagens nutricionais dos fermentados resultam não apenas do fato dessas bebidas serem feitas de cereais na forma de 'pão líquido', mas do aumento do seu valor, tanto em relação ao conteúdo proteico como de vitaminas e sais minerais, corrigindo, assim, as carências de uma dieta de ingestão pura de cereais" (CARNEIRO, 2011, p.137).
} 
Se levarmos em consideração que somente no século XX ocorreu a massificação dos processos de cloroficação da água, também entenderemos porque as bebidas fermentadas eram consideradas superiores à água pura - mesmo não conhecendo a teoria microbiológica, era sabido que a fermentação e a fervura evitava vários tipos de enfermidades. Por todas essas qualidades, as bebidas fermentadas podem ser consideradas um "alimento cultural por excelência" (CARNEIRO, 2011, p.135).

A centralidade que as bebidas fermentadas obtiveram nas culturas que se sedentarizaram no Oriente Próximo levanta a hipótese de que os cereais foram cultivados primeiro para fabricação de cerveja e não para fazer pão. Hipótese essa pouco provável, pois se acredita que os primeiros cereais provavelmente fossem feitos direto na brasa (como as pipocas) e depois transformadas em papa ou mingau. Apenas uma pequena parte desses cereais era usada para fazer cerveja, e a descoberta da fermentação não é uma consequência óbvia do crescimento de cereais, pois ele requer conhecimento da fermentação. A representação das bebidas fermentadas aparece desde o início no Egito e na Mesopotâmia, inicialmente como uma prática de elite e depois se popularizando. Evidências arqueológicas sugerem que as bebidas alcoólicas na Era do Bronze usavam uma mistura de mel, com frutas e alguns cereais - a cerveja pura não apareceu antes da Idade do Ferro. A técnica de produção de bebidas alcoólicas provavelmente foi copiada de um processo natural de fermentação de frutas e de seivas de árvores doces, particularmente a tamareira na Europa. A experiência usando frutas fermentadas deve ter sido um incentivo para tentar o processo em outras frutas, como nos vinhedos que eram particularmente adequados para áreas de cultivo no Mediterrâneo ao longo de toda o Levante e na costa da Ásia Menor, onde a vinicultura provavelmente começou. A experiência do processo de fermentação, e a transferência dessas fermentações naturais que existiam em frutas devem ter sido tentadas para produzir álcool do mel e de cereais (SHERRATT, 1995, p.24-26). Lima (1974, p.01-07) também aponta a importância desses processos naturais - as árvores cervejeiras - para o desenvolvimento das técnicas de fermentação na América.

$\mathrm{Na}$ Eurásia, portanto, onde a agricultura e a vida urbana se originaram primeiro as bebidas alcoólicas fermentadas de uva e de arroz foram os intoxicantes culturalmente privilegiados. Antes de seguirmos na análise do papel do vinho na civilização ocidental, cabe nos indagarmos sobre outros intoxicantes utilizados nas sociedades pré-históricas. Ao norte das civilizações do mediterrâneo e da chinesa, as folhas e sementes narcóticas de árvores anuais - papoula e cânhamo, cada uma na sua região - foram consumidas na 
forma de fumaça de acordo com antiguíssimos padrões de uso. Ao sul dessas zonas, estimulantes leves e frutas de arbustos perenes - kola, qat, café, chá, betel - foram mascados, inalado e até absorvidos através de infusão em algumas vezes. Mascar, inalar e fumar são formas originais de ingestão; o uso do líquido para consumo de substâncias psicoativas em muitas partes do mundo são reflexos de práticas originalmente associadas a algumas regiões que tem tradição no preparo de bebidas alcoólicas. Cortando essas três zonas, mesmo que tendo diferenças entre elas, estão os alucinógenos - cogumelos, cactos e vinhos tropicais - que são particularmente concentrados em volta do Pacífico (SHERRATT, 1995, p.32-34).

Importante atentarmos, no que se refere a essa diversidade de psicoativos e de formas de consumo nas sociedades pré-modernas, ao caráter estritamente regional do consumo. Somente com o advento da modernidade passará a existir consumos globalizados. O vinho tornou-se o inebriante privilegiado da civilização ocidental e sobre ele considerações especificas se fazem necessárias. Antes de entrarmos nesse importante tópico, é necessário fazer alguns esclarecimentos sobre três tipos de psicoativos: os alucinógenos em suas diferentes formas e efeitos; a dormideira e o ópio; a Cannabis.

Sobre os alucinógenos, são mais de 150 plantas conhecidas com capacidade de provocar forte alteração dos estados psíquicos. Todos os agrupamentos humanos, com exceção dos esquimós e de certos aborígenes australianos, possuíam hábitos de consumo de pelo menos um alucinógeno. Existe a hipótese, bastante aceita, que pintores rupestres na Europa se inspiravam em substâncias desse tipo. Desde a década de 1950, a antropologia tem mostrado que cogumelos e outros alucinógenos são centrais no complexo religioso xamânico. Desde o início do XX, entretanto, autores do porte de Mircea Eliade e Durkheim já apontavam o papel dessas substâncias nas técnicas de êxtase nas religiões mais antigas (CARNEIRO, 2002, p.137-149).

A centralidade desse tipo de experiência nos rituais religiosos antigos, encontrados com pequenas variações em várias partes do planeta, levou a construção da hipótese da centralidade dessas substâncias para a constituição da religião e da própria condição humana na pré-história (WASSON et al, 1992). A excitação mística provocada por tais usos e o reconhecimento da ignorância ocidental nessa matéria, conforme veremos em seguida, levaram à crítica da expressão alucinógeno para designar seus efeitos. Segundo Wasson (1992, p.32-34), a expressão enteógeno seria a mais adequada, pois sua filologia indica a ideia de "criar deus dentro de si" ou "ter deus 
dentro de si”, dando conta do sentido místico ignorado pela expressão psicodélico (ligado à contracultura) ou alucinógeno (ligado à ideia de falsidade dos sentidos). Segundo Carneiro (2002, p.145-147), o termo alucinógeno é relativamente recente data dos anos 1950 - e tecnicamente problemático, pois somente as substâncias atropínicas são aptas a fazerem percepções de objetos inexistentes ou falsos. Os efeitos dessas substâncias eram entendidos como uma forma de embriagues antes de 1950.

Existem ainda dois outros termos que podem ser utilizados para designar esse tipo de experiência: visionários, que enfatiza uma alteração da forma de percepção sem ênfase no aspecto religioso; onirogênico, que significa "criação de sonhos" e salienta a ativação de funções cerebrais ligadas ao onírico. O fato é que tais substâncias, que marcam grande alteração comportamental e que podem incluir a perda total do controle psíquico, podem ser poderosos símbolos de conhecimento esotérico ou de comunicação com outros mundos. Se essas qualidades podem ser atrativas para indivíduos ou comunidades pequenas, o mesmo não se diz para sociedades que exigem maior autocontrole e que os poderes políticos estão em processo de formação (SHERRATT, 1995, p.16; ESCOHOTADO, 2008, p.477-483; COURTWRIGHT, 2001, p.56-59). Esse tipo de técnica estática foi bastante comum entre nômades das planícies asiáticas e siberianas, particularmente com o cogumelo amanita muscaria (CARNEIRO, 2002, p.149-155).

Sobre a papoula, planta que é extraído o ópio, existe uma controvérsia sobre suas origens. Escohotado (2008, p.67) aponta que ela é originária da China ou da Ásia Menor, embora existam evidências pré-históricas do cultivo na Suíça. Courtright (2001, p.31) aponta que não existe certeza sobre a origem geográfica, existindo evidências no sudoeste da Europa e no oeste da China. Sherratt (1995, p.27-28) defende a hipótese que, antes da disseminação da técnica das bebidas fermentadas para o norte da Europa, que criou uma vigorosa tradição cervejeira, existia uma cultura da fumaça que privilegiava a queima da papoula como inebriante privilegiado. Ela seria originada do Mediterrâneo. Curioso destacar que Escohotado (2008, p.201) reconhece a tradição préhistórica da produção de cachimbo e outros instrumentos destinados à inalação da fumaça, porém atribui tais artefatos ao consumo de Cannabis. Sneader (2005, p.10), por sua vez, é bem menos otimista em relação ao consumo pré-histórico de ópio. As sementes que foram encontradas e usadas para atribuir o consumo de papoula na préhistória não tem quantidade de alcaloides suficientes para provocar qualquer efeito 
narcótico real. Elas provavelmente eram usadas para extração de óleo e não para finalidade psicoativa.

Independente de onde surgiu, o certo é que o ópio é uma substância extremamente útil para tratar uma série de males. Ainda hoje seus derivados são considerados analgésicos por excelência, sendo denominadas 'opiáceos sintéticos' as substâncias sintéticas que possuem efeitos similares. Entretanto, seus usos na antiguidade não se reduziam a esse. Ele era usado para combater a ansiedade, o tédio, a fadiga, a insônia, para acalmar os bebês e, principalmente, para conter a diarreia causada pela contaminação das bebidas e das comidas. Ele podia ser fumado, bebido e acrescentado como tempero para os alimentos.

$\mathrm{O}$ uso do ópio nas sociedades antigas ocidentais é muito documentado. $\mathrm{Na}$ Mesopotâmia ele está registrado em papiros desde o terceiro milênio antes de Cristo (ESCOHOTADO, 2008, p.73). No mundo grego ele era extremamente popular. A lenda diz que o "deus da medicina" foi fulminado por Zeus por ter ensinado as virtudes e os segredos da papoula aos homens. Essa planta possuía um difundido uso doméstico. Nas colônias gregas era costume fazer grandes jardins de papoula, permitindo um rápido autoabastecimento na forma simples do chá com as cabeças da planta. Ela também era cultuada como símbolo de fertilidade, por vários motivos e também por prolongar a ejaculação. Era elemento central nas saunas curadoras do notório templo de Asclépio, cuja prática ritual de cura parecem ter sido inspirada em similares de hititas e de babilônicos. Os compostos de ópio eram considerados os antídotos mais importantes (ESCOHOTADO, 2008, p.138-145). Presença esta que se reiterou e se ampliou no mundo romano (ESCOHOTADO, 2008, p.172-175).

Há quatro mil anos atrás, as sementes de papoula haviam se disseminado para o Oriente Próximo, e cultivada comercialmente pelos Citas para a produção de ópio líquido. Esse produto era exportado para o Levante próximo e para Egito na forma de frascos que representavam uma capsula de papoula invertida. Um comércio parecido foi realizado pelos gregos no período homérico, quando se utilizava pequenas embalagens grosseiras - frequentemente encontradas nas catacumbas de crianças nos santuários de Demeter e Hera (junto com vegetações e divindades infernais associadas com a morte e a ressureição). Homero descreve Helena colocando uma droga chamada nepenthes no copo de vinho de Menelaus, para diminuir a dor e induzir ao esquecimento, e é provável que essa mistura tenha sido na forma líquida (SHERRATT, 1995, p.31). 
O Oriente só foi ter conhecimento do ópio depois que começaram os contatos mais frequentes com o Ocidente. As caravanas de mercadores passavam por regiões produtoras de papoulas, fazendo desse produto caro, exótico e só utilizado pelas classes altas chinesas (ESCOHOTADO, 2008, p.87-89). Ele teria sido introduzido pelos árabes nessa região por volta do século VIII (COURTRIGHT, 2001, p.32).

Outra planta anual de extrema importância foi a Cannabis, também denominada de cânhamo. Essa variação da nomenclatura ocorre porque a primeira tem maior teor de princípios ativos responsáveis pelos efeitos psicoativos, embora as duas sejam a mesma planta. Essa distinção é importante porque um dos vetores de sua propagação foram suas qualidades como matéria prima para fibras destinadas à confecção de cordas e tecidos. E é da China que provém os registros mais antigos, que remontam ao neolítico (FRANÇA, 2015, p.07). Também foram nos tratados medicinais chineses de quatro mil anos atrás que estão registradas as primeiras receitas farmacêuticas que tem por base a Cannabis (FRANÇA, 2015, p.12). Sneader (2005, p.16), aponta que os primeiros registros chineses se relacionam unicamente com a fabricação de fibra, muito usadas para a compressão de cerâmicas e outros objetos. Não existiriam evidências de que ela era usada como droga - essa assertiva passou a ser repetida baseada na fala de um imperador chinês, de 5 mil anos atrás, mal traduzida.

Sherratt (1995, p.30) defende a hipótese que, assim como ocorreu no norte da Europa em relação à papoula, nas estepes ao norte da China existia uma cultura da fumaça que privilegiava a queima da Cannabis como inebriante privilegiado. A ela se contrapunha a cultura líquida chinesa com base no vinho de arroz. De fato, embora utilizasse a Cannabis para fins terapêuticos, o uso recreativo não se enraizou na China. Segundo Dikotter et al (2004, p.199-201), embora presente na farmacopeia desde a antiguidade, a Cannabis é rejeitada como droga recreativa porque existia a crença que ela facilitava a possessão pelo demônio e contribuía para a insanidade. Essa rejeição ocorria a despeito da difusão do uso lúdico no sul da Ásia. Segundo Rubin (1975, p.02), na Índia, o uso sagrado da Cannabis antecede os registros escritos.

A antropóloga Vera Rubin lançou, em meados da década de 1970, uma coletânea de artigos sobre a Cannabis propondo a existência de um fluxo de uso marcado por certos padrões que são similares em algumas regiões do Velho Mundo. Esses padrões seriam caracterizados por consumo secular e sagrado, baseado em uma economia de pequena escala de cultivo. A Cannabis seria usada para: fabricação de cordas e roupas; produção de artesanato; como elemento da culinária na forma de 
temperos, sopas, mingaus, ensopados e doces; na medicina de humanos e de animais; como energizante e revigorante para o trabalho; como parte de rituais religiosos; como euforizante geral utilizado nos rituais ordinários de hospitalidade. Com exceção dos usos para propostas rituais envolvendo membros das classes sacerdotais, regularmente os múltiplos usos desse fluxo tradicional são confinados às classes sociais mais baixas, como camponeses, pescadores, artesões rurais e urbanos e trabalhadores manuais. Esses usos tradicionais (folk) foram denominados de complexo da ganja (RUBIN, 1975, p.0110). Essa interpretação ainda é aceita atualmente (COURTRIGHT, 2001, p.39-42).

Importante para nosso propósito é explicitar o papel dos árabes na propagação do uso da Cannabis. Como guardiões da cultura clássica, eles tomaram conhecimento de suas finalidades médicas através das obras gregas, porém seu uso deve ter se difundido através do comércio com a Índia via Irã. Um peregrino indiano, de acordo com o folclore, introduziu nos usos iranianos a Cannabis como uma droga psicoativa em meados do século VI (COURTWRIGHT, 2001, p.40). Contudo, alguns estudiosos acreditam que a Cannabis apareceu mais cedo no antigo Oriente Próximo, pois existem referências sobre a planta tanto nos textos Hebreus do velho Testamento quanto nas traduções aramaicas (COURTWRIGHT, 2001, p.40; RUBIN, 1975, p.04). A Cannabis gerou controvérsia no mundo Islâmico, devido em parte à associação com os Sultões, que usavam para propósitos místicos que as autoridades mais ortodoxas lançavam suspeitas. Esporádicas tentativas para proibir o uso falharam e, no século XIV, a produção de hashish já estava estabilizada particularmente no Delta do Nilo (COURTWRIGHT, 2001, p.40). Os comerciantes árabes tiveram sucesso em introduzir a Cannabis para as regiões da costa lesta da África, que por sua vez a levaram para as regiões centrais e sul do continente africano (TOIT, 1975).

Assim como aconteceu na China, os ocidentais parecem não terem desenvolvido um interesse pelos usos psicoativos da Cannabis nos tempos antigos. Existe uma famosa descrição de Heródoto (446 a.C) de um ritual fúnebre onde os Citas se embriagavam com Cannabis na costa noroeste do Mar Negro (FRANÇA, 2015, p.21; CARNEIRO, 2010, p.48-49; ESCOHOTADO, 2008, p.106; CARNEIRO, 2002, p.208209; COURTWRIGHT, 2001, p.40; SHERRATT, 1995, p.26; RUBIN, 1975, p.02; DORIA, 1958, p.05). Os gregos conheciam o cânhamo e o utilizavam tanto para fins medicinais, quanto como potencializador do efeito embriagador do vinho. Ele era um entre outros 'aditivos' que podiam ser adicionados ao vinho, como o meimendro e a mandrágora (ESCOHOTADO, 2008, p.137-138). Por Galeno, sabemos que os nobres 
romanos ofereciam flores de Cannabis aos seus convidados. Apesar desse conhecimento, o hashish egípcio podia ser considerado uma excentricidade de alguns nobres. A difusão de seu uso é muito pequena se compararmos com a popularidade do ópio (ESCOHOTADO, 2008, p.182). Apesar de conhecerem a planta, os efeitos psicológicos eram pouco conhecidos e desdenhados até o século XVIII. Somente com a ampliação dos contatos com o Oriente é que se desenvolveu gradativamente a visão da Cannabis como afrodisíaco - no mundo medieval e moderno predominava a visão dessa planta como diminuidora do esperma masculino (CARNEIRO, 2002, p.199-217).

O mundo antigo pareceu conhecer uma variedade de substâncias que eram utilizadas de forma terapêutica, lúdica e enteógenas - dependendo do contexto. Difícil separar os usos de acordo com essas formas, uma vez que elas estavam intrinsicamente ligadas. O direito romano, nesse aspecto, tradicionalmente dividia a magia em branca que objetivava a cura - e negra - visando prejudicar as pessoas. Os ocidentais conheciam e apreciavam muito o ópio, principalmente na forma líquida, as solanáceas (meimendro, mandrágora, estramônio, beladona), a Cannabis (incluindo o haschish), além de outras substâncias visionárias - o princípio ativo muito próximo ao LSD, do ergot, por exemplo, era o enteógeno utilizado nos mistérios Eleusis nos quais passaram Aristóteles, Plutarco e Heráclito e muitos outros. ${ }^{3}$

Nenhum psicoativo, entretanto, foi mais importante do que o vinho no Ocidente. No mediterrâneo antigo ele era sinônimo de civilização, acompanhando a vida urbana. As pesquisas sobre a cultura material são repletas de representações dele, cobrindo produção, transporte, consumo, etc. Os utensílios para beber vinho faziam parte do estilo das elites. A desintegração política do período homérico fez do acesso ao vinho e a habilidade de provê-lo em importantes alavancas do poder político. Ele tinha inúmeros usos: como anestésico; como solvente; como vinagre; como ácido orgânico; como desinfetante - a primeira ajuda oferecida pelos bons samaritanos é colocar um pouco de óleo e vinho nas feridas. Como uma bebida, o vinho conserva melhor que a cerveja e até melhora com o tempo; é um elemento importante da dieta mediterrânea, além de se constituir em um produto de exportação. As variações locais de condições dão diferentes gostos e qualidade, e regiões especializadas em produtos consagrados são economicamente importantes tanto no mundo antigo quanto no moderno. Funcionava

\footnotetext{
3 A melhor compilação de fontes da antiguidade sobre o uso de drogas foi realizada por Antonio Escohotado, na sua enorme obra intitulada "História General de Las Drogas" (2008). Embora suas referências precisem ser analisadas com espírito crítico, é inegável o conhecimento do mundo grego e romano sobre essas substâncias. Conhecimento esse que seria preservado pelos árabes.
} 
como um fator de lubrificação social e como símbolo de hospitalidade. Quando a aristocracia militar armada deu lugar à falange, o simpósio se tornou a instituição masculina feita para o prazer e a tranquilidade - a harmonia política e a sociabilidade comunal estavam associadas à vida cívica, à música e à poesia. Misturar o vinho na água era um sinal de humanidade. $\mathrm{O}$ vinho era onipresente, exercendo papel vital tanto em ritos sociais laicos como religiosos (CARNEIRO, 2010, p.21-52; SHERRATT, 1995, p.17-20). ${ }^{4}$

$\mathrm{Na}$ tradição judaica o vinho era considerado, junto com o pão, uma dádiva divina, forma principal de libação depois dos sacrifícios, dos serviços de domingo, das celebrações da páscoa e cerimônias de passagem como os casamentos. Existem várias referências a ele no Velho Testamento. "Se no judaísmo o vinho foi importante, no cristianismo ele tornou-se essencial, corporificando a própria deidade" (CARNEIRO, 2010, p.105). Ele representa o sangue de cristo no rito central da eucaristia cristã. A vinha é a planta mais citada na Bíblia. Cristo comparou seus discípulos aos brotos do vinhedo. Segundo os apóstolos Mateus e Lucas, Cristo era acusado de ser um glutão e beberrão pelos seus detratores. Nos textos bíblicos ficam claras as diferenças entre tomar vinho, algo benéfico, e se embriagar, algo reprovável (CARNEIRO, 2010, p.106118; SHERRATT, 1995, p.18).

Com a ascensão do cristianismo, ocorreu a perseguição à cultura pagã clássica, com estabelecimento de censura, de queima de livros, de destruição de monumentos e de qualquer outro artefato cultural ligado a ela. Foi nesse contexto que o vinho se sobrepôs a todos os outros psicoativos, tomando a condição de quase monopólio. Todas as "drogas" distintas do álcool foram consideradas indignas, pois no paganismo a euforia - tanto positiva (para obtenção de felicidade), quanto negativa (para aliviar a dor) - constitui um fim em si mesmo. $\mathrm{O}$ viver bem e o prazer advindo das terapias eram entendidas como parte integrante das mesmas. No cristianismo, contrariamente, não se admite que a euforia seja um fim em si mesmo. A dor nessa sociedade é pensada como uma graça de Deus, como uma forma de mortificação da carne capaz de lembrar os homens e as mulheres do pecado original que os(as) colocaram na condição humana. $\mathrm{O}$ gozo sexual ofende o Criador, na proporção da sua intensidade, igualmente como o uso de analgésicos e de alteradores de ânimo visando o prazer - são formas de hedonismo que deviam não apenas ser rejeitadas, mas combatidas. O lugar da eutanásia nesse

\footnotetext{
${ }^{4}$ Especificamente sobre o simpósio, ver Carneiro (2010, p.78-87).
} 
pensamento é exemplar: o uso de substâncias para alcançar a morte no tempo certo, como era o uso considerado ético na antiguidade, passa a ser considerado o maior dos pecados porque a vida do fiel não pertence a ele. Pertence a Deus (ESCOHOTADO, 2008, p.234-235).

Todas as substâncias, outrora utilizada na cultura clássica, ficaram renegadas ao ostracismo, seja no repertório farmacológico popular - que posteriormente será perseguido a ferro e fogo pela inquisição - seja entre os árabes que se tornaram os herdeiros da cultura clássica. A rejeição da euforia como um fim em si mesma, própria da ética cristã, explica o porquê das drogas serem consideradas um atentado à ordem natural do homem, conforme defende Courtwright (2001, p.91-94). Além disso, segundo esse mesmo autor, um dos motivos pelos quais as drogas devem ser restritas ao uso médico é porque elas são desaprovadas pelas religiões verdadeiras, no caso o cristianismo, o islamismo e o hinduísmo. As demais crenças seriam "falsas religiões, [que utilizam] ídolos químicos que distraem os fiéis e levando-os ao caminho da autodestruição"5 (COURTWRIGHT, 2001, p.169).

Para finalizar a exposição sobre o velho mundo, ainda cabe destacar que a oposição entre cristãos e islamitas não era apenas em questão de crença e de religião. Enquanto as primeiras civilizações eram dominadas por aristocracias costeiras que bebiam vinho, o grupo que chegou ao poder com o Islã era fundado na ideologia tribal do deserto, baseado no camelo e no comércio das caravanas. A condenação do vinho bebido como uma prática deve ser visto como uma tentativa explícita de forçar uma mudança dos códigos culturais em direção oposta aos valores estabelecidos da velha civilização em áreas conquistadas pelo Islã. No lugar do vinho uma variedade de substâncias particulares - como o ópio, a canabis, o qat, a kola, e, mais tarde o café e o chá - tiveram usos religiosos e seculares, produzindo um leque de narcóticos e de estimulantes que foram empregados em diferentes contextos (SHERRATT, 1995, p.2023). Apesar de toda a rejeição teológica e cultural ao vinho, que muitas vezes se refletiu em normas proibitivas legais, a proibição total não funcionou. Carneiro (2010, p.118127) chama a atenção para a persistência do vinho na literatura e no cotidiano do islamismo.

\footnotetext{
5 "Drugs transiently mimic only the feeling, not the disciplined knowing, of the true mystical experience. They are false religions, chemical idols that distract the faithful and lead them down the path of selfdestruction" - tradução sugerida.
} 
Nosso giro pela história pré-moderna do uso de drogas termina com a América. Vários autores destacam a influência dos cultos xamãs dos povos siberianos, com base no consumo do cogumelo amanita muscaria, em práticas similares desenvolvidas em solo ameríndio (ESCOHOTADO, 2008, p.107; CARNEIRO, 2002, p.149; COURTWRIGHT, 2001, p.56). A diferença é que tal tradição foi inserida em um contexto de enorme riqueza e variedade de plantas psicoativas (ESCOHOTADO, 2008, p.107-108; GOOTEMBERG, 2008, p.04-05). Conforme foram se complexificando as sociedades ameríndias no Golfo do México, gradativamente a nobreza indígena passou a deter a exclusividade sobre as substâncias alucinógenas, estando seu consumo ligado ao culto dos mortos, à cura e à adivinhação. Tais substâncias eram um prestígio de alta autenticidade, como é o sonho e o orgasmo, e as elites preservavam para si o direito a esse extraordinário (ESCOHOTADO, 2008, p.124-129; CARNEIRO, 2002, p.176-177). Entre os astecas os sonhos eram utilizados como razão de Estado, existindo inclusive burocratas responsáveis por registrar e interpretar os sonhos das principais autoridades. Dentro desse padrão cultural as substâncias com caráter onirogênicas são muito valorizadas (CARNEIRO, 2002, p.193-195). Esse controle sacerdotal, por óbvio, não se desenvolveu nas sociedades mais simples que existiam as bordas dos grandes impérios ameríndios. No território que depois será criado o Brasil, existe a jurema - pequena árvore da catinga nordestina cuja casca podia ser fumada ou usada para fabricar bebidas. Na região amazônica existe o chá de ayahuasca. Ambas tem o DMT como principal princípio ativo. Todas essas substâncias tinham importantes usos religiosos e terapêuticos, visto que esses dois usos se confundiam dentro dos padrões culturais xamânicos.

Dentre essas substâncias, a mais popular e difundida no continente americano foi o tabaco. Embora, hoje, ela seja bastante popular na forma do cigarro, é preciso destacar que na América pré-colombiana seus usos eram bastante diversos. Com exceção do extremo norte e sul, seu uso era difundido por todo o continente. Escohotado (2008, p.68) chama a atenção para a dificuldade de classificar essa substância, pois ela funciona simultaneamente como estimulante e calmante. Dependendo da quantidade e da forma de utilização pode também ter efeitos alucinógenos. Carneiro (2011, p.153154), por sua vez, destaca que o tabaco podia ser absorvido por ingestão, aspiração nasal e até por enemas, embora tenha sido pela forma fumada que ele se disseminou. Existe um relato sobre o uso do tabaco na forma de bebida, tanto líquida como pastosa, 
pelos tupinambás. Escohotado (2008, p.384-386) destaca ainda que a ausência de tabaco era sinônimo de pobreza para os nativos americanos.

Os ameríndios também desenvolveram várias técnicas de produzir bebidas fermentadas, utilizando cereais, leguminosas, tubérculos e frutas em geral. A matéria prima mais comum era o milho, seguido da mandioca e em regiões específicas o algaroba e quinoa. Essas bebidas recebiam variadas denominações, como chincha, balchê, pajauru, caxirí, cauim, entre outros (CARNEIRO, 2010, p.138-140; SZTUTMAN, 2008, p.222-223; LIMA, 1974). As receitas não devem ser vistas de forma homogênea mesmo no interior de um mesmo grupo, pois a composição da bebida varia de acordo com os contextos de consumo e efeito embriagante desejado. Existem, portanto, os um fermentado de pouco teor alcoólico - pensado para acompanhar a alimentação - e outro como enteógeno (SZTUTMAN, 2008, p.223-255).

No território que formaria o Brasil existiam as cauinagens, grandes festas periódicas marcadas pela tentativa consciente de obter o máximo de embriaguez, visto que os indígenas - homens e mulheres - passavam dias seguidos bebendo sem ingestão de alimentos. Às vezes provocando o regurgito como forma a ampliar a capacidade de ingestão de bebida. Tais encontros podiam durar até três dias (CARNEIRO, 2011, p.141-145). A boa embriaguez está estritamente ligada à sociabilidade entre as famílias, os grupos e o sobrenatural. A quantidade de bebida ingerida não é o fator predominante, e sim se esse uso é integrado ou não. A moderação nas festas e nos rituais é vista como uma forma de ingratidão àqueles que as promovem e às divindades, por isso é preciso beber até acabar todo o estoque disponível. A embriaguez, em si, não era algo condenável. O que não se aceitava eram os maus comportamentos derivados dela (CARNEIRO, 2010; DIAS, 2008).

O continente americano também é caracterizado pelas múltiplas folhas, frutas e plantas estimulantes. Na América Central destacamos o cacau que possui leve teor de teobromina, utilizado como ingrediente de uma bebida apreciada pelas elites astecas. No Sul da América, particularmente na região do Paraguai e do Mato Grosso (Brasil), existe a erva-mate que possui cafeína e teobromina simultaneamente. Originário da região do Amazonas existe o guaraná, estimulante vegetal com teor de cafeína superior ao café (ESCOHOTADO, 2008, p.121-122). “Apesar do alto teor de cafeína, o guaraná não é considerado tão excitante como o café, talvez em decorrência dos efeitos das saponinas que ele também possui" (CARNEIRO, 2011, p.150). O guaraná tinha funções terapêuticas como puçanga, era ingerido nos rituais de guerra, fazia parte de ritos de 
passagem e podia ser utilizado até como moeda (MONTEIRO, 1965, p.21-35). Desde cinco mil anos atrás a região andina utiliza as folhas de coca como estimulante (ESCOHOTADO, 2008, p.115; GOOTEMBERG, p.2008, p.16), embora seu uso não possa se resumir a essa finalidade. Suas representações sagradas colocam essa planta como central na história cultural da região andina. Ela era usada na forma mascada, bebida e até inalada por alguns grupos amazônicos. Sua ação é importante mitigadora dos efeitos gerados pela altitude. O uso de coca, portanto, precisa ser entendido como um ato espiritual e ritual, como forma de afirmação cultural de certos grupos e como forma de trocas comerciais e simbólicas. Por todas essas funções ela não pode ser considerada um mero estimulante cotidiano (GOOTEMBERG, 2008, p.16-17). Na época da chegada dos europeus, os incas tinham transformado o uso dessas folhas em privilégio da nobreza e de seus agregados diretos, fazendo uso dentro dos marcos profanos como estimulante (ESCOHOTADO, p.115).

A chegada dos europeus à América e a intensificação do comércio transoceânico promove alterações significativas nesse quadro que tentamos esboçar do uso de substâncias ao longo da história humana. Os padrões locais e regionais de consumo passarão por mudanças significativas a partir do contato com psicoativos que se tornarão globais. Procurei mostrar que, apesar da busca de substâncias capazes de alterar os estados de consciência seja uma faceta universal das sociedades humanas, os usos precisam ser inseridos dentro de contextos sociais em que são realizados. Existem códigos e barreiras culturais, estratégias comunais de prevenção ao uso desregrado e significados espirituais, terapêuticos e profanos. Pensar o uso de drogas como uma “questão de exposição", como sugere Courtwright (2008, p.94-97), é aplicar ao uso de drogas a moralidade cristã em matéria de alteração da consciência e o padrão epidemiológico biomédico como suporte epistemológico da análise.

\subsection{A revolução psicoativa}

A modernidade foi um dos eventos mais importantes da história humana. Wallerstein (1990) propôs o conceito, ainda adequado, de economia mundo para caracterizar os efeitos da expansão europeia entre 1450 e 1640. Pela primeira vez, territórios em diferentes partes do mundo se interligaram economicamente a partir da ótica da acumulação de capitais dos países centrais em detrimento das regiões periféricas e semiperiféricas. Essa interligação teve fundamental importância na 
disseminação de alguns psicoativos ao longo de todo o globo terrestre, conforme veremos.

O comércio transoceânico foi responsável por transportar plantas, microorganismos e animais de um lado para o outro, sempre em benefício do nascente capitalismo europeu. A batata e o milho, produtos americanos, proveram a base material da população mundial. Um fator igualmente importante, porém não tão conhecido, foi a capacidade ampliada das populações ligadas a esse comércio de alterar a sua consciência com produtos psicoativos. Pela primeira vez se criaram condições para que determinadas substâncias pudessem ser consumidas globalmente. O estadunidense Courtwright (2001) denominou esse fenômeno de revolução psicoativa.

Essa mundialização, entretanto, não ocorreu com todos os psicoativos existentes. Ela seguiu, essencialmente, os padrões culturais do Ocidente cristão. A cristandade é historicamente grande inimiga das práticas tradicionais xamânicas - fato que explica a verdadeira cruzada que foi posta em prática contra o consumo de substâncias de característica enteógena, seja em território europeu contra as práticas pagãs entendidas como demoníacas (ESCOHOTADO, 2008, p.244-250), seja durante a colonização da América (idolatria ameríndia) (ESCOHOTADO, 2008, p.124; CARNEIRO, 2002, p.171-205; COURTWRIGHT, 2001, p.56-57). Além da rejeição aos fármacos com essas características, outros fatores também foram relevantes para entender porque algumas substâncias se tornaram commodities globais e outras não: $1^{\circ}$. Aversão inicial provocada pelo gosto ruim ou por formas de consumo desagradável; $2^{\circ}$. Efeitos estéticos indesejados, como problemas para os dentes ou para as vísceras; $3^{\circ}$. Produtos que estragam muito rápido e apresentam problemas logísticos para o comércio de longa distância (COURTWRIGHT, 2001, p.53-55).

Quais foram, portanto, as substâncias privilegiadas pelos europeus durante a expansão do comércio transatlântico? Courtwright (2001, p.09-52) propõe dois grandes grupos de substâncias: as grandes de enorme expansão e de impossível proibição bebidas alcoólicas e cafeinadas, o tabaco e o açúcar; e as pequenas de expansão limitada que possibilitaram a intervenção pública - o ópio, a Cannabis, a coca e todos os derivados provenientes dessas plantas. Essas substâncias tiveram em diferentes momentos trajetórias muito similares. Elas despertam interesse inicial pelo seu emprego terapêutico, como medicinas exóticas que geravam acalorados debates entre os físicos. Gradativamente, o interesse nos usos ultrapassa a fronteira das práticas de cura e, graças à ampliação da disponibilidade, passam a ser utilizadas para fins recreativos. "Elas 
fogem para um domínio mais amplo dos prazeres e travessuras populares, levando as autoridades nacionais e internacionais a elaborarem respostas públicas"6 (COURTWRIGHT, 2001, p.69).

As drogas efetivamente tiveram trajetórias muito similares, iniciando como uma forma de medicina e se popularizando posteriormente. Uma das raras exceções é o crack, que é uma droga derivada da coca que foi criada e lançada exclusivamente para o mercado ilícito. Esse, entretanto, é um efeito contemporâneo do modelo proibicionista adotado na segunda metade do século XX. Antes do crack, essa pareceu sim ser a trajetória da maioria das drogas. O que parece questionável dentro dessa interpretação de Courtwright (2001) é a naturalização do controle terapêutico e político e a associação do uso popular com a travessura e a irresponsabilidade. Mais uma vez será preciso contrastar essa visão com as concepções ideológicas que procuram inserir determinadas atitudes sociais no campo da ordem natural.

Durante a Idade Média, conforme vimos, toda a farmacopeia clássica foi acusada de pagã e reprimida como forma de bruxaria. O ponto de mudança nessa política puritana ortodoxa em matéria médica ocorreu entre os séculos XI e XIV, particularmente por causa das cruzadas. Ficou latente, durante os conflitos, a superioridade árabe em termos de terapêutica - o que gerou desconforto entre os nobres combatentes e uma atitude de maior tolerância sobre os fármacos em geral. No século XIII já é possível perceber a defesa do ópio para fins terapêuticos na Escola de Salermo - admitido, entretanto, somente para a cura por causa das paixões culpáveis que ele podia gerar. $\mathrm{O}$ uso era permitido se fundamentado na medicina e somente para pessoas com moral elevado. Um notável esforço é feito pelos humanistas no sentido de separar a farmacologia da magia, algo extremamente perigoso porque o físico ou estudioso dessa matéria precisava ser amparado na sua respeitabilidade profissional - qualquer descuido ético podia acarretar em risco de vida para todos envolvidos no processo de cura. Somente depois do século XVI que ocorreu a popularização dos fármacos clássicos em suas práticas de cura (ESCOHOTADO, 2008, p.294-299). O historiador Henrique Carneiro (2002, p.26) chama a atenção para o papel da Escola de Salermo na preservação do conhecimento do saber herbário clássico a partir do século XIII.

Esse foi o contexto que permitiu a reintrodução dos fármacos clássicos e a introdução das novas medicinas que surgiam a partir das grandes navegações. Para a

\footnotetext{
6 "They escaped into a larger realm of popular pleasure and mischief, prompting responses by national and international authorities" - tradução sugerida.
} 
tristeza dos clérigos e daqueles que defendem o monopólio médico sobre essas substâncias, os usos não se restringiram aos prescritos por essas autoridades. A introdução de novos fármacos capazes e a diversificação da experiência humana com eles ocorreu em um momento de mudança na mentalidade e na educação dos europeus ocidentais. A possibilidade aberta pelas novas formas de alterar as percepções da mente, primeiramente pelas classes mais prósperas e depois se popularizando, criou um temperamento introspectivo que visava um maior autoconhecimento. Na língua inglesa, por exemplo, aparece no século XVI a palavra "natureza de si" (self) no sentido moderno, derivando dela inúmeras outras como sugere o Dicionário de Inglês de Oxford: autoconhecimento (1613), abnegação (1640), temeridade (1646), autoexame (1647), autodestruição (1654), autocontradição (1658) e constrangimento (1687) ${ }^{7}$. No final do século XVII, a preocupação com a alteração do estado de consciência foi exemplificado por John Locke (1632-1704) no seu influente livro chamado Essay Concerning Human Understanding (1690). Ele argumenta que a mente humana não tem princípios inatos, mas sim um papel em branco preenchido pela experiência (tábula rasa). Essa alta valorização da experiência e da consciência pessoal será a marca da Idade da Razão europeia (DAVENPORT-HINES, 2002, p.40-44). Autoconhecimento e uso de substância para fins psiconáuticos não é o mesmo que alienação, como sugere Silva (2015).

A maior disponibilidade de psicoativos alterou, de uma forma ou de outra, as culturas de consumo dentro e fora da Europa. A capacidade de alterar a consciência não deve ser entendida somente como a maior disponibilidade dos fármacos por causa do comércio transcontinental, mas também pela maior potência psicoativa dos produtos europeus. Adaptando técnicas árabes, fato evidenciado por termos como "alambique" e “álcool” (CARNEIRO, 2010, p.129), os europeus desenvolveram um método, baseado na serpentina, capaz de obter álcool concentrado. A descrição mais antiga do processo é do século XII, utilizado inicialmente para a fabricação de perfume. Gradativamente, o álcool passou a ser utilizado como analgésico e, posterirormente, para fins industriais (ESCOHOTADO, 2008, p.299-302). A destilação permite que se extrapolassem os limites alcoólicos naturais, pois cria bebidas que contêm até dez vezes mais álcool que as cervejas e os vinhos tradicionais. A gradual disseminação dos destilados como produto de uso comum provocou importantes mudanças nas formas de beber

\footnotetext{
7 "Self-knowledge (1613), self-denial (1640), self-fearing (1646), self-examination (1647), selfdestructive (1654), self-contradiction (1658), self-conscious (1687)" - traduções sugeridas.
} 
tradicionais. Ao passo que as bebidas orgânicas o embriagamento vai ocorrendo de forma gradual, nas bebidas espirituosas ele ocorre com poucos copos, significando a possibilidade de alcançar a intoxicação completa de forma mais rápida do que era necessário antes (SCHIVELBUSCH , 1991, p.73-74).

O alambique, como técnica, teve importantes consequências no imaginário europeu. Ele foi a primeira máquina a servir de analogia para o funcionamento do corpo humano dentro dos marcos da teoria dos humores (CARNEIRO, 2010, p.131). Mas, principalmente, foi parte constitutiva do trabalho farmacêutico moderno que se formava a partir da abertura política iniciada na Escola de Salermo. Segundo Dagognet (2012, p.57-61), uma das regras constitutivas do remédio nessa época era extrair da matéria as energias escondidas que ela contém. $\mathrm{O}$ alambique interrompe a hegemonia da ciência grega dedicada à contemplação da natureza. A partir dessa experiência se consolida um intento purificador que será aplicado em diferentes produtos - vegetais, animais, cadáveres, etc.

Não foi apenas o álcool que teve sua potência ampliada através da introdução da destilação. O século XIX foi marcado pelo isolamento dos princípios ativos de substâncias até então vendidas in natura - morfina (1808), codeína (1832), atropina (1833), cocaína (1859), cafeína (1860), efedrina (1885), mescalina (1888), entre outras. A tecnologia e a indústria que se criou em torno dessas substâncias serão analisadas com mais detalhes no próximo Capítulo. Por ora, importante destacar que o desenvolvimento farmacêutico, o isolamento dos alcaloides e a injeção hipodérmica como fatores importantes da revolução psicoativa (COURTWRIGHT, 2001, p.76-77). Escohotado (2008, p.411-417) aponta ainda que essas novas tecnologias serão responsáveis por criar uma cisão entre os laboratórios produtores dessas substâncias que carregarão a marca da modernidade - e os herbanários que vendem plantas e seus extratos - que gradativamente serão associados ao atraso e ao charlatanismo.

A expansão marítima europeia, que iniciou no século XVI e avançou até a constituição de um mundo integrado como conhecemos hoje, criou condições para que determinados psicoativos tivessem seu consumo globalizado. Esse mercado global não foi composto apenas pelos produtos tradicionais, uma vez que o alambique e a filosofia técnica que advém dele criaram condições para a criação de novos e potentes psicoativos - as bebidas destiladas e as substâncias alcaloides. Esse novo padrão de consumo internacional, entretanto, não deve apagar as particularidades de cada contexto. As substâncias com raízes regionais continuaram sendo utilizadas e os novos 
produtos podiam ser absorvidos de diferentes formas de acordo com as preferências locais. O ópio, por exemplo, era consumido na forma líquida na Europa, enquanto na China a forma mais comumente utilizada era a fumada. Não muda, entretanto, que tanto no Ocidente, quanto no Oriente, o ópio passou a ser parte da dieta farmacológica das populações antigamente excluídas de seu consumo.

E o Brasil, como participou desse fenômeno mundial?

No que se refere às grandes drogas, de enorme expansão e de impossível proibição, a análise sobre o Brasil deve começar pelo açúcar, pois esse produto foi central no processo de colonização, constituindo-se o principal produto de exportação do país durante vasto período. Embora hoje ele não seja considerado uma droga, seu consumo também precisa ser considerado dentro dos padrões que adotamos para outros psicoativos. O uso abusivo pode trazer danos à saúde (COURTWRIGHT, 2001, p.28; LUSTIG, 2013). Assim como outras drogas, começou sendo vendido como uma potente medicina e um tempero exótico. Gradativamente, seu preço foi baixando, o tornando um produto popular. Ele foi fundamental como acompanhante de outras drogas, pois se acoplava as bebidas que surgiam, tornando-as palatáveis e incrementando a sua popularidade. Ele também se associava a preparados de cânhamo e de ópio na Ásia. A indústria do tabaco emprega o açúcar para preservar o sabor e a cor do produto até hoje (COURTWRIGHT, 2001, p.28-30).

O açúcar é originário da Nova Guiné e da Indonésia, tendo se espalhado para a China na antiguidade. Os mercadores árabes levaram o produto para o Mediterrâneo, incluindo a península Ibérica. Com a reconquista, os portugueses e os espanhóis passaram a cultivar o produto, explorando as ilhas mais próximas e depois as colônias portuguesas. A abundância de chuva, solos férteis e trabalho escravo tornou possível uma expansão da produção na zona tropical da América (COURTWRIGHT, 2001, p.2728). Desde a década de 1930 muitos autores adotam uma interpretação apontando a centralidade da experiência da grande lavoura açucareira para a formatação da estrutura multirracial e hierárquica própria do território brasileiro (SCHWARTZ, 1988, p. 09). Hoje, existe um campo de estudos históricos consolidado sobre o tema. ${ }^{8}$

A eficácia produtiva do complexo do açúcar brasileiro era baseada, sobretudo, no trabalho compulsório. Primeiro, das populações nativas e depois dos escravos

\footnotetext{
${ }^{8}$ Desde 2005 são organizados, pela Rede Internacional de História do Açúcar, eventos internacionais bienais somente para discutir a importância desse produto para a organização da economia e da sociedade americana. Destaca-se o silêncio sobre o tema da psicoatividade desse produto.
} 
africanos. É vasta a historiografia da escravidão no Brasil, bastando para nosso propósito apontar que, ao lado da venda e da compra de drogas, o trabalho compulsório foi a base da expansão comercial europeia em todos os continentes. No Brasil, os engenhos de açúcar estimulavam a instalação de alambiques, tornando o destilado de cana, popularmente conhecido como cachaça, parte importante da economia açucareira. O destilado de cana era um relevante produto utilizado no mercado de escravos. Existem estudos que apontam que $27 \%$ dos escravos de Luanda e Benguela trazidos para o Brasil tenham sido trocados por bebidas destiladas entre 1700 e 1830 (COURTWRIGHT, 2001, p.149).

O destilado de cana produzido no Brasil seguiu a mesma trajetória dos produzidos na Europa. Desde o século XVI, existem registros sobre uma aguardente de cana utilizada tanto no comércio de escravos, quanto como bebida local, porém até o século XVII ela ainda era vendida como um remédio ou produto de luxo, vulgarizando seu uso ao longo do século XVIII (CARNEIRO, 2011, p.145-149). Esses usos serão detalhados no próximo Capítulo. As bebidas destiladas, como a cachaça, tiveram importante impacto nas práticas de consumo popular, tanto na Europa, quanto em outras partes do mundo. Apesar disso, os efeitos sociais desse novo e potente psicoativo variaram bastante. A Europa "foi muito bem sucedida [...] na sua revolução do álcool. Encontrou nesse um dos seus excitantes cotidianos, de calorias baratas, seguramente um luxo de acesso fácil, de consequências brutais” (BRAUDEL, 1970, p.199). Os europeus teriam usado essa poderosa bebida como meio de desorganizar socialmente os outros povos, principalmente os ameríndios. "Os povos índios sofreram muitíssimo com esse alcoolismo que se lhe oferecia" (BRAUDEL, 1970, p.202). Essa posição em relação ao efeito dos destilados entre os indígenas é compartilhada por outros autores (FERNANDES, 2002, p.39-40; SZTUTMAN, 2008, p.228-229), sendo considerada "a mais importante razão para sua ruina demográfica e cultural"" (COURTWRIGHT, 2001, p.147).

Sem negar os efeitos ruins que o destilado gerou no interior das sociedades nativas da América, cabe se perguntar qual o sentido que essa nova e poderosa bebida passou a receber nos códigos culturais ameríndios. Ao se referir aos destilados europeus, os indígenas os associaram a ideia de "verdade/verdadeiro", "ardente/fogo" e “espírito/espirituosa", pois sua ingestão se constituía em uma técnica de êxtase mais 
eficiente do que aquelas permitidas pelos fermentados até então utilizados (CARNEIRO, 2011, p.142-145). Em um contexto cultural que valoriza os estados alterados de consciência, essas bebidas representavam um produto de grande interesse. O destilado como instrumento de troca com os indígenas ficou registrado nos relatos dos europeus que circulavam pelo país nos tempos coloniais e imperiais. Spix e Martius, por exemplo, somente conseguiam proteção e serviços dos indígenas enquanto durasse a cachaça.

[nos abandonaram] um após outro, todos os índios que eram domiciliados no Alto Japurá ou nos seus afluentes, e que nos haviam sido emprestados pelos diversos tubixabas, para caçadores e remadores. Assim se foi reduzindo a guarnição, em cada parada, e muitas noites víamos um ou outro, sem esperar pelo pagamento, tomar os seus poucos haveres e desaparecer, de manso, do acampamento para o mato, e não voltar mais. Cachaça, a poderosa panaceia para todas as disposições de ânimo do índio, não tínhamos mais bastante para conservá-los perto de nós. (Spix \& Martius, 1976, p.227, apud Fernandes 2002, p.42)

A cachaça conviveu com uma enorme diversidade de licores que eram produzidos artesanalmente para consumo privado. Existem alguns relatos de viajantes que são presenteados pelas elites com aguardentes de frutas produzidas localmente. Essas fortes bebidas alcóolicas podiam ser consumidas em várias ocasiões, como antes do almoço para "abrir o apetite" ou nas conversas no final da tarde. No interior dos registros, entretanto, existe ênfase na predileção das classes menos favorecidas pela aguardente de cana, independente de gênero, condição social - livre ou escravo - e cor. Certamente, elas eram apreciadas

"pelos efeitos próprios das bebidas espirituosas, mas não se pode ignorar o
nível calórico existentes nas bebidas alcoólicas e a importância que este fator
devia assumir em dietas pobres e insatisfatórias, como era a dos escravos" (ALGRANTI, 2005, p.85).

Outra droga que teve enorme difusão foi o tabaco. Antes da chegada dos europeus, como vimos, ele era difundido em todo o continente. Inicialmente, foi visto com desconfiança pelos religiosos ortodoxos, porém logo ele se generalizou entre os colonizadores. Apesar dos vários comentários negativos, ele não parece ter sido reprimido pela inquisição (ESCOHOTADO, 2008, 348-50). Vários autores 
(BERRIDGE, 2013, p.09; CARNEIRO, 2002, p. 195; COURTWRIGHT, 2001, p.6970) destacam o incipiente interesse pelos usos terapêuticos desse produto pelos europeus através dos relatos deixados por Nicolas Monardes. Conforme advertia com rancor, desde cedo, o frade Bartolomé de las Casas (1474-1566) esse hábito era extremamente vicioso (ESCOHOTADO, 2008, p.350). Em um breve período, do contato de Colombo, em 1492, até a publicação da história natural da medicina de Nicolas Monardes, em 1571, os europeus já tinham adquirido o hábito de consumi-lo. No começo do século XVII o tabaco já tinha se tornado um produto global (BERRIDGE, 2013, p.09). A disseminação mundial do uso não foi feita sem resistência. Em países não produtores a reação a esse hábito alcançou graus extremos de violência. Inúmeras penas - morte, mutilação, etc - foram criadas em várias partes do mundo Rússia, China, Império Otomano, Europa Oriental - sem sucesso. A popularização do consumo, incluindo Roma, obrigaram os países a taxarem o comércio (COURTWRIGHT, 2001, p.16-19; ESCOHOTADO, 2008, p. 378-382). No Oriente, os responsáveis por essa difusão foram os britânicos e os holandeses, enquanto na África foram os portugueses. As guerras eram importantes propulsoras do consumo (COURTWRIGHT, 2001, p.14-16).

O tabaco foi o cultivo de exportação mais importante que se desenvolveu no Brasil colonial depois do açúcar. Ele era cultivado no Pará, Maranhão, Pernambuco e, principalmente, no sul da Bahia. O tabaco brasileiro era elaborado na forma de cordas, tratado com melado (um líquido extraído da cana de açúcar). Era um cultivo que necessitava de cuidado intensivo, podendo também ser produzido por pequenas unidades familiares. Apesar da sua rentabilidade, esse cultivo tendeu a se concentrar em torno de um nível social mais baixo do que o do açúcar. (SCHWARTZ, 1988, p.220224). O comércio brasileiro de tabaco e de destilado era superior ao britânico no século XIX (COURTWRIGHT, 2001, p.150).

Sobre as formas de uso, elas eram bastante variadas no contexto nativo americano, conforme foi visto anteriormente. Nas sociedades ocidentais o tipo de uso predominante variou de acordo com a época e o contexto. A Grã-Bretanha, por exemplo, era responsável por mais da metade do consumo mundial de tabaco inalado (rapé) no começo do século XIX, porém essa proporção baixou rapidamente. O cachimbo ganhou evidência na metade do XIX - com o desenvolvimento das manufaturas o consumo acabou se massificando entre os trabalhadores (BERRIDGE, 
2013, p.34). Sabe-se que até a década de 1930 a preparação do tabaco em pó se constituía em uma especialidade farmacêutica (BERRIDGE, 2013, p.74-76).

No Brasil, as escavações em unidades domésticas, unidades de produção e espaços funerários vem desvendando, do ponto de vista material, a emergência do modo de vida burguês no Rio de Janeiro do século XIX (LIMA, 1996). Nessas pesquisas foram encontrados muitos registros de tabaqueiras - pequenas caixas destinadas a guardar tabaco em pó, denotando que a aspiração de rapé era um hábito sofisticado. "Sua finalidade básica era a de provocar prazerosos espirros que desobstruíssem as vias respiratórias, favorecendo dessa forma a eliminação dos humores mucosos" (LIMA, 1996, p.71). Além desses usos sociais, existia também o emprego de rapé para aliviar dores de dentes e descongestionar a narina. Esses usos sociais e empregos terapêuticos, contudo, caíram em desuso em fins do século XIX, acompanhando a crise da nosologia baseada na teoria dos humores (LIMA, 1996, p.71-74), conforme veremos no próximo Capítulo.

Durante o Império o uso de charuto se tornou forma de diferenciação social. O uso do tabaco também era importante demarcador de idade - prova de ser adulto. O rapé era disseminado, inclusive entre os escravos. Debret, famoso cronista do XIX, afirma que a indústria do tabaco "é muito lucrativa, porquanto não há brasileiro que recuse uma pitada de rapé” (DEBRET, 1949 [1839], p.250 apud SOUZA, 2004, p.93). Em 1850, o Jornal do Comércio destaca a perda de uma caixa de rapé feita em ouro ornamentado. Mostrando que tal prática era envolta de sofisticação. Na segunda metade do século XIX, o charuto gradativamente foi desbancando o rapé e se tornando um vício aristocrático por excelência (SOUZA, 2004, p.92-93).

Apesar dos indicativos trazidos acima, ainda faltam estudos de fôlego capazes de reconstituir a economia e o consumo do tabaco em toda a sua amplitude e variedade ao longo da história do Brasil. Parece provável, entretanto, que até o começo do século XX - quando o cigarro industrializado como conhecemos hoje se massificou - várias formas de consumo do tabaco coexistiram. Os versos da propaganda da Casa do Cacique, vinculada no jornal A Regeneração do Partido Liberal de Santa Catarina, em 20 de julho de 1880, mostram a variedade de marcas de cigarros e charutos (escritas em itálico) oferecidas ao público (FIGURA 01). 


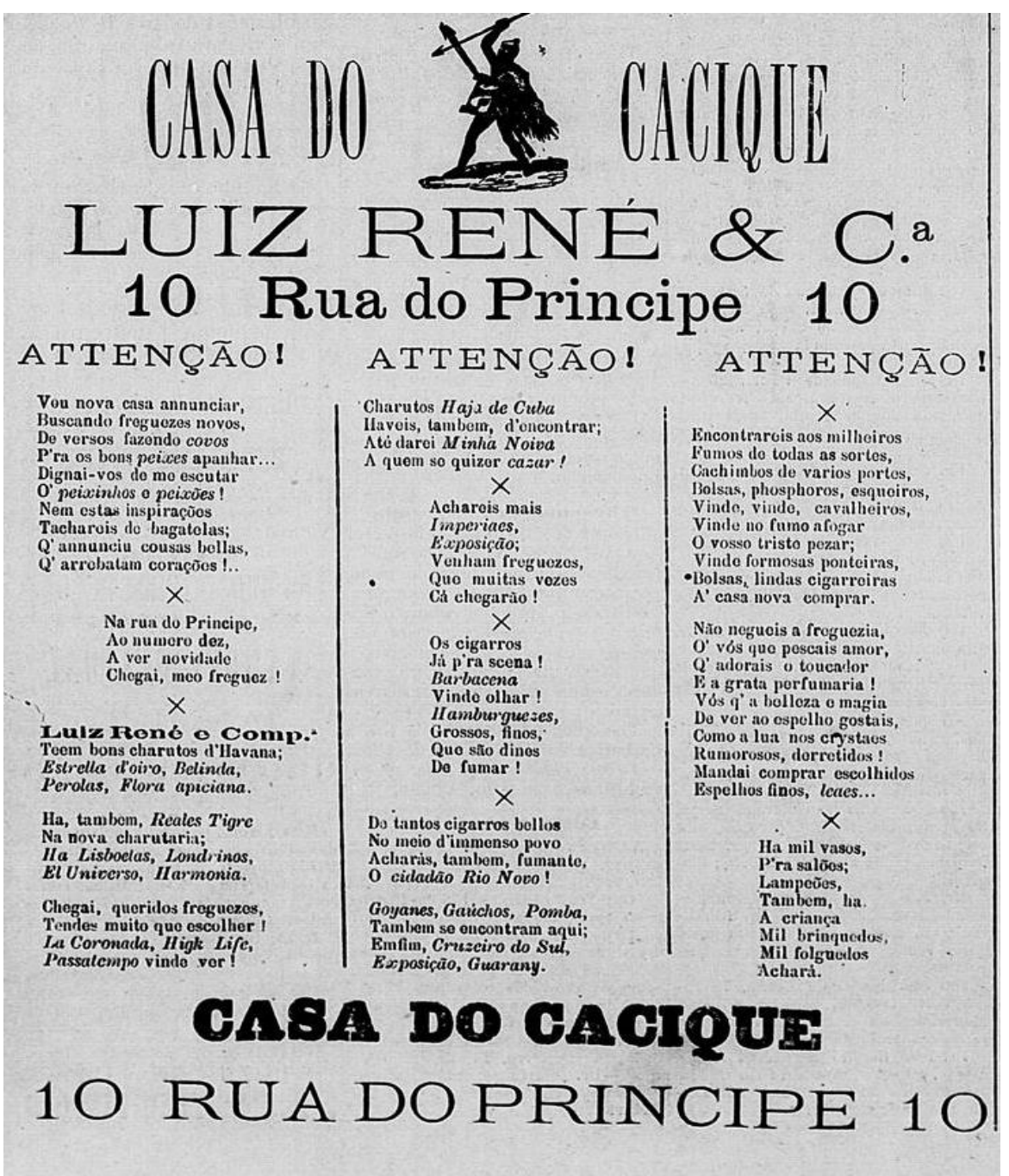

Figura 1 - Propaganda comercial de 1880.

FONTE: Fundação Biblioteca Nacional - Hemeroteca Digital

Para finalizarmos as grandes drogas de Courtwright (2001) ainda faltam as bebidas cafeinadas. As bebidas utilizadas pelos indígenas, destacadas anteriormente, tornaram-se importantes produtos regionais, porém não chegaram a se globalizar. É o caso da erva mate que podia ser bebida na forma de chá ou pela infusão em um cabaço. Segundo Boguszewki (2007, p.20-30), antes da chegada dos europeus, ela era um elemento básico da alimentação dos guaranis que se espalhavam ao longo das margens dos rios Paraná, Uruguai e Paraguai. Embora considerada uma "erva do diabo" em um primeiro momento, logo foi assimilada pelos europeus. Os jesuítas, que inicialmente foram contra seu consumo, logo perceberam possíveis vantagens materiais e passaram a cultivar e aperfeiçoar os cultivos. Os portugueses tomaram contato com essa cultura através das bandeiras - denominando-a de congonha. Auguste de Saint-Hilaire foi o botânico responsável pelo primeiro relado científico que lhe deu o nome oficial atual - 
Ilex paraguariensis. A erva-mate foi um produto que teve importância econômica na região sul do país desde o século XIX, principalmente no Estado do Paraná. Robert Avé-Lallemant, em passagem por essa região em 1858, deixou um relato da onipresença do mate na sociedade sul colonial.

\footnotetext{
Mate, mate e mais mate! Essa senha no planalto, a senha das terras baixas, na floresta e no campo. Distritos inteiros, aliás, províncias inteiras, onde a gente desperta com o mate, madraceia o dia com o mate e com o mate adormece. As mulheres entram em trabalho de parto e passam o tempo de resguardo sorvendo mate e o último olhar do moribundo cai certamente sobre o mate. É o mate a saudação da chegada, o símbolo da hospitalidade, o sinal da reconciliação (AVÉ-LALLEMANT, 1977, p.170).
}

O outro estimulante vegetal importante foi o guaraná, sendo nativo da região amazônica. Entre os colonizadores existiu a crença que ele era uma espécie de afrodisíaco que protegia contra os vermes e a malária. Ele teve seu princípio ativo extraído por Theodor von Martius, irmão do famoso viajante naturalista Carl Von Martius, em 1826. Inicialmente essa substância recebeu o nome de guaranina, porém mais tarde se descobriu tratar-se de um princípio ativo idêntico à cafeína (CARNEIRO, 2011, p.149-150).

O estimulante mais importante para a economia brasileira foi indiscutivelmente o café, cujo efeito psicoativo é o oposto ao provocado pelos inebriamento alcoólicos. Ele tem as propriedades que determinaram a forma como a sociedade europeia se desenvolveu a partir do século XVII. A cafeína, seu princípio ativo, provoca aceleramento das atividades intelectuais, fazendo desse fármaco a bebida burguesa moderna com enorme significação histórica. Difundido pelos burgueses em ascensão e tomado como seu símbolo, seus efeitos realizam o princípio racionalista - alterando a fisiologia do homem e o transformando para as exigências da modernidade. (SCHIVELBUSCH, 1991, p.29-30). As casas de café eram importantes locais de sociabilidade masculina, tornando-se verdadeiras incubadoras das ideias liberais e revolucionárias. Esses locais também se constituíam em importantes espaços de difusão do tabaco. Hoje sabemos que nicotina antecipa a absorção da cafeína (COURTWRIGHT, 2001, p.19-20).

No Brasil, o café tornou-se um emblema nacional, mercadoria mais importante da economia entre os séculos XIX e XX. Contrabandeado da Guiana em 1723, sua 
produção aumentou consideravelmente, ao longo do século XIX, motivado pelo crescente consumo europeu ligado às novas demandas psíquicas nascidas da revolução industrial. (CARNEIRO, 2011, p.152-155). Nos EUA, o café se constituiu, desde a Independência, em bebida patriótica em contraposição ao chá britânico. Suas importações tomaram tal vulto que o preço esse produto caiu até valores irrisórios no início do século XX (COURTWRIGHT, 2001, p.20). O café exportado para os EUA foi fundamental para o Brasil superar o forte déficit da balança comercial vivido entre 1822 e 1844, tornando-se o principal produto de exportação até o governo de Getúlio Vargas. A influência política estadunidense cresceu acompanhando a importância que o café adquiria na economia brasileira (CERVO et al, 2012).

Tratamos até agora das grandes drogas planetárias, cuja escala de produção, distribuição, consumo e o grau de integração com as culturas ao redor do mundo fizeram esses produtos impossíveis de proibir. A revolução psicoativa ainda é caracterizada por outras drogas globais, porém com menor consumo do que as outras apresentadas acima. Esses psicoativos eventualmente se tornaram alvos de restrições e proibições, embora permanecessem como commodities bastante rendosas (COURTWRIGHT, 2001, p.31).

Começamos pela Cannabis sativa. O termo "sativo" é originário do latim e significa "o que se cultiva", o que não é nativo ou o que não é selvagem (CARNEIRO, 2002, p.207). Assim como em várias outras partes do planeta, ela foi uma planta introduzida pelos que chegaram, no caso os portugueses e os africanos. Os primeiros a trouxeram para cultivá-la como cânhamo para cordas e tecidos. A Coroa chegou a atuar como protagonista nesse sentido, em fins do século XVIII, com a criação do a Real Feitoria do Linho Cânhamo no extremo sul do Brasil. Iniciativa essa que acabou fracassando economicamente (MENZ, 2005). Foram os africanos os principais responsáveis sobre difundir o uso costumeiro de Cannabis. Existem evidências, desde o século XVI, que os escravos plantavam Cannabis nas suas hortas caseiras. Os senhores permitiam que eles fumassem nos períodos de inatividade do trabalho, reproduzindo um uso costumeiro entre os agricultores africanos. Esse padrão não se verificou na América no Norte, embora o cânhamo tenha sido mais amplamente cultivado lá do que na América do Sul. A explicação que se dá para isso é que os escravos que vieram para as colônias britânicas eram da costa ocidental da África, onde a Cannabis não tinha estabelecido raízes (COURTWRIGHT, 2001, p.41). 
A historiografia da Cannabis no Brasil ainda é incipiente, porém vem trazendo contribuições importantes para nosso entendimento. Souza (2012, p.176) aponta para a similaridade das formas de consumo na África e no Brasil e para a nomenclatura de origem banto que a Cannabis ganhou no Brasil (liamba, riamba e diamba). Isso denota a predominância do elemento africano no consumo. Saad (2013), por sua vez, reconstrói todo o contexto higienista e elitista anterior proibição que associava o consumo da erva ao negro e a degeneração.

Existem outras referências que fazem associação direta com os escravos. Uma famosa passagem, do diplomata e explorador britânico Richard Burton em passagem pelo Brasil entre 1865 e 1868, trazida por Souza (2004, p.95) e França (2015, p.36) diz o seguinte: "Os preguiçosos e dissolutos iriam gozar a santidade do dia à moda africana, deitados ao sol e, se puderem, bebendo e fumando haxixe, como os semisselvagens da Serra Leoa”. Existem também outras referências à proibição à Cannabis em pleno século XIX. As Posturas da Câmara Municipal do Rio de Janeiro, no Título $2^{\circ}$ Sobre a Venda de Gêneros e Remédios, E Sobre os Boticários diz

\footnotetext{
$\S 7$ - É proibida a venda e o uso do Pito do Pango, bem como a conservação dele em casas públicas: os contraventores serão multados, a saber, vendedor em $20 \$ 000$, e os escravos, e mais pessoas que dele usarem, em 3 dias de cadeia (Dória, 1958, p.14)
}

Essa norma legal, conforme bem alerta Fiore (2005, p.263), parece não se dirigir a Cannabis em si, mas aos segmentos étnicos e sociais - "os escravos, e mais as pessoas" - que a consumiam. Ela também denota o fato da Cannabis ter usos medicinais uma vez que estava inserida no título que trata dos remédios e boticários. Existem algumas evidências que apontam para a disseminação desse conhecimento terapêutico também entre as elites. Benoit Mure (1809-1858), médico da corte e um dos introdutores da homeopatia no Brasil, não teve dificuldades para encontrar um pé de Cannabis no interior do palácio imperial de São Cristóvão com objetivo de realizar experiências com haxixe (FIORE, 2005, p.263-264). Sobre os usos terapêuticos entre as elites, ainda cabe destacar a existência dos Cigarrettes Indiennes, produzidos pelo laboratório francês Grimault \& Cie e anunciado no jornal O Estado de São Paulo em fins do século XIX e início do XX. A propaganda o apontava para quem sofresse de “opressão, sufocações e insônia" (SAAD, 2013, p.69), tendo reconhecidas "propriedades antiasmáticas" (SAAD, 2003, p.69). 



Figura 2 - Cigarretes Indiennes da Grimault \& Cia FONTE: SAAD, 2013, p.70

Parece, entretanto, que foi entre os segmentos populares que seu emprego terapêutico se disseminou com maior força, fato que vem reforçar a hipótese da influência cultural e do pertencimento brasileiro ao complexo da ganja (RUBIN, 1975, p.04; COURTWRIGHT, 2001, p.41). Ela era usada para diversas finalidades.

Na medicina popular [...] é dada na asma, onde aliás a tosse provocada pela fumaça faz receitar um uso mais extenso na moléstia; nas perturbações gastrointestinais, nas nevralgias, nas cólicas uterinas, e finalmente como afrodisíaco (DORIA, 1958, p.09). 
França (2015, p.26-27) recupera relatos do médico português Garcia da Orta, afirmando que os portugueses do mar que transitavam pelas colônias também ficaram adeptos do hábito de fumar haxixe. Não parece, entretanto, que esse hábito tenha ficado restrito aos portugueses do mar e aos africanos e seus descendentes. Na distante região do Amazonas, conforme nos relata Monteiro (1966, p.299), o dirijo (como era conhecida a Cannabis) era fumada pelos caboclos como remédio infalível para certas doenças, como as nevralgias dentárias, e como parte integrante dos ritos xamânicos e de cura. Recentemente, também foram apresentadas algumas evidências bastante relevantes da presença da Cannabis entre os indígenas e pescadores maranhenses. ${ }^{10}$ Todas essas evidências apontam que o consumo de Cannabis se tornou arraigado entre as classes populares das regiões nordeste e norte do Brasil durante largo período - do início da colonização até hoje. ${ }^{11}$

É importante destacarmos que, ao lado dessas práticas características do complexo da ganja, também se desenvolveu no Ocidente um segundo fluxo de dispersão do consumo de Cannabis com características distintas. Tendo como suporte intelectual uma mudança de mentalidade nas sociedades ocidentais, conforme destacamos com Davenport-Hines (2002) anteriormente, outro complexo passou a se desenvolver a partir do final do século XIX, ganhando força na segunda metade do século XX. Diferentemente do fluxo mais antigo, que era disseminado pelos estratos mais baixos da sociedade e possuía múltiplas funções (lúdicas, terapêuticas, espirituais), o novo complexo era caracterizado pela inclusão de estratos sociais mais elevados (principalmente jovens) e pela quase exclusividade da função psicodélica - buscar estados alterados de consciência com objetivo de entretenimento. Esse novo fluxo tem como exemplo clássico o Clube dos Hachichins de Paris. Essa nova modalidade de difusão de uso foi denominada de complexo da marijuana (COURTWRIGHT, 2001, p.43-46; RUBIN, 1974, p.04).

Ao contrário dos círculos cultos da Europa do final do século XIX, que utilizavam a Cannabis para explorar efeitos alteradores da consciência, no Brasil tal tipo de uso não parece ter acontecido até meados do século XX. Existe um conto escrito por

\footnotetext{
${ }^{10}$ Esses dados foram reunidos e apresentados pela Professora Doutora Isabela Oliveira na apresentação intitulada "Diamba no Maranhão" realizada no IV Encontro Nacional sobre a Sócio Antropologia do uso de psicoativos (IV ENSSAUP) ocorrido na Faculdade de Saúde Pública da Universidade de São Paulo (USP) entre 08 e 10 de setembro de 2015.

${ }^{11}$ A historiografia da Cannabis no Brasil ainda é incipiente. Novos estudos certamente trarão mais informações sobre o perfil social dos usuários, os locais de consumo e os padrões de uso nas diversas regiões em que esse hábito se arraigou antes de meados do século XX.
} 
Olavo Bilac, intitulado Haxixe, publicado no jornal Gazeta de Notícias (RJ) e reproduzido no livro de Beatriz Rezende (2006). Nele a experiência com essa substância não foi nada agradável. Existem também algumas referências à rainha Carlota Joaquina. Segundo Carlini (2006, p.315), ela teria o hábito de tomar chá de Cannabis - fato que seria entendido como uma das suas extravagâncias. França (2015, p.33-34), por sua vez, afirma que ela teria supostamente bebido chá de diamba com arsênio como eutanásico. Existe ainda a hipótese de Hutchinson (1975) que aponta o hábito da Corte portuguesa, tanto de Lisboa, quanto do Rio de Janeiro, de consumir haxixe desde o início do contato com os orientais.

Menos difundida no Brasil foi a folha de coca e seus derivados. O país não possui território nas áreas subtropicais dos Andes onde o uso pela população ameríndia era mais difundido. No começo da expansão europeia e da revolução psicoativa, durante o século XVI, a coca foi recusada na Europa. Isso ocorreu por causa da rejeição que os europeus tinham aos produtos mastigados pelas populações nativas de outros continentes e pela dificuldade de transportar a folha por largas distâncias sem que ela perdesse grande parte de seu princípio ativo. Na América espanhola, entretanto, depois de uma rejeição inicial, ela se tornou importante produto regional utilizado no comércio com Potosí em meados do século XVII - tendo peso importante nas finanças da sociedade colonial. Em um primeiro momento, a coca era vista com desconfiança, pois era associada à decadência indígena (GOOTEMBERG, 2008, p.18-20).

Essa visão negativa da coca gradativamente vai se desfazendo através de dois eixos independentes. O primeiro eixo "está relacionado com a expansão de novos achados sobre botânica ou a ciência dos alcaloides depois de 1800, modificando as noções de racionalidade dos indígenas"12 (GOOTEMBERG, 2008, 21). Várias expedições são feitas ao território dos Andes, levando para a região influentes viajantes estrangeiros e mercadores, que entravam no debate científico e se interessavam pelos curiosos recursos disponíveis pelo bioma local. Escohotado (2008, p.445-448) traz inúmeros exemplos das expedições realizadas por esses europeus. $\mathrm{O}$ princípio ativo da planta foi obtido, em 1860, por Albert Niemann e denominado cocaína. Até a descoberta de sua utilidade anestésica, essa substância foi utilizada pela comunidade científica pelas suas propriedades de estimulação física e psicológica (ESCOHOTADO, 2008, p.449-450; GOOTEMBERG, 2008, p.23-24).

\footnotetext{
12 "This was related to expanding new fields like botany or alkaloidal science after 1800 and to changing about the rationality of indians" - tradução sugerida.
} 
No Brasil, aparentemente, o uso da cocaína como estimulante não foi alvo de maior atenção. Foi localizada apenas uma referência nos Annaes Brasilienses de Medicina em 1884. Trata-se da divulgação de um artigo, publicado originalmente em 1873, no Edimburgh Medical Journal, sobre as relações psicológicas geradas pela "teína, cafeína, guaranína, cocaína e teobromina” feitas pelo Sr. Alexandre Bennet. Ele defende que esses "cinco princípios imediatos parecem gozar de propriedades idênticas" (SILVA, 1874, p.438). Esse desinteresse pela cocaína como estimulante contrasta com o frenesi posterior em relação aos seus usos anestésicos, conforme veremos no Capítulo quatro quando tratarmos da anestesiologia brasileira.

O segundo eixo de legitimação da coca ocorreu a partir da França, graças ao mundialmente famoso Vinho Mariani surgido na década de 1860. Inventado por Ângelo Mariani foi um sucesso comercial que levou a difusão de vários produtos similares tanto na Europa, quanto nos EUA. Esse produto ajudou a dissolver os obstáculos de difusão da coca por três motivos: $1^{\circ}$. A transformação da coca em líquido favoreceu sua aceitação, pois os europeus são caracterizados pela preferência dessa forma de consumo - acabou com a associação da coca com a mastigação; $2^{\circ}$. A mistura com o álcool ajudava a preservar o princípio ativo - resolveu o problema da deterioração do princípio ativo; $3^{\circ}$. As classes altas francesas da segunda metade do século XIX eram caracterizadas pela aceitação dos produtos utilizados pelos nobres selvagens de outras partes do mundo (GOOTEMBERG, 2008, p.18-19). Esse vinho era divulgado por autoridades de prestígio, como o Papa Leão XIII, que "concedeu uma medalha de ouro ao inventor, em reconhecimento a capacidade de essa bebida para 'apoiar o ascético retiro de Sua Santidade""13 (ESCOHOTADO, 2008, p.447).

Quanto à popularidade desse vinho no Brasil, existem apenas algumas referências esparsas nos jornais. A primeira delas é de 1869, em propaganda da Pharmacia Chevrier. Em uma pequena nota aponta-se que nesse estabelecimento "acham-se o VINHO e ELIXIR de coca" (Diário do Rio de Janeiro, 27 de março de 1869) sem mencionar marcas. Depois, encontramos vinte e oito referências idênticas em propagandas da Pharmacia Lopes, entre 1879 e 1886, anunciando entre vários outros produtos o "Vinho de coca da Bolívia" e o "Vinho de coca Mariani" (Gazeta da Bahia, 21 de dezembro de 1879). Em 1881, encontramos outra evidência. Dessa vez em uma firma de representações. Essa agência, localizada "defronte do portão d'Alfandega",

\footnotetext{
13 “concedió una medalla de oro al inventor, em reconocimiento a la capacidade de esa bebida para
} 'apoiar al ascético retiro de Su Santidad"” - tradução sugerida. 
oferecia livros, conhaques e "Vinhos medicinais. Vinho de Marsa. Vinho Eupéptico. Vinho de coca. Vinho Banyus Crilles" (O Monitor, 11 de janeiro de 1881). Somente em 1889 o vinho Mariani deixa as notas para tomar um lugar de destaque.

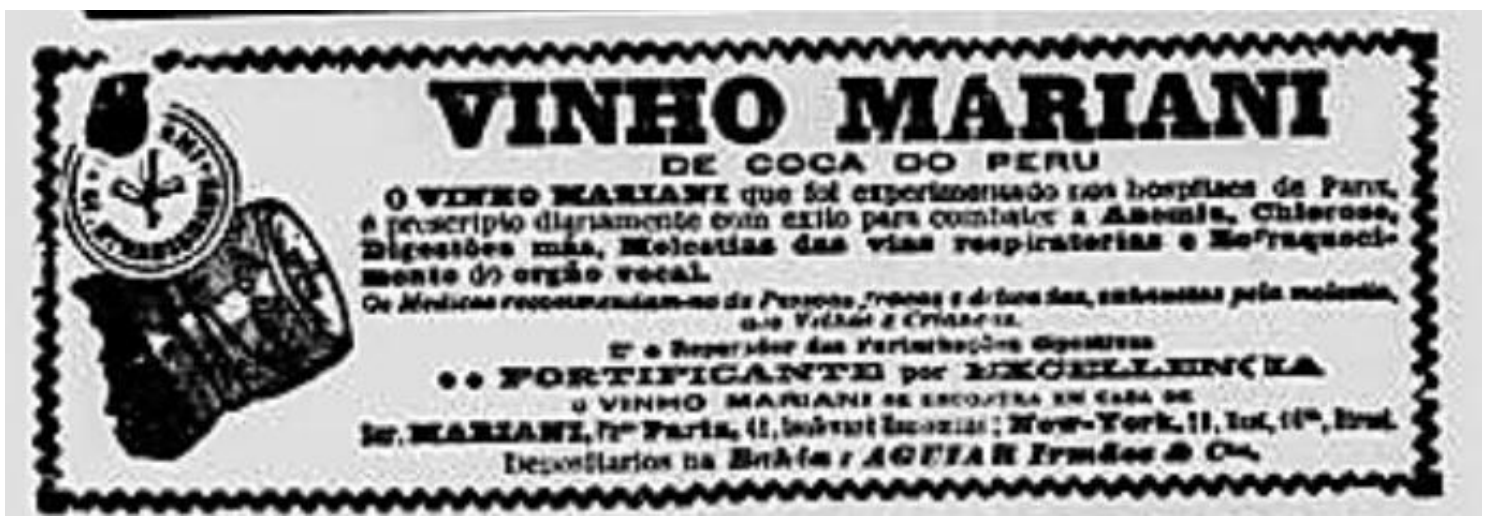

Figura 3 - Propaganda do Vinho Mariani

FONTE: Diário da Bahia, 12 de novembro de 1889.

Essas referências não são suficientes para avaliar a difusão desse produto no Brasil. Sabe-se também, a partir de pesquisa realizada pelo delegado Guido Fonseca (1994), que existem também alusões à coca e seus produtos no Correio Paulistano. Essa propaganda abaixo é do ano de 1874.

\section{Vinho de Coca}

Preparsdo rom as iothas verdes da planta (Erythrexele Coea) seguede a formela de dr. Gibsen pele pharmacentico d Pedro Moreno Vin himilla do Lims (Perú.)

Empregado com soectesso cootra hs febtet eatermiltentes, st affeceōes rbeamoticas, as moleatia do estomago, as affeçбes dos orgāos respiratories, a auemia, a ebiorouis, os toberculos pulmonares e mesme phtysica no seu peíncipio

Vende se em todas as boss plarmacias do imperio.

No Rio de Janeiro; a Drogaria de Rufier Martulet e Conmanbia, 56 rua da Ansemblía.

Ees S Paulo na phertnacia central á rus de 5 . Bentos. 64. 3-1

Figura 4 - Propaganda do Vinho de Coca

FONTE: Fonseca, 2004, p.41.

Essa disseminação inicial da coca, principalmente como vinho e extratos medicamentosos, não foi capaz de afastar totalmente identificação que esse produto tinha com os segmentos indígenas. A notícia que será apresentada agora procura associar o Vinho de Coca do Dr. Gibson (Figura 04) aos supostos efeitos superhumanos da folha de coca e seu princípio ativo, a cocaina. 
Folhas de coca - os nossos leitores conhecem provavelmente a coca pelos anúncios do vinho de coca, segundo a fórmula do Dr. Gibson. A coca Erythoxilon coca - é um arbusto da América do Sul, cujas folhas exercem poderosa influencia na constituição, permitindo aqueles que mastigam suportar grandes fadigas por longo tempo com pouco ou nenhum alimento. Von Tschudi empregou durante cinco dias, um índio em trabalho pesado; durante esse tempo o índio não tomou alimento algum, dormia apenas duas horas, porém mastigava uma onça de folhas de coca, de duas ou de três em três horas. Findo os cinco dias, ele nada tinha sofrido e pode fazer uma longa viagem. Dr. Schezzer, menciona um índio que andou 480 milhas, transpondo na viagem uma serra de 13.000 pés de altura, o qual, só descansou um dia, e além das folhas de coca só comeu um pouco de milho. O principio nitrofeno da coca chama-se cocaína (O Apostolo, 05 de julho de 1876).

Relatos como esse misturam a tradição indígena de consumo, o incipiente uso como revigorante e energético e os primórdios do conhecimento sobre a cocaína como princípio ativo. Por suas qualidades é bastante provável que os extratos de coca e a cocaína tenham sido usados nas fórmulas dos remédios com fórmulas secretas que prometiam curar tudo e que eram detestados pela classe médica oficial. Esses parecem ter sido os usos da cocaína e da coca antes do advento da anestesia local, precisamente em 1885. Como bem destacou Escohotado (2008, p.448), até o advento da cocaína como droga anestésica e depois recreativa, não se observa nos comentários de viajantes, médicos ou botânicos uma tendência de considerar essa planta e seu alcaloide como um fármaco. Ela era algo semelhante a um elemento nutritivo e tônico, como o café, o mate e o guaraná.

Nosso giro pelas pequenas drogas da revolução psicoativa termina com o ópio e seus derivados. Como vimos anteriormente, o ópio era uma substância que possuía inúmeras utilidades terapêuticas, fato que fez dele um importante produto comercial. Ele é um potente analgésico natural que diminui o ritmo de atividade das funções do intestino - por isso era usado para obter a constipação (em casos de diarreias muito fortes, como na cólera). Também diminui o apetite, o que gera uma economia para os menos desfavorecidos. Ele também ajuda a aguentar o calor excessivo e os trabalhos monótonos (COURTWRIGHT, 2001, p.32-33). Por todas essas utilidades, não é surpresa que ele tenha se tornado um importante produto comercial. 
O crescimento da importância e do conhecimento sobre o ópio derivou, primeiramente, por ter sido o primeiro produto de interesse dos orientais fora a prata. Foi ele que possibilitou a ampliação do comércio com o Oriente, perspectiva que levou os ingleses a impor plantações de papoula em suas colônias asiáticas. Paralelamente, esse produto vai ganhando espaço na terapêutica europeia na forma de compostos medicamentosos - que podiam receber o nome de triaga ou de láudano. Primeiramente restritas as classes mais altas, foi gradativamente se popularizando - principalmente quando os holandeses passaram dominar esse comércio a partir do século XVII. As zonas de influência protestante foram as primeiras a aceitarem o ópio como produto terapêutico. Na Inglaterra foi inventado o láudano de Sydenham que se tornou um dos mais famosos remédios dos séculos XVII e XVIII (ESCOHOTADO, p.365-377). Um dos segredos do láudano de Sydenham foi “combinar o ópio com a ipecacuanha, um vegetal emético, tônico, purgante e sudorífero, especialmente eficaz para a ameba da

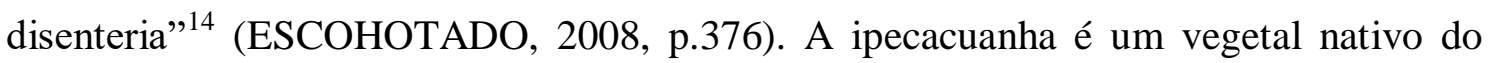
Brasil explorado inicialmente na França como remédio. No final do século XVIII, a Coroa portuguesa organiza sua exploração comercial que cresce vertiginosamente até meados do século XIX - quando o produto começa a ficar escasso (RIBEIRO, 2005b, p.175-178).

No Brasil, foram os jesuítas os principais difusores da medicina europeia até sua expulsão em meados do século XVIII. Esses religiosos mantinham boticas e elaboravam preparações com base em plantas que vinham da Europa e do Oriente. Gradativamente, eles passaram a incorporar plantas medicinais nativas e elaboraram importantes produtos combinando ingredientes dos três continentes. Muitas dessas receitas eram exportadas para a Europa - como a famosa Triaga Brasílica. Em todas essas formulações, era constante a presença do ópio (MARQUES, 1999, p.243-246; CAMARGO, 2014, p.176-177). Os físicos, cirurgiões e outros curandeiros, que peregrinavam pelas cidades em busca de clientes, em geral não tinham um status social elevado. Muitos cristãos novos se dedicavam a essas profissões. Esses curandeiros peregrinos para "orientarem suas prescrições, adotavam as farmacopeias europeias, destacando-se os tratados de plantas medicinais e as coleções de receitas de autores portugueses consagrados, como Garcia da Orta e João Curvo Semedo” (TEIXEIRA et

\footnotetext{
14 “al combinar el opio com la ipecacuanha, un vegetal emético, tónico, purgante y sudorífico, especialmente eficaz para la ameba de la disenteria" - tradução sugerida.
} 
al, 2012, p.46). No segundo Capítulo trataremos com mais detalhes as fórmulas e as farmacopeias desse período.

O ópio, que já era conhecido e utilizado no Brasil, passou a ser inscrito nas teses doutorais no começo do século XIX - concomitantemente à fundação das Faculdades de Medicina (ADIALA, 2011, p.72-73). A Tese de Luiz Antonio Chaves, intitulada $O$ opio, de sua acção sobre a economia animal, e dos casos que reclamão seo uso, precedida de considerações geraes sobre o systema nervoso, denota de maneira exemplar a centralidade desse fármaco na terapêutica da época. Segundo ele

\footnotetext{
"Essa é a substancia que tem sido mais celebre na história da medicina, não só pela antiguidade de seu emprego, como pelas suas altas virtudes. A dor mais atroz, acalma-se como por encanto; concilia o sono que abandonava as pálpebras, mitigam nossos males, mesmo os mais incuráveis, tudo isto são os benéficos efeitos causados pelo uso bem entendido do ópio [...] Milhares de doenças admitem o ópio no seu tratamento, e este medicamento é sem comparação o mais heroico entre todos àqueles que empregam a terapêutica." (CHAVES, 1839, p.16-17).
}

Mais adiante, antes de abordar os principais usos clínicos do ópio o mesmo autor afirma que

\footnotetext{
"não poderemos falar de todos [usos] no curto espaço de uma tese, e nem nos propormos narrar o seu emprego em todas as doenças, em todos os casos particulares, por que então seria necessário percorremos a patologia inteira: todavia não ha doenças em que ele não tenha sido empregado; dadas certas condições" (CHAVES, 1839, p.32).
}

Essas afirmações não deixam dúvidas sobre a centralidade do ópio na terapêutica na primeira metade do século XIX, mesmo com as frequentes adulterações. O início do século XIX, entretanto, esses problemas irão acabar a partir de uma importante do desenvolvimento da ciência dos alcaloides. A partir daí foi possível precisar a dosagem possibilitando, tanto a precisão da prescrição, quanto o controle sobre a modulação da consciência e do intelecto - levando a necessidade de revisar toda a toxicologia clássica. Nasce a etnobotânica como ramo específico da farmacologia e se inicia uma corrida em busca do conhecimento tradicional nos diferentes cantos do planeta (ESCOHOTADO, 
2008, p.421-423). Como vimos anteriormente, esse foi um dos eixos que levou a revalorização da coca como produto comercial.

A morfina, derivada do ópio, foi o primeiro e mais importante desses alcaloides. Isolada entre 1803 e 1805, foi saudada como um das maravilhas modernas. Porém, somente no final da década de 1820 ela passou a ser produzida em escala industrial graças ao método inventado por Heinrich Emanuel Merck - que fundou a partir dela uma verdadeira "dinastia farmacêutica"15 (COURTWRIGHT, 2001, p.36). Solúvel em água, ela teve seu uso disseminado depois da invenção da agulha hipodérmica - cuja primeira fábrica começou a funcionar em 1856. Na década de 1870, a injeção hipodérmica já estava consolidada como instrumento médico (ESCOHOTADO, 2008, p.425-426; COURTWRIGHT, 2001, p.37). Essas inovações e os crescentes preparados médicos com esses produtos marcaram cada vez mais a distância entre a medicina popular e a medicina oficial cosmopolita (ESCOHOTADO, 2008, p.426).

Parece difícil definir com exatidão quando a morfina passou a ser utilizada no repertório médico brasileiro, porém como outras inovações da medicina ela pareceu ser contemporânea à Europa. A primeira referência encontrada foi de 1827 contemporânea à industrialização efetuada por Heinrich Emanuel Merck. A pioneira revista médica brasileira, O Propagador das Sciencias Medicas (OPCM), em seu primeiro número, já apresenta uma discussão, na Seção de Farmácia, sobre o acetato de morfina. Veremos esse ponto com maiores detalhes no próximo Capítulo. Importante, para nosso argumento, é mostrar que no Brasil essas substâncias eram conhecidas, discutidas e divulgadas concomitantemente à Europa e aos EUA.

Por ora, a proposta é trazer uma visão panorâmica sobre o consumo. Para finalizar esse intento, ainda é preciso se referir a um último psicoativo que teve uma incidência importante na região do Amazonas sem, contudo, participar do processo de globalização até fins do século XX: a ayahuasca. Até meados do século XIX, ela foi citada apenas ocasionalmente por missionários e viajantes da Amazônia Ocidental. Ela foi identificada cientificamente pelo botânico Richard Spruce em 1852. Este e outros exploradores localizaram inúmeras tribos indígenas que utilizavam esse chá de forma enteógena. As dinâmicas econômicas e sociais que levaram ao desenvolvimento urbano na região amazônica também popularizaram o uso de ayahuasca nas regiões da periferia - fenômeno conhecido como vegetalismo. Curandeiros populares emergem como um 
personagem urbano, ressignificando cultos xamânicos e promovendo práticas terapêuticas e de diagnósticos, muitas vezes incorporando elementos do catolicismo popular. Esse será o caldo cultural onde se desenvolverá as primeiras religiões ayahuasqueiras com influência católica no início do século XX (ANTUNES, 2012, p.16-28).

Vimos, portanto, que nosso país foi, durante toda sua história, um grande produtor de drogas, sendo um dos responsáveis pela vulgarização de alguns itens, como o açúcar, o café e o tabaco. Além de produtor, ele também era um consumidor desses itens. Associado ao complexo do açúcar, os destilados alcóolicos tiveram grande relevância no estabelecimento de comércio com os africanos e de contatos com os indígenas. Fora esses produtos, também existem alguns fármacos de expansão regional, como o guaraná, o mate/chimarrão (estimulantes vegetais), a jurema, a ayahuasca (visionários) e a Cannabis. Esta última foi consumida nas regiões nordeste e norte, com pautas culturais de consumo que ligam o país à antiga tradição do complexo da ganja. $\mathrm{O}$ ópio e a coca, assim como seus derivados sintéticos, foram trazidos para o Brasil como importantes medicinas ligadas às tradições europeias em matéria de terapêutica. A medicina oficial que se desenvolvia em terras tupiniquins era contemporânea à realizada na Europa, sendo os usos desses fármacos quase concomitantes entre o velho e o novo mundo.

\subsection{Conclusão}

Procurei, ao longo desse Capítulo, abordar o enorme período de tempo que vai da pré-história ao século XIX. Essa abordagem certamente não foi capaz de esgotar todas as questões colocadas, porém pode ajudar na problematização de algumas ideias sobre o tema das drogas na sociedade.

A primeira dessas ideias se refere à universalidade do consumo. É verdade a preposição que praticamente todas as sociedades desenvolveram algum tipo de consumo de psicoativos. Porém, é preciso também destacar que esse consumo ocorre de acordo com códigos culturais que variam de acordo com a classe social, gênero e geração. Esse consumo também é dividido por fronteiras e identidades culturais. Vimos também que os padrões de uso tradicionais sofreram forte alteração com a criação do mundo globalizado, pois o desenvolvimento do capitalismo é acompanhado de uma crescente capacidade de alteração da consciência pelas populações no mundo inteiro. Veremos, 
nos Capítulos que seguirão, que contrariamente ao que comumente se pensa, os controles instaurados no século XX, ao invés de frear, intensificaram esse processo.

A segunda ideia que precisa ser relativizada é aquela que enfatiza o antagonismo de posições: dos que são contra (antiliberais ou proibicionistas) e dos que são a favor (liberais ou antiproibicionistas) da descriminalização. Essa dualidade esconde que por trás da proibição existem diversos tipos de controle, alguns mais racionais do que outro. Esse tipo de reducionismo nos leva a posições como essa expressa por Courtwright.

\begin{abstract}
A forma mais extrema de reação tem sido a chamada legalização. Uma forma de libertarianismo reacionário, que combina elementos ideológicos da esquerda e da direita, visando retroceder a política em cem anos ${ }^{16}$ (COURTWRIGHT, 2001, p.201).
\end{abstract}

Esse discurso é extremamente redutor da complexidade da questão, pois credita ao proibicionismo a ascensão de uma política ética que iniciou em fins do século XIX e que continua até hoje - apesar dos problemas. Nessa perspectiva, cabe continuar ajustando os controles com objetivo de reduzir ao máximo a exposição às drogas sem patentes - independente dos custos sociais. Conforme veremos nos próximos Capítulos, a mudança de uma farmacopeia para outra resultou em alterações que consolidaram a classe médica oficial como hegemônica e a saúde como uma mercadoria. Existem diferenças nas práticas, controles e ideologia nas políticas instauradas na primeira metade do século XX e na segunda metade do mesmo século, que impedem um retorno ao que existia no século XIX. O alarmismo de Courtwright parte do pressuposto que o proibicionismo é uma política centenária, homogênea e em contínuo acréscimo punitivista. No final da Tese veremos como isso não faz sentido.

O terceiro e último ponto se refere ao significado atribuído ao consumo de drogas. Quando se coloca que o consumo está diretamente relacionado a uma questão de exposição à droga (COURTWRIGHT, 2001, p.94-97), se ignora o fato que tal consumo só existe como uma construção social. ${ }^{17}$ A hipótese da exposição parte do pressuposto que a relação "natural" do cérebro com o prazer é de extrema parcimônia, por isso alterações nessa relação gerariam um desequilíbrio e, fatalmente, uma patologia. Não se

\footnotetext{
16 "The most extreme form of the backlash has been the call for legalization. A form of reactionary libertarianism, combining elements of left and right-wing ideology, legalization would reset the policy clock by more than a hundred years" - tradução sugerida.

17 É preciso destacar que Courtwright (2001, p.92) reconhece a importância do contexto social para explicar o consumo de drogas. Porém, como a civilização se constitui em uma espécie de jaula, as drogas se constituiriam em uma perigosa arma contra a condição humana.
} 
pode reduzir o prazer à sua função biológica ou neurológica. É a cultura que impede que sejamos meros animais. Esse pensamento é tão redutor quanto à leitura que percebe a ingestão de alimentos meramente como uma forma de obter nutrientes. Como bem lembra Cascudo (2004, p.21), o homem pré-histórico podia ser considerado onívoro, mas o proto-histórico e o contemporâneo já não cabem nessa categoria porque a cultura definirá o que é adequado ou não comer e beber.

Essa questão da exposição é fundamental para compreendermos os limites técnicos e as ideologias que norteiam os atuais indicadores oficiais ${ }^{18}$. O viés epidemiológico que concebe todo o consumo como prejudicial (conforme definido pela psiquiatria tradicional), ignora os significados dos usos e as vantagens sociais que o consumo de dada substância psicoativa pode trazer para a vida das pessoas. Ignorar esses fatos e atribuir à droga, e não à pessoa, a agência sobre o uso é menosprezar a capacidade de discernimento das pessoas. Ou ainda pior: considerar que as pessoas "não tem preparação evolutiva"19 (COURTWRIGHT, 2001, p.206) para lidar com o seu próprio prazer. Nesse tipo de concepção, caberia às elites ilustradas (na nossa sociedade esse papel é exercido por médicos e religiosos) proibir e dificultar ao máximo o acesso aos "frutos proibidos do Éden"20 (COURTWRIGHT, 2001, p.207). A proposta de análise que trazemos nessa Tese, contrariamente, percebe as pessoas como seres humanos complexos inseridos em contextos sociais que dão sentido e racionalidade ao uso de drogas. Por isso, como bem alerta Carneiro (2008, p.65-87), a discussão política sobre drogas acarreta sentidos mais amplos sobre a autonomia e a heteronomia dos estados de consciência.

18 Exemplos desses trabalhos podem ser retirados do Observatório Brasileiro de Informações sobre Drogas. <http://www.obid.senad.gov.br/portais/OBID/index.php> último acesso: 07/08/2014

19 "It is the political awareness of the dangers of exposing people to psychoactive substances for which, it is increasingly clear, they lack evolutionary preparation" - tradução sugerida.

20 "So why should certain drugs be off limits? Be happy and partake, except of the forbidden fruit, has always been a hard message to swallow. Genesis tells us that Adam and Eve no abide by it in the old Eden. It is hard to imagine that our prospects are much better in today's new one". - Na íntegra. 


\section{CAPÍTULO 2 - AS DROGAS E AS ARTES DE CURAR NO BRASIL}

\subsection{Introdução}

Um dos principais pontos do debate realizado em relação à proibição das drogas no início do século XXI gira em torno da visão dualista que opõe o liberalismo em matéria de alteração da consciência, de um lado, e o papel moral e/ou autoritário do saber médico nas restrições, por outro lado. Procurou-se mostrar, no primeiro Capítulo, que o desenvolvimento da sociedade burguesa e a formação de um mercado mundial permitiram a expansão do consumo, alterando os padrões de uso tradicionais. Também critiquei as interpretações que atribuem às drogas, e não às pessoas, a agência sobre o uso. Vamos ver agora que a questão da agência e o grau de influência da classe médica sobre as práticas das pessoas é um tema polêmico na história da medicina, influenciando inclusive a historiografia das drogas.

Silva (2015) é uma autora que procurou entender o processo de criminalização a partir de uma perspectiva que enfatiza a afirmação do poder dos médicos na sociedade. Esses profissionais "passam a intervir em um número cada vez maior de instâncias da vida social" (SILVA, 2015, p.73), obtendo gradativamente credibilidade com a população. Nesse processo as “antigas 'fórmulas' e preparados caseiros, até então largamente usados, eram frequentemente desacreditadas por "especialistas"” (SILVA, 2015, p.73), fazendo que as pessoas abandonassem os curandeiros e os feiticeiros tradicionalmente preferidos. As novas noções de doença que efetivaram a superioridade da medicina científica também contribuíram para "subjugar o espaço urbano às novas práticas higienistas" (SILVA, 2015, p.92) graças à afirmação da medicina social. "A elaboração da legislação dos entorpecentes foi um exemplo de tal intervenção" (SILVA, 2015, p.92), sendo permitidos somente os usos adequados à formatação de uma mão de obra apta ao trabalho. A regulação das drogas dependia dos interesses econômicos, por um lado, e dos meios de "convencimento, adequação, subordinação e alienação das massas ao projeto do capitalismo em sua fase monopolista" (SILVA, 2015, p.92), por outro lado. Nesse cenário de modernização os médicos foram um dos grupos de elite que "tomaram para si a incumbência de pensar o país e a sociedade brasileira como um todo" (SILVA, 2015, p.110).

Essa interpretação foi, recentemente, criticada por Sarti (2015, p.43-54). Segundo essa autora, ao focar somente os discursos médicos e os documentos de suas instituições, a historiografia das drogas - Silva (2009; 2015) e Adiala (2011) - seria 
tributária de uma perspectiva foucaultiana, cujos principais representantes no Brasil seriam Cunha (1978) e Roberto Machado e seus colaboradores (1978). A influência de Foucault sobre o tema das drogas é tema relevante (RIBEIRO et al, 2015; TORCATO, 2015), porém o que interessa por ora é destacar a intenção crítica de Sarti (2015) em dar voz à experiência dos sujeitos internados que existem para além do discurso científico dominante através do uso de documentos clínicos.

Esse Capítulo procurará mostrar que existe uma falsa oposição entre domínio médico (medicalização da sociedade) e a experiência de sujeitos concretos. Mais do que elucidar as práticas sociais e o processo que levou a criminalização das drogas, tais enfoques tendem a obscurecer a compreensão da historicidade das formas de dominação e de resistência produzidas em torno do corpo, da dor e dos meios de mitigar os infortúnios da existência através do uso de fármacos. A separação entre cultura popular - que resiste ao intento normalizador - e erudita - que desqualifica os saberes tradicionais - esconde vários pontos de intersecção e de diálogo que o tema do uso das drogas pode evidenciar.

\subsection{A terapêutica nas sociedades tradicionais}

A modernidade é caracterizada, conforme vimos anteriormente, pela capacidade ampliada das populações em todo o mundo de alteraram suas consciências através do uso de psicoativos. No meio do embate entre liberais e antiliberais, a tendência é destacar as consequências negativas da ampliação do uso, por um lado, e o autoritarismo que significa as restrições às liberdades individuais, por outro lado. A exposição que realizarei agora pretende elucidar um aspecto em geral negligenciado pela historiografia, a saber, os impactos que essas substâncias tiveram sobre as artes de curar tradicionais e as formas de administrar as dores e os sofrimentos. Para conseguir alcançar esse objetivo o primeiro passo é refletirmos sobre o que é a dor.

A Sociedade Brasileira para Estudos da Dor, filiada da Internacional Association for the Study of Pain, define dor da seguinte forma: "Experiência sensitiva e emocional desagradável associada ou relacionada à lesão real ou potencial dos tecidos. Cada indivíduo aprende a utilizar esse termo através das suas experiências anteriores"21 Mesmo reconhecendo, posteriormente, que a "expressão da dor varia não somente de

21 Definição elaborada pelo Prof. Dr. Manoel Jacobsen Teixeira, Neurocirurgião da Faculdade de Medicina da USP e apresentada no site da Sociedade Brasileira para Estudos da Dor.

<http://www.sbed.org.br/materias.php?cd_secao=76\#.Vkt0jDZdHIU> Último acesso: 17/11/2015. 
um indivíduo para outro, mas também de acordo com as diferentes culturas",22, não deixa de ser relevante que tal definição relaciona dor com uma lesão real ou potencial dos tecidos.

Esse conceito, ilustrativo da visão biomédica, é insuficiente porque vincula a dor à anatomia e à fisiologia. Mais do que uma resposta emocional ou sensitiva a um desvio biológico/psicológico, a dor é uma experiência intimamente relacionada aos significados que ela reveste no momento em que afeta o indivíduo. $\mathrm{Na}$ antiguidade clássica Aristóteles definia dor como uma forma particular de emoção, bem diferente da tradição moderna que a considera uma sensação produzida pela máquina corporal. A dor é a manifestação de um sofrimento e, por isso, não existe dor sem o "significativo afetivo que traduz a inserção de um fenômeno fisiológico no cerne da consciência moral do indivíduo" (BRETON, 2013a, p.15). Apesar de frequentemente associada a um desvio fisiológico, a dor pode prescindir a lesão anatômica. Isso pode ser verificado, por exemplo, nas sugestões realizadas em pessoas hipnotizadas ou nas dores de origens psicológicas. Se, em alguns casos, a dor pode escapar da esfera fisiológica, sua característica antropológica lhe é inerente porque ela é "simultaneamente experimentada e avaliada, integrada em termos de significado e de valor. Nunca puramente fisiológica, a dor pertence à esfera simbólica" (BRETON, 2013a, p.16).

A dor pode ser considerada um mecanismo fundamental na defesa do organismo, fato que pode ser verificado nas dificuldades enfrentadas pelos indivíduos incapazes de senti-la. Porém, é errôneo diminui-la a esse aspecto, pois ela não é o sinal seguro de uma lesão ou de uma patologia. Em algumas doenças, como o câncer, ela geralmente se manifesta tarde demais (BRETON, 2013a, p.16-17). Embora na nossa sociedade atual a dor seja o abominável e uma experiência que a medicina e a técnica deveriam eliminar com rapidez, nem sempre ela teve esse estatuto.

Os usos sociais da dor nas sociedades tradicionais são variados: ela pode ser uma forma de inscrever na carne uma filiação ou uma fidelidade a uma comunidade, como rito de passagem do jovem ao adulto ou como forma de testar a determinação e a força do caráter (BRETON, 2013a, p.19-20). Os sistemas religiosos em geral, e isso vale também para o cristianismo, procuram justificar a dor ao olhar de Deus, dos deuses, do cosmo ou da natureza e, a partir dela, procurar a causa moral que explique o sofrer atual. "Desde os tempos mais remotos de nossa história, percebe-se o esforço de

${ }^{22}$ Ibidem. 
integração e de dominação da dor, a vontade de inseri-la numa coerência e num significado" (BRETON, 2013a, p.81). Por isso, a cura para a dor dentro das perspectivas tradicionais passa pela incorporação do corpo doente a uma cosmogonia, cujo papel do curador ou da curadora é ser um(a) intermediador(a) que busca a harmonia entre o ser e o todo. Estão ai o fundamento da homeopatia, da visão astrológica, do magnetismo, do radiestesista, do benzedor, do pajé, do encantador, etc. "Eles operam uma eficácia simbólica, sem preocupar-se com as causas do problema ou com as modalidades de funcionamento dos órgãos" (BRETON, 2013b, p.133). Essa integração também pode ocorrer através do contato com certos objetos (restos mortais de santos, por exemplo) ou elementos da natureza (pedras, fontes, córregos, árvores, lugares, etc).

O corpo humano, portanto, é definido de acordo com uma variedade de imagens, com os sistemas de conhecimento que explicam sua natureza e com as performances que ele é capaz de realizar. Dessa forma, é possível afirmar que os sistemas terapêuticos procuram traduzir o corpo dentro de dada linguagem (BRETON, 2013a, p.61). A biomedicina, ao separar a alma do corpo e inscrever a doença como patologia, obteve uma série de êxitos na superação de enfermidades que antigamente causavam a morte. O sucesso dessa empreitada também tornou inevitável algumas dores que se desenvolvem com o envelhecimento. Além disso, apesar desse sucesso, ela não foi capaz de livrar a humanidade da dor - são chamados "doentes funcionais" aqueles(as) sofredores(as) que a medicina não consegue diagnóstico (BRETON, 2013a, p.55-58). Tampouco a medicina conseguiu acabar com as dores crônicas geradas pelo reumatismo, gota, artrite, artrose entre outras (BRETON, 2013a, p.149-151). Em suma, nenhum sistema terapêutico ou coquetel medicamentoso conseguiu uma vitória definitiva sobre a dor.

As mudanças epistemológicas operadas pela biomedicina que resultaram na solução de várias enfermidades foram obtidas através da separação absoluta da doença e do doente, e o foco de estabelecer sobre a primeira um saber objetivo (CANGUILHEM, 2009; FOUCAULT, 2013). Essa configuração, apesar de hegemônica, é incapaz de se tornar absoluta porque ignora um recurso fundamental - que são os símbolos e seus efeitos. Mesmo em situações onde a confiança no médico e na medicina oficial é extrema, tal confiança é ameaçada pela posição social e cultural do médico - possuidor de um status e de um saber que raramente é compartilhado com o paciente - e do caráter estritamente técnico dos cuidados dispensados. O paciente é despossuído do saber sobre 
a doença, ignorante de seus significados e sem papel na cura (BRETON, 2013b, p.294296). Não se trata, aqui, de uma crítica pela crítica à medicina oficial. Mas ressaltar que, apesar dos avanços obtidos na terapêutica, não existe um progresso em marcha ou a superioridade de um sistema sobre outros - existem diferentes pontos de vista e coexistência de concepções terapêuticas. Em outras palavras: a adoção de um tratamento na perspectiva biomédica não exclui outros tratamentos, pois a pessoa está inserida em múltiplos sistemas simbólicos que podem dar sentido ao seu sofrimento (BRETON, 2013a, p.55-58).

Essas considerações iniciais são importantes para rechaçarmos, de pronto, as perspectivas analíticas que creditam a coexistência de vários sistemas simbólicos e, consequentemente, terapêuticos à carência ou despreparo de médicos formados nos quadros oficiais. Para Lycurgo de Castro Santos Filho, por exemplo, a medicina praticada no período colonial e imperial

\footnotetext{
“experimentou o toque da terra, do ambiente, sofrendo as deficiências dos agentes incultos que a veicularam, tornando-se, por sinal, má expressão da ciência contemporânea, pois mal conhecida e mal praticada, achando-se, ademais, prenhe de abusões e superstições” (SANTOS FILHO, 1991a, p.03).
}

Contrariamente, a tendência hegemônica na historiografia das artes de curar no Brasil colonial é apontar as semelhanças entre a medicina popular e erudita, enfatizando o compartilhamento de noções sobre natureza, sobrenaturalidade e crenças (RIBEIRO, 1997; MARQUES, 1999).

O Brasil colonial é marcado pela carência de físicos formados e pela ausência de drogas e de remédios consagrados na Europa. Essa situação dava ampla margem de atuação para curadores leigos, mesmo nos principais centros da administração colonial. No final do século XVIII, por exemplo, o governador da cidade de Salvador escrevia em relatório apontando que eram os negros sangradores os que medicavam e curavam com maior pontualidade naquela localidade (WISSENBACH, 2002, p.118). Durante todo o século XVIII, os físicos, cirurgiões e boticários diplomados ocupavam formalmente o ápice da pirâmide profissional. Eles constituíam, entretanto, uma ínfima proporção de uma vasta comunidade terapêutica, tanto na Europa, quanto no Brasil. A situação da colônia era ainda de mais escassez pela inexistência de instituições de ensino. No interior das profissões oficiais, pelo menos teoricamente, aos cirurgiões cabiam os ofícios manuais, considerados socialmente inferiores, sendo-lhes vedada a 
administração de remédios - prática que seria um privilégio dos físicos (TEIXEIRA et al, 2012, p.44).

Esse rebaixamento da cirurgia é explicado no interior da tradição medieval, pois o homem e seu corpo faziam parte de uma ordem criada por Deus e, por isso, "fazer correr o sangue, ainda que se o faça como terapia, equivale a rasgar a aliança, a transgredir um tabu" (BRETON, 2013b, p.58). Existia uma infâmia pública que cercava a figura do cirurgião, do barbeiro, do açougueiro e do carrasco. A partir do XII, mudanças na profissão médica vão opor os clérigos "mais hábeis em especulações terapêuticas do que em eficácia terapêutica" (BRETON, 2013b, p.58) que intervém nos doentes sem tocar no corpo, e os cirurgiões que intervém ousando romper o tabu do sangue. No caso dos terapeutas e sangradores populares, não raro eram ridicularizados por não conhecer o latim e os clássicos consagrados pela escolástica. "Sutil hierarquia que faz da maior distância do doente e do corpo a marca da posição social mais invejável e aquela do melhor prestígio" (BRETON, 2013b, p.59).

A tradição medieval em terapêutica teve uma sobrevida em Portugal porque o ensino acadêmico esteve fechado, até fins do século XVIII, ao questionamento do racionalismo gerado pela anatomia. Dominada pela escolástica e pela força da Igreja Católica, a intenção do ensino não era elaborar novos saberes, mas preparar os profissionais a partir do conhecimento já estabelecido. Físicos que estudavam em outros países e que tomavam conhecimento das últimas descobertas da anatomia elaboravam duras críticas àquilo que era denominado de "fillosofia peripatética", os métodos tradicionais, as terapêuticas fundadas em medicamentos sancionados pela prática e as "triagas" que prometiam curar tudo sem revelar a sua composição (ABREU, 2007b, p.80-86).

Todas essas críticas à cultura livresca e a defesa do conhecimento obtido pela experiência clínica culminaram na modificação dos Estatutos da Universidade de Coimbra em 1772. A partir dela, enfatizou-se o ensino de física mecânica, de hidráulica e das disciplinas capazes de demonstrar as propriedades dos remédios e do funcionamento do corpo. Grande destaque foi dado à anatomia, ignorando o Decreto Real de 1739 que proibia a dissecação de cadáveres. “Até a reforma da universidade, a cirurgia era vista como uma atividade inferior, não sendo digna dos médicos" (ABREU, 2007b, p.90). Essa inferiorização ocorria através do critério de separação entre ofícios mecânicos e liberais. Ribeiro (2005a, p.65-66), chama a atenção para o status do 
cirurgião presente no Vocabulário Português e Latino, de 1713, que define "Estado do Meio" da seguinte forma:

Entre os mecânicos e nobres há uma classe de gente que não pode chamar-se verdadeiramente nobre, por não haver nela a nobreza política ou civil, nem a hereditária, nem podem chamar-se rigorosamente de mecânica por se diferenciar dos que o são, ou pelo trato da pessoa, andando a cavalo e servindo-se com criados na forma de ordenação... ou pelo privilégio e estimação da arte, como são os pintores, os cirurgiões e boticários que por muitas sentenças dos senados foram em vários tempos escusos de pagar jugadas e outros encargos a que mecânicos estão sujeitos (BLETEAU, Raphael apud RIBEIRO, 2005a, p.66).

Os Estatutos de 1772, que modificaram o currículo de acordo com os preceitos do iluminismo e levaram a construção de laboratórios e outros estabelecimentos científicos (como o teatro anatômico e o dispensário farmacêutico), não conseguiram acabar com a influência das concepções mais tradicionais. Físicos e cirurgiões demoraram para obter o mesmo patamar de respeitabilidade. A influência da escolástica e dos clássicos da antiguidade se manteve e passou a coexistir com as novidades introduzidas pela ilustração (ABREU, 2007b, p.95-97; ABREU, 2006, p.179-184). Mais do que se impor pela razão, essas modificações institucionais oferecem uma abertura no pensamento médico às concepções fisiológicas.

Esse desprestígio que os cirurgiões encontravam em Portugal não era sentido da mesma forma no Brasil e outras colônias, pois a situação de penúria dessas localidades dava a eles a oportunidade de ocupar cargos de prestígio que dificilmente conseguiriam alcançar na Europa. Por isso, até a extinção da Fisicatura, em 1828, a medicina oficial no Brasil era exercida em grande parte por cirurgiões. Segundo Santos Filho (1991a, p.304) "os cirurgiões compuseram a maior parte dos profissionais habilitados, sobrepujando vantajosamente aos físicos, por eles substituídos na prática médica”. Esse foi o caso do português José Antônio Mendes, relatado em artigo de Ribeiro (2005). Com a descoberta do ouro nas Minas Gerais, outros tantos vieram tentar a vida na colônia em busca de enriquecimento.

Um dos cirurgiões mais conhecidos que também veio ao Brasil em busca do enriquecimento foi Luís Gomes Ferreira, que escreveu um dos primeiros manuais de medicina brasileira de grande circulação. Trata-se do Erário Mineral de 1735. Nesse livro estão contidas as suas experiências de cura a partir da confrontação do 
conhecimento adquirido em Portugal (antes dos Estatutos de 1772) com as condições do clima e da patologia encontradas no Brasil, criando procedimentos e diagnósticos que em alguns casos substituiu as receitas e recomendações apreendidas na metrópole. Como outros europeus que aqui chegavam, ele precisou adequar seus conhecimentos e visões de mundo a uma realidade marcada por informações sobre doenças e drogas até então desconhecidas. A dificuldade encontrada nos locais de moradia improvisados e a imersão em uma sociedade escravista exigiam ainda mais flexibilização das regras da medicina metropolitana (WISSENBACH, 2002, p.106-110).

A circulação dos cirurgiões não se restringia à América portuguesa. Mais do que uma particularidade brasileira, os novos contextos de morbidade somados a ausência de remédios europeus e de físicos diplomados abria espaço para uma ampla mescla de experiências dos diversos agentes de cura em todo o mundo atlântico (WISSENBACH, 2009 , p.281-282). Os conhecimentos ameríndios e africanos foram fundamentais para a sobrevivência dos homens brancos nas áreas de contato e de colonização, abrindo espaço para a elaboração de uma medicina própria das áreas tropicais e intertropicais. Focava-se, sobretudo, as doenças que os europeus brancos estavam mais sujeitos, multiplicando-se os cuidados e as recomendações que deveriam ser observadas nesses territórios (WISSENBACH, 2009, p.299). Paralelamente, olhavam-se as doenças que poderiam sofrer os negros africanos, uma vez que esse elemento era central na escolha das melhores "peças" que seriam destinadas ao comércio.

$\mathrm{Na}$ descrição da etiologia e da natureza das doenças, os autores coloniais se mostravam profundamente apegados à fisionomia étnica das populações que estudavam. Não raro, as doenças recebiam nome de etnias ou de localidades, como vermes da Guiné ou mal do Brasil. Entre os ingleses e franceses, acreditava-se que a miscigenação estava ligada a construção de novos quadros mórbidos (WISSENBACH, 2009, p.285-286). Os tratados luso-brasileiros, por sua vez, deram menos ênfase à questão racial e maior aos fatores físicos e geográficos, atribuindo as morbidades ao clima, aos ventos, à qualidade da água e dos alimentos. Também se percebe uma maior sensibilidade aos ganhos de resistência obtidos a partir da miscigenação associada às táticas de aclimatação (WISSENBACH, 2009, p.296-298). No que se refere à origem social dos tratadistas portugueses, percebe-se que a maioria era homens ligados ao comércio colonial que, proveniente dos estratos renegados da sociedade portuguesa (como os cristãos-novos), fizeram fortunas e tornaram-se parte da elite econômica (WISSENBACH, 2009, p.286287). 
Esse perfil social também se verifica nos cirurgiões que circulavam no interior da Colônia. Estudos que vem trazendo as suas trajetórias mostram bastante heterogeneidade nesse grupo, mostrando que muitos deles se dedicavam ao comércio de bens e escravos, podendo ser donos de engenhos ou homens livres que viviam nas vilas. Não raro, tornavam-se andarilhos (WISSENBACH, 2002, p.122-125). Uma das práticas comerciais recorrentes era comprar escravos doentes, com baixo custo, tratá-los para depois revendê-lo obtendo ótimos lucros (WISSENBACH, 2009, p.288; FIGUEIREDO et al, 2011, p.105-106). Esse desinteresse pelas práticas de cura abria ainda mais espaço de atuação para os terapeutas leigos.

Essa situação gerava uma grande tolerância com as práticas não oficiais, fato que pode ser percebido pela possibilidade aberta pela administração para que os curandeiros, barbeiros, sangradores, parteiras e outros(as) curadores(as) obtivessem concessão do poder público, representado pela Fisicatura, para aturem praticando cura. Para tanto, era preciso uma carta de recomendação da comunidade em que atuavam (incluindo das autoridades) e prestar um exame capaz de garantir a qualidade do serviço. Sabe-se que a ampla maioria desses curadores não tinha interesse em buscar reconhecimento oficial e, quando faziam, em grande parte, eram motivados por alguma iniciativa fiscalizadora. Uma vez obtido o reconhecimento tal outorga podia ser usada para forçar o poder público a reprimir a concorrência. Esses registros, apesar de não serem representativos de todo o universo de cura, mostram que a maioria dos sangradores era de origem africana e escrava. Também era comum o anúncio de aluguel e venda de escravos sangradores nos jornais (PIMENTA, 2003, p.307-315). O fato de essa atividade ser realizada em grande parte por escravos mostra, sem dúvida, a permanência do desprestígio dos doutos pelo contato com o corpo doente.

As décadas de 1820 e 1830 foram de indefinições legais aos terapeutas populares. Ressaltando novamente que a grande maioria não se registrava e não se interessava por esse reconhecimento oficial, é relevante o fato de que a extinção da Fisicatura em 1828 - motivada pelo sentimento antilusitano - e a formação de instituições de ensino médico no Brasil acabaram com a possibilidade dos terapeutas populares se oficializarem. Na cidade do Rio de Janeiro esses obstáculos legais não parecem ter diminuído sua importância, pois os anúncios de aluguel de escravos barbeiros e sangradores continuaram aparecendo nos jornais. 


\begin{abstract}
"Sangrar era muito importante para a terapêutica acadêmica, mas constituía um ofício mecânico, menor aos olhos dos médicos, que, portanto, precisavam de sangradores para executarem suas determinações" (PIMENTA, 2003, p.319).
\end{abstract}

A persistência dos sangradores como atores terapêuticos requisitados, apesar de ilegítimos do ponto de vista da lei, pode ser explicada pela permanência dos princípios hipocráticos na sociedade brasileira dos oitocentos. O que gostaria de chamar atenção, por ora, é que não existia preocupação com a analgesia na maioria dessas práticas terapêuticas. A dor nas sociedades tradicionais era entendida como algo inevitável ao longo da vida, cabendo aos indivíduos se conformarem com ela, sendo a resignação uma atitude elegante e respeitável. Os métodos utilizados para aplacá-la, na maioria das vezes, pressupunha uma dor ainda maior. "A dor estava integrada na economia da vida [...] suportava-se a dor por ela ser inerente a um destino que era, primeiramente, uma condição social" (BRETON, 2013a, p.166). O limiar da tolerância era alto, como se percebe no recurso voluntário às sangrias e outros métodos dolorosos, por exemplo (BRETON, 2013a, p.166-167).

O Rio de Janeiro era sede do poder central na Colônia desde 1763, quando o eixo econômico mudou para o sudeste em função da descoberta do ouro na região de Minas Gerais. Desde o início do XVII, foi grande o fluxo de colonos e de metropolitanos para a região das Minas Gerais em busca de ascensão social. Desse processo resultou uma sociedade amplamente diversificada, com forte presença da população de origem africana. Em torno das Minas, rotas comerciais com diferentes regiões da colônia se desenvolveram, dando origem a uma rica classe de comerciantes que era voltada para o abastecimento da região. Foi formada uma estranha sociedade escravista não baseada na plantation, nem exclusivamente voltada para o comércio externo (FAUSTO, 2002, p.53-55). Nessa sociedade, vários tipos de curadores se estabeleciam nas vilas, disputando clientela e, em alguns casos, levando denúncias aos tribunais eclesiásticos que promoviam devassas sobre práticas associadas ao misticismo e à bruxaria. Os documentos gerados nesse contexto são interessantes portas de entrada para a compreensão das práticas populares de cura, principalmente da população negra (NOGUEIRA, 2004, p.15-16).

Foi com objetivo de compreender essas práticas que Nogueira (2014, p.16-18) apresentou dois conjuntos de práticas curativas. O primeiro se refere ao uso de 'bênçãos', 'palavras' e orações. Percebe-se que, apesar das diferenças de tratamento 
entre os curadores brancos e negros, era comum o recurso às rezas realizadas em favor de santos católicos frequentemente lembrados por seus poderes de cura em Portugal. Em um contexto acusatório, esse tipo de referência pode ser uma estratégia de aproximação do acusado com seus inquisidores. A devoção dos brasileiros aos santos católicos, independente da cor da pele, aparece em diversas referências de viajantes e cronistas ao longo do século XIX, conforme bem demonstra Figueiredo (2008, p.98101). Com base nesses relatos, esta autora construiu uma ilustrativa lista de santos católicos e suas especialidades terapêuticas. No cristianismo, como lembra Breton (2013a, p.19-20), a dor e o sofrimento são entendidos como forma de lembrar a morbidade da carne adquirida pela humanidade no pecado original e sofrida por Cristo na ocasião de seu sacrifício. O calvário, nesse sentido, se impõe ao fiel e purifica sua alma. Segundo Abreu (2006, p.130-136), os tratados de medicina, a confecção de remédios e a própria teoria humoral, no contexto luso-brasileiro do século XVIII, compartilhavam a noção de que a doença e a cura faziam parte das ações de Deus e do sobrenatural.

Outro aspecto ainda referente à questão do recurso ao sobrenatural como prática de cura e como fontes de dores e doenças são os feitiços e os maus olhados. São várias as referências encontradas sobre rezas realizadas em línguas distintas do português. Foi o caso do escravo João, conhecido por retirar feitiços na Freguesia de Santo Antônio do Rio Verde (NOGUEIRA, 2014, p.22). Certamente, não se trata de um aspecto específico da cultura africana. A convivência e a interpenetração de vários credos culturais africanos, indígenas e europeus marcaram a religiosidade popular e a presença da feitiçaria nos diversos aspectos da vida cotidiana da colônia (SOUZA, 1986). Crença que não se reduzia às classes populares. Europeus formados nos quadros do ensino médico formal também acreditavam no poder dos feitiços. Luís Gomes Ferreira, autor do Erário Mineral, também creditava aos poderes sobrenaturais sintomas como falta de apetite, a impotência sexual, inchaço do corpo e insensatez. Eram comuns, nos depoimentos colhidos nas devassas, referências às dores, às enfermidades e aos óbitos gerados por feitiços (NOGUEIRA, 2012, p.273-277; ABREU, 2006, p.152-153). Nas sociedades tradicionais o corpo é pensado como vetor de comunhão com o mundo, com os deuses ou com Deus, ou seja, inscrito em um tecido holista que pode ser alterado pela força do feitiço (BRETON, 2013b, p.49-52). Na sociedade luso-brasileira dos setecentos era comum a crença, entre médicos e curandeiros, de que as afecções 
desconhecidas ou que não podiam ser explicadas segundo a lógica médica fossem enfrentadas por meio de esconjuros e exorcismos (RIBEIRO, 2003, p.89-108).

As práticas populares de cura também se utilizavam de um segundo elemento além de rezas e feitiços - o recurso às ervas, raízes e pós. A “manipulação do reino vegetal para a produção de mezinhas seria, indisputavelmente, o recurso terapêutico mais encontrado em meu universo de pesquisa" (NOGUEIRA, 2014, p.18). Nas devassas não existem, entretanto, referências às plantas específicas utilizadas por esses curandeiros. Escohotado (2008, p.241-244), analisando a perseguição da inquisição às práticas pagãs na Europa, também aponta a censura e a falta de curiosidade botânica dos inquisidores cristãos. O abominável, na visão dos padres, não era o uso de drogas ou plantas em si, mas o pacto com o satã. $\mathrm{O}$ uso desse tipo de recurso terapêutico é entendido como apostasia - rejeição da própria salvação - e idolatria - venerar a natureza física e animada e seus respectivos espíritos. No caso das Minas setecentistas, conforme averiguou Nogueira (2014, p.18-19), as plantas e recursos vegetais locais eram os principais recursos terapêuticos das classes populares e, também, alvo de interesse oficial por representarem possíveis recursos a serem explorados. Existia, porém, uma nítida separação entre medicina de pobre, sustentada no conhecimento da flora, e medicina de rico baseada nos remédios europeus provenientes das boticas.

Um remédio importante utilizado por todas as classes eram as aguardentes. Luís Gomes Ferreira a receitava para "várias funções, fosse para 'lavar as feridas', curar os 'incêndios de uma erisipela' aplicando 'panos molhados com aguardente', sendo também ingerida, misturada a outros ingredientes, na produção de 'beberagens"” (NOGUEIRA, 2014, p.20). Existia também entre os médicos portugueses a preferência pela aguardente europeia por ser de melhor qualidade. Entre os populares, existem referências à utilização de ervas para confecções de cachaças medicinais que podiam ser usadas como simples remédios ou associadas a rituais e bênçãos. As fontes consultadas por Nogueira (2014, p.21-23) - tratados médicos, lista de produtos em boticas e devassas eclesiásticas - sugerem a circularidade dos recursos botânicos e terapêuticos locais, aplicados na forma de emplastros ou de beberagens com aguardente. $\mathrm{O}$ uso dos mesmos recursos, entretanto, porem esconder diferentes formas de perceber a cura e a doença, pois eles podem ser usados para equilibrar ou purgar determinado humor ou para cumprir funções religiosas e rituais.

Aos usos já destacados acima por Nogueira (2014), que inclui limpeza de feridas, confecção de bebidas terapêuticas a partir da mistura de ervas e aplicada nas 
feridas, somam-se outras utilidades à aguardente. Segundo Figueiredo et al (2011, p.103-128), ela podia também ser usada como ingrediente de estimulantes, fortificantes e xaropes. Podia também ser usada diretamente sobre fraturas e deslocamentos "dos ombros e dos quadris, das vértebras e do espinhaço" (FIGUEIREDO et al, 2011, p.113). Quando usada diretamente sobre os ferimentos, a aguardente era aquecida, podendo ser aplicada sobre os nervos em caso de fratura exposta. Acompanhada de outros produtos era usada para limpar as feridas advindas do sarampo e da varíola. Existia também a doença conhecida como maculo, achaque, corrupção do bicho, entre outros. Seus sintomas são parecidos com a hemorroida, porém podem se tornar persistentes e gerar hemorragia capaz de levar ao óbito. A terapêutica indicada incluía lavagem do ânus com suco de limão e água do mar e a aplicação de saca-trapos (uma espécie de supositório) de aguardente.

O principal manual de medicina popular a circular no Brasil nesse período foi o de Buchan, intitulado Medicina Doméstica, somente suplantado por Chernoviz em meados do XIX (SANTOS FILHO, 1991b, p.437-348; GUIMARÃES, 2003, p.53). Manual escocês, de enorme sucesso editorial, foi traduzido para quase todas as línguas europeias, inaugurando um modelo de publicação que serviria de molde para outras iniciativas do gênero. Para o português ele teve duas traduções (GUIMARÃES, 2003, p.41). Nesse manual, e em outros, existia uma seção indispensável chamada "Formulário" que apresentava os remédios e as suas indicações. "O Formulário se manteve em praticamente todos os manuais do século XIX” (GUIMARÃES, 2003, p.42). Dentre os vários tipos de remédios descritos, existia uma sessão exclusiva para as bebidas espirituosas. Seus usos eram tão variados que a aguardente podia ser "considerada uma panaceia universal para tratar diversos problemas que afligiam a população que habitava o Brasil até os séculos XVIII e XIX” (FIGUEIREDO, 2011, p.121).

Todas essas observações sobre as práticas de cura em Minas Gerais procuraram mostrar que, no Brasil, desenvolveram-se artes de curar peculiares, caracterizada pelo sincretismo cultural e pela formação de medicinas multifacetadas afeitas ao universo da magia. Eram amplas as liberdades para a atuação de terapeutas populares, que incorporavam ervas, raízes e outros ingredientes naturais na cura das moléstias (RIBEIRO, 1997, p.15-16). É no interior desse universo cultural, que mistura o místico com o racional, que se desenvolveu a cultura dos remédios com fórmulas secretas. 
Sobre esse ponto cabem algumas últimas observações sobre as práticas terapêuticas tradicionais no Brasil.

A primeira autora que procurou trabalhar de forma mais sistemática essa questão foi Marques (1999; 2003). Ela mostra que em Portugal, seguindo uma prática existente em outros países da Europa, era comum a venda de medicamentos com fórmulas secretas. Esses remédios podiam ser feitos por uma grande variedade de agentes, que iam das profissões credenciadas - físicos, cirurgiões e boticários - até pessoas não ligadas diretamente as artes da cura, em um espectro que variava de reis a escravos (MARQUES, 1999, p.241-242).

No Brasil temos notícias desse tipo de medicamento desde início do século XVIII. Em 1718, por exemplo, um remédio secreto produzido por um francês contra o morbo-gálico (sífilis) fez tanto sucesso que a Câmara se viu na contingência de comprar o produto para oferecer a população (MARQUES, 1999, p.242). Foram, entretanto, os jesuítas os mestres na elaboração de receitas secretas. A Triaga Brasília, o mais famoso desses remédios, era importante fonte de lucro para esses religiosos e tornou-se objeto de disputa com o poder metropolitano depois da expulsão desses religiosos do Brasil. Descrita como panaceia para diversos males, também era receitada como antídoto para envenenamentos. Esse remédio, como todos os outros similares,

\footnotetext{
"constitui composição exemplar de terapêutica empregada no século XVIII, mas concebida no mundo antigo. As teriagas ou triagas continham ópio em sua formulação, droga essa usada em muitas receitas desde a Antiguidade, tanto no Egito, como na Grécia ou em Roma" (MARQUES, 1999, p.246).
}

Sabe-se que, embora fossem os ingleses os que mais ganharam e os que mais expandiram o comércio de ópio com o Oriente, particularmente com a China, foram os portugueses os primeiros a descobrir que os chineses também aceitavam ópio na troca de chá, sedas e especiarias. Foi para acabar com o florescente comércio lusitano que o imperador Yung-Cheng decretou a primeira proibição ao comércio de ópio em 1729. Os portugueses seguiram negociando o produto baseado nas produções de Goa e, depois, de Macau. Gradativamente, entretanto, os ingleses foram substituindo os portugueses nesse comércio até os segundos ficarem com uma posição totalmente marginal (ESCOHOTADO, p.526-528). Importante, para nosso propósito, é apontar que os jesuítas também atuavam no Oriente e incorporavam elementos daquela cultura em suas formulações. Os portugueses tinham familiaridade com o ópio e, provavelmente, como 
já aponta Marques no excerto mostrado acima, esse foi um ingrediente fundamental em muitos remédios secretos.

O fato dos portugueses conhecerem e negociarem ópio no Oriente não significa que esse produto tenha se massificado. Escohotado (2008, p.255-256), aponta para o papel dos árabes hispânicos na divulgação do ópio como elemento terapêutico, cabendo ao árabe Ibn Sinna de Avicena e divulgação dos remédios na forma de triaga. Inexistem ou se desconhece pesquisas que abordem o uso de ópio e seus derivados em Portugal. Sobre a Espanha, sabe-se que o comércio de ópio era livre até meados do século XIX. A primeira estatística, de 1858, aponta que o país importava quase duas toneladas de ópio bruto (ESCOHOTADO, 2008, p.706). Sabe-se, entretanto, que em algumas regiões do país (Valência) existia um uso popular de dormideiras, provavelmente na forma de chá de cabeças. Desde 1762, o Jardim Botânico Real conseguia extrair ópio puro dessas plantas, porém sua produção jamais se organizou (USÓ, 1995, p.21-23). Os remédios secretos, por sua vez, foram vendidos e divulgados na imprensa espanhola, apesar de algumas restrições legais, até o início do século XX (USÓ, 1995, p.28).

Em outros países europeus, na mesma época, o ópio era considerado um produto de amplo e fácil acesso. Na Inglaterra, Berridge (2013, p.15-16) mostra que ele era vendido no mercado comum ao lado de outros produtos até 1868. Embora ele fosse usado para o tratamento de inúmeros males à saúde, sua principal utilização era como paliativo. O ópio oferecia alívio para a dor e ajudava a criar condições que ajudavam na recuperação física. Nas áreas industriais, as mulheres trabalhadoras compravam o ópio e seus derivados nas farmácias e boticas e revendiam no comércio miúdo para incrementar a renda da família. Samuel Flood, cirurgião que trabalhava em uma indústria em Leeds na década de 1840, deixou registrado que comprava pílulas e poções de ópio no mesmo local onde habitualmente adquiria vegetais e carnes. Ou seja, era vendido no mercado público. Médicos herboristas e parteiras sem formação, nas áreas proletárias, tinham receitas próprias. Uso que se estende também à emergente classe burguesa. Ele era um remédio padrão, existente em qualquer lar. Sem querer alongar nesse ponto, também nos EUA, segundo Musto (1999, p.02-03), desde o início do século XIX o ópio era importado para fabricação de sais e remédios. Comércio e indústria que se ampliaram enormemente após a década de 1870.

Se o consumo de analgésicos se globalizava, cabe nos perguntarmos até que ponto ele era acessível ou não para a população no Brasil ao longo dos séculos XVIII e XIX. A historiografia brasileira tende a associar o uso de remédios secretos às mezinhas 
domésticas que utilizavam simpatias e produtos da polifarmácia ensinados pelas tradições indígenas e populares. Soares (2001, p.424) chega a afirmar que não existe "qualquer evidência que os próprios segmentos populares se ressentissem da ausência de médicos e suas drogas". Essa ausência era reclamada, sobretudo, pelos administradores, viajantes estrangeiros e os próprios médicos. O vice-rei, conde de Resende, em 1796, escreveu uma carta desse tipo lamentando a falta de médicos, porém admite que esse problema não afetava os segmentos populares, pois "os ignorantes e curadores (eram) escolhidos muitas vezes com preferência por espalharem que possuem certos remédios e segredos para todo o gênero de moléstia" (RESENDE, 1796 apud SOARES, 2001, p.424).

A extensão dos remédios de segredo e do uso de ópio e seus derivados nesse tipo de medicamento ainda precisa ser alvo de uma investigação mais apurada. De qualquer forma, parece relevante que até final do século XIX a popularidade desses remédios seja atribuída unicamente aos efeitos sugestivos próprios da medicina popular. Seria tão difícil obter ópio e/ou seus derivados para a fabricação de medicinas? O reclame que será apresentado abaixo, publicado no Diário do Rio de Janeiro no dia 17 de Setembro de 1867 , sugere que esse produto podia ser obtido sem maiores problemas no comércio legal.

HOJE, Terça-feira 17 de corrente ás 10 1/2 horas em ponto. M. P. Bastos Junior faz leilão em casa dos srs. Fratelly Zignago. Rua do Sabão, 19, de um importante e variado sortimento de drogas, papel, corda, etc. constando principalmente de alpiste, incenso, pedra pomes, raiz de jalapa, galha, erva doce, quina, alcaçuz, linhaça, goma-esponjas, maná-lagrima, meia-lagrima e comum, noz moscada, ópio, pentes de marfim, papel almaço, florete para chá; um variado sortimento de corda, cordel, fio em porretes, e muitos outros artigos que serão vendidos ao prazo do costume (DIÁRIO DO RIO DE JANEIRO, 17 de setembro de 1867, p.4).

O ópio era vendido como um produto qualquer, junto com papel, pentes, artigos de comida, cordas e outras substâncias próprias para fazer remédios, como a quina. Não parece, portanto, nenhum absurdo supor que muitos dos remédios de segredo incorporassem em suas fórmulas mais ou menos quantidade de ópio ou seus derivados para gerar analgesia. Na historiografia, a desqualificação dos remédios de segredo como isento de qualquer qualidade farmacológica e a ênfase no fantástico e do não científico duram todo o século XIX. Os remédios estrangeiros, que começavam a chegar depois da 
abertura dos portos, eram "tão destituídos de valor terapêutico, ou tão nocivos como as triagas e panaceias dos tempos coloniais" (SANTOS FILHO, 1991b, p.367). Figueiredo (2008, p.88-89) atribui o sucesso do remédio do barbeiro Domingos d’Ascenzo ao apoio da propaganda e a fama e ao mistério que envolvia a figura do fabricante. Sampaio (2001, p.78-79), se resume a apontar que os "remédios não científicos" eram usados para uma infinidade de males como uma alternativa a medicina oficial. Sem menosprezar o poder sugestivo gerado pelo segredo e pela propaganda, em nenhum momento se cogita que tais remédios tinham qualidades antálgicas baseado em fármacos com comprovados efeitos analgésicos - iguais àqueles utilizados pela medicina oficial.

Procurei mostrar, ao longo dessa sessão, que as concepções terapêuticas eram essencialmente vinculadas as visões holísticas que ligavam o corpo e as enfermidades ao universo circundante, tanto entre populares, quanto entre os doutos. Embora muitas escolhas possam parecer insensatas e aberrantes para a perspectiva atual, é preciso destacar que em alguns casos elas andavam lado a lado com o positivo e a racionalidade. Lavar as feridas com aguardente, utilizar produtos com base de ópio e outras práticas estavam ancoradas no empirismo e nos resultados obtidos. A associação do empirismo ao embuste é a reprodução da ideologia racionalista que se desenvolveu com a farmacologia.

\subsection{A polifarmácia e o racionalismo}

Nós vimos no item precedente que a dor e a doença não podem se resumir a um dado meramente fisiológico, estando intrinsicamente ligadas aos aspectos culturais e sociais. Vimos também que a terapêutica no contexto tradicional era baseada em concepções holistas que procuravam criar um significado para o sofrimento, muitas vezes até prescindindo do uso de remédios, como nos recursos às rezas e aos feitiços. Se nesse cenário não é possível separar os significados mágicos e religiosos do empirismo, tampouco existe um antagonismo irreconciliável entre empirismo e racionalidade. Sneader (2005, p.01), ao abordar a relação do empirismo e a descoberta de fármacos, chama atenção que as sociedades quentes ou desérticas desenvolveram mais facilmente loções ou bálsamos para serem aplicados sobre a pele e os olhos, enquanto outras com consumo deficitário de fibras procuravam ervas capazes de auxiliar na constipação. 
Sociedades acostumadas ao consumo de plantas contaminadas eram conhecedoras de recursos capazes de induzir ao vômito e assim por diante.

Com base nesse princípio empírico, sugeri no item anterior que grande parte dos remédios secretos vendidos como panaceias não eram simples embustes, cuja eficácia residia unicamente no efeito sugestivo ou placebo. Essa hipótese é sustentada com a análise mais ampla do fenômeno da revolução psicoativa, cujo um dos aspectos é a maior acessibilidade de um dos mais conhecidos e comprovados antálgicos: o ópio. Sneader (2005, p.03) chama a atenção para os limites do empirismo através da disponibilidade natural de produtos efetivamente eficazes para o tratamento de moléstias. Segundo ele, são estimadas que existem aproximadamente trezentos e vinte mil espécies vegetais no planeta. Destas, apenas vinte e cinco mil foram usadas nos sistemas de medicina tradicionais. Depois que se conheceu a química e os princípios ativos, aproximadamente uma centena e meia tiveram efeitos efetivamente comprovados. Para esse autor, isso não deve ser uma surpresa uma vez que as plantas não evoluem para produzir remédios.

Se os números apresentados por Sneader (2005) acima tem fundamento do ponto de vista químico, é preciso atentar para o fato de o remédio não se reduzir a sua constituição molecular. A pessoa que utiliza um remédio está carregada da esperança de cura, do temor da doença ou de outras expectativas que impedem que ele apresente uma "fórmula absolutamente rigorosa" (DAGOGNET, 2012, p.13) ou, em outras palavras, que ele tenha uma "robusteza ontológica" (DAGOGNET, 2012, p.30). Para entendermos a subjetividade implícita dos fármacos é necessário que façamos algumas observações a respeito do efeito sugestivo ou placebo.

Mostrei no item anterior que a eficácia terapêutica dos remédios secretos ou tradicionais era creditada ao efeito sugestivo criado pela propaganda, pela reputação do medicamento ou do ritual que procura inserir tal mezinha em uma crença que dê sentido ao sofrimento daquele ou daquela que busca a cura. Tentei nessa exposição mostrar que o efeito placebo era potencializado e enaltecido como parte do tratamento - embora muitas vezes também comportasse efeitos farmacológicos.

A farmacologia moderna, por sua vez, procura atuar intervindo sobre o efeito placebo com objetivo de retirar a subjetividade inerente aos processos de cura e obter o máximo de objetividade. O "experimentador moderno reduz o efeito placebo a um grau zero para evidenciar a ação farmacológica" (PIGNARRE, 1999, p.23). A mistura dos medicamentos testados com os placebos visa eliminar a cura espontânea, os efeitos 
ambientais e a expectativa de resultados pela pessoa que experimenta o fármaco. A tentativa de superar os fatores antropológicos levou à sofisticação dos protocolos, porém até hoje não foi possível separar completamente as curas esperadas com o remédio das curas espontâneas. Por isso a eficácia do medicamento moderno é sempre proveniente da comparação que visa "saber se a diferença entre os resultados é "estatisticamente significativa"” (PIGNARRE, 1999, p.26).

É por esse motivo que o rito de passagem de uma molécula para o status de medicamento não é uma simples prova de purificação que consiste em isolar o efeito farmacológico. Os testes são o início da socialização das moléculas, transformando-as em medicamentos (PIGNARRE, 1999, p. 32). Essa observação não tem objetivo de ignorar os efeitos positivos que os métodos modernos de verificação farmacológica trouxeram para a terapêutica, mas apontar que é impossível distinguir "o imaterial e o estritamente biológico, os fatores antropológicos e os efeitos farmodinâmicos" (DAGOGNET, 2012, p.25). É correto afirmar, portanto, que o falso e o verdadeiro ainda estão interligados, perdurando no remédio "uma franja irredutível de magia" (DAGOGNET, 2012, p.40).

Ao destacar o aspecto antropológico dos remédios não pretendo fazer uma crítica pela crítica à medicina oficial, como ressaltei acima ao refletir sobre a dor. Os avanços obtidos, e nós vamos compreender mais como isso ocorreu no decorrer dessa Tese, não significam simplesmente a superioridade de um sistema racional científico sobre outro irracional e sugestivo: existem diferentes pontos de vista e coexistência de sistemas. "Tal como a corporeidade, fonte infinita de significações, a terapêutica se introduz em um mundo mais cultural que natural" (DAGOGNET, 2012, p.12), por isso a atmosfera antropológica é fundamental para a obtenção do sucesso terapêutico, inclusive com o uso de remédios.

Outro equívoco bastante sensível é reduzir o remédio simplesmente à questão terapêutica. Mais do que aquilo que cura, os fármacos são responsáveis por transformar os homens e as mulheres. Dagognet (2012, p.12), sobre esse aspecto, chama atenção para as fenotiazinas (usados no tratamento da esquizofrenia), os tímicos (utilizadas na suspensão da melancolia), os sedativos, os estimulantes e os euforizantes. Eu ainda poderia adicionar nessa lista as substâncias usadas em ritos xamânicos, com potencial enteógeno, capazes de propiciar fortes experiências místicas.

Essas observações acima me permite definir a farmacologia moderna como uma ciência autônoma que está na eterna busca pela independência da imprevisibilidade 
proveniente da experimentação. "Ela é um racionalismo impedido, uma razão que se emancipa da magia, mas que não pode, no entanto, emergir de suas brumas" (DAGOGNET, 2012, p.16).

Os desafios trazidos pela experimentação podem ser melhor visualizados se considerarmos os dois princípios fundantes de qualquer fármaco: $1^{\circ}$. Todas as substâncias são portadoras de uma dualidade e até de uma ambivalência. O ópio, por exemplo, é comumente pensado como sedativo e calmante, porém pode também agir como estimulante. O mesmo ocorre com o álcool (DAGOGNET, 2012, p.13-14). Nesse aspecto, Almeida (2011, p.110) destaca ainda que o remédio pode apresentar até efeitos contrários se administrado em grandes ou pequenas doses, característica que é chamada de ação bifásica do medicamento; $2^{\circ}$. Os efeitos são determinados também pela habituação. A força do costume é importante ser considerada porque o organismo está sempre em franca adaptação e reação aos efeitos medicamentosos (DAGOGNET, 2012, p.14-15). Por isso os remédios também se modificam com o passar do tempo, iniciando uma fase ascensional e triunfante para depois recuarem em "uma lenta e aflitiva descida" (DAGOGNET, 2012, p.36). Várias medicações - como os antileucêmicos, os hipnógenos, os antibióticos - gradativamente vão perdendo sua eficácia. "A habituação pode degradar as mais notáveis ou mais sagradas das drogas" (DAGOGNET, 2012, p.36), como os antibióticos que revolucionaram a terapêutica em meados do século $\mathrm{XX}$ (ALMEIDA, 2011, p.114-118).

Essas considerações sobre o remédio se justificam porque não é objetivo dessa Tese escrever a história triunfal da farmácia, que inicia no tempo do irracionalismo até as luzes do cientificismo e a realização da indústria. O que busquei chamar a atenção é que mesmo hoje em dia, com as mais avançadas tecnologias, o remédio não conseguiu se reduzir a uma estrutura molecular objetiva - ele está intrinsecamente embrenhado em aspectos antropológicos. Seguindo o argumento apresentado por Almeida (2011, p.4748), não se trata de negar os avanços obtidos pela quimioterapia que são de enorme significância história, mas nos precavermos para que esses avanços não atropelem fatos e criem os mitos de cientificidade. A caracterização da polifarmácia antiga como bizarra e irracional e a sua superação pelas luzes da racionalidade científica é um desses mitos que pretendo discutir abaixo analisando o caso do Brasil colonial e imperial.

Verificamos no item anterior, a partir da análise das artes de curar nas Minas setecentistas (NOGUEIRA, 2014, p.20-21), que eram vários os recursos vegetais locais usados como fins terapêuticos. Eram aplicados suadouros de ervas, pó de pau de 
laranjeira brava para cicatrizar e estancar sangrias, raízes de orelha de onça, de figueira brava e de uma planta que era denominada "paratudo". Gomes Ferreira, autor do Erário Mineral, recomendava as tais raízes de orelha de onça para todos os venenos e malefícios, incluindo feitiços.

A medicina praticada nas terras brasílicas com esses recursos botânicos não deixava nada a dever a Portugal e ao restante da Europa. Nesses locais era comum também o uso de excretos do corpo humano: saliva de homem em jejum contra picada de serpente; cera de orelha para cólicas; resíduo do ventre humano sobre bubões pestilentos e sobre feridas na epiderme; restos de múmia remediavam dores pungitivas do baço, a tosse, a inchação e outros males. Parte desse arsenal terapêutico também estava presente no Erário Mineral, tais como urina de menino macho ou de homem sadio para opilados, óleo de unto de homem para curar sinais de bexigas e esterco humano para picada de cobra (ABREU, 2006, p.142-143). Esses exemplos, que poderiam se multiplicar, caracterizariam na visão da historiografia triunfalista biomédica

\footnotetext{
"o estado da terapêutica clássica, do empirismo e do charlatanismo. Os três reinos da natureza entraram no preparo dos remédios. A par de prescrições bem indicadas e bem combinadas, resultantes do saber e da experiência, usaram-se no país, como aliais em toda a parte, fórmulas as mais extravagantes, esdruxulas, quando não impuras e mesmo nocivas [...] chegavam a ser prescritos excrementos humanos e animais, e águas de serventia" (SANTOS FILHO, 1991a, p.332).
}

Todas essas combinações estranhas podem ser objeto de fáceis risadas nos dias atuais às pessoas que se interessam pela história da medicina. Optei, entretanto, pelo caminho mais difícil e menos teleológico ao tentar mostrar a racionalidade existente por trás dessas escolhas. Almeida (2011, p.77-78) aponta que a terapêutica antiga respeitava o princípio do símile, ou seja, que a comparação de duas coisas podia servir para a terapia desde que construísse uma ponte entre o macrocosmo e o microcosmo. A noção de physis na medicina hipocrática seria resultado da expressão particular do indivíduo inserido em dada constituição cósmica. A terapêutica, nesse contexto, seria de auxílio à physis. Esse princípio explica, segundo Dagognet (2012, p.59-61), porque a mumificação que preserva o corpo poderia preservar a vida ou o pulmão da raposa, outro exemplo, era um remédio para aquilo que sufoca - uma vez que ela é um animal 
que corre rápido e por muito tempo. Almeida (2011, p.104) ainda chama atenção para o fato da leitura de Galeno, ao propor a predominância de quatro humores, acabar transformando a terapêutica dos símiles em uma dos contrários, pois se baseava na prescrição de fármacos, dietas ou exercícios voltados para contrabalancear os humores em excesso ou faltante.

Com base nos exemplos de racionalidades acima propostas, que não esgotam a terapêutica tradicional, é possível destacar algumas particularidades do trabalho do boticário medieval. Segundo Dagognet (2012, p.51-52), o manejo de substâncias traduzia-se, sobretudo, em provocar modificações com objetivo de obter uma segunda natureza. Tudo aquilo que se transformava, que fosse gomoso, gelatinoso ou capaz de alterar de volume era muito valorizado. "O conglutinante, as colas e o viscoso entrarão, portanto, no grupo fundamental dos reparadores, dos tônicos, tanto quanto no dos suavizantes, dos calmantes" (DAGOGNET, 2012, p.54). Podia haver por de trás dos temas fantásticos e das bizarrices, algumas regras e princípios como o do naturalismo que privilegia a mudança.

Além daquilo que se transforma, outra operação possível era aquela que visava extrair das matérias suas energias escondidas. Ao contrário de transformar, como destacado acima, nesse caso o que importava era a depuração, a obtenção do concentrado ou daquilo que a natureza apresenta de forma dispersa. Busca-se o princípio, o aroma, o espírito ou a vida. A filosofia árabe do alambique interrompe a hegemonia da ciência grega que era dedicada à contemplação da natureza, aos equilíbrios. Para conseguir o puro ou mover o princípio vital muitas vezes era necessário "recorrer aos ingredientes contrários e antinômicos, ao cadavérico, ao desagradável, ao peçonhento, às podridões” (DAGOGNET, 2012, p.59). A fermentação é capaz de revelar a renovação que surge das matérias corrompidas, lembrando que até a difusão de Pasteur era comum a crença que a vida surge das matérias que se decompõem. A natureza dá inúmeros exemplos desses renascimentos. Essas observações nos ajudam a compreender o motivo pelo qual as farmacopeias se serviam

"do excrementicial, das cinzas ou das fermentações, e até mesmo por enaltecerem a mumificação (em licor ou em pó), preparada com ajuda de restos humanos, de cadáveres exumados ou dos corpos dos enforcados" (DAGONET, 2012, p.59). 
Nesse ponto fica bastante claro o "cruzamento do místico e do físico, do religioso e do positivo" (DAGOGNET, 2012, p.59).

Uma última característica, bastante presente nos inúmeros formulários de receitas - que eram difundidos até o início do século $\mathrm{XX}$, conforme veremos na próxima seção - é a valorização do múltiplo, da adição quantitativa, qualitativa ou de oposição. A grande quantidade de essências reunidas multiplica o poder do remédio, amplia a dificuldade da preparação e, consequentemente, o valor da mistura. As fórmulas medicamentosas eram compostas, basicamente, de quatro grupos de elementos: o essencial (base), o corretivo, o estimulante e o excipiente que os reúnem (DAGOGNET, 2012, p.62-64). Isso explica porque, durante todo o século XIX, no Brasil, perdurou a ideia de que "receita boa era aquela preparada de modo individualizado e com diversos componentes" (FIGUEIREDO, 2008, p.94). Quanto maior o número de ingredientes acrescido em dado remédio, maior era entendida a atenção dada pelo físico/farmacêutico ao seu cliente (FIGUEIREDO, 2008, p.94-95). Chernoviz definia a triaga como "uma mistura de todas as drogas até então conhecidas" (CAMARGO, 2011, p.45).

Todos esses princípios e características da polifarmácia medieval e da terapêutica hipocrática ou galênica não devem ser tomados como imanentes a todas as práticas tradicionais, mas como exemplos de uma racionalidade possível. Vimos acima como a teoria de Hipócrates podia se diferenciar daquilo que defendia Galeno na questão do símile e dos contrários. A ideia de que o corpo era composto por humores e que a harmonia ou a desarmonia deles com o meio eram fatores primordiais ao bem viver atravessou os milênios, compondo a vigorosa tradição hipocrática. A diferença entre os princípios do símile e do contrário, em Hipócrates e Galeno, é exemplar dos perigos de interpretar tal tradição como uma linha de continuidade que une sociedades distintas ao longo do tempo.

Se entre as tradições grega e romana já existiam diferenças, ainda mais acentuadas serão as mudanças se compararmos o antigo e o moderno. Segundo Czeresnia (2001, p.343-345) o conceito fundamental para entender a doença a partir da perspectiva antiga é a physis, que significa a união de tudo, incluindo o que hoje entendemos por natural, psíquico, social, cósmico e sobrenatural. Não existiria corpo e alma, mundo inteligível e sensível, razão e emoção. A doença seria a ruptura com a natureza, apresentada em termos de agregação e desagregação, separação e unificação. O corpo humano era pensado como parte de tudo que o circunda - o ar, a terra, a água e 
o fogo - assim como por determinadas qualidades - frio, quente, seco e úmido. Caberia ao curador observar a natureza e, no máximo, propor algumas atitudes para evitar certas circunstâncias ou facilitar a retomada do equilíbrio perdido - em consonância com a racionalidade grega da contemplação da natureza e o princípio dos símiles destacado acima.

A modernidade trouxe mudanças nessa forma de compreender a doença, com a progressiva desconexão entre o corpo, o espaço e o tempo (CZERESNIA, 2001, p.346). Breton (2013b, p.70-96), chama atenção para o papel das dissecações - que iniciariam no século XV na Itália e que se banalizaram nos séculos XVI e XVII - na ruptura da episteme ocidental entre o homem e seu corpo. Esse empreendimento abre caminho para a construção do saber biomédico em contraposição às concepções populares, reificando o corpo. Nesse sentido, o cogito de Descartes é "um eco do ato anatômico, ele distingue no homem o corpo da alma, conferindo essa última o exclusivo privilégio de um valor" (BRETON, 2013b, p.95). Se o cogito pertence à alma e ao intelecto, o corpo passará a ser considerado um resto com pouco valor.

Portugal se apresentou, até fins do século XVIII, como um espaço de resistência à anatomia. A Igreja católica tinha imensa influência política e conseguiu manter a hegemonia em torno das concepções de corpo e de cura. Os religiosos tinham enorme interesse sobre os saberes botânicos, mesclando o conhecimento empírico adquirido a partir da expansão comercial e as concepções religiosas. As ervas utilizadas pelos indígenas brasileiros e outras substâncias curativas buscadas no Oriente eram usadas na formação de vários remédios com fórmulas secretas, como a Triaga brasílica já comentada. Posteriormente, os críticos iluministas condenariam essa monopolização do saber herbário pela Igreja. Não existia, entretanto, um esforço de racionalização desse saber, tampouco uma abertura a anatomia. O ensino médico em Portugal se baseava, sobretudo, nos textos clássicos.

\footnotetext{
"Em decorrência do contato estabelecido com os textos de Hipócrates, Galeno e Avicena, os padres da Igreja apropriaram-se da teoria dos humores e procuraram explicar o desequilíbrio humoral a partir de preceitos teológicos" (ABREU, 2006, p.135).
}

Por causa dessa formação particular, ao lado das concepções tradicionais que atribuem ao divino as doenças e a morte, também figurava a teoria dos humores derivada dos clássicos. Mesmo em outras partes da Europa, mais tocadas pela tradição 
anatômica, a influência do hipocratismo se manteve nas práticas de cura até o século XIX, não obstante a existência de outras teorias médicas. A necessidade terapêutica de expulsar e controlar humores malignos estiveram na base da grande popularidade da aplicação de clisteres, de purgas, de sangrias e o gosto pelos purgantes, vomitórios e laxantes. A prática da sangria, por exemplo, era objeto de regulamentação em Portugal desde início do século XVII (ABREU, 2006, p.136-141).

A resistência aos estudos anatômicos também pode ser percebida na relação da metrópole com suas colônias. No Brasil, além da proibição dos estabelecimentos de ensino aos civis, também aos militares eram feitas restrições. Na província de Mato Grosso, que fazia fronteira com a América hispânica, onde hoje estão localizadas a Bolívia e o Paraguai, foram feitas solicitações para o estabelecimento de aula de cirurgia na região. Tal demanda se justificava tanto para a assistência à escassa população, quanto às necessidades militares. Os oficiais de Sabará mandaram uma representação ao rei Dom José I, em 1768, solicitando permissão, que lhes foi negada. Em 1799, as necessidades geradas por um possível ataque espanhol à região motivou novo pedido, dessa vez por parte da Câmara Vila Bela, para instalação de um hospital militar com professores. Solicitação que também foi negada. (JESUS, 2004, p.95-97). As propostas esbarravam no receio que as aulas pudessem favorecer a ilustração e as críticas ao absolutismo e ao sistema colonial. Essa demanda da comunidade só foi atendida depois da chegada da corte ao Brasil em 1808 (JESUS, 2004).

A crítica que se estabeleceu pelo iluminismo em Portugal não se resumia, entretanto, somente à ausência de estudos anatômicos. Ela se estendia a todos os medicamentos e a terapêutica que utilizavam da mágica e das explicações metafísicas provenientes dos clássicos. Todo um debate se travou a respeito da influência dos astros nas doenças e nas epidemias, perceptível em obras que contestavam os almanaques astrológicos. Posição crítica que ganhou força depois do terremoto ocorrido em Lisboa em 1755. A partir desse evento, a astrologia perde lugar para a meteorologia na orientação do saber médico. "As enfermidades, nesse caso, não poderiam ser explicadas mediante a força dos astros, mas sim a partir da complexidade dos fenômenos da natureza, como as variações do ar e o curso dos ventos" (ABREU, 2006, p.165).

Além do campo terapêutico, propriamente dito, as críticas ilustradas também buscavam ampliar o escopo de atuação dos físicos no tratamento da alma, contrapondose ao Direito e a Teologia que tradicionalmente consideravam esse tema próprio à sua jurisdição. Mais do que reformular a ordem pública e os costumes, esses discursos 
pretendiam afirmar a autoridade médica sobre os padrões de comportamento aceitos, fato que denota um processo de laicização dos discursos sem contestar o status quo (EDLER et al, 2009).

Nós vimos no item anterior, quando verificávamos os motivos do desprestígio da cirurgia, que a crítica à cultura livresca baseada na repetição do saber clássico culminou na modificação dos Estatutos da Universidade de Coimbra em 1772 e, consequentemente, na valorização das disciplinas que pudessem explicar o funcionamento do corpo (anatomia) e as propriedades dos remédios (química). Permitiu-se, enfim, a dissecação. Como bem salienta Abreu (2007b, p.92-97), mais do que uma vitória da razão sobre o obscurantismo, essas modificações significaram uma abertura no pensamento médico então vigente. A valorização da tradição hipocrática pode ser percebida, por exemplo, na calorosa acolhida que a obra de Herman Boerhaave (1668-1738) teve em Portugal. Esse físico concebeu o corpo como um conjunto de tubulações feitas de canos e vasos, capazes de canalizar os líquidos corporais. Dentro desse espírito cientificista, o novo equilíbrio se instauraria pelas sangrias e purgações, como já se fazia, mas também pela adoção de remédios com propriedades químicas conhecidas. Desprende-se daí que os remédios também passariam a atuar no controle dos fluídos e dos sólidos no organismo (ABREU, 2006, p.180-184).

A influência do iluminismo, que salientava a importância de conhecer o mecanismo de ação e a dosagem correta do remédio, levou a uma crítica aguda aos remédios secretos. Manuel José Curvo Semedo, que era uma figura proeminente no meio médico português no século XVIII (RIBEIRO, 1997, p.61-62), foi um defensor da utilidade das medicinas secretas apesar de se contemporâneo ao período das reformas. Suas receitas médicas passaram a ser ridicularizadas por pessoas como o padre Verney. O "pó de cotovia", por exemplo, que era produzido a partir da queima de uma ave, era considerado uma aberração terapêutica, pois “"considere quantas substâncias diferentes entram nos pós de cotovia queimada: penas, ossos, entranhas, carne, sangue, esterco, etc', a qual dessas se deve atribuir a cura da doença?" (VERNEY, 1746, apud ABREU, 2006, p.156).

As críticas esboçadas pelo padre Verney são exemplares daquilo que será bastante comum, posteriormente, na história triunfalista da medicina: a ridicularização e o desprezo pelos remédios tradicionais a partir da ênfase no bizarro. Procurei mostrar, entretanto, que essas práticas também possuíam aspectos racionais se consideradas dentro dos sistemas holistas que elas estão inseridas. Os remédios, mesmo os modernos, 
possuem um irredutível aspecto antropológico que o antagonismo entre racionalismo e empirismo tende a negar. As críticas do iluminismo e as novas concepções de corpo, de meio e de produzir conhecimento gradativamente vão alterando a predominância da escolástica no ensino médico português, embora o hipocratismo continuasse prestigiado. A institucionalização da medicina acadêmica no Império brasileiro se desenvolverá no interior desse caldo cultural descrito ao longo desse Capítulo, gerando uma cultura médica e farmacológica bastante particular com forte intercâmbio com essas percepções tradicionais, conforme veremos agora.

\subsection{Os fármacos e a terapêutica oitocentista brasileira}

O início do século XIX será marcado por duas inovações no campo da cultura médica e farmacêutica que serão saudadas, pela historiografia biomédica triunfalista, como grandes avanços do racionalismo contra o obscurantismo. Procurarei mostrar, contrariamente, que essas inovações não são entidades abstratas que pela sua superioridade técnica tornam tudo aquilo que se praticava no campo da terapêutica obsoleto. Ao contrário, elas são alvo intensas disputas e negociações com as práticas então vigentes, passando a coexistir com outros modelos epistemológicos. Isso se aplicará, inclusive, às mudanças ocasionadas pelo campo da microbiologia no final do século XIX, conforme veremos ao final desse Capítulo.

A primeira das inovações que gostaria de destacar se refere ao advento da ciência dos alcaloides. Vimos, acima, que a polifarmácia medieval foi influenciada pela filosofia árabe do alambique. Segundo Carneiro (2010, p.31), o alambique teria sido a primeira máquina a servir de analogia para explicar o funcionamento do corpo humano, no sentido de que ele agiria como uma espécie de depurador dos humores - do sólido para o líquido e deste para o gasoso. Da mesma forma que os trabalhos anatômicos vinham modificando a concepção de corporeidade, também as pesquisas alquímicas desenvolvidas desde Paracelso passaram a questionar os pressupostos da farmácia galênica. Sneader (2005, p.74) aponta sobre esse assunto que, apesar dos avanços no campo da química (principalmente com os metais), o processo de descobrimento de novas drogas progrediu pouco com Paracelso e os alquimistas por causa das especulações teóricas sobre a natureza do corpo que acompanhava seu pensamento. Escohotado (2008, p.339-344), por sua vez, destaca o papel de Paracelso na divulgação do ópio através da consagração da ideia de láudano que perduraria nos anos posteriores. 
Almeida (2011, p.80-83) considera Paracelso um dos grandes injustiçados da história da medicina, pois ele era um empírico que desenvolveu vários remédios úteis no período. Em minha opinião, essas controvérsias a respeito do papel de Paracelso e seus seguidores no desenvolvimento da farmácia e a influência do mágico em seu pensamento não deve obscurecer a importância que a filosofia da busca das essências teve na formação da ciência dos alcaloides.

O método de extração de cristais por meio da utilização de solventes foi utilizado de forma mais sistemática, pela primeira vez, na Alemanha no processo de obtenção do açúcar a partir da beterraba em meados do século XVIII. Exportado para a Suécia, ele foi usado também para isolar cristais provenientes das plantas produtoras de sucos, embora não tenha tido muito sucesso comercial por causa da acidez desses produtos. Essas experiências foram importantes na formação do entendimento que a essência das plantas se apresentava na forma de ácidos. Só no início do século XIX, quando os franceses tomaram conhecimento dessas metodologias, que a ciência dos alcaloides efetivamente teve início. A supressão dos privilégios da monarquia e o contexto propício ao experimentalismo teriam composto o cenário político que deu a França a liderança nesse campo na primeira metade do século XIX. Ao longo deste século, vários outros países europeus passaram a explorar essa tecnologia para obter alcaloides, principalmente a Alemanha. A farmacologia experimental como ciência teve na Universidade de Strasbourg, localizada na fronteira entre a França e a Alemanha, o principal centro de estudos. Essa instituição foi fundamental para a construção da supremacia alemã no campo da farmacologia entre o final do século XIX e o estourar da segunda guerra mundial (SNEADER, 2005, p.88-89).

Mais do que entrar na polêmica se foi este ou aquele o primeiro a descobrir a morfina, acho mais relevante marcar o contexto social e cultural de valorização da busca das essências e os avanços tecnológicos prévios que viabilizaram essa técnica. Vimos, anteriormente, o embate entre Verney e Semedo e as críticas que se faziam, desde o fim do século XVIII, aos remédios que não tinham o seu funcionamento plenamente esclarecido. É importante também destacarmos, como bem lembra Sneader (2005, p.03), que mesmo as plantas com notável e conhecido efeito farmacológico contém sempre uma mistura complexa e variável de químicos, sendo difícil controlar seus efeitos. Os princípios ativos se modificam em quantidade e qualidade de acordo com o ciclo da planta, com as variações climáticas (chuvas, calor, frio, etc), as condições do solo, etc. Fora as adulterações que eram bastante comuns. 
A busca pela essência do ópio e a criação do primeiro alcaloide, a morfina, também pode ser creditada ao entendimento cada vez mais difundido da necessidade de conhecer produtos com efeitos químicos comprovados e, principalmente, estáveis. Era impossível estabelecer uma posologia precisa do ópio por causa dessas inseguridades próprias dos fitoterápicos. A partir do desenvolvimento dos alcaloides foi possível precisar as substâncias, fato de enorme significado para a terapêutica e para o imaginário em torno dos fármacos em geral. A disponibilidade das essências vegetais relativizou as interpretações mágicas sobre os efeitos das plantas, tornando-as definitivamente livres da mitologia. Essas características dos alcaloides permitiram cada vez mais "marcar a distância entre a medicina popular e a medicina cosmopolita" 23 (ESCOHOTADO, 2008, p.426). Além da farmacologia, propriamente dita, também se desenvolve a etnobotânica e a busca pelos saberes tradicionais sobre as plantas visando à descoberta de novas substâncias químicas estáveis. Toda a toxicologia começa a ser revisada a partir de então (ESCOHOTADO, 2008, p.421-423).

Por ora, gostaria apenas de salientar o contexto social e cultural que permitiu o desenvolvimento da ciência dos alcaloides. Veremos, com detalhes no Capítulo quatro, como foram utilizados os derivados alcaloides do ópio e da coca na medicina oficial do Brasil ao longo dos oitocentos. Mais do que avanços que se impuseram pela sua superioridade tecnológica, esses novos recursos tiveram que dialogar com as técnicas e as epistemologias então vigentes, perdurando como instrumentos terapêuticos até meados do século XX.

O foco da última seção desse Capítulo recairá sobre as mudanças no interior da terapêutica oficial, o que nos leva a segunda inovação importante do começo do século XIX. O entendimento sobre a enfermidade sofrerá mudanças importantes com a consolidação da anatomoclínica na França republicana. Conforme demonstrou Foucault (2013), essa teoria se fundou na transformação do sujeito - e seu corpo - em objeto da experiência clínica. Nessa epistemologia era fundamental estabelecer uma relação entre os sintomas e a anatomia, cabendo ao médico a identificação do signo capaz de diagnosticar o patológico. Isso explica o recurso ao tato, à audição, a medição do pulso e de tudo aquilo que podia contribuir para identificar a lesão. Diferente do pensamento clínico anterior, que procurava inserir as experiências individuais colhidas no leito em uma série estatística com objetivo de buscar regularidades, a anatomoclínica visaria o

\footnotetext{
23 "marcar distancias entre medicina popular y medicina cosmopolita" - tradução sugerida.
} 
conhecimento da doença independente do doente a partir da lesão. Essas considerações tiveram uma "profunda ressonância em toda a cultura médica acadêmica, dentro e fora da Europa" (EDLER, 2001, p.929) tornando-se "a primeira tradição médica verdadeiramente internacional" (EDLER, 2001, p.929).

A medicina francesa tornou-se a referência fundamental das instituições de ensino médico que passaram a se desenvolver no Brasil durante o século XIX, fato que ajudou na divulgação dos princípios anatomopatológicos. Essa inovação no campo epistemológico oficial não acabou, pela sua superioridade, com tudo aquilo que se praticava na terapêutica até esse momento. Mostrarei abaixo que, pelo contrário, houve intensa negociação com as concepções então vigentes, principalmente com a tradição hipocrática.

Vimos, anteriormente, que, a partir do século XVIII, o contato dos portugueses com as novas teorias anatômicas significou uma abertura no pensamento escolástico, culminando na mudança nos Estatutos da Universidade de Coimbra. No que se refere aos cirurgiões que atuavam no comércio colonial, houve também uma intensificação dos intercâmbios com outras comunidades científicas, a maior proximidade dos cirurgiões lusos com os tratados médicos antilhanos e a criação de associações que orientavam a matéria médica em direção as ciências naturais. Isso contribuía para alterar os padrões médicos tradicionais. A necessidade de tratar escravos com doenças desconhecidas teria provocado uma inflexão no entendimento sobre as enfermidades, diminuindo a influência dos humores e ampliando a concepção de que os cativos tinham uma adaptação melhor ao clima e regime de trabalho tropical. Todos esses fatores teriam contribuídos a

\footnotetext{
"uma tendência em deixar de lado as velhas teorias dos humores e, principalmente os remédios de segredo, em favor dos produtos fornecidos pela flora e fauna medicinais, bem como por meio da correspondência entre as doenças e os fatores físicos e geográficos, atribuindo a suas causas ao clima, aos ventos, à qualidade dos alimentos e das águas" (WISSENBACH, 2009, p.297).
}

Esse processo descrito por Wissenbach (2009) acima, se ampliaria ao longo do século XIX. De acordo com Edler (2001), no século dezenove se percebe uma ruptura das antigas concepções de meio ambiente do hipocratismo com o advento da climatologia. Os novos métodos de análise seriam totalmente distintos dos antigos. 
Instrumentos meteorológicos - termômetro, barômetro, pluviômetro, aparelhos para medir a velocidade dos ventos, da composição química do ar, o eudiômetro - dava aos físicos a possibilidade de inserir em séries sistemáticas antigos conceitos. Se a grande reputação de Hipócrates estimulava os estudos de fatores ambientais, o "conceito de meio era preenchido por entidades físicas totalmente diversas, em interação com processos fisiológicos radicalmente estranhos a fisiologia humoral" (EDLER, 2001, p.927). Dessa forma, a partir do século XVIII, as bases de estudo daquilo que era entendido como hipocratismo se alteraram bastante daquelas do renascimento e da antiguidade, pois seus princípios ambientais foram traduzidos nos termos físicoquímicos ou orgânicos entendidos pela medicina oficial como indicadores das patologias (EDLER, 2012, p.27-52).

Importante ressaltar que essa leitura dos fatores ambientais, atualizada com padrões científicos da época, não era incompatível com os preceitos da anatomoclínica. A literatura médica do início do século XIX dá exemplos disso. Os periódicos médicos, que tinham grandes dificuldades de sobreviver economicamente por causa da falta de recursos e de leitores, tiveram que inicialmente se dirigir para um público mais amplo. Essa situação ficava latente na análise dos editoriais dessas revistas. Esse fato acabava obrigando "os médicos-periodistas ao confronto direto com as opiniões leigas a respeito da medicina" (FERREIRA, 2003, p.104).

Foi com esse objetivo que, em 1836, a Revista Médica Fluminense, que era a revista oficial da Academia Imperial de Medicina (AIM), lançou um longo artigo "esclarecendo como cada uma das teorias médicas em voga concebia a natureza da doença" (FERREIRA, 2003, p.114). De Hipócrates a Galeno, passando pelo mecanicismo de Boerhaave, do vitalismo até as teorias anatomopatológicas emergentes no final do século XVIII, cujo maior expoente foi Broussais, tal matéria teria o objetivo de

\footnotetext{
"chamar a atenção para as profundas diferenças entre as doutrinas antigas e as teorias médicas daquele tempo. Enquanto o humorismo definia a doença como resultado de alterações dos fluidos corporais (humores) a medicina moderna procurava explicar os fenômenos patológicos localizando-os nas lesões observáveis nos tecidos orgânicos" (FERREIRA, 2003, p.114).
}

Apesar desse aparente antagonismo entre hipocratismo e anatomoclínica, a leitura do artigo dá exemplos de várias intersecções possíveis. Segundo o citado artigo, 
embora o problema médico na teoria de Hipócrates não fosse "observado nos tecidos orgânicos, e é nisto que a medicina dessa época difere mais da dos nossos dias" (RMF, 1836, p.409), o estado mórbido continua sendo "um combate dos órgãos contra humores, donde nasciam as crises" (RMF, 1836, p.409). Somadas às contribuições de Galeno, essas ideias "por muitos anos servirão de base ás crenças dos médicos, e conservaram-se até hoje confundidas em todos os sistemas de medicina em proporções mais ou menos abundantes" (RMF, 1836, p.411). Era ao mecanicismo de Boerhaave "que se devem as maiores considerações sobre o papel dos humores na moléstia" (RMF, 1836, p.412). Foi a partir de suas ideias que a medicina saiu das abstrações e penetrou na realidade dos órgãos, na medida em que as doenças passam a ser entendidas como uma congestão de humores que obstruem as vísceras e se opõem ao livre exercício das suas funções. A terapêutica continuaria, portanto, sendo a iniciativa de provocar evacuações. Graças a Boerhaave "todas as ideias do hipocratismo foram antes obumbradas do que esclarecidas pelas noções, que a mecânica podia facilitar a apreciação das modificações, que humores naturais apresentam algumas vezes no estado de moléstia" (RMF, 1836, p.414). É por isso que para muitos práticos "o humorismo racional está hoje posto em evidencia, depois de ter sido admitido, por assim dizer, intuitivamente pelos antigos" (RMF, 1836, p.414). Não é por acaso que, ao final do texto, ao enumerar todas as condições passíveis de provocar moléstias, também aparece a "hiperdiacrinia variável segundo o órgão segregante, e depois segundo as qualidades dos fluidos" (RMF, 1836, p.449).

Se a teoria permite esse tipo de simbiose, o exame clínico baseado nos preceitos anatomopatológicos também é bastante permeável a outras concepções de doenças. Conforme caracterizei acima, ele se fundamenta na busca pelo corpo dos sinais patológicos capazes de identificar a lesão, antecipar o patológico. Dessa forma, são feitos do exame físico, percussão mediata, estetoscópio, etc, e, posteriormente, confirmar o diagnóstico através da autópsia e da identificação da patologia tissular. Esses procedimentos adotados pelo físico na busca pelo sinal patológico através dos sentidos foram denominados por Edler (2003, p.145-147) como epistemologia sensualista. Embora a anatomopatologia fosse o critério de cientificidade, os procedimentos de obtenção do diagnóstico eram fracos porque se baseavam na capacidade dos físicos e cirurgiões em "agir de acordo com o protocolo sensualista imposto pela educação médica emblematicamente traduzidos pela ideia algo obscura de ‘tato clínico"” (EDLER, 2010, p.744). Essa fragilidade metodológica, que não diminuía 
o caráter científico e a ênfase no empirismo, permitiu a coexistência de diversas correntes entre os curadores acadêmicos. Não existia, portanto, oposição inconciliável entre a clínica anatomopatológica e o neohipocratismo.

A persistência do hipocratismo era um fator que aproximava as concepções científicas da pequeníssima parcela de doutos e as concepções difundidas entre os leigos. A popularidade do hipocratismo na população pode ser medida também através dos resultados da pesquisa de Lima (1996), que procurou desvendar, do ponto de vista material, a "emergência de um modo de vida burguês no Rio de Janeiro do século XIX" (LIMA, 1996) através de escavações em unidades domésticas, unidades de produção e espaços funerários, demonstrando a forte presença cultural das concepções hipocráticas no cotidiano carioca. Foram encontradas grandes quantidades de frascos com substâncias laxantes, instrumentos para a aplicação de clisteres, para a remoção de excrementos e recipientes para recolhimento de matérias fecais e urinas, os populares "urinóis". Conforme apontado no primeiro Capítulo, esse estudo também registrou a presença de tabaqueiras para guardar tabaco em pó, usados para provocar espirros e favorecer a eliminação de humores mucosos. Conforme lembra Carneiro (2010, p.177179), essas concepções também se expressam nos significados que os usos de bebidas alcoólicas adquiriam, tanto fermentadas, quanto destiladas.

Portanto, todas as inovações metodológicas trazidas na leitura dos fatores ambientais faziam do hipocratismo uma tradição médica presente e atualizada com os padrões científicos da época. Compatível, inclusive, com a anatomoclínica e com as percepções mais gerais da população sobre adoecimento. Existe, entretanto, uma tendência bastante marcante de usar a expressão hipocratismo como uma forma de desqualificar os padrões de cientificidade do século XIX. Como bem apontou Edler (2003, p.139), a "medicina acadêmica imperial, suas instituições, crenças e personagens não gozam de boa reputação entre os historiadores brasileiros”. Parte dessa má reputação que paira sobre a medicina acadêmica do século XIX foi construída em fins desse século e no início do século XX, como meio de afirmação de uma nova classe de cientistas especializados. Eles lutavam contra uma matriz cultural ibero-americana que teria estagnado o ensino superior até 1870 (EDLER, 2003, p.139-141).

"E nessa crítica, além da censura ao enciclopedismo humanista, incluíram também o que chamavam de o 'empirismo' da clínica médica com suas 
terapêuticas baseadas nas argúcias da memória em bem relacionar conhecimentos teóricos a casos clínicos" (SÁ, 2006, p.185).

Tradição bacharelesca que passou a ser simbolicamente associada a um obstáculo ao progresso do país. É no final do século XIX que se construí um discurso que liga o hipocratismo a especulação física. $\mathrm{Na}$ visão da historiografia biomédica triunfalista, a fundação das escolas médicas da Bahia e do Rio de Janeiro, apesar de ser um marco de profissionalização importante, não teria conseguido alterar esse quadro, pois adotando

\footnotetext{
"sistemas e teorias médicas antiquados, alguns já ultrapassados na Europa, baseando-se nos tratados e compêndios franceses - lidos no original ou traduzidos - os professores das duas escolas nacionais ministravam uma ciência eminentemente teórica, profundamente livresca" (SANTOS FILHO, 1991b, p.11).
}

O discurso que liga o hipocratismo às especulações e a ausência de critérios racionais e científicos foi uma construção ideológica do final do século XIX, momento em que os cientistas de laboratório buscavam sua afirmação social, conforme veremos mais abaixo. As críticas à medicina oficial do Império não se reduziam, porém, a uma disputa corporativa por legitimidade científica. A má reputação da medicina imperial entre os historiadores e historiadoras também provém da relação que esses médicos estabeleceram com as classes populares.

Sampaio (2001) foi uma autora que procurou enfatizar o antagonismo entre saber médico oficial e erudito e as crenças disseminadas na população. A medicina acadêmica, exclusiva dos setores de elite, falhou em conquistar a confiança das pessoas. Graças a esse fato os médicos teriam tido pouco retorno do mercado, fazendo que eles buscassem apoio das autoridades imperiais para banir, da forma mais agressiva, o charlatanismo fruto da ignorância do povo. A medicina científica nesse contexto seria ainda rudimentar, ainda nos seus primeiros passos, sem a eficácia capaz de diferenciá-la de seus concorrentes.

Nessa leitura os "médicos teriam forjado uma ciência apenas como um escudo protetor contra os seus concorrentes leigos, muito mais numerosos e procurados", havendo "uma mera briga por mercado" (GUIMARÃES, 2003, p.25). Outros autores adeptos da hipótese do antagonismo entre popular e erudito ainda apontam que esta medicina não teria um corpo teórico e prático organizado, carecendo algumas vezes da 
completa noção dos procedimentos médicos que praticavam. Soberbos e afrancesados, eles desrespeitavam fundamentos religiosos e mágicos presentes no cotidiano da população. Além disso, suas iniciações na ciência europeia lhes colocariam na oposição aos conceitos patriarcais de moral, justiça e política (GUIMARÃES, 2003, p.22-25).

A ênfase na persistência do caráter tradicional das curas e na oposição radical das práticas populares e a medicina acadêmica ocorrem, em grande parte, porque essas pesquisas procuravam se contrapor a hipótese da medicalização da sociedade. Segundo essa hipótese, os médicos teriam sidos responsáveis pela formação de um ideário higienista que serviu para implantar a ordem burguesa contra os costumes da antiga sociedade patriarcal (MACHADO et al, 1978; COSTA, 1979) ou para controlar e dominar as classes perigosas ou indesejáveis (CHALHOUB, 1996). O que se percebe nessas perspectivas é uma explicação heterônoma da institucionalização da medicina no Império (EDLER, 2003, p.140-141).

Em consonância com Edler (2003) e Guimarães (2003), acredito ser necessário trazer uma visão mais dialética, com intuito de relativizar as dualidades redutoras como são ciência/metafísica e moderno/tradicional. É preciso se contrapor, de um lado, ao discurso evolucionista biomédico que tendeu a menosprezar as terapêuticas desenvolvidas a partir da tradição clínica oficial. De outro lado, a historiografia que buscou obscurecer a amplitude e a apropriação que a população fazia dos alcaloides e das técnicas acadêmicas ao enfatizar o tradicional em oposição à medicalização da sociedade.

Com esse objetivo, pretendo fazer algumas observações a respeito da literatura médica do século XIX, principalmente no que se refere aos formulários. Vimos acima que os principais jornais médicos na primeira metade do século XIX sofreram muito com o desinteresse dos físicos e dos cirurgiões no debate científico, fato que obrigou os editores a se direcionarem ao público leigo. (FERREIRA, 1999, p.331-334; FERREIRA, 2003, p.103-104). Essa situação de desinteresse, entretanto, contrasta enormemente com a popularidade e o sucesso editorial que obtiveram os manuais de medicina, cujos mais conhecidos foram os lançados por Pedro Luiz Napoleão Chernoviz (1812-1882).

"Diante da impossibilidade de fazer frente à presença dos terapeutas populares, essas obras de vulgarização da medicina constituíram, sem dúvida, 
uma espécie de substituto dos médicos, que delegavam suas funções aos ‘doutores' de papel” (FERREIRA, 2003, p.117).

O sucesso dos manuais desse médico chega até a obscurecer a existência de vários outros precedentes e contemporâneos a ele. Na verdade, a circulação desse tipo de livros é bastante tradicional, acompanhando o desenvolvimento da impressão. Desde o século XVIII, os manuais de medicina prática se tornaram muito difundidos na Europa visando à aproximação das áreas rurais, que tradicionalmente careciam de médicos acadêmicos, com as teorias médicas vigentes. Os mais famosos foram: $A$ medicina doméstica do escocês William Buchan (1729-1805), que teve mais de 100 edições e foi traduzido para praticamente todas as línguas europeias; Aviso ao povo sobre a sua saúde do suíço Samuel Tissot (1728-1797) que teve 47 edições em francês e foi traduzido em 15 línguas; Curso de Matéria Médica do escocês Willian Cullen (1710-1790) que, além de ter várias traduções, serviu de referência para o médico alemão Samuel Hahnemann (1755-1843) fundador da homeopatia. Eles eram divididos pedagogicamente em temas e eram direcionados para o público rural que não tinham acesso aos médicos (Tissot) ou para as donas de casa e mães que precisavam saber como melhor cuidar das crianças e do restante da família (Buchan). Entre as causas das doenças, esses autores

\footnotetext{
"concordam que todas dependem de um grande número de condições adversas, ou do próprio indivíduo ou externas a ele e se dedicam a estudar os temperamentos, os sentimentos, as variações atmosféricas, o clima, as variações térmicas - que predispõem os indivíduos às doenças [...] fiéis a medicina acadêmica tradicional que aspira afastar os charlatões de seu caminho" (GUIMARÃES, 2003, p.41-42).
}

Embora Guimarães (2003) em nenhum momento esteja preocupada em caracterizar ou apontar a influência do hipocratismo, parece bastante claro nessa passagem destacada e em outras de sua Tese a influência dessas concepções, conforme já caracterizei. O manual de Buchan foi o mais popular do Brasil Colonial e Imperial até o advento de Chernoviz em meados do XIX (SANTOS FILHO, 1991b, p.437-438; GUIMARÃES, 2003, p.53). Esse tipo de empreendimento intelectual serviu de modelo para a escrita de outros manuais, como o Erário Mineral, de 1735, já citado. Este livro foi um dos primeiros tratados de medicina brasileira de grande circulação, divulgando "uma ciência que possuía sua gênese em concepções astrológicas, diretamente 
vinculadas ao conceito de influências, das simpatias e antipatias da natureza antropomórfica, e de efeito à distância" (GUIMARÃES, 2003, p.39). Essas concepções estão de acordo com os fundamentos mais holísticos ensinados em Portugal antes das reformas da Universidade de Coimbra em 1772.

O Erário Mineral não foi o primeiro escrito em língua portuguesa a tratar do quadro nosológico da Colônia ${ }^{24}$, porém se distingue dos demais por não se direcionar a administração colonial na descrição dos problemas locais e das condições que favorecem as epidemias, mas ao público interessado em obter conhecimento de procedimentos médicos capazes de ajudá-los nos problemas cotidianos (WISSENBACH, 2002, p.115). Ele também manteve o modelo inaugurado por Buchan de destinar uma sessão de seu tratado para a arte de formular remédios, que trataremos logo abaixo.

No início do século XIX, a partir da institucionalização do ensino médico no Brasil, vários físicos que atuavam na AIM se aventuraram no mercado editorial dos livros de medicina prática. Jean-Baptiste Alban Imbert escreveu o Manual do Fazendeiro, que teve duas edições, o Guia Médico das Mães de Família, de 1843, e o Ensaio Higiênico sobre o Clima do Rio de Janeiro de 1837. Luiz Francisco Bonjean publicou $O$ Médico e o Cirurgião da Roça e Primeiros Socorros. Theodoro Langgard foi autor do Dicionário de Medicina Doméstica e Popular e do Formulário Médico. Este último, ao lado de Chernoviz que veremos logo abaixo, foi obrigatório nas farmácias até a publicação da Farmacopeia Brasileira em 1929. Esses manuais estão em consonância com o espírito dos seus antecessores que é dar instruções de higiene às populações de regiões rurais carentes de médicos formados. Munidos dos pressupostos climáticos e anatomoclínicos característicos do ensino médico do período, eles são fieis ao ideal pedagógico iluminista, com inspiração higienista, filantrópica e civilizadora (GUIMARÃES, 2003, p.43-45). Esses manuais "desempenhavam o papel de divulgadores do conhecimento médico, estabelecendo uma comunicação entre o saber

\footnotetext{
${ }^{24}$ Simão Pinheiro Morão escreveu o Tratado único das bexigas e do sarampo de 1683; João Ferreira da Rosa escreveu o Tratado único da constituição pestilental de Pernambuco em 1694; Miguel Dias Pimenta escreve o livro Noticia do que é o achaque de bicho em 1707; José Rodrigues de Abreu publicou Luz de cirurgiões embarcadiços, que trata das doenças epidêmicas de que costumam enfermar todos os que embarcam para as partes ultramarinas em 1711, e o livro Historiologia médica em 1732. Este autor ainda publicou em período posterior ao Erário Mineral a obra Relação cirúrgica, e médica, na qual se trata, e declara especialmente um método para curar a infecção escorbútica, ou mal de Luanda em 1741. Essa relação de obras foi apresentada por Wissenbach (2002, p.114). Para uma visão completa do universo documental disponível no período, ver Santos Filho (1991a, p.57-86).
} 
acadêmico (estruturado e sistematizado) e o conhecimento popular" (FIGUEIREDO, 2005, p.65).

Para efeito de comparação, nos EUA esse tipo de empreendimento editorial também foi bastante exitoso, tanto na venda dos clássicos internacionais citados acima, quanto de outros manuais produzidos pelos próprios estadunidenses. Esses guias eram escritos por médicos e leigos com objetivo de divulgar conhecimentos botânicos, ecléticos, homeopatas, hidropatas, remédios vegetais que evitassem a sangria e outros temas que se acreditava ter utilidade doméstica (GUIMAR ÃES, 2003, p.28-29). Ao contrário do que ocorria nos EUA,

"onde esses manuais eram a expressão de um movimento de afirmação de setores da medicina popular contra os privilégios reivindicados pela profissão médica, no Brasil esse tipo de literatura era produzida por médicos com a chancela da Academia Imperial de Medicina (AIM)" (Edler et al, 2003, p.129).

Dentre todos os manuais produzidos no Brasil durante o período imperial com esse tipo de proposta, os mais populares foram sem dúvidas aqueles escritos por Pedro Luiz Napoleão Chernoviz, o misterioso doutor capa preta, que ninguém vê a cara, porém todo mundo conhece. ${ }^{25}$ Para se ter uma noção da popularidade de seus livros, o Formulário ou Guia Médico teve dezenove edições em português e três em espanhol, ultrapassando as fronteiras da América portuguesa (GUIMARÃES, 2003, p.34).

Chernoviz nasceu na Polônia em 1812, lutando quando adulto contra a ocupação russa que o levou a se exilar na França. Estudou e se formou em medicina na escola de Montpellier, se filiando ao exército polonês em fins dos anos de 1830. Desembarcou no Rio de Janeiro em 1840 em missão militar, porém decidiu ficar na cidade e exercer a clínica. Validou seu diploma e se filiou na AIM, ficando no Brasil até 1855, quando voltou para a França. ${ }^{26}$ No período que esteve no Brasil, foi responsável por um dos mais exitosos empreendimentos editoriais de meados do século XIX, iniciativa que contrariou as expectativas pessimistas dos principais empresários do setor, tendo em vista os problemas enfrentados anteriormente com as revistas médicas.

\footnotetext{
25 "Dr. Pedro Luiz Napoleão Chernoviz / Tem a maior clientela da cidade / Não atende a domicílio / Não tem escritório / Ninguém lhe vê a cara / Misterioso doutor capa preta [...] Esse que cura todas as moléstias / De preferência as incuráveis / Socorre os afogados / Asfixiados / Assombrados de raio / Sem desprezar defluxo, catapora / Sapinho, nariz cobreiro/ Bicho do pé, andaço, carnegão..." Verso de Carlos Drummond de Andrade apresentados originalmente no artigo de Figueiredo (2001).

${ }^{26}$ A trajetória completa desse médico e sua inserção na sociedade da corte foram apresentadas por Guimarães (2003, p.57-77).
} 
Esses manuais, de forma geral, se colocavam como porta-vozes de mensagens civilizadoras e iluministas uma vez que esses eles se apresentavam como instrumento de popularização da ciência. Esse intento não estava isento do dilema ético e de conflitos com os objetivos de monopolização da terapêutica por parte das instituições oficiais, que defendiam ser somente o médico e o cirurgião formados aptos a realizar operações terapêuticas (GUIMARÃES, 2003, p.47). A carência de médicos no interior do país e a rejeição que a população tinha à medicina oficial abriu espaço para esse tipo de iniciativa. Por isso, em 1842, a publicação e o sucesso das obras de Chernoviz "foi aplaudida como fato de suma importância para o esforço de popularização da medicina" (FERREIRA, 2003, p.117).

O dilema nascido da necessidade de popularizar a medicina oficial, por um lado, e de monopolizar a prática terapêutica, por outro lado, levaram esses manuais a conciliar os argumentos da indispensabilidade de um médico com a popularização dos procedimentos terapêuticos e cirúrgicos. Apesar dos avisos constantes para buscar auxílio médico sempre que possível, é relevante perceber que existiam, em quase todos os manuais, orientações para a realização de amputações - considerada até fins do século XIX uma cirurgia de alta complexidade (GUIMARÃES, 2003, p.49-52). É possível aferir desse fato que tais livros foram responsáveis pela instrumentalização de inúmeros cirurgiões e terapeutas práticos. Também é plausível pensar que tais orientações não eram tão distantes das praticadas pela ciência oficial, fato que reforça a relativização do antagonismo entre cultura popular e medicina acadêmica.

Esses manuais também se predispunham a ensinar a arte de formular remédios. Nós vimos que desde o período colonial eram populares os medicamentos com fórmulas secretas. Muitas dessas fórmulas consagradas eram publicadas nesses manuais, às vezes gerando polêmica. Foi o caso do livro Relação cirúrgica e médica: composta por João Cardoso Miranda, cirurgião aprovado de 1751. Nele foi publicada a fórmula de um remédio para o escorbuto. Essa publicação se fazia necessária, segundo o autor, porque ele já tinha encaminhado a fórmula às autoridades públicas, que a desdenharam, e também porque ela tinha sido apresentada errada no Erário Mineral. Miranda acabou gerando a ira dos físicos que ficaram indignados com a presunção de um 'reles cirurgião' em atrever-se a curar em medicina (MARQUES, 2003, p.168-171).

Uma das mais antigas coleções de receita, da Europa, foi Antidotarium produzida no interior da Escola de Salerno no século XIII (SANTOS FILHO, 1991a, p.335). Nós vimos, no primeiro Capítulo, a importância dessa escola na divulgação do 
saber herbário clássico e na revalorização do ópio como instrumento terapêutico no período medieval. O advento da impressão, em fins do século XIV, teve como correlato o início da divulgação de compêndios de fórmulas - com alguns títulos em português. No final do século XVIII já eram variados os títulos publicados, tanto em português, quanto em outras línguas, que ocasionavam inconveniências e enganos. Isso motivou D. Maria I a oficializar, em 1794, a Farmacopéia geral para o Reino e Domínios de Portugal, publicada por ordem de sua Majestade (SANTOS FILHO, 1991a, p.335339).

Todas as pessoas que eram formadas nos quadros oficiais do ensino médico aprendiam a arte de formular remédios, embora esse fosse um privilégio dos físicos. Essa arte, entretanto, não ficou restrita a eles, estendendo-se aos cirurgiões e farmacêuticos e, até, aos leigos. Os manuais de medicina dos séculos XVIII e XIX também eram didáticos em relação a isso - a maioria possuía uma seção intitulada "Formulário" onde eram descritos a forma e os ingredientes necessários para produzir os medicamentos indispensáveis à prática médica. Vale ressaltar que nas revistas médicas do século XIX também era frequente a publicação de receitas úteis.

Uma boa maneira de avaliar a utilidade dos fitoterápicos e dos seus alcaloides é verificarmos como eles apareciam nos Formulários publicados nas obras de Chernoviz. Na edição do Dicionário de Medicina Popular, de 1851, o autor recomendava que a botica caseira contasse com três pílulas de extrato de ópio. Na edição de 1890, esse número subia para vinte e quatro. Eles deveriam ser usados como calmantes, analgésicos e para obter o sono (hipnóticos). Além disso, o ópio aparecia como remédio útil em mais de 40 verbetes, atestando a variabilidade de males que era direcionado. Ele também ensinava a extraí-lo diretamente da papoula. O cloridrato e o sulfato de morfina também eram substâncias presentes, sendo precisa a posologia e os procedimentos necessários para a aplicação via injeção hipodérmica. Igual ao ópio, ela foi ampliando sua presença no dicionário. Na década de 1850, contava com apenas um parágrafo que explicava suas propriedades, alertando que era mais forte que o ópio. Na edição de 1890, o verbete sobre essa substância "desdobrava-se em diversos sais como acetato, cloridrato e sulfato de morfina com explicações sobre suas utilidades e formas de uso, totalizando quase três páginas sobre o assunto" (SARTI, 2015, p.43). Ainda é possível encontrar os verbetes sobre a Cannabis índica, sativa e o haxixe. Ele conta com uma rica descrição dos usos ao redor do mundo, apontando tanto os efeitos narcóticos, como também indicações sobre a fabricação de tecido e de óleo para fabrico de lamparinas e 
sabão. A coca aparece desde antes da invenção da cocaína como alimento energético. A cocaína é saldada por Chernoviz como "uma das descobertas mais úteis e brilhantes da medicina moderna" (CHERNOVIZ apud SARTI, 2015, p.47). Ela era vendida na forma de cristais e podia ser dissolvida em álcool ou éter. Sua aplicação mais comum era na forma aquosa por meio de injeções subcutâneas, porém também na forma de colírio sempre que necessária operação nos olhos. A ação anestésica da cocaína podia ser direcionada para quaisquer procedimentos cirúrgicos que envolvessem a boca, olhos, nariz ou órgãos genitais. Além dessas aplicações clínicas, ela também era

\footnotetext{
"empregada domesticamente na analgesia de dores estomacais, dentárias, e, assim como o ópio, no tratamento dos inconvenientes da gravidez como vômitos e rachaduras do seio decorrentes da amamentação. Até mesmo para os enjoos causados pelo balanço do mar eram recomendáveis poções contendo cloridrato de cocaína" (SARTI, 2015, p.49).
}

Essa grande lista de usos era acompanhada de advertências. O ópio e a morfina administrados de maneira excessiva poderiam gerar o óbito do doente. A cocaína em excesso gerava palidez, vertigem e enfraquecimento, podendo também levar a morte em casos extremos (SARTI, 2015, p.41-54). O que se percebe, a partir dessa exposição, é que as orientações científicas ensinada nesses manuais, durante todo esse período, estiveram intrinsicamente ligadas à arte de formulação de remédios.

Com base nessas informações é possível verificarmos a existência de alguns tipos de remédios. Existiam aqueles cujas fórmulas eram secretas, já tratados anteriormente, e que estavam disponíveis ao público sem necessidade de receita. Eles alimentavam uma cultura da automedicação e eram odiados pelos médicos formados, porque a arte de formular era formalmente uma exclusividade sua e porque os efeitos analgésicos e estimulantes inibiam as pessoas a procurarem seus serviços. Altamente concentrados e de composição obscura, podiam representar um risco para a saúde daqueles ou daquelas que usavam.

Além dos remédios com fórmulas secretas, ainda existiam outros dois tipos que estavam na base da terapêutica alopata: os officinaes, que eram xaropes, vinhos, extratos, tinturas, conservas, emplastos e unguentos cujas fórmulas eram previstas nos códigos farmacêuticos e que eram encontrados prontos nas boticas e farmácias; os magistrais, que eram os preparados pelos físicos segundo as necessidades específicas do pacientes (TEIXEIRA et al, 2012, p.64-65; EDLER et al, 2003, p.133-134). Durante 
todo esse período, a utilização de vários componentes na formulação do remédio era visto como propriedade de alto valor, independente se existia ou não razão para esses acréscimos - vimos isso na caracterização da polifarmácia medieval.

Procurei caracterizar, ao longo desse Capítulo, a terapêutica e o remédio tradicional e como eles foram se transformando ao longo do tempo. O hipocratismo, que é uma tradição médica milenar, foi parte integrante das concepções terapêuticas do período - embora o que se entendesse por equilíbrio, corpo, meio, etc variasse ao longo do tempo. As inovações que foram introduzidas no ensino médico oficial, a ciência dos alcaloides e a anatomoclínica, se mesclaram nessas epistemologias mais antigas gerando um caldo cultural que denominarei a partir de agora de neohipocratismo. Vimos também que os manuais de medicina tiveram um papel importante nos intercâmbios entre o campo terapêutico popular e o acadêmico.

Antes de finalizar esse Capítulo, ainda é preciso que abordar uma terceira e última inovação que gerou intensos debates na prática médica oficial e na tradição neohipocrática brasileira: microbiologia e a medicina experimental. Esse campo de estudo e práticas científicas tem sido tomados como marcos revolucionários da medicina, ponto de intersecção que mudou radicalmente o que se fazia até então. Claude Bernard, médico cirurgião francês considerado um dos fundadores da medicina experimental, acreditava que até ele toda a medicina

\footnotetext{
“então praticada era hipocrática. Segundo ele, o hipocratismo teria como característica a proposta de uma medicina de observação e, por isso mesmo, de uma medicina passiva, contemplativa, descritiva como uma ciência natural. São hipocráticos, portanto, todos os médicos modernos preocupados com a definição e classificação das doenças e com o diagnóstico e prognóstico e não com a cura" (FERREIRA, 1993, p.50).
}

Nesse mesmo embalo, a historiografia triunfalista tende a associar esses eventos ao nascimento da medicina científica no Brasil.

\footnotetext{
"Entravada por uma formação pedagógica deficiente e de sabor puramente retórico, não estimulada e quase que ignorada pela administração pública que a auxilia com usura, avança a Medicina no Brasil, apesar dos óbices encontrados, para um estágio de estudos e adoção de métodos experimentais de investigação que a elevam a nível verdadeiramente 'científico', onde se acentua o caráter nacional, a ponto de poder-se, nos dia que correm, chama-la de "Medicina Brasileira" (SANTOS FILHO, 1991a, p.13).
} 
Essa medicina é nacional, porque deixara de ser mera cópia do que se produzia no exterior, e verdadeiramente científica, porque baseada em experimentos laboratoriais. São expoentes dessa nova fase Osvaldo Cruz, Adolfo Lutz, Carlos Chagas, Vital Brazil, Pirajá da Silva e outros. Todos esses homens eram ligados aos institutos de pesquisa, como o Manguinhos, o Bacteriológico e o Butantã (SANTOS FILHO, 1991a, p.12-13). A ênfase nos avanços científicos, nos principais pesquisadores e suas instituições faz parte de uma retórica triunfalista e evolucionista que marca o discurso tecnicista até hoje.

A historiografia contemporânea a qual procuro me inspirar, entretanto, apresenta esse processo não como a ascensão e queda de paradigmas científicos, mas a partir da coexistência de vários sistemas parcialmente articulados que recebem preposições científicas "a partir de um complexo processo de acomodação, negociação e interpretação, tão contingente quanto aquele envolvido em sua produção" (EDLER, 2012, p.20). Nesse sentido, a helmintologia, identificada como um dos campos experimentais pioneiros no Brasil, estava inicialmente em sintonia com as concepções ambientalistas e anatomoclínicas (EDLER, 2012, p.117-142). Como esse campo de estudo se desenvolveu em um espaço alternativo à AIM, acabou se tornando uma especialidade. Gradativamente, o estudo dos vermes parasitas começa a ameaçar a etiologia da AIM que privilegiava a experiência clínica (baseada na epistemologia sensualista) e a anatomopatologia como explicação legítima da doença. Junto com a microbiologia, depois da consagração de Pasteur, ela foi decisiva para revisar os princípios epistemológicos sustentados pela tradição clínica e higiênica vigente (EDLER, 2012, p.143-269).

A teoria pasteuriana foi marcada por diversas controvérsias envolvendo cientistas em todo o mundo. Na América do Sul e Central existia uma disputa pelo rótulo de 'Pasteur' dos trópicos, porém para tanto era preciso satisfazer as rigorosas regras de verificação elaboradas por Robert Koch e os parâmetros defendidos pela epidemiologia. Esse ramo de pesquisa se converteu no polo mais dinâmico da medicina brasileira, apesar da desclassificação que sofria nos fóruns internacionais. Porém, se fazer ouvir na Europa e América do Norte era apenas um dos desafios encontrados pelos pesquisadores brasileiros na busca por legitimidade científica. Também era necessário

“conquistar lugar e legitimidade para este programa no cenário interno, ainda dominado por um ou mais paradigmas que conferiam grande força a inércia 
das instituições, mentalidades e práticas sociais de médicos e leigos" (BENCHIMOL, 1999, p.12).

Portanto, foi necessária a essas novas especialidades a persuasão dos físicos e leigos praticantes da terapêutica a mudarem suas formas de pensar e de agir. Em fins do século XIX, embora já amplamente aceita a microbiologia, ainda não se tinha certeza nas formas como as doenças eram transmitidas, se existiam relações com o meio ambiente e quais ações, efetivamente, deveriam ser tomadas para efetuar o saneamento. A primeira geração de bacteriologistas teve necessidade de atuar em polêmicas públicas defendendo suas concepções de doenças e a sua legitimidade enquanto médicos e cientistas (BENCHIMOL, 1999).

Durante algum tempo as noções mais recentes do campo da patologia, como a microbiologia e a helmintologia, coexistem com as noções mais antigas do neohipocratismo. Isso pode ser percebido, por exemplo, no desenvolvimento do campo sanitário no Estado de São Paulo. Este estado foi "praticamente o único que se dedicou a uma ampla política sanitária, desde o início da República” (HOCHMAN, 2006, p.40), fato que lhe permitiu dispensar os convênios que caracterizavam as iniciativas federais nesse campo. Isso possibilitou, por exemplo, que o Estado de São Paulo erradicasse a febre amarela na sua forma urbana em 1904, antes do Rio de Janeiro (TELAROLLI JUNIOR, 1996, p.13). A comparação das políticas sanitárias paulistas em saúde pública não tem paralelo na América Latina, pois seus esforços são difíceis de serem observados "até mesmo em países mais avançados da Europa e América do Norte" (HOCHMAN, 2006, p.210). Os períodos limites, criados com o advento das epidemias, podem elucidar as permanências do neohipocratismo brasileiro mesmo nesse cenário de excelência no campo da saúde pública.

No final do século XIX, assim como outras localidades, São Paulo teve que enfrentar o desafio representado pela febre amarela. A política migratória, que gerava forte fluxo de imigrantes, era ameaçada por causa dessa doença. Embora a teoria de Pasteur já fosse conhecida e amplamente aceita, não existia certeza sobre as formas de transmissão da doença. O conceito de miasma, e suas emanações pestilenciais, se combinavam com a microbiologia estabelecendo uma leitura multicausal para a difusão da doença. Essa percepção teve como resultado um "conjunto heterodoxo de técnicas empregadas pela Diretoria do Serviço Sanitário" (TELAROLLI JUNIOR, 1996, p.95). Foram feitos o isolamento hospitalar, a desinfecções dos domicílios e a destruição de 
objetos pessoais dos infectados seguindo os parâmetros bacteriologistas. Por outro lado, ampliava-se a fiscalização da alimentação pública e uma série de obras de melhoria do saneamento que procuravam modificar o ambiente ampliando a salubridade (TELAROLLI JUNIOR, 1996, p.94-95). Essa incerteza em relação à maneira de transmissão da doença não ficou restrita ao círculo médico, tomando as páginas da imprensa diária e opondo diversas autoridades. A teoria da transmissão hídrica, rejeitada pela maioria da classe médica, influenciou inúmeras obras em Santos e em Campinas (TELAROLLI JUNIOR, 1996, p.103-105).

A busca pelo agente causador da febre amarela foi cercada de "elementos de um nacionalismo com características ufanistas que já impregnava as questões de saúde na última década do século XIX" (TELAROLLI JUNIOR, 1996, p.115). Existia forte apoio oficial as pesquisas e um empenho para que o 'Pasteur' dos trópicos fosse brasileiro, sobrepujando a ciência estrangeira. Foi por isso que a confirmação da transmissão pelo mosquito realizado em Cuba gerou incredulidade nos cientistas nacionais. Isso seria admitir o erro de tudo que vinha sendo feito, ainda mais com os bons resultados que estavam sendo obtidos - a epidemia já estava controlada. E o pior: excluía as tradicionais ações sobre a salubridade urbana. Os médicos receavam que, ao aceitarem a nova doutrina, "haveria um aumento da imundice das cidades e um retorno a hábitos pessoais insalubres, com consequências desastrosas" (TELAROLLI JUNIOR, 1996, p.116). Aceitá-la seria reduzir a medicina a mero ramo da zoologia. Experimentos, reproduzindo aquilo que foi realizado em Cuba, foram feitos no Instituto de Bacteriologia e reduzindo as resistências à nova interpretação. Inovações tecnológicas foram realizadas contribuindo para eliminar dúvidas e comprovar a não contagiosidade da febre amarela através do vômito, fezes e roupas. Em 1903, uma missão de Paris veio a São Paulo fazer novos testes, confirmando novamente os resultados. Também as ações visando a erradicação do mosquito, feitos desde 1898, com excelentes resultados, permitiu a erradicação da doença nos meios urbanos em 1904 (TELAROLLI JUNIOR, 1996, p.114-118).

Estava decretada a morte do modelo de intervenção estatal [...] de uma medicina social em sua vertente urbana [...]. Abandonavam-se os resquícios da teoria dos miasmas que ainda havia no modelo de intervenção sanitária [...], e em lugar de um complexo de medidas de saneamento urbano, para o controle da circulação do ar e da água, e da quarentena dos doentes, com seu 
isolamento nos lazaretos, adotava-se em sua plenitude o modelo bacteriológico (TELAROLLI JUNIOR, 1996, p.119)

Se as experiências de Cuba foram suficientes para dar plenitude ao modelo bacteriológico em relação à febre amarela, elas certamente não enterraram a influência do neohipocratismo em São Paulo. Quatorze anos depois, o Estado é novamente assombrado pelo temor de uma nova epidemia: a gripe espanhola. Nos círculos médicos oficiais havia ceticismo quanto à terapêutica que devia ser aplicada, propondo profilaxia individual com base em sais de quinino - para baixar a temperatura corporal. Todo o remédio que tinha esse ingrediente passou a ser anunciado como 'infalível' para a cura da gripe, além de outros que também prometiam curar esse mal. Quando ela efetivamente chegou na capital causou pânico e correria até as farmácias, gerando falta de medicamentos. O Serviço Sanitário passou a distribuir os remédios, acusando os droguistas de estarem especulando com os produtos. Importante, para nosso propósito, é apontar que a incerteza em relação à terapêutica a ser adotada levou o poder público a distribuir variada medicação, desde vacinas para varíola até remédios possuidores de propriedades laxantes e purgativas, em clara sintonia com o neohipocratismo que defendia o expurgo dos humores malignos (BERTUCCI, 2003, 197-206).

$\mathrm{O}$ que se procurou mostrar, com esses exemplos limites representados pelas epidemias em São Paulo, foi a permanência das práticas terapêuticas que eram consagradas pelo neohipocratismo característico do século XIX. A confirmação da existência de bactérias presentes em todos os locais, prontas para atacar e provocar doenças e infecções, contrariava uma ideia de natureza benfazeja que pressupõem que o corpo doente é capaz de recuperar a saúde. Com a maior aceitação da microbiologia gradativamente a fé vitalista perde força e um enorme ceticismo toma conta da terapêutica (SAYD, 1998, p.82-90). Ceticismo que pode ser percebido, também, em relação à ausência de uma orientação terapêutica precisa em relação à gripe espanhola relatada acima.

Uma das principais consequências da aceitação da microbiologia foi a consolidação de uma concepção de doença pensada como autônoma ao doente. Nessa mudança o "remédio passa a ser específico para a doença, e não para o doente, e mais: específico contra a causa da doença, não contra as suas consequências no organismo" (SAYD, 1998, p.92). O ceticismo, nesse cenário, muda de roupagem em relação ao anterior. Até o advento da microbiologia os remédios eram criticados pela pouca 
efetividade que possuíam, depois por serem inadequados para extinguir a doença. $\mathrm{O}$ conhecimento do micróbio "relegou a terapêutica ao estatuto de prática inócua, supersticiosa e primitiva" (SAYD, 1998, p.132). O mesmo não ocorreu com a higiene pública. O conhecimento das bactérias e dos agentes causadores das doenças dava aos sanitaristas a possibilidade de ações mais efetivas na prevenção das doenças, cujo sucesso nas profilaxias adotadas dava prestígio a saúde pública e as políticas implementadas. As medidas contra a febre amarela em São Paulo, descritas acima, são um exemplo. O mito que se construiu em torno de Oswaldo Cruz, outro. Isso permite que a medicina invada, com maior propriedade, o âmbito jurídico. Assim, "naturalização da realidade social corresponde a uma espécie de jurisprudência biológica: a doença passa a ser uma infração ou delito frente à sociedade" (SAYD, 1998, p.139).

Uma das mais curiosas consequências da relação entre higiene pública e terapêutica nesse período é que o desenvolvimento da ideia que a ampliação da higiene pública levaria ao fim das doenças - entre outros, Afrânio Peixoto expôs essa hipótese no livro A antiga e a nova medicina de 1913. Esse prognóstico estava ancorado em um desdém que os sanitaristas alimentavam frente aos "terapeutas ortodoxos do séc. XIX" (SAYD, 1998, p.146) que usavam os novos conhecimentos "segundo os princípios hipocráticos reconstruídos no Iluminismo" (SAYD, 1998, p.146), diferentes do procedimento propriamente científico. A ineficiência da terapêutica contrastava com a microbiologia e a prevenção e tratamento etiológico dela derivada, cuja "eficácia realmente impressionante para a época, com bases científicas nítidas, mudaram o quadro [da ciência médica] de forma rápida e radical" (SAYD, 1998, p.147). Graças a essa situação, "todas as correntes doutrinárias perdem espaço e prestígio, e assim, a própria luta entre elas" ${ }^{27}$ (SAYD, 1998, p.148). A virada do século XIX para o XX é marcada pelo niilismo mais acabado.

\footnotetext{
“A figura do terapeuta se enfraquece, perde importância. Isso porque, ao mito de que a ciência exterminará as doenças, corresponde uma figura de médico um tanto peculiar: a de um educador e disciplinador, um repassador de regras e condutas preventivas ou saudáveis, organizadas para o controle, tanto da natureza externa, hostil, quanto dos próprios desregramentos inerentes às paixões da natureza humana" (SAYD, 1998, p.149).
}

${ }^{27}$ Grifo no original. 
A medicina nesse período parece, portanto, dividida em duas, "entre higiene e terapêutica" (SAYD, 1998, p.154). O médico cientista é o sanitarista que propõe a norma social, e não o terapeuta que tenta salvar as vidas individualmente. O resultado é esse duplo papel que exerce a medicina nessa época;

\begin{abstract}
"um, o do representante de um corpo de normas e conhecimentos, passíveis de acolher o delírio do controle social total; outro, englobado no primeiro, mas submetido a regras mais antigas, não normatizadas de forma explícita, por onde penetram outras facetas do imaginário: o de terapeuta frente a um caso, um doente, uma situação humana" (SAYD, 1998, p.155). ${ }^{28}$
\end{abstract}

Conforme é possível perceber, a despeito da retórica triunfalista adotado por Sayd (1998), é que a ascensão da microbiologia não significou o triunfo imediato da ciência sobre as práticas terapêuticas influenciadas pelo neohipocratismo e seu arsenal terapêutico. Não surpreende, portanto, que Figueiredo (2008, p.113-115) tenha encontrado evidências de um barbeiro que, além de aplicar sangrias, criava e alugava sanguessugas no início do século XX em Belo Horizonte. O Guia Prático de Saúde de Chernoviz continuou a ser atualizado e publicado até o início do século XX.

Prova da vitalidade do arsenal terapêutico neohipocrático na clínica do início do século XX é a obrigatoriedade dos estabelecimentos farmacêuticos disponibilizarem formulários médicos. Essa prática, inaugurada pela Junta Central de Higiene Pública (JCHP) em 1852, seguiu valendo até a promulgação da primeira farmacopeia brasileira (GUIMARÃES, 2003, p.33). Esse regulamento se atualizou diversas vezes, sendo prestigiados pelas autoridades os formulários de Chernoviz e Langgaard. A Farmacopeia brasileira só foi publicada em 1926, sendo revisada em 1943 e, por último, em 1959 (SANTOS FILHO, 1991b, p.386-387). A arte de formular remédios persiste e penetra firme e forte no século XX.

“O médico da segunda metade do século XX já não mais formula. E o
farmacêutico não mais avia receitas, apenas comercializa o que é preparado a
granel nos laboratórios industrializados. Na evolução da Terapêutica,

28 A autora, na sessão do livro apresentada sucintamente acima, também discute o conceito de medicalização da sociedade, tecendo uma crítica à leitura estruturalista derivada dos "mitos denunciados por Foucault" (SAYD, 1998, p.155). Mostrou-se, em outra ocasião, que a relação da agência com as práticas discursivas em Foucault precisa ser matizada, pois a discussão epistemológica das suas últimas obras difere da forma como suas ideias foram apropriadas por parte da historiografia. Sobre essa discussão ver Ribeiro e Torcato (2015). 
desapareceram a farmácia oficinal e a arte de formular" (SANTOS FILHO, 1991b, p.387).

A história dos usos médicos das drogas que hoje são consideradas ilícitas acompanha o longo declínio do neohipocratismo brasileiro. É a época que os profissionais das artes de curar possuíam “o seu 'pecúlio', isto é, o seu caderno de receitas, manuscrito" (SANTOS FILHO, 1991b, p.380). Receitas essas que eram acessíveis à população em geral, consultadas nas farmácias, guardadas juntas as boticas caseiras existentes nas casas mais abastadas, carregadas pelos mais diversos tipos de agentes dispostos a curar ou aliviar as dores e as afecções que não deixaram de existir por causa do maior conhecimento em microbiologia. $\mathrm{O}$ médico, oficialmente, e muitos outros, extraoficialmente, na primeira metade do século XX ainda formulam. As primeiras leis proibitivas serão promulgadas visando controlar e cercear essa cultura que sancionava os usos dos fármacos clássicos em terapêutica na forma de formulários e suas receitas.

\subsection{Conclusão}

Esse Capítulo percorreu a história de alguns séculos, buscando trazer elementos capazes de relativizar a visão bastante difundida que coloca, de um lado, o remédio mágico e não científico cuja eficácia se liga ao efeito sugestivo e, de outro lado, o remédio moderno prescrito com efeitos plenamente conhecidos e esperados. Procurei mostrar que o Brasil, apesar de estar localizado em uma região marginal do comércio transatlântico, também participou do fenômeno da revolução psicoativa. O ópio, com conhecido e comprovado efeito analgésico, esteve inicialmente restrito aos setores de elite que tinham acesso aos remédios europeus - em consonância com a orientação aristocrática da sociedade brasileira. Gradativamente, entretanto, com a ampliação do comércio começou a se generalizar o ópio e outros produtos industrializados, principalmente através do uso de remédios com fórmulas secretas de autores consagrados.

A historiografia triunfalista da medicina tendeu a reduzir a multiplicidade das práticas curativas e teorias etiológicas entre dois grupos: os especuladores metafísicos, agarrados as teorias de Galeno e Hipócrates, e os que promoviam observações metódicas e científicas. Nessa perspectiva, o giro rumo à verdadeira ciência teria ocorrido no final do século XIX graças ao advento da "revolução pasteuriana" e a 
medicina experimental. Procurei mostrar, contrariando essa visão, que as inovações no campo da farmácia e da medicina foram sendo incorporadas pela terapêutica em um processo que envolvia acomodações, negociações, resistências e conflitos com as tradições médicas já existentes.

A crítica à visão triunfalista e evolucionista da historiografia tradicional da medicina não é novidade. Ela vem sendo feita de diversas formas desde a década de 1970, como pode ser percebido nas obras de Machado et al (1978) e Costa (1979). Esses autores procuraram relativizar o marco revolucionário da microbiologia apresentando um processo mais amplo de disciplinarização da sociedade brasileira a partir dos preceitos da medicina social. Esse processo, que teria ganho ímpeto no Império, seria responsável por criar uma relação entre desenvolvimento do Estado e medicina, resultando nas condições adequadas à consolidação de uma sociedade capitalista. Novos estudos, produzidos a partir da década de 1990, procuraram questionar a ideia de medicalização da sociedade no século XIX a partir de recortes temáticos menos abrangentes, porém tendo como horizonte a rejeição da ideia que leva do pitoresco ao racional ou que postula um nexo estrutural entre ciência e sociedade (EDLER, 1998).

Inspirada na crítica ao conceito de medicalização elaborado nos anos de 1990, Sampaio (2001) procurou mostrar que "a crença na medicina científica não era algo consolidado, mesmo no final do Império" (SAMPAIO, 2001, p.149). Os médicos, que tentavam construir sua identidade em contraposição aos charlatões, eram "ironizados e combatidos abertamente pela imprensa" (SAMPAIO, 2001, p.145), fato que gerava a necessidade deles irem a público diversas vezes manifestar sua fé na ciência e desprezo pela ignorância do povo que preferia os curandeiros aos seus serviços. Por outro lado, a imprensa também criticava a tolerância às outras práticas de cura, juntando força com a classe médica na crítica à inércia das autoridades públicas. Em meio a essa disputa não existiria, entre os médicos, consenso sobre os melhores procedimentos da sua ciência. Por isso, entre a classe médica haveria a

\footnotetext{
"necessidade de que houvesse crença na medicina científica, ainda tão iniciante no Brasil do século XIX, para que a mesma tivesse êxito. Sem entrar nos detalhes dos procedimentos, refiro-me à 'eficácia simbólica' que faltava a medicina científica, aquela pensada pelo antropólogo Lévi-Strauss" (SAMPAIO, 2001, p.150)
} 
Nessa perspectiva, a ausência de legitimidade e de eficácia simbólica à medicina científica reitera o mesmo antagonismo apontado acima em relação aos remédios. De um lado, as práticas de cura populares caracterizadas como democráticas por estarem mais de acordo com os preceitos da medicina tradicional e igualmente ou mais eficazes que a prática oficial por estarem repletas de efeitos sugestivos e crenças. De outro, a medicina científica antipopular, autoritária e ineficiente, pois carecia do elemento "crença" nos seus processos curativos. Procurei mostrar, contrariamente, que existiam vários intercâmbios entre um campo e outro. Os formulários, as receitas e a arte de formular eram instrumentos e práticas terapêuticas que não eram exclusividade dos médicos treinados nos estabelecimentos oficiais. Faziam parte do repertório terapêutico daquilo que denominei de neohipocratismo brasileiro.

O mesmo foi feito em relação ao impacto da microbiologia sobre a terapêutica. Segundo Almeida (2011, p.62-64), a incorporação da anatomopatologia as ciências médicas não teve como consequência a criação de uma nova terapêutica. Pelo contrário, ela foi antes "uma manifestação de desconfiança em relação à terapêutica tradicional" (ALMEIDA, 2011, p.63), resultando em uma tendência niilista - que defendia a abstenção e a crença na força vitalista do corpo - e na crítica radical - que se restringia a negar a eficácia da medicina tradicional. $O$ florescimento de práticas terapêuticas não agressivas durante o século XIX (homeopatia, osteopatia, fitoterapia, naturopatia, etc) seria o resultado da não efetividade da expectação, derivada da fé vitalista, e do neohipocratismo. A vitória da medicina oficial teria sido alcançada graças ao advento da microbiologia e da quimioterapia.

A discussão sobre a dor e os remédios antigos, contrariando a visão triunfalista que enfatiza a vitória de uma concepção sobre outra, buscou mostrar que jamais existiu a supremacia de uma concepção médica sobre as demais. Nenhum coquetel medicamentoso proveniente da quimioterapia foi capaz de uma vitória definitiva sobre o sofrimento humano. O que existe são avanços que devem ser reconhecidos e comemorados, porém sem que sejam reduzidos aos seus aspectos meramente biológicos. A terapêutica utiliza-se do conhecimento biomédico sem se reduzir a ele, pois ela é essencialmente antropológica. A visão triunfalista tão criticada ao longo desse Capítulo, mais do que explicativa, é uma ideologia construída no sentido de garantir privilégios de uma pequena parte da classe terapêutica nos dias atuais. 


\section{CAPÍTULO 3 - A EMERGÊNCIA DAS DROGAS COMO UM PROBLEMA GLOBAL}

\subsection{Introdução}

Em 1971 foi instituída a Fundação Alexandre de Gusmão, vinculada ao Ministério das Relações Exteriores (MRE), com objetivo de "levar a sociedade civil informações sobre a realidade internacional e sobre aspectos da pauta diplomática brasileira" (SILVA, 2013, p.02). Essa fundação foi responsável pela publicação do livro A Questão das Drogas nas Relações Internacionais: Uma perspectiva brasileira de autoria de Luiza Lopes da Silva em 2013. Atenta aos problemas do país, essa conceituada instituição não poderia ficar isenta de tema político tão importante, visto a radicalização das medidas de interdição recentes provocadas pelo acirramento da guerra às drogas.

A diplomacia brasileira atual está diretamente relacionada com o tema porque os problemas decorrentes do tráfico internacional geram "implicações para a agenda bilateral brasileira com os países vizinhos, bem como europeus e africanos ocidentais, inseridos em diversas formas na cadeia do narcotráfico" (SILVA, 2013, p.11). O mapeamento das principais questões sobre segurança brasileira no pós-guerra fria através dos discursos dos gestores públicos e dos acordos internacionais celebrados, entre 1990 e 2011, mostra que o tema do narcotráfico é o segundo em importância, perdendo apenas para a questão ambiental e a fronteira com a Amazônia (BRIGOLA et al, 2012).

Essa posição altiva é recente, entretanto. O Brasil tardou "a se tornar verdadeiro ator nos debates e negociações internacionais" (SILVA, 2013, p.11), pois a postura ao longo da maior parte do século XX foi de alheamento. "Apesar de algumas iniciativas pontuais, somente em meados dos anos oitenta o governo se deu conta da necessidade de engajar-se no tema" (SILVA, 2013, p.47). Dois são os eventos que sinalizam essa nova orientação autônoma: a Conferência Especializada Interamericana sobre Tráfico de Entorpecentes, em 1986; criação da Comissão Interamericana para o Controle do Abuso de Drogas (CICAD). O CICAD tornou-se um modelo de cooperação multilateral, tendo exportado seu sistema para a Organização das Nações Unidas (SILVA, 2013, p.248-253). Hoje iniciativas desse tipo coexistem com práticas unilaterais estadunidenses no campo de controle hemisférico (SILVA, 2013, p.370372). 
Um problema alheio que tardou a se tornar objeto de atenção por parte dos burocratas brasileiros, uma vez que o país não tinha interesses imperialistas no Oriente. As iniciativas diplomáticas na região eram escassas e nem sempre bem recebidas internamente. Uma missão enviada à China, em 1881, visando obter braços para a lavoura, acabou enfrentando resistências, tanto internas, quanto externas: o "Parlamento brasileiro, insurgiu-se a opinião contra a iniciativa do governo" (CERVO, 2012, p.147) graças aos problemas relatados pelas "experiências migratórias chinesas para a Califórnia, Peru, Cuba e Austrália" (CERVO, 2012, p.147); governo chinês, por sua vez, resolveu restringir a saída de populações "diante da situação humilhante em que se encontravam pelo mundo seus emigrados, chamados de coolies" (CERVO, 2012, p.147). O governo brasileiro seria totalmente subserviente ao que definiam as potências estrangeiras, perdendo com isso "a ocasião de sacudir a diplomacia mundial, aliando-se política e juridicamente a uma grande nação dependente, com a qual podia-se identificar" (CERVO, 2012, p.148).

Schwarcz (1993, p.241) percebe na rejeição da entrada de asiáticos no país um dos fatores pragmáticos que aproximavam as Faculdades de Direito do Recife e de São Paulo, apesar das divergências teóricas. Esses imigrantes seriam portadores de "línguas e costumes estranhos aos nossos, praticantes do suicídio e do ópio". Essa precaução acabaria evitando que o Brasil tivesse problemas com o uso de drogas.

\footnotetext{
"Independentemente da forte dose de preconceito daquela postura, o fato é que, com essa proibição, deixou-se importar no Brasil o hábito do fumo do ópio, que nunca chegou, portanto, a popularizar-se. O consumo de drogas em larga escala no país ainda tardaria várias décadas” (SILVA, 2013, p.92).
}

Essa interpretação exposta acima ignora as modificações nos padrões culturais de consumo que ocorreram com o advento da modernidade, principalmente no que se refere aos psicoativos. Apesar de estar em uma posição periférica do mercado mundial, o Brasil também participou do fenômeno da revolução psicoativa - conforme vimos no Capítulo um. Outro pressuposto equivocado se refere à crença de que o Brasil não consumia ópio porque a forma fumada não era usual. Em uma sociedade que valorizava as práticas de automedicação, conforme vimos no Capítulo dois, o ópio e os seus derivados fitoquímicos exerciam funções muito importantes nas práticas terapêuticas, sejam entre os populares, sejam na academia. Os remédios líquidos de fórmula secreta 
eram difundidos em todas as classes - sendo alvo de críticas das classes terapêuticas oficiais que viam nessa prática um abuso.

A percepção de que o Brasil estava incólume ao problema das drogas é decorrente também da adoção, sem criticidade, da ideologia da nação submetida pelo vício estrangeiro e imperialista que se desenvolveu na China após as vitórias ocidentais em meados do século XIX. Essa narrativa diplomática se resume da seguinte forma:

O ópio era consumido tradicionalmente por via oral na China pelas elites, "sendo estimulado ainda entre as concubinas como forma de manter sua submissão" (SILVA, 2013, p.65). Isso oferecia "certa margem de segurança, pois a baixa concentração dos componentes biologicamente ativos dificultava fisicamente a possibilidade de superdose" (SILVA, 2013, p.59). Com a introdução do hábito de fumar, primeiro pelo tabaco e depois pelo ópio, a situação mudou e o consumo foi ampliado. O governo chinês tentou proibir o uso, porém foi derrotado nas armas pelos britânicos nas duas Guerras do Ópio ocorridas em meados do século XIX. "Impedido, durante as décadas seguintes, de tentar controlar o consumo interno de ópio, o Governo chinês buscaria sensibilizar a comunidade internacional para os níveis de dependência de drogas em seu território" (SILVA, 2013, p.68). A China se tornava vítima da ganância do imperialismo.

No final do século XIX, enquanto "as potências ocidentais impingiam exportações de ópio para a China" (SILVA, 2013, p.68), no Ocidente o uso de drogas ia aumentando por causa da ausência de regulações, pois essas eram criticadas "como uma violação dos ideais democráticos" (SILVA, 2013, p.69). Essa situação começa a mudar a partir da anexação das Filipinas pelos EUA entre 1899 e 1902. Nesse local "foi encontrado sério problema de dependência da minoria chinesa, que havia facilitado pelo regime mercantilista espanhol" (SILVA, 2013, p.71). O contexto estadunidense interno - pressão dos missionários, conscientização crescente sobre "as implicações da dependência para a saúde pública" (SILVA, 2013, p.72) e o movimento da temperança - levaram o governo de ocupação nas Filipinas a acabar com o comércio de ópio nos seus domínios. Na Inglaterra aumentava também a conscientização graças à atuação de organizações civis e religiosas contra esse comércio.

\footnotetext{
"Animados pelo sucesso obtido com os controles estabelecidos nas Filipinas, os EUA propuseram-se a estabelecer uma política global sobre o tema, oposta à das potências coloniais europeias, envolvendo países produtores e consumidores" (SILVA, 2013, p.75).
} 
Como os EUA eram inferiores militarmente aos impérios globais da época, "recorriam ao argumento ético da imoralidade das drogas" (SILVA, 2013, p.75). A defesa da agenda chinesa contra o vício externo era uma forma dos estadunidenses atenuarem os ressentimentos que haviam tido com os chineses imigrantes, além de colocar os ingleses em condições desfavoráveis frente a sua opinião pública interna minando, assim, o entrincheiramento europeu no comércio com a China. EUA e China montaram um bloco diplomático em defesa da proibição das drogas, levando número crescente de países "a aceitar a ideia de que o controle da dieta farmacológica constituía efetivamente uma incumbência estatal" (SILVA, 2013, p.87-88).

A posição sul-americana seria de distanciamento da questão. Os países andinos Bolívia e Peru - tinham interesse na exportação da coca que era utilizada pelas empresas europeias. Por isso esses países atuaram na defesa de seus negócios. O Brasil não se envolveu nas disputas internacionais, tornando a sua cooperação ainda mais reduzida depois que resolveu se retirar da Liga das Nações em 1926. "Além da verbalização tímida de suas posições, os países latino-americanos parecem ter cometido um segundo erro de cálculo, ao julgarem que se esquivariam do cumprimento dos dispositivos de controle dos acordos assinados" (SILVA, 2013, p.91). Os EUA conseguiram impor sua agenda depois que se tornaram potência mundial no pósSegunda Guerra.

\footnotetext{
"Quanto ao Brasil, seu distanciamento com relação aos foros e às negociações internacionais sobre o tema parecia a princípio justificar-se. Com efeito, o país se manteve em grande medida incólume ao problema das drogas durante décadas" (SILVA, 2013, p.91).
}

Essa narrativa diplomática será problematizada nesse Capítulo. Esse discurso ainda dominante ignora uma série de fatores que levaram a emergência das drogas como um problema internacional. A ideologia da nação submetida pelo vício estrangeiro e imperialista é uma das retóricas dominantes que impede a compreensão da emergência do proibicionismo como uma política pública histórica. Se o Brasil foi um agente com pouca voz nos fóruns internacionais, não foi por ausência de iniciativa. Internamente ele procurou lidar com a questão das drogas de forma incisiva, atuante e de acordo com os padrões do moderno proibicionismo - conforme veremos a partir de agora. 


\subsection{A ascensão do proibicionismo chinês e as disputas imperialistas no Oriente}

Com a expansão comercial europeia e a sua presença cada vez mais incisiva no Oriente, o ópio tornou-se um produto comercial privilegiado. Vimos, no primeiro Capítulo, que os portugueses foram os pioneiros em atentar para a demanda chinesa desse produto - até então de uso privilegiado entre as elites. Não foi, entretanto, a China o único país a ampliar o consumo, pois no Ocidente ele também foi inserido na dieta farmacológica a partir das triagas e outros remédios líquidos. Foi mostrado também que o Brasil consumia esse tipo de fármaco, aumentando bastante o comércio depois da abertura dos portos.

A civilização chinesa, ao contrário da brasileira, possui uma história milenar, por isso vimos que algumas das primeiras referências escritas ao uso de drogas ocorreram nos tratados medicinais chineses antigos. Durante toda a sua história a China foi um país bastante fechado aos ocidentais, considerados inferiores. Nas primeiras fases da expansão comercial, entre os séculos XVII e XVIII, foi forte a resistência da monarquia chinesa aos intentos comerciais e diplomáticos ocidentais. O comércio com o exterior era considerado um privilégio, tanto para os membros da corte agraciados por esse monopólio, quanto para os estrangeiros autorizados a fazer transações. Os chineses consideravam seu reino o centro do mundo e a todo o momento afirmavam a inferioridade cultural e geográfica dos estrangeiros (SPENCE, 1996, p.129-131).

$\mathrm{Na}$ China não existia judiciário e a justiça era exercida por funcionários. As execuções eram comuns, incluindo as dos estrangeiros. Não existiam advogados e qualquer um que interferisse na ação do funcionário também era punido. A severidade do tratamento dos suspeitos e dos presos levavam os chineses a evitar a justiça, apelando somente em casos seríssimos. Era possível evitar a prisão e os maus tratos com a distribuição de recursos. As penas também respeitavam a hierarquia social, os homens velhos, as crianças e as mulheres. Existia um conselho comunitário onde era eleito um chefe que devia zelar pelo pagamento de impostos e pela ordem local (SPENCE, 1996, p.135-139).

As nações europeias desde cedo visavam estabelecer relações comerciais com a China. Portugal e Holanda tentaram negociar diretamente com a Corte, porém foram reduzidas a nações tributárias. Os ingleses, mais pragmáticos, entravam em contato direto com as províncias do sul e gradualmente iam conseguindo construir uma rede e obter autorização para o comércio. Conforme foram se estabelecendo na Índia, e 
aumentando a presença no Oriente, os ingleses ampliam seu peso comercial - fato que gerou inúmeros incidentes por causa da posição xenófoba alimentada pelos chineses. A aplicação da lei local em estrangeiros e os inúmeros casos de agressões e execuções de europeus levaram as nações ocidentais a reivindicar que seus conterrâneos fossem julgados por tribunais especiais (SPENCE, p.136-138).

Os chineses, inicialmente, dispunham de uma série de produtos - chá, porcelana, seda, artigos decorativos, entre outros - que interessavam os europeus. Porém, não existia demanda por produtos europeus - o único pagamento aceito era a prata, fato que levou a um fluxo intenso desse metal para o Oriente e problemas na balança comercial europeia. Esse problema teria sido resolvido a partir do comércio com ópio, pois ocorreu maior disponibilidade do produto, dos meios de consumo e aumento crescente da demanda, fato que levou "a China a esse ciclo particularmente doloroso de sua história moderna" (SPENCE, 1996, p.140). Criou-se um problema econômico e social. “A extensão do vício do ópio colocava um dilema social particularmente complexo. Estudiosos, funcionários e o próprio imperador estavam divididos sobre se deviam legalizar a droga ou proibi-la totalmente" (SPENCE, 1996, p.151). A situação teria chegado a tal ponto no século XIX, que a Corte acabou optando pela saída tradicional, ou seja, o reforço da autoridade, a proibição do ópio e a restrição do comércio com os estrangeiros. Essa política levou a duas guerras, entre 1839-1842 e 1856-1860. Derrotada, a China se viu obrigada a se abrir para o comércio com os estrangeiros e assistir a disseminação do vício entre seus compatriotas.

Desde a década de 1860, os missionários estrangeiros que se inseriam no país percebiam o ópio como grande obstáculo a cristianização. Seus escritos denotavam o horror com a expansão do vício, a degeneração que ele provocava e o enfraquecimento que gerava ao Império Chinês. Desses religiosos se consolida uma representação contra a imoralidade desse comércio (COURTWRIGHT, 2001, p.182). Esse discurso missionário é o sustentáculo da ideia que o tráfico de ópio para a China é o mais continuado e sistemático crime internacional dos tempos modernos - e o caso chinês passou a ser considerado clássico no debate de drogas da atualidade ${ }^{29}$ (DIKOTTER et al, 2004, p.01-02). Estudo recente (DIKOTTER et al, 2004), entretanto, tem apontado

\footnotetext{
${ }^{29}$ No Brasil, por exemplo, um dos principais defensores do proibicionismo em matéria de drogas é o Deputado Federal Osmar Terra (PMDB-RS). Ele repete exaustivamente nos meios de comunicação dominante, como o jornal Zero Hora (10 de julho de 2013, O povo como Cobaia) e o Correio Brasiliense (28 de agosto de 2015, Liberar o uso de drogas?), o exemplo do perigo das drogas e da experiência chinesa com o ópio. Essas notícias e outras estão disponíveis no blog do parlamentar. <http://www.osmarterra.com.br> Último acesso: 13 de outubro de 2015.
} 
alguns problemas nessa visão do comércio de ópio com o Oriente, conforme veremos abaixo.

O primeiro equívoco se refere aos escassos problemas de saúde ou com a longevidade trazidos pelo uso habitual de ópio: o fumador moderado poderia até se beneficiar, ainda mais porque o ópio era praticamente o único remédio para os mais diversos males antes do advento das medicações modernas (penicilina e a aspirina). As representações negativas frequentemente confundem os sintomas médicos das doenças, as quais o ópio funcionava como paliativo, com os imaginados efeitos psicológicos da adição. Essa má impressão era somada aos casos de desnutrição - os visitantes estrangeiros passavam pelas 'vilas de ópio' e atribuíam os efeitos físicos dos famintos ao ópio (DIKOTTER et al, 2004, p.02-03).

Em segundo lugar, o ópio era vastamente cultivado e consumido na Índia, Pérsia e Turquia. Mesmo na Europa e na América existia, na mesma época, amplo acesso a qualquer fármaco nas boticas - haxixe, exóticas psicodelias, derivados fitoquímicos mais potentes que o próprio ópio. O problema do ópio no século XIX costuma focar somente o caso chinês, ignorando os contextos sociais e culturais de consumo, e o fato desse produto ser uma commodity global (DIKOTTER et al, 2004, p.03-04).

"O terceiro aspecto sobre o mito do ópio na China se refere à recusa de aceitar que a maioria do uso de ópio na Europa, no Oriente Médio e Ásia era leve e moderado"30 (DIKOTTER et al, 2004, p.04). Admitir que existia uma classe de usuários moderados minaria o discurso de condenação dos cultivos de papoula e os argumentos médicos de que o incremento da dosagem poderia ser revertido e a adição inevitável. As fontes mostram claramente que os usuários buscavam produtos de confiança e não suprimento infinito - não existia a tensão por aumentar constantemente a dose (DIKOTTER et al, 2004, p.04-05).

Outro ponto se refere à leitura que privilegia as propriedades farmacológicas em detrimento das dimensões sociais e culturais do uso. É a famosa "questão de exposição" que credita todo o uso à doença. Importante salientar que a maioria das pessoas que experimentam o ópio pela primeira vez não sentem nada ou apenas algumas sensações desagradáveis. No Ocidente, vingou a errônea ideia de que o fumador penetra em um mundo de sonhos agradabilíssimos - resultado obtido através de grandes ingestões de láudano líquido. Não existe um impulso irresistível ao consumo de ópio: é uma opção

\footnotetext{
30 "A third element of the opium myth is the refusal to accept that the most opium use in Europe, the Middle East and Asia was light and moderate" - tradução sugerida.
} 
pela familiarização. O ópio era preparado e apreciado em um complexo ritual que rejeitava usos abusivos - muito parecido com o ritual do chá britânico. Ele poderia ser alternativamente ou simultaneamente um produto médico, um signo de hospitalidade, um item recreacional, uma forma de distinção social ou símbolo de uma cultura de elite. "Em uma cultura do constrangimento, o ópio era o lubrificante social ideal que permite ao usuário manter o decoro e a compostura, em contraste com o álcool que era rompedor de modos e de comportamentos"31 (DIKOTTER et al, 2004, p.07).

Igualmente errado é o pressuposto que o suplemento determina a demanda. Essa ideia parte do pressuposto que as substâncias inanimadas têm grande agência, enquanto seres humanos são objetos passivos. Pesquisadores que tem essa abordagem trabalham exclusivamente com as questões da oferta e da demanda. Porém, essas substâncias não tem vida própria: elas ganham vida a partir de seus usuários. A agência das pessoas sumiu na fumaça do ópio. Dar agência às pessoas tem sido o motor da revisão historiográfica que iniciou na década de 1960: em vez de ver todos os usuários como adictos e governados por uma dependência química, se passou a percebê-los como complexamente humanos e inseridos em experiências sociais (DIKOTTER et al, 2004, p.07-08).

Escohotado (2008, p.402-406), por sua vez, destaca que os europeus gradativamente invadiram a economia chinesa com aguardente, tabaco e ópio. Conforme essas substâncias iam ganhando importância comercial, eram editados decretos proibindo o comércio - fato que favorecia a pirataria. Foi quase concomitante o contato com os europeus e a ascensão da dinastia Manchu originária da região da Manchúria. Estrangeiros em território chinês, eles introduziram saques inquisitoriais, queimaram bibliotecas, destruíram os barcos para navegação e aumentavam significativamente os impostos. Pequim, que abrigava a corte, tornou-se uma cidade proibida para os chineses. A adesão à pirataria e às insurreições civis, principalmente nas províncias do sul, também precisa ser compreendidas como forma de desobediência a um poder que não gozava de ampla legitimidade. Spence (1996, p.141) também aponta a difusão prévia do tabaco como uma das causas da proliferação do hábito de fumar. Dikotter et al (2004, p.24-36) apresentam a importância do tabaco para a criação

\footnotetext{
31 "In a culture of restraint, opium was an ideal social lubricant which could be helpful in maintaining decorum and composure, in contrast to alcohol wich was believed to lead to socially disruptive modes of behaviour" - tradução sugerida.
} 
da cultura da fumaça chinesa e, com as restrições, esse produto passa a ser misturado com o ópio - compondo o madak.

Percebe-se, portanto, que não existe nenhuma veracidade na afirmação de que a corte Manchu reprimia o uso de ópio por razões humanitárias. A proibição, assim como a anterior do tabaco, foi motivada pela incapacidade econômica do Império celeste em negociar com o Ocidente. A proibição do tabaco, primeiro, e depois do ópio esteve ligada ao interesse da população nesses produtos e, logo, para evitar a evasão de riquezas. Depois de todas as derrotas e humilhações, a corte imperial passou a apresentar-se como um governo pacífico afligido pelo mal de um fármaco estrangeiro. O ópio era usado livremente na China desde o século IX, sendo o uso controlado o mais difundido. Proibir o povo de utilizar uma das mais importantes formas de medicina não pode ser interpretado como um ato de benevolência dos governantes chineses - pelo contrário, era mais um dos autoritarismos da corte Manchu. Atribuir a proibição aos efeitos perniciosos do ópio é um erro grosseiro (ESCOHOTADO, 2008, p.542-544).

A ideologia da nação submetida pelo vício é uma construção social que teve profunda difusão, chegando inclusive ao Brasil. A atuação dos missionários cristãos no Oriente era assunto desde cedo (1869) nos periódicos brasileiros. O Diário do Rio de Janeiro, por exemplo, em uma coluna dedicada a "Variedades", apresentou um texto intitulado "Usos e Costumes da China". Depois de apresentar as características do comércio realizado naquele país, se iniciam as considerações sobre o ópio.

Os missionários têm falado muitas vezes dos estragos, que na China produz o uso do ópio, e o progresso rápido em que este uso se espalha no Império [...] Hoje não ha distrito na China, em que não exerça o seu império: penetrou no palácio dos soberanos, e cabanas dos pobres. O governo chim não pode remediar esse mal: tem todos contra si. Debalde decretou pena de morte contra quem fumar ópio: as mesmas mulheres do Imperador Hien Foung não temem violar essa proibição em seu próprio palácio [...] Com efeito os chins, que têm tabagias de ópio, subtraem-se á lei fazendo presentes consideráveis as autoridades que fecham os olhos [...] O uso de ópio é irresistível uma vez principiado. Para o deixar seria preciso uma energia rara, e demais arriscar a vida, pois que o estomago privado dessa substancia, se contraem com dores horríveis [...] Tal é o mal que corre e desmoraliza a China, e sem escrúpulo lhe causa a humanitária Inglaterra, tão vigilante e melindrosa quando se trata da negrofilia (Diário do Rio de Janeiro, 04 de janeiro de 1869). 
Nesse excerto já é possível perceber todos os elementos do paradigma da nação escravizada pelo vício, incluindo o papel ético dos missionários na denúncia desse comércio supostamente infame. E também é possível perceber outro aspecto do discurso que será bastante recorrente quando o assunto era a Inglaterra - a condenação da escravidão dos negros, enquanto a escravidão do ópio é negligenciada. Em outro artigo, publicado no mesmo jornal, intitulado "Questão Anglo-Brasileira encarada por um militar", é feito "um retrospecto [...] da história criminal do governo inglês" de modo que "avivemos os traços da ignominia e da injuria que sobre nós tem sido lançada". E nesse retrospecto não falta referência ao envenenamento da população chinesa.

"Na China trata primeiramente o governo inglês de mandar enfraquecer seus habitantes e sua soldadesca por meio do ópio, com que a Inglaterra faz grandioso comercio, tendo antes monopolizado a cultura da planta papoula, donde se extrai aquele principio nocivo tanto físico como ao moral do homem. Reconhecendo o imperador da China o mal proveniente de um comercio tão funesto para os seus súbditos, proibiu, sob penas mui severas, a introdução do ópio nos seus estados; os ingleses, porém importando-se pouco com os decretos do governo chinês, continuam a introduzir o ópio, comerciando como contrabandistas, e protegidos pelo ministro residente" (Diário do Rio de Janeiro, 20 de fevereiro de 1863).

As relações entre Brasil e Inglaterra foram se deteriorando ao longo do século XIX por causa da posição inglesa em relação ao tráfico de escravos. Depois de 1845, a relação entre os dois países entrou em uma fase de ruptura e conflito, marcada pela ação unilateral e violenta dos ingleses em relação aos navios negreiros. A iniciativa brasileira de levar aos tribunais da marinha o crime de tráfico de escravos, e assim acabar definitivamente com ele, foi uma forma de conter a animosidade com os ingleses que parecia evoluir para o conflito aberto e armado. Os ressentimentos, entretanto, perduraram vários anos (CERVO et al, 2012, p.89-92). O comércio do ópio, nesse contexto, servia como uma forma de denunciar a hipocrisia da ética inglesa em matéria comercial.

Paralelamente a construção da ideologia da nação subjugada pelo vício introduzido pelo imperialismo, também ocorriam os conflitos com os chineses em países que recebiam esses imigrantes. Nos EUA, as casas de consumo de ópio foram desde cedo elemento de atração da juventude e potencializador do conflito geracional (DAVENPORT-HINES, 2002, p.167). Courtwright (2001, p.171-173) aponta que um 
dos fatores que justifica a proibição é a percepção que a juventude é mais vulnerável ao consumo. Esse tipo de argumento foi usado em vários contextos históricos, desde as casas de ópio no XIX, passando pelo discurso da temperança nos anos de 1920 e da reação à contracultura nos anos de 1970. O reforço da autoridade sobre a juventude, visando obter a virtude por meio virulento, é um tipo de medida que favorece a transgressão. "A indução ao mau comportamento que fomenta a proibição [...] constituí no grande dilema da política vinculada às drogas"32 (DAVENPORT-HINES, 2002, p.196-197). O uso de drogas acabou se tornando um rito de passagem para a vida adulta na sociedade contemporânea.

Nos EUA, não eram apenas os jovens que buscavam esses locais. Escohotado (2008, p.550), afirma que as casas de ópio também foram o destino procurado por vários veteranos da guerra civil estadunidense que tinham se viciado em morfina durante o confronto. Outros autores (MUSTO, 1999, p.01-02; COURTWRIGHT, 2001, p.36), entretanto, tem relativizado a importância da guerra civil como propagador do uso de opiáceos. Independente, o fato é que a imigração chinesa gerou uma série de conflitos e o ópio, como fármaco preferencial dessa etnia, acabou sendo alvo de políticas restritivas - resultando no Chinese Exclusion Act de 1882. Na Inglaterra, segundo Berridge (2013, p.78-79), apesar de a comunidade chinesa ser menor e geograficamente isolada do restante, também foram registrados conflitos com a comunidade local. O ópio fumado se inseriu na paisagem urbana e os jornais sensacionalistas e os literatos exploravam a imagem desses locais como perigosos paraísos. Davenport-Hines (2002, p.207-208) aponta que Austrália, Nova Zelândia e África do Sul também adotaram leis restringindo o uso de ópio como meio de conter a chegada desses imigrantes, conhecidos como chins ou coolies. Veremos logo adiante que também no Brasil os jornais sensacionalistas exploravam a imagem de chineses consumidores de ópio no Rio de Janeiro.

Um dos fatores mais importantes para determinar a proibição de determinadas drogas se refere a sua relação com grupos sociais desviantes ou antipáticos. Os Estados Unidos, apesar de ser uma sociedade formada por imigrantes, são repletos de exemplos desse tipo. Além dos chineses, destacado acima, existiam também os mexicanos consumidores de Cannabis, os negros no sul que eram associados à cocaína e a heroína ligada aos delinquentes das grandes cidades. O baixo status social e a dimensão

\footnotetext{
32 "The inducements to misconduct set up by prohibition - the fostering of vice when virtue is pursed to extremes - furnish the great conundrum of drug policy" - tradução sugerida.
} 
relativamente pequena desses grupos os tornam alvos mais fáceis de legislações que tentam restringir seus direitos (COURTWRIGHT, 2001, p.171).

Esse tipo de argumento xenófobo e intolerante leva em consideração não apenas a substância em si, mas o tipo de pessoas que a utilizam. Uma resposta pública autoritária é mais aceitável quando os usuários não fazem parte da maioria dominante. A associação do uso com minorias reflete um esforço de marginalização cultural e política de grupos que ameaçam posições ocupadas por segmentos sociais tradicionalmente estabelecidos (BERRIDGE, 2013, p.77-78). O desprezo por uma minoria conduz ao desrespeito pelos veículos de cura e recreação empregados pelos seus membros, que passam a ser entendidos como traços de perversidade e inconveniência próprios daquele grupo (ESCOHOTADO, 2008, p.607). Existem vários exemplos desse tipo de perseguição social, política e cultural - variando conforme os contextos nacionais e locais.

Apesar de a xenofobia apresentar diversas facetas, foram fundamentais para a construção de um sistema internacional os chineses e o ópio por causa da abrangência internacional da sua presença. Tanto Escohotado (2008, p.551-554) em relação aos EUA, quanto Berridge (2013, p.82) em relação à Inglaterra, apontam o desafio que tais imigrantes representavam aos trabalhadores locais. Eles eram competentes, industriosos e habituados a forte disciplina no trabalho - geralmente aceitando salários menores que os locais. E o ópio faz parte desse êxito produtivo. Courtwright (2001, p.135-136) lembra da utilidade dessa substância para o aumento da produtividade em trabalhos repetitivos e monótonos - sendo inclusive distribuído aos trabalhadores em locais onde esse uso é sancionado culturalmente. A declaração do diplomata estadunidense Charles Denby feita em 1899, no contexto da guerra das Filipinas, resume bem a descontentamento que esse tipo de imigrante gerava.

\footnotetext{
"Em qualquer parte do mundo onde os chineses chegam eles superam todos. Um vai a Singapura e se encontra ali com vinte a trinta mil chineses; você vai a Colombo [capital do Sri Lanka] e acontece o mesmo. Eles têm êxito em vender mais barato que todos e trabalham por salários menores que as outras pessoas, e depois de ter feito certa quantidade de dinheiro retornam a China" ${ }^{\text {33 }}$ (DAVENPORT-HINES, 2002, p.203).
}

\footnotetext{
33 "Wherever the Chinese go in the world they supplant everyone else. You go to Singapore and you find twenty or thirty thousand there; you go to Colombo and you find the same thing. They undersell everybody and they work cheaper than any other person, and after they have made a certain amount of money, they return to Chine" - tradução sugerida.
} 
A lenta crise do sistema escravista e os conflitos com a Inglaterra em relação ao tráfico negreiro levou a um impasse que ameaçava o próprio modelo produtivo brasileiro. A imigração surgia como alternativa e os asiáticos passaram a ser considerados. Os Congressos Agrícolas que ocorrem no Rio de Janeiro e em Pernambuco no ano de 1878 nos mostram que a imigração chinesa era considerada polêmica. Os defensores argumentavam que eram trabalhadores dóceis, baratos e muito mais qualificados que os jornaleiros europeus do período. Os opositores os caracterizavam como imorais, de raça inferior, corruptos e depravados por natureza. Eram degenerados que espalhavam o vício para o mundo todo, conforme o exemplo dos EUA, de Cuba e da Austrália (SIMÃO, 2001, p.98-102). Trechos da fala de Christiano Ottoni, opositor aos chineses, denota vários dos aspectos destacados acima sobre a imagem do chinês.

O ilustre cidadão inglês que obsequiou o Congresso, comunicando os frutos da sua longa experiência neste e em outros países, não se ocupou, senão de provar que esta importação de braços podia dar trabalhadores com salario baixo e que estes podiam produzir resultados que animassem a grande lavoura; mas reconheceu que é da índole desses trabalhadores retirar se depois de algum tempo, reconheceu que não é costume fundirem-se eles na população [...] Não basta o trabalhador que venha ganhar salários e formar pecúlio, deve-se procurar, de preferencia, o homem que venha fundir-se com a população [... Existe a] opinião de um senador americano muito ilustrado, que clamara contra o mal que á raça caucasiana, ao futuro da sociedade americana, resultava da grande importação de chins [...]. O colono africano que o orador, ao contrario dos ilustres plantadores de cana de Campos, reputa como muito superior ao coolie (apoiado e não apoiados), está em grande parte fundido na população; está afeito aos nossos hábitos, e senão é fácil, certo que (não é impossível) aproveita-lo, localiza-lo no país, fundando família, vivendo de seu trabalho (O Paiz, órgão especial do commercio, 14 de Agosto de 1878).

Christiano Ottoni, irmão do famoso político liberal Teófilo Ottoni, teve uma experiência direta com a imigração de chineses no vale do Mucuri - último reduto selvagem das Minas Gerais no século XIX. Essa não foi, entretanto, uma experiência isolada. Outras iniciativas também se desenvolveram ao longo do século XIX. Entre 1812 e 1819, a Coroa trouxe da colônia de Macau trezentos colonos com objetivo de 
promover a cultura do chá no Brasil - eles ficaram alojados nas fazendas da família imperial. Em 1882, foi fundada a Companhia de Comércio e Imigração Chinesa que planejava trazer mais de 21 mil trabalhadores, porém sem alcançar o objetivo proposto. Constituíram-se, portanto, em uma pequena comunidade. Depois disso, somente na década de 1950 haveria nova onda migratória dessa vez para São Paulo (LESSER, 2001, p.37-85).

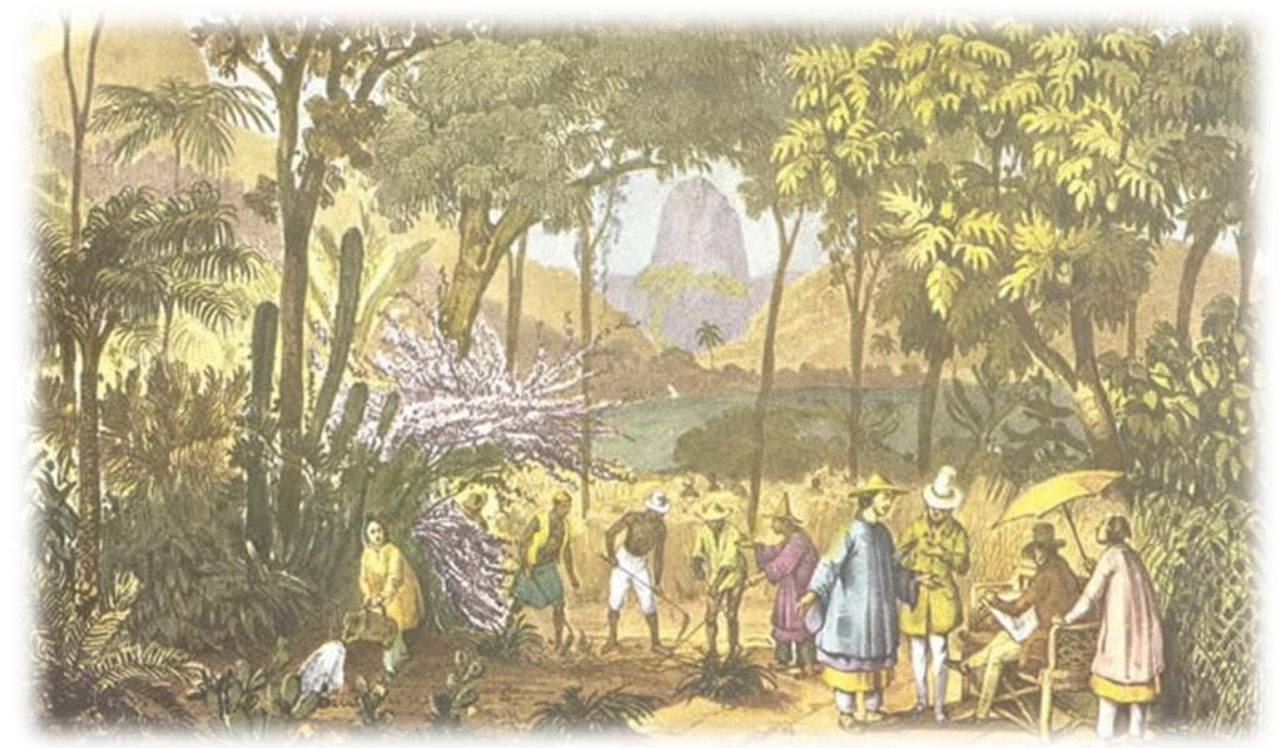

Figura 5 - Chineses no Rio de Janeiro por Johann Moritz Rugendas FONTE: CHANGSHENG, Shu (2009, p.45)

Os chineses constituíam uma pequena comunidade no Brasil, porém provavelmente também adepta do uso de ópio - conforme indica a bibliografia e as fontes. Assim como ocorreu na Inglaterra (Berridge, 2013, p.78-79), no Brasil assistimos o advento de uma linha jornalística investigativa que tinha enorme interesse pelas casas de ópio e seus paraísos artificiais. Esses relatos associavam esses locais à paisagem mais ampla de insalubridade que existia nas moradias populares do Rio de Janeiro. O famoso cronista João do Rio escreveu vários artigos contando suas experiências nesses locais (SARTI, 2015, p.54-61). Existem fontes que confirmam os relatos de João do Rio. Os chineses que foram encaminhados ao Pavilhão de Observação, no final de 1920, por causa do fumo de ópio foram presos nas mesmas ruas descritas pelo cronista (SARTI, 2015, p.170). Depois da morte de João do Rio, ele foi representado como o "gênio degenerado de Lombroso" (SILVA, 2015, p.134) pelo médico Inaldo de Lyra Neves-Manta, que caracterizou sua obra como "mórbida" por influenciar indivíduos são as práticas degenerativas. 
No século XIX os imigrantes chineses que viviam no Império brasileiro, mesmo sendo pouco numerosos, pareciam adeptos do ópio. Uma pequena nota, na sessão de "Notícias" do Diario do Rio de Janeiro, aponta os artifícios utilizados por um chinês para introduzir ópio na prisão.

Os habitantes do celeste império mesmo longe de seus lares, não renunciam
facilmente os perniciosos usos que os têm tornado o ludibrio dos outros
povos. Anteontem foi preso no $2^{\text {o }}$ distrito de Sant'Anna o chim Manoel, por
introduzir na prisão onde se acham alguns de seus patrícios, uma porção de
ópio, oculta em uma empada! (Diario do Rio de Janeiro, 13 de agosto de
1863).

Gradativamente, entretanto, a aceitação social do ópio entre os chineses começa a sofrer um revés dentro do seu país. Segundo Hobsbawm (1988, p.389-392), a China em fins do século XIX era um país em colapso. A guerra civil gerada pela ascensão do movimento Taiping somente foi superada a custa da entrega do poder administrativo às potências estrangeiras: A Rússia tomou conta da Manchúria; os japoneses avançaram sobre Taiwan e Coréia; os britânicos alargaram seu poder em Hong Kong e sua influência sobre o Tibete; a Alemanha ganhou posições no norte; os franceses avançaram a partir de sua colônia na Indochina; até Portugal conseguiu a concessão de Macau. Existiam, entretanto, três tradições políticas chinesas que se apresentavam como foco de resistência: os burocratas confucionistas da Corte que se inspiravam na modernização japonesa; a tradição de revolta popular abafada com a derrota Taiping com forte sentimento xenófobo e antimodernista; os republicanos das províncias do sul com tradição de resistência à dinastia Manchu.

Importante ressaltar que, ao contrário da América Latina e de outras partes de mundo que viam os europeus e a América do Norte como exemplo de civilização, os chineses viam os estrangeiros como bárbaros. Escohotado (2008, p.533) aponta que as derrotas da dinastia Manchu e o caos social ligado ao imperialismo aumentava a xenofobia - e o ópio gradativamente passou a ser associado à exploração colonial e a presença estrangeira. Depois de 1860, o ato de fumar ópio já não era mais um signo de rebeldia à dinastia Manchu. Dikotter et al (2004, p.93-94), analisando os discursos produzidos pelo movimento nacionalista, mostra que o ópio se tornou o símbolo da degeneração e da dependência externa. Nessa visão, ele teria sido introduzido pelos imperialistas como modo de enfraquecer a nação. Contribuía também para essa 
representação a nascente classe médica chinesa que objetivava monopolizar o mercado terapêutico.

A ascensão da opiofobia entre os chineses é saudada pelos missionários, tradicionais opositores do consumo de ópio, como a comprovação dos males trazidos por essa substância. Nascem as condições para uma aliança política entre missionários e nacionalistas em relação às drogas. Paralelamente ao crescimento da opiofobia, o governo chinês passa a permitir as plantações em seu território de modo a diminuir a dependência econômica externa (COURTWRIGHT, 2001, p.179-180). Essa política econômica teve êxito na redução das importações de ópio por parte dos chineses e, consequentemente, a importância comercial desse gênero para a Grã-Bretanha. Em 1892, com a vitória do Partido Liberal na Inglaterra, grande expectativa foi criada no movimento antiópio sustentado pelos Quakers - financiadores de jornais e organizações civis que forçavam a entrada desse tema na agenda política inglesa. O governo eleito teve que dar uma resposta a esses anseios, resultando na criação da Royal Opium Commission e da Indian Hemp Drugs Commission para investigar o consumo dessas substâncias no Oriente (BERRIDGE, 2013, p.52-53). Toda essa expectativa, entretanto, virou decepção. Depois de longo trabalho e milhares de entrevistas, o relatório final da Royal Opium Commission foi conclusivo sobre a inviabilidade e o inconveniente de uma proibição (BERRIDGE, 2013, p.53). Tendo por base a realidade indiana de consumo, este documento mostrou que o ópio era mais parecido com as bebidas ocidentais do que com uma substância temida e perigosa (MUSTO, 1999, p.28-29; ESCOHOTADO, 2008, p.545).

Davenport-Hines (2002, p.180-194) investigou a trajetória e os principais argumentos apresentado por essas comissões inglesas do final do século XIX. Apesar das acusações posteriores feitas pelos missionários, de elas estarem a serviço da Companhia das Índias Orientais, os relatórios parecem bastante fidedignos. Podendo, portanto, ser considerados técnicos. Eles defendem, em suma, que a proibição desses fármacos geraria um incremento na ilegalidade e na criminalidade, pois eram atividades sancionadas socialmente e de difícil controle. Os problemas gerados pela proibição seriam superiores aqueles provocados pelas próprias substâncias. Mesmo algumas práticas altamente condenadas, como o costume de dar ópio para os bebês, deveriam ser enfrentadas com campanhas informativas. O relatório da Indian Hemp Drugs Commission, por sua vez, é até hoje o principal documento etnográfico dos usos tradicionais, médicos e religiosos da Cannabis no Oriente - principal registro 
documental do complexo da ganja. Nesse sentido, essas recomendações oferecem "alternativas inteligentes a proibição e constituem modelos respeitáveis para a política do século XXI nesse sentido" ${ }^{34}$ (DAVENPORT-HINES, 2002, p.193).

Esse revés do movimento antiópio na Inglaterra, no final do século XIX, não foi uma derrota do esforço ético como pressupõe o discurso diplomático que atribui o uso de ópio a uma mera ação criminosa gerada pela ganância do imperialismo. As guerras do ópio e o apoio das potências ocidentais aos Manchu contra a revolução Taiping foram fundamentais para consolidar a presença estrangeira em território chinês, não restam dúvidas disso. Entretanto, atribuir a decadência chinesa à degeneração proposital de sua população pela introdução de um veneno é um erro, pois ignora que o ópio era tradicionalmente usado. A China, como todos os países da época, tiveram que passar pela tensão social resultante da popularização de antálgicos que, anteriormente, eram privilégios das minorias dominantes.

É possível perceber no argumento que atribuiu ao ópio a função de veneno estrangeiro que arruína a nação uma faceta mais ampla que dá suporte a política proibicionista. Segundo Courtwright (2001, p.171), a ameaça que as drogas representam para o futuro do grupo, da tribo, da nação ou da raça é perceptível em vários outros contextos além do chinês: entre elites nativas americanas em relação ao álcool destilado; foi denunciado pelos EUA contra os japoneses antes da segunda guerra e contra os soviéticos depois desta; no Irã, nos anos de 1980, o governo revolucionário acusava o Ocidente e a URSS de estarem distribuindo heroína como meio de enfraquecer a sua nação; e assim por diante. Não podemos, entretanto, tomar esses discursos como cópias fiéis da realidade. É preciso considerar, no caso das sociedades tradicionais como são as indígenas americanas, a valorização que os estados alterados de consciência possuem no interior dessas culturas. Em épocas de conflito com outras coletividades é comum a ampliação da perseguição aos dissidentes internos, como são os usuários de drogas fora dos contextos tradicionalmente consagrados.

Para entender a ascensão do intento proibitivo é preciso, portanto, considerar as pautas culturais de consumo e os conflitos sociais gerados a partir da maior disponibilidade dos antálgicos e inebriantes em geral. Na China, o ópio era inicialmente um símbolo de uma cultura de elite altamente refinada e identificada com a burocracia da dinastia Ming. Para Silva (2013, p.65), esse uso elitista tinha como uma de suas

\footnotetext{
34 "Both the Brassey and Young reports offered intelligent alternatives to Prohibition: they provide honorable models for twenty-first-century policy makers" - tradução sugerida.
} 
funções o reforço da submissão das concubinas. Essa visão, que parece um pouco exagerada por se fundamentar na ideia de que uma substância como o ópio fumado pudesse escravizar uma pessoa, tem uma ligação com a percepção de que o ópio pudesse funcionar como um afrodisíaco. A questão das propriedades sexuais dessa substância foi investigada no inquérito que gerou o relatório da Royal Opium Commission (1894-1894). Foram entrevistadas meretrizes australianas para saber sobre tais efeitos, sendo apontado que o ópio tendia a deixar os clientes menos interessados no contato sexual (DIKOTTER et al, 2004, p.89-90). Farmacologicamente isso parece ter todo o sentido, pois ele funciona como um sedativo e analgésico.

Vimos, no Capítulo dois, que as fórmulas químicas que definem os efeitos dos fármacos não possuem robusteza ontológica - elas podem variar de acordo com o contexto de uso. O ópio nesse caso é um exemplo clássico desse tipo de fenômeno. $\mathrm{Na}$ China, ele aparece nos tratados medicinais como "terapia para cama", expressão traduzida erroneamente como afrodisíaca. Ele não era usado para estimular ou excitar o desejo, mas para estender e aumentar a performance sexual. Nas casas de ópio ele era servido com outros afrodisíacos, como pó de pérola e ginseng. Nesses locais essa substância era associada a outras atividades, como o jogo, contribuindo para a descontração e o contato com as mulheres. Também na Europa existem relatos de usos semelhantes (DIKOTTER et al, 2004, p.88-92). A dinastia Manchu que assumiu o poder no século XVIII era de origem mongol e via nesse hábito, crescentemente popularizado, um símbolo da decadência dos costumes e ícone de um setor ilustrado que lhe fazia oposição. Difusão essa que gerava intenso mal-estar (ZHENG, 2005).

Essa combinação de fatores muito peculiares explica porque foi na China, e não em outro país, que a percepção do ópio como problema público tomou proporção de política de Estado mais cedo. E somente isso torna compreensível a insólita aliança entre classes dirigentes chinesas e os missionários cristãos nessa questão. Os EUA utilizarão essa congruência de interesses como um meio de se reaproximar da China e se colocar como ator político nas disputas imperialistas que ocorriam no Extremo Oriente.

Devido à liderança política dos religiosos estadunidenses no começo desse processo diplomático, creio ser importante um parêntese sobre o papel atuante da religião como sustentáculo ideológico desse novo sistema de controle. Courtwright (2001, p.169-171) aponta que as religiões verdadeiras desaprovam o uso de drogas. Rezas, jejuns, meditação e exercícios seriam as únicas formas legítimas de buscar estados alterados de consciência, pois os enteógenos seriam imitações da verdadeira 
experiência mítica que levariam os fiéis à autodestruição. ${ }^{35}$ A Cannabis, que é utilizada pelo Hinduísmo e pelo Islamismo, é exceção. Porém, mesmo para ela, os hinduístas e islamistas costumam desaprovar o uso fora do contexto ritual. Os agnósticos seriam mais propensos ao hábito em drogas do que as pessoas que seguem alguma religião e os antigos viciados, geralmente, se tornam os devotos mais entusiásticos.

Esse argumento é interessante porque permite adentrarmos em um aspecto geralmente negligenciado quando abordamos a questão da alteração da consciência e religião. Rezas, jejuns, meditações e outros exercícios podem levar a mente ao extremo, provocando sensações e experiências idênticas às provocadas por substâncias com características enteógenas. É dessa forma que o ascetismo cristão se comunica com a divindade, por isso Winkelman (2001, p.340-341) aponta que os estados alterados de consciência são valorizados como experiência mística mesmo em sociedades que falham em providenciar meios legítimos de acesso a esses estados com psicoativos. A alteração de consciência, nesse sentido, precisa ser entendida como uma característica humana básica - fator que também deve ser considerado no tratamento dos usos abusivos. O aspecto religioso continuará sendo relevante para essa política durante todo o século XX, principalmente em relação à contracultura e ao uso de ayahuasca conforme veremos no Capítulo cinco.

O estreitamento da aliança dos EUA com os missionários que atuavam no Oriente ocorre logo depois de findado os conflitos com a Espanha - iniciados em 1898. Nessa guerra os estadunidenses conquistam Porto Rico, Guatemala, Cuba e as Filipinas. Neste último país, depois de vitória contra os espanhóis ainda foi preciso enfrentar uma longa guerra civil, pois os filipinos não aceitavam a substituição de uma metrópole por outra. A pacificação, alcançada em 1902, finalmente colocou os EUA em uma nova posição em relação à política Oriental. Nessa região atuava o reverendo e missionário Charles Henry Brent, que acabou se tornando o primeiro czar estadunidense contra as drogas. Crítico ao sistema de vendas realizado até então pelo governo espanhol, conseguiu convencer o novo governo de ocupação em proibir a comercialização em 1905, inclusive entre os chineses. O governo estadunidense das Filipinas ainda financiou a Philippine Opium Commission com a coordenação de Brent - que

35 "They are false religions, chemical idols that distract the faithful and lead them down the path of selfdestruction" - tradução sugerida. 
providenciou a correta consciência moral ${ }^{36}$ da equipe investigadora (MUSTO, 1999, p.25-26).

Os acontecimentos das Filipinas eram medidas propagadas pelos defensores das restrições comerciais, inspirando medidas semelhantes na África do Sul. Na Inglaterra, o relatório do reverendo Brent reforçou as críticas ao trabalho realizado pela Royal Opium Commission. A presença estadunidense no Oriente e a necessidade de dar uma resposta para a opinião pública interna fez o governo inglês, novamente com os liberais em 1906, adotar nova posição em relação à questão do comércio do ópio na China. Em 1907, entrou em vigor um acordo firmado com o governo chinês para diminuir o comércio e o consumo de ópio em $10 \%$ ao ano, que previa encerrar o comércio legal do produto até 1917 (DAVENPORT-HINES, 2002, p.202-211; MUSTO, 1999, p.29). Essa iniciativa foi a primeira política pública proibicionista nacional em âmbito mundial, uma vez que a experiência filipina em 1905 foi uma iniciativa imposta de fora. Foi a primeira vez que os sentimentos populares e os anseios missionários deslocam a opinião dos especialistas na definição das políticas nesse campo (DAVENPORT-HINES, 2002, p.207-206) - fato que se tornaria uma tradição na segunda metade do século XX.

Essa iniciativa comercial da Grã-Bretanha também tinha relação e estava respaldada pela diminuição das exportações e a crescente importância que a produção chinesa tinha para esse mercado. Em 1895, os chineses já produziam 85\% daquilo que era consumido no país - fato que levava a Companhia das Índias a temer que em breve os chineses passassem a exportar o produto (ESCOHOTADO, 2008, p.534; COURTWRIGHT, 2001, p.183). Crescia a opinião no seio da diplomacia inglesa que era necessário uma intervenção sobre essa questão, pois em breve a relação histórica se inverteria e os britânicos passariam a importar o produto (KNEPPER, 2011, p.07). Além disso, ainda existia o receio que o fim do tráfico levasse a Pérsia e a Turquia a substituir os ingleses nesse comércio (MUSTO, 1999, p.28).

É preciso destacar também que esses números brutos ignoram a variedade de efeitos e de qualidades que os ópios produzidos na China e fora dela tinham - o ópio inglês era considerado de melhor qualidade (DIKOTTER et al, 2004, p.05-07). Existia certo ceticismo em relação à capacidade da China em realmente diminuir o consumo, porém o governo se empenhou bastante apesar da resistência de algumas províncias fato que surpreendeu os observadores externos. Os chineses conseguiram manter seu

\footnotetext{
36 "providing a moral conscience for the Philippine Commission that had responsibility under the War Department for the management of the Islands" - tradução sugerida.
} 
empenho até 1911 - ano que ocorre a queda do Império (COURTWRIGHT, 2001, p.183).

Paralelamente à iniciativa sino-anglicana os EUA procuravam protagonismo nessa política. Brent e os missionários tinham conseguido proibir o ópio nas Filipinas, fato que não diminuiu o consumo e estimulou o tráfico ilícito. Musto (1999, p.28) admite que até a década de 1930 era mais fácil comprar ópio ilegal nas ilhas do que nas regiões regulamentadas. Escohotado (2008, p.616) afirma que em 1926 o ópio na região das Filipinas era mais barato do que na época permitida. Também os britânicos, segundo Knepper (2011, p.123-124), estavam cientes do fracasso do modelo estadunidense em conter o consumo. Em 1929, o representante britânico na Liga das Nações reportava esse fracasso na London School of Economics ao mesmo tempo em que elogiava a consciência moral da política dos EUA. Essas observações nos obrigam a relativizar, novamente, a posição apresentada por Silva (2013, p.75) no início desse Capítulo. Nem os EUA, nem os britânicos, nem nenhum outro país considerava as medidas de controle implementadas nas Filipinas um sucesso. Ela era tão ruim ou pior do que já estava sendo realizado, porém era "moralmente" digna. Rodrigues (2004, p.47) salienta ainda que a não participação dos EUA no comércio do ópio no Oriente facilitava a adoção de uma posição oficial de proibição. Inaugura-se, também, a tradição de culpar a produção de outros países pelo malogro dos controles internos.

O fracasso na redução do consumo de ópio nas Filipinas era um fator menor na consideração sobre o tema nesse contexto político. O discurso proibicionista era capaz de diminuir as tensões dos EUA com a China, que estavam estremecidas desde o Chinese Exclusion Act, e criar um contexto de projeção dos EUA como nova potência Oriental. Com esses argumentos e forte tráfico de influência, os missionários conseguiram financiamento para promover a Shanghai Opium Commission em 1909 (MUSTO, 1999, p.30-35). Essa conferência é tomada como um marco.

Foi pioneira ao obter, pela primeira vez, o reconhecimento da existência de um problema de âmbito mundial e do perigo da dependência química. Determinou a compilação, pela primeira vez, de informações sobre a produção mundial de ópio. Abriu o precedente de discutir a situação interna dos países no tocante à questão das drogas. Levou a Índia a cessar as exportações de ópio para as Filipinas e demais jurisdições que proibissem sua importação (SILVA, 2013, p.79). 
Essas considerações apontadas acima sobre a Shanghai Opium Commission precisam ser tomadas unicamente nos seus aspectos simbólicos, pois, na época, o resultado do encontro foi considerado ruim - tímido, na melhor das hipóteses. Escohotado (2008, p.619-621) descreve a decepção dos estadunidenses com os seus resultados. A Turquia, grande produtora, não compareceu. A Pérsia causou mal-estar ao mandar um negociante. Os países europeus enviaram, ao encontro, técnicos farmacêuticos que falavam a partir de uma perspectiva laica, fato que criou atritos com a visão teológica da delegação estadunidense. Além disso, Grã-Bretanha e China já tinham um acordo bilateral que parecia estar solucionando o problema. Eles não conseguiram nem mesmo aprovar a recomendação para a realização de um novo encontro. Musto (1999, p.38-40), entretanto, destaca que apesar do aparente fracasso, tal evento favoreceu a continuação dos esforços proibicionistas dando justificativa a adoção de medidas internas de controle nos EUA.

Para Courtwright (2001, p.184-185) parece ter sido mais importante para a posterior consolidação do proibicionismo os resultados do acordo entre britânicos e chineses em relação ao comércio de ópio do que essa conferência. A experiência política chinesa deixava duas lições para os proibicionistas: $1^{\circ}$. Era possível diminuir o vício se o Estado realmente se engajasse nessa questão; $2^{\circ}$. A redução da oferta era o meio do sucesso para eliminar o problema do abuso de drogas e restringir o uso às necessidades médicas legítimas. Rodrigues (2004, p.48) lembra, entretanto, que a Shanghai Opium Commission marcou o lançamento de dois conceitos que se tornariam dominantes posteriormente: somente o uso médico é legítimo; o problema se resolveria com a redução da oferta dos países produtores.

Essas novas atitudes perante as drogas, que são colocadas por Courtwright (2001, p.166) como supremacia da ética sobre os interesses econômicos e políticos, trazem inúmeros problemas. O primeiro deles é o caráter eurocentristas da ideia de uso médico legítimo, porque ele pressupõe como critério os parâmetros da ciência e da medicina ocidental (BERRIDGE, 2013, p.125). Não apenas isso: por trás da humanidade existem claros interesses da classe médica e farmacêutica organizada (ESCOHOTADO, 2008, p.619), incluindo na própria China (DIKOTTER et al, 2004, p.93-94). A proibição também está ligada aos interesses das indústrias farmacêuticas que passavam a vender os produtos fitoquímicos. Segundo Davenport-Hines (2002, p.214-218), o cerco ao ópio teve como consequência o crescimento do uso de morfina, em um primeiro momento, e depois da heroína. Esse fenômeno pode ser verificado 
também nos EUA, na Alemanha e na França. Escohotado (2008, p.616-617) aponta que uma das medidas profiláticas do governo estadunidense nas Filipinas foi oferecer heroína para aqueles que procuravam ajuda pública para tratar do vício em ópio. Prática que, segundo Dikotter et al (2004, p.119-120), também foi adotada pelos missionários na China.

A questão do ópio até hoje sobrevive no imaginário político chinês. O século de humilhação nacional é elemento vivo da legitimação do Partido Comunista Chinês (PCC) - que se coloca como único capaz de defender o país contra a conspiração ocidental que existe desde o século XIX (BERRIDGE, 2013, p.122). Essa função política explica a persistência de um modelo de controle que foi um verdadeiro desastre. Foram consequências dessa política na China: a popularização da morfina e da heroína como fármacos alternativos (DIKOTTER et al, 2004, p.125-126); encarceramento de doentes sem tratamento e infecção de outros presos, levando a morte milhares nos presídios por doenças (DIKOTTER et al, 2004, p.128-130); execução judicial de usuários e traficantes (DIKOTTER et al, 2004, p.142-145); difusão da injeção hipodérmica com o desenvolvimento do tráfico ilícito e, consequentemente, a proliferação de doenças (DIKOTTER et al, 2004, p.152-154; p.173-191); a promoção do tabaco em forma de cigarro como substituto, sendo a droga mais beneficiada com a proibição - China é hoje o maior mercado mundial desse produto (DIKOTTER et al, 2004, p.201-205). Entre outros.

A China e o Oriente eram o principal campo de atuação missionária e proibicionista desde meados do século XIX até início do século XX. Ocupações estrangeiras, fragmentação territorial e disputas internas pela hegemonia política (nacionalistas x comunistas) fizeram o pioneirismo chinês em matéria proibicionista demorar longos anos até se consolidar - somente com a unificação promovida pelo PCC, em 1949, foi possível, de fato, avançar com a perseguição política aos usuários de ópio (COURTWRIGHT, 2001, p.183-184). Até hoje a China é uma das principais defensoras desse regime político. Na reunião preparatória para a Special Session Of The United Nations General Assembly On The World Drug Problem ocorrida em 2015 para o evento do ano seguinte, ela fazia parte de um bloco influente disposto a barrar qualquer mudança no regime de controle, que contava também com Rússia, Paquistão, Egito e outros países asiáticos (BOITEAUX, 2015, p.19)

O proibicionismo conforme se desenvolveu no Oriente era uma questão essencialmente regional, que acabou tomando proporções planetárias porque teve como 
um dos seus principais defensores os EUA, que se tornariam ao longo desse século uma potência de caráter sistêmico. Por isso, além da China, também é preciso olharmos com atenção para os desenvolvimentos estadunidenses internos que geraram esse engajamento em uma cruzada internacional contra o uso de drogas.

Os EUA foram um dos países que desenvolveu uma forma de proibicionismo autônomo. Segundo Escohotado (2008, p.495), esse é o país onde melhor se observa o fenômeno do controle público sobre a ebriedade. Em parte, isso se explicaria pela severidade dos costumes e das crenças dos protestantes puritanos que foram os pioneiros na colonização. Ao lado do republicanismo radical e da defesa da liberdade contra o absolutismo, também se percebe uma preocupação em manter a ordem moral e dos costumes - as primeiras leis antialcoólicas datam do século XVII. Em 1794, a tributação sobre os destilados foi o motivo econômico que levou a Rebelião do Whisky na Pensilvânia. Carneiro (2010, p.193-196) mostra que o protestantismo, inicialmente com Lutero e Calvino, entendia a temperança como equilíbrio. Porém, gradativamente essa noção foi alterando e adquirindo uma característica condenatória aos prazeres da carne - sexo, bebida e comida. Os dois autores (CARNEIRO, 2010, p.182-183; ESCOHOTADO, 2008, p.497-498) destacam a influência desses valores no primeiro tratado médico a considerar o consumo de bebidas destiladas como prejudicial ao corpo e à mente. Trata-se do livro de Benjamin Rush, que assinou a independência dos EUA e é considerado um dos fundadores da psiquiatria, intitulado Inquiry into the Effects of Ardent Spirits on the Human Body and Mind, de 1785. Importante destacar que essas considerações não se aplicavam as bebidas alcoólicas fermentadas.

Existia também a percepção, compartilhada por estrangeiros e estadunidenses, que os habitantes dos EUA eram mais propensos ao esgotamento nervoso. Criou-se uma literatura médica a respeito disso, incluindo a elaboração do termo neurastenia como categoria patológica. Esse nervosismo fazia parte das exigências psíquicas do mundo industrial. As drogas são usadas nesse contexto para insensibilizar as pessoas contra os tormentos físicos e mentais impostos pelo trabalho. Por isso, o uso de drogas era parte inseparável do funcionamento da economia estadunidense (DAVENPORT-HINES, 2002, p.168-170). Carneiro (2010, p.218-219) aponta que correntemente o mal-estar da sociedade industrial é visto como um dos elementos centrais para o crescimento do consumo. As drogas funcionariam como uma espécie de válvula de escape à exploração e como meio privilegiado de lazer. 
Courtwright (2001, p.173-176) chama atenção para outras consequências da industrialização. Foram as suas técnicas que permitiram a produção de bebidas destiladas e alcaloides, drogas fortes, a custos baixíssimos. "Isso torna fácil, barato e rápido para as massas saturar seus cérebros com químicas, dando uma duradoura face aos seus mais primitivos prazeres e sistemas motivacionais" ${ }^{37}$ (COURTWRIGHT, 2001, p.173). Junto a isso, somam-se a popularização de outras tecnologias auxiliares, como a injeção hipodérmica e os isqueiros, que facilitam a administração das drogas. Porém, se “a industrialização fez o abuso em drogas mais agradável e mais visível, gerando preocupação crescente, o abuso ameaça o próprio processo industrial" 38 (COURTWRIGHT, 2001, p.174). Por causa dessa consequência para a produção, além dos bispos e dos clérigos, também a burguesia, como Rockefeller e Ford, apoiavam a causa proibicionista. Mesmo os próprios operários passaram a rejeitar o álcool em certos momentos, pois a sobriedade seria uma forma de obter autorespeito e confiança. Carneiro (2010, p.201-202), por sua vez, destaca que entre as camadas proletárias e as da classe média baixa a abstinência alcoólica se colocava como uma forma particular de distinção social. A abstinência era uma forma de definir e separar aqueles que são dignos de respeito e os que não são. O mesmo valeria para a adoção do ideal burguês de vida familiar, ambos objetivos das campanhas de moralização dos pobres.

Além da moral protestante e das tensões que são próprias de uma sociedade de precoce industrialização, também contribuiu para o intento proibicionista a denúncia promovida pela farmácia, medicina e a saúde pública. A venda indiscriminada, promovida por modernos meios de propaganda, de produtos contendo psicoativos derivados do ópio, da Cannabis e da coca mascarariam os sintomas das doenças e prejudicariam o correto diagnóstico. Começaram a ser realizadas estatísticas que mostrariam os riscos do consumo dessas substâncias. Esses argumentos médicos foram adotados pelos partidários da proibição como forma de dar uma roupagem científica as suas argumentações (COURTWRIGHT, 2001, p.179-182). Por ora, é importante atentarmos para o fato das classes terapêuticas serem importantes sustentáculos ideológicos para o proibicionismo. Sua ascensão tem a ver com mudanças epistemológicas, com o seu grau de organização como classe e da sua articulação

\footnotetext{
37 "It became easier, cheaper, and faster for the masses to saturate their brains with chemicals, making a lasting impression on their most primitive pleasure and motivational systems" - tradução sugerida. 38 "If industrialization made drug abuse more likely and more visible, prompting increasing concern, abuse threatened the industrial process itself' - tradução sugerida.
} 
política - resultando na medicalização da sociedade através da expropriação dos meios tradicionais de cura (ILLICH, 1975), conforme veremos nos Capítulos que seguem.

A intervenção da classe terapêutica sobre o uso abusivo de drogas geralmente é um dos argumentos usados na sustentação ideológica do proibicionismo. Segundo Courtwright (2001, p.169), os custos sociais do uso e o utilitarismo seriam um dos fundamentos desse regime de controle, pois segundo essa doutrina política é um imperativo perseguir um grande bem para o maior número de pessoas possível. O abuso de drogas, especialmente o álcool, gera uma série de males à saúde, provoca acidentes e crimes. Além desses problemas, o abuso de drogas prejudica o trabalho, destrói a família e traz prejuízos econômicos diretos à sociedade (COURTWRIGHT, 2001, p.169).

É inegável que o álcool e as demais drogas podem gerar problemas de saúde, causando doenças graves e crônicas. A questão que se coloca é, até que ponto, a abstinência obrigatória é uma forma de fazer o bem para o maior número possível de pessoas. Do ponto de vista cultural, conforme bem alertou Carneiro (2010), a atitude dominante das sociedades ao longo da história perante a embriaguez foi a temperança no sentido de consumo moderado. A abstinência como política pública é uma imposição da ética protestante radical que se desenvolveu no século XIX. Mesmo Courtwright (2001, p.205-206) admite que não existem indícios médicos e científicos que comprovem ser o uso moderado de álcool algo prejudicial à saúde - que é a atitude predominante em relação à embriaguez.

Essa sustentação ao proibicionismo não se compatibiliza nem mesmo do ponto de vista do utilitarismo, pois parece ser mais benéfico para a maioria que drogas financiem o apoio médico e social nos casos onde ocorrem os usos abusivos. Obrigar a todos à abstinência ainda traz os custos sociais do tráfico ilícito e outras consequências nefastas da proibição, como os envenenamentos. O movimento da temperança inglês, segundo Berridge (2013, p.37-38), publicava anualmente os prejuízos econômicos gerados pelo álcool na sociedade. Essas estimativas apesar de terem sérios problemas metodológicos, serviam como meio de forçar o governo a adotar medidas restritivas, reforçando um suposto argumento utilitarista e humanitário. Esses estudos ignoram, entretanto, o fato de que a proibição das drogas retira do Estado importante fonte de financiamento e desloca para o setor ilícito os ganhos econômicos com essas atividades - levando a uma maior vulnerabilidade famílias e trabalhadores, principalmente dos setores mais pobres da população. A proibição das drogas cria um contexto de 
heteronomia sobre a dor, restringindo o acesso aos antálgicos. Definitivamente, o proibicionismo não pode ser considerado uma política utilitarista - embora ele tenha sido colocado dessa forma no início do século XX.

O movimento proibicionista estadunidense agregava, portanto, vários setores sociais: clérigos e missionários; burguesia e proletariado; classes terapêuticas oficiais. Organizado como partido político em 1869, tal movimento defendia que os males coletivos e individuais advêm dos maus hábitos que deveriam ser corrigidos por meio de reformas educativas e meios coercitivos. Como bem salienta Carneiro (2010, p.199202), embora o proibicionismo tivesse imbuído de traços conservadores e racistas, ele também coexistia com setores progressistas como o feminismo, a luta contra a escravidão, a defesa do favor do sufrágio universal e da maior intervenção estatal no campo da saúde e da previdência. É importante enfatizar também, como bem lembra Hobsbawm (1988, p.351-353), que a melhoria racial da população passava pela escolha das estirpes humanas de melhor valor, mas também pela mudança dos hábitos causadores da degenerescência. Tanto a esquerda, quanto a direita política nessa época eram influenciadas pelos argumentos do tipo eugênico visando a evolução social.

Toda essa base social foi o fermento que permitiu a ascensão de leis reguladoras em inúmeros Estados dos EUA no final século XIX. Porém, essas regulações locais eram limitadas porque existia o tráfico interestadual e era precária a estrutura de vigilância. As leis restritivas e fiscalizadoras tinham o apoio da classe médica que não concordava que as medicinas de patente, com fórmula secreta, fossem vendidas livremente (MUSTO, 1999, p.08-09). Interessante que esse fenômeno de contrabando interestadual parece ter ocorrido no Brasil depois que ele adotou como sistema político a república federalista. A Constituição de 1892 previa autonomia para os Estados organizarem seus serviços sanitários - veremos esse aspecto com mais detalhes no Capítulo cinco.

Esse problema do tráfico interestadual pode ser verificado no posicionamento do diretor do Serviço Sanitário do Estado de São Paulo, em 1925, quando encaminhou documento solicitando maior rigor na fiscalização do comércio de entorpecentes ao Departamento Nacional de Saúde Pública. Segundo a autoridade paulista, era necessário que todos os Estados respeitassem o regulamento e estabelecessem uma "relação dos entorpecentes autorizados a despacho" (RODRIGUES, 1931, p.60) para que fosse possível viabilizar a certificação. Era solicitado também que as repartições de higiene exigissem licenças para o tráfico interestadual (RODRIGUES, 1931, p.60). 
Nos EUA, os limites do proibicionismo em âmbito estadual e o lobby dos missionários que atuavam no Oriente levou o governo federal a promover um grande estudo estatístico sobre a importação e produção de narcóticos nos EUA na virada do século. O Committee on the Acquirement of the Drug Habit mostrou que, em cinco anos (1898-1902), a importação de morfina subia em 600\%, ópio 500\% e cocaína em $40 \%$, enquanto a população cresceu somente $10 \%$. Como a administração por receita médica tinha sido reduzida, a conclusão óbvia era que tais substâncias eram destinadas para sustentar o vício que se disseminava rapidamente (MUSTO, 1999, p.16). Os números apresentados pelo Committee on the Acquirement of the Drug Habit precisam ser problematizados na visão de Escohotado (2008, p.561-562). Um ano antes de começar a pesquisa, em 1897, foi inaugurada a tarifa Dingley - fato que levou a mais baixa importação de ópio desde 1865 no ano de 1898. Além disso, o número total de viciados girava em torno de duzentas a trezentas mil pessoas - o que significava apenas $0,5 \%$ da população. O que aterrorizava nesse relatório era menos o número de habituados em si do que a falsa tendência de subida.

A base social ampla e heterogênea, a influência do lobby das associações terapêuticas oficiais e as primeiras leis estaduais foram elementos centrais para a promulgação das primeiras leis nacionais em relação às drogas. Escohotado (2008, p.621) e Musto (1999, p.38-40) fazem uma leitura histórica tradicional, apontando a atuação do bispo Charles Henry Brent, de Hamilton Wright e de outras pessoas que teriam influenciado à presidência dos EUA em momentos decisivos - tanto com Theodore Roosevelt, quanto com William Howard Taft (que era administrador das Filipinas na época das primeiras leis restritivas do ópio). Brent teria sido uma espécie de líder mundial estadunidense contra as drogas, posição que depois seria assumida por Harry Jacob Anslinger.

A primeira lei de controle foi a Food and Drug Act de 1906. Ela não era uma normativa proibicionista, pois não impunha restrição à comercialização. O principal objetivo da lei era exigir dos fabricantes rótulos informando os conteúdos e a quantidade dos ingredientes vendidos ao consumidor. Para Rodrigues (2004) essa lei "insere o Estado interventor na conduta individual, sob o pretexto paternalista de proteção institucional” (RODRIGUES, 2004, p.46). Escohotado (2008, p.518-519), por sua vez, aponta que ela foi um corretivo para os fabricantes inescrupulosos, pois dava acesso às informações necessárias a correta compra pelos consumidores. Seu princípio era colaborar com a administração privada, impedindo que os fabricantes informassem 
de modo defeituoso ou parcial seus produtos. Foram proibidas as fórmulas secretas. As informações divulgadas arruinaram inúmeros produtores. O público se deu conta que várias drogas com preços totalmente diferentes continham praticamente a mesma fórmula. Musto (1999, p.56-57) ainda enfatiza que a mobilização da Associação Médica Estadunidense em torno dessa lei foi importante pelos contatos criados no Conselho de Saúde e de Instrução Pública, favorecendo o lobby da corporação para novas leis sobre o tema.

O interesse dos médicos em proibir a venda de remédios ao grande público se somava a questão da política estadunidense no Oriente em relação ao ópio. Apesar de rejeitada logo após o encontro de Xangai, a insistência estadunidense e o novo status de potência acabaram levando a um novo encontro que se realizaria em Haia em 1911 (RODRIGUES, 2004, p.48). Foi com esse pano de fundo que foi enviado ao Congresso o Foster Antinarcotic Bill em 1910. Era importante para os missionários mostrarem aos outros países que os EUA já tinham uma legislação interna a respeito. Os defensores do projeto utilizaram larga retórica racista, apontando o uso de cocaína entre os negros no sul, porém acabaram derrotados pelos interesses da indústria farmacêutica e dos próprios farmacêuticos, que entendiam ter suas prerrogativas roubadas (ESCOHOTADO, 2008, p.621-626; MUSTO, 1999, p.44-48). Musto (1999, p.44) ainda aponta a resistência dos democratas, maioria na Câmara naquele ano, em aceitar a interferência federal no comércio estadual. O projeto foi derrubado e os missionários tiveram que ir para Haia sem a legislação interna aprovada, conforme veremos em seguida.

$\mathrm{Na}$ volta de Haia, nova tentativa foi realizada internamente. Dessa vez, os missionários procuraram um deputado democrata, Francis Burton Harrison, para representá-los. E também buscaram um diálogo maior com as categorias profissionais que estavam diretamente envolvidas com essa questão - era preciso diminuir a burocracia necessária para receitar. A saída política foi garantir o monopólio médico e farmacêutico através de ampla liberdade dessas categorias para receitar psicofármacos, fato que gerou certo descontentamento nos setores religiosos. O Harrison Act finalmente foi promulgado em Dezembro de 1914 (ESCOHOTADO, 2008, p.632-635; MUSTO, 1999, p.59-65). Musto (1999, p.65) destaca ainda que o Harrison Act somente indiretamente estava relacionado à proibição do álcool - fato que pode ser percebida na aprovação unânime e sem controvérsia do projeto que originou essa lei, o que contrasta com a polêmica que girava em torno da proibição do álcool. 
A controvérsia em torno do Harrison Act não era se as drogas precisavam ser controladas, mas a forma como isso ocorreria. Musto (1999, p.66-68) aponta que essa lei gerou uma batalha jurídica que transformou uma forma de regulação em uma lei de estilo proibitivo - em 1919 a Suprema Corte legalizou as prerrogativas policiais para controlar as terapias que utilizavam narcóticos. Escohotado (2008, p.636-637), por sua vez, chama atenção para o fato do Harrison Act não prever a proibição porque nesse caso seria preciso uma emenda da constituição - o que precisou ser feito em relação ao álcool. Mas os proibicionistas conseguiram contornar essa necessidade através de ações na Suprema Corte. Tanto o Harrison Act, quanto a Lei Seca eram operacionalizadas pelo mesmo departamento do Estado.

Se, conforme Musto (1999, p.65), o Harrison Act era uma lei de controle moral de menor importância parecida com outras (como o combate ao tráfico de pessoas e as loterias ilegais), o mesmo não se podia dizer do Volstead Act - que levou a famosa $18^{\text {a }}$ Emenda constitucional que aprovou a Lei Seca. Escohotado (2008, p.650-651) lembra o apoio da classe médica à proposta, uma vez que somente com receita médica era possível obter licores e bebidas alcoólicas. É preciso destacar também, conforme bem alerta Behr (2011, p.03-05), a existência de outros interesses em jogo além da iniciativa de criar uma regulação moral pela força. A proibição era uma forma de reação, da elite branca, rural e protestante, contra os outros imigrantes que chegavam obtendo posições de destaque na sociedade, particularmente alemães (cerveja) e italianos (vinho). Esse grupo dominante, descendente dos primeiros colonos britânicos, se colocava como guardião dos valores tradicionais.

Os EUA, nos anos de 1920, tinha se tornado não apenas uma liderança internacional na luta pela restrição da venda e da produção de drogas, como, internamente, implantou o "maior experimento social dos tempos modernos", conforme as palavras usadas pelo presidente estadunidense Calvin Coolidge para caracterizar a Lei Seca (BEHR, 2011, p.03). Essa política estava longe de ser hegemônica, sendo vista com desconfiança pelos países europeus e, até mesmo, pelos sul-americanos. O Brasil foi um país que optou por outro sistema de controle da embriaguez por considerar a abstinência compulsória um erro.

Um posicionamento bastante ilustrativo da posição dominante na época é a apresentada por Evaristo de Moraes. Esse jornalista, professor e jurista participou ativamente do debate entre liberais e positivistas sobre o tema da inimputabilidade (CANCELLI, 2001, p.129-130). Ganhou fama como advogado criminal, atuando em 
casos que mobilizavam a opinião pública, como o "crime da mala" realizado por Miguel Trad em 1908 (CANCELLI, 2001, p.138-140) (FAUSTO, 1984, p.16-17). As descrições sobre os circuitos chineses do ópio no Rio de Janeiro dos anos de 1920 também estão vinculadas a essa literatura do crime e do seu submundo que existia nos periódicos da época. ${ }^{39}$ Evaristo de Moraes foi atuante na política de seu tempo, apoiando a República em fins do século XIX e as forças varguistas nos anos de 1930. Chegou a ser nomeado Consultor Jurídico do novo Ministério do Trabalho, em fins de janeiro de 1931, porém se desligou do governo federal um ano depois por desavenças políticas. Faleceu em 1938.

Ele foi autor de um livro intitulado Ensaios de patologia social: vagabundagem, alcoolismo, prostituição e lenocínio, de 1921 - lançado pouco antes do Decreto 4.294, de 06 de julho do mesmo ano. As suas posições antecipam vários aspectos que acabaram se tornando normativa federal, conforme veremos no Capítulo cinco. Interessante perceber, além das questões doutrinais, como Evaristo de Moraes analisava as experiências sobre o controle da embriaguez em outras partes do mundo.

A experiência internacional no que tange ao controle de álcool era desanimadora, pois

"alcoolismo é, antes de tudo, produto da atual desorganização social-
econômica e da imoralidade individual, esta resultante dos defeitos da
educação e da dissolução da família. Cumpre, portanto, agir sobre as
condições existenciais da sociedade e sobre o espirito dos indivíduos" (MORAES, 1921, p.87).

O Estado, entretanto, não teria se mostrado com força moral para intervir nesse aspecto, pois a indústria do álcool é aquela que dá mais recursos a ele. Muitos países (Suíça, Suécia e Rússia) tentaram criar sistemas de monopólio na venda, porém eles acabaram se transformaram em bons negociantes. "A conclusão vem a ser esta, dolorosa e cruel - o governo mais bem intencionado vê-se obrigado a transigir com o alcoolismo, porque tem necessidade de dinheiro" (MORAES, 1921, p.88). Houve também os países que tentaram vencer o problema do alcoolismo com a proibição absoluta do fabrico e consumo, como nos EUA. Essas medidas realizadas ao longo do XIX, entretanto, acabaram sendo revogadas posteriormente. "Como sucede sempre, quando a proibição é

\footnotetext{
39 Já é tradicional nos eventos nacionais da ANPUH o Simpósio Temático sobre "História do crime, da polícia e da justiça criminal". Nesses eventos se consolidou uma campo de pesquisa voltada unicamente para "representações sociais a respeito do criminal, notadamente a imprensa, mas igualmente a literatura".
} 
muito rigorosa, deu-se largamente a infração da lei” (MORAES, 1921, p.85). O resultado desse tipo de política é o fortalecimento do mercado clandestino que, em certos momentos, consegue alastrar mais a bebida que nos mercados regulados (MORAES, 1921, p.84-87).

Evaristo de Moraes termina pessimista sua análise sobre o controle do álcool no Brasil. Segundo ele, "os projetos de Medeiros e Albuquerque e de Corrêa de Freitas" sobre o tema foram criticados pelos "representantes dos produtores do álcool". Essa "lamentável dependência torna a ação do Estado difícil, morosa, acanhada e tardia" (MORAES, 1921, p.89). Contrariamente a suas expectativas, pouco tempo depois do seu livro seria publicado o Decreto 4.294, de 06 de julho de 1921, incorporando várias de suas sugestões para a política antialcoólica brasileira dos anos seguintes. Esse discurso pessimista em relação ao movimento antialcoólico brasileiro seria adotado pela historiografia contemporânea posteriormente, conforme veremos nos próximos Capítulos.

Essas considerações mostram que o proibicionismo estadunidense encontrava resistência inclusive no Brasil, em uma época em que estávamos alinhados aos EUA. Nessas disputas em torno da melhor forma de regular o comércio e o consumo de drogas, o Brasil apresentava-se como um exemplo de política exitosa - nem tão radical quanto os EUA, não tão depravado quanto o "Velho Bloco do Ópio" (SILVA, 2013, p.85-88). Os encontros internacionais realizados no período anterior à Segunda Guerra Mundial e as promulgações de diversas leis nacionais derivadas desses eventos escondem políticas públicas plurais que, na maioria das vezes, são pouco engajadas nos ideais puritanos defendidos pelos EUA e pela China.

\subsection{A política de drogas na Liga das Nações}

O cenário político para os proibicionistas não era nada otimista no começo do século XX. A primeira experiência, realizada pelos EUA nas Filipinas a partir de 1905, se mostrava um fracasso no objetivo de diminuir a circulação de ópio nas ilhas, além de criar e fortalecer as redes ilícitas. Em 1907, iniciou a parceria entre Grã-Bretanha e China que sustentou a primeira experiência política soberana de um controle público da ebriedade, com resultados que pareceram animadores até 1911 - porém que se encerrou com a queda da dinastia Manchu. A guerra civil e a posterior invasão pelo Japão levariam novamente a China a adotar a posição de denunciante do envenenamento da 
sua população, apontando o tráfico de drogas como uma estratégia do imperialismo ao longo de toda a primeira metade do século XX.

As primeiras iniciativas dos setores missionários estadunidenses no âmbito externo foram igualmente desanimadoras. A Shanghai Opium Commission, conforme vimos, tinha sido frustrante. No âmbito interno, esse mesmo grupo sofrera derrota com a rejeição do Foster Antinarcotic Bill em 1910. Os setores religiosos atuantes no Oriente, entretanto, seguiram articulando o apoio do Department of State sustentando seu argumento na necessidade de estreitar as relações com a China. Dessa forma conseguiram organizar outro encontro internacional. Conforme Berridge (2013, p.125126), a Grã-Bretanha só aceitou participar de novo encontro se o evento não focasse somente na questão do ópio - as novas modalidades fitoquímicas e químicas precisariam fazer parte do acordo. Rodrigues (2004, p.48) aponta que a magnitude do problema e a importância cada vez maior dos EUA impediam os demais Estados de simplesmente se absterem.

A International Opium Convention, ocorrida em Haia, aconteceu em fins de 1911 e início de 1912. Os impasses percebidos no evento anterior e que levaram ao seu fracasso se repetiram novamente, frustrando as expectativas. Países com grande produção, como Turquia, Áustria-Hungria, Suíça, Peru e Bolívia simplesmente não compareceram. Isso gerou protestos da delegação alemã, que não aceitava assinar um acordo sem a presença de outros produtores. Portugal, que colonizava Macau, e a Pérsia não aceitaram os controles que seriam postos sobre sua produção. A Holanda tinha enormes plantações de coca nas suas colônias orientais, Java principalmente, e não estava disposta a diminuir sua produção. Japão e China estavam em conflito, com tradicional queixa chinesa a respeito do envenenamento sistemático do seu povo. A Itália se retirou no segundo dia, pois somente aceitava discutir se a Cannabis fosse incluída na lista. A França tinha interesse comercial no ópio na Indochina, defendendo somente o controle dos fitoquímicos e químicos. Rússia e Tailândia (Sião) também tinham suas produções de ópio, embora menores - e não estavam dispostas a diminuir. (ESCOHOTADO, 2008, p.628-629; MUSTO, 1999, p.50-51).

Frente a tantas divergências, era difícil a adoção de uma resolução de consenso. Ficou decidido que as medidas restritivas só seriam implantadas internamente se todos assinassem, incluindo os países que não participaram do evento. Até isso ocorrer nada valia (BERRIDGE, 2013, p.126-127). Os EUA ratificaram o encontro em 1913 e isso serviu de justificativa para a aprovação do Harrison Act, conforme vimos. Porém, como 
bem alerta Musto (1999, p.52-53), eles não tiveram êxito em fazer os outros países assinarem, nem mesmo o latino-americano Peru no auge da diplomacia do dólar.

Todas essas dificuldades mostram, claramente, que o puritanismo proibicionista não gerava entusiasmo na comunidade internacional. Antes da Primeira Guerra Mundial (1914), apenas oito países tinham ratificado a International Opium Convention de Haia (BERRIDGE, 2013, p.127). A Grande Guerra, entretanto, foi um divisor de águas porque impactou as indústrias dos países beligerantes (Grã Bretanha, França e Japão) que tiveram de ampliar enormemente a produção para satisfazer as demandas da guerra. Até mesmo o Partido Comunista Chinês produzia ópio como meio de obter fundos para o conflito. O contrabando cresceu enormemente (BERRIDGE, 2013, p.132-133). O conflito mundial também foi importante para resolver o problema das adesões, pois a International Opium Convention foi incluída no Tratado de Versalhes (1919) que deu fim das hostilidades (BERRIDGE, 2013, p.118-119; ESCOHOTADO, 2008, p.630$632)$.

Depois do final da Grande Guerra, a recém-criada Liga das Nações tomou a iniciativa de coordenar os esforços internacionais em torno do comércio de drogas. Logo na primeira assembleia da nova instituição foi criado o Advisory Committee on Traffic in Opium and others Dangerous Drugs. Essa instituição trabalhou na cobrança das ratificações dos primeiros tratados, porém era difícil manter um controle sobre os eventos que se sucederiam em cada nação a partir dessa ratificação (BERRIDGE, 2013, p.130-131). Os EUA estavam dispostos a seguirem na liderança da luta antinarcótica, por isso nessa questão eles seguiram colaborando com a Liga das Nações apesar de não aderirem formalmente à nova instituição.

Nos anos de 1920 consolida-se, na posição política estadunidense sobre drogas, a percepção que os países produtores são os únicos responsáveis pelo consumo de drogas. David Musto (1999, p.197-198), adepto de uma história mais tradicional, destaca as convicções pessoais de Stephen G. Porter, líder da House Committee on Foreign Affair e porta-voz dos interesses dos EUA no campo das políticas internacionais de drogas até 1930. Ele seria obsessivo com a ideia de que a produção de ópio puro e folhas de coca deviam ser controladas antes de qualquer outro aspecto, pois sem essa restrição, nem a regulação internacional, nem o Harrison Act poderiam funcionar adequadamente. Várias notificações foram enviadas solicitando que países produtores, como Grã-Bretanha, o governo inglês na Índia, Pérsia, Turquia, Peru, Bolívia e a Java holandesa diminuíssem a produção de narcóticos na forma bruta. 
As fontes primárias indicam que a propaganda estadunidense também chegava ao Brasil de outras formas. O conceituado farmacêutico Silva Araújo, em debate sobre as substâncias entorpecentes realizado na ANM, em 14 de maio de 1920, exortava os médicos brasileiros para não serem indiferentes "a esta série de desgraças", ao se referir “aos envenenamentos produzidos pelo uso da morfina, da cocaína e de outros hipnóticos" (ARAÚJO, 1920 apud SILVA, 2015, p.247). Ele também alertava sobre a responsabilidade do governo federal com o controle do comércio, citando a propaganda estadunidense.

\footnotetext{
"Os importadores dessas matérias primas têm recebido das casas americanas circulares levando-lhes ao conhecimento que o governo americano dirigiu-se a todos os governos do mundo, propondo pôr-se esse comércio controlado por todos os governos, isto é, que a exportação e a importação das referidas matérias se fizesse sob a responsabilidade dos governos. Dizem mais as circulares que, de todos os governos do mundo, apenas os de seis países não corresponderam ao apelo - e um desses seis é o nosso" (ARAUJO, 1920 Apud SILVA, 2015, p.252).
}

Essa manifestação é bastante elucidativa de um tipo de propaganda lançada pelos EUA na época diretamente aos importadores, inflamando a posição contra o governo brasileiro. O conteúdo do panfleto, conforme relato acima, não parece corresponder com exatidão aos fatos. Se naquele ano o país ainda não dispunha de uma legislação nacional que previsse pena de prisão para quem não respeitasse o monopólio médico, a grande maioria dos países também não tinha. Além disso, o Brasil tinha sido um dos pioneiros na adesão das novas orientações internacionais. Segundo Carvalho (2013, p.77-80), o governo holandês convidou o país a participar da segunda fase da International Opium Convention de Haia, entre 1 e 9 de julho de 1913, e da terceira fase entre 15 e 25 de junho de 1914. O representante brasileiro foi o embaixador José Pereira da Graça Aranha que na ocasião era cônsul na Holanda. Ele assinou todos os protocolos e enviou ao Congresso Nacional, que ratificou a participação com o Decreto $\mathrm{n}^{\circ} 11.481$ de 10 de fevereiro de 1915.

O Brasil, nessa época, esbanjava autoconfiança e superestimava seu peso internacional em razão da sua participação na Grande Guerra. Sua posição não era questionada em um primeiro momento, pois ele não colocava em causa "a divisão internacional do trabalho, cumprindo o país a função de típico exportador de produtos primários" (CERVO et al, 2012, p.216). Nas conferências que participava acatava as 
principais orientações pensando "estar participando das decisões internacionais" (CERVO et al, 2012, p.216). No caso das políticas sobre drogas, o Brasil não era produtor de plantas para produzir entorpecentes, por isso não existiam atritos com a pretensão de seu principal parceiro, os EUA, de erradicarem o consumo de certas plantas ao redor do planeta.

Disposto a levar a cabo sua campanha mundial contra as substâncias entorpecentes através da diminuição da produção de narcóticos na forma bruta, os EUA ajudaram a Liga das Nações a promover o Geneva Convention on Opium and Other Drugs entre 1924 e 1925. E mais uma vez, como ocorreu em todos os encontros anteriores, os EUA saíram contrariados do evento. Todas as nações que produziam papoula, com exceção da China e do Egito, não aceitavam as imposições dos EUA. Os EUA não conseguiram adesão para suas propostas nem mesmo de seus tradicionais aliados britânicos e, consequentemente, da Índia. Não foram aceitas também: o fim da produção manufaturada de heroína; proibição de produtos farmacêuticos com pouco conteúdo de ópio (permitido na Conferência de Haia); medidas para banir o consumo de ópio fumado no Extremo Oriente. Houve somente pequenos avanços segundo a concepção estadunidense. Foram eles: a inclusão da Cannabis na lista das substâncias só permitida para uso médico; a criação de um órgão permanente, Permanent Central Board, para verificar o comércio e se os tratados estavam sendo cumpridos. A insatisfação foi tanta que a comitiva estadunidense, em companhia dos chineses, se retirou do evento - gerando protestos gerais dos demais países (MUSTO, 1999, p.202203). Escohotado (2008, p.699) lembra que a partir dessa data os EUA se autointitularam autoridade para decidir o quanto e o que os países poderiam plantar, independente de quais fossem suas tradições.

O historiador David Musto (1999, p.202), que escreveu um dos clássicos do assunto, afirma que naquela ocasião os únicos países importantes a apoiar a causa estadunidense eram a China e o Egito, porém o primeiro não tinha controle sobre a produção do seu país e o segundo não produzia ópio para exportação. Sobre o Egito, Knepper (2011, p.125-127) lembra que nessa época ele fazia parte do Império Britânico. O governador, Sir Thomas Wentworth Russell, vulgo Russell Pasha, tornou-se uma espécie de celebridade no campo da política de drogas. Em 1925, ele aprovou uma série de leis antidrogas e criou uma brigada especializada a combater o tráfico ilícito na região. Essas movimentações políticas passaram a ser divulgadas pela imprensa londrina como um exemplo que devia ser seguido pelas demais partes do Império. As 
ações policiais promovidas pela polícia egípcia eram noticiadas com detalhes, na onda de popularidade dos enredos policiais e investigativos que vingava nos jornais daquela época.

Embora desconsiderado por Musto (1999, p.202) como um ator relevante nas disputas, o Brasil participou desse evento e acompanhou os impasses ocorridos. Segundo Carvalho (2013), o embaixador Gurgel de Amaral encaminhou ao MRE uma carta explicando a posição dos EUA ao secretário da Liga, assim como uma notícia do jornal The Washington Post criticando a posição inglesa na ocasião. Foram designados como delegados brasileiros no evento os médicos Pedro Pernambuco Filho, dono de uma clínica privada no Rio de Janeiro e autor do livro clássico Vícios Sociaes Elegantes, e o jurista Demócrito de Almeida. Porém, no último momento, eles não conseguiriam ir e o país acabou representado novamente pelo embaixador da Holanda. O país defendeu "a tese da limitação da produção as necessidade médicas e cientificas" (Relatório do MRE, 1926 apud CARVALHO, 2013, p.81), apresentando com orgulho o Decreto $\mathrm{n}^{\mathrm{o}}$. 4.294 de 14 de julho de 1921, considerado rigoroso em relação às importações e ao uso de substâncias tóxicas. Na visão da diplomacia brasileira, era preciso modernizar os meios de fiscalização, porém isso esbarrava nos interesses comerciais dos impérios.

Essas negociações ocorriam paralelamente à deterioração das relações entre o Brasil e a Liga das Nações. Com a entrada da Alemanha no organismo, criou-se a expectativa de uma reforma do Conselho da Liga das Nações e o ingresso brasileiro como membro permanente. Era uma posição também almejada por Espanha, Polônia, China e Bélgica. Após ver o seu pedido rejeitado, o país se retirou da Liga em 1926. "Na opinião brasileira, aquela que deveria ser a antítese da Santa Aliança estava se distanciando do ideal americano, pois, ao invés de preparar o futuro, perpetuava o passado" (CERVO et al, 2012, p.244). O Brasil passou a denominá-la de "Liga das grandes potências, quase que exclusivamente europeia" (CERVO et al, 2012, p.244). A retirada do Brasil e da Espanha, que também se afastou depois de ver suas pretensões ignoradas, foi o primeiro grande golpe na Liga. Entretanto, apesar dessa posição, o Brasil manteve atitude amistosa e de colaboração em consonância com os propósitos dessa organização internacional. Seguiu pagando a contribuição anual e participou, inclusive, da elaboração de um centro de investigação sobre a hanseníase na OMS em 1931. 
Nas conferências internacionais o debate sobre as formas adequadas de controlar o comércio de drogas era tema polêmico, opondo diversos interesses comerciais que eram incendiados pela posição puritana estadunidense. Nesse cenário o Brasil se colocava como defensor de um sistema americano, supostamente ético e científico, contra os interesses comerciais dos impérios europeus. Desde 1921, ou seja, quatro anos antes do Egito começar a implantar sua legislação antinarcótica, o Brasil já tinha uma lei que apresentava como modelo a todos os outros países. Modelo este que era rejeitado pelos grandes impérios, que também lhe negavam uma vaga Conselho da Liga das Nações.

O posicionamento do Brasil nos fóruns e o seu posterior desligamento da Liga das Nações parece contradizer a hipótese de que o país se comportou "como observador distante e pouco curioso de uma tempestade que parecia dirigir-se a outras regiões" (SILVA, 2013, p.200). Existe uma interpretação, exposta por José Carlos de Macedo Soares, em 1927, que aponta como causa principal da saída do Brasil da Liga das Nações a prepotência do então presidente Artur Bernardes no sentido de exaltar o sentimento nacionalista interno (CERVO, 2012, p.245-246). Contrariamente, percebe-se a posição do Brasil em relação às drogas nos fóruns internacionais desse período como atuante. Ele se colocava na condição de representante de uma política americana. Nada mais natural de que ele assumisse a condição de porta-voz dessa política na ausência dos estadunidenses através de um assento permanente no Conselho da Liga das Nações. Sabiam, entretanto, as grandes potências que os "Estados Unidos manter-se-iam arredios ao organismo de Genebra" (CERVO, 2012, p.244) mesmo se o Brasil assumisse essa vaga. Além disso, essa suposta política americana contra as drogas não contava com unanimidade nem dentro do próprio continente americano.

Algumas observações sobre os países americanos mostram que o proibicionismo, como defendido pelos estadunidenses e brasileiros, também estava longe de ser uma unanimidade. Bolívia e Peru foram os principais produtores de coca durante todo o século XIX. A Bolívia foi a primeira a exportar o produto com destino à França, usado como matéria prima para o vinho Mariani (GOOTEMBERG, 2008, p.5657). Com a descoberta das propriedades analgésicas, foi o Peru que tomou a dianteira na produção para exportação graças à técnica de produção da "cocaína crua". Até 1905, os peruanos eram os principais produtores dessa matéria prima, fato que alçou a família Durand à poderosa facção política da região de Huánuco - opositora aos intentos centralistas de Lima. Essa indústria entrou em crise depois de 1905, pois iniciou a fase 
de expansão da produção de coca para o Oriente com os holandeses e com os japoneses. Em 1915, a produção peruana para o mercado mundial era inexpressiva. Principalmente por causa da Holanda que introduziu novas técnicas produtivas que dispensou a “cocaína crua”. Nessa época Java se constituía no principal produtor mundial de coca. Também os japoneses tiveram importância econômica regional, abastecendo a demanda do grande parte do Oriente (GOOTEMBERG, 2008, p.125-131).

A tentativa de restrição à produção via Liga das Nações era percebida com enormes restrições, tanto na Bolívia, quanto no Peru. Os dois países, entretanto, promoveram distintas estratégias de resistência a esses intentos. A Bolívia procurou defender sua produção de coca através de uma ativa diplomacia. A posição boliviana era sustentada pelo lobby das elites que produziam coca e se organizavam em sindicatos de classe - Sociedad de Propietarios de Yungas. Em 1923, a Bolívia entrou decidida nos debates em não permitir que a coca adquirisse o rótulo de narcótico, se opondo a adoção de leis anticoca no seu país, pois fazia parte da sua cultura e era uma necessidade indígena. Na segunda fase da conferência de Haia, o delegado boliviano defendeu ativamente a legalidade da folha de coca. Em debate acalorado com os estadunidenses sobre essa questão foi registrado o aplauso dos presentes perante a sua fala. O impasse gerado por essa questão levou a Liga das Nações a enviar uma delegação de cientistas para estudar o uso de coca na Bolívia (GOOTEMBERG, 2008, p.214-216).

A atuação boliviana no interior da Liga mostra que o país estava longe de ser passivo frente às tentativas de intervenção nos hábitos tradicionais de seu povo. Ao contrário do que crê Silva (2013, p.176-180), não foi Evo Morales que inaugurou a diplomacia cocaleira. A resistência boliviana fortaleceu ainda mais as frustrações estadunidenses em 1924. Em 1927 e 1932, o Congresso Boliviano reiterou que o país não iria restringir o cultivo de coca, nem proibir o seu uso entre a população indígena, fazendo um desafio direto às pretensões da Liga das Nações. Essa atitude contribuiu para a Bolívia permanecer como um mercado regional de coca. O governo boliviano também promoveu relatórios defendendo as propriedades da coca, posição independente que perdurou até a Single Convention on Narcotics Drugs de 1961 (GOOTEMBERG, 2008, p.214-216).

Curioso notar que, na primeira metade do século XX, a coca mascada era um elemento associado ao atraso e à degeneração indígena, enquanto a cocaína era percebida como fruto benéfico da modernidade. Posição totalmente oposta à ideia atual que entende a folha como uma tradição respeitável e a cocaína como vício intolerável 
(GOOTEMBERG, 2008, p.100-102). O Peru era o país que tinha, além de uma população indígena consumidora de coca, uma indústria legal de cocaína. Ao contrário da Bolívia, que optou por uma resistência no interior da Liga das Nações, ele rejeitou participar da Liga das Nações e, quando foi obrigado a isso por causa do tratado de Versalhes, criticou bastante a preferência dessa instituição ao Chile na questão da fronteira. Teve uma adesão meramente nominal aos seus tratados (GOOTEMBERG, 2008, p.214). Durante a convenção de Haia o Peru simplesmente se absteve, no auge da diplomacia do dólar.

\begin{abstract}
"A posição peruana teve repercussões além da coca, pois inspirou a abstenção de estados produtores de papoula nos Bálcãs, levando ao impasse que gerou o chamado para uma segunda conferência em Haia. Peru finalmente assinou os princípios de Haia em 1921 via Tratado de Versalhes, porém seu papel continuou nominal ${ }^{\circledR 40}$ (GOOTEMBERG, 2008, p.210).
\end{abstract}

Essas colocações sobre o Brasil, Bolívia e Peru mostram que esses países estavam longe de terem uma "verbalização tímida de suas posições" (SILVA, 2013, p.91), ou apostassem que o silêncio os levaria a não necessidade "do cumprimento dos dispositivos de controle dos acordos assinados" (SILVA, 2013, p.91). Se o Peru se absteve, foi como uma estratégia de resistência que também serviu de exemplo a outros países atingidos pelas arbitrariedades estadunidenses. Brasil e Bolívia colocaram e defenderam suas posições nos fóruns, de acordo com os interesses de cada um. A divergência de posição do Brasil em relação aos países andinos sobre a coca pode explicar a oposição que ele enfrentava de seus vizinhos nos fóruns internacionais. $\mathrm{O}$ Brasil não teve apoio dos países da região na sua reivindicação no Conselho das Nações Unidas. Os "governos latino-americanos não concordavam com a reivindicação brasileira e chegaram mesmo a trabalhar contra" (CERVO et al, 2012, p.246).

Infelizmente a historiografia latino-americana sobre as drogas na primeira metade do século XX ainda é incipiente. ${ }^{41}$ Não foi localizado nenhum trabalho sobre a Argentina e Uruguai. Labbé (2011, p.37-38), que estuda o Chile, chega a apontar a

40 "Peru stance, in one opinion, had repercussions beyond coca, having inspired abstention by poppygrowing states in the Balkans, leading to the 1912 impasse behind the call for a second Hague conference. Peru finally signed on Hague principles in 1921 via Versailles, but its role remained nominal" - tradução sugerida.

${ }^{41}$ Entre os dias 02 e 03 de março de 2016, participei do IV Simposio Internacional Delitos, Policías y Justicias en America Latina, ocorrido na Universidade Federal do Rio de Janeiro (UFRJ). A revisão historiográfica apresentada abaixo foi discutida na exposição "O Brasil e a proibição internacional das drogas no início do século XX". 
participação de argentinos no contrabando de drogas para este país na década de 1940 . Existia a crença, por parte da Polícia do Estado de São Paulo, que o Estado do Rio Grande do Sul era parte de uma rota ilegal de tráfico criada a partir da região do Rio da Prata. Essa pelo menos era a opinião do Dr. Juvenal Piza, Delegado de Costumes e Jogos de São Paulo.

O Estado do Rio Grande do Sul, pela estrada S. Paulo - Rio Grande, nos envia muito toxico, que ali entra pelas fronteiras. Por ocasião da prisão de Miguel Trade, tivemos a oportunidade de observar que ele fez varias viagens ao Rio Grande, por mar e terra, afim de suprir de cocaína e morfina (PIZA apud GALVÃO, 1928, p.13).

Por isso, com exceção do comércio de coca e cocaína na Bolívia e no Peru por causa da obra de Gootemberg (2008), quase nada se sabe - menos ainda sobre a luta antialcoólica. As exceções são o Chile e o México, que veremos brevemente abaixo.

No Chile, é possível perceber desde meados do século XIX a presença de coolies chineses associada ao uso de drogas. Eles desembarcavam no país para trabalhar nas lavouras do litoral desde meados do século XIX (DONGHI, 2012, p.188). Até a década de 1950 existiam registros policiais referentes à prisão de chineses por tráfico de ópio, fato que denota a persistência dessa prática naquela comunidade (LABBÉ, 2011, p.43). As farmácias chilenas seguiram vendendo entorpecentes para a população até a década de 1960, acompanhando o tráfico ilícito de cocaína que crescia desde os anos de 1940. Os primeiros laboratórios clandestinos de refino começaram a ser fechados nos anos de 1950 (LABBÉ, 2011, p.37-48). De modo geral o consumo de drogas aparece como algo exótico, estrangeiro e repulsivo. Como uma espécie de efeito indesejado da modernidade tão almejada (LABBÉ, 2011, p.12-14). A vitória na guerra do Pacífico também trouxe para o Chile populações habituadas ao consumo de coca. Segundo Labbé (2011, p.23), existia a preocupação, por parte das autoridades chilenas, de restringir a presença da coca nas regiões conquistadas ou, pelo menos, circunscrever sua utilização para as comunidades peruanas e bolivianas que ali viviam. Gootemberg (2008, p.117-118), por sua vez, aponta que as áreas de exploração mineira, incluindo a chilena, eram importantes consumidoras de coca. A exportação boliviana desse produto para países vizinhos, incluindo o norte da Argentina, se constituía em metade dos proventos de La Paz nos anos de 1920 e 1930.

Os discursos sobre as drogas no Chile articulava de forma incisiva a questão da raça, da eugenia e da degeneração (REBOLLEDO, 2013, p.151-160), um dos temas 
frequentes que sustentaram a proibição no início do século - conforme se tem destacado. Essa mesma prática discursiva se aplicava ao álcool. As antigas noções de correção e de caridade vão sendo abandonadas em prol de um discurso médico que pretende intervir nos corpos com objetivo de melhorar a raça e fortalecer a nação (REBOLLEDO, 2013, p.146-147). Importante destacar que esses discursos estavam em consonância com o intento do Estado em alcançar uma renda permanente a partir do imposto sobre as bebidas. No nível municipal, entretanto, os vendedores de bebida tinham importância política eleitoral - fato que acabou favorecendo desvios ao intento antialcoólico implantado até os anos de 1930 (LABBÉ, 2006).

Outro país que a historiografia avançou bastante foi o México, principalmente em relação ao tema do álcool. O discurso que associa a decadência do indígena ao consumo excessivo de bebidas alcoólicas é tão antigo quanto à própria colonização. Várias leis locais foram feitas no sentido de taxar as bebidas, limitar o consumo e regular as formas de beber. Essa tradição de condenação do uso excessivo de álcool ganha um novo ímpeto no final do século XIX com a ascensão do Porfiriato. O positivismo, adotado com entusiasmo pelas classes dirigentes, criava a sensação de que o governo era feito a partir dos cânones da ciência. Vários estudos foram feitos no sentido de compreender melhor as patologias sociais, principalmente o alcoolismo e a criminalidade. Essa visão ganhava ares de ciência com a antropologia criminal, ideologia que servia para reforçar as hierarquias tradicionais (PICCATO, 1997).

Interessante paralelo é possível fazer em relação ao contexto brasileiro. Existia no Brasil "um grupo político organizado, o dos positivistas" (CORREA, 2013, p.76) que "questionava o privilégio da transmissão institucionalizada do saber por intermédio das faculdades, incentivando o debate a respeito da 'liberdade profissional' que deveria ser inscrita na primeira Constituição republicana" (CORREA, 2013, p.76). Essa posição esbarrava no argumento médico que buscava o monopólio da profissão a partir da sua titulação - argumento que, apesar das resistências, acabou vencedor no Código Penal de 1890, conforme veremos no Capítulo cinco. As Faculdades de Medicina estavam associadas a uma tradição bacharelesca que passou ser entendida por alguns setores como um obstáculo ao progresso do país. No Rio Grande do Sul o positivismo tomou conotações de ideologia oficial, gerando um contexto de enfrentamento à classe médica. Se positivismo do Partido Republicano Rio-grandense (PRR) serviu como barreira às restrições no comércio de medicamentos, o positivismo do Porfiriato apoiava as limitações de consumo de um público considerado despreparado. O discurso triunfalista 
da ciência é pródigo em transformar princípios morais em verdades científicas, se adaptando a diferentes contextos.

No México, esse discurso legitimou a repressão policial, a segmentação do espaço urbano, o desprezo pela cultura popular e a segregação das classes sociais. A condenação dos pulques e das pulquerias - locais identificados como degradantes, de libertinagem e de pouco decoro - era exemplar desse desprezo pelos hábitos e práticas populares. Essa representação contrasta com as cantinas, lugares que vendiam bebidas importadas - cerveja e vinho - e frequentada por estrangeiros. A predileção à ingestão de grandes quantidades de álcool era percebida como um traço de degeneração do índio, obstáculo ao progresso (PICCATO, 1997). Foi, entretanto, a partir da Revolução que as iniciativas contra o álcool ganharam mais força. Pierce (2008) mostrou que o movimento antialcoólico foi se fortalecendo conforme o Estado mexicano se consolidava, alcançando o auge no governo de Cárdenas em fins da década de 1930.

Outro paralelo pode ser construído a respeito dos diferentes significados que os tipos de bebida assumiam. No Brasil, o movimento pró-temperança

\footnotetext{
"teve raízes nos anos 1870, com a difusão do cientificismo, ou crença no papel da ciência como instrumento para explicar o comportamento dos indivíduos e garantir as bases para a formulação de políticas de intervenção na ordem social" (MARQUES, 2014, p.225).
}

A ampliação da urbanização e a necessidade de coexistência de vários estratos sociais levou a consideração de distintos meios de lidar com o problema dos hábitos indesejados nos espaços públicos, como a embriaguez. Existiam divergências sobre a forma de lidar com a questão: liberais contra positivistas (SILVA, 2015, p.190-198) ou escola francesa contra escola italiana (MARQUES, 2014, p.225-226). Porém, assim como no México, os alvos principais do discurso antialcoólico brasileiro eram "os hábitos de consumo da população pobre e mestiça” (MARQUES, 2014, p.222). As indústrias de cerveja apresentavam suas bebidas como um produto industrial, frutos de técnicas modernas de produção desenvolvida na Europa. O vinho e a cerveja eram tradicionais no velho mundo e, por isso, respeitáveis. Se diferenciavam da parati (aguardente) que era sinal da degradação do negro. As formas de consumir e o tipo de bebida compunham sinais de demarcação entre os grupos sociais (MARQUES, 2014, p.257). 
Tanto no México, quanto no Brasil é possível identificar a influência do movimento da temperança dos EUA, porém não devemos considerá-lo uma cópia ou um fracasso porque ele não conseguiu a proibição total da venda. O México nunca teve uma proibição nacional, nem desejou isso porque tal medida infringia o direito individual, ameaçava a economia e criava um problema sério de desrespeito à lei. Os problemas ocasionados pela Lei Seca dos EUA, que depois levaram ao seu abandono, eram acompanhados pelos mexicanos. Por isso, respostas autônomas foram criadas para dar conta desse problema (MONFORT, 1997, p.150). Vimos acima como essa opinião era compartilhada por Evaristo de Moraes.

Além do álcool existem pesquisas sobre as outras drogas no México. Desde meados do século XIX, tanto a papoula (MONFORT, 1997, p.150,) quanto a coca (ASTORGA, 1999, p.183) eram vistas como plantas com enorme potencial comercial por causa de suas qualidades medicinais. O contrabando para os EUA foi fundamental para o desenvolvimento do tráfico ilícito principalmente no norte do país. Valdivia (2014), que analisou a região da Baixa Califórnia, mostrou que a presença de milhares de chineses na região exacerbou as tensões étnicas e trabalhistas, contribuindo para a criação de estereótipos relacionados à prática de consumir ópio. A venda de bebidas alcoólicas era reprimida junto com outras práticas, como os jogos de azar e a prostituição. Existia também a percepção de que o uso de ópio começava a ultrapassar a comunidade chinesa e atingir a população em geral, com prejuízo à construção da nação. Médicos e farmacêuticos eram acusados de favorecer o vício das pessoas, culminando com a redução da prerrogativa da classe terapêutica em receitar produtos narcóticos. Assim como no Chile,

$$
\begin{aligned}
& \text { o "degeneracionismo" teve grande alcance porque era um fato } \\
& \text { "cientificamente comprovado" que se converteu em paradigma hegemônico } \\
& \text { para explicar as consequências do consumo que certas substâncias possuíam }{ }^{42} \\
& \text { (VALDIVIA, 2014, p.232). }
\end{aligned}
$$

As características gerais das políticas de drogas no Chile e no México nos mostram três pontos importantes: em ambos locais existiam tensões étnicas com populações chinesas, igual como ocorria em outras partes do mundo; existia preocupação com o aperfeiçoamento da população através de concepções eugênicas,

\footnotetext{
${ }^{42}$ El "degeneracionismo" tuvo gran alcance porque era un hecho "científicamente comprobado" que se convirtió en el paradigma hegemónico para explicar las consecuencias que el consumo de ciertas sustancias tenía - tradução sugerida
} 
fazendo das drogas objetos de intervenção do poder público; existia uma influência política por parte dos organismos internacionais e dos EUA por controlar o comércio e restringir o consumo de substâncias entorpecentes. Apesar disso, tal comércio seguiu existindo durante toda a primeira metade do século XX.

Essas preocupações com o futuro da raça e o apelo à ciência como meio de explicar os rumos da civilização fazem parte de uma percepção de decadência bastante difundida no mundo ocidental durante os anos de 1920 e 1930. A ciência é capaz de construir vários mitos que convertem princípios morais em verdades científicas. Isso é perceptível, por exemplo, nas análises econômicas, raciais e psicanalíticas do social que utilizavam o vocabulário da doença, do declínio físico e da instabilidade mental (KNEPPER, 2011, p.02-03). Segundo Hobsbawm (1988, p.359-362), o mundo intelectual europeu, ainda bastante reduzido em função do acesso restrito ao ensino superior (diferentemente dos EUA que já começava a massificá-lo), era caracterizado por um enorme pessimismo. Nietzsche era o que melhor expressava esse sentimento, uma vez que apontava para a decadência da vanguarda e a submersão do gênio à mediocridade produzida pela democracia e o socialismo. Apenas o marxismo destoava desse amargor intelectual característico da belle époque.

A proibição das drogas, na maioria dos países, estava mais relacionada com as tensões geradas pela democratização de fármacos que antes eram privilégios de uma elite do que ao puritanismo estadunidense ou o excepcionalismo da política proibicionista chinesa. O que gerava alarde social era o perigo da ampla disponibilidade de um "veneno" a uma população despreparada moralmente. Na Europa, existia a percepção de que ocorria o "crescimento da degeneração nervosa e a exaltação difusa e sinistra da decadência"43 (DAVENPORT-HINES, 2001, p.170), abrindo espaço para teorias criminológicas como a de Cesare Lombroso. O degenerado, assim como o drogado, não tinha controle sobre suas emoções e ameaçava toda a coletividade.

Segundo David Courtwright (2001, p.168-169), o "perigo direto a outros inocentes é o mais potente argumento moral contra o uso de drogas, válidos em todas as culturas." ${ }^{44}$ Vários relatos, independente de serem verdadeiros ou não, associavam as drogas e o álcool como promotores da violência - percepção que foi um importante

\footnotetext{
43 "The context for drugs was diferente across the Atlantic. There seemed during the 1880 s and 1890 s to be a strange and intolerable atmosphere hanging over Europe: the effluvium of nervous degeneration and the diffuse, sinister exhalation of decadence" - tradução sugerida.

44 "Direct harm to innocent others is the most morally forcefull argument against drug use, and one that cuts across all culture" - tradução sugerida.
} 
suporte da proibição. O álcool, por exemplo, seria responsável por vários acidentes de trânsito, pela violência doméstica e por gerar doenças crônicas nos consumidores. O não fumante sofre quando convive com fumantes. Por isso, o Estado tomou para si a defesa da sociedade em detrimento da liberdade individual. Evaristo de Moraes (1921, p.94), por exemplo, acreditava que a íntima relação entre alcoolismo e criminalidade era uma espécie de lugar comum entre os juristas brasileiros, ponto em que "se harmonizavam clássicos e positivistas".

Esse argumento, entretanto, apresenta uma série de problemas. Atribuir ao álcool ou à cocaína a violência doméstica ou às brigas é uma forma de eximir os homens das consequências de seus códigos de virilidade - é a sociedade que reitera e legitima a violência como forma de solução dos conflitos. Sobre a Cannabis, Davenport-Hines (2002, p.202) mostrou o caráter sensacionalista das notícias envolvendo mexicanos tomados por suposto instinto assassino depois de usar a erva. Na verdade, a Cannabis tem um efeito oposto à excitação nervosa. Sobre as outras drogas, principalmente os opiáceos, Escohotado (2008, p.1138-1139) lembra do perfil dos usuários quando começou a proibição. Eles eram pessoas de segunda e terceira idade, integradas ao nível familiar e profissional que adquiriam o hábito por motivos iatrogênicos. O jovem, criminoso e não integrado socialmente é um dos frutos da política de proibição. Não sua causa.

Vimos, brevemente acima, as motivações políticas que levaram o Chile e o México a adotarem medidas restritivas em matéria de comércio de entorpecentes. As motivações de cada país variavam e o proibicionismo estava longe de ser unanimidade, tanto na América, quanto na Europa. A comparação entre as políticas britânica e estadunidense - que são dois países tradicionalmente aliados, predominantemente protestantes e com prematuro desenvolvimento industrial - mostrará que a divergência ocorria mesmo nessas condições.

Tanto nos EUA, quanto na Grã-Bretanha, o movimento da temperança surgiu em 1830 e com objetivos bem parecidos - era uma minoria militante que procurava moralizar o proletariado. A partir da década de 1840, o movimento começa a se diversificar nos EUA, incorporando religiosos, pessoas da classe média e da classe trabalhadora contra o crime e a pobreza. O mesmo não ocorre na Grã-Bretanha. A retórica da luta pela liberdade contra a tirania do álcool continuava similar e, gradativamente, ela foi sendo adotada pelo movimento feminista - existem vários relatos de intercâmbio de liderança nos dois países (BERRIDGE, 2001, p.47-49). 
Algumas dessas lideranças também estiveram no Brasil, legitimando núcleos brasileiros de ação antialcoólica.

A Liga Nacional Contra o Alcoolismo (LNCA) do Brasil foi fundada em fins dos anos de 1910 e início de 1920. Em 19 de agosto de 1920, O Jornal do Rio de Janeiro convocava os fundadores e aderentes para tratar da criação de estatutos e organização. No dia 21 de maio de 1921 ocorreu o evento de lançamento da Liga, com discurso do médico Belizário Penna sobre o alcoolismo - no evento estavam representadas inúmeras associações e autoridades públicas (noticiado em vários jornais). A Sociedade Vegetariana do Rio de Janeiro, por exemplo, exaltou a nova entidade como "conquista na ordem dos assuntos que a Sociedade advoga". No discurso do seu presidente, foi citada uma frase feliz de um dos sócios que "afirmara que pode-se ser omnívoro abstinente, mas que não existe absolutamente nenhum vegetariano alcoólico" (O Jornal, 11 de junho de 1921). Pouco antes desse evento, desembarcava no Rio de Janeiro “Anna Gordon, presidente da World Women's Christian Temperance Union, uma das sociedades internacionais" (O Jornal, 20 de maio de 1921).

Ela foi recebida por representantes da Associação Cristã de Moços, Associação Cristã Feminina, por Erasmo Braga presidente da LNCA e Sr. Morgan embaixador dos EUA. Na sua palestra a Sra. Gordon falou sobre as suas impressões obtidas através da viagem realizada pela América do Sul, assinalando o excelente trabalho realizado no Uruguai na propaganda antialcoólica. Depois de falar sobre os males do vício, assinalando esperar o êxito da campanha no Brasil. No evento Erasmo Braga ainda teve tempo de expor o desenvolvimento da propaganda antialcoólica no país (O Jornal, 20 de maio de 1921). 


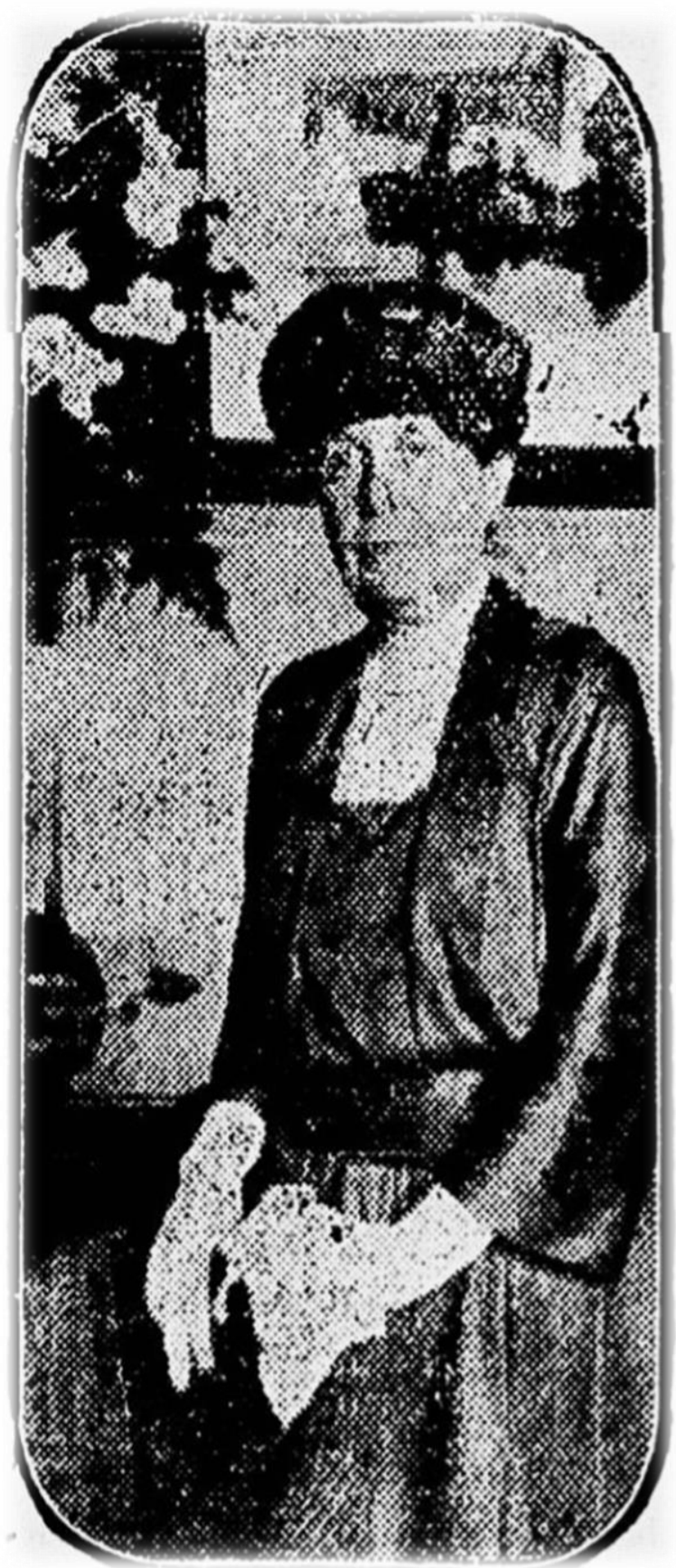

Figura 6 - Miss Gordon na Associação Cristã Feminina do Rio de Janeiro (1921) FONTE: O Jornal, 20 de maio de 1921.

A presença de Miss Gordon era entendida como o ingresso do movimento antialcoólico brasileiro na luta mundial, pois a partir de então a LNCA entraria "em correspondência no seu início com as grandes organizações internacionais que se acham empenhadas em conseguir até 1930 a extinção do comércio do álcool em todo o mundo" (O Jornal, 19 de maio de 1921). A presença desse tipo de militância, entretanto, precisa ser contextualizada. Qual o impacto desses grupos na elaboração de políticas públicas 
nesse campo? Veremos ao longo dos próximos Capítulos que esse movimento não era tão inexpressivo assim como supõem a historiografia.

Essa mesma pergunta feita acima pode ser aplicada na comparação dos movimentos britânicos e estadunidenses. A proximidade entre os dois países não significou políticas similares nesse campo. Na Inglaterra não ocorreu restrição legal do consumo, pois o movimento antialcoólico se alinhava com o Partido Liberal e incluía nas suas reivindicações maior autonomia para as localidades. A aparente força obtida no final do século XIX, quando finalmente os liberais conseguem vencer os conservadores, pouco adiantou. Eles não fizeram valer seus intentos, conseguindo somente aprovar uma lei restritiva ao álcool na Escócia em 1913. Olhamos, pouco antes, a decepção gerada pela Royal Opium Commission e a Indian Hemp Drugs Commission. O movimento antiópio britânico era quase exclusivamente voltado para a questão chinesa analisada anteriormente. No que se refere à questão de classe, nos EUA os grandes homens de negócio olhavam vantagens com a proibição, fato que não tem paralelo na Inglaterra porque os grandes industriais e as igrejas Quaker tinham aliança com o Partido Conservador. Os ideais abstêmios tiveram menos seguidores no interior da classe trabalhadora britânica (BERRIDGE, 2013, p.48-51). Veremos também, no Capítulo cinco, como a política de regulamentação dos fármacos e da medicina nos casos estadunidense e britânico se diferenciava, comparando-a com o Brasil.

A Grã-Bretanha e EUA mostram como os movimentos sociais que aparentemente possuem as mesmas bases e objetivos sociais podem gerar diferentes resultados, pois são inseridos em contextos culturais, sociais, políticos e institucionais diversos. Courtwright (2001, p.175) aponta ainda que os alemães e os irlandeses não tinham o mesmo senso de disciplina da sociedade protestante estadunidense, fato que gerou insatisfações com o consumo de álcool nos EUA. Berridge (2013, p.50-51) mostra que os movimentos políticos contra o álcool foram mais importantes no norte da Europa do que no sul. Nos países católicos existiam outras formas de lidar com o abuso. As respostas à questão, entretanto, podiam variar mesmo entre países escandinavos. Os suecos eram mais influenciados pela tradição anglófila, enquanto os dinamarqueses seguiam a maior tolerância alemã.

O contraste entre o norte protestante e o sul católico pode ser explorado para dar mais um exemplo dessa diversidade. Na Espanha, até o final da Primeira Guerra Mundial, os consumidores de drogas eram uma minoria tolerada e integrada socialmente. As drogas eram valorizadas entre uma elite esnobe - a expressão "dar 
ópio" significava popularmente bajular/persuadir. O consumo de ópio e papoula são tradições milenares em algumas regiões, se ampliando em épocas de epidemias. Em geral, os espanhóis eram tolerantes com esses usos tanto internamente, quanto nas suas possessões ultramarinas - como eram as Filipinas antes dos EUA. O láudano, os extratos de coca e os "remédios de autor" eram populares, ao contrário das substâncias fitoquímicas que eram restritas às elites. O cloral era o hipnótico mais difundido e o éter usado como substituto do álcool em algumas situações (USÓ, 1995, p.33-39).

Esse cenário se modifica a partir do final do século XIX por causa de alguns fatores. Primeiramente, cabe destacar os acordos externos assinados em Haia. As leis de controle do mercado já previam, desde meados do XIX, o exclusivismo farmacêutico em matéria de venda de fármacos. Porém, essa prática foi pouco respeitada - parecido com o que acontecia com o Brasil, conforme veremos no Capítulo cinco. Os "meios sociais e legítimos" eram entendidos na Espanha como pertencentes à elite. Embora não existissem tensões étnicas, como ocorreu nos EUA, o crescimento urbano gerou mudanças nas formas de sociabilidade - fato que desafiou setores católicos conservadores. Na Espanha, a Igreja era ligada ao Estado. Os estrangeiros que viviam no país, presença que se ampliou durante a Primeira Guerra Mundial, se envolviam na prostituição e na venda de drogas - cujo consumo se tornava símbolo da modernidade almejada. O proibicionismo espanhol, nesse contexto, tem como base o fundamentalismo católico ameaçado por aquilo que eles entendiam como a perversão dos costumes. Por isso, nesse primeiro momento, a restrição aos fármacos está intimamente ligada a maior intervenção do Estado na regulação dos costumes: prostituição, cinema, pornografia, etc. Não é a toa que a primeira lei de restrição de 1918, que reafirmava o exclusivismo farmacêutico previsto na Lei de Farmácia de 1860, incluía nas substâncias proibidas os anticoncepcionais e os abortivos (USÓ, 1995, p.4266). Escohotado (2008, p.707-709) afirma que na Espanha eram mais importantes os valores familiares do que o controle social da embriaguez em si, faltando a este país o estereótipo do adicto e do traficante.

Os intelectuais europeus no entre-guerras estavam preocupados com os efeitos das imigrações e das crises econômicas sobre a criminalidade em seus países, sobre a influência das novas tecnologias, como os aviões, sobre as técnicas de contrabando. O cinema era visto com preocupação, pois essa nova forma de divertimento poderia afetar o desenvolvimento moral dos jovens. A ciência social foi chamada para dar respostas, 
transformando preconceitos morais em verdades científicas (KNEPPER, 2011, p.03) - a democratização dos fármacos fazia parte do mal estar da civilização.

$\mathrm{Na}$ virada do século XIX para o século XX, portanto, os EUA começavam a se colocar como nova potência no Oriente, buscando através da política puritana uma forma de se aproximar da China. Formou-se a exótica aliança do proibicionismo. Os países com tradição no uso dessas plantas e os que tinham importantes indústrias ligadas a elas não aceitaram de forma passiva a destruição de suas culturas e a criminalização de suas tecnologias. Até o início da Segunda Guerra Mundial predominou um mundo multipolar com pouca adesão aos princípios supostamente éticos e científicos dos estadunidenses.

O controle do comércio de substâncias era uma das ambições da Liga das Nações, que se tornou cada vez mais importante ao longo da história dessa instituição. Os burocratas dessa instituição encontram enormes problemas para criar uma resposta coordenada sobre o fornecimento de medicamentos, pois existia relutância comercial dos países envolvidos na produção desses produtos, a retórica de vitimização dos chineses e de superioridade moral dos estadunidenses. No começo dos anos de 1930 já era latente o fracasso da Liga das Nações, até mesmo o triunfo britânico no Egito era ameaçado pelo tráfico ilícito que não deixava de crescer com a proibição (KNEPPER, 2011, p.138-139). Para os EUA isso era mais uma prova da superioridade de sua política, apesar de todos os resultados até então obtidos com a proibição provarem justamente o contrário.

Nesse cenário, o Brasil estava do lado daqueles que se sentiam contrariados pela Liga das Nações. Em 1936, logo após o país criar a Comissão Nacional de Fiscalização de Entorpecentes (CNFE), o Jornal do Brasil noticiava a crise que se abatia sobre a Comissão Consultiva do Ópio em Genebra.

Ocorreu curioso incidente no seio da comissão consultiva do ópio, da Sociedade das Nações, causada pelo [...] presidente do comitê executivo central encarregado da questão dos entorpecentes. [Ele] disse que os métodos até agora empregados na luta contra o tráfico ilícito tinham fracassado. A maioria dos membros da comissão quis que o presidente do comitê atenuasse esse julgamento, mas o Sr. Lyall recusou e propôs provar publicamente o fundamento das suas afirmações. A comissão receando que a revelação desses fatos, produzisse má impressão no momento que o Instituto passa por uma crise, discutiu a questão para saber se a sessão devia ser pública. A comissão consultiva do ópio decidiu finalmente que a discussão relativa ao 
relatório apresentado pelo Sr. Lyall fosse efetuada em sessão secreta (Jornal do Brasil, 20/05/1936 apud Silva 2015, p.300).

O fracasso da Liga das Nações era noticiado no Brasil, talvez com certo orgulho daquele que não viu suas preposições e pretensões atendidas. Quando nova rodada de tratados internacionais foi feita na década de 1930, o país apresentava com orgulho um arcabouço legal proibicionista consolidado e aperfeiçoado a partir de uma experiência que durava mais de uma década na repressão da ebriedade. Mais do que leis inócuas, sem sentido e feitas unicamente para agradar os EUA, o país procurava se colocar na vanguarda do controle público da ebriedade.

\subsection{Conclusão}

Amado Luiz Cervo, professor emérito em Relações Internacionais, escreveu o prefácio do livro A Questão das Drogas nas Relações Internacionais: Uma perspectiva brasileira. Nesse texto ele faz um balanço sobre essa "nova fase histórica com traços específicos" (CERVO, 2013, p.38) que vivem os países sul-americanos - como agentes ativos das relações internacionais e não mais meros subordinados aos interesses maiores. É nesse contexto que os países da região se colocam em relação aos desafios, de coordenação política internacional, exigidos pelo proibicionismo. Os acordos elaborados na primeira metade do século XX estabeleceram regulações definidoras "de um regime internacional específico, que amarra a América Latina" (CERVO, 2013, p.38).

Entre a literatura especializada não existe uma definição consensual sobre o que sejam drogas ou uso abusivo. As classificações profissionais enquadram nessa categoria “substâncias de uso habitual não médico" (SILVA, 2013, p.51), como o álcool, o tabaco e as bebidas cafeinadas. Desde 1963, quando a OMS "esclareceu que as medidas proibicionistas legais eram injustificadas em termos biológicos” (SILVA, 2013, p.375), se sabe que

\footnotetext{
“a tolerância ou intolerância em relação ao consumo das diferentes drogas evoluiu, ao longo da história, mais a partir de convenções sociais arbitrárias resultantes de fatores econômicos, históricos e culturais - do que de seus reais danos para a saúde.” (SILVA, 2013, p.52).
}

Dentro desse contexto, é preciso que a diplomacia brasileira tenha uma 
"atitude aberta e receptiva para o questionamento do próprio regime proibicionista em vigor. Cem anos de agravamento progressivo do problema das drogas e sua metamorfose em questão de segurança pública apontam para a necessidade de se examinarem estratégias alternativas." (SILVA, 2013, p.371).

O problema é que, mesmo "á luz da comprovada falência do regime proibicionista atual” (SILVA, 2013, p.371), qualquer mudança esbarra em

\footnotetext{
"compromissos internacionais já sacramentados, nos interesses consolidados, nas considerações de caráter eleitoreiro e na rígida estrutura das burocracias antidrogas, tanto no âmbito nacional quanto multilateral (ONU, OEA), cuja sobrevivência poderia vir a ser afetada no caso de uma mudança radical do regime" (SILVA, 2013, p.371).
}

A análise da política exterior atual trazida pela Fundação Alexandre de Gusmão, através desse livro, parece extremamente pertinente e adequada ao que referente aos limites e aos desafios apresentados pelas pessoas que lidam com o tema das drogas. Essa leitura bastante progressista na agenda política atual convive, entretanto, com alguns limites interpretativos importantes referentes à primeira metade do século XX. $\mathrm{O}$ principal deles é entender o uso de drogas como "uma questão de saúde pública" que se transforma "em um problema de criminalidade organizada transnacional, conectando toda uma série de delitos" (SILVA, 2013, p.370). Essa questão teria sido tratada sem participação dos países sul-americanos, pois

\footnotetext{
"ao se absterem durante o período inicial de criação do sistema internacional antidrogas, os países da região permitiram que outros atores estabelecessem o arcabouço jurídico que passaria a regulamentar a questão do controle de drogas no mundo. Esse arcabouço foi proibicionista e desequilibrado, centrando-se durante décadas nas três principais drogas de origem vegetal" (SILVA, 2013, p.370).
}

Foi construída, ao longo desse Capítulo, uma narrativa que problematiza essa visão de que ocorria um grave problema de abuso de drogas nas sociedades do início do século XX, fato que teria levado as elites políticas a aceitarem o argumento médico e religioso em favor da restrição. Na verdade, mais do que uma opção ética ou de saúde pública, foi uma série de fatores econômicos e políticos peculiares que alçaram a China 
e os EUA à condição de aliados contra o comércio de ópio. Nesses países temos as primeiras experiências autóctones do controle político da ebriedade - com péssimos resultados. Por isso, embora ela tenha sido colocada em termos utilitaristas e humanitários em um primeiro momento, seus efeitos no curto, médio e longo prazo se mostram exatamente o contrário. A heteronomia como política pública gerou a dissidência farmacológica e o colapso dos controles - com ascensão da criminalidade organizada em âmbito internacional.

A história do proibicionismo no Brasil tradicionalmente é contada através da ascensão das políticas de restrição da ebriedade nos EUA (CARVALHO, 2013, p.3676; DELMANTO, 2013, p.18-63; LIMA, 2009; RODRIGUES, 2004, p.41-92; SILVA, 2013, p.68-158), ignorando o papel fundamental que a questão do ópio teve na China. Não somente no interior deste país, mas também entre as comunidades chinesas espalhadas pelo mundo. A xenofobia é um fator importante para explicar o advento do proibicionismo, podendo adquirir várias facetas de acordo com o contexto social analisado. A comunidade chinesa, entretanto, foi um elemento de tensão existente em vários países - incluindo, mesmo que levemente, o Brasil.

Sem desconsiderar o papel que os EUA tiveram na defesa da política proibicionista, foi mostrado que existia um contexto de descontentamento geral derivado da democratização de alguns fármacos que antes eram privilégios das elites. $\mathrm{O}$ processo de ampliação do consumo e do acesso à cidadania gerava um profundo mal estar e um discurso que associava o uso de drogas por uma população inculta como prática indesejada, promotora do crime e da degeneração da raça. Esse é o caldo cultural presente em vários países ocidentais, tanto americanos, quanto europeus, que dava sustentação ideológica as políticas públicas restritivas. Por isso o pioneirismo político do puritanismo estadunidense e do excepcionalismo chinês, por mais importantes que sejam, não deve ser superestimado.

Contrariando essa retórica triunfalista da proibição estadunidense, que também dá suporte a hipótese do continuísmo e da ascensão punitivista (conforme veremos no Capítulo cinco), buscou-se apresentar a pluralidade de controles e de políticas públicas referentes à regulamentação do comércio de gêneros terapêuticos. Por isso, concordo com o argumento de Berridge (2013, p.06-07) que o termo proibição como categoria generalizante oferece uma ideia estanque, incapaz de caracterizar adequadamente a pluralidade de sistemas de controle que existiam - principalmente na primeira metade do século XX. Por isso, mais do que a ascensão do proibicionismo em escala global 
através da liderança estadunidense, verifica-se a coexistência de vários modelos de controle - é mais adequado falarmos de "proibicionismos" no plural, principalmente antes da Segunda Guerra.

Para reconstruir esse cenário plural se utilizou algumas fontes primárias e a consulta de obras históricas sobre os países latino-americanos (GOOTEMBERG, 2008; LABBÉ, 2011; REBOLLEDO, 2013; PICCATO, 1997; PIERCE, 2008; MONFORT, 1997; ASTORGA, 1999) e de outras partes do mundo (BEHR, 2011; BERRIDGE, 2013; COURTWRIGHT, 2001; DAVENPORT-HINES, 2002; DIKOTTER et al, 2004; ESCOHOTADO, 2008; KNEPPER, 2011; MUSTO, 1999; USÓ, 1995; ZHENG, 2005). A movimentação da diplomacia brasileira somente recentemente foi estudada pela historiografia brasileira (CARVALHO, 2013; SOUZA, 2012). Percebe-se que, com exceção de alguns clássicos, a maioria dessas obras é bastante recente - estamos de frente a um campo de pesquisa que ainda dá seus primeiros passos.

Por isso, esse Capítulo procurou apenas problematizar a ideologia da nação submetida pelo vício introduzido pelo imperialismo (China) e o centralismo atribuído às políticas estadunidenses nos estudos sobre a ascensão do proibicionismo em escala global. Muito será preciso avançar em relação à pesquisa da região sul-americana, tanto para conhecermos a situação de países como a Argentina e o Uruguai, quanto às redes construídas pelos agentes da repressão e pelo tráfico ilícito na região. Também será preciso atenção sobre as políticas de outros países europeus com influência cultural (França) e econômica (Alemanha) sobre a América Latina. Sobre os franceses, especificamente, Evaristo de Moraes aponta a grande prestígio dessa nacionalidade para as nações latinas - uma "espécie de obediência intelectual que os povos da mesma raça prestam á França” (MORAES, 1921, p.92) e seu “espírito eminentemente ridicularizador" (MORAES, 1921, p.92), onde se prega apenas a moderação ao beber. Por conta dessas limitações, mais do que hipóteses fechadas buscou-se problematizar certezas e recolocar questões que deverão ser objetos de novas pesquisas. 


\section{CAPÍTULO 4 - OS USOS TERAPÊUTICOS DE DROGAS ATÉ MEADOS DO SÉCULO XX}

\subsection{Introdução}

Um dos fenômenos característicos da sociedade moderna é a maior circulação de drogas e a capacidade ampliada das populações, em todo o mundo, de alterarem suas consciências. É tendo como pano de fundo essa revolução psicoativa que se buscou, anteriormente, relativizar a visão dualista que opõe o remédio mágico e não científico ao medicamento moderno com efeitos conhecidos e esperados. A popularização dos antálgicos e outras substâncias modeladoras do ânimo geraram tensões sociais em várias partes do mundo, especialmente no Extremo Oriente por causa da maior aceitabilidade do ópio. A China e os chineses estiveram no centro dessas disputas, favorecendo a emergência da ideologia da nação subjugada pelo vício estrangeiro e imperialista. Esse discurso que se tornou hegemônico, e que foi problematizado no Capítulo precedente, é um dos pilares da percepção de que a restrição do comércio dessas substâncias era uma atitude ética e humanitária.

O presente Capítulo tem como principal objetivo problematizar outro pilar ideológico que justificou as políticas restritivas no início do século XX. Nós vimos no Capítulo dois que o discurso triunfalista da medicina tendeu a reduzir a multiplicidade de práticas curativas e teorias etiológicas em dois grupos: os charlatões ou especuladores filosóficos, por um lado, e os observadores metódicos e científicos de outro lado. Esse tipo de divisão ainda teria sido reforçado, recentemente, pelo debate que opunha a ênfase na medicalização da sociedade à agência de sujeitos concretos que operam suas práticas de cura a partir dos preceitos tradicionais. Procurou-se, entretanto, relativizar esses antagonismos mostrando que os formulários, as receitas e a arte de formular, teoricamente monopólio do saber erudito, não eram assim tão exclusivistas. Os usos desses recursos farmacológicos e dos remédios com fórmulas secretas faziam parte do repertório terapêutico popular, daquilo que foi denominado de neohipocratismo brasileiro.

Nesse cenário as drogas que hoje são ilícitas eram parte integrante da terapêutica, apesar do discurso triunfalista da medicina tentar desqualificar, desde cedo, esse tipo de utilização. Vimos no Capítulo precedente que era difícil, para os missionários e outros proibicionistas, admitir que a maioria do uso era moderado e não 
ocasionava mal. Essa mesma dificuldade também é verificada em relação às qualidades terapêuticas das substâncias que são hoje proibidas, como é exemplar o discurso abaixo.

\footnotetext{
"Complicações clínicas com o uso da cocaína, algumas trágicas, levaram a pesquisas com outros anestésicos locais menos tóxicos. Após investigações com mais de uma centena de amino-ésteres, derivados dos ácidos paraminobenzóico, Einhom, em 1904, sintetizou a procaína (éster dietilaminoetílico), obtendo grande avanço científico e prático no campo da anestesia regional. Outros anestésicos locais foram sintetizados até 1932, como benzocaína, piperocaína e tetracaína. A partir de 1943, iniciou-se a fase dos anestésicos locais modernos, amino-amidas, como lidocaína, pricaína, etidocaína, bupivacaína, levobupivacaína e ropivacaína" (REIS JR, 2008, p.301).
}

Segundo esse discurso, "complicações clínicas" teriam levado a cocaína ao ostracismo desde fins do século XIX. Esse recorte temporal dos usos, baseado nas descobertas farmacológicas em matéria de anestésico, parece deixar pouca margem para especulações, pois sua objetividade técnica leva a naturalização da periodização biomédica. Isso é perceptível mesmo em trabalhos históricos recentes. Adiala (2011, p.66-69), por exemplo, fez uma análise ampla da literatura médica do final do século XIX e início do XX, propondo a seguinte cronologia para o debate a respeito das substâncias entorpecentes: inicia em 1880, focada na questão dos anestésicos e motivada pela reforma no ensino médico; a cocaína se torna central no debate sobre cirurgia na revista Brazil Médico nos anos de 1890; a partir de 1905, as publicações mais correntes sobre o tema migram para a área da psiquiatria; nos anos de 1920, a noção de toxicomania torna-se dominante. Percebe-se, de outra forma, a reprodução da cronologia proposta acima por Reis Junior (2008), pois ele desqualifica os usos terapêuticos da cocaína a partir da ênfase na transferência da questão para a nascente psiquiatria.

A caracterização das drogas atualmente proibidas como ineficazes (do ponto de vista terapêutico) e prejudiciais (da perspectiva social e racial) é outro pilar da percepção hegemônica que associa a restrição de acesso aos fármacos a uma atitude ética e humanitária. Inspirado na discussão proposta por Maria Cecília Ferro Donnangelo (1979) sobre a medicina, será mostrado que a escolha de dados analgésicos e anestésicos por outros não pode se resumir a uma questão técnica pertencente unicamente ao campo dos especialistas biomédicos. Existe, para além da questão 
puramente técnica, uma série de fatores políticos, econômicos e culturais que incidiram sobre os fármacos, definindo a posição terapêutica legítima de uns e não de outros. Veremos, nesse Capítulo, que as inovações técnicas e a afirmação de especialidades médicas não excluíram os usos terapêuticos da farmacopeia clássica e às técnicas já consolidadas; e que os diversos repertórios terapêuticos coexistiram em um processo de conflitos e acomodações que resultaram no estabelecimento de novos padrões de cientificidade voltados a diferenciar médicos legítimos dos "charlatões".

\subsection{O álcool e a patologização da ebriedade}

Uma das formas mais comuns de obter alteração da consciência, em diversas sociedades espalhadas pelo planeta, é através da ingestão de bebidas fermentadas. Mais do que alterar a consciência, tais líquidos exerciam funções centrais como bebida segura em contextos tradicionais. Em ambientes com dietas deficitárias, elas também adquirem importância nutritiva pelas calorias que carregam. As bebidas destiladas, inicialmente entendidas como medicinas, se popularizaram a partir da Europa e provocaram alterações nos padrões tradicionais de alcoolização.

Essa popularização das bebidas espirituosas, entretanto, não foi capaz de apagar as várias prerrogativas terapêuticas que a elas eram atribuídas. No segundo Capítulo foi mostrado como elas estavam presentes nas várias tradições de cura que coexistiram no Brasil colonial - recebendo inclusive o rótulo de panaceia universal, por Figueiredo (2011, p.121), entre os séculos XVIII e XIX. Presente no dia a dia das práticas de cura, usada como analgésico popular, na confecção de bebidas tônicas e terapêuticas, a aguardente podia também ser receitada para combater doenças específicas.

Um exemplo desse tipo de utilização pode ser encontrado na Gazeta Médica do Rio de Janeiro (GMRJ) no ano de 1862, através da divulgação de um experimento do Dr. Hutchinson, originalmente divulgado na imprensa médica de Dublin. Segundo a nota, além de ser usada para obter analgesia e enfraquecimento muscular, "abolindo d'este modo inteiramente a motilidade" (GMRJ, 1862, p.70), a embriaguez alcoólica também foi exitosa em uma criança de nove anos de idade na cura do tétano. Práticas adotadas no Brasil corroboravam com tal experimento, pois o

“emprego da aguardente para combater-se o tétano, é muito comum em algumas fazendas do interior da província do Rio de Janeiro, e pessoas dignas 
de confiança afirmam ter obtido com semelhante meio, verdadeiras curas" (GMRJ, 1862, p.70).

A ideia de que o álcool poderia ter aplicações terapêuticas para curar doenças ou realizar procedimentos de purificação pode ser verificada até meados da década de 1930. Segundo Sales (2011, p.111), o médico Américo Valério, docente da Faculdade de Medicina do Rio de Janeiro, publicou no jornal A Folha Médica um artigo intitulado "Dois casos de séptico-toxemias e álcool intravenoso", abordando as qualidades do álcool como purificador do sangue. Segundo esse médico, o ostracismo dessa substância na terapêutica se deu por causa da campanha antialcoólica, porém isso não desqualificava a eficiência da alcoolterapia para diversas enfermidades.

Essas duas referências, uma da década de 1860 e outra de 1930, são exemplares da permanência do uso do álcool como agente terapêutico para tratar malefícios específicos, tétano no primeiro caso e intoxicação do sangue no segundo. Ao longo das sete décadas que separam uma referência da outra, a produção médica a respeito do álcool foi enorme. Os trabalhos historiográficos que focam a análise da literatura médica sobre esse tema ainda são restritos, basicamente os realizados por Fernando Dumas Santos (1993; 1995; 2006). Para ele, os conhecimentos em torno do uso de álcool sofreram alterações com a "crescente especialização, bem como a introdução de novos processos para a pesquisa biomédica, acelerados a partir da metade do século XIX” (SANTOS, 1995, p.91). Essas alterações levaram à

\footnotetext{
“problematização do uso ou abuso dos alcoólicos a tomar, grosso modo, duas linhas distintas: uma delas, utilizava preferencialmente os estudos de anatomia patológica, privilegiava as lesões causadas pelo álcool nos diversos órgãos do corpo humano. A outra, vinculou-se aos trabalhos de alienistas e preocupava-se com as repercussões do consumo de bebidas sobre o sistema nervoso e, em particular, o cérebro" ${ }^{45}$ (SANTOS, 1995, p.91).
}

A nova percepção das causas patogênicas a partir dos micróbios teria favorecido "outro tipo de explicação para os efeitos do consumo de bebidas alcoólicas” (SANTOS, 1995, p.135). Baseado nos conhecimentos de química, biologia e fisiologia passou-se a pensar o consumo de álcool em termos de enfraquecimento do corpo e facilitador da ação dos bacilos - aproximando assim a figura do alcoólatra e do tuberculoso e afastando "um pouco o perigo hereditário" (SANTOS, 1995, p.136). Apesar disso, "as degenerações e

\footnotetext{
${ }^{45}$ Grifos meus.
} 
a hereditariedade, já entranhadas no imaginário social burguês, permaneceram assolando os discursos médicos no século XX” (SANTOS, 1995, p.137). Os discursos formados sobre essa questão, portanto, tinha um "caráter social" voltado "para a disciplinarização de uma tradição popular" (SANTOS, 1995, p.153). O saber médico não se constituía em "um corpo de conhecimentos único e fechado a respeito da questão" (SANTOS, 1995, p.153), pois havia muita discordância sobre o diagnóstico, o tratamento adequado e as representações sociais que envolviam o bêbado. Entretanto, dentro dessa diversidade se perceberia a penetração da noção de alcoolismo nos "saberes cotidianos da sociedade burguesa" fazendo que "a antiga figura do bêbado tenha efetivamente se transformado no alcoólatra dos "tempos modernos"” (SANTOS, 1995, p.153).

Essa percepção do desenvolvimento do conceito de alcoolismo como doença reitera o discurso triunfalista biomédico. O pensamento médico que condenava o uso excessivo de álcool como um comportamento libertino capaz de provocar doenças nos órgãos gradativamente teria se transformado em outro, que entendia o uso de álcool como uma doença específica - alcoolismo - e que gerava, além de consequências individuais, problemas sociais como a degeneração da raça através das taras hereditárias. Essa narrativa acaba reiterando o discurso biologicista que transfere o uso de álcool da terapêutica para a psiquiatria depois que se alcançou um maior conhecimento sobre os seus efeitos fisiológicos - da mesma forma que fez Adiala (2011) com a cocaína, conforme foi mostrado anteriormente.

A consolidação da psiquiatria enquanto especialidade foi um eixo importante de problematização médica do uso do álcool, que ganhou força a partir do conjunto discursivo que associava os conceitos de perversão, hereditariedade e degenerescência. Ao contrário do que destacou Santos (1995) acima, os “alienistas" preocupados com o efeito das bebidas no sistema nervoso e no cérebro não estão em oposição aos estudos de anatomopatologia. Essas "duas linhas" estão inscritas na mesma ordem discursiva que pretende reduzir os fenômenos da ingestão a uma leitura biologicista, noção que perdurará até a separação da psiquiatria da anatomopatologia a partir dos anos de 194050. Healy (1997, p.29) destaca que muitos dos comportamentos entendidos como patológicos eram resultados de infecções que afetavam o cérebro, como na sífilis e alguns tipos de tuberculose, ou por influência de outras infecções. Os antibióticos teriam sido os primeiros remédios efetivos contra diversos males entendidos como psicológicos até então. A psiquiatria somente iria se divorciar da anatomopatologia 
depois do seu afastamento das teorias eugênicas; se reaproximará em novos termos a partir da emergência das imagens cerebrais e da nova leitura dos estímulos em fins do século XX, conforme veremos no Capítulo cinco.

Durante o final do século XIX e a primeira metade do século XX, as práticas psiquiátricas procuraram consolidar sua especialidade médica através da desqualificação do saber médico entendido como "erudito" e as práticas populares de automedicação. Nessas disputas a emergência da patologização da ebriedade coexistiu com duas tradições médicas de uso do álcool que precisam ser destacadas. A primeira delas é referente à clínica e à terapêutica, onde se vinculam os dois exemplos de uso trazidos no início dessa seção. Ao lado do tétano e das suas qualidades como depurador do sangue, o álcool também tinha inúmeras outras potencialidades terapêuticas.

O álcool é uma verdadeira espada de Dâmocles. Mata, quando ingerido demasiadamente, arrastando o homem a última degradação das misérias sociais. Dá vida, quando administrado segundo os preceitos científicos, arrancando não poucas vezes das bordas do túmulo dezenas de vitimas, decretadas a uma morte quase inevitável (CARNEIRO, 1883, p.11).

Esse excerto foi extraído da Tese Acção physiologica e therapeutica dos alcoolicos, escrita por Manoel C. de Barros Carneiro em 1883. Ele é exemplar daquilo que Edler (2003, p.145-147) denominou de epistemologia sensualista. Seria através "da experimentação fisiologia e da observação clínica, que o médico vai encontrar racionalmente a indicação terapêutica de uma substancia a empregar" (CARNEIRO, 1883, p.73). Dessas observações seria possível dividir as utilidades terapêuticas dos alcoólicos em dois grandes grupos: aplicações externas, como substituto do ácido fênico de Lister, no curativo "das feridas resultantes de amputações e extirpações dos tumores no seio" (CARNEIRO, 1883, p.75), para provocar "uma estimulação reflexa nos casos de síncopes, asfixia, nas moléstias acompanhadas de algidez" (CARNEIRO, 1883, p.77), entre outras; aplicações internas, para auxiliar nos fenômenos nervosos "revelados pela agitação, pela insônia e pelo delírio" (CARNEIRO, 1883, p.83), em moléstias "do aparelho respiratório, tais como - as bronquites, as broncopneumonias, a pleurisia crônica e a tuberculose pulmonar" (CARNEIRO, 1883, p.83), entre outras.

Dentre as várias utilizações, se destacam aquelas usadas sobre as afecções respiratórias, cujos "os sucessos obtidos pela medicação tônica e por conseguinte a do álcool" (CARNEIRO, 1883, p.83) são notáveis. Os 


\begin{abstract}
"métodos ordinariamente instituídos para debelar a pneumonia, por exemplo - o tratamento pelo tártaro emético, - a sangria, - o método misto e o expectante - a medicação pelos tônicos; reconhecemos ser sem dúvida alguma esse último método o que registra resultados mais animadores no tratamento da pneumonia" (CARNEIRO, 1883, p.82).
\end{abstract}

Nos casos onde "o tuberculoso estiver realmente tísico" (CARNEIRO, 1883, p.86) eram recomendados "um licor fortemente alcoolizado, por exemplo - o conhaque, adicionando-lhe o creosoto vegetal" (CARNEIRO, 1883, p.86). Pereira da Cunha, que escreveu uma Tese de mesmo título no ano de 1882, apontava que o Hospital de Misericórdia do Rio de Janeiro utilizava larga quantidade de álcool como meio de evitar as mortes por pneumonia (SANTOS, 1995, p.29-30). O álcool poderia ser usado para tratamento de "tifo, escarlatina, varíola, cólera, tétano, hemorragia puerperal pós-parto, tísica pulmonar, bronquites infantis, febres palustres, etc.” (SANTOS, 1995, p.28).

Ao longo do final do século XIX e início do século XX, as críticas contra essa terapêutica do álcool se repetem em algumas Teses - Joaquim José da Nova, em Capacidade Civil dos Alcoolistas (1895); Lindolpho Pinheiro dos Santos em Alcoolismo (1913) (SANTOS, 1995, p.50); Francisco de Assis Bandeira em Gangrena Social: alcoolismo (1904) (SANTOS, 1995, p.40-42). Mais do que uma posição que se tornava hegemônica por causa da evolução do conhecimento médico, tais reclamações pareciam denotar a persistência de uma prática clínica e terapêutica ancoradas nos preceitos do neohipocratismo. Isso fica bastante evidente nas críticas realizadas por Oscar Clark no artigo Alcool e Climas de 1917. Ele analisa “o dogma estabelecido em patologia [...] que o álcool nos climas quentes é muito mais terrível em seus efeitos dos que nos países frios" (CLARK, 1917, p.365). Tais interpretações, na visão desse autor, são fantasias de "historiadores, geógrafos, patologistas e higienistas que se ocuparam das zonas tropicais no XIX século" (CLARK, 1917, p.365).

Percebe-se, portanto, que a afirmação da psiquiatria enquanto ciência era baseada na tentativa de redução do saber clínico à categoria dos especuladores metafísicos - desqualificando os entendimentos de geografia médica ainda prestigiados. Além do uso médico derivado da tradição clínica também existia outra forma de utilização do álcool como elemento terapêutico: as práticas populares de automedicação com medicamentos tônicos e revitalizantes. Nós vimos no Capítulo dois que entre os físicos portugueses e terapeutas populares existia a prática de confeccionar aguardentes 
medicinais usadas como remédios ou associadas a rituais e benções. Esses preparados agregavam "veículos alcoólicos - vinho branco ou cachaça - e substâncias de origem vegetal, mineral e animal" (CAMARGO, 2011, p.45), sendo conhecidos pela alcunha de garrafadas. Em dicionário de 1878 esse termo era sinônimo de "medicamento que vem da botica em garrafa" e, em meados do século XX, significava mesinha grosseira ou "medicamento de curandeiro ou de charlatão posto em garrafa" (CAMARGO, 2011, p.45). Esse tipo de composto medicamentoso até hoje é parte integrante da cultura popular brasileira (CAMARGO, 2011).

O uso de álcool como base medicamentosa não se reduzia, entretanto, as fórmulas caseiras populares. A crescente indústria farmacêutica, estrangeira e nacional, também oferecia uma série de produtos que prometiam solucionar os males de uma vida moderna. Um desses era a polêmica Poção de Todd, um preparado medicamentoso desenvolvido pelo britânico R. Bentley Todd - uma das principais referências de Carneiro (1883, p.81) na sua abordagem dos usos internos do álcool na terapêutica, conforme destacado acima. Tito de Sá Macedo Carvalho, na sua Tese intitulada Dos alcoolicos; sua acção physiologica e therapeutica, de 1880, receitava esse medicamento “em todas as moléstias em que existe uma tendência à depressão das forças vitais, e não há moléstia nenhuma aguda onde essa depressão deixe de existir" (apud SANTOS, 1995, p.26). Todd era professor de medicina em Londres e entendia que a doença possuía um ritmo natural de desenvolvimento, cabendo ao médico levar em conta "a maior ou menor resistência do indivíduo frente à moléstia" (SANTOS, 1995, p.27).

Essa mesma preocupação com a idiossincrasia é perceptível em Carneiro (1883). Depois de apresentar as fórmulas de alguns remédios para pneumonia, adverte esse médico que "não nos deixemos fascinar unicamente pela fotografia numérica" porque é preciso considerar as condições "em que se achavam os doentes". As indicações e contraindicações do método de tratamento exposto

\footnotetext{
"deve estar subordinado ás condições dos doentes, a quem tivermos de prestar os nossos ofícios. Não será de certo a simples leitura dos compêndios, que nos poderá orientar; porém sim a longa prática e a reflexão adquiridas á cabeceira do homem que sofre" (CARNEIRO, 1883, p. 83).
}

A Poção de Todd e outros medicamentos alcoólicos eram alvo de críticas por parte da literatura médica. Cesar Augusto Pereira da Cunha, em 1882, na sua Tese intitulada Acção physiológica e therapeutica dos alcoolicos, criticava a ausência de 
critério em relação aos tônicos, pois as suas utilizações terapêuticas "faziam o uso degenerar com facilidade em abuso" (apud SANTOS, 1995, p.42). Essa polêmica em torno da Poção de Todd não deve ser tomada como restrita à década de 1880 . Ele permaneceu como produto médico utilizado inclusive por psiquiatras ao longo da primeira metade do século XX, conforme é possível perceber no prontuário abaixo.

Manuel Pereira da Silva, português, com 38 anos, viúvo e de profissão estocador deu entrada no Pavilhão de Observações, no Rio de Janeiro, em 8 de março de 1930, ficando exatos 12 dias internado na instituição. Apresentou-se ao médico de forma calma e respondendo regularmente as perguntas que lhe eram dirigidas. Alegou que "fuma muito e abusa das bebidas alcoólicas" por insistência dos seus companheiros. Fazia um mês, aproximadamente, que sofria de perturbações do olfato e começava a escutar vozes; também relatou já ter uma passagem encaminhada para retornar à Portugal. $\mathrm{O}$ exame de motilidade mostrou tremores na língua e nas extremidades. Foi receitada a ele a Poção de Todd, provavelmente como meio de evitar uma crise de abstinência (Pavilhão de Observações, Livro de Observações Clínicas n 346, p.127130).

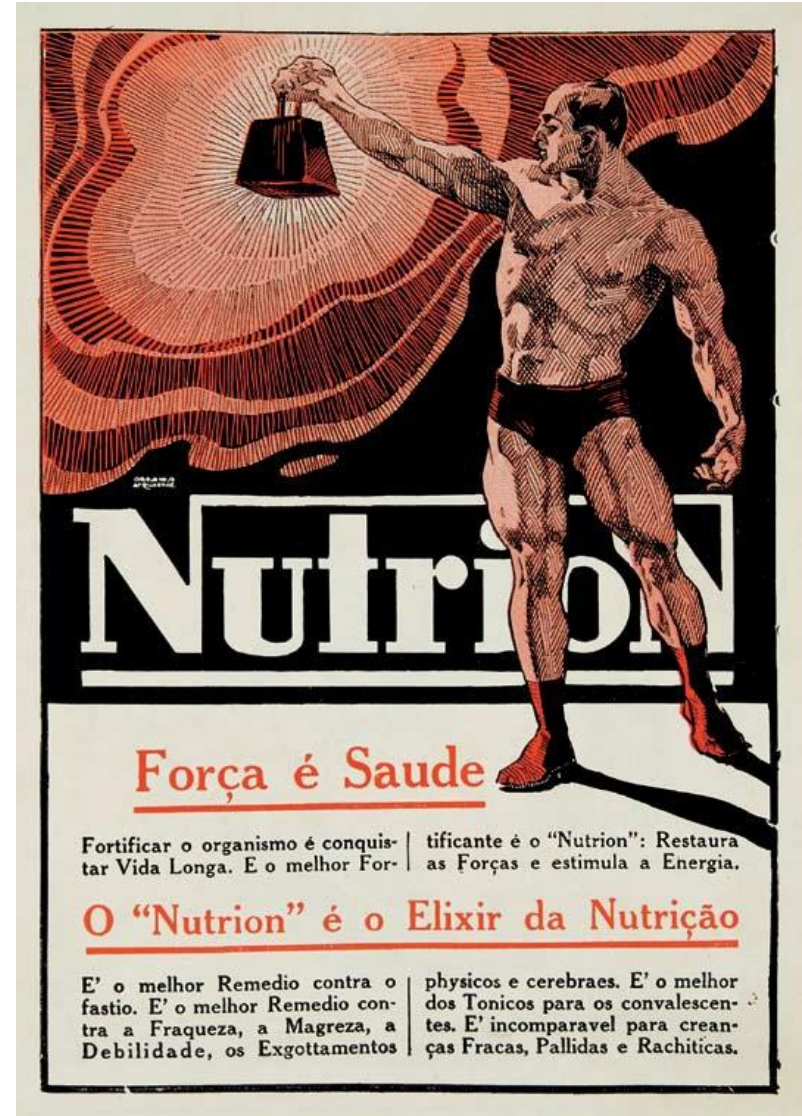

Figura 7 - Fortificante Nutrion (1928)

FONTE: BUENO et al (2008, p.07) 
Essas polêmicas sobre a Poção de Todd servem para ilustrar os debates a respeito de uma série de remédios que utilizavam álcool em sua composição. O final do século XIX e o início do século XX foi um período de expansão da atividade comercial da indústria farmacêutica no Brasil, com vários tônicos, energizantes e fortificantes, como o Nutrion destacado na Figura 7. Alguns desses produtos, embora hoje menos divulgados, ainda permanecem vivos no mercado brasileiro. Somente em 19 de abril de 2001, a Resolução nº 543 emitida pela ANVISA determinou como limite máximo 0,5\% de álcool para fórmulas de complexos vitamínicos voltados para crianças e de até $2 \%$ quando destinados ao público adulto. Isso obrigou o centenário remédio Biotônico Fontoura a baixar o seu teor alcoólico que "era de 9,5\%, o que equivale a uma garrafa de vinho alemão ou uma lata de cerveja extraforte" (BUENO et al, 2008, p.66).

Salles (2011, p.103-109) analisou a propaganda de medicamentos em jornais do Recife no começo do século $\mathrm{XX}$, apontando que alguns produtos alcoólicos como vinhos e cervejas eram vendidos "como medicação próxima aos diversos produtos revigorantes nacionais e internacionais oferecidos na época para a recuperação ou manutenção da energia e saúde da população, a exemplo da Emulsão de Scott” (SALES, 2011, p.105). Marques (2014, p.221-241), por sua vez, procurou compreender a inserção da cerveja no cotidiano carioca na primeira metade do século XX. Ela mostrou que o movimento da temperança criou desafios a crescente indústria cervejeira brasileira, que passou a investir em propagandas capazes de criar uma imagem de uma bebida industrial, moderna, leve, propícia ao convívio social ameno e com qualidades nutritivas. Esse também foi um dos motivos que levou as empresas a investir nas cervejas tipo Pilsen que eram mais leves que outros tipos com maior teor alcoólico.

Nessa luta por legitimidade entre indústria cervejeira e movimento antialcoólico, grande polêmica girava em torno do uso da cerveja preta como forma de estimular a produção de leite pelas parturientes. Galeno de Revorê de Barros, na Tese intitulada Do alcoolismo na infância sob o duplo ponto de vista clinico e social, em 1905, já criticava esse hábito estimulado pela imprensa da época (SANTOS, 1995, p.51). Sales (2011, p.103-109) reuniu várias propagandas em Recife, de cervejas, vinhos e tônicos, que prometiam melhorar a amamentação. Marques (2014, p.242-244) também aponta a existência desse tipo de reclame nos jornais cariocas, mostrando que esse tema era alvo de controvérsia no interior da classe médica. Rinaldo De Lamare, no livro A vida do bebê de 1964, descarta a ideia de que o uso desse tipo de cerveja tenha algum efeito na 
amamentação. Por outro lado, "aceita que as nutrizes bebam uma quantidade mínima de vinho ou de cerveja. Em outros termos, não recomenda o uso de bebida, mas também não condena" (MARQUES, 2014, p.244).

A coexistência de uma visão patologizante da ebriedade com usos clínicos sancionados e a popularidade de medicamentos com base alcoólica levou a uma visão negativa da capacidade da psiquiatria em interferir nas práticas sociais. Para Santos et al (2010, p.419), existia uma "fé na positividade dos preceitos científicos e, especialmente, psiquiátricos, no Brasil da última década do século passado", porém ela carecia "de uma prática clínica e fundamentalmente política que a embasasse". Por isso, assim como as ideias republicanas, "as práticas" não corresponderiam "aos ideais". Sales (2011, p.107109) destaca que a variedade de remédios com base de álcool, que seguiam sendo receitados por parte da classe médica, denota a indiferença de grande parte dos clínicos à convocação para a luta antialcoólica. Para Santos (1995, p.11), o descompasso entre teoria e prática deriva do "fato da definição da 'doença alcoolismo' deu-se no cenário do desenvolvimento do capitalismo europeu", sofrendo problemas "na transposição deste modelo para a realidade brasileira". A "aplicação acrítica e forçada de muitos conceitos" somou-se ao preconceito contra os costumes que vigoravam no Brasil, afastando médicos das classes que eles pretendiam controlar. Dessa forma, fica "patente que a medicina brasileira, em verdade, observava com as observações dos europeus e concluía as conclusões deles, ao menos até o último quartel do século passado" (SANTOS, 1995, p.59).

A resistência dos clínicos em renunciar a sua competência sobre os medicamentos de base alcoólica era somada a percepção de que o sentimento antialcoólico não criava raízes entre a população em geral. O jurista Evaristo de Moraes, que serviu de referência de vários trabalhos contemporâneos (SANTOS, 1995, p.89-91; SANTOS, 2006, p.70-73; CANCELLI, 2001, p.153-154; SALES, 2011, p.131; COSTA, 2009, p.147) apontava a obediência intelectual dos brasileiros aos franceses e seu espírito ridicularizador para explicar a não adesão dos ideais antialcoólicos no Brasil. Além disso, segundo esse jurista, o Congresso estaria tomado pelos "representantes dos produtores do álcool. Essa lamentável dependência torna a ação do Estado difícil, morosa, acanhada e tardia” (MORAES, 1921, p.89). O quadro desenhado por esse jurista, portanto, mostra mais uma vez o baixíssimo engajamento nos ideais antialcoólicos e os fortes obstáculos políticos a adoção de leis e políticas públicas. 
A historiografia contemporânea incorporou esse discurso. Para Marques (2014, p.222-223) a restrição do consumo do álcool "demorou muito a se tornar uma política de Estado explícita. Em verdade, a primeira política antiálcool de alcance nacional foi promulgada apenas em 1997: a conhecida 'Lei Seca', que busca conter o uso de álcool por motoristas". A ausência de políticas públicas nesse campo talvez estivesse no fato de que "a elite política jamais tenha se convencido do acerto de atribuir ao Estado o papel de controlar as escolhas de consumo da população". Por isso, no Brasil, "a campanha pró-temperança assumiu contornos ideológicos próprios, cerrando fogo contra os hábitos de consumo da população pobre e mestiça, condenando especialmente o uso da aguardente de cana”. Para Antunes (1999), que estudou a medicina-legal entre 1870 e 1930, esse campo do pensamento médico "dirigiu-se especificamente ao conhecimento e à intervenção sobre os fenômenos de ordem moral" (ANTUNES, 1999, p.28). Porém, “os profissionais da arte de curar não conseguiram implantar a maioria das medidas preconizadas no âmbito da moral" (ANTUNES, 1999, p.272), tendo como um dos seus maiores fracassos o combate ao alcoolismo. "Nada obtiveram contra a comercialização de bebidas alcoólicas” (ANTUNES, 1999, p.273). Costa (2009, p.153155), por sua vez, destaca que no Brasil não houve uma mentalidade que considerasse o uso de álcool um problema, e que no Ceará os interesses dos exportadores de cachaça e importadores de bebidas do eixo Rio-São Paulo foram articulados de forma a impedir medidas proibitivas à venda de bebidas alcoólicas naquele Estado.

Percebe-se, em todas essas considerações, uma visão bastante pessimista em relação à capacidade de intervenção dos psiquiatras na organização social, visto que nem mesmo no interior da classe médica eles tinham hegemonia. Seus conceitos seriam anacrônicos à realidade social tradicional que legitimava os usos de álcool. O argumento que foi desenvolvido até agora parece corroborar com essa interpretação ao destacar a vitalidade do pensamento clínico e a multiplicidade de produtos de base alcoólica que sustentavam a cultura de automedicação. Porém não é esse o objetivo que é almejado. A psiquiatria e a medicina-legal, ao se consolidarem como especialidades médicas, se constituíam em importante eixo de problematização médica do uso de álcool, tanto no indivíduo, quanto na sociedade em geral.

Ao final do segundo Capítulo foi mostrado que a separação entre medicina bacharelesca, na qual se vinculavam os clínicos, e medicina experimental, onde atuavam os verdadeiros cientistas, fazia parte de um discurso que procurava legitimar novas especialidades médicas, como era o caso dos higienistas que idealizavam uma sociedade 
sem doenças. A clínica diária, que defendia a autoridade médica sobre o álcool como instrumento terapêutico, entrou em um momento de autocrítica, resultando naquilo que foi denominado de ceticismo terapêutico. Mostrou-se que esse discurso da medicina experimental era uma estratégia de afirmação dos profissionais ligados aos institutos de pesquisa financiados pelo poder público, como Manguinhos (RJ) e o Butantã (SP).

Nesse cenário a medicina acadêmica, ensinada dentro das Faculdades do Rio de Janeiro e da Bahia, sofria inúmeras críticas. Essa oposição existente no interior das fileiras da medicina oficial encontrava ressonância no campo político, graças à atuação de "um grupo político organizado, o dos positivistas" (CORREA, 2013, p.76), que "questionava o privilégio da transmissão institucionalizada do saber por intermédio das faculdades, incentivando o debate a respeito da 'liberdade profissional' que deveria ser inscrita na primeira Constituição republicana” (CORREA, 2013, p.76). Esse poderoso argumento ainda agregava setores políticos que eram contra a intervenção arbitrária do Estado em questões como a vacinação obrigatória. Por isso, "o processo de criação das especialidades médicas estava imbricado com outros processos sociais mais amplos" assim como "parte de uma luta política interna à medicina" (CORREA, 2013, p.77).

Levando esse aspecto acima em consideração, percebe-se que a heterogeneidade de pensamento no interior do campo médico oficial e a dificuldade da classe médica, como um todo, em monopolizar os instrumentos terapêuticos não devem diminuir a importância da consolidação de algumas especialidades médicas e sua crescente intervenção sobre práticas sociais que anteriormente lhes eram alheias. As Faculdades procuraram reagir a esse quadro desfavorável, buscando criar contextos de valorização do conhecimento produzido em suas fileiras através da ênfase na ciência empírica e positiva. Esse arcabouço teórico "implicou a negação da responsabilidade individual e a ênfase na 'defesa social', no predomínio da sociedade [...] sobre o indivíduo" (CORREA, 2013, p.233). As garantias constitucionais teoricamente conquistadas com o advento da República não contavam com o apoio desses médicos cientistas, que procuraram demostrar a inadequação de determinados indivíduos "aos cânones de normalidade coletivos, decididos então em termos médicos, ou jurídicos, ou ambos" (CORREA, 2013, p.233).

Os médicos que lutavam para consolidar as novas especialidades médicas, a partir das Faculdades de Medicina, tentavam valorizar suas atividades a partir da ênfase nos dados empíricos, como as características raciais, sociais e culturais da população. Era com base nesse discurso pretensamente técnico e positivo que se questionavam os 
preceitos do liberalismo em matéria de consumo de psicoativos, buscando através de articulações políticas transformarem seus anseios profissionais e de classe em leis e políticas públicas. Os resultados alcançados por esse movimento político nos levam a necessidade de relativizar um pouco o quadro desolador exaltado pelo movimento da temperança e a historiografia contemporânea, conforme foi mostrado acima.

É inegável o pessimismo em relação à capacidade do Estado brasileiro em tocar adiante uma política de restrição do consumo do álcool de maneira adequada. Porém isso não era uma exclusividade do Brasil. Evaristo de Moraes (1921, p.79-89), por exemplo, analisando as políticas de vários países europeus é categórico em afirmar que em todas as partes o resultado desse movimento é desanimador. Até mesmo nos EUA o contrabando e as dificuldades de implantar a sobriedade compulsória eram sinais inequívocos da resistência das populações à restrição aos veículos de ebriedade. Além disso, a Lei $\mathrm{n}^{\circ}$. 4.294, de 14 de julho de 1921, geralmente lembrada como percussora do proibicionismo no Brasil, era também uma lei que endurecia as penalidades contra os abusadores de álcool. E, principalmente, previa a criação de estabelecimentos especiais para a internação dos intoxicados, conforme solicitavam os médicos engajados na luta antialcoólica. O próprio Evaristo de Moraes (1921, p.109-124) justificava a necessidade de instituições desse tipo tendo por base o princípio da defesa social contra uma doença (alcoolismo) que ameaçava a sociedade como um todo, medida "semelhante á que se aplica, hoje, aos pesteados, e que se aplicará, no futuro, aos sifilíticos em período de contágio" (MORAES, 1921, p.134).

O contexto legal e institucional das políticas proibicionistas em matéria de ebriedade e terapêutica será abordado com maiores detalhes no próximo Capítulo, junto com uma caracterização do movimento da temperança - que definitivamente não se resumia aos anseios elitistas e sem efeitos práticos de alguns médicos. A psiquiatria, a medicina-legal, as instâncias da justiça criminal e outras iniciativas de controle social tiveram por base um discurso racial e biologicista que buscava justificar as desigualdades e defender as hierarquias sociais. Os cientistas brasileiros buscavam comprovar seus modelos darwinistas a partir dos "exemplos de embriaguez, alienação, epilepsia, violência ou amoralidade" (SCHWARCZ, 1993, p.277). Era preciso intervir na raça brasileira como meio de criar uma nação forte e sadia. As propostas para alcançar esse objetivo variavam desde a importação de genes adequados, a necessidade de educação física para jovens até a proibição do casamento entre pessoas que 
“carregassem vícios ou doenças transmissíveis, como a tuberculose, a epilepsia, a loucura e o alcoolismo" (SCHWARCZ, 1993, p.283).

Dentro desse contexto, os conceitos de alcoolismo e a patologização da ebriedade em geral não são meras transposições de modelos elaborados na Europa para a realidade brasileira. Eles faziam parte de um discurso racial, bastante original, que ganhava força no Brasil em fins do século XIX como uma reação à República e a igualdade de todos perante as leis. Esses setores de elite engajados na crítica aos preceitos liberais não se limitaram a atuar na esfera pública através de propostas de mudanças dos códigos legais e políticas públicas voltadas à formação de uma população eugenicamente saudável. Esses médicos construíram novos espaços de atuação profissional nas fileiras da burocracia estatal e, também, na construção de uma rede de serviços privados em matéria de assistência mental.

Um paralelo muito ilustrativo pode se construído entre a medicina-legal e a psiquiatria nas suas lutas por se estabelecerem como nichos profissionais. A medicinalegal teve que lutar pelo reconhecimento da perícia criminal como tema fundamentalmente médico, gerando protestos, tanto de setores populares "contra a mutilação de seus mortos" (CORREA, 2013, p.105), quanto dos profissionais já estabelecidos nas delegacias de polícia. Essas práticas realizadas fora do contexto médico acabaram englobadas pelas Faculdades de Medicina, ciosas em mostrar a aplicabilidade social do conhecimento produzido através dela. Nesse processo os gabinetes médico-legais da Polícia acabaram se tornando instituições médicas Instituto Nina Rodrigues, Instituto Oscar Freire, Instituto Afrânio Peixoto. Isso foi resultado das demandas apresentadas e defendidas por círculos de especialistas que fundavam federações, sociedades, revistas especializadas, etc.

No que se refere à psiquiatria, foi constante a luta dessa especialidade médica para se consolidar como autoridade principal dos hospícios desde o século XIX. Ao lado dessas instituições tradicionais, como Hospital Nacional de Alienados (RJ), o Hospital do Juqueri (SP), o Hospital São Pedro (RS), etc, várias outras foram sendo fundadas desde fins do século XIX e durante as primeiras décadas do século XX. Refiro-me ao Pavilhão de Observações (RJ), que servia de espaço de triagem dos indivíduos que deveriam ser internados em definitivo e os que precisavam ser soltos, as colônias de alienados e, posteriormente, os manicômios judiciários. A luta por ocupação desses cargos no serviço público é paralela à construção de uma rede de serviços de assistência psiquiátrica na iniciativa privada, representadas por instituições como o 
Sanatório Botafogo (RJ), a Clínica Pinel (SP) e a Clínica São José (RS). Igual às redes científicas da medicina legal, também os psiquiatras se organizavam em federações, sociedades e divulgavam suas ideias através de revistas e jornais.

As diversas mudanças na legislação criminal que tiveram por base os preceitos do positivismo, a diversificação e multiplicação das instituições de caráter médico e/ou jurídica e a construção de uma rede de assistência mental privada são provas inequívocas de que a psiquiatria tornava-se uma tradição médica relevante do ponto de vista social e cultural. Os papéis do alcoolismo e das toxicomanias nesse processo de expansão ainda precisam ser objeto de maiores estudos, principalmente através dos prontuários médicos. Os entraves burocráticos criados pela CONEP através dos CEP inviabilizaram uma abordagem sistemática dessa documentação. Ainda não existe a cultura do respeito aos preceitos da Lei de Acesso à Informação nas instituições responsáveis pela guarda dessa documentação. $\mathrm{O}$ acesso que foi obtido, mesmo que parcial, mostra que o alcoolismo representava grande parte dos motivos de internação.

Mais do que esgotar o tema, o objetivo dessa seção foi reconstruir os vários papéis que o álcool assumia nas práticas terapêuticas durante o final do século XIX e a primeira metade do século XX. Vimos que dentro das fileiras oficiais a clínica diária foi reticente em renunciar ao álcool como instrumento terapêutico, apesar das críticas que lhe eram dirigidas pelas novas especialidades médicas e o movimento antialcoólico. Fora do âmbito oficial, o álcool era parte integrante de inúmeros compostos medicamentosos que eram vendidos como fortificantes, tônicos e revitalizantes essenciais à vida moderna. Uma das estratégias da indústria cervejeira na defesa de seus produtos frente ao movimento da temperança foi a construção de campanhas publicitárias que associassem seus produtos às qualidades terapêuticas, fato que era respaldada por uma cultura farmacológica que valorizava a automedicação. Nesse cenário plural a redefinição dos usos legítimos e ilegítimos de álcool era fundamental na estratégia de consolidação de algumas especialidades médicas, que se articularam politicamente para transformar suas demandas em leis e políticas públicas.

Esse quadro apresentado contrasta fortemente com a leitura proposta por Antunes (1999). Segundo esse autor, as iniciativas políticas defendidas pela classe médica, entre 1870 e 1930, teriam sido inócuas. Por isso ele propõe substituir a ideia de "medicalização da sociedade" por "socialização da medicina", uma vez que ela era restrita a uma área do pensamento social. Essa situação teria durado todo o período analisado, alterando-se somente a partir dos anos de 1930 por causa do 


\begin{abstract}
"avanço das técnicas cirúrgicas (mormente os recursos antissépticos e anestésicos) e das práticas clínicas (então apoiadas nos desenvolvimentos laboratoriais e farmacêuticos) permitiu um progresso nunca antes imaginado da assistência médica individualizada, de seu potencial diagnóstico, terapêutico e reabilitador. Concentrando-se nesses avanços, as melhores cabeças do meio médico teriam relegado a medicina pública a um segundo plano, ao contrário do que se verifica com o período anterior, sobre o qual estivemos detidos" (ANTUNES, 1999, p.277);
\end{abstract}

A evolução das técnicas, portanto, teria permitido a medicina, a partir de 1930, abandonar as

"controvérsias em que esteve envolvida, passando a seguir o caminho da experimentação, a indicação metodológica proposta pela microbiologia para todos os ramos da atividade científica. Com isso, a medicina legal teria encontrado um novo ponto de equilíbrio nos sucessos dos laboratórios, na segurança das dosagens e titulações" (ANTUNES, 1999, p.278).

O antagonismo entre pensamento social e técnicas objetivas, explorado por Antunes (1999) para explicar a falência das medidas de intervenção social como é a contenção do alcoolismo, é resultado da adoção irrestrita do discurso triunfalista da medicina que se pretende colocar-se como verdade acima da sociedade. Vimos nessa seção, contrariamente, que a patologização da embriaguez era bem mais do que um discurso acadêmico sem ressonância política ou social. Ela fazia parte de uma estratégia política imbricada, tanto com processos sociais mais amplos, quanto com disputas internas à medicina.

Da mesma forma que não podemos resumir o pensamento médico a simples devaneios intelectuais sem ressonância social, igualmente é inadequado pensarmos que a ascensão das especialidades médicas e de novas tecnologias terapêuticas tenha levado ao abandono completo das práticas até então realizadas. Nas próximas seções vamos ver as técnicas terapêuticas que o discurso proibicionista fez questão de desqualificar desde cedo como meio de exaltar as novas tecnologias que passaram a ficar disponíveis ao longo do século XX. 


\subsection{Os opiáceos e a analgesia no Brasil}

O ópio, conforme foi visto no Capítulo precedente, foi uma substância central nas disputas comerciais e imperialistas que ocorriam no Oriente. Vimos também no segundo Capítulo que a presença desse antálgico no Brasil foi subestimada, pois a historiografia procurou dar ênfase às práticas de cura com os produtos da flora nativa. $\mathrm{A}$ ausência de remédios europeus, sempre reclamada pelos colonos, reforçou a ideia que o Brasil estava apartado desse comércio. Essas percepções foram sendo desconstruídas ao longo dessa Tese. O ópio foi parte integrante da botica jesuítica e portuguesa, pois Portugal manteve iniciativas comerciais no Oriente por vasto período. O enfoque nas práticas tradicionais de cura, nativas, em antagonismo ao erudito europeu tendeu a obscurecer os reais efeitos analgésicos e estimulantes que os medicamentos secretos provocavam, independentes de terem sido ou não fabricado pelos jesuítas.

Entre os séculos XVII e XIX o ópio se tornava elemento central na terapêutica ocidental, usado para combater as moléstias ou para se sentir melhor. Desde o século XVIII, nos EUA e na Europa, a industrialização gradativamente vai substituindo o comércio de ópio líquido e sólido vendido a peso pelos remédios já prontos. Muitas boticas se transformam em pequenos laboratórios, desenvolvendo preparações vendidas como panaceias capazes de curar todos os males - com ou sem fórmulas secretas. Nos países anglo-saxões, desde o início do século XIX, esses produtos passam a fazer parte da economia operária (ESCOHOTADO, 2008, p.409-417). 


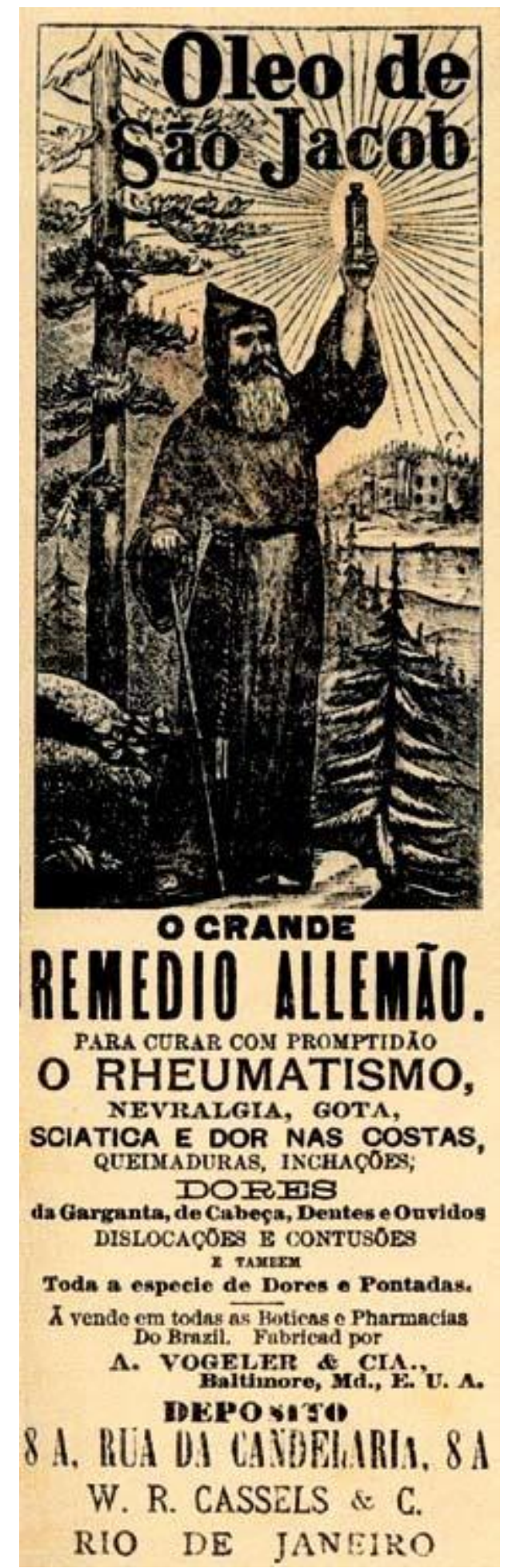

Figura 8 - Óleo de São Jacob (1889) FONTE: BUENO et al (2008, p.21)

Esses produtos eram importados e vendidos no mercado brasileiro, como o Óleo de São Jacob destacado na Figura 8. A carência de produtos de origem europeia, tão reclamada pelos colonos que viviam no Brasil no tempo de domínio português, parece ter sido amenizada depois da abertura dos portos. Santos Filho (1991b, p.362) chama a 
atenção para a gradual substituição dos produtos com base nos recursos locais por medicamentos importados, em geral franceses. Anunciados desde os primórdios da imprensa brasileira, eles prometiam curar de tudo.

\footnotetext{
“Elixires, panaceias, drogas ditas 'secretas', de livre entrada no Brasil após a abertura dos portos ao comércio estrangeiro, abarrotaram as prateleiras das farmácias - ainda chamadas 'boticas' - e de outros estabelecimentos comerciais" (SANTOS FILHO, 1991b, p.362)
}

Até que ponto esse tipo de medicamento era disponível para a população em geral é uma questão controversa. O que se pode afirmar é que o único requisito necessário para o acesso aos antálgicos opiáceos como os destacados acima era o financeiro, pois não existia restrição médica. Os médicos tinham seus cadernos de fórmulas e procuravam prescrever as medicinas de acordo com a idiossincrasia individuais e ambientais. Consideravam-se superiores tecnicamente por isso. Uma vez conhecida a receita a própria pessoa poderia solicitar o medicamento nas boticas sem constrangimentos. Os medicamentos importados e os nacionais, que gradativamente foram sendo criados, eram oferecidos como fórmulas infalíveis contra diversos males. A habituação ao uso de opiáceos, em geral, era uma opção para as pessoas que conviviam com enfermidades. O uso não médico por recreação era considerado uma forma de excentricidade - o estereótipo do toxicômano só se consolida a partir da maior presença da psiquiatria na sociedade.

Veremos nessa seção exemplos colhidos na literatura médica sobre os usos terapêuticos de ópio e seus derivados. As fórmulas e discussões apresentadas denotam grande apreciação por esse fármaco. As qualidades terapêuticas da morfina eram discutidas no Brasil desde o início da imprensa médica, conforme foi visto no primeiro Capítulo. Segundo nota publicada na Sessão de Farmácia de OPCM, o "acetato de morfina é de grande uso em Medicina, sem que haja vantagens assaz grandes na morfina pura, e nos outros sais, que tem a mesma base" (OPCM, 1827, p.331). Por isso, ao invés de manipular a substância na forma de acetato, é preferível usar como sulfato. Isso evita a necessidade de utilizar "carvão animal para despojá-lo de sua parte corante" (OPCM, 1827, p.331). Como acetato ela poderia ser utilizada na fórmula que segue, de seis a vinte e quatro doses por dia, "para substituir o láudano líquido, as gotas de Rousseaux, a tintura de ópio, etc” (OPCM, 1827, p.332). 
Gotas Calmantes

\begin{tabular}{|c|c|}
\hline \multicolumn{2}{|l|}{ Acet } \\
\hline Água destilada .......... & \\
\hline 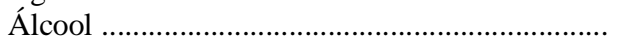 & \\
\hline 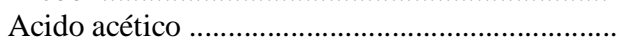 & \\
\hline
\end{tabular}

Percebe-se, nessa referência, que a utilidade da morfina reside justamente na possibilidade de substituir o ópio. Friedrich Wilhelm Sertürner (1783-1841), a quem coube o mérito de ter inventado essa substância, teria tido essa iniciativa porque

\begin{abstract}
"lhe irritava as inseguridades derivadas de usar ópio, pois as distintas remessas - incluindo a de um mesmo produtor - provocava algumas vezes efeitos insuficientes e outros excessivos, e que esse inconveniente geral era acompanhado de uma persistente dor de dente que ele possuía" ${ }^{46}$ (ESCOHOTADO, 2008, p.424).
\end{abstract}

Se a morfina tinha a vantagem de permitir uma dose mais precisa, com efeito analgésico superior, ela foi incapaz de superar de imediato o prestígio do ópio em terapêutica. Vimos, no primeiro Capítulo, que o ópio se tornou objeto de estudo na Tese de Luiz Antônio Chaves defendida em 1839. Essa substância seguia sendo "a mais celebre na história da medicina, não só pela antiguidade de seu emprego, como pelas suas altas virtudes" (CHAVES, 1839, p.16). Para esse autor, se fosse necessário descrever todas as formas de utilização do ópio, seria necessário "percorrermos a patologia inteira: todavia não ha doenças em que ele não tenha sido empregado; dadas certas condições" (CHAVES, 1839, p.32).

Essa centralidade do ópio em terapêutica não deve ser creditada, entretanto, a uma ausência ou dificuldade de obter a morfina ou outros alcaloides. Em 1845, um curioso episódio envolveu a edição do Archivo Médico Brasileiro (AMB). Uma carta foi enviada ao editor "sem saber de onde, nem de quem. E não obstante, é ela de tão subido mérito, e de tal utilidade, que lícito fosse o seu autor apresentar-se sem medo de coima" (AMB, 1845, p.141). Ela defende que nas plantas "se empregam todos os veículos de que o experimentador se puder lembrar, a fim de dissolverem-se seus princípios medicamentosos" (AMB, 1845, p.141). Praticas essas

“quase impossíveis nas Províncias por falta de aparelhos, de pratica dos
experimentadores, e nem todas as plantas medicamentosas merecem esse

\footnotetext{
46 "le irritaban las inseguridades derivadas de usar opio, pues las distintas remesas - incluso del mismo productor - provocaban unas veces efectos insuficientes y otras excesivos, y que a ese inconveniente genérico vino a añadirse un pertinaz dolor de muelas proprio" - tradução sugerida.
} 
trabalho. Além de que eu penso que o composto, que a natureza produziu, é quase sempre preferível ao principio ativo que a química extrai. A quina tem mais propriedades, que a quinina e seus sais, e não tem a morfina todas as propriedades do ópio" (AMB, 1845, p.141).

A preferência pelos efeitos conjuntos do ópio não era opinião isolada de um prático brasileiro anônimo, acuado frente ao cientificismo acadêmico. Segundo Escohotado (2008, p.548-549), boa parte dos terapeutas treinados nas instituições oficiais continuava a preferir o produto extraído da dormideira, pois ele era menos tóxico e aditivo, não excitava tão rapidamente, não levava ao colapso respiratório nem deprimia o sistema nervoso. Nos EUA, o tratado de G. Wood, que é considerado um dos mais populares do século XIX, considerava o ópio “o remédio sem dúvida mais importante e valioso de toda a farmacopeia"47 (WOOD, 1886, p.712-713 apud ESCOHOTADO, 2008, p.549). Posição bastante parecida com a do brasileiro Luiz Antônio Chaves, exposta em 1839 e apresentada acima.

Percebe-se que, ao longo do século XIX, algumas boticas vão se especializando na produção de medicamentos, tornando-se pequenos laboratórios que produzem, tanto produtos prontos para o uso, quanto os ingredientes puros necessários para a formulação de remédios. Na Ásia e na América predominava o uso na forma natural entre as classes desfavorecidas (ESCOHOTADO, 2008, p.412). Nós olhamos no primeiro Capítulo, em anúncio de jornal de 1867, como era possível comprar em leilão ópio e quina na forma bruta, junto a outros produtos ordinários.

A ideia de que os alcaloides do ópio agindo em conjunto tinham maior eficácia do que seus princípios ativos separadamente foi a base do sucesso do Pantopon, um remédio produzido pelo Laboratório alemão Roche. Em 1950, ou seja, um pouco mais de um século depois da carta anônima descrita acima, o Dr. Mario Rangel ${ }^{48}$ descrevia dessa forma esse medicamento:

“é uma preparação contendo os alcaloides totais do ópio. Foi preparado baseado no ponto de vista que a associação de vários alcaloides do ópio teria

\footnotetext{
47 "el remédio sin duda más importante y valioso de toda la farmacopeia" - tradução sugerida.

${ }^{48}$ Mario Rangel era médico liberal que atuava no Rio de Janeiro com consultório na av. Rio Branco. Sócio dos Laboratórios Raul Leite, atuava como médico responsável pelo Laboratório Margel que pertencia a esse grupo. Foi atuante no Sindicato dos Proprietários de Pharmacia, Drogarias e Laboratórios nos anos de 1930, se tornando posteriormente colaborador do jornal A Gazeta da Farmacia. Neste jornal escreveu contos, matérias discutindo novos remédios e divulgando matéria científica. Em parceria com a editora dos Irmãos de Giordio, publicou vários livros de medicina prática, entre eles $A$ Prática da Medicina (1945), Alergia (1945), Cirurgia de Consultório (1944).
} 
ação mais forte e mais rápida do que a da morfina. De fato, Pantopon que se tornou amplamente empregado na clínica diária, oferece diversas vantagens sobre a morfina: ação mais rápida; menos emetizante; menos constipante; ocasiona menos depressão respiratória. Apesar dessas vantagens, a ação analgésica da morfina continua sendo mais forte" (RANGEL, 1950, p.42-43).

O Dr. Mario Rangel é um típico representante da medicina liberal que entraria em declínio na segunda metade do século XX, conforme veremos no próximo Capítulo. Importa, para presente discussão, é a permanência do uso do Pantopon ao longo do século XX como analgésico.

Uma laudatória ao Pantopon é encontrada em uma Tese de 1913, intitulada Anesthesia Obstetrica, de autoria do Dr. Ayres Oswaldo Loureiro. O autor apresenta uma longa discussão sobre todos os analgésicos empregados em anestesia obstétrica, até aquela data, defendendo a injeção intravenosa de Pantopon como a mais eficaz. Irei me referir a esse trabalho em outros momentos, conforme avançarmos na discussão de outros fármacos. Curioso, tratando-se do ópio, que um dos primeiros métodos criticados pelo autor é a aplicação de “clisteres laudanizados” (LOUREIRO, 1913, p.05).

Para este médico obstétrico, o ópio seguia sendo "uma das drogas mais importantes que nosso arsenal terapêutico possui” (LOUREIRO, 1913, p.19), usados para resolver o problema da insônia, da exageração das secreções glandulares, espasmos, dor e outros. Existia, entretanto, o grave impedimento dele não poder ser aplicado por injeção hipodérmica. O cloridrato de morfina, que o substitui nesse tipo de administração, tem "os inconvenientes de ser mais depressiva e mais brutal em suas ações, mais tóxica, predispondo a intolerância e tornando os organismos facilmente predispostos a mania" (LOUREIRO, 1913, p.20). Haveria, portanto, a necessidade de

\footnotetext{
"uma droga que seja uma mistura definida dos alcaloides do ópio e que tivesse todas as propriedades benéficas, que fosse o ópio terapêutico, mas que ao mesmo tempo não encerrasse inconvenientes, que fosse solúvel, predispondo menos falta para o hábito" (LOUREIRO, 1913, p.20).
}

Essa necessidade teria sido plenamente satisfeita com a invenção do Pantopon.

"O costume e a mania que tão comumente se assinala com o emprego da morfina, não são observados com o Pantopon, sendo esta a opinião da maior parte dos autores, pois podemos emprega-lo em doses idênticas e repetidas, e os seus efeitos alcançam sempre os mesmos resultados. Alguns empregam 
nos morfinômanos as injeções de Pantopon com o fim de que eles possam perder o hábito e a necessidade da morfina" (LOUREIRO, 1913, p.22).

Esse remédio, vendido "sobre duas formas oficinais" (LOUREIRO, 1913, p.24) - comprimidos e ampolas - podia ser utilizado como poção, xarope ou injeções hipodérmicas. Foi este último método que foi adotado, com grande sucesso, no serviço clínico de obstetrícia da Faculdade de Medicina do Rio de Janeiro (FMRJ). Essa Tese traz o relato de 50 partos.

Esses elogios não estavam restritos à literatura médica. Em 1912, o jornal Gazeta de São Paulo publicava uma matéria com o título "O Pantopon desbanca a morfina", destacando que "absorve-se rapidamente, não faz prisão de ventre, não ensaburra como a morfina, nem como esta produz fenômenos tão nocivos, a juízo dos experimentadores" (A Gazeta, 27 de setembro de 1912, p.01 Apud CARNEIRO, 1993, p.98). Em 1915, os médicos da Sociedade de Medicina de São Paulo, entretanto, já alertavam para os casos de mania nesse novo fármaco, anunciado como não criador de hábito (CARNEIRO, 1993, p.98).

Existem alguns casos onde o Pantopon foi a porta de entrada para a toxicomania. Foi o caso de José Torres, homem de 28 anos, que buscou internação no Sanatório Pinel em São Paulo (SPSP) para fins de se desintoxicar. Viajado, levou "uma vida desregrada, sendo bastante amigo das noitadas e das mulheres" (SPSP, Prontuário $n^{\circ} 240,1931$ ), nunca obteve "amor pelo trabalho, porque seus desejos sempre foram satisfeitos pelos pais" (SPSP, Prontuário $\left.n^{\circ} 240,1931\right)$. Teve histórico de abuso de cocaína, porém abandonou o uso. Tornou-se toxicômano depois de uma forte cólica hepática, quando “fez uso em excesso de Pantopon" (SPSP, Prontuário no 240, 1931), passando para a morfina posteriormente. Foi o noivado que o levou a se internar.

Ao longo de todo o século XIX e até meados do século XX o ópio e seus derivados era um remédio central na terapêutica - trazendo alívio para dores diversas. Seu prestígio pode ser medido pelo fato de que foi dele o primeiro princípio ativo extraído de uma planta, dando origem à ciência dos alcaloides. A morfina, principal fitoquímico do ópio e precursora da ciência dos alcaloides, também serviu de modelo à constituição do primeiro preparado químico derivado de uma planta - apomorfina (1901) (SNEADER, 2005, p.115). Depois de Sertürner ter reportado o seu isolamento da forma de sal, em 1804, outros experimentos foram sendo realizadas e novas substâncias conhecidas, como a narcotina e a tebaína. O conhecimento sobre o ópio e 
seus derivados seguiu progredindo. Somente em 1923 a estrutura química da morfina foi conhecida.

\begin{abstract}
"A despeito da tendência à adição, o perigoso efeito depressivo sobre o centro respiratório e a tendência de provocar náuseas e constipação, a morfina ainda se mantém como a mais efetiva droga conhecida para aliviar a dor severa. Seu poder analgésico é reforçado pelo estado de euforia e liberdade de espírito" ${ }^{\text {49 }}$ (SNEADER, 2005, p.92).
\end{abstract}

Se até hoje ela segue sendo a mais cultuada substância analgésica, o mesmo se deu durante todo o século XIX - apesar dela ser mais forte que o ópio e propensa a gerar acidentes por causa de seu efeito sobre o aparelho respiratório. Envenenamentos, voluntários como eutanásico ou involuntários, eram comuns. Esse foi o caso do "jovem Cirurgião Brasileiro" (RFM, 1836, p.102) Dr. Gomes, que, em 1829, tentou suicidar-se na França tomando vinte e quatro gramas de acetato de morfina dissolvidos em água. Esse caso foi um dos "mais bem caracterizados sintomas deste envenenamento" (RFM, 1836, p.109), levando ao registro da ação pelo Dr. Orfila da Escola de Medicina de Paris responsável por acudir o jovem. Ele prescreveu "uma sangria do braço, de seis xícaras, um clister emético" (RFM, 1836, p.105) e gelo na cabeça. Esperou também o intoxicado conseguir engolir para prescrever água acidulada, porém isso não foi possível. Assim, introduziu-se a bebida vinagrada por meio de uma sonda de goma elástica. "O clister não tardou em ser administrado, mas foi expulso quase imediatamente sem produzir efeito que dele se esperava" (RFM, 1836, p.105). O doente gradativamente se reestabeleceu graças, segundo o Dr. Orfila, ao tratamento dispensado. Nas reflexões finais, ele apontou que seria inútil recorrer a um antidoto, pois a substância dissolvida em água já tinha sido absorvida pelo organismo. Como em experimentos anteriores tendo sido obtido bons resultados com a sangria de homens e animais, "não hesitamos em tirar grande quantidade de sangue" (RFM, 1836, p.109) do paciente. As bebidas aciduladas, tão preconizadas pelos antigos ao envenenamento por narcóticos, "só são uteis no envenenamento pelo ópio, quando o veneno não se acha mais no canal digestivo, e tem sido expelido por cima e por baixo" (RFM, 1836, p.110). Porém, se a substância se encontra no canal digestivo, as bebidas aciduladas dissolvem

\footnotetext{
${ }^{49}$ Despite its addictive liability and hazardous depressive effect on the respiratory centre plus a tendency to cause nausea and constipation, morphine still remains the most effective drug available for the alleviation of severe pain. Its analgesic power is enhanced by the associated state of euphoria and detachment - tradução sugerida.
} 
seus princípios ativos agravando o caso. Experimentos com vinagre e ópio em cães mostraram que o envenenamento fica mais grave quando elas atuam em conjunto. No caso em questão, a medicação acidula prestou grandes serviços. O gelo sobre a cabeça também produziu bons efeitos, ainda que não utilizado por muito tempo. $\mathrm{O}$ "clister emético" durou pouco tempo, por isso não foi possível tirar conclusões. Por último, vale a recomendação de usar um emético muito forte no caso de ingestão recente como meio de expulsar o veneno, depois aplicar "uma larga sangria, aplicado refrigerantes a cabeça, e administrado frequentemente e por muitas vezes bebidas aciduladas: esta última medicação só seria empregada depois da expulsão do veneno por cima e por baixo" (RFM, 1836, p.111).

Esse relato clínico provavelmente foi a primeira divulgação de procedimentos que devem ser adotados em casos de envenenamento por morfina. Com o passar do tempo, os meios para reanimar os intoxicados ganhavam novas formas, algumas menos "heroicas" do que esta. Em 1847, o AMB publica uma nota apontando a "eficácia do café como antidoto da morfina" (AMB, 1847, p.43). Segundo ela,

Certo doente engolira de uma vez quatorze grãos de acetato de morfina. Administraram-lhe 4 grãos de tártaro de estibiado, que não produziram vômitos. Três horas depois da introdução do acetato de morfina, quando já o doente jazia em profundo coma, começaram a dar-lhe infusão muito concentrada de café com borra. Em doze horas tomou 101,2 onças. Breve saiu do coma, e sarou (AMB, 1847, p.43).

A associação do café com o ópio é antiga. Escohotado (2008, p.383) lembra que desde fins do século XVII popularizou-se nos cafés das principais cidades da Europa uma bebida conhecida pelo nome de eau herö̈que que era uma mistura de café com 5\% de ópio líquido. Essa bebida teria sido precursora das misturas de café com licor, que passou a substitui-lo depois do bloqueio continental napoleônico e da alta do preço do ópio. O café e o ópio parecem se combinar por causa dos seus efeitos contrários, pelo menos essa é a opinião divulgada no Boletim da Sociedade de Medicina e Cirurgia de São Paulo (BSMCSP). Em 1896, uma nota com o título "Café e ópio" apontava que

“o efeito analgésico do ópio não sofre modificação em presença do café; assim, todas as vezes que se desejar obter ação calmante do ópio e seus preparados, pode-se lhe corrigir os inconvenientes, associando-o ao café, verbi gratia com o fim de combater nevralgias" (BSMCSP, 1896, p.23). 
Apesar dos perigos que a morfina representava, ela era plenamente acessível para qualquer indivíduo que sentisse dor. Embora em alguns casos ela pudesse gerar usos habituais, a maioria das pessoas que dela lançavam mão eram aquelas que sofriam com dores provenientes de afecções. Bastante distante da representação atual que lhe credita o rótulo de vício irremediável e irresistível, a habituação era antes uma opção. Um caso clínico ocorrido no planalto serrano do Rio Grande do Sul, e publicado no Archivos Rio Grandenses de Medicina (ARGM), pode ser elucidativo nesse sentido.

Durante passagem por cidade da serra gaúcha, o médico e professor da Faculdade de Medicina de Porto Alegre (FMPA), César Ávila, foi chamado para conferência por um distinto colega da região para avaliar um caso considerado perdido. Tratava-se de uma mulher, descendente de italianos, branca, solteira, com 36 anos de idade e que há quatro anos começava a sentir dores na região suboccipital. Na primeira consulta se percebia que ela "acabara de receber dose grande de morfina que sistematicamente vinha usando, há vários meses, diversas vezes ao dia” (Ávila, 1940, p.129). Ela já tinha sido submetida a "injeções de ouro, tuberculina, imobilização em minerva gessada, etc. etc.” (Ávila, 1940, p.129). Nas radiografias e exames de laboratório todos os diagnósticos até então feitos apontavam para o Mal de Pott. O Dr. Ávila fez alguns exames para excluir as hipóteses de se tratar de artrite cervical e sífilis, confirmando os diagnósticos anteriores. O prognóstico era sombrio, pois era "grande enfraquecimento da doente, proveniente principalmente das altas doses de morfina, já habituadas" (Ávila, 1940, p.132). Como nenhum tratamento teve efeito, optou-se por tentar tratar a artrose por enxerto. A operação foi executada com anestesia local no Hospital Santo Antônio de Caxias. "Anestesia local da região tibial esquerda e da face posterior do pescoço e ociput (sic) com infiltração de novocaína a meio por cento com algumas gotas de solução milesimal (sic) de adrenalina" (Ávila, 1940, p.133). A cicatrização foi lenta, porém o resultado final foi um sucesso. "A doente tendo melhorado das dores logo depois da artrodese, abandonou o uso da morfina. Atualmente está perfeitamente restabelecida, engordou cerca de 20 quilos e retomou suas ocupações quotidianas" (Ávila, 1940, p.133).

O que se percebe, nesse exemplo, é que tal mulher tinha ao seu dispor grande quantidade de morfina sem que isso causasse recriminação dos médicos ou das pessoas. O recurso ao antálgico, assim como a quantidade que dele se fazia, era uma decisão pertencente àquela que sofria a afecção. Hoje, para efeitos de comparação, quem define 
qual a dose de morfina que cabe a cada doente, e somente nos casos seríssimos, é a autoridade médica - independente da dor sofrida ou alegada pelo paciente. Outro aspecto que chama a atenção é o fato da doente optar, espontaneamente, a deixar de usar a morfina tão logo a dor que a incomodava cessou. Um último aspecto que chama atenção é a anestesia local por novocaína, que será tratada logo abaixo quando abordarmos a cocaína. O Mal de Pott é uma doença rara, tratando-se de uma infecção das vértebras pelo bacilo da tuberculose. As bactérias seguiam sendo, durante toda a primeira metade do século XX, um fator patológico de enorme importância, pois até o advento dos antibióticos era grande a morbidade com esse tipo de doença. Sem meios eficazes capazes de gerar uma cura definitiva aos males gerados pelos microorganismos, cabia ao ópio, e seus derivados, importantes funções terapêuticas. Principalmente em relação à tuberculose por causa dos efeitos que a maioria dos opiáceos gerava no sistema respiratório.

Em 1912, o Archivo da Sociedade de Medicina e Cirurgia de São Paulo (ASMCSP) divulgava um caso clínico sobre pleurisias agudas tratadas com sucesso pelo Dr. Hirtz. O artigo trata de distinguir as pleurisias simples, causadas pela tuberculose, de duas outras formas principais: mínima, que resulta em pequeno derrame e febre; aguda, com derrame abundante, temperatura elevada e estado-geral mal. A terapêutica clássica e comum às duas causas é gerar pequena "revulsão local" (ASMCSP, 1912, p.188) e o tratamento sintomático contra a tosse. Os doentes "ficam abandonados a si mesmo e a natura medicatrix" (ASMCSP, 1912, p.188). O ASMCSP "revolta-se contra isso. As pleurisias francamente agudas e febris carecem da terapêutica das afecções pulmonares agudas e cumpre agir sobre a inflamação da pleura e sobre o estado geral" (ASMCSP, 1912, p.189). Nesses casos se aconselha: $1^{\circ}$. Aplicar "ventosas escarificadas, dez a doze logo no começo da moléstia" (ASMCSP, 1912, p.189); 2. Aplicar compressas húmidas sobre tórax de 24 graus, frequentemente renovadas, suspendendo a aplicação à noite. Contra a tose se sugere duas receitas que devem ser dadas de meia colher de meia em meia hora até o alívio.

\begin{tabular}{|c|c|c|c|}
\hline Xarope de morfina ........................... & 20,0 & Xarope de codeína ................................. & 60,00 \\
\hline Xarope de éter ................................ & 60,0 & 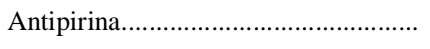 & 1,50 \\
\hline Xarope de beladona ....................... & 15,0 & & \\
\hline
\end{tabular}


Com esse tratamento é esperado que a pleurisia ceda, porém "é preciso lembrar que ela é a expressão duma bacilose" (ASMCSP, 1912, p.189) então não é possível curar completamente o doente.

O tratamento divulgado acima é relevante porque mostra, tanto a reiterada influencia do neohipocratismo ao fazer referência à revulsão e as ventosas escarificadas. Mostra também a presença de dois opiáceos, morfina e codeína, para o tratamento sintomático das tosses. Por último, chama atenção o uso da beladona, uma solanácea usada milenarmente em medicina com fortíssimo poder alucinógeno.

A centralidade dos opiáceos no tratamento das afecções respiratórias pode ser percebida, também, na Tese defendida por Francisco Ursaia na FMRJ. Com o título Dos derivados de morphina no apparelho respiratorio, ela foi aprovada com distinção e teve orientação do professor Pedro Augusto Pinto. ${ }^{50}$ Esse trabalho consiste em uma descrição detalhada da fisiologia do aparelho respiratório, por um lado, e da história e das propriedades farmacológicas dos opiáceos, por outro. Ele pretendia mostrar que "a medicação sedativa o medico tem necessidade de recorrer a miúde, principalmente nas afecções respiratórias" (URSAIA, 1924, p.02). A morfina seria uma substância forte que utilizada em altas doses poderia gerar uma ação paralisante, causando inclusive a morte. Porém, o envenenamento agudo teria menos interesse que o crônico, pois este último “é uma intoxicação mais grave e largamente disseminada” (URSAIA, 1924, p.36). A codeína seria preferível porque ela teria propriedades idênticas, porém "é menos toxica para o organismo do homem e sua ação depressiva sobre o cérebro é menor que a da morfina" (URSAIA, 1924, p.41). Ela poderia ser usada no tratamento das afecções do aparelho respiratório, principalmente contra as tosses rebeldes, bronquite e tuberculose. Usadas em pastilha, pílulas e na forma de xarope, conforme receita abaixo.

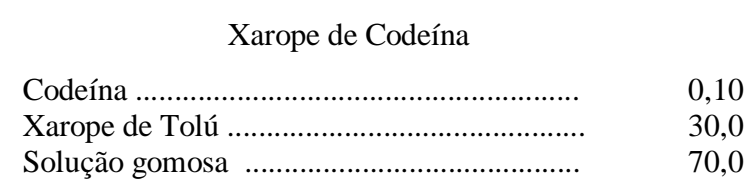

50 Ele foi professor da cadeira de Farmacologia e arte de formular entre 1904 e 1950. FONTE: Dicionário Histórico-Biográfico das Ciências da Saúde no Brasil (1832-1930). Em entrevista ao Instituto Virtual de Fármacos, o professor Nuno Álvares Pereira diz que "Pedro Augusto Pinto foi o primeiro catedrático a dar um aspecto novo ao estudo da farmacologia". FONTES:

<http://www.dichistoriasaude.coc.fiocruz.br/iah/pt/verbetes/escancimerj.htm> Último acesso: 12/01/2016

< http://www.ivfrj.ccsdecania.ufrj.br/ivfonline/edicao_0041/prof_nuno.html> Último acesso: 12/01/2016. 
Como substituto da codeína o autor ainda sugere a Dionina e a Peronina. Outra substância que o autor não poupa elogios é o Pantopio, definido como "a reunião de cloridrato de todos os alcaloides do ópio" (URSAIA, 1924, p.41). Pelo que vimos a respeito do Pantopon, ou se trata de um erro ortográfico ou de outro produto industrializado, de nome parecido, porém mantendo a mesma proposta. O Pantopio funcionaria como o ópio em doses fracas, porém com propriedades analgésicas tão pronunciadas quanto à morfina e não produzindo náuseas nem depressão. Em doses fracas ele produziria "ação tonicardiaca (sic) e eupneica" (URSAIA, 1924, p.41). Sobre o ópio, o Pantopio teria a vantagem de ter forma mais regular e poder ser administrado em injeções hipodérmicas. Para as afecções pulmonares ele pode ser usado externamente em injeção ou internamente sobre a forma de poção, segundo receitas que seguem.

\begin{tabular}{|c|c|c|}
\hline Em injeção & & Internamente \\
\hline 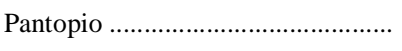 & 20,0 & 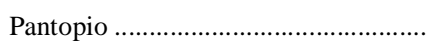 \\
\hline 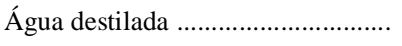 & $10 \mathrm{cc}$ & Xarope de flores de laranjeira ................. \\
\hline 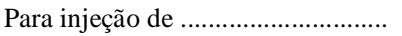 & $1 \mathrm{cc}$ & Água destilada \\
\hline
\end{tabular}

Antes de finalizar, ele ainda trata de uma última substância: a heroína. Também para essa não faltam elogios. Ele seria capaz de gerar "amplitude dos atos respiratórios" e provocar "grande calma muscular em todo o organismo" (URSAIA,1924, p.42). Em doses pequenas ela consegue diminuir a frequência da respiração, baixando a temperatura corporal. Ela tem a vantagem de não provocar constipação ou qualquer outra perturbação gástrica, porém em doses grandes pode gerar convulsões e deprimir o centro respiratório. Com cuidados, ela "pode prestar ótimos serviços nas afecções do aparelho respiratório. É especialmente recomendada contra a tosse dos tuberculosos e contra as dores nevrálgicas" (URSAIA,1924, p.44). Ele recomenda o uso em gotas de duas a três vezes por dia, conforme a receita abaixo.

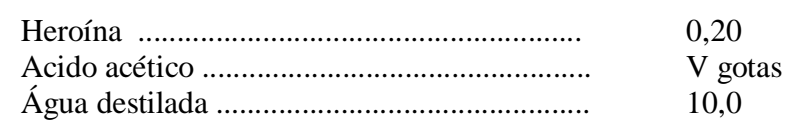

De uma maneira geral, a Tese de Ursaia vem confirmando tudo aquilo que se colocou a respeito dos opiáceos, porém com ênfase no tratamento sintomático das afecções respiratórias. A principal novidade diz respeito à heroína, por isso deteremos atenção sobre ela. 
Vimos, anteriormente, que, no início do século XIX, vários estudos foram desenvolvidos buscando conhecer as propriedades químicas do ópio, gerando a morfina - que foi o primeiro alcaloide extraído de uma planta - e a apomorfina - que foi o primeiro medicamento análogo construído tendo por modelo um alcaloide. Esses experimentos, que seguem até os dias atuais, visam à obtenção de novos e potentes analgésicos sem os inconvenientes apresentados pela morfina.

\footnotetext{
"Nota-se em toda a parte a preocupação de encontrar o substituto ideal da morfina, que seria o produto que tivesse igual ou mais forte ação analgésica e sedativa sem as reações colaterais e sem, principalmente, a possibilidade de formar hábito" (RANGEL, 1950, p.41).
}

O excerto trazido acima, trazido pelo Dr. Rangel, traz uma novidade em relação aos anteriores. Ele está inserido dentro de um contexto onde a toxicidade do medicamento e a margem de segurança (diferença entre dose mínima e dose fatal) é menos importante do que a capacidade de uma substância de formar hábito ou mania. Apesar dessa diferença, ele simboliza uma busca em torno de novos analgésicos que não cessou até os dias atuais e que tem a morfina como parâmetro de eficácia.

A heroína é resultado dessa busca, substância que foi patenteada pela indústria farmacêutica alemã Bayer. Ela foi o primeiro opiáceo colocado no mercado que conseguia resolver o problema da irritação do estômago e da constipação. Ela atuava sobre o sistema respiratório sem deprimir todo o organismo, se tornando, portanto, excelente alternativa para abrandar os efeitos das crises respiratórias comuns naquela época por causa da tuberculose. Ela foi isolada em 1897 e no ano seguinte vendida como paliativo para esse tipo de doença. Tornou-se um sucesso comercial e passou a ser vendida em escala global por volta de 1911. Paralelamente ao uso para doenças respiratórias, passou a ser indicada para substituir a morfina em diferentes modalidades de analgesia. Apesar de ser, hoje, considerada a droga mais aditiva da história, nos seus primeiros anos ela era anunciada como opiáceo não aditivo, servindo inclusive para o tratamento de manias. O que pouca gente sabe é que muitas pessoas que a usavam oralmente, durante os curtos períodos de crise respiratória, conseguiam controlar suas crises sem com isso se tornarem habituadas. Ela dava aos pacientes com tuberculose crônica, e outros com doenças parecidas, a possibilidade de um tratamento para períodos de crise respiratória sem manifestação da síndrome de abstinência (SNEADER, 2005, p.116-117). Escohotado (2008, p.1214-1224) chama a atenção para 
estudos realizados na década de 1920 que apontam ser necessários de quatro a cinco semanas para que se manifestem leves sintomas de síndrome de abstinência - tendo por base a ingestão de um grama de heroína por dia. Questionário aplicado com 150 pessoas sãs que a injetaram mostrou que nenhuma delas teve vontade de repetir a experiência. Ou seja, a habituação aos opiáceos era uma opção geralmente adotada por aquelas pessoas que sentiam dores ou que precisavam curar uma crise respiratória, cessando o uso depois de recuperadas. Situação que descrevemos acima no caso clínico relatado pelo Dr. César Ávila em relação à morfina.

No Brasil, ela foi rapidamente acolhida e com certo entusiasmo. O Dr. Clemente Pereira apresentou na Sociedade de Medicina e Cirurgia do Estado de São Paulo, em sete de agosto de 1899, uma comunicação com o título "Do emprego clínico do cloridrato de heroína". Segundo ele, assim que "foi possível obtê-la, comecei a emprega-la tendo até hoje recorrido a este agente em 6 casos: 2 tuberculosos, 1 asmático, 1 de bronquite e 2 enfermos de manifestações gripais para o aparelho respiratório" (BSMCSP, 1899, p.305). No caso de asma, uma senhora de 60 anos que havia 30 sofria com a doença, cheguei no momento da crise, receitando 2 centigramas em uma poção. No outro dia os sintomas tinham melhoras acentuadas. Nos dois tuberculosos, que estavam com uma tosse que "se mostrava tenaz e ferina [...] uma acalmia apreciável sob a ação do cloridrato de heroína na dose de 2 centigramas em 36 horas" (BSMCSP, 1899, p.305). Melhoras também foram verificadas nos outros casos. É notória a intensidade e conhecida a rebeldia desse tipo de tosse, afeita a crises violentas e prolongadas. Porém, mesmo nesses casos, doses de 1 a 2 centigramas são suficientes para que o paciente tenha melhoras apreciáveis sem que sejam acusadas "nem tonteiras, nem náuseas, como se suceder quando se lança mão de morfina" (BSMCSP, 1899, p.306). Esses resultados animadores precisam ser amplificados e a heroína utilizada "largamente afim de que se apure suficientemente a sua eficácia e se assentem sobre bases firmes as suas indicações terapêuticas" (BSMCSP, 1899, p.306).

Segundo o relato acima destacado, poucos centigramas de heroína eram suficientes para que o doente obtivesse melhora sintomática sensível, fato que foi corroborado na Tese de Francisco Ursaia, de 1924, apresentada acima. Neste mesmo ano, entretanto, já começa a repercutir no Brasil os debates em torno da interdição da heroína. Segundo o jornal Gazeta Clínica, (GCSP) de São Paulo, a Comissão Permanente da Repartição Internacional de Higiene Pública, com sede em Paris, estava divulgando um plano para ser interditada a fabricação e a venda de heroína. A razão 
invocada era que "a heroína, do ponto de vista social, é mais perigosa que a própria morfina" (GCSP, 1924, p.09). Essa posição foi defendida pelos EUA que, desde 1916, proibira o uso de tal substância em hospitais públicos. Mesmo com grande atuação na guerra em cerca de 10 a 15 mil doentes, "em nenhum caso os médicos se queixaram da interdição da heroína” (GCSP, 1924, p.09). As opiniões recolhidas por outras comunidades médicas, entretanto, se mostravam divididas.

\footnotetext{
"Houve muita insistência no facto da heroína ser um medicamento ativo, que tem seu lugar ao lado da morfina e da cocaína, e que certas pessoas suportam melhor um dos medicamentos do que outros dois, assim como que a heroína é particularmente indicada em certas afecções" (GCSP, 1924, p.09).
}

A administração sanitária italiana, por exemplo, fez um inquérito entre os professores titulares das suas cátedras de clínica e de farmacologia. Perguntou-se se era possível substituir, para uso médico, em todos os casos, "a codeína, a apocodeína ou a dionina, pela heroína" (GCSP, 1924, p.09). Houve divisão entre os médicos italianos. Essas e outras divergências levou a Comissão a "considerar aberta a questão" (GCSP, 1924, p.09).

A notícia destaca acima, inserida dentro de um periódico médico, é um indício de que em meados dos anos de 1920 a controvérsia em torno do perigo social da heroína gerava interesse da classe médica paulista, porém sem que houvesse uma defesa da proibição. Ela seguia utilizada como produto terapêutico, principalmente para as afecções pulmonares. Outra fonte, trazida por Sarti (2012, p.34-35), mostra o caso do dentista Mario Nazaré que procurou o $12^{\circ}$ Distrito Policial da cidade do Rio de Janeiro em junho de 1921. Ele alegou ao delegado que, tendo tomado muito sol na semana anterior e se achando nervoso por causa da perda do pai, foi tratado por seu médico em sua residência com uma injeção de heroína. Sentindo uma sensação desagradável, acreditou que o produto estava adulterado e, por isso, levou o frasco até a delegacia. $\mathrm{O}$ delegado mandou proceder à análise do produto que foi considerado normal. Vimos acima com Escohotado (2008, p.1214-1224) que a primeira dose de heroína em geral não gera sensações agradáveis em pessoas sãs.

Se a heroína é especialmente eficaz para as afecções pulmonares, o caso do dentista Mario Nazaré nos mostra que ela pode ser indicada para uma multiplicidade de situação, até mesmo para melhorar os incômodos de uma insolação. É possível também encontrar outros registros quando passamos a analisar os prontuários médicos. O 
Sanatório Pinel, localizado no bairro Pirituba na capital paulista, era uma instituição particular que oferecia serviço de assistência psiquiátrica. Era uma alternativa aos tratamentos públicos oferecidos pelo Instituto Paulista e Hospital de Juqueri, recebendo pessoas de municípios do interior e de outros Estados. Todos os casos que serão apresentados abaixo são próximos ao de José Torres, mostrado anteriormente quando se tratava do Pantopon. Pessoas que passaram a usar o fármaco por causa de alguma moléstia, adquirindo o hábito e por isso buscando ajuda para se desintoxicar. A maioria dos casos de tratamento de mania é de origem iatrogênica.

O caso de Carlos Araújo é emblemático porque ele passou por várias instituições psiquiátricas antes de chegar ao Sanatório Pinel. Iniciou o uso de morfina depois de uma doença e somente conseguiu se livrar do vício depois de uma estadia para desintoxicação no Sanatório Botafogo (RJ). Limpo, voltou a fazer uso de outro opiáceo, dessa vez a heroína. Estava usando 0,16 diários quando "rebentou o movimento revolucionário constitucionalista, em julho de 1932” (SPSP, Prontuário $n^{0}$ 551, 1932) . Alistando-se como voluntário, "permaneceu por quase 30 dias nas trincheiras, sempre fazendo uso do tóxico" (SPSP, Prontuário $\mathrm{n}^{0}$ 551, 1932). Escasseando este, foi acometido de grande mal estar e diarreia, fato que o obrigou a procurar o Hospital de Cachoeira. Removido para São Paulo, permanecendo 2 dias no Hospital de Juqueri, vindo em seguida para o Sanatório Pinel de Pirituba, onde deu entrada. Seu tratamento consistiu em redução gradual da heroína, iniciando em 0,06 e terminando em zero no prazo de 12 dias.

Thamires Sarti (2015, p.137-140) pesquisou os prontuários médicos do Pavilhão de Observações no Rio de Janeiro. Essa instituição servia como ponte entre a polícia e o Hospital Nacional de Alienados, sendo encontrados 127 casos de toxicomania - vale destacar que esse número é irrelevante se considerarmos todo o conjunto documental. Destes, "57 faziam uso de um ou mais opiáceos, significando quase $45 \%$ dos toxicômanos" (SARTI, 2015, p.137). Destes 57, quinze foram internados por vontade própria como meio de largar o uso continuado de fármacos. Esse foi o caso de Amélia que, não tendo recursos para buscar uma clínica particular, procurou a polícia pedindo ajuda para entrar em algum hospício. Ela tinha 37 anos, era casada porém foi abandonada pelo marido. Ela começou a usar heroína depois de uma operação no braço "por necessidade de acalmar as dores" (Apud SARTI, 2015, p.138). Passou a administrá-la por vício depois de curada e aumentou progressivamente a dose, quando começou a apresentar deficiência na memória e alucinações, sobretudo à noite. Cheia de 
abscessos nos braços e nas pernas, foi notado o descuido asséptico das suas aplicações. Esse relato, junto com outros parecidos, aponta que a heroína era uma substância acessível também para pessoas de baixo poder aquisitivo; usada como antálgico para diversas ocasiões.

A heroína foi um dos primeiros fármacos clássicos a perder sua condição de medicina. Segundo Carvalho (2013, p.167), a CNFE adotou uma política de zerar as importações desse produto a partir de 1939, fato que pode ser confirmado na tabela de importações de entorpecentes produzidas pelo órgão entre 1939 e 1946. Para Roberval Cordeiro de Farias, coordenador da CNFE, em texto publicado no Boletim da Oficina Sanitária Pan-americana em julho de 1946, a "heroína, o mais traiçoeiro dos entorpecentes foi cancelado da nossa importação, atendendo à justa solicitação da Sociedade das Nações” (FARIAS, 1958, p.583). Essa política da CNFE logo é sentida entre os clínicos. O Dr. Mario Rangel aponta que

\footnotetext{
"dos alcaloides do ópio, a heroína é o mais ativo. Tem ação analgésica quase duas vezes maior que a morfina. E é também o que mais facilmente provoca o hábito e o mais difícil de curar quando o hábito se formou. São de tal monta seus perigos nesse particular que uma comissão de farmacologistas da Liga das Nações fez um apelo para o completo banimento da heroína da terapêutica humana" (RANGEL, 1950, p.42).
}

Mostrou-se, portanto, como o ópio e os seus derivados foram, durante todo o período analisado, uma ferramenta farmacológica central. Se, no final da década de 1930, a heroína começa a deixar de ser importada, os demais opiáceos seguiram sendo apreciadíssimos elementos terapêuticos da clínica diária. O perigo da intoxicação ou da obtenção de hábito não era suficiente para apagar a sua importância na terapêutica que ainda era, em grande medida, essencialmente sintomática. Se o ceticismo terapêutico era um sentimento alastrado entre os médicos, conforme vimos, os mesmos não deixaram de lançar mão de todos os recursos antálgicos existentes para minorar o sofrimento das pessoas. Também vimos que a classe médica não detinha sobre esses recursos um monopólio, sendo os próprios doentes que definiam o modo e a quantidade de fármaco que seria tomado para aplacar seus sofrimentos físicos e, também, emocionais. A opiofobia atual não se aplica à primeira metade do século $\mathrm{XX}$, fato que pode ser comprovado a partir da análise da fonte abaixo. 
Usando a experiência adquirida em anos de atuação na Policlínica de Crianças da Santa Casa de Misericórdia, no Rio de Janeiro, o pediatra A. A. Santos Moreira escreveu o livro Formulario de Therapeutica Infantil que se tornou rapidamente um sucesso editorial. O autor percebia que, por se tratar de crianças, muitos terapeutas davam doses diminutas receosos de provocarem intoxicações. Muitos remédios, ao apresentarem sua posologia, dividiam as doses por idade, fato que ignora a orientação mais salutar de considerar o peso e outras variáveis. Isso o motivou a escrever esse formulário. Para sua surpresa, a primeira edição se esgotou em apenas um mês. A segunda tiragem duplicada durou apenas um ano. Esse fato é comemorado pelos editores do livro, em declaração feita antes do Prefácio, onde anunciam a expectativa da repetição desse grande sucesso nas próximas edições. O autor do livro, por sua vez, no Prefácio da segunda edição, aponta esse sucesso editorial como "a melhor demonstração do franco acolhimento que [a obra] encontrou em o meio médico desta Capital e dos Estados" (MOREIRA, 1920, p.17).

No verbete "ópio" ele descreve as características físicas desse produto, apontando que sua principal qualidade é inibir a excitabilidade do sistema nervoso. Como hipnótico, ele poderia ser usado para combater a insônia alimentada pelo sofrimento físico, e na qualidade de analgésico suplanta a dor em suas inúmeras formas. Como se caracteriza como "eupneico, é prescrito contra a asma e o enfisema, modera as secreções e, por preencher essa indicação, costuma receita-lo nas bronquites e enterites" (MOREIRA, 1920, p.66) abrandando também a tosse. Apesar de todas essas utilizações é preciso ter cuidado.

\footnotetext{
“As crianças são sobremaneira sensíveis á ação dos opiáceos. Sem lhes querermos sonegar os bons efeitos, quando empregados com moderação, nem os divorciar da terapêutica infantil, manda a prudência, entretanto, que os arrolemos entre os medicamentos traiçoeiros, dos quais muito se deve temer, si bem que deles muito também possa esperar" (MOREIRA, 1920, p.66).
}

Depois de descrever brevemente as características físicas da codeína, morfina, heroína, dionina, pó de Douver e o xarope diacódio, apresenta a fórmula do elixir paregórico que o autor considera "uma das melhores preparações de ópio e de manejo cômodo" (MOREIRA, 1920, p.67).

Elixir Paregórico

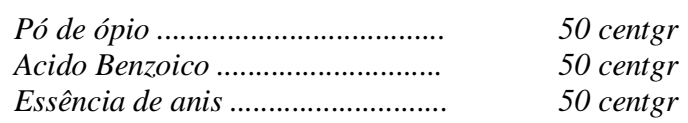




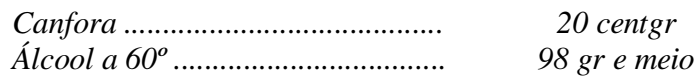

O autor também passa a fórmula do láudano de Sydenham, que deve ser dissolvida na água e no álcool. "Em oculista é empregado em colírio contra certas conjuntivites crônicas. Internamente prefira o precedente" (MOREIRA, 1920, p.67).

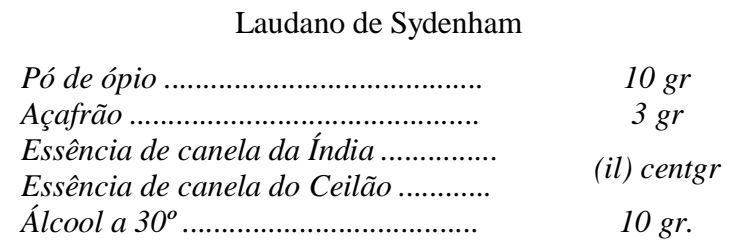

O Elixir Paregórico, a dionina, a morfina, a heroína e o "xarope diacódio", bem manejados, satisfazem quase todas as indicações da terapêutica infantil. A fórmula que segue deveria ser dada de duas em duas horas em colher de chá, somente para crianças acima de três anos (MOREIRA, 1920, p.190-192).

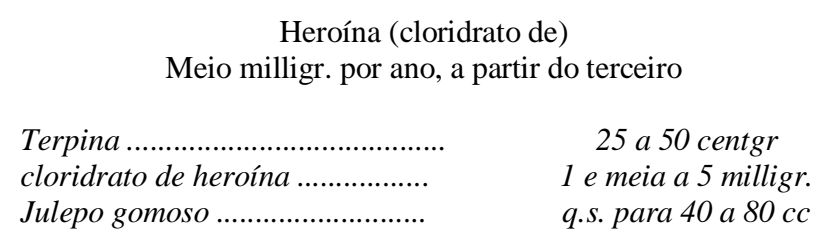

Essas demonstrações do uso de ópio e seus derivados na literatura médica, entre o século XIX e a primeira metade do século XX, denotam que ele tinha um lugar privilegiado como analgésico e como paliativo às afecções do sistema respiratório. A recomendação de heroína em baixas doses até mesmo para as crianças denota de maneira emblemática a ausência da opiofobia tão característica da segunda metade do século XX. Com o avançar dos anos se percebe uma alteração nas preocupações a respeito do emprego dos opiáceos: a posologia adequada e os meios de lidar com intoxicações gradativamente vão se transformando em uma fobia à formação do hábito. Durante o período analisado nesse capítulo, entretanto, a habituação não era uma prática moralmente condenada - geralmente ela era uma escolha individual que decorria de um estado de enfermidade. Nessa época cabia a pessoa enferma a opção pela habituação, muitas vezes apoiado pelos clínicos que não se eximiam de utilizar os antálgicos existentes para minorar os sofrimentos: a autonomia sobre os estados da dor era um valor mais importante do que a "defesa social" contra o avanço da toxicomania. 


\subsection{A cirurgia e as anestesias gerais}

As substâncias como o ópio e seus derivados eram eficazes analgésicos que foram usadas também como meio de abrandar a dor nas operações cirúrgicas. Grandes quantidades de aguardente e ópio eram comumente consumidas nesses eventos, porém não eram capazes de acalmar completamente o corpo. As reações físicas involuntárias geradas pelos procedimentos cirúrgicos, mesmo em casos de extrema embriaguez, dificultavam a intervenção precisa. Por causa dessa limitação a cirurgia passou largo período sendo considerada uma situação limite, um martírio permitido voluntariamente frente ao desespero da morte.

Durante vasto período da história ocidental cristã, a proximidade com o corpo doente e suas feridas que supuram levaram a cirurgia a ocupar uma posição de inferioridade frente aos outros quadros da medicina oficial (físicos e boticários). Vimos, no segundo Capítulo, que os estudos anatômicos começaram a mudar esse quadro, levando a ruptura que permitiu que o corpo fosse entendido como algo reificado, ausente de valor (BRETON, 2013b, p.93-96). Em Portugal e nas suas colônias a influência da anatomia foi mais restrita, pois a Igreja mantinha grande influência política. O Brasil foi um lugar marcado pela escassez de quadros médicos formados nos parâmetros oficiais, fato que criava espaço de atuação para quadros menos prestigiados - como eram os cirurgiões. Eles exerceram um importante papel na produção e na troca de informações sobre a adaptação dos europeus nos novos territórios - levando ao questionamento dos preceitos escolásticos tradicionais e renovando, assim, os padrões científicos vigentes na época colonial.

Até meados do século XIX, a cirurgia se manteve basicamente a mesma dos tempos coloniais, ou seja, praticava amputações, ressecções, desarticulações, redução de fraturas e luxações, ligadura de artérias, sutura de órgãos internos eventualmente rompidos, lancetamento de abcessos e tumores, avivamento de fístulas e cauterização de feridas. A amputação ainda era um dos atos cirúrgicos mais importantes e praticados. Vários cirurgiões brasileiros conquistaram renome "graças à maestria, habilidade e presteza em uma amputação" (SANTOS FILHO, 1991b, p.345). A popularidade desse tipo de aplicação sugere que "elas eram praticadas na prevenção da gangrena, da supuração e nos casos de fraturas de difícil consolidação" (SANTOS FILHO, 1991b, p. 346). Algumas cirurgias um pouco mais complexas, como trepanação, correção de hérnias, ligadura de artérias - para corrigir os aneurismas comuns no passado por causa 
da sífilis - e até uma polêmica ligadura da aorta abdominal foram realizadas no Brasil da primeira metade do século XIX (SANTOS FILHO, 1991b, p.345-349).

Esse quadro iria se alterar profundamente, e gradativamente, a partir da década de 1840. Primeiramente com a descoberta do efeito anestésico do éter e, depois, do clorofórmio. Em 1846, a anestesia por éter foi efetuada com sucesso nos EUA e rapidamente se alastrou pela Europa. No Brasil, já em 1847 era realizada a primeira anestesia com éter no Hospital Militar do Rio de Janeiro. Repetido semanas depois na presença de médicos ilustres da corte, rapidamente o procedimento se disseminou. Ainda em 1847 já existe relato de uma amputação sem dor realizada na província do Ceará. Nesse mesmo ano, foram descobertas as qualidades anestésicas do clorofórmio por James Yong Simpson na Universidade de Edinburgh. Rapidamente se instaurou uma controvérsia entre defensores do éter e do clorofórmio, sendo que o segundo gradativamente se impôs na preferência da classe médica brasileira (ADIALA, 2011, p.37-38; SANTOS FILHO, 1991b, 339-340).

Santos Filho (1991b, p.340) alerta que não devemos inferir desses episódios que a anestesia geral tenha se tornado de uso rotineiro. Os profissionais tinham medo de acidentes e só empregavam esses recursos em grandes intervenções. O poeta Castro Alves, por exemplo, por estar em estado de enfraquecimento, teve o pé esquerdo amputado sem qualquer anestesia em 1884, apenas atordoado com pequenas doses de beladona. No interior, a maioria dos doentes era operada a frio, ou seja, sem anestesia até o final do século XIX.

No interior das instituições oficiais os anestésicos geraram um vivo interesse, com publicações de Teses, artigos, traduções e relatos clínicos. ${ }^{51}$ Pouco antes dos primeiros relatos de utilização de cocaína para fins anestésicos, em meados da década de 1880, eram defendidas na FMRJ duas Teses com idêntico nome - Anesthesicos. Elas são um retrato das técnicas de anestesia geral que perdurariam por largo período, que só passariam a ser contestadas em dois momentos: no início da década de 1910 e, bem posteriormente, depois da década de 1950 quando se organiza de fato a classe dos anestesiologistas. Por outro lado, elas também relatam uma série de tecnologias que estava prestes a desaparecer com a ascensão da anestesia local como critério de modernidade e de excelência cirúrgica. Por esses motivos, se analisará com bastante atenção o conteúdo dessas Teses.

\footnotetext{
${ }^{51}$ Uma listagem dessas obras pode ser encontrada em Santos Filho (1991b, p.341-342).
} 
Conforme vimos acima, o advento da anestesia foi acompanhado de uma polêmica envolvendo a escolha de qual seria o melhor anestésico, éter ou o clorofórmio. No início da década de 1880, o clorofórmio era "de todos os agentes anestésicos o que apresenta maior grau de energia e que é quase exclusivamente empregado na clínica" (SANTOS, 1882, p.21). Vampré, por sua vez, vai ainda mais longe ao afirmar que no "Brasil, me parece, que não há um cirurgião que hesite empregar o clorofórmio. No Hospital de Misericórdia da Corte, onde há quatro anos frequentamos as clinicas, ainda não vimos uma só vez se preferir o éter ao clorofórmio" (VAMPRÉ, 1881, p.23). Se a disputa entre esses dois anestésicos parece definitivamente decidida em favor do clorofórmio, é preciso também destacar que outras substâncias passaram a ser divulgadas como anestésicas - acetona, brometo de etila, Licor dos Holandeses (biclorureto de etileno), éter clorídrico, éter metílico, éter metileno, biclorureto de metileno, aldeida (sic), cloral e gás hilariante (SANTOS, 1882, p.12-20).

Apesar da variedade de derivados do éter e de outras substâncias, apenas quatro tipos de anestesia parecem ter sido usados até início da década de 1880. As realizadas com éter foram as primeiras, porém rapidamente rejeitadas em favor do clorofórmio. Podem ter sido dois os motivos que levaram a essa preferência: o éter causa irritação sobre a mucosa respiratória; o clorofórmio pode ser aplicado com um lenço, dispensando custosos equipamentos. Anestesia com clorofórmio, segundo tipo, era a mais comum.

O terceiro tipo não se trata de uma anestesia propriamente dita, mas do entorpecimento com cloral. Segundo Sneader (2005, p.363-364) essa substância foi isolada em 1832, porém permaneceu desconhecida até a descoberta de seus efeitos hipnóticos em fins da década de 1860, quando se passou a utilizá-la antes das cirurgias para acalmar a pessoa que passaria pela intervenção e como meio de facilitar a ação do clorofórmio. Em pouco tempo, o cloral se tornou o primeiro hipnótico seguro vendido no mercado, a despeito do seu gosto ruim e de provocar irritação gástrica. Na Inglaterra alcançou preços populares na virada do século XIX para o XX. No Brasil, o professor da cadeira de clínica Torres-Homem recomendava sua utilização para minimizar os efeitos do delirium tremens. Ele também podia ser usado nas dores violentas, porém uma polêmica se instaurou sobre a segurança de seu uso nas pessoas cardíacas (VAMPRÉ, 1881, p.14). Tratava de uma substância que 


\begin{abstract}
"tem ação calmante e sedativa muito pronunciada; que possui como o clorofórmio propriedades sedativas, como o ópio propriedades hipnóticas, e que administrado pela via gástrica é o mais poderoso dos anestésicos" (VAMPRE, 1881, p.14)
\end{abstract}

Santos (1882, p.18), além de apontar suas qualidades anestésicas, afirma que o cloral é utilizado por alguns parteiros "com feliz êxito na obstétrica" (SANTOS, 1882, p.18).

O quarto tipo de anestesia foi denominada de "Mista" por Vampré (1881, p.1719). Essa técnica, apresentada por Claude Bernard, em 1864, consistia na aplicação de uma injeção de morfina no anestesiado de forma a ser necessárias apenas pequenas doses de clorofórmio. Quando estudante, em procedimento realizado pelo Dr. Saboia, ele viu "com admiração que a narcose se prolongava durante horas, e que com muita rapidez tudo se dissipava, ficando o doente em completo repouso, o que não sucede com o emprego exclusivo do clorofórmio" (VAMPRE, 1881, p.18). Por causa do rebaixamento da temperatura corporal, essa técnica não seria indicada nas feridas por armas de fogo, na algidez e no abalo nervoso. Outras misturas, como éter e clorofórmio, foram consideradas ineficazes. Segundo Santos Filhos (1991b, p.340), a Tese do Dr. Saboia apresentada em 1859 e denominada de Anesthesia Cirurgica defendia a aplicação de uma injeção hipodérmica de morfina, na dose de 25 miligramas, para prevenir acidentes com clorofórmio.

A anestesia poderia ser recomendada em praticamente todos os casos. Ela deveria ser usada "sempre que houver dor intensa, insuperável, e que a moléstia abandonada a si mesma constituir perigo real, será indicada a anestesia" (VAMPRÉ, 1881, p.25). Para Santos (1882, p.33) o clorofórmio bem administrado não gerava o menor acidente, "quer nas operações simples, como a incisão do tendão de Aquiles (tenotomia), quer para fazer um curativo doloroso, como o de uma ressecção das articulações do cotovelo". Somente para os "espíritos tímidos e atrasados a anestesia só deve ser reservada para as operações longas". Percebe-se, nessa fala, que o principal obstáculo à popularização desse método seria o medo dos acidentes, que deixava "de parte as pequenas operações, como extirpação de pequenos tumores, dilatação de um abcesso; etc.” (VAMPRÉ, 1881, p.26). Porém até mesmo nessas operações seria possível fazer anestesia, desde que o médico tivesse conhecimento sobre a condição do paciente, se o anestésico fosse de boa procedência e bem aplicado (VAMPRÉ, 1881, p.25-29). Mesmo sem obter uma anestesia completa, era possível usá-la até nos “indivíduos que se entregam ao abuso do álcool” (SANTOS, 1882, p.25), porém, nesses 
casos, seria "necessário muito tempo, muita paciência e muito clorofórmio" (SANTOS, 1882, p.25). Vampré (1881, p.21) recomenda, ainda, que no momento de despertar é necessário "si está fraco e abatido, dá-se lhe uma a duas onças de vinho generoso, ou qualquer poção excitante".

É possível perceber, também em relação ao estudo dos anestésicos, a influência da estatística médica que Edler (2010, p.745-747) verificou nos estudos de geografia médica. Igualmente, a frágil epistemologia sensualista colocava tais dados em suspeita, conforme já verificavam os contemporâneos. Ao apresentar as estatísticas de mortes provocadas por clorofórmio, Santos (1882, p.27-28) aponta a necessidade de examinar os fatos em que se produziu "um resultado infeliz", pois "esse agente nem sempre é o elemento principal dos acidentes". É preciso que o anestésico esteja "nas mãos de homens hábeis e conscienciosos" (SANTOS, 1882, p.31), pois "empregados a esmo, sem critério e discernimento, os anestésicos têm produzido acidentes fatais e repetidos" (SANTOS, 1882, p.31). É possível perceber nesse ponto um discurso bastante recorrente entre os médicos oficiais a respeito da inabilidade de outros curadores em utilizar esses recursos farmacológicos. Sobre isso, é necessário abrir um parêntese.

Vimos, nas sessões precedentes, que a historiografia subestimou os reais efeitos farmacológicos e antálgicos presentes na dieta farmacológica da população com objetivo de enfatizar a dualidade popular/erudito. Abordagem essa entendida como necessária para se contrapor a perspectiva demasiadamente estruturalista dos estudos sobre a medicalização da sociedade. Buscou-se, ao longo dessa Tese, construir uma perspectiva mais dialética entre esses dois campos, enfatizando as apropriações dos antálgicos através do consumo de remédios secretos e da cultura da formulação de medicamentos, amplamente difundidas nos manuais de medicina prática. Acredita-se que essa abordagem também deva ser adotada agora na análise dos anestésicos.

A posição da historiografia tem sido de negar o uso ou enfatizar a inépcia dos cirurgiões brasileiros. Santos Filho (1991b, p.340), conforme se mostrou acima, alertou que não se deve inferir da literatura médica que "a anestesia geral tornou-se logo de uso rotineiro no país". Leitura que corrobora a representação médica de que somente o profissional habilitado nas instituições oficiais tem capacidade de anestesiar sem perigo. Adiala (2011, p.72-73) também reitera essa leitura, apontando que na Guerra do Paraguai (1864-1870) “a morfina e a anestesia não teriam feito parte do arsenal terapêutico dos médicos brasileiros que estiveram no campo de batalha". 
"O serviço de saúde do Exército brasileiro [...] foi 'escandalosamente deficiente'; a falta de assepsia fazia com que raramente escapasse da morte quem tivesse que amputar um braço ou uma perna [...]. Também havia a impossibilidade de aplicar clorofórmio - o anestésico mais usado - de forma precisa, improvisando-se esponjas e chumaços de algodão para aplicá-lo, o que resultava em excesso ou insuficiência de anestesia, crise de vômito do paciente durante a cirurgia e, muitas vezes, a morte" (DORATIOTO, 2002, p.223 apud ADIALA, 2011, p.73).

Nesse cenário, a rapidez permaneceria como a marca do bom cirurgião.

Esse tipo de interpretação, além de corroborar com a representação médica oficial, ignora que em outros conflitos de grandes proporções contemporâneos, como a Guerra Civil estadunidense (1861-1865) e a Guerra Franco-prussiana (1870), as condições da assistência médica não eram muito diferentes daquela descrita acima. Também é preciso destacar que a assepsia em cirurgia não era conhecida nesse período, então as mortes por infecções e outras complicações congêneres eram esperadas. Mais de 10 anos já tinham sido percorridos desde o fim do conflito com os paraguaios e Santos (1882, p.33), apresentando estatísticas médicas produzidas em Londres, discutia se "a infecção purulenta e a febre cirúrgica tornaram-se mais frequentes do que antes da administração do clorofórmio". Até a popularização da assepsia, a superação da febre e das infecções era parte integrante do processo de recuperação daquelas pessoas que se submetiam ao procedimento cirúrgico.

A crítica ao uso e emprego de anestésicos por pessoas não treinadas dentro dos quadros oficiais antecede a guerra do Paraguai. É em Campinas, uma das mais importantes cidades do interior paulista, polo dinâmico de produção de café para exportação e, por isso, com enorme presença escrava, que encontramos a queixa do Dr. Langaard. Em 1858, quando a cidade era castigada pela varíola, ele afirmava que o governo não tem nenhuma consideração pela classe médica, pois protege

\footnotetext{
“os curandeiros e charlatões, esse cancro da sociedade brasileira, [...], esses aventureiros que especulam com a saúde e a vida da humanidade, são eles aqui nomeados e empregados cirurgiões mores da guarda nacional, exercendo desse modo impunemente a sua industriosa profissão, cloroformizando até morrer, fazendo operações sem nenhum conhecimento de anatomia ou do perigo que expõe os doentes, dando doses exageradas de veneno e vê-se desse modo sancionado o assassínio, contando que esses crimes sejam
} 
praticados por indivíduos que se intitulam médicos" (LANGAARD, 1858 apud XAVIER, 2003, p.337).

Esses práticos "sem noção de anatomia" eram contratados pelo governo sancionados pela sua experiência. Vimos no segundo Capítulo que os manuais de medicina prática, apesar de ressaltarem a importância dos médicos oficiais, também ensinavam a realizar as mais diversas operações, incluindo a amputação que era considerada um dos mais difíceis procedimentos. A anestesia, igualmente, era divulgada. No manual de 1890, Chernoviz aponta que de

\footnotetext{
"alguns anos a esta parte recorre-se a elas quotidianamente para anular a dor nas operações cirúrgicas. A anestesia é uma das descobertas mais úteis e brilhantes da medicina moderna. [...] O clorofórmio, o éter e a cocaína são empregados com preferência. Respirados por alguns instantes produzem uma espécie de sono e a abolição geral da sensibilidade" (CHERNOVIZ, 1890, p.164 apud SARTI, 2015, p.39).
}

É difícil avaliarmos até que ponto essas substâncias passaram a fazer parte da botica caseira. É possível, entretanto, especular com algumas fontes. No dia dois de janeiro de 1931, na residência do capitão Ubaldo Godinho, localizada na cidade de Porto Alegre (RS), reuniam-se amigos para comemorar o aniversário do dono de casa. Foi quando Euclides Martins Alvez, alcoolizado, passou a cometer despautérios. Tal "ponto atingiu seu mau procedimento que sua esposa foi acometida por uma crise nervosa e, sem consideração nenhuma para com ela e para com o dono da casa, Euclides brutalmente a levou para sua casa" (AHRGS, 1931, p.01). Logo depois desse ocorrido, Euclides volta a casa do aniversariante "em busca de um vidro de éter, pois que o estado nervoso de sua esposa persistia" (AHRGS, 1931, p.01). Prontamente foi atendido pelo dono da casa, porém ele acabou se desentendendo com outro convidado. Nesse entrevero, Euclides sacou uma arma e atirou naquele que o admoestava, sendo preso em flagrante.

Esse episódio trágico traz evidências que o éter era uma substância presente na botica caseira, sendo elemento de troca entre vizinhos. Fato que vem corroborar a hipótese de que tais substâncias não eram restritas a prática médica oficial, mas presentes nos lares e usadas sempre que houvesse necessidade. Chernoviz, 40 anos antes, já destacava que a anestesia vinha sendo usada cotidianamente sempre que é necessário abrandar a dor. É provável que, entre 1880 e 1930, com o maior poder 
aquisitivo e o menor preço dos produtos, essas substâncias cada vez mais tenham se feito presente no cotidiano dos brasileiros.

Feito esse longo parêntese sobre os usos de anestésicos fora do campo médico oficial, voltamos a um último ponto presente nas Teses sobre anestésicos gerais defendidas no começo dos anos de 1880: a anestesia obstétrica. Nesse campo, a técnica inventada por James Yong Simpson, o mesmo que pioneiramente utilizou clorofórmio, permanecia como referência - consistia na aplicação esparsa para gerar entorpecimento, porém sem perda total da consciência. Sobre isso, Santos (1882, p.47) afirma que "todos os parteiros são unanimes em declarar que o emprego do clorofórmio jamais tem exercido a menor influencia funesta sobre a saúde da mãe, a anestesia na obstetrícia é hoje uma realidade científica". Ele também aponta que o cloral, administrado "convenientemente é inofensivo a mãe e a criança e não cessa as contrações uterinas" (SANTOS, 1882, p.50). Vampré (1881, p.44), aponta que não existem acidentes registrados com essa técnica, por isso a anestesia deveria ser usada em todas as situações desfavoráveis, como "câimbras musculares, dores no plexo sacro, vômitos, cólicas, falsas contrações, dores vivíssimas e intermitentes, quando a retração do colo não for vencida pela beladona, a anestesia é sempre bem indicada". É possível perceber aqui mais uma referência à beladona, uma atropina com alto poder alucinógeno.

Esse estado da arte anestésica, descrito a partir dessas Teses, permaneceu o mesmo até fins do século XIX. Em 1899, o BSMCSP retomava as polêmicas entre o clorofórmio e o éter. Segundo essa publicação, desde "tempos imemoriais este assunto revestiu-se de geral interesse, despertando atenção de todos os práticos" (BSMCSP, 1899, p.18). Nessa disputa o "menor perigo na administração do éter contrapunha-se o espirito de novidade e maior facilidade no manejo do clorofórmio" (BSMCSP, 1899, p.18). Percebe-se uma vitória franca do clorofórmio, pois "entre nós onde tem sido quase único empregado" (BSMCSP, 1899, p.18). Recentemente, entretanto, "nosso colega contemporâneo e distinto cirurgião Daniel de Almeida" (BSMCSP, 1899, p.18) defendeu a Tese Do valor do ether como anestésico em cirurgia, porém ela foi "acolhida friamente e a discussão limitou-se á alocução no ato da proposta" (BSMCSP, 1899, p.18). O artigo segue descrevendo como funciona uma anestesia por éter, com elogios ao aparelho aplicador Julliard e Wanscher, além de uma lista de autoridades estrangeiras que preferem o éter ao clorofórmio.

Esse reinado do clorofórmio somente começa a ser questionado na década de 1910, conforme se ampliava o conhecimento sobre os efeitos fisiológicos gerados pelo 
seu uso. Nesse mesmo ano, a Doutora Maria Rennotte apresentou uma comunicação à Sociedade de Medicina e Cirurgia de São Paulo para sua admissão como sócia-titular. Essa exposição foi resultado das observações realizadas pela autora com a anestesia combinada de "bichlorureto de methyla (sic)" (RENNOTTE, 1910, p.27) e clorofórmio levemente quente. A autora expõe o êxito alcançado na prevenção dos vômitos com a aplicação de oxigênio, fato que a levou a aplicá-lo no tratamento do "vômito incoercível da prenhes" (RENNOTTE, 1910, p.31). Essa substância que acompanha o clorofórmio, na técnica descrita pela Doutora Rennotte, foi denominada anteriormente de "bichlorureto de methyleno" por Santos (1882, p.15), porém ele desaconselhava seu uso porque ela provocava muitos vômitos e também podia gerar anestesia mais rápida, fato que poderia contribuir para acidentes.

Mas, se nesse artigo, destacado acima, a Dra ${ }^{a}$ Rennotte apenas se reserva a apontar que os desastres nas operações com clorofórmio "não são raros" (RENNOTTE, 1910, p.28), outros dois textos publicados pela ASMCSP são bem mais críticos. O primeiro deles, de 1912, afirma que descobriram muitas mortes atribuídas à intervenção cirúrgica serem, na verdade, causadas pelo clorofórmio. "Os cirurgiões modernos, por isso, procuram cada vez mais empregar, em vez do clorofórmio, o protoxido de azoto, o protoxide de azoto com oxigênio e éter" (ASMCSP, 1912, p.214). Como esses métodos exigem aparelhos "dos quais nem todos podem dispor" (ASMCSP, 1912, p.214), a revista se propõe a ensinar um método de administração do éter com um aparelho simples, inventado por um cirurgião estadunidense. As modificações que o éter provoca no sangue, tão anunciadas pelos partidários do clorofórmio, podem ser revertidas com "um pronto suprimento de lipoides, o que praticamente se consegue por meio de um clister de óleo de azeitonas" (ASMCSP, 1912, p.215). Um ano depois, o tema novamente aparece nas páginas da ASMCSP. Dessa vez, ela apresenta a similaridade das ideias do Dr. Descarpentier, eminente cirurgião francês, com o método já apresentado do cirurgião estadunidense. O entendimento sobre a necessidade de substituir o clorofórmio por éter foi se difundindo entre os "sem ideias preconcebidas, [que] levam em conta os ensinamentos da clínica, da fisiologia e da estatística, os quais todos mostram a superioridade do éter como anestésico geral" (ASMCSP, 1913, p.215216). Diferentemente do século XIX, quando vários efeitos ruins do éter eram registrados, hoje a anestesia por esse fármaco seria realizada sem perigo porque foi possível depurar o gás carbono que era o responsável pelas intoxicações. Com o correto aparelho, seria possível manter a temperatura elevada e constante por meio de agua 
quente a 32 graus. O paciente dorme tranquilamente, profundamente e sem episódios ruins, situação bem diferente "da eterização a antiga, que Nelaton descrevia como repugnante, fastidiosa e aterradora" (ASMCSP, 1913, p.216).

Percebe-se, portanto, que o clorofórmio começa a enfrentar oposições que revivem a velha polêmica sobre qual é o anestésico mais adequado. É na anestesia obstétrica onde as objeções serão mais fortes. Em 1912, a ASMCSP divulgava estudo de um jornal estadunidense apontando que, embora o colapso cardíaco e respiratório seja raramente observado em mulheres cloroformizadas, observações anatomopatológicas têm mostrado forte "degeneração gordurosa" (ASMCSP, 1912, p.122) do fígado. Embora isso não seja verificado em todas as parturientes, essa informação se constituiu em obstáculo a esse tipo de anestesia porque não é possível verificar previamente quando existe predisposição a essas sequelas hepáticas. Também já ficou demonstrado que os fetos também são afetados pelo clorofórmio, fato que pode gerar a sua morte.

\footnotetext{
"Sem duvida nenhuma, estas observações e experiências mostram que é errônea a antiga crença na inocuidade da cloroformização durante o parto e que, ao contrario, o clorofórmio, em obstetrícia, é um mal e um perigo, para a mãe e para o filho" (ASMCSP, 1912, p.123).
}

É dentro desse contexto de crise dos velhos métodos anestésicos que Oswaldo Ayres Loureiro defendeu o uso da injeção intravenosa de Pantopon como método mais indicado para anestesia obstétrica, conforme vimos acima. Esse autor também não poupa crítica às outras substâncias. O "cloral também tem sido administrado em clisteres com o fim de atenuar as dores, porem sua absorção é muito lenta e pouco atenuando a sensibilidade da parturiente, quando esta é bastante exagerada" (LOUREIRO, 1913, p.05). A injeção de morfina, por sua vez, "agem de uma maneira mais rápida, tendo porem uma ação paralisante sobre o útero gravido, atrasando a contração uterina, tornando-a mais curta, enfim interrompendo-a completamente" (LOUREIRO, 1913, p.05). Mas é sobre o clorofórmio e a atitude das mulheres perante a dor que merecem mais atenção e maiores críticas por parte desse médico obstetra.

"Muitas mulheres indóceis não querendo suportar dor alguma, reclamam desde o começo a aplicação da anestesia pelo clorofórmio como se esta pudesse ser aplicada desde o principio até o fim do trabalho de parto, como se não houvesse inconvenientes em uma anestesia prolongada e completa, 
como se o parteiro não tivesse obrigação de esperar que a dilatação do colo uterino complete afim de que a intervenção manual pelo fórceps seja posta em pratica quando preciso for, ou se qualquer dificuldade no prosseguimento do parto por uma anomalia dos diâmetros da bacia ou por um desenvolvimento maior da cabeça do feto ou ainda por uma apresentação irregular" (LOUREIRO, 1913, p.11-12).

Assim, convém ao obstetra, mesmo "sem necessidade de intervenção instrumental, quando a parturiente não é dócil" (LOUREIRO, 1913, p.12) ou quando ela tiver "um temperamento nervoso" (LOUREIRO, 1913, p.12), aplicar um pouco de clorofórmio "de modo que a dor forte e prolongada produzida pela passagem da cabeça do feto [...] e a saída se faça com regularidade e sem sofrimento" (LOUREIRO, 1913, p.12). O clorofórmio e o éter deveriam ser evitados porque criam perigo de morte, aumentam a duração do trabalho de parto ao retardar e diminuir a intensidade da contractilidade e enfraquecer a retratilidade uterina, além de provocar hemorragias. Eles ainda são contra indicados em mães com doenças pulmonares, como a tuberculose (LOUREIRO, 1913, p.13-14). Outro ponto que gerava controvérsia, e onde é clara a presença do neohipocratismo, se refere aos procedimentos que devem ser adotados nos casos de eclampsia.

"tratamento da eclampsia não consiste somente na anestesia, pois que sem tirar do organismo as toxinas produtoras da intoxicação, por meio de sangrias, purgativos, grandes clisteres e lavagens do tubo digestivo, ela só por si não permite vencer as dificuldades do momento fazendo desaparecer o mal" (LOUREIRO, 1913, p.18).

Com base em tudo que foi exposto, é possível aferir que representação médica oficial que creditava inocuidade às anestesias, desde que administrada por profissionais devidamente treinados e diplomados, foi substituída por outra. No começo dos anos de 1910 as consequências fisiológicas do clorofórmio já eram mais conhecidas, fato que deu novo fôlego a antiga polêmica com o éter. Novas técnicas anestésicas, como o emprego de oxigênio para conter os vômitos (incorporado pela $\operatorname{Dr}^{\mathrm{a}}$. Rennotte) ou a mistura de substâncias, foram incorporadas a prática cirúrgica como meio de contornar as intoxicações.

No ano de 1930, apesar do arsenal farmacológico pouco ter mudado em relação às Teses da década de 1880, mostram que as técnicas anestésicas eram mais sofisticadas 
e ecléticas. Isso pode ser verificado a partir da análise do Manual de Cirurgia do professor Augusto Paulino Soares de Souza. Tendo como público alvo os estudantes de medicina, seu objetivo era orientar "o novo cirurgião inexperiente na resolução [...] das situações cirúrgicas comumente encontradas" (PAULINO, 1930, p.01) através de

\footnotetext{
"uma série de conselhos práticos, que a experiência alheia ou do autor, tem demonstrado serem os melhores [...] Como diagnosticar? Como tratar? Em suma, dando solução, em cada caso, aos dois eternos e empolgantes problemas da clínica diária" (PAULINO, 1930, p.01).
}

Esse cirurgião inexperiente não deveria menosprezar a anestesia geral, pois ela pode em certas condições levar o paciente a morte. Poderiam ocorrer surpresas mesmo quando a anestesia fosse de qualidade e o anestesista experiente. Alerta que é preciso resguardar o anestesiado, pois "o doente, embriagado com o anestésico, perde o controle e diz cousas, em geral verdadeiras, porém, por vezes, comprometedoras" (PAULINO, 1930, p.15). A anestesia era constituída por várias fases que deveriam ser conferidas a partir da análise do reflexo córneo. "As modificações da íris constituem o barômetro da anestesia",52 (PAULINO, 1930, p.17). Percebemos, novamente, um tom bem diferente daquele da década de 1880, quando a anestesia geral era considerada segura desde que realizada por pessoas habilitadas.

Conforme vimos anteriormente, a anestesia por clorofórmio poderia ser aplicada utilizando-se apenas um lenço.

\footnotetext{
${ }^{52}$ Grifo no original.
} 


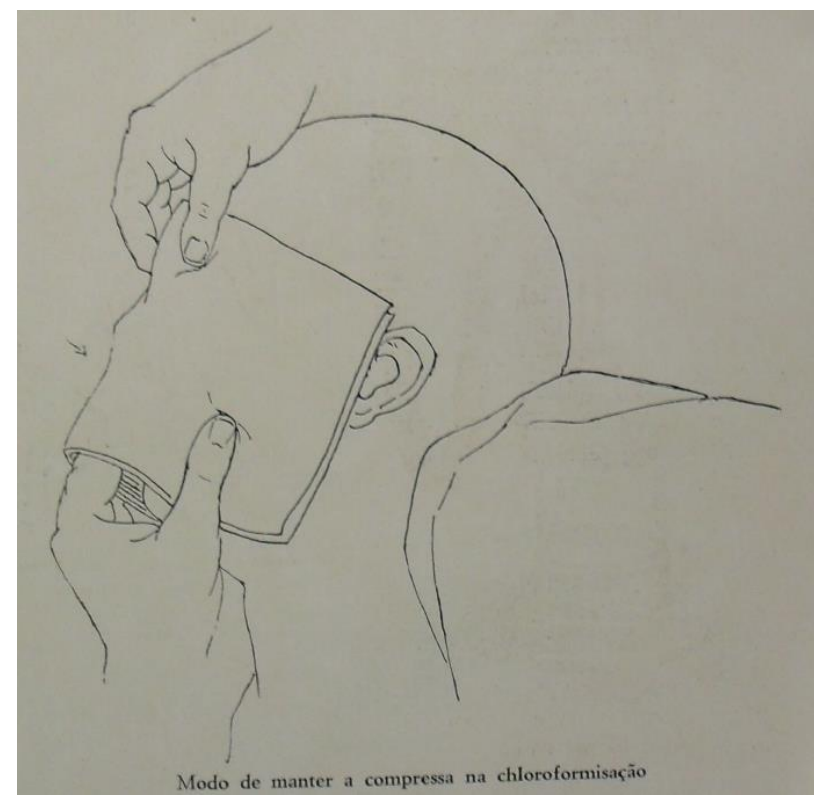

Figura 9 - Anestesia por clorofórmio com lenço FONTE: PAULINO, 1930, p.20.

A anestesia por clorofórmio seria aquela que mais se conhece, pois não existe "nenhuma droga que tenha sido mais minuciosamente estudada, nem que tenha dado maior número de discussões do que o clorofórmio" (PAULINO, 1930, p.14). Ele possui uma ação prejudicial sobre todo o organismo, tanto nos momentos que está sendo aplicado como depois. Em 1928, foram publicados estudos mostrando que o "choque operatório" é resultado da intoxicação do fígado, fato comprovado pela anatomopatologia.

Na época em que o livro Manual de Cirurgia foi publicado, no ano de 1930, as cirurgias eram mais rápidas e a anestesia menor, diminuindo assim o número de intoxicações mortais. O autor aconselha fazer a prova do fígado, pois em casos hepáticos essa anestesia deveria ser evitada. Era preciso estar sempre atento para os casos de sincope, que em geral eram a de dois tipos: branca, impossível de prever e quase sempre moral; azul, que pode ocorrer a todo o instante, e resulta no colapso do sistema respiratório. Frente a uma crise, o importante era manter a calma. Nas paradas cardíacas (sincope branca) se recomendava a injeção de adrenalina e nas respiratórias (sincope azul) a realização de manobras de Laborde (PAULINO, 1930, p.13-17). Reis Junior (2009, p.498) caracteriza a respiração artificial desse período como manobras praticamente inúteis. Paulino (1930, p.14), contrariamente, diz que assistiu casos de reanimações inacreditáveis. Por isso, o anestesista "não se deve desanimar logo, 
abandonar as manobras e aplicações necessárias nestes casos, mas, sim, persistir, com constância e sem desânimo. Têm-se visto verdadeiras ressurreições... ${ }^{53,}$

Existem alguns cirurgiões que preferiam anestesia por éter sulfúrico, argumentando que esse tipo de fármaco é menos propenso para acidentes. Paulino (1930, p.24-26) discorda, apontando que ele é igualmente perigoso. Além disso, cria irritação sobre a mucosa respiratória e maior quantidade de vômitos. A literatura estrangeira tem relatado o uso pela via retal, como meio de evitar esses problemas, porém não existe conhecimento desse tipo de aplicação no Brasil. Como se trata de uma substância volátil, sempre existe o risco de queimaduras, fato que também impede a administração por lenço. A vantagem do éter é que ele agride menos o rim.

Existiam também as misturas de clorofórmio, éter e álcool. A mistura de Bilroth, por exemplo, é composta de uma parte de álcool, uma de éter e três de clorofórmio.

\footnotetext{
"Uma mistura, modernamente empregada, é o balsofórmio, que contém 6 partes de éter, 2 de clorofórmio, 1 de Keleno (sic) e 0,6 de gomenol. Temos obtido boas anestesias com o balsofórmio e nunca observamos acidentes" (PAULINO, 1930, p.32).
}

Em meados da década de 1940, o médico e futuro anestesista Carlos Parsloe apontava ser o balsofórmio a substância mais popular para obter anestesia geral (REIS JUNIOR, 2009, p.497).

Existiam ainda as anestesias com cloreto de etila, que era um bom anestésico, porém com características perigosas ao provocar a anestesia muito rapidamente. Características parecidas com o "bichlorureto de methyla" da Dra Rennotte (1910, p.27) e o "bichlorureto de methyleno" do $\operatorname{Dr}^{\circ}$ Santos (1882, p.15) destacados anteriormente. Assim como a Dra Rennotte, Paulino (1930, p.32) aconselhava o uso mínimo prévio ao clorofórmio como meio de buscar mais rapidamente o sono. Também existiam notícias sobre o brometo de etila, porém acidentes relatados na literatura desmotivaram testes com essa substância. Paulino ainda aponta uma Tese defendida pelo Dr. Genésio Sampaio sobre esse medicamento, sendo relatado que ele não acarreta vômitos ou excitação excessiva. Por último, temos ainda o Etileno, que entrara recentemente em voga, capaz de provocar o sono por um período maior do que os demais. Ele tem sido empregado em São Paulo com um aparelho importado dos EUA pelos doutores Benedicto Montenegro e Martins Costa.

${ }^{53}$ Grifo no original. 
Ao longo de toda essa trajetória das técnicas de anestesia geral, que vai dos seus primórdios (em fins da década de 1840) até os anos de 1930, pouco mudou em relação à lista de fármacos disponível. Em grande medida ainda perduravam as disputas, e as misturas, entre o clorofórmio e o éter. É possível perceber também que, apesar dessa permanência, o conhecimento sobre os efeitos fisiológicos desses fármacos foi crescendo e com ele a maior certeza de suas consequências para o organismo. Novos equipamentos eram criados, misturas testadas e procedimentos aperfeiçoados em busca de maior segurança na aplicação dos fármacos. Sinal de que a anestesia geral gradativamente deixa de fazer parte da clínica diária é o fato de que, nem o clorofórmio, nem o éter fazem parte do formulário do Dr. Rangel publicado em 1950. Nessa época o anestesista, geralmente um assistente do cirurgião principal, passa a reivindicar status de especialidade médica que deveria ser a responsável por controlar o uso de anestésicos e de analgésicos, inclusive no interior da classe médica. Como outras especialidades, ela se organizará em associações e promoverá literatura própria através da Revista Brasileira de Anestesiologia - tema que será abordado no próximo Capítulo.

A praticidade do uso, através do lenço, deu ao clorofórmio a supremacia sobre outras substâncias na clínica geral durante todo o século XIX, porém ele foi perdendo espaço na clínica diária. Isso se deve, sem dúvidas, ao maior conhecimento sobre os perigos que seu emprego acarretava. Além disso, contribuiu para esse desuso o desenvolvimento da anestesia local - conforme veremos a partir de agora.

\subsection{A cocaína e as anestesias locais}

No começo desse Capítulo foi apresentado um excerto de Reis Junior (2008, p.301-302) onde foi apresentada uma breve história dos anestésicos locais. A anestesia com cocaína inaugurada por Koller, em 1884, teria sido o ato fundador da anestesia local. Porém, as “complicações clínicas, algumas trágicas”, acabaram levando a pesquisa com outros anestésicos, resultando no abandono da cocaína como fármaco terapêutico - principalmente depois do lançamento da procaína em 1904. Esse pequeno enredo, que é repetido à exaustão desde cedo, é exemplar da retórica triunfalista ávida em apresentar descobertas e avanços que levaram à evolução das técnicas até o momento atual. Nesse discurso nenhuma outra substância foi mais degradada do que a cocaína, provavelmente pela simbologia que ela acabou adquirindo posteriormente no tráfico ilícito. 
É objetivo, desta seção, apresentar uma problematização desse enredo da evolução técnica das técnicas anestésicas. Já foi visto, no primeiro Capítulo, que a cocaína era uma substância conhecida desde o início da década de 1860. A pesquisa nos periódicos médicos mostrou que ela despertou um interesse marginal, quase nulo, como elemento terapêutico - era usada para estimulação física e psicológica ao lado da cafeína, teobromina e outros alcaloides estimulantes. Também vimos que ela podia ser usada para fabricação de vinhos tônicos e como ingredientes de fórmulas secretas.

Para efeito de comparação, nos EUA essa situação foi diferente, pois desde a década de 1860 a coca e seus extratos foram se tornando populares ingredientes dos remédios de autor, muitos deles com fórmulas secretas (GOOTEMBERG, 2008, p.2728). Em meados dos anos de 1880, foi lançado o xarope de coca e de cola que se tornaria símbolo da cultura estadunidense no século XX: a Coca Cola. Inventada pelo farmacêutico John Pemberton (1831-1888), que era habituado à morfina por causa de ferimentos sofridos na guerra civil, ela foi inspirada na crença "dos fabricantes estadunidenses de medicamentos que proclamavam que seus produtos de coca podiam liberar as pessoas de sua adição à morfina" ${ }^{54}$ (DAVENPORT-HINES, 2002, p.152).

Essa mesma popularidade, entretanto, não era percebida na Europa. A despeito disso, na mesma década de 1880, a cocaína passou a ser defendida por alguns médicos, cujo mais famoso foi Sigmund Freud - que depois se tornaria a principal referência da psicologia. No seu livro Uber Coca, de 1885 , ele defendia que a cocaína poderia ser usada

“como estimulante geral, como remédio contra a indigestão, contra a perda e má nutrição associada a enfermidades como a anemia e a tuberculose, contra a tifo e a diabete, como tratamento para a psicose e a depressão e como uma forma de incrementar a intolerância ao mercúrio nos sifilíticos",55 (DAVENPORT-HINES, 2002, p.155)

O uso mais polêmico era, justamente, a utilização de cocaína para curar o hábito em opiáceos. Característica que teria supostamente influenciado Pemberton a elaborar produtos com a coca, como vimos acima. Vários experimentos foram realizados, com

\footnotetext{
54 "These claims rested on the belief the claims of American medicine-makers that their coca products could be used to wean people from morphine addiction" - tradução sugerida.

55 "It discussed using cocaine as a general stimulant, as a remedy for indigestion, for the wasting and malnutrition associated with such diseases as anaemia and tuberculosis, for typhoid and diabetes, as a treatment for psychosis and depression, and as a way of raising tolerance to mercury in syphilitics" tradução sugerida.
} 
esse objetivo, no médico e amigo de Freud chamado Fleischl-Marxow. DavenportHines (2002, p.154-158) considerou esses experimentos imprudentes e antiéticos, entre outros motivos pela divulgação dos resultados precipitadamente - em apenas um mês de tratamento. Conforme o uso da cocaína foi se ampliando, e se percebendo que ela também criava hábito, varias críticas foram feitas em relação a esse estudo - acusando Freud de ser um apologista da droga. Escohotado (2008, p.451-454) aponta, por sua vez, que Freud admitiu que o tratamento foi equivocado, porém evitou de demonizar a cocaína por causa de suas múltiplas qualidades. Ele também mostra, comparando a versão original de Uber Coca com as que foram traduzidas para o inglês pelo laboratório E. Merck, que esse livro foi alterado em várias partes para tornar a cocaína mais atraente comercialmente. Essa prática se constitui em um dos vários exemplos "das manipulações que se entregava a indústria farmacêutica"56 (ESCOHOTADO, 2008, p.455).

Coube a Freud também o papel de correspondente e divulgador da cocaína a Carl Koller, que, em 1884, anunciou que com poucas gotas de uma solução desse fármaco era capaz de obter anestesia do globo ocular (DAVENPORT-HINES, 2002, p.158-160). Essa descoberta foi saudada como uma verdadeira revolução para a cirurgia ocidental e em pouco tempo essa notícia varreu o mundo, motivando novas experiências também exitosas (GOOTEMBERG, 2008, p.23-24). Uma das formas de medir o impacto desses episódios no contexto brasileiro é avaliar a incidência da palavra "cocaína" nos periódicos catalogados pela Fundação Biblioteca Nacionais no projeto da Hemeroteca Digital: entre 1870 e 1879, foram localizadas 7 ocorrências em 6 jornais; entre 1880 e 1889, foram localizadas 2.045 ocorrências em 107 periódicos; entre 1890 e 1899, foram localizadas 3.807 ocorrências em 95 periódicos. Mesmo que a tecnologia OCR não seja perfeita, essa disparidade de referências, antes e depois de 1884, aponta que a receptividade dessa substância, depois de Koller, ultrapassa, e muito, o âmbito médico. Longe de esgotar o tema ${ }^{57}$, buscaremos apresentar algumas problematizações a esse respeito.

Tamanha utilidade e repercussão tornaram rapidamente a cocaína em um produto farmacêutico requisitado. Muita ênfase tem se dado na historiografia, conforme vimos acima, na divulgação de Freud e nos experimentos de Koller. Se toda essa

\footnotetext{
56 “de las manipulaciones a que se entrega la industria farmaceutica" - tradução sugerida.

${ }^{57}$ Esse universo documental sugere a necessidade de uma pesquisa de fôlego voltada exclusivamente para a compreensão dos significados dessa popularidade nos jornais de grande público e os demais.
} 
movimentação nos meios acadêmicos europeus conseguiu colocar a cocaína em evidência, pouca atenção é dada ao fato de que ela era um produto perecível, de difícil transporte e sem uma estrutura de produção capaz de suprir a imensa demanda que se criou a partir desses eventos. Antes de 1885, embora houvesse alguns produtos rentáveis, como os Vinhos Mariani, e alguns usos médicos, principalmente nos EUA, a coca e a cocaína não se constituíam em um produto de massa. O crescimento exponencial da demanda, gerado pela divulgação das suas qualidades anestésicas, levou a uma crise de produção em 1885, pois as principais produtoras alemãs encontravam problemas com a qualidade das folhas importadas (GOOTEMBERG, 2008, p.56-57).

Esse problema foi acompanhado com interesse pela imprensa brasileira, incluindo a destinada ao público em geral. Em 13 de maio de 1885, o jornal do PRR, $A$ Federação, publica uma nota sobre o assunto. Nela é apontado que desde muito tempo “os cirurgiões da Europa e da América procuram encontrar um anestésico que deixe uma certa parte do corpo insensível e evite a necessidade do clorofórmio ou do éter". Foi quando se descobriu a capacidade de anestesia de cocaína na forma de colírio. Infelizmente, seu

\footnotetext{
"enorme custo impede por agora o seu uso geral. A cocaína vale mais que o ouro, pois custa 8 dólares o gramo ou 224 dólares por onça. $\mathrm{O}$ farmacêutico que possuísse uma libra de esta substância teria 3,500 ou 7:000:000 dólares. [...] É de se esperar que se consiga reduzir o preço de este valioso anestésico, facilitando assim a popularização do seu emprego" (A Federação, 13 de maio de 1885).
}

Nesse ponto é importante destacarmos a intensa participação dos cientistas peruanos que desde antes da utilização da cocaína para fins anestésicos vinham trabalhando sobre a coca e seu alcaloide. Foi nesse caldo científico e cultural que Alfredo Bignon desenvolveu, entre 1884 e 1887, a tecnologia da cocaína crua (GOOTEMBERG, 2008, p.37-38). Esse produto semirefinado, com 50-80\% de sulfato de cocaína, permitia que ela mantivesse sua potência sem estragar - contornando, assim, o problema da deterioração da folha. Assim, entre 1885 e 1910, a cocaína exportada aumentou constantemente no Peru, se consolidando como uma commodity comercial. Ela se tornou o mais rentável produto da empresa Merck, contribuindo decisivamente na sua capitalização e, posteriormente, para a diversificação dos produtos oferecidos. Hoje ela é uma empresa global do ramo farmacêutico (GOOTEMBERG, 2008, p.57-58). As 
pesquisas históricas que pretendem fazer uma reconstituição da produção e do consumo de cocaína durante esse período esbarram na resistência dos grandes laboratórios (Merck, Bayer e outros) que "declinam hoje sistematicamente a atender qualquer solicitação de dados concretos" $" 58$ (ESCOHOTADO, 2008, p.560).

Se ponderarmos o que já foi colocado a respeito do éter e do clorofórmio e considerarmos essa receptividade que a cocaína teve na imprensa, acreditamos ser possível rejeitar a ideia de que essas substâncias eram restritas à classe médica, servindo "para diferenciar um determinado tipo de medicina em relação à prática curativa tradicional" (ADIALA, 2011, p.78). Principalmente se entendermos que as práticas de cura tradicionais estão diretamente relacionadas com o neohipocratismo e as artes de formular remédios, conforme se mostrou anteriormente. A cocaína e demais novidades farmacológicas se adaptaram as concepções terapêuticas vigentes. Por isso, se discorda da hipótese de que a incorporação de drogas

\footnotetext{
“como clorofórmio, a morfina e a cocaína na prática terapêutica dos médicos brasileiros representaram [...] a introdução de novos instrumentos conceituais de uma medicina dita moderna, apoiada na ciência experimental" (ADIALA, 2011, p.79).
}

Esse tipo de interpretação incorpora a retórica triunfalista ao apresentar as novas técnicas como avanços da medicina experimental que naturalmente são incorporados à prática oficial, sem diálogo, negociação ou resistência com a cultura médica vigente. Ignora que também os práticos e demais atores curadores possuem agência e são capazes de incorporar esses instrumentos farmacológicos dentro suas práticas terapêuticas.

Mais uma vez, podemos recorrer à Chernoviz como meio de relativizarmos a incapacidade dos leigos e dos práticos em incorporarem a cocaína na clínica ordinária. O Dicionário de Medicina Popular, de 1890, aponta que essa substância poderia ser usada em diversas finalidades, porém principalmente para insensibilizar e facilitar operações que envolvesse a boca, os olhos, o nariz ou os órgãos genitais. Era possível, por exemplo, obter a insensibilidade vaginal através da aplicação de cloridrato de cocaína com pincel ou injeção hipodérmica. Outro uso possível era na odontologia para extrair dentes. Chernoviz recomendava a insensibilização do dente através de algodão mergulhado em sua solução de cocaína, esfregado em torno da gengiva e do dente

58 “declinan hoy sistemáticamente atender cualquier solicitud de datos concretos" - tradução sugerida. 
objeto de remoção. A cocaína se tornou um diferencial de dentistas que anunciavam procedimentos sem dor nos jornais (SARTI, 2015, p.48-49).

Também podemos recorrer à descrição de um caso clínico como meio de atestar a presença, na botica caseira, de medicamentos com alta concentração de cocaína. Em 1898, o Dr. Alfredo Nascimento fez a comunicação intitulada "O cocainismo agudo" na Academia Nacional de Medicina. Ele conta a história de uma cliente que após o jantar teria se dirigido até

\footnotetext{
"um armário da sala das refeições, onde se achava um pequeno vidro de medicamento de que fazia uso; mas, descuidada, tomou por equívoco um outro frasco que imprudentemente fora também ali guardado, e encerrando um odontálgico que lhe prescrevera um dentista, constante uma solução de 0,50 gr. de cloridrato de cocaína, 5 gr. de cloral hidratado e gr. de cânfora em 15 gr. de álcool a $40^{\circ}$ (NASCIMENTO, 1898, p.99 Apud ADIALA, 2011, p.94-95).
}

O inusitado envenenamento foi tratado com éter, cafeína e canela. Ele chegou a pensar em recorrer à morfina, porém desistiu porque temeu introduzir mais um alcaloide na paciente. Adiala (2011, p.84) conclui desse episódio que a cocaína era ingrediente comum das preparações e prescrições médicas, estando por isso presente no comércio de drogas. Embora a receita fosse prescrita por um dentista, acredita-se que é possível inferir também que, pelo fato desse remédio estar juntos a outros em local acessível, a cocaína era um recurso farmacológico disponível para qualquer dor que eventualmente ocorresse na boca. Ou seja, não era um produto restrito ao consultório odontológico ou médico, tampouco só disponível mediante receita habilitada. Uma vez conhecida a fórmula, qualquer farmácia poderia fazê-lo.

Outra forma de medir o impacto do uso anestésico local da cocaína é uma comparação com as tecnologias que existiam antes, pois ao contrário do que acredita a narrativa triunfalista (REIS JR, 2008, p.300), existiam técnicas de anestesia local que antecedem as comunicações de Koller. Vampré (1881, p.46) defendia que, apesar de limitada, a anestesia local era valiosíssima em grande número de operações, como

\footnotetext{
"dilatação de abscessos superficiais, panarícios, unhas encravadas, amputação de falanges, desbravamento de flegmões, excisão de vegetações, de botões hemorroidários e muitas outras produções mórbidas" (VAMPRÉ, 1886, p.46).
} 
Por causa de sua ação limitada, deveriam ser usadas somente nas extremidades. Ela partia do princípio que os anestésicos gerais produzem o mesmo efeito topicamente, sendo preferível o clorofórmio em relação ao éter porque ele era menos volátil. Vimos, anteriormente, que o mau manejo do éter poderia provocar queimaduras. Existiam, inclusive, para vender no mercado pomadas de clorofórmio para essa finalidade. Além dos anestésicos gerais clássicos, outras substâncias também eram oferecidas com esse fim: o "éter-clorídrico-clorado" (VAMPRÉ, 1881, p.49) poderia ser aplicado nos casos de nevralgias e queimaduras; o "acido carbônico" (VAMPRÉ, 1881, p.50) teria sido empregado com sucesso nas superfícies mucosas da vagina e do útero - para o mesmo fim poderia se usar cataplasmas de cerveja; brometo de potássio era recomendado nas operações da boca, nasais e uretrais. Existiam também algumas técnicas que prescindem de fármacos, como são os casos da eletricidade (usada com êxito nos EUA) e das compressas com gelo e cloreto de sódio.

\footnotetext{
"A irrigações continuas são diariamente empregadas no Hospital da Misericórdia do Rio de Janeiro, e em um sem número de feridas, esmagamentos, fraturas cominativas, etc. etc temos presenciado os seus vantajosíssimos resultados. Quantas cefalalgias rebeldes, quantas meningites agudas têm cedido aos capacetes de gelo?” (VAMPRÉ, 1881, p.29).
}

Santos (1882, p.51-52), por sua vez, parece bem menos otimista quanto aos usos desse tipo de procedimento. Ele aponta também que os anestésicos gerais podem ser usados topicamente, funcionando como anestésico local pelo resfriamento que produzem no corpo. Relata o uso de injeções hipodérmicas com alcaloides do ópio, porém essas técnicas não tem se generalizado porque "sobre a anestesia local ainda não se disse a última palavra, não obstante ter ocorrido muitas vezes para o bom êxito de uma operação" (SANTOS, 1882, p.52). Como seu efeito é muito restrito e de curta duração, ela só é indicada às partes superficiais como "operação da úngula incarnata (sic), a abertura de abcessos, a extirpação de tumores superficiais e punções em cavidades serosas, etc" (SANTOS, 1882, p.52). Alguns exemplos de experiências realizadas na Europa e nos EUA são apresentados para apontar possíveis êxitos capazes de serem obtidos com essas aplicações tópicas. Mas, é sobre os métodos de misturas refrigerantes que o autor deposita os maiores elogios - igualmente como fez Vampré acima. Diferentemente deste, Santos aponta que o melhor meio de obter a refrigeração é 
pela aplicação do método da vaporização dos líquidos voláteis como o éter e o clorofórmio, embora as misturas pudessem incluir "canfora [...] ácido carbônico, o cloreto de etileno, o éter clorídrico clorado proposto por Mialhe e empregado algumas vezes com sucesso e finalmente certos óleos ligeiros do petróleo" (SANTOS, 1882, p.55).

Sobre o uso de líquidos voláteis na forma de gás visando à obtenção da anestesia local, a historiografia tradicional vem relatando

\footnotetext{
"que em 1866 um certo médico inglês, Richardson, inventou em Londres um 'aparelho' (vaporizador) que insensibilizava a pele e os tecidos com vapores de éter sulfúrico a eles diretamente dirigidos. Através do congelamento obtinha-se um certo abrandamento da dor" (SANTOS FILHO, 1991b, p.340).
}

Esse aparelho teria sido trazido nesse mesmo ano para o Brasil e usado pioneiramente por Joaquim Antônio Alves Ribeiro no Ceará. Sua comunicação sobre essa técnica teria animado outros médicos a adotarem o moderno procedimento, porém ela não teria se propagado porque geraria insensibilidade incompleta e os vapores incomodavam o operador e os ajudantes.

Sobre as técnicas que prescindem de fármacos, Santos (1882, p.56-58) ainda destaca outras duas: a eletricidade, usada com êxito nos EUA para a extração de dentes, e o hipnotismo. Sobre esse último, ele aponta que a hipnose foi usada com entusiasmo na França pelos professores Broca e Cloquet, porém "foi por toda a parte reconhecido senão quimérico, ao menos inútil e ineficaz na prática das operações cirúrgicas" (SANTOS, 1882, p.58). Breton (2013a, p.75) chama atenção para o fato de a hipnose agir por meio de sugestões realizadas em estado de transe. A palavra do hipnotizador seria capaz de provocar dor mesmo sem lesão, ou o contrário. Ele cita uma ablação de um seio, de uma mulher de sessenta anos, realizada por Jules Cloquet, e uma amputação feita por James Ward, ambos sem dor. Foi, entretanto, o cirurgião escocês James Braid que escreveu a mais influente obra do assunto, em 1843, traduzida para o francês em 1866.

Porém o insólito do procedimento, sua inconstância, o fato de não se aplicar a todos (a fortiori se o médico é cético), contribuem para desacreditar a hipnose apesar de seu sucesso. A partir de 1847, a anestesia por meio do éter ou do clorofórmio e, depois, a possível analgesia de uma parte limitada do 
corpo, trazem para a medicina o argumento de um procedimento racional e independente da qualidade da relação com o doente (BRETON, 2013a, p.78).

Essas técnicas que dispensam fármacos ou que utilizam anestésicos locais de maneira tópica não desapareceram por completo como sugere a historiografia triunfalista (REIS JR, 2008) e a tradicional (SANTOS FILHO, 1991b), conforme veremos logo abaixo. Porém é inegável o grande entusiasmo gerado pela cocaína nos meios médicos acadêmicos.

Em 1888, ou seja, apenas quatro anos depois da comunicação de Koller, um detalhado estudo era defendido na FMRJ por Eugênio Augusto de Oliveira Borges. A Tese Cocaina e seus usos apresenta essa substância em todos os aspectos possíveis: botânico; a cultura dos usos na América indígena (incluindo territórios brasileiros limítrofes com Peru e Bolívia); seis diferentes processos de preparação (Niemann, Lossem, Duquesnel, Squibb, Moreno y Maíz e Mariani); as propriedades químicas e físicas; os efeitos gerados em cada função e sistema do organismo; por fim, os usos terapêuticos. Abaixo, iremos focar esses últimos.

A "ação analgésica e anestésica da cocaína é largamente aproveitada na terapêutica cirúrgica" (BORGES, 1888, p.57). Sem relacionar a arte dentária, que mereceria um capítulo à parte, sobre a boca e a língua são várias as aplicações possíveis; contribuiu para combater a intolerância "faringianas, que certos indivíduos apresentam ao exame laringoscópio" (BORGES, 1888, p.57); foi usada com êxito para insensibilizar a garganta e viabilizar a retirada de uma "massa papilomatosa" (BORGES, 1888, p.58) do local; aplicada com êxito para lavagens de estômago; nos tumores do nariz e da orelha, ela permitiu a extração e cauterização sem necessidade de anestesia geral.

“Uma das mais dolorosas operações da cirurgia hodierna é sem contestação a dilatação forçada do ânus e, portanto, uma das mais terminantemente indica anestesia; entretanto os acidentes mortais ai algumas vezes observados levaram cirurgiões notáveis, como Nicaise e Courty, a rejeitar o emprego do clorofórmio. Obissier foi o pioneiro a usá-la em um caso de fenda anal, provocada por três pequenos tumores hemorroidários" (BORGES, 1888, p.60) 
No Brasil, o professor Pereira Guimarães realizou uma anestesia com cocaína em operação anal na casa de saúde Nossa Senhora da Ajuda, "colhendo dela o mais esplendido resultado" (BORGES, 1888, p.61).

No que se refere aos órgãos genitais e urinários "tem se já recorrido a cocaína desde as operações mais simples de cateterismos até as ureterostomias, litotricia, vesicoplastia" (BORGES, 1888, p.61). Nas afecções da vagina e do útero ela é indicada "toda a vez que a dor for um obstáculo ou um sintoma" (BORGES, 1888, p.61). Existem relatos no exterior de uso com sucesso para extração de cálculo vesical.

No Brasil, o Dr. Barão de Saboia conseguiu operar um doente que sofria de estreitamento crônico da uretra que causava grande dor "com uma sonda à $5 \%$ de cloridrato de cocaína" (BORGES, 1888, p.61). No Recife, o Dr Malachias "praticou uma operação de uterotomia em que intervenção da cocaína foi requerida pelo doente" (BORGES, 1888, p.62). O moço em que foi aplicada a cirurgia era irmão de um oculista que usava cocaína com grande sucesso em sua clínica. "Nas operações de hidrocele, ela é diariamente empregada no hospital de Misericórdia, com o fim de evitar os horríveis sofrimentos devidos a injeção iodada" (BORGES, 1888, p.62). Enfim, ela pode ser usada nas pequenas operações como extirpação de "quistos, praticar quase sem dor a traqueotomia e, em uma palavra, evitar a dor em todas as operações em que a incisão da pele constitui a parte mais penosa" (BORGES, 1888, p.63). Por último, ainda é recomendada para a fimose e os problemas gerados por edemas.

Em oftalmologia, já se tornava "cada vez mais assustador e repulsivo o emprego da anestesia geral" (BORGES, 1888, p.63) quando Koller anunciou as suas descobertas. Elas vieram "marcar uma nova era para este ramo das ciências medicas” (BORGES, 1888, p.63). A cocaína

\footnotetext{
"presta incontestáveis serviços nos casos em que ha inflamação nas partes superficiais do olho com fotofobia, dores espontâneas ou a pressão. Em doentes afetados de ulceras da córnea, de conjuntivite linfática com erupções, [...] aliviar notavelmente os sofrimentos dos mesmos, fazendo desaparecer o blefaroespasmo" (BORGES, 1888, p.63).
}

Ela era capaz de tornar indolores as cauterizações com nitrato de prata e sulfato de cobre; substituiu com vantagem a atropina, sendo preferível nos casos de perfuração da córnea ou prolapso da íris; também poderia ser usada em combinação com a atropina. 


\begin{abstract}
"As operações, tais como sejam: a extração dos corpos estranhos, tatuagem da córnea, paracenteses da câmara anterior, operações de pterígio, extração e discisões (sic) de cataratas, etc., fazem-se hoje graças a cocaína sem a menor dor" (BORGES, 1888, p.65).
\end{abstract}

No Brasil, o professor Hilário de Govêa foi um divulgador da substância, defendendo que ela fosse usada inclusive "nos casos de extrações de cataratas com fluidez de humor vítreo" (BORGES, 1888, p.65), procedimento não recomendado por especialistas europeus.

Outra especialidade que não ficou inativa "diante o novo anestésico de Koller" (BORGES, 1888, p.66) foi a arte dentária. As propriedades odontálgicas e dentifrícias da coca já eram conhecidas e aproveitadas nesse campo quando se divulgou seu alcaloide. Não tardou e "proclamaram-no como odontálgico maravilhoso, auferindo desse exagero especulativo grandes proveitos" (BORGES, 1888, p.66). Vimos, acima, um caso de envenenamento acidental com um remédio desse tipo. Porém, não existiria consenso sobre seus usos, pois vários dentistas apontam serem falaciosas essas qualidades.

Fizemos uma longa e cansativa descrição dos usos anestésicos, porém as qualidades medicinais da cocaína não se resumem a esse tipo de uso.

\footnotetext{
"Pouco a pouco as aplicações médicas da cocaína vão ganhando terreno e sobre elas poderíamos escrever grande número de páginas se quiséssemos citar todas as observações em que esta substância tem sido ensaiada com mais ou menos resultado" (BORGES, 1888, p.67).
}

Por isso, o autor destaca apenas algumas. Nas moléstias do tubo digestivo ela tem sido usada para tratar as estomatites em geral e as ulcerosas; nos espasmos se tem "grande probabilidade de diminui-los ou anula-los" (BORGES, 1888, p.68); útil nos casos de moléstias dolorosas do estômago e nas intolerâncias da mucosa que o reveste; pode ser usada nos vômitos de origem nervosa, histérica ou puerperal; nos casos de gastralgia, enjoo ou nos vômitos incoercíveis da gravidez. Nas moléstias das vias aéreas, pode ser usada na hipertrofia da mucosa nasal, nas corizas agudas ou crônicas e nas laringites; bons resultados têm sido apresentados no tratamento da asma.

"Finalmente para evitarmos repetições fastidiosas e dispensando uma ordem rigorosa, vamos citar aqui seguidamente alguns outros casos médicos em que se tem aplicado ou se poderá aplicar com vantagem a cocaína: nas aftas 
ulceradas e dolorosas privando as crianças de mamar; nas estomatites, nas cistites e tenesmos; nas blenorragias para combater as ereções dolorosas ou para minorar a dor das injeções cáusticas, aliás tão aproveitáveis nas mucosas inflamadas; no vaginismo; nas nevralgias em injeções hipodérmicas; nos morfinômanos, e do álcool nos alcoolistas; nas afecções dolorosas do ânus e do reto; nas hemorroidas, nas diarreias, igualmente dolorosas; nas ulceras dolorosas como poderoso calmante, etc." (BORGES, 1888, p.69)

No Brasil, o professor Gouvêa a empregou no combate do vômito negro produzido pela febre amarela com grande sucesso.

Apenas dois anos depois, em 1890, outra Tese é defendida por Francisco de Andrade Botelho. Com o título Do valor anesthesico da cocaina em cirurgia em geral, tal trabalho retoma várias das utilidades já mencionadas acima. Para não ser enfadonho e repetitivo, apenas atentaremos para os usos realizados no Brasil e descritos pelo autor. Adiala (2011, p.81), se referindo a essa obra, aponta a predileção do professor de clínica oftalmológica e otorrinolaringológica, da FMRJ, pela cocaína no serviço clínico desta instituição. Com essa substância ele pode dispensar o uso do clorofórmio em quase todas as operações, com exceção da prótese palpebral. Outro médico que passou a utilizar cocaína foi o Dr. Camargo. Ele retirou dois abcessos de uma senhora com cocaína a $2 \%$ sem nenhuma dor, fato que "muita surpresa causou não só à paciente como também às demais pessoas residentes" (BOTELHO, 1890, p.48) na casa onde fora realizada a operação. Outras duas aplicações foram feitas pelo autor da Tese. No primeiro caso, um senhor de 55 anos de idade com enorme inflamação de pus na nádega teve o foco purulento retirado sem nenhuma dor com uma aplicação de cocaína a $5 \%$. No segundo caso, foi retirado um tumor da região do cóccix de um médico de 25 anos, colega do autor. Rejeitando a aplicação de injeção em um primeiro momento, foram utilizadas compressas embebidas em solução de cocaína a 5\%, fato que insensibilizou o local e, somente assim, o doente consentiu com a aplicação da injeção. A operação foi feita sem nenhuma dor para espanto do paciente, que "viu terminada a batalha que tanto o acobardara" (BOTELHO, 1890, p.52). Existem também relatos de extração de tumor, com método semelhante, pelo Dr. Martins Ribeiro.

Nas operações da boca, tão perigosas com clorofórmio por causa do sangue que pode asfixiar ou seguir para o esôfago ou estômago, “a cocaína veio remover estes inconvenientes, aliais sérios, e facilitar muitas operações poupando grandes padecimentos aos infelizes que precisam recorrer a cirurgia para esta dar-lhes lenitivo" 
(BOTELHO, 1890, p.60). Foi utilizando de cocaína que o Dr. Pereira Guimarães extirpou "um epitelioma do lábio para o que empregou 3 injeções de cocaína a 5\%" (BOTELHO, 1890, p.61). Nas operações de ânus ela é bastante recomendada, sendo utilizada com sucesso na Europa. No Brasil, o

"Dr. Clemente Ferreira cita um caso de fissura anal em que a cocaína não apresentou resultado satisfatório; mas é isto justificável, pois Dujardin e Réclus exigem, para bom êxito da operação, que injete-se na espessura do sprinter anal a solução de cocaína e o Dr. C. Ferreira limitou-se a fazer embrocações com uma solução de 6\%" (BOTELHO, 1890, p.65).

Também já estavam sendo feitas e divulgadas operações no aparelho gênitourinário. $\mathrm{O}$ autor da Tese relata um caso de um médico, de 27 anos, que sofria de um cancro duro no prepúcio por consequência de uma fimose. A aplicação com algodão embebido em solução de cocaína a 5\%, aplicada de dois em dois minutos cinco vezes, gerou anestesia completa. Ela foi "tão perfeita que o doente, colega distinto, querendo dar prova da sua calma, ofereceu seus serviços como auxiliar da operação, o que não foi aceito" (BOTELHO, 1890, p.68). Nos casos de hidrocele "quotidianamente é a cocaína empregada por quase todos os operadores na pratica desta operação" (BOTELHO, 1890, p.72).

A descrição trazida acima dos principais usos anestésicos e terapêuticos da cocaína é exemplar da importância que essa substância adquiriu para a cirurgia e a medicina logo após a comunicação de Koller. Vimos não apenas relatos de usos nas principais salas cirúrgicas da Europa e dos EUA, mas também a crescente adesão que os médicos brasileiros iam fazendo desse poderoso fármaco, tornando-o uma realidade no dia a dia da clínica. Sua utilidade foi tão diversa que ela pode até se confundir com uma panaceia, porém não no sentido pejorativo de uma substância usada a esmo com a promessa de curar qualquer doença. Vimos que as técnicas de aplicação e a posologia variavam de acordo com a afecção que se buscava curar ou a dor que se tentava minimizar. Em 1890, seis anos após a comunicação de Koller, a cocaína já era amplamente conhecida, discutida e aplicada na clínica médica pelas altas eminências da FMRJ. No mesmo ano, conforme vimos, Chernoviz apresentava inúmeras utilidades desse fármaco no seu Dicionário de Medicina Popular. A frequência de notícias sobre a cocaína nos jornais não deixa dúvida sobre a sua notoriedade. 
Ao contrário do que acredita a historiografia triunfalista, que aponta serem as novidades terapêuticas capazes de acabar por completo com as práticas precedentes pela superioridade técnica, a cocaína também teve que encontrar seu espaço no interior das práticas já existente. Desde cedo apareceram críticas referentes à tendência de construir hábito. Botelho (1890, p.05), por exemplo, já alertava que a cocaína era igual "a morfina, o álcool, o tabaco, o ópio, etc, ela escraviza os infelizes que entregam-se a seu uso, a ponto de não poderem, ás vezes, evita-la". O "cocainomaníaco" (BOTELHO, 1890, p.05) pode se tornar um intoxicado crônico, doenças que se denomina "cocainismo" (BOTELHO, 1890, p.05). Outro tipo de questionamento, entretanto, foi elaborado tendo por base as técnicas precedentes.

Em 1894, dez anos após a comunicação de Koller e do frenesi em torno da cocaína, já é possível perceber outro tom em relação a essa substância. A Tese de Domingos Pinto de Figueiredo de Mascarenhas, intitulada Da anesthesia local em cirurgia operatória, é a primeira a ressaltar alguns inconvenientes de seu uso. Segundo o autor, o tema da anestesia local teria se tornado uma verdadeira "controvérsia", sendo um "assunto conhecido, está claro, debatido mesmo [...] quer para os cirurgiões, quer para os doentes, e que tem o cunho de eterna atualidade" (MASCARENHAS, 1894, p.03). Seria preciso chamar atenção, entretanto, para o fato de que, depois da descoberta da cocaína, "a anestesia local, com o auxílio deste agente, tem sido algum tanto empregada [...] de maneira a parecer que só a cocaína possui a propriedade da insensibilização local” (MASCARENHAS, 1894, p.08). Não "faltam a cocaína, nem documentos que a justifiquem, nem paladinos que a exaltem" (MASCARENHAS, 1894, p.17), fato que faz ela parecer um "partido preestabelecido" (MASCARENHAS, 1894, p.17). Por trás desse sucesso, duas foram as acusações que lhe foram impostas: a inconstância dos resultados e a possibilidade de acidentes. Em sua defesa cabe salientar que não existem substâncias isentas de condenação. Esses fatos, entretanto, têm alimentado uma polêmica com os partidários do clorofórmio que passaram a criticá-la como meio de exaltar a anestesia geral. Os adeptos da cocaína, por sua vez, fazem o mesmo ao isentá-la de perigos e condenar o clorofórmio. Nesse debate "a parcialidade é chocante!” (MASCARENHAS, 1894, p.20) Mais do que tomar posição por este ou aquele partido, cabe ao bom médico avaliar as idiossincrasias e optar pelo anestésico mais adequado. Em alguns casos, será necessária a anestesia geral. Em outros, a anestesia local. E mesmos nestas últimas, nem sempre a cocaína deverá ser sempre aplicada. Nos tecidos ulcerados, sede de focos purulentos, etc, a "impossibilidade de 
obter uma boa absorção do agente torna, então, quase nula a anestesia. Em tais casos preferimos o cloreto de etila, mas, a cloroformização pode ter cabimento" (MASCARENHAS, 1894, p.22).

Segundo esse autor, o sucesso do uso da cocaína dependeria do uso adequado e prudentemente feito - a velha retórica que creditava aos médicos formados a excelência técnica. Ela deveria ser usada sempre com o paciente na posição horizontal, orientação que nem sempre era respeitada, principalmente na arte dentária. Quanto à aplicação, ela nunca deve ser hipodérmica - sempre endérmica - e a solução não deve ultrapassar a marca de 2\%. "As soluções de 5 e 10/100 como alguns aconselham, não seremos nós que as defenda" (MASCARENHAS, 1894, p.28). Tomando esses cuidados, o risco de intoxicação seria mínimo. Caso elas venham a ocorrer, serão sempre leves (delírio loquaz, enternecimento), bastando ao médico fazer o paciente deitar ou dar-lhe "a beber um licor excitante qualquer, um liquido quente particularmente a infusão de café" (MASCARENHAS, 1894, p.23). Vimos, anteriormente, a relevância e o prestígio que o café assume como antídoto e acompanhante do ópio e seus derivados. Esse fato talvez explique o motivo pelo qual se adota um excitante, e não um calmante, como meio de contrabalancear os efeitos de outro excitante como é a cocaína.

Uma substância que é alternativa e, ao mesmo tempo, complemento da cocaína em anestesia local é o "cloreto de etila". Restrito, em um primeiro momento, a arte dentária, "ele ganha terreno atualmente e de modo acentuado em cirurgia geral" (MASCARENHAS, 1894, p.29). Em vários centros europeus essa substância vem "parecendo ser [...] superior aos conhecidos, inclusive a cocaína, já pela facilidade e comodidade de seu emprego, já pela ausência absoluta de acidentes que o acompanham, já pela certeza de sua ação" (MASCARENHAS, 1894, p.25). No Brasil, sua ação anestésica local é quase desconhecida. Em cirurgia dentária são poucos os que aproveitam seu benefício. Em cirurgia geral, foi o professor Brant P. Leme o primeiro a emprega-la. O professor Marcos Cavalcante também usa e manifesta sua predileção. Além desses, outros tem usado a título de curiosidade. "Em fermatoterapia (sic) ele tem sido empregado pelos Srs. Doutores Silva Araújo e Bueno de Miranda, acompanhado este pelo distinto estudante de medicina Sr. Javet Madureira, bem como ultimamente pelo Prof. Gabizo" (MASCARENHAS, 1894, p.30). Essa substância só pode ser usada por meio de um vaporizador de Richardson ou Lüer com técnica idêntica ao éter. Com esses aparelhos a técnica de aplicação seria mais simples, pois dispensaria as injeções que aterrorizam os pacientes. Além disso, eliminaria por completo a possibilidade de 
abcessos subcutâneos ou qualquer outro acidente, além do fato de mais rapidamente se obter a anestesia.

\footnotetext{
"Entre nós os melhores resultados têm sido colhidos com o emprego deste agente pelo Prof. Brant P. Leme, que em sua clínica civil, quer hospitalar. Assistimos efetuadas com pleno sucesso, além de toda sorte de operações simples, ressecções ósseas, ablações de volumosos tumores, nucleações de gânglios linfáticos degenerados, abrasões pelo termo cautério, operações de hidrocele e hematocele, etc. Na clínica do Prof. Marcos Cavalcanti o mesmo tem sucedido ... Este cirurgião já recorreu mesmo, com vantagem ao cloreto de etila, verdade seja que associado a cocaína, em operações de hérnia [...] No futuro se ampliarão seus usos!” (MASCARENHAS, 1894, p.37-38).
}

Por todas essas vantagens, tendo a sua disposição o cloreto de etila o cirurgião deveria optar por esse meio anestésico, relegando a cocaína à oftalmologia e a um ou outro caso especial, como nas cirurgias de ânus (MASCARENHAS, 1894, p.38-39).

$\mathrm{O}$ discurso triunfalista da biomedicina, que procura criar uma perspectiva progressiva, com ênfase na continuidade e no estabelecimento de uma linha evolutiva de suas técnicas, ignora as negociações, as acomodações e as permanências. O aparelho de Richardison, que é simplesmente ignorado por Reis $\operatorname{Jr}(2008$, p.300) como antecessor da anestesia local ou descrito como uma técnica rapidamente abandonada por Santos Filho (1991b, p.340), se manteve ainda atuante por largo período. Em 1902, ou seja, quase quatro décadas depois da introdução dos vapores congelantes como técnica de anestesia local, existe relato de aplicação do cloreto de etila, pelo Dr. Juliano Moreira, como meio de insensibilizar o local de uma punção (CARVALHO, 1902, p.202). Esse mesmo discurso triunfalista tentará, desde cedo, apagar da história os usos da cocaína como anestésico local. Antes de abordar essa questão, ainda cabe descrever uma última técnica anestésica com cocaína que parece ter se difundido entre o meio médico acadêmico.

Na virada do século XIX para o XX, mais precisamente em 1902, localizamos a divulgação de um novo meio de anestesia por Oscar Pereira de Carvalho. Na Tese intitulada Analgesia cirúrgica por meio de injeções sub-arachnoideanas lombares de cocaína se percebe as primeiras experimentações de uma técnica que se tornaria bastante comum na segunda metade do século XX. A raquianestesia, anestesia raquidiana ou paravertebral consiste na aplicação do anestésico local no canal raquidiano com a finalidade de sensibilizar a parte inferior do abdômen ou dos membros 
inferiores. O primeiro cirurgião a tentar a insensibilidade das partes inferiores do corpo por meio da introdução de cocaína na região medular foi o estadunidense Corning, embora ele não tenha introduzido a agulha no espaço raquidiano. Coube, por causa disso, ao alemão August Bier o mérito de ter inventado esse método. Em 1900, essa técnica já tinha se disseminado em vários países da Europa e nos EUA, sendo usado para diversos tipos de cirurgia e como meio de anestesia obstétrica (CARVALHO, 1902, p.01-20).

Os centros acadêmicos brasileiros não ficaram inertes a essa novidade. Em 1900, o professor Barata Ribeiro publicou um artigo na Revista Médica de São Paulo descrevendo nove aplicações clínicas. Ele teria sido o primeiro a aplicar o método em crianças, com bons resultados. Rapidamente a técnica se difundiu e outros médicos do país passaram a utilizá-la.

\footnotetext{
"Têm ainda empregado, no Brasil, a analgesia cirúrgica por meio das injeções subaracnóideas de cocaína, os Drs. Crissiuma, Pinto Portella, Henrique Monat, Henrique Autran, Theophilo Torres e Vieira Souto (Rio de Janeiro), Cerqueira Lima, Lydio de Mesquita, João Martins Pacheco Mendes (Bahia) e Arnobio Marques (Recife)" (CARVALHO, 1902, p.23).
}

Oscar Pereira de Carvalho ainda descreveu nove observações clínicas realizadas no Hospital de Caridade de Santa Izabel, em Salvador, que foram as primeiras aplicações desse método no local (CARVALHO, 1902, p.201-219). Segundo Adiala (2011, p.82), esse método teria sido introduzido no Brasil, em 1898, pelo professor Augusto Paes Leme. Ele teria aprendido a técnica com o próprio August Bier durante estadia na Alemanha. A difusão desse tipo de anestesia também poderia ser verificada pelos vários artigos sobre o assunto publicados no jornal Brazil Médico entre 1901 e 1904.

No momento em que estava sendo publicada a Tese discutida acima, em 1902, e que se disseminava a técnica de anestesia raquidiana com cocaína no Brasil, vários experimentos iam sendo realizados na Alemanha em busca de um substituto sintético para essa substância. Essa busca teria ganhado força a partir de 1892, quando Albert Einhorn - pesquisador da Universidade de Munique na época - descreveu a estrutura química da cocaína. A partir desse momento, várias substâncias foram sendo descobertas e colocadas comercialmente como substitutas. A primeira droga lançada foi a alpha-Eucaine, porém logo se relatou uma sensação de queima no início da aplicação. A beta-Eucaine, que tentou corrigir esse problema, também não teve adesão dos 
clínicos. Novos experimentos foram sendo realizados e lançou-se a orthocaine, porém essa apresentava problemas de viabilidade econômica, uma vez que o processo de fabricação era muito oneroso. As alterações moleculares se seguiram, sendo lançada a stovaine, a tropacocaine e, finalmente, a procaine (também conhecida por novocaine) em 1904. Essa última finalmente apresentou um poder anestésico próximo ao da cocaína, porém com uma capacidade intoxicante bastante inferior. Rapidamente ela se tornou a preferida em anestesia local, mantendo essa posição durante toda a primeira metade do século XX (SNEADER, 2005, p.127-129).

Em 1908, coube também a August Bier o crédito de ter inventada outra técnica de anestesia que se disseminaria na segunda metade do século XX: a Anestesia Regional Intravenosa. Nessa época, a novocaína já se consolidava como fármaco preferido para anestesia local. Grosso modo, essa técnica consiste na aplicação de um anestésico local em um membro ou região do corpo previamente isolado com isquemia. Coube a Zeferino Alves do Amaral ser o "príncipe da introdução da Anestesia Regional Intravenosa" (REIS JR, 2011, p.268) do Brasil, introduzindo a técnica pioneiramente na Santa Casa de Misericórdia em São Paulo a partir de 1910. Ele teria aprendido a aplicala com o próprio Bier, quando estudou com o famoso cirurgião em 1908 (REIS JR, 2011). Outro brasileiro que também foi estudar com Bier foi o professor Carlos Wallau, que se tornou um divulgador das técnicas de Bier na recém-inaugurada (1898) FMPA (MANICA, 2004, p.58). Foi por incentivo dele que algumas Teses foram defendidas sobre o tema da anestesia nessa instituição na primeira metade do século XX (REIS JR, 2008, p.302; MANICA, 2004, p.58). Teuto-brasileiro, Carlos Wallau se tornou signatário da Sociedade Germânica de Cirurgia, se constituindo em um elo entre a FMPA e as instituições médicas alemãs. Ele também foi um dos defensores do peculiar sistema de licenciamento da medicina instaurado pelo PRR (GERTZ, 2013, p.143-144), que gerou uma facilidade na venda de entorpecentes até fins dos anos de 1920, conforme veremos no Capítulo cinco.

Um fenômeno que se percebe na análise da literatura médica, principalmente aquelas que tratam das técnicas anestésicas a partir do início do século XX, é o silêncio a respeito do agente farmacológico usado. Manica (2004), na sua breve reconstituição histórica da anestesia no Brasil, também lamenta que "numerosas referências sobre procedimentos cirúrgicos realizados no século XIX e até meados do século XX não mencionam o tipo de anestesia e o agente anestésico" (MANICA, 2004, p.44). Uma das poucas exceções a esse respeito é a Tese de Euclides Silveira da Cunha Lopes, 
defendida na FMPA e aprovada com distinção em 1912, intitulada Da anesthesia local nas hérnias inguinaes. Embora o foco seja a técnica anestésica para auxiliar uma cirurgia bem específica, cabe verificarmos suas considerações a respeito dos anestésicos disponíveis, com suas respectivas qualidades e defeitos.

A cocaína teria sido empregada, a partir de 1884 quando descoberto seus efeitos anestésicos, em operações simples e complexas. Era aconselhado, para evitar intoxicações, não ultrapassar a medida de 2\% (LOPES, 1912, p.25). Vimos anteriormente, na Tese de Mascarenhas (1894), igual recomendação. Com esse fármaco "a analgesia é completa e se prolonga por cinquenta a sessenta minutos" (LOPES, 1912, p.26). Com as antigas injeções de 20, 10 e 5\% a operação podia iniciar imediatamente. Além da dose, também é preciso observar algumas medidas para evitar acidentes. $\mathrm{O}$ anestesiado deve estar sempre na posição horizontal e não ir em jejum para a mesa de operação. Ele deve tomar "uma xícara de café um tanto forte e quente. Durante a operação dar-se lhe um pouco de álcool ou café” (LOPES, 1912, p.27). Ao terminar o procedimento cirúrgico, deverá

\footnotetext{
"o doente permanecer deitado ao menos uma hora após a injeção, não abandonando esta posição, quer para sentar-se quer sobretudo para andar, senão depois de haver feito uma ligeira refeição, acompanhada de álcool e café" (LOPES, 1912, p.27).
}

Tomando essas precauções são raros os acidentes, pois em doses terapêuticas o máximo que pode ocorrer é “certa excitação, ligeira embriaguez e loquacidade passageira" (LOPES, 1912, p.27). Essa anestesia deve ser evitada em caquéticos, velhos, pessoas com problema nas artérias, cardíacos e outras. Ela tem a desvantagem de não pode ser esterilizada convenientemente porque quando fervida ela perde a capacidade anestésica (LOPES, 1912, p.25-28).

Vamos agora olhar as demais substâncias. A stovaina possui menor toxidade e menor poder anestésico, com a desvantagem de ter efeito anestésico muito rápido. Uma forma de aumentar seu efeito é fazer soluções alcoolizadas "tendo em vista a propriedade do álcool de retrair os tecidos e portanto determinar vasoconstricção" (LOPES, 1912, p.29). O efeito anestésico demora cinco minutos, fazendo suas injeções serem dolorosas. Com a estovaína não é necessário seguir os preceitos pós-operatórios da anestesia cocaínica. Outra alternativa é misturar estovaína com cocaina para ampliar o efeito anestésico. A tropococaina, por sua vez, é um alcaloide extraído da coca de 
Java. Mesmo sendo "um bom anestésico; seu poder, porém, é inferior ao da cocaína" (LOPES, 1912, p.30). As injeções são indolores. A eucaína, por sua vez, é dividida em eucaína A e B, sendo a segunda superior, apresentando bom poder anestésico, porém inferior a cocaína. A alipina é outra substância que pode ser usada, porém essa tem muitas desvantagens: toxidade variável, irritante para o tecido e produtora de infiltração e, por vezes, gangrena. Finalmente, temos a novocaína. Pode ser esterilizada porque não se dissolve a altas temperaturas. Ela teria o mesmo poder anestésico da cocaína, entretanto seu efeito é curto - dura apenas 25 minutos em média. Para remover esse inconveniente, é possível misturá-la com adrenalina a 1\%. Essa mistura é a que teria sido usada pelo Prof ${ }^{\circ}$ Wallau e nas ocasiões que o autor da Tese teve para verificar seus efeitos ela foi totalmente eficiente. A adrenalina é um vaso constritor, fato que facilita a operação devida à menor quantidade de sangue que incide no local operado. Sua principal vantagem é a sua menor toxidade, que lhe permite aplicar uma solução de 5\% (LOPES, 1912, p.29-34).

Pelas vantagens descritas acima, justificou-se a escolha da novocaína associada à adrenalina como anestésico adequado à operação de hérnias inguinais (LOPES, 1912, p.34-47). Em 1930, quase vinte anos depois, pouco parece ter mudado nesse quadro. Paulino (1930, p.51-66) também faz uma defesa da mistura de novocaína e adrenalina como o mais adequado anestésico local. A mistura nem precisava mais ser feita manualmente, pois era vendida pronta com o nome de sinalgan. Porém, mesmo que "a cocaína possa ser considerada completamente abandonada como anestésico local" (PAULINO, 1930, p.53), é bom lembrar que "este anestésico nunca deve ser empregado com o estomago cheio" (PAULINO, 1930, p.53). Médicos renomados perderam clientes depois de aplicar cocaína em pacientes que recém tinham almoçado.

\footnotetext{
"Outro cuidado a observar é nunca empregar a mistura de adrenalina, senão quando associada à novocaína (outra vantagem da novocaína), pois, com a solução cocaína-adrenalina se tem verificado casos de gangrena, falsamente atribuídos à anestesia local” (PAULINO, 1930, p.54)
}

As intoxicações com a cocaína teriam levado os médicos a optarem por doses mais fracas e outras precauções para evitar acidentes. A anestesia local não teria se generalizada por causa da fragilidade desse fármaco. "O decúbito horizontal obrigatório, quando se empregava a cocaína, não é necessário com os seus sucedâneos; assim as operações sobre o encéfalo beneficiam-se justamente da posição sentada" (PAULINO, 
1930, p.58). A novocaína também teria substituído a cocaína nas anestesias raquidiana, pois "notando-se a toxidez da cocaína, foi esta substituída pela stovaina, pela alipina, pela tropacocaína e, sobretudo, pela novocaína, que parece apresentar o máximo de poder anestesiante com o mínimo de toxidez" (PAULINO, 1930, p.37).

O que se percebe claramente, ao se analisar a literatura médica sobre a cocaína trazida para debate, é que pouquíssimo se alterou em termos de cuidados necessário a aplicação de cocaína entre Mascarenhas (1894) e Paulino (1930): o paciente deve tomar a anestesia na posição horizontal; deve se evitar doses superiores a $2 \%$. Existe uma controvérsia se o paciente deve (LOPES, 1912) ou não deve (PAULINO, 1930) ingerir alimentos antes da operação. Depois do início do século XX, se passou a defender a adoção de uma solução de novocaína com adrenalina, porque provoca menor intoxicação e vazão de sangue por causa da característica vasoconstritora desta última. Vermos, logo abaixo, que essa situação permaneceu praticamente a mesma até a década de 1950. Porém, quero abrir um parêntese para mostrar que o discurso triunfalista da biomedicina, desde cedo, procurou enterrar os usos anestésicos e terapêuticos da cocaína, como se o simples fato de existir uma nova e promissora tecnologia novocaína/adrenalina - fosse suficiente para apagar tudo que vinha sendo praticado em termos de anestesia local até aquele momento.

Em 1935, na FMPA - que se apresentou como um espaço de inovação no campo da anestesia graças à atuação do Prof ${ }^{\circ}$ Carlos Wallau, conforme vimos - era defendida a Tese de Elpidio Fialho intitulada Da Anestesia Endovenosa em Grande e Pequena Cirurgia. Segundo Manica (2004, p.58), essa Tese foi uma das primeiras a apontar a relevância dos barbitúricos como elemento integrante da prática anestésica. O nosso propósito, entretanto, será apontar o discurso em torno da cocaína como fármaco anestésico e terapêutico. Para este autor, seus efeitos anestésicos teriam sido descobertos em meados dos anos de 1880 como meio de insensibilizar a córnea e a conjuntiva.

\footnotetext{
"Seguindo a mesma trilha dos anestésicos gerais, a cocaína logo é aplicada com exagero por todos, até que acidentes verificados, ora por excesso de dores, ora por susceptibilidades especiais dos pacientes, venham lançar the a desconfiança, o que em seguida a levou ao abandono" (FIALHO, 1935, p.14).
} 
Dessa forma, estava "assim a cocaína voltada ao esquecimento [...] quando em 1902 a adjunção de adrenalina, e mais ainda a descoberta dos anestésicos sintéticos, vieram trazer-lhe novamente a sua reputação" (FIALHO, 1935, p.14-15).

Essa leitura, que acabou se tornando hegemônica na segunda metade do século XX, é muito parecida com aquela apresentada no excerto de Reis Jr (2008, p.301) que abriu esse Capítulo. Se em 1902 não se usava anestesia local na FMPA, o mesmo não podia ser dito em relação a outros ambientes. Vimos, anteriormente, que nesse mesmo ano era defendida uma Tese na Faculdade de Medicina da Bahia (FMBa) onde era divulgada a anestesia raquidiana com cocaína - prática que não se restringia aquela praça. Em 1930, o manual de cirurgia de Paulino ainda possuía recomendações a respeito do uso dessa substância, fato que denota, no mínimo, que ela ainda era vendida no comércio e poderia ser usada para finalidade anestésica. Outras fontes, que serão mostradas agora, pretendem ratificar que esse discurso triunfalista não passa de uma ideologia.

Vimos acima como Fialho, em 1935, havia sugerido que a cocaína teria sido abandonada depois de abrandado o entusiasmo inicial acerca de seu uso como anestésico local. Essa posição não parece ter confirmação nas fontes. Em 1939, era movido em Porto Alegre um processo-crime contra o médico Arnaldo Koehln por transgressão às ordens da Diretoria de Higiene que o proibiam de comprar substâncias entorpecentes. Ele foi a uma cidade vizinha a Porto Alegre buscar Pantopon e outros opiáceos para a sua esposa que sofria dores crônicas por causa da artrite. Mais do que discutir a crueldade da proibição do consumo de opiáceos por quem sofre dores, esse documento jurídico inclui um testemunho feito em juízo pelo também médico Aldo Chaves. Questionado se ele tinha prescrito alguma substância de caráter entorpecente para a esposa do Réu, ele disse que certa vez ela apresentou uma angina purulenta, fato que teria obrigado o depoente a prescrever um tratamento local de solução de cocaína diretamente na amigdala como meio de proceder à extração do pus (APERGS, Processo-Crime $\left.n^{\circ} 448,1939\right)$. Esse indício aponta que também no Rio Grande do Sul houve a persistência do uso clínico da cocaína, apesar da rejeição de alguns integrantes da medicina acadêmica.

Em 1950, ou seja, quase meio século depois do anunciado "esquecimento" da cocaína, o Dr. Mário Rangel ainda se via na contingência de explicar as vantagens e desvantagens dessa substância em comparação às suas sucedâneas. Segundo ele, embora "praticamente posta de lado" (RANGEL, 1950, p.71), ela tem a vantagem 


\begin{abstract}
"de produzir rápida e completa anestesia dolorosa e táctil quando aplicada por via subcutânea ou nas mucosas, sua ação se acompanha dos seguintes inconvenientes: ação tóxica no miocárdio; excitação seguida de depressão nos centros respiratórios, nos centros cardíacos, nos centros nervosos superiores, nos centros da medula" (RANGEL, 1950, p.71)
\end{abstract}

Por isso, "embora às vezes [de ação] não tão intensa" (RANGEL, 1950, p.71), os seus sucedâneos são preferíveis porque são menos tóxicos e podem se combinar com outras substâncias que lhes reforçam a ação, como a adrenalina - "a associação de procaínaadrenalina é de uso corrente" (p.72). Passados exatos 20 anos da publicação do manual de cirurgia do Professor Paulino (1930), se percebe o mesmo quadro - a exaltação das qualidades dos anestésicos sintéticos em relação à cocaína. Este fato denota, no mínimo, a recorrência da defesa da necessidade de substituí-la por outros anestésicos mais seguros.

Outra forma de argumentarmos contra a hipótese triunfalista que aponta o desaparecimento do uso terapêutico de cocaína no início do século XX é colocarmos ela dentro de um contexto mais geral. Vimos, quando abordamos a anestesia geral, que gradativamente foi se ampliando o conhecimento dos efeitos fisiológicos da narcose por clorofórmio e éter e, consequentemente, se tomando maior consciência de seus perigos. Mascarenhas (1894, p.17) relatou que, após a descoberta da cocaína, verdadeiros "partidos" se criaram a favor e contra a anestesia local e geral, cada qual defendendo a supremacia de um método anestésico sobre outro. Parece bem pouco provável que, antes da descoberta, da divulgação e da comercialização em larga escala dos sucedâneos da cocaína, os anestésicos gerais ou as técnicas congelantes tenham suplantado a cocaína como anestésico predominante em pequena cirurgia. Os riscos de intoxicação se mostravam relativamente pequenos se tomadas as precauções já conhecidas desde meados da década de 1890. As fontes têm sugerido é que, na busca pela anestesia perfeita, a anestesia geral perdeu espaço para a local.

Um bom exemplo da crescente preferência pelos anestésicos locais pode ser encontrado no artigo de Luiz Perreira Barreto publicado nos Annaes Paulistas de Medicina e Cirurgia (APMC), em 1915, em artigo intitulado A cura radical das hemorrhoides por processo sem sangue, sem dor e sem chloroformio, a cirurgia de hontem e a cirurgia de hoje. Segundo este autor, a descoberta da anestesia geral e, depois, da assepsia, teriam libertado os cirurgiões das antigas amarras que impediam o 
desenvolvimento da sua ciência. Porém, conforme foi se descobrindo os efeitos perniciosos desse tipo de anestesia, novamente se fez necessária a rapidez do ato cirúrgico como meio de minimizar os riscos representados pela narcose total. Essa limitação, entretanto, teria levado cada vez mais os cirurgiões a se dedicarem ao estudo da anestesia local que, graças a isso, teria passado por notáveis desenvolvimentos. Na época em que escreve, algo em torno de três quartos das cirurgias já seriam feitas com insensibilização local e se o desenvolvimento técnico continuar "em breve todas as operações cirúrgicas sem exceção poderão ser feitas sem narcose geral!” (BARRETO, 1915, p.218). Com a anestesia local o cirurgião pode

\footnotetext{
"fazer não só uma obra completa, mas ainda uma obra elegante. O doente não corre perigo com a demora $[. .$.$] não há mais razão para os insensatos golpes$ de bisturi decepando o útero e anexos em 55 segundos; não há mais lugar para as tropelias e precipitações; as mais extensas suturas podem ser feitas com capricho, a hemóstase pode ser levada a perfeição; e, como não há vômitos, nem bronquites, estão garantidos todas as reuniões por primeira intenção. Terminada a operação, o doente conversa animadoramente com os amigos e por alimentar-se desde a tarde do mesmo dia. Bem longe, portanto, estamos dos antigos tempos. Está totalmente transformado o ponto de vista ideal na arte. Hoje, o mais hábil cirurgião não é aquele que gasta menos minutos em uma operação, mas, sim, aquele que executa com mais encanto para o doente, com menos sangue, menos dor e menos risco" (BARRETO, 1915 , p.218).
}

Quinze anos mais tarde, Paulino (1930, p.53) também apontará que a "tendência moderna hoje é, justamente, quando possível, preferir a anestesia local, á narcose”.

Sobre a preferência do anestésico local, ainda vale destacar as suas considerações sobre a cocaína. Segundo ele, a comunicação de Koller, em 1884, representou a primeira carta de alforria passada aos cirurgiões, não sendo "culpa da cocaína o abuso que dela se fez" (BARRETO, 1915, p.219). Depois do advento da anestesia local, "não mais se vê nos lábios dos cirurgiões o mal disfarçado amedrontado sorriso com que escondiam os sombrios presságios, que atravessavam sua alma no momento de empunhar a faca operatória” (BARRETO, 1915, p.219). Comparada com a anestesia geral, a local é menos agressiva e possível de ser usada em diabéticos, nos “arteriosclerosos (sic)" (BARRETO, 1915, p.219), nos tuberculosos e outros tipos fragilizados. Frente a tantas vantagens, como ainda explicar a persistência da narcose 
geral? Para Barreto seriam dois os motivos: a maior complexidade da técnica anestésica local, que precisa ser pensada e calculada em cada caso, e ao hábito dos cirurgiões de descarregarem sobre os seus ajudantes toda a pesada responsabilidade do resultado da narcose geral. A sofisticação da anestesia local contrasta com a simplicidade do método de narcose geral, que "é sempre o mesmo processo para todos - o da sufocação. É indiscutivelmente brutal o mecanismo da narcose clorofórmica" (BARRETO, 1915, p.220).

É por esses motivos que ele propõe um método de anestesia local para a cirurgia de hemorroidas. Na véspera da cirurgia, de madrugada, o doente deve tomar um laxante (meia fórmula de limonada com citrato de magnésio) e seguir uma dieta láctea. Também é recomendado dar um hipnótico analgésico - vernal com aspirina - de forma a facilitar o sono e combater a ansiedade. No dia da operação é necessária uma higienização com tintura de iodo a 5\%, seguida da aplicação de uma injeção hipodérmica de uma ampola de Pantopon. Ela pode ser feita em qualquer lugar, porém "tendo em vista o efeito psicológica, faço-a de preferência na circunvizinhança e bem perto do ânus; é assim mais seguro o poder sugestivo da aplicação" (BARRETO, 1915, p.221). Depois de cinco minutos, passa-se a aplicar os anestésicos. A substância que tem sido usada com maior eficácia é o "Anestésico local de Waite” (BARRETO, 1915, p.221) que consiste em "um pouco de cocaína atenuada por vários corretivos, tais como ácido fênico, glicerina, iodo, timol, eucalipol (sic), mentol, gaulteria e ácido benzo-boracico (sic)" (BARRETO, 1915, p.221). Essa substância tem sido usada com frequência sem tido jamais ocasionado o mínimo acidente, "a não ser uma certa loquacidade com tendência para a declamação de poesias" (BARRETO, 1915, p.221). Em operações que necessitam doses mais elevadas de anestésicos é recomendada uma receita com novocaína e adrenalina.

Esse artigo apresentado vem reforçar o argumento que apresentamos acima: não parece ter havido, em fins do século XIX, um abandono da cocaína por causa do perigo de intoxicações; contrariamente, aperfeiçoaram-se as técnicas de anestesia local por causa dos perigos da narcose geral; o conhecimento da dupla novocaína/adrenalina não substituiu a cocaína nas operações mais simples, apenas naqueles procedimentos onde eram necessárias doses maiores; por último, verifica-se, desde meados dos anos 1910, a tendência de aplicar múltiplos fármacos (hipnóticos, opiáceos e anestésicos locais). 
Cinco anos depois, em 1920, também no APMC encontramos uma nota escrita pelo Dr. Laudelino Gomes e intitulada Anesthesia Local. Seguindo a linha anteriormente apontada, ele critica o atual estágio da anestesia em São Paulo porque

"nos nossos hospitais, os colégios que se dedicam à cirurgia estão muito afeitos á narcose geral e desde que experimentarem, sem receio, a anestesia regional, evitarão muitos e graves incidentes, inclusive o mais desagradável, como seja a morte do operado" (GOMES, 1920, p.68).

Um acidente fatal teria ocorrido, recentemente, "com um dos nossos reputados colegas em uma simples operação de pleurostomia" (GOMES, 1920, p.68). Por causa desse tipo de situação é necessária a substituição da anestesia geral pela local, fato que já vem sendo verificado com êxito em vários campos. Na maioria dos casos, entretanto, era utilizada a "anestesia por infiltração" (GOMES, 1920, p.68) que requer grande quantidade de anestésico. Para evitar intoxicações, o autor sugere substituir a infiltração pela anestesia regional. O fármaco utilizado por ele é o anestésico de Waite, que vem sendo aproveitado em diversas operações "sem que jamais tivéssemos tido o menor acidente antes, durante ou pós-operatório" (GOMES, 1920, p.68).

Vemos, portanto, que, em 1920, mesmo com a plena utilização da novocaína/adrenalina, ainda existiam cirurgiões que preferiam soluções com cocaína. Eles a utilizavam sem que houvesse acidentes causados pela tão alardeada toxicidade desse anestésico. Esta última referência é também exemplar de uma tendência, que se consolidará na segunda metade do século XX, de substituir a anestesia por infiltração pela regional e as aplicadas diretamente no canal raquidiano - que exigem uma quantidade menor de anestésico e, também, maior domínio técnico por parte do aplicador.

Para finalizar a exposição sobre a cocaína ainda é necessária uma breve exposição sobre obstetrícia e pediatria. Vimos, anteriormente, que a Tese de Loureiro (1913) defendia o uso de Pantopon como analgésico para o parto. Uma das mais longas críticas foi feita, justamente, para o uso anestésico da cocaína nessas situações. Segundo ele, ela tem "sido empregada diversas vezes, sem grandes resultados, em aplicações locais sobre o colo" (LOUREIRO, 1913, p.05), algo que teria sido feito desde 1885 depois da exposição dos Drs. Doleris e Dubois na Academia de Medicina em Paris. Vimos que, em 1888, Borges (1888) já anunciava essa possibilidade. Esse método consistia em 
"uma solução, contendo água, glicerina e cocaína a 5\% com a qual faziam pincelagens repetidas, durante dois ou três minutos, tanto no colo uterino como nos fundos de sacos vaginais, na vulva e em toda a extensão das paredes vaginais por meio de um speculum-útero, podendo substitui-lo por tampões de algodão ensopados na solução, os quais eram introduzidos na vagina até o colo, com intervalos de três minutos um do outro, procurando, desta maneira atenuar ou fazer desaparecer a dor determinada pelas contrações uterinas e produzidas pela dilatação forçada do colo e do orifício vulvar, sem que o parto fosse perturbado e sem prejuízo do tempo necessário para sua terminação, modificando portanto as fortes e intensas dores manifestadas por gritos dilacerantes em simples gemidos" (LOUREIRO, 1913, p.05-06)

O autor da Tese e outros obstetras criticavam esse método, pois o efeito anestésico era quase nulo durante o período de dilatação e a cocaína podia causar intoxicações. Quando esse método estava quase abandonado

\footnotetext{
"Tuffier vulgarizou o método das injeções intraraquidianas na dose de 0,01 , usada no momento em que o período de dilatação atingisse uma palma de mão, se estabelecendo a analgesia de 3 a 10 minutos após, durando uma hora e quinze minutos, mais ou menos, agindo a cocaína ao mesmo tempo como eutócico e hemostático, nos fazendo ver que durante a analgesia a parturiente não sentia nenhuma dor na ocasião das contrações e que estas aumentavam de intensidade, duração e frequência" (LOUREIRO, 1913, p.06).
}

Acidentes graves acabaram levando ao abandono dessa técnica, assim como "as injeções intraraquidianas de cocaína" (LOUREIRO, 1913, p.06). Tudo isso teria levado à abdicação quase completa do uso desse fármaco em analgesia obstétrica.

Todas essas observações trazidas por Loureiro (1913, p.05-06) mostram que a cocaína foi usada em diversas ocasiões, inclusive com o método raquidiano, visando analgesia do parto. Se as críticas continuaram ao longo de toda a primeira metade do século XX era porque seu uso não tinha desaparecido, conforme sugere a versão biomédica da medicina. Mesmo que o resultado com a cocaína não tenha sido satisfatório, se percebe, claramente, é a tentativa de modificar e aprimorar as técnicas com os anestésicos locais, pois, conforme mostrado acima, elas eram entendidas como mais seguras que a anestesia geral então disseminada na obstetrícia. Dos sucedâneos da 
cocaína o único citado é a "stovaina", que "é usada para o mesmo fim que a cocaína" (LOUREIRO, 1913, p.08).

O último ponto abordado será a pediatria. O Formulario de Therapeutica Infantil, de 1920, apresentado anteriormente, reserva um lugar de destaque para a cocaína. Nas moléstias do aparelho digestivo ela poderia ser usada com êxito para tratamento de "vômitos pertinazes" (MOREIRA, 1920, p.140) e, além disso, "em último recurso e com prudência, aos lactantes de mais idade" (MOREIRA, 1920, p.140). É, sobretudo, na oftalmologia que está sua principal utilidade, sendo apresentada como substância muito usada "para a anestesia local em cirurgia ocular" (MOREIRA, 1920, p.41). Isso ocorre porque, embora diversas substâncias possam ser empregadas como anestésico local em oftalmologia “a cocaína é ainda a mais eficaz e preferível. Entretanto, os colírios de cocaína devem ser empregados nas crianças com certa parcimônia, porque podem ocasionar sintomas de intoxicação" (MOREIRA, 1920, p.358). A fórmula apresentada abaixo é suficiente para anestesiar em poucos minutos a córnea e a conjuntiva, aumentando o efeito em doses repetidas.

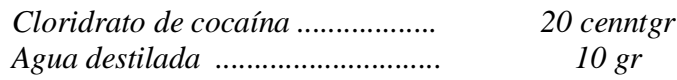

Quando é necessário fazer uma operação cirúrgica mais forte, se pode ampliar a dose para 50 centigramas. Essa substância também produz a dilatação da pupila, propriedade que pode ser aproveitada para o exame do fundo do olho. Ela não pode ser usada para anestesia da conjuntiva inflamada, porque seu efeito é muito deficiente. Por outro lado, o mesmo não ocorre na córnea, "na qual uma ulcera pode ser cauterizada com o termo ou galvano cauterio sem grande incômodo" (MOREIRA, 1920, p.358). A anestesia produzida pela cocaína também pode ser usada para abrandar o "blefaroespasmo, tão frequente nas crianças atacadas de kerato (sic) conjuntivites. Nesse caso é bom associala a dionina ou à adrenalina" (MOREIRA, 1920, p.359) conforme as fórmulas que seguem:

\begin{tabular}{|c|c|c|c|}
\hline 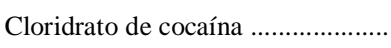 & 20 centigr. & 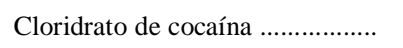 & 20 centigr. \\
\hline 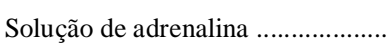 & X Gotas & Dionina & 20 centigr. \\
\hline 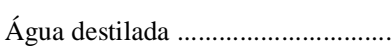 & $10 \mathrm{gr}$ & Água destilada ........ & $10 \mathrm{gr}$ \\
\hline
\end{tabular}

Um último ponto a ser ressaltado é que "a cocaína, além de ser um anestésico poderoso, é também um analgésico, atuando porém passageiramente em casos de corpos estranhos ou lesões superficiais da córnea e da conjuntiva” (MOREIRA, 1920, p.359). 
Os usos terapêuticos destacados acima mostram, claramente, que a cocaína seguia sendo a substância predileta em anestesia ocular mesmo com a existência dos sucedâneos. Também mostra a sua utilidade para as moléstias do aparelho digestivo, função que vinha sendo destacada desde a década de 1880, incluída nas prescrições do Dr. Chernoviz. Se for verdade que a dupla novocaína/adrenalina substituiu a cocaína nas aplicações na região raquidiana, se tornando gradativamente a referência na anestesia local por infiltração, isso não significa que a cocaína tenha sido abandonada ou ignorada pela clínica diária. Até meados do século XX ela seguia sendo uma alternativa farmacológica, apesar de todo o esforço da retórica triunfalista de apagar esses usos.

\subsection{Conclusão}

Ao longo desse Capítulo foi realizada uma longa revisão sobre a literatura médica do século XIX e da primeira metade do século XX. Traçou-se o papel do álcool como elemento terapêutico, o histórico da analgesia com opiáceos e uma leitura das técnicas cirúrgicas a partir dos anestésicos, primeiro os gerais e depois os locais. Impossível esgotar todos os documentos e os aspectos que esses temas colocam, porém parece claro que as substâncias analisadas faziam parte do arsenal terapêutico utilizado na clínica diária. Essas tradições terapêuticas, ainda muitas vezes identificadas com os preceitos neohipocráticos apresentados no Capítulo dois, precisavam ser esquecidas e/ou diminuídas em função das novas técnicas e fármacos manejados com maior complexidade - o que justificaria a formação de novas especialidades. Os documentos apresentados, entretanto, mostram que a invenção de novos fármacos e a crescente complexidade das técnicas não foi suficiente para destituir os fármacos clássicos de sua posição na terapêutica. Seus usos se modificaram, se adaptaram aos novos conceitos da microbiologia e da higiene para se manterem vivos durante boa parte do século XX.

Vimos, no Capítulo dois, como o campo da terapêutica foi tomado por um enorme pessimismo em relação a sua capacidade de dar uma resposta adequada às mais diversas doenças que ficaram conhecidas em fins do século XIX. Consolidou-se a visão que a maioria dos fármacos, até então utilizados, não era capaz de resolver satisfatoriamente as doenças que assolavam as pessoas. Esse quadro, entretanto, se modificou bastante ao longo da primeira metade do século XX. A exposição dos usos cirúrgicos e médicos dos fármacos clássicos, realizados nesse Capítulo, procurou mostrar como essas substâncias se adaptaram aos novos padrões de conhecimento sobre 
a enfermidade para se manterem como importantes ferramentas terapêuticas. O sentimento de impotência, que caracterizava o final do século XIX, foi gradativamente substituído pela ideia de era preciso reconstruir a terapêutica a partir de novas bases, sem negar a utilidade das principais substâncias do escopo farmacológico então vigente.

Nesse sentido, o Formulario de Therapeutica Infantil, que foi utilizado em vários momentos para mostrar o uso dos fármacos clássicos no campo da pediatria, apresenta um resumo da nova confiança que os clínicos foram adquirindo nos instrumentos terapêuticos tradicionais.

Segundo Moreira (1920, p.05-13), a ideia de escrever esse formulário para pediatria teria surgido da reorganização efetuada, pela equipe da Policlínica de Crianças do Rio de Janeiro, das receitas que eram guardadas em "modestos livros. Percebeu-se que eram guardadas apenas na "memória umas tantas receitas afortunadas" e se ignorava "a indispensável posologia dos simples". Nos últimos tempos, entretanto, a "oficina galênica foi contrastando com os corolários do ensino de PASTEUR",59 com sua "terapêutica oriunda de soros, por sua vez preventivos". Os "arautos do laboratório" manifestam um desdém pela "medicação sintomática" e um perigoso ceticismo avassalava a consciência de muitos médicos. Dessa terra arrasada, entretanto, acabou restando "um acervo de farmácia expurgada (e susceptível de maior poda), a fisioterapia, alguns soros, e as vacinas de WRIOHT" ${ }^{\prime 60}$. Hoje - na época que escreve o autor - a higiene trouxe uma série de regras que rejeita "o emprego vetusto das drogas": deixou-se de dar poções milagrosas para tratar dores de cabeça; as anemias passaram a ser combatidas com o regime alimentar; as lesões cardíacas e a "avantesma das xaropadas" deram lugar a higiene do esforço; caíram todos os aparatos para conter a tuberculose com a simples luz solar. A ideia, tão vigente anteriormente, da desinfeção intestinal por agentes químicos se desfez porque nessa prática além dos germes perniciosos também se matam os úteis. Os clínicos que receitam fórmulas "para constipação, dispépticas ou decomposição" são ridicularizados, porém é difícil a vitória dos novos ideais porque "viceja ainda o preconceito". Nesse sentido, grandes males fez o remédio calomelano feito de mercúrio (que é um poderoso purgante), tanto em crianças, quanto em adultos. Levando esses preceitos em consideração, o desígnio do livro é "apontar que os formulários hodiernos não devem expor ao público médico os preconizados preconceitos". É preciso ressaltar, também, a existência de alguns clínicos

\footnotetext{
${ }^{59}$ Caixa alta no original.
}

${ }^{60}$ Caixa alta no original. 
"mimados" que dificultam "o emprego racional da medicação". Por isso, é preciso abandonar "a prescrição de poções, clisteres e unções", transformando-nos em "médicos que dão poucos remédios". A elegância da arte de formular, tão aclamada, é como um anel de ouro acompanhado de um sapato velho. É preciso que os médicos se tornem "ao menos parcimoniosos em nossa triste medicação sintomática”, o que não significa, certamente, prescrever doses inúteis. Alguns médicos notáveis são muito tímidos em relação às crianças, receitando doses fraquíssimas incapazes de alcançar o fim desejado. Esse livro procurou, portanto, ajudar na difusão do conhecimento científico traduzindo, assim, "a orientação da Policlínica de Crianças: à caridade exige em prol dos doentes o mais apurado instrumento científico".

Fica claro, nessas ideias, o intento de expurgar da farmacopeia todos os purgantes e outras substâncias desnecessárias, as elevadas doses rejeitadas pela higiene e reconstruir a terapêutica a partir do mais apurado conhecimento científico. Nesse expurgo os fármacos clássicos apresentados ao longo desse item se mantiveram como válidos e legítimos instrumentos terapêuticos. Esse manual (MOREIRA, 1920), assim como outros que foram utilizados (PAULINO, 1930; RANGEL, 1950), são exemplos do mesmo espírito iluminista existente nos antigos manuais do século XIX, porém com a diferença de serem voltados para a atualização dos clínicos e não para instruir o público em geral. Essa tendência de monopolização da prática terapêutica se intensificará a partir da segunda metade do século $\mathrm{XX}$, quando os fármacos clássicos serão substituídos por outros fornecidos prontos pela indústria farmacêutica encerrando definitivamente a era da formulação de remédios. Esse será um dos temas do próximo Capítulo. 


\section{CAPÍTULO 5 - O PROIBICIONISMO COMO POLÍTICA HISTÓRICA: ou uma crítica à hipótese do continuísmo e da ascensão punitivista.}

\subsection{Introdução}

Ao longo dos Capítulos anteriores fizemos uma longa viagem que vai, literalmente, da pré-história à metade do século XX. O consumo moderno foi caracterizado, diferenciando-o do antigo, de modo a questionar a visão dualista tão comum que opõe liberalismo em matéria de consciência no século XIX, de um lado, e o papel autoritário/moral do saber médico no século XX, do outro lado. Ou, ainda, a falsa oposição entre saber médico normativo e a experiência de sujeitos concretos. Vimos, também, que as primeiras leis proibitivas foram realizadas em um contexto plural no âmbito internacional. O discurso médico que sustentou a proibição era baseado nas premissas da racionalização do uso, da contenção do abuso e da denúncia à degeneração da raça brasileira.

O presente Capítulo, último dessa Tese, pretende reconstruir a história das políticas sobre drogas no Brasil, discutindo o sentido das normativas e os principais marcos temporais. A crise do modelo atual é um fenômeno singular, com características próprias, o que torna impossível um retorno ao passado - como imagina Courtwright (2001, p.201) ao perceber a crise atual como um projeto ligado ao libertarianismo reacionário (com elementos de esquerda e direita) que procura retroceder a política de drogas em cem anos. A percepção de que é possível retornarmos ao passado parte do pressuposto de que o sistema proibicionista é um modelo único, coeso que foi construído ao longo do século XX com uma crescente ordem punitivista.

Essa perspectiva é apresentada de forma modelar por Carvalho (2007, p.11-21): a primeira norma proibitiva aparece no início do século XVII "quando da instituição das Ordenações Filipinas", que inaugura o conceito de 'substâncias venenosas' que perdurará longo tempo. Ignorado no Código Penal de 1830, o tema ressurge no Código Penal de 1890 no Título referente aos crimes ligados à saúde pública. Nas primeiras décadas do século XX “o aumento do consumo de ópio e haxixe, sobretudo nos círculos intelectuais e na aristocracia urbana, incentiva a edição de novos regulamentos". A punitividade segue se ampliando. Com “a Consolidação das Leis Penais em 1932, ocorre nova disciplina da matéria, no sentido de densificação e complexificação das condutas contra a saúde pública”. A pluralidade dos verbos nas incriminações e a 
substituição do termo 'substância venenosa' por 'substância entorpecente', entre outras novidades, "passam a delinear novo modelo de gestão repressiva". Assim, a "formação do sistema repressivo ocorre quando da autonomização das leis criminalizadoras (Decreto 780/36 e 2.954/38) e do ingresso do país no modelo internacional de controle (Decreto-Lei 891/38)". Esse sistema se consolida no Código Penal de 1940, com algumas alterações nos anos seguintes. Esse arcabouço legal perdurará até a década de 1960, época que o Brasil ingressaria definitivamente no cenário internacional de combate às drogas, através da "aprovação e promulgação da Convenção Única sobre Entorpecentes pelo Decreto 54.216/64 subscrita por Castelo Branco". ${ }^{61}$ A partir dessa época será configurada a ideologia da diferenciação social, cuja principal característica é a distinção entre consumidor e traficante, entre doente e delinquente. O incremento da punitividade seguiria ao longo dos anos de 1960, borrando a diferença entre essas duas figuras. O Decreto-lei 385 de 26 de dezembro de 1968 passará a punir ambos com reclusão, até chegar ao ápice com a Lei 6.368 de 21 de Outubro de 1976, que acompanha "as orientações político-criminais dos países centrais, refletidas nos tratados e convenções internacionais". A diferença entre a lei de 1968 e a de 1976 não está nas figuras típicas do código, mas no maior peso da pena: de três a quinze anos de prisão.

Essa brevíssima apresentação da legislação de drogas no Brasil é exemplar daquilo que denominarei de hipótese do continuísmo e da ascensão punitivista, conforme representado no Gráfico 01 exposto abaixo.

${ }^{61}$ Grifo no original. 


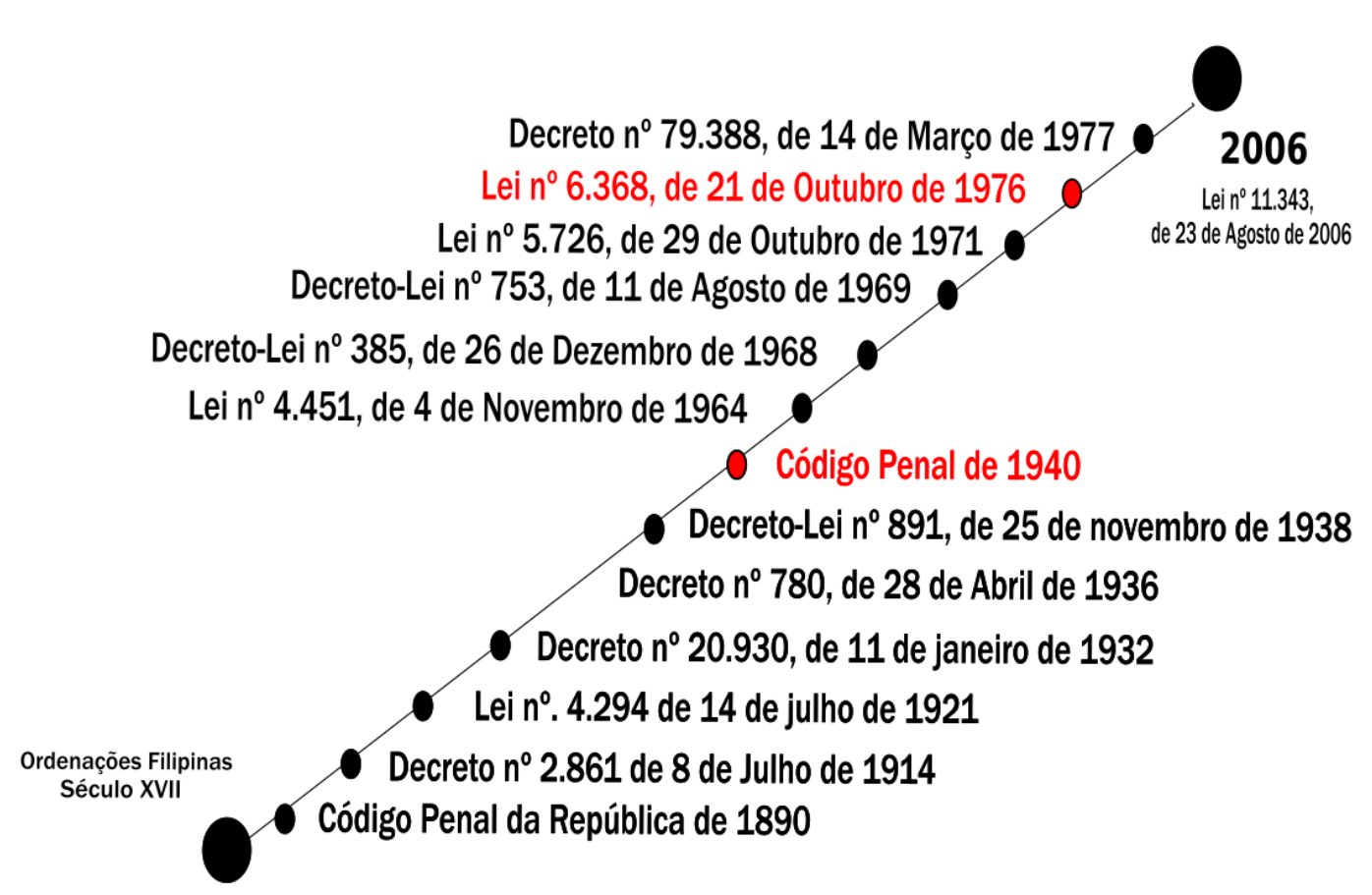

GRÁFICO 1 - Hipótese do continuísmo e da ascensão punitivista

Veremos nesse Capítulo que as leis sobre drogas no Brasil, na primeira metade do século XX, não eram simples "resquícios de criminalização" (CARVALHO, 2007, p.12). Respeitando a autonomia federativa, cada Estado desenvolveu uma política própria nesse campo, ora investindo contra os 'entorpecentes', ora contra o álcool. Esses fármacos faziam parte da cultura de automedicação, estando fortemente presente nos veículos culturais - que denotavam pautas de consumo bastante diferentes daquelas que se constituíram na segunda metade do século XX. A classe médica era caracterizada pela retórica do uso racional e pelo anseio de tutelar o acesso aos fármacos no sentido de evitar o abuso. As políticas proibicionistas e as pautas culturais de uso foram substancialmente alteradas a partir de meados do século XX.

O tema da proibição das drogas na segunda metade do século XX é vasto, por isso não tenho a menor pretensão de esgotá-lo. Esse será um Capítulo de síntese, reunindo fontes e apresentando sugestões de marcos temporais que podem ajudar os futuros estudos que se debruçarão sobre esse período. $\mathrm{O}$ esforço por entender as particularidades das políticas sobre drogas na primeira metade do século XX levou a uma série de questionamentos sobre o sentido da proibição contemporânea, principalmente no que se referem aos seus principais marcos e características. 
Argumentarei que a hipótese do continuísmo e da ascensão punitivista é inadequada para entendermos as particularidades de cada sistema de controle, por isso ao final irei propor uma nova hipótese interpretativa sobre a proibição das drogas no Brasil.

\subsection{O liberalismo brasileiro (1824-1904)}

A sociedade moderna foi caracterizada pela interligação de várias partes do mundo e pelo crescimento das trocas comerciais entre os povos - e as drogas tiveram um papel fundamental nesse processo, conforme vimos na caracterização do fenômeno da revolução psicoativa no primeiro Capítulo. A leitura sobre as artes de curar, eruditas e populares, mostrou que existia uma forte cultura de automedicação. Os formulários, as receitas e a arte de formular eram instrumentos que faziam parte do repertório terapêutico daquilo que foi denominado de neohipocratismo brasileiro, não restrito às classes terapêuticas oficiais. Nesse cenário é difícil imaginar que em Portugal, e depois no Brasil, o tema das drogas tenha ficado ausente da agenda pública.

Uma das mais antigas e importantes referências legais sobre o tema provém das Ordenações Filipinas (1870, p.1240), conforme vimos acima. O Livro V, Título LXXXIX, proibia - "salvo se for Boticário examinado, e que tenha licença para ter Botica, e usar do Ofício" - as pessoas de terem rosalgar (arsênico), escamônea (planta purgativa) e ópio; afirma ainda que "os Boticários poderão meter em suas mezinhas os ditos materiais, segundo pelos Médicos, Cirurgiões, e Escritores for mandado"; caso “outras pessoas, que não forem Oficiais conhecidos" vendam esses produtos, elas ficam sujeitas à multa e a qualquer outra pena em caso de reincidência. É possível especularmos sobre a real efetividade de uma ordem desse tipo, porém é indiscutível a pretensão da Coroa em monopolizar tão importante gênero comercial desde o início do século XVI.

A concepção de atividade econômica como privilégio real entrava em conflito com a doutrina do livre comércio e, no caso do Brasil colonial, com a escassez de gêneros tão importantes. Era interesse da população da colônia que houvesse disponibilidade desses fármacos, lutando contra os farmacêuticos diplomados que desde os primórdios se articulavam pela defesa dos seus privilégios. Antônio da Mota, em 1726, foi o primeiro boticário estabelecido em São Paulo. Desde sua chegada, ele procurar defender as suas prerrogativas oficiais, argumentando que os "mercadores negociavam normalmente os 'purgativos opiados, mezinhas fortes e perigosas' na cidade de São Paulo" (MARQUES, 1999, p.182). Conflitos esses que entraram o século 
XIX, ampliando os antagonismos entre a Corte e a população que necessitava dos medicamentos. Marques (1999, p.180-183) aponta que durante a colônia a política de licenças era contraditória, pois ora defendia os monopólios, ora liberava o comércio.

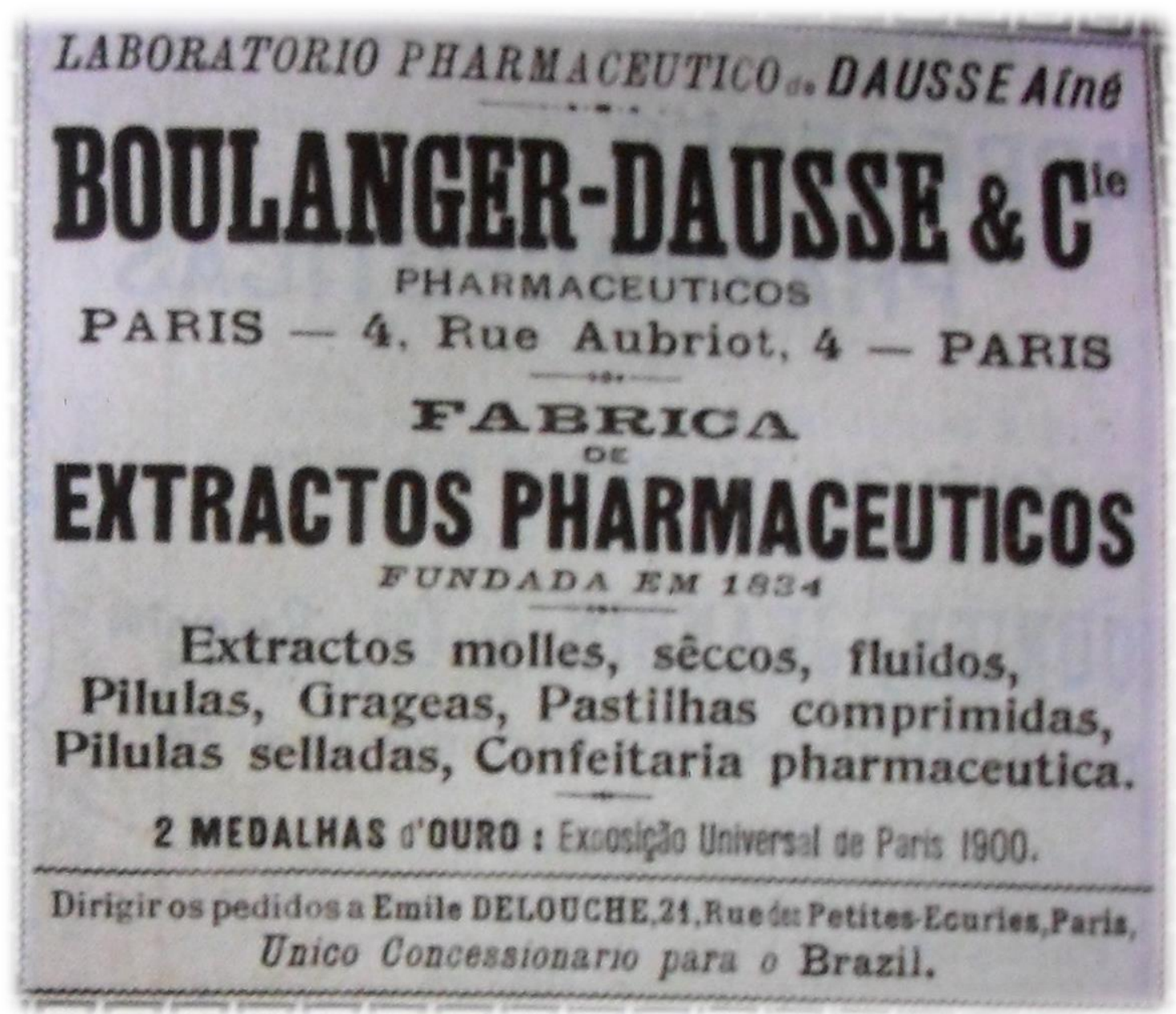

FIGURA 11 - Propaganda de representante de laboratório francês no Brasil século XIX FONTE: STÜKER et al, 2007, p.15

Depois de 1808, com a chegada da Corte, houve a abertura dos portos e a instalação de representantes dos laboratórios estrangeiros no Brasil - a Figura 11 é um exemplo de escritório francês funcionando no Brasil. Essa nova orientação comercial teria sido responsável pela maior disponibilidade de produtos importados, abarrotando as prateleiras das farmácias e de outros estabelecimentos comerciais com "elixires, panaceias, drogas ditas 'secretas"” (SANTOS FILHO, 1991b, p.362), tais como os produtos oferecidos pela empresa Roche - ver Figura 12. 


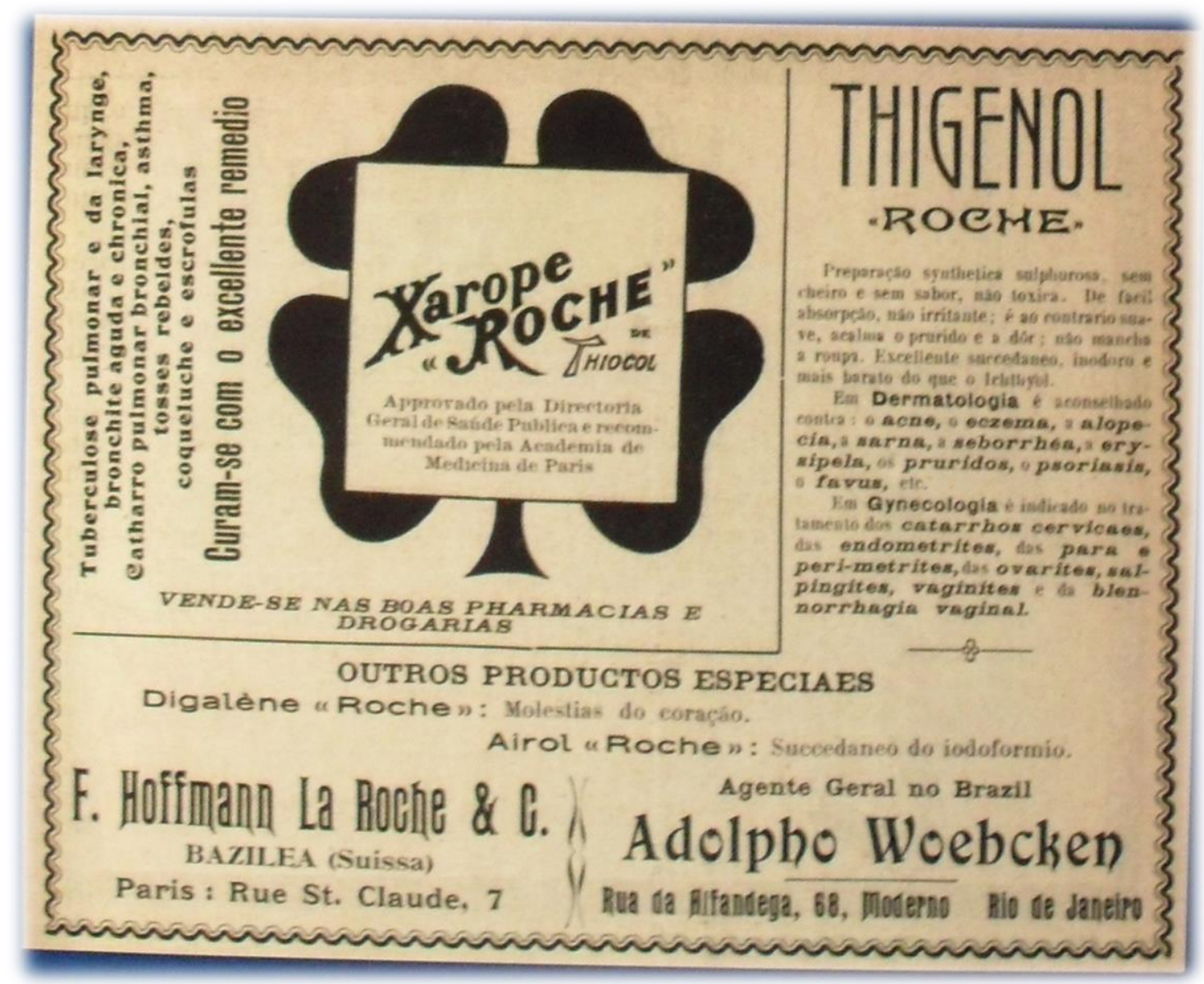

FIGURA 12 - Propaganda do laboratório Hoffmann La Roche \& C. no Brasil século XIX FONTE: STÜKER et al, 2007, p.15

No campo jurídico e político a liberdade do comércio era acompanhada do pensamento iluminista que consagrou os preceitos da Escola Clássica do direito: igualdade dos indivíduos perante a lei, o livre-arbítrio, a responsabilidade moral pelos atos praticados, a punição proporcional ao crime cometido, entre outros.

Nesse arcabouço institucional pós-independência grandes atribuições foram dadas as Câmaras Municipais. A Constituição de 1824 previu a existência de uma Câmara em cada cidade ou vila, "as quais compete o Governo econômico" (Artigo 167). A Regulamentação das Câmaras ocorreu com a Lei de $1^{\circ}$ de Outubro de 1828 , determinando que caberia a estas instituições "tudo quanto diz respeito a policia, e economia das povoações, e seus termos" (Artigo 66). Ou seja, cabia aos vereadores eleitos definir as formas como se organizaria o comércio, a exposição de produtos à venda, a balança, os pesos e os padrões para regular as aferições e à circulação de mercadorias e pessoas. 
Outra novidade da Constituição de 1824 foi a criação dos Juízes de Paz (Artigo 162), leigos ou não que seriam eleitos como os vereadores. O tema das atribuições desses magistrados foi polêmico, tornando-se assunto recorrente nas pautas parlamentares entre 1826 e 1842. Suas atribuições eram amplas e estavam relacionadas com a guarda nacional, o juiz de órfãos, as eleições, o júri e a liberdade de imprensa, que compreendiam "além da esfera judicial e conciliatória, atividades policiais, administrativas e eleitorais" (MOTTA, 2013, p.63). A Lei de 15 de outubro de 1827, que regulamentou as funções dos Juízes de Paz, foi a primeira normativa de âmbito nacional com dispositivos contra o uso de álcool. Além de fazer observar as posturas policiais promulgadas pelas Câmaras (Artigo 5, § 10), também cabia aos Juízes de Paz "pôr em custodia o bêbedo, durante a bebedice" (Artigo 5, § 4) e "corrigir os bêbedos por vicio, turbulentos, e meretriz escandalosas, que perturbam o sossego publico, obrigando-os a assinar o termo de bem viver" (Artigo 5, § 5).

Essa é a configuração institucional que permite entender a promulgação da primeira normativa legal contra a Cannabis no Rio de Janeiro em 1830, conforme já foi destacado no primeiro Capítulo. Esse evento, que ocorreu dez anos antes da criação do Clube dos Hachichins de Paris, provavelmente foi a primeira normativa ocidental contra essa droga (MOTT, 1986, p.131). Fiore (2005, p.263) destacou também o caráter racial dessa legislação, menos voltada para o fármaco e mais para a necessidade de não permitir a aglomeração de escravos no centro comercial. Além desses dois aspectos antiguidade do uso e da repressão; caráter racial e social - também é preciso destacar o aspecto estritamente comercial das medidas municipais. Ela foi inserida em um Título das Posturas que tratava sobre a venda de gêneros, remédios e a atuação dos boticários. Era o poder local que definia as formas como deveria ocorrer o comércio, contra a multiplicidade de regulamentos impostos pela Coroa portuguesa.

\footnotetext{
“As Ordenações Filipinas e uma miríade de leis 'extravagantes', provisões, regulamentos e alvarás, passarão a ser o alvo mais visível e atacado dos projetos de reforma de uma elite que iniciava a sua obra de construção de um Estado e de uma "civilização"” (VELLASCO, 2003, p.04).
}

Nesse sentido, uma importante medida adotada pelo governo recémindependente foi a promulgação do Código Criminal do Império através da Lei de 16 de dezembro de 1830, bastante avançado em termos liberais inclusive em relação aos países europeus. O Brasil foi o primeiro país da região latino-americana a ter um código 
penal autônomo, influenciando, assim, os países vizinhos. É preciso destacar, entretanto, que por trás desses avanços existiam normas sociais de uma sociedade patriarcal e escravocrata que criava uma forte hierarquia com base no gênero, na raça ou nas condições sociais (CAULFIELD, 2000, p.57-58). A única referência ao nosso tema nesse código diz respeito ao infanticídio: o artigo 200 prevê pena de dois a seis anos de prisão com trabalho para quem fornecer com conhecimento de causa drogas ou qualquer outro meio para produzir aborto, mesmo que esse não se realize. Pena dobrada para médico, boticário, cirurgião "ou praticante de tais artes".

A descentralização da política e a regulação econômica a partir dos municípios explicam porque as determinações em relação ao comércio de gêneros farmacêuticos ficaram de fora do Código Penal - eles passaram a ser regulados a partir da esfera local. São as pesquisas sobre as realidades municipais que poderão nos trazer mais informações sobre o sistema de controle da ebriedade no século XIX. A Lei de $1^{\circ}$ de Outubro de 1828, que regulou as Câmaras, previu no Artigo 84 que caberia aos fiscais de freguesia a fiscalização das posturas promulgadas pelo legislativo municipal, incluindo a venda de drogas.

Os médicos brasileiros, desde cedo, se colocariam contra as disposições da Constituição de 1824, apontando "a incoerência do que se poderia chamar de higiene desmedicalizada" (MACHADO et al, 1978, p.184). A extinção da Fisicatura e dos constrangimentos provenientes dos privilégios portugueses eram vistos com satisfação, porém a categoria teria ficado órfão de um órgão de controle capaz de defender os interesses das classes terapêuticas oficiais e da saúde pública. As amplas atribuições das Câmaras Municipais eram interpretadas "pelos médicos como usurpação de poder" (MACHADO et al, 1978, p.218). Foi para sensibilizar as autoridades do país inteiro que a AIM enviava ofícios para as Câmaras oferecendo seus serviços em matéria de saúde pública, publicando os retornos favoráveis das autoridades locais nos periódicos médicos. "A tática de assessoria [...] tem como objetivo criar demanda dentro da administração municipal” (MACHADO et al, 1978, p.221).

Ao lado dessa estratégia descrita acima, também ocorriam no interior da AIM e na Câmara dos Deputados debates a respeito dos serviços sanitários do Império e a defesa da necessidade de colocá-los em jurisdição de uma autoridade técnica; as Câmaras organizadas por leigos organizavam esses serviços de forma negligente na opinião da classe médica oficial. A partir da década de 1840, acompanhando o movimento mais amplo de centralização do Império, também começa a gradativa 
desmunicipalização da saúde pública (DELAMARQUE, 2011). É nesse contexto de reforço da centralização que é criada a JCHP, instituição que é carregada de polêmicas.

As colocações acima sobre a posição crítica da AIM à organização do serviço sanitário no Império são apresentadas, na obra de Machado et al (1978), como meio de confirmar o argumento que a consolidação da medicina social é etapa que contribuiu para a formação de uma sociedade capitalista. Nessa perspectiva a medicina "penetra em tudo e inclusive no aparelho do Estado. Relação que não é de justaposição ou de apropriação, mas de imanência" (MACHADO et al, 1978, p.157). A criação da JCHP seria, nessa leitura, um passo fundamental na consolidação do fenômeno da medicalização da sociedade caracterizado basicamente por dois aspectos: a transferência para o âmbito médico dos conflitos sociais através da normalização; a expropriação da capacidade de cuidado das pessoas, principalmente dos setores populares, tornando-os dependentes do cuidado dispensado pela classe terapêutica oficial.

A ideia de que a sociedade oitocentista viveu o fenômeno da medicalização foi alvo de várias críticas, conforme foi mostrado no segundo Capítulo. Contra essa perspectiva vários estudos foram promovidos pela história social, enfatizando a “experiência de sujeitos concretos" que resistiam à medicina oficial através das práticas populares de cura. Argumentou-se, entretanto, que os formulários, as receitas e as artes de formular eram instrumentos terapêuticos que não eram restritos à classe oficial, estando presente também entre aqueles que a medicina costumou chamar de "charlatões", ou seja, entre práticos e leigos. Outro aspecto importante na crítica à leitura medicalizante dos oitocentos, e ainda não destacado, refere-se à atuação da JCHP. Edler (1998) afirma o seguinte sobre as atribuições feitas por Machado et al (1978) às funções desse órgão.

\footnotetext{
"Tomando como dado relevante da realidade social o que não passava de um projeto defendido por segmentos da corporação médica [...] este autor vai afirmar equivocadamente que a partir de 1850, quando se criou a Junta Central de Higiene Pública, o poder das câmaras municipais foi esvaziado" (EDLER, 1998, p.175).
}

O modelo médico instaurado no Brasil inspirava-se no Francês, tomando a Academia de Medicina de Paris como modelo de organização de classe, por isso a AIM buscava centralizar o fluxo de informações com objetivo de compreender as patologias nacionais. A AIM era um órgão consultivo em termos de saúde pública, embora os 
médicos possuíssem enorme apetite por poderes administrativos. Essa pretensão teria durado até 1850, quando foi criada a JCHP. A criação deste órgão

\footnotetext{
“subordinou as ações oficiais no campo da saúde pública e polícia médica à pauta política e administrativa mais geral, o que gerou queixas e lamúrias por parte de acadêmicos e da imprensa médica independente, na Corte e na Bahia" (EDLER, 2002, p.365).
}

Por isso, a criação da JCHP ao invés de representar o ápice do poder dos higienistas, representou o esvaziamento do poder da AIM com a "subordinação das ações oficiais no campo da saúde pública e polícia médica à pauta política e administrava mais geral" (EDLER, 2003, p.150), levando a lamúrias no setor até a reforma da década de 1880.

Outra questão que colocou a JCHP no centro de uma polêmica foi a suposta preferência dessa instituição na solução do problema da febre amarela em detrimento da tuberculose. Para Chalhoub (1996) o foco na primeira em detrimento da segunda seria o sinal inequívoco do racismo dos médicos e das políticas sanitaristas. Para Maio (2010, p.69-71), essa hipótese desconsidera que: a tuberculose era uma doença crônica e uma ameaça a todos; os médicos defendiam que as condições de habitação eram seu principal vetor de contaminação; tinha uma visibilidade reduzida em relação à febre amarela; as medidas de notificação compulsória, isolamento de doentes e desinfecções eram caros e geravam altos custos sociais e políticos. Por isso, é

\footnotetext{
"possível relativizar a perspectiva monocausal de Chalhoub de que no âmbito da saúde pública médicos racistas, conscientes dos problemas macroeconômicos, tornaram-se intelectuais submetidos aos interesses dos grupos dominantes em função do plano de criação de uma supremacia branca" (MAIO, 2010, p.71).
}

Além de submeter o sentido da política sanitária a uma explicação heterônoma em relação à própria medicina, também existia um exagero por parte de Chalhoub em relação ao poder higienista, pois ele não distinguiu profisssão médica, autoridade de saúde pública e ações governamentais. Mesmo que a AIM e a JCHP tivessem "ambições de formular e implementar políticas de saúde, de 'medicalizar a sociedade', as duas instituições tinham importância lateral na burocracia estatal" (MAIO, 2010, p.71). 
Essas observações sobre as polêmicas envolvendo a JCHP são realizadas para que as colocações que serão colocadas a respeito dessa instituição não sejam superestimadas, como uma marcha inequívoca do avanço da medicina sobre o social. A real influência dos regulamentos precisa ser avaliada em cada contexto social - não podemos projetar para o Brasil inteiro regulamentos que talvez nem mesmo no Rio de Janeiro fossem cumpridos. Por isso, apesar das novas instituições e regulamentos, na

\footnotetext{
"corte ou nas províncias pululavam os vendedores ambulantes de remédios secretos. A população não associava competência terapêutica com os diplomas oficiais e as autoridades faziam vista grossa à multiplicidade de anúncios que ofereciam, para os mais diversos males, remédios que prometiam curas imediatas" (EDLER, 2010, p.44).
}

Vimos, no segundo Capítulo, que os remédios secretos também continham muitos dos fármacos que eram usados pela medicina oficial. Por isso, sua popularidade contrasta com a ideia de que o "acesso aos produtos das farmácias, boticas e drogarias, muitos deles importados, era quase sempre uma prerrogativa dos brancos ricos" constituindo, assim, “indícios da ostentação senhorial” (EDLER, 2010, p.44). Contrariamente, percebia-se que a popularidade dos medicamentos - principalmente os secretos - era um obstáculo à consolidação das classes terapêuticas oficiais que reclamavam a necessidade de racionalizar esse comércio.

Um discurso realizado pelo farmacêutico Eugène Soubeiran na Academia de Medicina de Paris, em 1850 (mesmo ano que foi criada a JCHP no Brasil), e amplamente divulgado pelo jornalismo médico brasileiro da época, destacou a ação dos remédios que geravam riqueza a determinadas pessoas "à custa da saúde e da credulidade da população" (VELLOSO, 2007, p.138). Para esse farmacêutico, era preciso abandonar a farmácia galênica e simplificar as prescrições e os compostos. Os remédios deveriam ser investigados por um comitê de notáveis antes de serem liberados para o público em geral. Esse tipo de medida, por atentar para interesses econômicos e aos hábitos populares, era inaplicável. "O charlatanismo era visto então, como um mal invencível pelos interesses da moralidade e da saúde pública" (VELLOSO, 2007, p.144), tanto na França, quanto no Brasil.

Francisco Paulo Cândido, médico que coordenou a JCHP entre 1850 e 1864, declarou serem os principais objetivos desta instituição, tanto promover estudos sobre as causas da insalubridade pública, quanto à apresentação de medidas higiênicas 
capazes de garantir "a saúde e o vigor do corpo, e a consequente elevação da moral" (apud VELLOSO, 2007, p.149). As inspeções e demais tarefas de polícia médica, vistas como tão necessárias pela AIM e outras instituições médicas e farmacêuticas do período, eram entendidas como uma sobrecarga para a JCHP. Para ele, o ideal seria que tais atribuições fossem de alçada da justiça territorial, pois as comissões de higiene que atuavam nas capitais não tinham estrutura para fazer a fiscalização que era necessária nesse campo.

A partir da segunda metade do século XIX percebe-se também a institucionalização das associações farmacêuticas - Sociedade Farmacêutica Brasileira (1851) e Instituto Farmacêutico do Rio de Janeiro (1858). Esses círculos de profissionais atuavam em outros espaços institucionais representativos da arte de curar, como a AIM, JCHP e a FMRJ, procurando imprimir uma agenda política própria (VELLOSO, 2007, p.10-13). Eles defendiam que os produtos farmacêuticos poderiam e deveriam ser fabricados no Brasil, garantindo assim a qualidade e a autonomia ao mercado interno. Também criticavam muito a orientação liberal que permitia a venda de remédios a partir do critério de adesão da população, mesmo quando eles eram desaconselhados pelas associações farmacêuticas. Essas associações atuaram junto à JCHP na elaboração e revisão das listas de medicamentos indispensáveis para o país (VELLOSO, 2007, p.150-155). É dentro desse contexto que a JCHP solicitava as farmácias a posse de manuais de medicina com os formulários dos principais medicamentos, conforme visto no Capítulo dois. Até a década de 1880, entretanto, a JCHP não tinha contratado um farmacêutico permanente para seus quadros. Existia no interior dos quadros dessa instituição, assim como entre a população em geral, a preferência pelos produtos importados. Até o fim do Império essas sociedades seguiam reclamando que "ferragistas, livreiros, vendedores ou negociantes de fazendas" (VELLOSO, 2007, p.156) continuassem a vender os produtos que deveriam ser monopólio de farmácias e de drogarias.

Até meados da década de 1880, portanto, existiam duas esferas de controle que atuavam de maneira sobreposta: a primeira sustentada pelo poder local e representada pelos Juízes de Paz e as Câmaras Municipais; a segunda sustentada pelo poder imperial e representada pela JCHP e seus delegados que atuavam nas capitais das Províncias. No final do período imperial esse sistema sofreu uma modificação na esfera imperial através do Decreto $\mathrm{n}^{\circ}$ 9.554, de 3 de fevereiro de 1886. A JCHP foi extinta e no seu lugar foram criados: o Conselho Superior de Saúde Pública, com representantes da 
medicina oficial e altos burocratas; Inspetoria Geral de Saúde dos Portos; Inspetoria Geral de Higiene (HOCHMAN, 2006, p.95). O desmembramento da JCHP foi motivado por duas razões:

\footnotetext{
"a necessidade de formular uma legislação precisa com relação à fiscalização dos gêneros alimentícios, em especial os vinhos e os preparados farmacêuticos e delinear medidas eficazes para fiscalização dos portos a fim de impedir que a pandemia do cólera reinante desde 1882, chegasse aos portos brasileiros" (ALVES, 2015, p.02).
}

As mudanças realizadas no âmbito imperial não duraram - pouco se sabe ainda sobre a atuação dessas novas instituições. Mas não deixa de ser relevante a preocupação com o ingresso, no país, de "gêneros ilícitos ou de má fé" (ALVES, 2015, p.04).

A mudança de regime político, da monarquia para a república, alterou o desenho institucional acima descrito. No século XIX existia o lobby por parte das classes terapêuticas organizadas em defesa de uma restrição do comércio, justificada por motivos "técnicos". O poder político, tanto em nível local, quanto imperial, era reticente a esse tipo de medida porque a identificava como uma forma de privilégio associado aos autoritarismos portugueses. A questão da embriaguez pública foi objeto de preocupação das elites desde o início da formação do Estado brasileiro - atribuição que ficou ao encargo das autoridades locais.

Assim que foi realizado o golpe militar que derrubou a Corte, vários grupos passaram a se mobilizar para definir mudanças na ordem institucional do Estado. Koerner (1998, p.144-147) identifica algumas dessas forças políticas: os positivistas; os militares ligados à Deodoro que pretendiam manter a centralização; líderes regionais de Estados mais pobres que pretendiam ampliar sua autonomia, porém mantendo prerrogativas do poder central; liberais e republicanos históricos, que se aliavam às oligarquias dos Estados mais ricos na defesa de um federalismo radicalizado. Essas disputas se manteriam bastantes vívidas entre 1889 e 1891, quando se define pelo presidencialismo federalista inspirado nos estadunidenses.

Uma das primeiras medidas do novo governo foi o Decreto $\mathrm{n}^{\circ} 847$, de 11 de outubro de 1890, promulgando um novo Código Penal - antes mesmos da Constituição de 1891. Ao contrário do que aconteceu com o código anterior (1830), esse foi recebido com críticas pelos positivistas por ainda estar demasiadamente preso às concepções clássicas iluministas (CAULFIELD, 2000, p.69-71). Koerner (1998, p.161-162), adepto 
de uma história mais tradicional, destaca a atuação de Campus Sales na articulação política pela antecipação da promulgação do Código Penal. Essa teria sido uma resposta dos paulistas à derrota da sua proposta de dualidade do direito material (civil, comercial e criminal). Em compensação, no direito processual - complexo de normas jurídicas que dispõem sobre a organização das competências da justiça - foi permitida essa dualidade. Isso viabilizou aos Estados promulgarem códigos processuais próprios e garantissem a sua autonomia sobre os sistemas de justiça criminal.

O Código Penal de 1890 trouxe algumas normativas que interessam ao tema dessa pesquisa. Foi publicado um Capítulo sobre Saúde Pública prevendo: prisão para o exercício ilegal da medicina (artigo 156) e para aqueles que ministrarem ou prescreverem "sob qualquer forma preparada, substancia de qualquer dos reinos da natureza, fazendo, ou exercendo assim, o ofício do denominado curandeiro" (artigo 158). Outra normativa penalizava quem expõe a "venda, ou ministrar, substâncias venenosas, sem legitima autorização e sem as formalidades prescritas nos regulamentos sanitários" (artigo 159). A embriaguez pública, antes de esfera do Juiz de Paz, também foi introduzida na lei no Capítulo sobre Mendigos e Ébrios. Era prevista prisão, por até quinze dias, para aqueles que se embriagassem por hábito ou se apresentassem bêbados no espaço público (artigo 396) e para os donos de estabelecimento que vendiam bebidas “ou substâncias inebriantes" (artigo 398). Embriagar ou aumentar a embriaguez de alguém em lugar frequentado pelo público era igualmente punido com pena de quinze a trinta dias de prisão (artigo 397).

O privilégio das classes terapêuticas oficiais e a repressão aos ébrios não são novidades - isso já estava previsto nos ordenamentos do período anterior. A grande diferença está nas esferas responsáveis pela efetivação dessa normativa. A unidade do direito material, que impedia os estados de promulgarem seus próprios códigos criminais, impunha urgência na promulgação de um novo Código Penal como meio de garantir aos estados a autonomia "a respeito dos delitos que, no regime anterior, eram da competência dos municípios" (KOERNER, 1998, p.162). Passou-se, portanto, da esfera municipal para a esfera estadual.

A autonomia estadual também foi obtida no que se refere à organização sanitária. Logo que assumiu, o governo provisório buscou "ampliar o poder da Inspetoria Geral de Higiene sobre os estados e adicionar-lhe mais atribuições, 'desmunicipalizando a higiene'” (HOCHMAN, 2006, p.95). Essa tendência, entretanto, foi revertida na Constituição de 1891. "Ainda que não haja nenhuma menção à saúde e 
ao saneamento no texto constitucional, estabeleceu-se a interpretação, por meio dos artigos $5^{\circ}$ e $6^{\circ}$, de que esses assuntos caberiam aos municípios e estados" (HOCHMAN, 2006, p.95-96). Coube ao governo federal unicamente atividades referentes aos serviços sanitários marinhos, antigamente de alçada da Inspetoria Geral de Saúde dos Portos que acabou extinta. Para seu lugar foi criada a Diretoria Geral de Saúde Pública (DGSP), diretamente subordinada ao Ministério da Justiça e Negócios Interiores, responsável também pelas ações de saúde no Distrito Federal - entre elas a fiscalização da medicina e da farmácia, conforme veremos mais abaixo.

A partir de 1891, portanto, temos a consolidação da descentralização da justiça criminal e dos serviços sanitários. A natureza do novo regime político fica evidenciada em uma polêmica ocorrida entre dois conceituados médicos e professores, pessoas influentes na política da época - Azevedo Sodré e Nina Rodrigues. O primeiro, fluminense, criticava a indicação de um médico baiano para o cargo de inspetor-geral da DGSP por esse não conhecer a realidade sanitária da capital federal. Nina Rodrigues sai em defesa do seu conterrâneo argumentando que o ocupante desse cargo deveria se ocupar não apenas do Distrito Federal, mas do país inteiro. Para o baiano, as organizações em bases estaduais só se justificariam nesse primeiro momento como uma etapa para a construção de uma política nacional. A

\footnotetext{
"licenciosidade na autonomia concedida não garantiria que todas as unidades implementariam medidas higiênicas. O resultado disso seria que os estados com mais recursos teriam um serviço sanitário regular, outros teriam serviços precários, e , talvez, a maioria nada ofereceria",62 (HOCHMAN, 2006, p.116)
}

A descentralização do serviço sanitário levaria a uma retomada do velho problema de uma higiene desmedicalizada comandada por autoridades locais sem conhecimento técnico. Nina Rodrigues, nas páginas da Gazeta Médica da Bahia, procurou influenciar as decisões do estado da Bahia defendendo a centralização dos serviços na esfera estadual. "Lutando pela aprovação de uma legislação estadual centralizada, caminho que lhe parecia o mais viável para chegar a uma centralização federal, o que Nina Rodrigues combatia em primeiro lugar era a autonomia municipal" (CORREA, 2013, p.83). O atraso do município e a interferência "surda dos interesses partidários" sobre os parâmetros internacionais de organização sanitária, que se

\footnotetext{
${ }^{62}$ Itálico no original.
} 
pretendiam universais, eram os principais problemas que deveriam ser enfrentados pela classe médica (CORREA, 2013, p.80-84).

Essas considerações de Nina Rodrigues são exemplares dos limites e das contradições impostas pelo modelo institucional federativo que foi consagrado na carta constitucional de 1891. As políticas adotadas pela DGSP na capital federal deveriam ser consideradas parâmetros para as demais cidades do país - porém isso não significava que elas seguiriam a mesma política adotada na capital, tanto por causa dos limites orçamentários, quanto pela possibilidade de seguir outra política com a autonomia federativa. Mostrou-se, na seção anterior, que a repressão à embriaguez pública e a regulação do comércio de gêneros farmacêuticos dependeu dos esforços dos poderes locais - as Câmaras Municipais e os Juízes de Paz. Somente nas capitais existiam escritórios da JCHP com incumbência de fiscalizar os regulamentos sanitários. Depois da mudança de regime, a união se retirou das províncias deixando a higiene pública a cargo dos Estados, que deveriam providenciar um novo pacto com os municípios.

Essas considerações realizadas acima abrem espaço para uma verdadeira agenda de pesquisa. Muito ainda existe para se conhecer a respeito do esforço antialcoólico realizado em âmbito local no período imperial, com análise dos jornais, dos Códigos de Postura e dos Termos de Bem-Viver. A partir do advento da República, as pesquisas sobre as políticas de controle da ebriedade e de venda de medicamentos terão que considerar também a organização dos serviços sanitários em âmbito estadual. $\mathrm{O}$ federalismo como modelo institucional abrirá espaços para a formulação das primeiras medidas proibicionistas no Brasil, ainda que restritas a determinados Estados.

\subsection{O proibicionismo federalista (1904-1932)}

A definição de um marco temporal para o estudo histórico precisa respeitar as particularidades do objeto analisado. O liberalismo, conforme caracterizado acima, não deve ser confundido com ausência de regulamentação. Vimos que o monopólio farmacêutico em matéria comercial era defendido desde os tempos coloniais e o intento antialcoólico esteve presente desde o inicio da formação das instituições brasileiras. A defesa do monopólio farmacêutico era uma forma de privilégio comercial que não afetava o livre acesso aos fármacos, pois a obtenção de antálgicos ou estimulantes não dependia da classe terapêutica oficial. O que limitava o acesso eram os recursos 
financeiros e não a receita médica. $\mathrm{O}$ álcool, igualmente, não era restrito - o que era motivo de reclusão era a embriaguez em espaço público.

É no interior do sistema político federalista, caracterizado no final da seção anterior, que serão feitas as primeiras experiências efetivamente proibicionistas no Brasil. A própria natureza do modelo político impede de pensarmos em uma política nacional propriamente dita, pois a adoção das medidas nesse campo dependia dos estados e dos arranjos realizados com os municípios. Impossível para uma única pesquisa, nos moldes da atual, percorrer a realidade de todos os entes federados. Por isso, o foco dessa exposição será feito sobre três estados específicos em diálogo com a historiografia, quando houver. São eles: Rio de Janeiro, por ser a capital federal e teoricamente seguir de exemplo a todos os outros; São Paulo, por ser o mais rico estado da federação e por ter desenvolvido uma política sanitária exemplar e autóctone; Rio Grande do Sul, por sem um estado com forte influência do positivismo e por ter uma organização sanitária particular em decorrência disso. Certamente essas escolhas não esgotarão o tema, mas servem para colocar algumas questões e parâmetros de comparação para futuros estudos que abordarão outros estados e regiões do país.

A primeira normativa importante que precisa ser destaca é o Decreto $\mathrm{n}^{\mathrm{o}} 2.449$, de $1^{\circ}$ de fevereiro de 1897, que extingue o Instituto Sanitário Federal e a Inspetoria Geral de Saúde dos Portos, passando seus serviços para uma única repartição que foi denominada de DGSP (artigo 1). Entre as suas competências está "físcalizar o exercício da medicina e da farmácia" (artigo 2), porém ela "em caso algum poderá intervir administrativamente em serviço de higiene municipal" (artigo 8), salvo "mediante solicitação" dos Estados "e verificado o caso de calamidade publica" (artigo 2). A autonomia dos serviços sanitários, que era uma interpretação dos artigos $5^{\circ}$ e $6^{\circ}$ da constituição, se torna uma normativa.

Em 1904, ou seja, cinco anos antes da Conferência de Xangai (1909) que iniciava os esforços estadunidenses no Oriente, o Brasil promulgava sua primeira normativa proibicionista. A reorganização dos "serviços da higiene administrativa da União" - através do Decreto no 1.151 , de 5 de janeiro de 1904 - foi completada com a promulgação do novo regulamento "dos serviços sanitários a cargo da União" - através do Decreto $\mathrm{n}^{\mathrm{o}} 5.156$, de 8 de março do mesmo ano. A Parte IV, que trata da Fiscalização do Exercício da Medicina e da Farmácia, proíbe o anúncio da venda de remédios secretos ou "preparados medicamentosos" em estabelecimentos que não estejam licenciados. Com exceção dos remédios 
"de uso ordinário e inofensivo, consignados nas tabelas aprovadas pelo Governo, e os preparados oficinais licenciados pela Diretoria Geral de Saúde Pública, nenhum outro medicamento ou preparado poderá ser vendido pelo farmacêutico ou fornecido a quem quer que seja, sem receita de médico competentemente habilitado" (Artigo 264, §1).

Era prevista pena de multa de $100 \$ 000$ e o dobro na reincidência.

É possível questionarmos se esse regulamento foi efetivamente cumprido e até mesmo a sua abrangência, uma vez que ele só valia para os serviços sanitários administrados pela união. Sarti (2015, p.99-102) destaca que antes da promulgação da Lei de 1921 - que veremos mais abaixo - as autoridades sanitárias vinham coibindo a venda dessas substâncias com base no artigo 159 do Código Penal. O problema é que o Código Penal não restringia a venda de medicamentos ao público em geral, mas apenas restringia a venda às pessoas "sem legitima autorização e sem as formalidades prescritas". O farmacêutico ou o boticário, devidamente cadastrado estava habilitado a vender qualquer um dos produtos colocados à venda.

O primeiro ordenamento efetivamente proibicionista era limitado em termos geográficos e, possivelmente, não foi respeitado automaticamente por farmacêuticos e outras pessoas que consumiam as substâncias a partir de então com venda restrita. Não é possível determinar se ocorreu uma tentativa real de fazer essa normativa se efetivar sem uma pesquisa exaustiva com a documentação da justiça/polícia sanitária do Distrito Federal. Até que novos estudos sobre esse tema sejam efetuados, parece que a ação fiscalizadora nesse campo foi mais reativa do que proativa - como sugere as fontes que serão apresentadas abaixo.

Em 04 de janeiro de 1913, o jornal A Noite do Rio de Janeiro lançou uma matéria de capa intitulada "A cocaína, o veneno da moda, é vendida sem a menor cerimonia. Em meia hora a reportagem da 'A Noite' compra, em diversos bairros, 37 gramas de cocaína!" Segundo essa reportagem "não foi preciso nenhum disfarce, nenhum artifício. Bastava cada repórter entrar na farmácia e pedir: um vidro de cocaína". A única variação encontrada pelos jornalistas foi no preço, que variava entre $1 \$ 000$ e $2 \$ 500$, fato que mostrava como "é bastante elástica a consciência dos nossos farmacêuticos..." Era preciso dar um basta nesse tipo de abuso porque, segundo o jornal, noventa por cento dos suicídios que ocorriam na capital teriam sido realizados com emprego dessa substância. "Os manuais de medicina previnem que basta às vezes um 
grama para provocar fenômenos de envenenamento. Por esse calculo os nossos 37 vidrinhos mandariam ao cemitério apenas 37 cadáveres!"63 Os repórteres que se espalharam pela cidade e compraram a referida substância de vários estabelecimentos puderam constatar que ela era vendida até mesmo para crianças. A matéria termina com a enumeração de todas as farmácias visitadas, apontando que apenas poucas delas exigiam receita médica como prevê o regulamento sanitário.

Dois dias depois, o mesmo jornal volta ao tema. A nota de título "A venda de cocaína - os infratores vão ser multados" trazia uma manifestação do Diretor Geral de Saúde Pública apontando que as farmácias que venderam cocaína seriam multadas por infringirem o regulamento sanitário. O jornal publica na íntegra o artigo 264 destacado anteriormente. A promessa do diretor efetivamente foi cumprida, pois foram encontrados no Arquivo Nacional alguns processos instaurados por esse tipo de infração do regulamento sanitário.

Foi o caso do farmacêutico Júlio Cezar de Paula Freitas, que contratou um advogado para defendê-lo perante a justiça. Ele trouxe duas testemunhas para negar a denúncia: A primeira disse que é proprietário de outra farmácia e que fornece cocaína para o acusado, podendo afirmar que ele não vendia cocaína para o estabelecimento do acusado ha mais de dois anos; A segunda testemunha, morador da mesma rua da farmácia do acusado, disse que nunca viu venderem cocaína naquele local. O juiz, porém, decidiu que versão da autoridade sanitária competente tem fé pública, salvo prova em contrário. As testemunhas não estavam no dia e na hora da infração, logo, não invalidam a multa de $100 \$ 000$. Foi expedido um mandato de intimação para o réu pagar a multa, porém ele se negou. Dessa forma, o juiz determinou que ele fosse preso e encaminhado a Casa de Detenção pelo prazo de 20 dias, 4 horas e 30 minutos. Frente a essa determinação o réu decidiu pagar a multa (AN, Infração Sanitária de Júlio Cezar de Paula Freitas, 1913). O farmacêutico Carlos Martins Vieira, por sua vez, alegou que estava viajando na ocasião e que tinha deixado regras explícitas para seus funcionários não venderem cocaína, porém o juiz manteve a condenação (AN, Infração Sanitária de Carlos Martins Vieira, 1913). O farmacêutico Luiz de Mattos Pimenta, por sua vez, alegou que tudo isso não passava de um factoide do jornal $A$ Noite, porém igualmente foi multado em $100 \$ 000$ (AN, Infração Sanitária de Luiz de Mattos Pimenta, 1913). Outros preferiram não se defender e simplesmente pagar a multa.

\footnotetext{
${ }^{63}$ Negrito no original.
} 
Essa ofensiva da polícia sanitária, apesar de ter inibido os abusos, não parece ter resolvido o problema. Essa é a opinião do jornal $A$ Noite em matéria intitulada "Podemos obter veneno? O abuso da venda da "cocaína"” publicada em 11 de abril de 1913. Segundo essa reportagem, com sua campanha do começo do ano, o jornal "lembrou à Saúde Pública o texto de velhos regulamentos sobre as farmácias" fazendo que "os envenenamentos por meio desse veneno diminuíram e chegaram mesmo a desaparecer de todo". O mesmo teste realizado anteriormente mostrou que a maioria das farmácias passou a exigir receita "temendo a ação da Saúde Pública", porém ainda existem farmacêuticos que descumprem o regulamento. "Mas o abuso já está bastante restrito. Com um novo esforço das autoridades sanitárias, fazendo cumprir a lei, certamente que desaparecerá".

Esses episódios descritos acima sugerem que o problema da venda de tóxicos estava associado aos suicídios e que o serviço sanitário era relapso com a fiscalização. Os jornais parecem ter tido um papel importante na formulação de um problema das drogas durante a década de 1910 na cidade do Rio de Janeiro. ${ }^{64}$ Mais que a difusão do tema, gostar-se-ia de salientar que tais regulamentos e iniciativas de controle antecedem os decretos $\mathrm{n}^{\mathrm{o}} 2.861$, de 8 de julho de 1914, e $\mathrm{n}^{\mathrm{o}} 11.481$, de 10 de fevereiro de 1915, que aprovam as disposições acordadas em Haia. Frente a essas evidências fica um pouco difícil crer que o Brasil tenha se mantido "em grande medida incólume ao problema das drogas durante décadas" (SILVA, 2013, p.91), apenas aceitando orientações que tenham vindo do exterior.

Outro ponto de comparação com o que acontecia no exterior pode ser estabelecido também através da confrontação entre o Decreto ${ }^{\circ} 5.156$, de 8 de março de 1904, e a Food and Drug Act, promulgada nos EUA em 1906. Rodrigues (2004, p.46) considera essa lei um marco da intervenção estatal na conduta individual "sob o pretexto paternalista de proteção institucional’". Escohotado (2008, p.518-519) elogia o regulamento porque seu princípio era colaborar com a administração privada com informações. O regulamento dos serviços sanitários da união determinava, em 1904, que os "preparados oficinais" deviam utilizar somente produtos da farmacopeia vigente - francesa naquela ocasião. Qualquer alteração na fórmula era proibida, assim como vender produtos adulterados ou falsificados (artigo 263). Eram "expressamente proibidos o anúncio e a venda de remédios secretos" assim como a venda em lugares

\footnotetext{
${ }^{64}$ Pesquisa na Hemeroteca Digital da Fundação Biblioteca Nacional com a palavra "cocaína" nos jornais do Rio de Janeiro, entre 1910 e 1919, aponta 2351 ocorrências.
} 
não autorizados. "São considerados remédios secretos os preparados oficinais de fórmula não consignada nas farmacopeias admitidas e os não licenciados pela" DGSP (artigo 264). Depois de obter a autorização da DGSP, “deverá nos respectivos rótulos indicar a farmacopeia em que as fórmulas dos preparados se acharem inscritas". Serão considerados secretos os remédios que não tiverem essa informação no rótulo (artigo 265). "O inventor de qualquer antisséptico, remédio ou perfumaria" deverá solicitar licença da DGSP através de um relatório indicando a composição do produto e as finalidades que ele deve ser aplicado. Esse relatório será lacrado e aberto somente pelo diretor geral e, depois de analisado, será novamente lacrado e depositado no "arquivo da repartição"; Junto com o relatório deverá ser enviado uma mostra do produto para que seja remetido ao Laboratório Nacional de Analises, a fim de que seja emitido um parecer (artigo 266). No que se refere ao "melhoramento em fórmulas já conhecidas", também se fará necessária à licença da DGSP (artigo 267).

Todas essas considerações apontadas mostram a similaridade com o que foi determinado posteriormente pela Food and Drug Act estadunidense. Ao permitir apenas a venda de produtos que estejam licenciados na DGSP, a união restringe como legítimas somente as fórmulas previamente consideradas - transformando a arte de formulação em monopólio médico. Ao mesmo tempo, é uma forma de proteção ao consumidor porque passa a exigir que os fabricantes expunham a fórmula em rótulos. Até alguém descobrir o "arquivo da repartição" com as fórmulas licenciadas ou outras referências será difícil avaliar até que ponto essa lei se efetivou. Mas é indiscutível a motivação proibicionista da normativa.

Antes de avançar para os anos de 1920 e discutir a lei de 1921, que transferiu da justiça sanitária para a justiça penal a questão das substâncias de caráter entorpecente, cabe também apresentar o contexto de emergência do proibicionismo em São Paulo. Esse estado era o mais rico do país, considerado a "locomotiva" do Brasil (LOVE, 1982). A ampla disponibilidade de recursos permitiu a adoção de uma das mais avançadas políticas sanitárias do continente, podendo ser comparada inclusive com as da Europa (HOCHMAN, 2006, p.210). A política sanitária desse estado, na visão da elite médica e política, era a base de transformação de São Paulo em "centro civilizador e fundador de um Brasil progressista e nitidamente superior” (MOTA, 2005, p.16).

Vimos que, com a definição do federalismo, a união se retira dos estados deixando a higiene pública a cargo dessa entidade e dos municípios. Vimos também o engajamento de Nina Rodrigues pela estadualização desses serviços na Bahia, pois ele 
creditava aos municípios a causa do atraso do país nesse campo. Em São Paulo, a política sanitária esteve em consonância com a perspectiva defendida por Nina Rodrigues, pois buscou a centralização dos serviços e esvaziamento das competências municipais. As instituições sanitárias estaduais desenvolveram uma série de ações interventoras que encontravam resistências nas populações rurais, criando rivalidades entre as elites citadinas e rurais (MOTA, 2005, p.53-59). Existia o imaginário de que o interior de São Paulo estaria tomado por doenças por causa do abandono de sua população. A figura do Jeca Tatu, desenvolvida por Monteiro Lobato, é aquela que precisava ser superada a partir da intervenção saneadora do poder público (MOTA, 2003, p.83-84).

O Decreto $n^{\circ} 233$, de 2 de março de 1894, que estabeleceu o Código Sanitário de São Paulo, não tinha nenhuma referência à regulamentação do uso ou do comércio de drogas ou ao exercício da medicina. Isso talvez seja justificado pelo fato dos paulistas terem articulado a promulgação do Código Penal de 1890 e essas atividades estarem previstas em um título específico sobre a saúde pública, conforme foi visto. A ausência dos regulamentos específicos, entretanto, não impediu que a questão fosse abordada a partir da grande imprensa paulista.

Um dos primeiros temas que surgiu foi a questão do ópio, tanto através da repercussão do evento de Xangai, em fins da década de 1910, quanto com matérias que explicavam cientificamente o poder viciante do ópio e seus alcaloides. "Entretanto, a partir de 1912, o teor das notícias locais sobre entorpecentes ganharam um novo componente: a advertência da 'livre venda dos venenos', como tema das campanhas jornalísticas de "saneamento moral"” (CARNEIRO, 1993, p.91). Em 1913, o jornal A Gazeta transcreveu na íntegra à notícia da venda de cocaína feita pelo jornal A Noite, destacada anteriormente (CARNEIRO, 1993, p.99). Depois de 1914, as notícias sobre venda de entorpecentes se intensificam, mostrando que não apenas as farmácias vendiam "venenos" livremente, mas em cabarés e até mesmo em charutarias eram possíveis adquiri-los. O bar que ficava dentro do Teatro Municipal era um dos locais evidenciados nas notícias. Fonseca (1994, p.76) descreve o Municipal como "o quartelgeneral do vício". Carneiro (1993, p.136-141) aponta ainda a campanha moralizadora realizada pelo jornal A Capital, em 1916, criticando fortemente a omissão do Serviço Sanitário com esse tema. Para esse jornal, era necessária a criação de uma Polícia dos Costumes para resolver o problema. A polícia reagiu a esse quadro e alguns farmacêuticos foram conduzidos à delegacia e autuados. Percebe-se nessas notícias que 
a política sanitária de São Paulo - orgulho da classe política e instrumento de regeneração da população - era fustigada pela imprensa no que se refere ao controle sobre os entorpecentes.

A maioria das notícias trazidas por Carneiro (1993) se referem aos suicídios, geralmente com cocaína, envolvendo meretrizes e tramas amorosas. Em março de 1917, entretanto, um evento acabou percorrendo os vários jornais da capital paulistana - os clubes da morte. Eram locais onde jovens paulistanos se reuniam para se embriagar com diversos tipos de substâncias, em especial à cocaína, e confraternizarem com as meretrizes. O adjetivo "morte" foi adicionado depois que cinco pessoas faleceram em um único dia por usos abusivos de drogas. Esse evento teve repercussão na literatura médica paulista da época, (CARNEIRO, 1993, p.150). Também foi encontrada referência a esse acontecimento na obra Toxicomanias: meios para combatel-as, escrita por Plínio Martins Rodrigues em 1931 - quatorze anos depois do fato. Outro fator sintomático do efeito simbólico desse evento é a referência ao evento por parte da historiografia contemporânea (CARNEIRO, 1993; FONSECA, 1994).

Parece que essa mobilização da opinião pública foi importante para que houvesse a inclusão do tema das drogas na reforma do Código Sanitário de São Paulo que foi promulgada pela Lei $\mathrm{n}^{\circ}$ 1.159, de Dezembro de 1917. Em 9 de abril de 1918, foi publicado o Decreto n $\mathrm{n}^{\circ}$ 2.918, que dava "execução ao Código Sanitário" do ano anterior. Esse decreto seguia, em linhas gerais, o mesmo espírito do código sanitário federal no controle dos preparados oficinais. Algumas diferenças dignas de nota são: a exigência de prescrição médica seria necessária para os preparados medicamentosos, com exceção dos de uso ordinário e inofensivo. Se os medicamentos vendidos se tratassem "de anestésicos, especialmente a cocaína, o ópio e seus derivados, poderá ser ordenado, além da multa, o fechamento da farmácia" (artigo 122); a alusão à "Farmacopeia Paulista”, publicada em 31 de maio de 1917 (VASCONCELLOS, 1917), e que deveria servir de referência "enquanto não estiver organizada a Farmacopeia Brasileira" (artigo 139). Amplia-se o poder punitivo da autoridade sanitária em relação à venda de cocaína e analgésicos.

Em 1918, portanto, a "locomotiva" já estava com uma legislação proibicionista em funcionamento. As fontes utilizadas até agora, basicamente jornais e normativas legais, podem ainda dar a impressão que o tema das drogas no Brasil era uma invenção da imprensa ciosa em defender os costumes contra estrangeirismos indesejados. Para Carneiro (1993, p.109), o consumo de drogas era apresentado como uma moda 
estrangeira que afetava as classes altas como um vício chique. Essa é a mesma opinião de Dona Laura, esposa de Sousa Costa, ao descobrir que o marido tinha contratado a amante profissional Fräulen Elza para iniciar a vida amorosa de Carlos, seu filho.

Laura, Fräulein tem o meu consentimento. Você sabe: hoje esses mocinhos... é tão perigoso! Podem cair nas mãos de alguma exploradora! A cidade... é uma invasão de aventureiras agora! Como nunca teve!. COMO NUNCA TEVE, Laura... Depois isso de principiar... é tão perigoso! Você compreende: uma pessoa especial evita muitas coisas. E viciadas! Não é só bebida não! Hoje não tem mulher-da-vida que não seja eterômana, usam morfina... E os moços imitam! Depois as doenças!... Você vive na sua casa, não sabe... é um horror! (ANDRADE, 1927, p.57).

A crítica sagaz à sociedade burguesa paulista, feita por Mario de Andrade no clássico Amar, verbo intransitivo, não tinha como deixar de fora os medos tão comuns na elite da época. Mais do que uma passagem isolada, a referência ao uso de drogas, como a realizada pela Dona Laura, é recorrente na literatura. Referências que são duplamente esquecidas, como nos lembra Resende (2006, p.17-18), tanto pela "censura que tinha como base o conservadorismo, a religiosidade e a misoginia", quanto pelo "sucesso do ideário e da estética modernista, sobretudo a partir dos anos de 1930" que implicou na desqualificação das propostas artísticas do período anterior. Não são poucos os escritores e poetas que se dedicaram a esses temas: Olavo Bilac, João do Rio, Lima Barreto, Benjamin Costallat, Orestes Barbosa, Coelho Netto, José do Patrocínio Filho, Manuel Bandeira, Álvaro Moreira, Patrícia Galvão, entre outros; na música popular, com Sinhô. Em São Paulo, Fonseca (1994, p.117-126) nos lembra de Oswald de Andrade, Silvio Floreal, Laura Vilares, Amando Franco Caiuby e Raul de Polillo além do Mário de Andrade já destacado acima.

Dentre todos esses escritores o mais recordado pela historiografia contemporânea das drogas é Lima Barreto, pois suas memórias do hospício são uma referência original da experiência daqueles que sofreram o arbítrio do poder médico psiquiátrico da época (SARTI, 2015, p.76-82; SALLES, 2011, p.111-115). Os conflitos entre a classe artística e a intelectualidade científica podem ser medidos pela polêmica envolvendo a figura de João do Rio. Esse cronista carioca, que deixou descrições das casas de ópio do Rio de Janeiro, conforme vimos, foi alvo de uma biografia escrita pelo psiquiatra Inaldo de Lyra Neves-Manta que buscava caracterizá-lo como um "gênio 
degenerado de Lombroso" (SILVA, 2015, p.134). Suas investidas pelo submundo da cidade eram resultados dos "anseios de um incontrolável desvio de caráter" (SILVA, 2015, p.137) que o inspiravam a escrever uma "literatura mórbida" ao incitar a curiosidade da população sobre "contextos deflagradores e instituidores de atavismos" (SILVA, 2015, p.137).

Essas críticas à literatura "mórbida" representada por João do Rio, na polêmica acima, é resultado das preocupações morais - travestidas de científicas - geradas também pelas novas linguagens artísticas que surgiam nesse período, como o cinematógrafo, a fotografia e o gramofone. Existia a suspeita de que elas trouxessem "manipulações deliberadas e falsas" (SILVA, 2015, p.135). Se o tema do consumo de drogas é abundante na literatura e nos jornais, o mesmo pode ser dito em relação ao nascente cinema nacional. Uma pesquisa na Cinemateca Brasileira mostra que não foram poucos os filmes nacionais que abordaram essa temática: Depravação (1926), Vício e Beleza (1926), Entre as montanhas de minas (1928), Morfina (1927/1928), Traídos pelo Vício (1928), Sintonia da Floresta (1929), Romance de Linda (1930), Vício e Perversidade (1932). Às produções nacionais, acrescentam-se aquelas produzidas em outros países e que também entravam no circuito nacional, como o filme norueguês Sonhos do Ópio (1914).

A cultura como elemento de degeneração da população é tema frequente na literatura médica. Um exemplo é a obra de Álvaro Guimarães Filho, intitulada $D a$ hygiene mental e sua importância em nosso meio, defendida na Faculdade de Medicina de São Paulo (FMSP), em 1926. No Capítulo IV, onde ele aborda os "quais os principais fatores predisponentes das moléstias mentais entre nós" (FILHO, 1926, p.87), estão presentes tanto o "cinematografo", quanto à "literatura". Quanto ao cinema, ele se tornou "a principal distração do povo de todo o universo. Agrada a todas as idades e a ambos os sexos" (FILHO, 1926, p.128). Atraindo para suas salas grande quantidade de pessoas, os cinematógrafos se tornaram "uma verdadeira escola" (FILHO, 1926, p.128). Infelizmente, as instruções que esse tipo de passatempo tem trazido "são as que representam o crime e o vicio" (FILHO, 1926, p.129). Ele seria responsável "pela naturalidade que se apresentam os vícios mais degradantes da espécie humana" (FILHO, 1926, p.129). Por isso o "cinema é responsável por grande parte do desregramento social dos nossos tempos" (FILHO, 1926, p.130) constituindo em um "verdadeiro fator predisponente da alienação" (FILHO, 1926, p.130). Quanto à literatura, existem várias obras que pregam conselhos úteis para se compreender "a vida 
nos seus encantos e belezas, mas estes não são os mais procurados e lidos, e ficam como que abandonados" (FILHO, 1926, p.132). Os verdadeiros sucessos nas livrarias "são os livros da época, em que a malícia é percebida de principio a fim, ou que as obscenidades são descritas sem o mínimo pudor" (FILHO, 1926, p.132). Era preciso, na opinião desse médico,

\footnotetext{
"que houvesse um meio de evitar a exuberância de tais escritores, que nos romances, quer nas obras teatrais e principalmente nos que escrevem as folhas diárias, que muitas vezes trazem ao publico e ao alcance de todos, os factos mais degradantes da vida social" (FILHO, 1926, p.133).
}

O que é possível aferir de todas essas colocações é uma presença incessante do tema das drogas nos veículos culturais, sejam nos jornais, seja na literatura ou cinema. A intelectualidade científica, principalmente a medicina psiquiátrica, se preocupava com a influência desses temas sobre a moralidade pública, transcrevendo para termos técnicos preocupações de ordem moral. Esse era o contexto cultural no qual as normativas proibicionistas sobre drogas iam ganhando espaço no Brasil.

Paralelamente à questão das drogas, exposta acima, outro tema com maior impacto social começou a tomar relevância na agenda pública em fins dos anos de 1910 - contribuindo decisivamente para o recrudescimento do proibicionismo em 1921: o movimento antialcoólico ou da temperança no Brasil. No Capítulo anterior foi visto como o álcool se constituía em importante substância terapêutica, usado, entre outras formas, como um tônico; as cervejarias aproveitaram essa associação com as práticas medicinais para apresentar seus produtos como bebidas industriais, modernas, leves, propícias ao convívio social ameno e com qualidades nutritivas. Essas utilizações terapêuticas e a presença incessante da embriaguez na sociedade brasileira levaram parte da historiografia (MARQUES, 2014; SILVA, 2015) a adotar uma visão pessimista sobre a abrangência do movimento antialcoólico no Brasil, visão que era compartilhada pelos médicos militantes do início do século.

Essas considerações já começaram a ser relativizadas no Capítulo precedente. A crescente afirmação de algumas especialidades médicas, como a psiquiatria e a medicina-legal, criou um campo de atuação para médicos que se colocavam como profissionais alheios à tradição erudita identificada com a prática clínica; multiplicaramse as instituições, tanto no âmbito público, quanto no privado, voltadas para a internação de alcoolistas e toxicômanos; ganha espaço um discurso científico que 
associa um discurso racial e biologicista que buscava justificar as desigualdades e defender as hierarquias sociais. Nesse contexto os médicos são entendidos como os verdadeiros militantes da temperança no Brasil, isolados de outros grupos sociais. Marques (2014, p.222), comparando o movimento daqui com o dos EUA - que tinha forte presença dos religiosos - aponta que

\footnotetext{
Contrariamente à temperança nos EUA, o movimento aqui sempre foi leigo, pois os ativistas brasileiros eram em grande maioria médicos higienistas que não invocavam razões de ordem religiosa para que o Estado intervisse nos costumes etílicos da população (MARQUES, 2014, p.222).
}

Nós vimos, no Capítulo três, a convocação por parte dos moços cristãos para a fundação da LNCA do Brasil, fato que teria levado ao elogio da Sociedade Vegetariana do Rio de Janeiro. Miss Gordon, liderança internacional desse movimento foi recebida pelos representantes desta liga e conectado os militantes nacionais ao movimento anglosaxônico. Essa não foi uma iniciativa isolada. Segundo Marques (2014, p.224-225), entre os militantes que atuavam contra o álcool se destacam as feministas. A União Brasileira Pró-Temperança foi fundada por uma feminista estadunidense em 1894, porém assumida pelas brasileiras posteriormente. Uma das figuras de destaque nessa associação foi Jerônima Mesquita, que foi presidenta entre 1925 e 1950. Nas assembleias dessa organização só era permitido voto de mulheres. Para a autora, entretanto, mais do que mostrar a força do movimento antialcoólico essa presença das feministas demostra que "o consumo de álcool pelas classes populares esteve no centro dos embates da elite em torno do mais adequado projeto de nação para o Brasil". Segundo Machado (2007, p.230), em Florianópolis existia o serviço organizado dos "Mensageiros da Regeneração" que podiam ser solicitadas pelas esposas que precisassem de ajuda com seus maridos alcoólatras. As mulheres eram entendidas "como guardiãs do sossego do lar e responsável pela felicidade dos maridos e dos filhos, portanto, deveriam ajudar na regeneração dos alcoólatras".

Além das mulheres é possível encontrar a influência dessas concepções antialcoólicas no movimento operário. Em Fortaleza, por exemplo, as agremiações operárias e artesãs, como o Círculo Operário São José e a Escola de Aprendizes Artífices, se juntaram ao Centro Médico Cearense e as autoridades públicas ligadas ao Serviço de Saneamento Rural, tendo "uma participação decisiva na propagação das campanhas antialcoólicas na capital cearense” (COSTA, 2009, p.91). Essas associações 
operárias tinham forte influencia de lideranças católicas (COSTA, 2009, p.95-96). Aravanis (2005, p.151), que estudou as concepções de corpo operário presentes entre os seus militantes, mostra que a frequência à taberna, aos bailes e o consumo de álcool eram criticados como meio de enfraquecimento da luta de classes - discurso também verificado na militância de São Paulo. Existiria "uma clara relação de causa e efeito entre um corpo operário combalido pelo álcool e a impossibilidade de consciência e ação operária" (ARAVANIS, 2005, p.187).

A referência aos vegetarianos, ao feminismo, ao movimento operário e as ligações com a militância internacional são feitas no sentido de apontar a diversidade de agentes capazes de serem atraídos pelas bandeiras antialcoólicas - além da classe médica. Mais do que atividades isoladas, esses grupos poderiam dialogar e até mesmo se intercambiarem. A religião católica, com sua defesa da família, era mais um elemento a compor esse caldo cultural de rejeição ao consumo de álcool. Mota et al (2013, p.99114) vem destacando a influência do catolicismo sobre as concepções médicas da eugenia. Segundo Silva (2013, p.119), a Sociedade Eugênica de São Paulo de 1918, a primeira da América Latina, era composta basicamente por médicos, mas não somente por eles. Além dos interesses corporativos, os anais da sociedade apontam debates sobre “à legalização de exames pré-nupciais para prevenção e controle de casamentos e doenças venéreas, bem como as campanhas antialcoólicas".

Todos esses movimentos, de vários campos ideológicos e que não se resumiam a classe médica, compartilhavam entre si a bandeira antialcoólica. O movimento sanitarista que ganha força depois do relatório da expedição médico-cientista para o interior do Brasil, organizada pelo Instituto Oswaldo Cruz em 1912, tinha "uma vocação política e pelo apego a militância fora dos círculos estreitos do mundo médicosocial" ${ }^{65}$ (SANTOS et al, 2015, p.81). Esse movimento considerava as doenças o principal problema nacional, resultado do descaso das elites, entrave que faria da "brava gente" um bando de

“inválidos, exangues, esgotados pela ancilostomíase e pela malária; estropiados e arrasados pela moléstia de Chagas; corroídos pela sífilis e pela lepra; devastados pelo alcoolismo; chupados pela fome, ignorantes, abandonados, sem ideal e sem letras"66 (MOREIRA, 1916 apud HOCHMAN, 2006, p.64).

\footnotetext{
${ }^{65}$ Itálico dos autores.

${ }^{66}$ Grifo meu.
} 
Esse excerto foi retirado de um discurso famoso de Juliano Moreira, considerado o marco fundador do movimento sanitarista, por inaugurar a imagem de que o Brasil é um grande hospital (HOCHMAN, 2006, p.63). Eram populações que não tinham nenhuma identificação com os ideais da pátria, isoladas "pelo abandono por parte do Governo federal, presente apenas para extrair recursos de uma população que quase não os possuía" (HOCHMAN, 2006, p.67). Importante destacar que essa ideia de interiorano ou sertanejo não deve ser tomada como uma categoria geográfica, mas social, pois sua "sua localização espacial dependeria da existência do binômio abandono e doença" (HOCHMAN, 2006, p.70). É nesse sentido que a fala de Afrânio Peixoto, de que o sertão começava na Avenida Central do Rio de Janeiro, deve ser compreendido. O combate ao alcoolismo era uma espécie de tema transversal que aparecia em diversos militantes engajados nas causas progressistas da época.

Esses poucos, embora muito atuantes em uma profusão de ligas e movimentos associativos, particularmente após os anos da Primeira Guerra Mundial, encontravam a oposição de uma espécie de massa inercial poderosa, resultante de uma tradição de descrença que remontava às elites do Império (SILVA et al, 2015, p.78).

O discurso antialcoólico precisa ser compreendido, portanto, como parte de uma crítica mais ampla à política oligárquica que dominava o cenário político da Primeira República. Segundo Marques (2014, p.232-236), ao longo dos anos de 1910 vários projetos visando à restrição da venda de álcool, e até a proibição total como nos EUA, foram enviados ao Congresso Nacional. Mesmo que contassem com a simpatia da imprensa e dos movimentos progressistas, os "projetos pró-temperança encontravam forte resistência de parlamentares ligados à lavoura de açúcar”. Os fracassos desses projetos estão por trás da visão bastante negativa sobre a capacidade do movimento antialcoólico em interferir nas políticas públicas, exposta por Evaristo de Moraes e reproduzida pela historiografia, conforme vimos no Capítulo precedente.

Para Santos (1995, p.150), o discurso contra o alcoolismo só teria sentido em uma sociedade capitalista como a europeia, por isso os médicos "não atinavam com as características próprias da sociedade com a qual dialogavam”. Seus discursos, mesmo que repercutissem na imprensa, "não tinham de fato influência na organização sociojurídica”. A mesma conclusão chega Marques (2014, p.256) ao apontar que as 
iniciativas no campo político "não foram capazes de aprovar projetos de lei apresentados o Congresso", levando a militância a se restringir as disputas no campo da ética cotidiana.

Essa ideia de que o movimento da temperança foi ineficaz ao elaborar políticas públicas e pressionar o governo a adotar medidas antiálcool é tão fortemente arraigada que contraria até mesmo as evidências empíricas. Marques (2014, p.232-233), ao comparar a cerveja com a aguardente, aponta que a primeira ficou livre das medidas restritivas que foram sendo feitas ao consumo de álcool no distrito federal: em 1907, a cerveja ficou de fora das bebidas que deviam estar sujeita a repressão antialcoólica por parte das autoridades policiais; em 1912, foi criado um regulamento que proibia a venda de bebidas destiladas depois da 19 horas. A autora, então, destaca que essa bebida era produzida por "um número enorme de produtores dispersos na zona rural, longe do alcance da fiscalização". Apesar da incapacidade de acabarem com o consumo, tais "medidas restritivas ao funcionamento do comércio muniam a polícia de instrumentos para coibir o lazer popular". Ou seja, as restrições ao comércio de bebidas alcoólicas são pensadas com um sentido diferente da sua finalidade.

Essa não é a interpretação que faço dessas normativas. Ao lado das medidas restritivas ao comércio de entorpecentes, motivadas pelos reclames da imprensa e pela sensação de degradação dos costumes, todos esses regulamentos até o momento destacados fazem parte de uma resposta, por parte do poder público, aos anseios e à mobilização política do movimento antialcoólico. Esse movimento fazia parte de um contexto político mais geral de crítica à organização oligárquica, aristocrática e bacharelesca dos principais quadros políticos da Primeira República.

Esse foi o contexto político, cultural e social que motivou a promulgação do Decreto $\mathrm{n}^{\circ} 4.294$, de 6 de julho de 1921. Sarti (2015, p.107), que analisou os debates legislativos que levaram essa lei, lembra bem que não existia nada no compromisso firmado em Haia que previsse o estabelecimento de prisão para os casos de venda de tóxicos.

\footnotetext{
A penalização através do encarceramento como forma primordial de efetivar o combate aos usos considerados indevidos destes produtos não era uma determinação internacional, mas sim uma predileção de Metello. A opção por esse modelo não correspondia a um mero cumprimento aos acordos internacionais tratava-se do estabelecimento de uma maneira específica de efetuar a repressão em território nacional (SARTI, 2015, p.107).
} 
Essa interpretação, apesar de correta no que se refere ao caráter autóctone das medidas repressivas, ainda corrobora com uma visão de fraqueza dos movimentos sociais que lhe davam sustentação ao enfatizar como causa do recurso à prisão a predileção do autor do projeto original, o antigo delegado José Maria Metello Júnior.

O Decreto $\mathrm{n}^{\circ}$ 4.294, de 6 de julho de 1921, manteve a mesma linha daquilo que já vinha ocorrendo nos códigos sanitários destacados anteriormente: era proibido vender substâncias sem autorização nos regulamentos sanitários, com pena de multa de 500 a 1.000 por infração. Caso se tratasse de substância entorpecente, era prevista pena de prisão celular de um a quatro anos (artigo 1); Apresentar-se em público bêbado causando escândalo ou desordem, multa de $20 \$$ a $200 \$$, dobrando no caso de reincidência (artigo 2); o hábito de embriagar-se passou a ser punido com internação em "estabelecimento correcional adequado" (artigo 3); fornecer ou favorecer o embriagamento de outrem, multa de $100 \$$ a $500 \$$ (artigo 4); ficava estabelecida multa, igual a do artigo anterior, para dono de casa que promovesse comércio de "bebida ou substância inebriante" fora das horas fixadas pelas posturas municipais ou que venda esses produtos a menores de 21 anos, mesmo que destinado ao consumo de outrem (artigo 5).

No modelo federalista adotado pelo Brasil foi prevista unidade do direito material, ou seja, que as leis promulgadas na esfera federal seriam válidas para o país inteiro. Estava estabelecida a possibilidade de repressão, embora o artigo $1^{\circ}$ fosse claro que essas punições só seriam realizadas nas transgressões "as formalidades prescritas nos regulamentos sanitários" de alçada dos estados. Os restantes dos artigos desse decreto são destinados à organização da justiça e dos estabelecimentos correcionais que seriam usados na punição aos infratores; a previsão de regulamentação da entrada das substâncias tóxicas no país; orientações que podiam seguir de exemplo aos outros estados.

Poucos meses depois foi promulgado o Decreto $\mathrm{n}^{\circ} 11.969$, de 3 de setembro de 1921, com o regulamento do decreto de 1921. Silva (2015, p.261-297) analisou detalhadamente essa normativa apontando que ela apresentava três questões: $1^{\mathrm{a}}$. A regulamentação da entrada e da saída de substâncias entorpecentes do país; $2^{\mathrm{a}}$. As especificidades do rito processual e definição das penas; $3^{\text {a }}$. Previa a criação de uma organização especial de toxicômanos e alcoólatras. No que se refere a esse último item, consagra-se a "estratégia da segregação - à maneira da quarentena dos higienistas" 
(SILVA, 2014, p.287). Exatamente a mesma medida defendida por Evaristo de Moraes (1921, p.109-124) como a mais eficaz em matéria de repressão à embriaguez.

A opinião de outros especialistas a respeito dessas normativas do ano de 1921 pode ser elucidativa do significado desses decretos. Pernambuco Filho e Adauto Botelho escreveram um dos livros mais célebres a respeito da toxicomania, intitulado Vícios Sociaes Elegantes. (Cocaína, ether, diamba, ópio e seus derivados etc) - estudo clínico, médico-legal e prophylatico em 1924. Segundo eles, durante muito tempo nossas leis eram fracas, fato que "permitiam que as toxicomanias se espalhassem rapidamente até que o clamor das sociedades científicas conseguiu despertar, um pouco, o interesse dos poderes públicos" (BOTELHO et al, 1921, p.130). Graças aos esforços do Dr. Raul Camargo, "esforçado batalhador em prol da repressão dos vícios pelos tóxicos” (BOTELHO et al, 1921, p.130), foi aprovado pelo então Dr. Epitácio Pessoa o Decreto $n^{\circ} 4294$, estabelecendo penalidades para os contraventores da venda e "um estabelecimento especial para internação dos intoxicados pelo álcool ou substâncias venenosas" (BOTELHO et al, 1921, p.131). Na opinião dos autores, "nossa lei é boa, exequível e bem cuidada; merece porém, alguns adendos, apontados pelo correr do tempo e para intensificar a campanha com mais vigor" (BOTELHO et al, 1921, p.131).

Se a legislação era adequada, do ponto de vista médico, resta saber se houve esforços por parte das autoridades policiais e sanitárias no sentido de fazer cumprir os novos regramentos. No Rio de Janeiro, os Relatórios do Chefe de Polícia mostram que, até 1926, a perseguição aos entorpecentes figurava "ao lado de crimes e contravenções mais tradicionais, como os crimes contra a ordem pública, prostituição e lenocínio, jogos de azar, vadiagem e mendicância, acidentes com veículos, crimes contra a saúde pública etc" (SILVA, 2015, p.267). Esse ano, entretanto, é um marco da repressão aos tóxicos na capital porque é criada a $3^{\mathrm{a}}$ Delegacia Auxiliar encarregada especificamente de reprimir o comércio de entorpecentes e a embriaguez pública. O delegado Augusto Mendes ficou a frente dessa repartição entre 1926 e 1930. Sarti (2015, p.162-163) aponta que, no período em que essa delegacia especializada funcionou, "o fluxo de internações por toxicomania no Pavilhão de Observações dobrou, passando a uma média de 20 pacientes por ano até o fim da década de 1920”. Isso por causa das ações planejadas e executadas pela polícia.

Interessante perceber que a ideia de que o movimento da temperança no Brasil era inexpressivo é tão disseminado que contraria até mesmo as evidências empíricas ao contrário. O Relatório Oficial do Departamento Federal de Segurança Pública trouxe, 
em 1928, um mapa estatístico da natureza dos toxicômanos internados para tratamento durante o ano interior. De um total de 405 internados, 346 (76,88\%) eram em razão das bebidas alcoólicas e o restante de outras substâncias. Esses números

\footnotetext{
"atestam o quanto o abuso alcoólico foi alvo da ação policial e jurídica, especialmente diante de situações que, segundo os termos da lei, envolviam 'embriagado(s)', e correlatos, e 'bebida(s)', e não apenas 'substâncias entorpecentes'. No que se refere ao álcool, no entanto, a lei acabou não sendo assimilada, não surgindo efeito, de modo que a substância jamais chegou a entrar no rol oficial das substâncias ditas entorpecentes, narcotizantes ou mesmo tóxicas" (SILVA, 2015, p.245).
}

O fato do álcool não ser caracterizado de substância entorpecente, como sugere a autora, não faz dele uma preocupação menor do poder público. Pelo contrário, a sua difusão e popularidade o fazia alvo privilegiado de controle, conforme sugerem as próprias estatísticas policiais. Futuros estudos baseados nos processos-crimes e com os internados pelas campanhas policiais poderão trazer maiores informações sobre os territórios privilegiados pelas ações policiais e o perfil social dos processados.

Em São Paulo, infelizmente, não estão disponíveis as fontes policiais e da justiça durante a primeira república. O Arquivo Público desse estado somente disponibiliza fontes policiais até o início do século XX. Talvez seja possível recuperar alguma informação através dos processos-crime, porém o Arquivo do Tribunal de Justiça só permite a busca pelo nome dos réus - nesse caso seria necessário encontrar esses nomes em outras fontes, como na imprensa. De qualquer forma, seria um levantamento incompleto. Plínio Martins Rodrigues, que escreveu uma Tese sobre as toxicomanias na FMSP, em 1931, também tentou levantar dados sobre o número de viciados na cidade, sem sucesso.

“O Serviço Sanitário e a Policia de S. Paulo, encarregados de fiscalizar e descobrir um e outro grupo, respectivamente, de toxicômanos, e que com grande eficiência veem trabalhando nesse sentido, não possuem ainda, infelizmente, dados suficientes para o calculo de que nos vimos ocupando" (RODRIGUES, 1931, p.22).

Como vimos anteriormente, São Paulo demorou um pouco mais em relação ao Rio de Janeiro para promulgar os regulamentos sanitários proibicionistas. Antes de 1917, todo o esforço de fiscalização dependia do artigo 159 do Código Penal - 
normativa demasiadamente branda na opinião de Rodrigues. "Apesar disso, a nossa Polícia não se descuidava, como prova a intensa campanha movida pelo Dr. CANTINHO FILHO, então delegado auxiliar"67 (RODRIGUES, 1931, p.58). A partir de 1917, a legislação estadual ganhou em eficiência por causa do "dispositivo legal então criado" (RODRIGUES, 1931, p.58) que previa pena de multa e fechamento do estabelecimento de infratores. Sofriam os poderes públicos, entretanto, em decorrência da insuficiência de pessoal do serviço sanitário.

O governo federal se mostrava inerte ao flagelo social que tomava conta da sociedade. Felizmente, graças "à campanha mantida pela imprensa, pelas sociedades médicas e por todos que já se interessam no nosso país pelo problema, entre os quais cumpre destacar o Dr. RAUL CAMARGO"68 (RODRIGUES, 1931, p.55), foi promulgado o Decreto $\mathrm{n}^{\circ} 4.294$, de 6 de julho de 1921. Essa normativa ainda

\footnotetext{
"era completada no Estado pela lei de 30 de Dezembro do mesmo ano, que tirava do júri popular a competência para julgar os crimes previstos naquela, saneando-se os inconvenientes notados logo nas suas primeiras aplicações em S. Paulo, pois eram absolvidos todos os acusados á barra do tribunal” (RODRIGUES, 1931, p.59).
}

Para o delegado Guido Fonseca (1994, p.132), a Lei $\mathrm{n}^{\mathrm{o}} 1.859$, de 30 de dezembro de 1921, foi importante para acabar "com as escandalosas absolvições promovidas pelo Tribunal Popular". Com essas leis São Paulo tornava-se o mais engajado estado proibicionista da federação, como também o pioneiro em instalar uma Delegacia especializada com incumbência de reprimir esse tipo de delito com a Lei $\mathrm{n}^{\circ}$ 2.034, de 30 de dezembro de 1924, que reformou os serviços policiais. Segundo Fonseca (1994, p.137), que teve acesso exclusivo aos Anais do Gabinete de Investigações, o comércio de entorpecentes passou a ser uma das práticas mais combatidas pela Delegacia de Costumes e Jogos. Destacou-se como grande repressor ao tráfico de drogas o delegado Juvenal Piza.

Um aspecto interessante que podemos utilizar como comparação com outros países, e que denotam a força do proibicionismo paulista, diz respeito às terapias de manutenção. Muitas pessoas sofrem de dores crônicas até os dias atuais, fato que não era diferente naquela época. Uma das formas mais comuns de lidar com esse problema

\footnotetext{
${ }^{67}$ Caixa alta no original.

${ }^{68}$ Caixa alta no original.
} 
era através do consumo de opiáceos - em um primeiro momento de venda livre nas farmácias e, depois dos regulamentos proibicionistas, somente com receita médica. $\mathrm{O}$ aumento da autoridade médica, portanto, ajudou a criar um tratamento diferenciado conforme o poder aquisitivo - aos pobres se tornava mais difícil obter os antálgicos por causa do acréscimo dos custos com os médicos.

Conforme os aparatos repressivos vão se consolidando, esse tipo de habituação terapêutica começa a ser percebida com desconfiança pelas autoridades policiais - os médicos passam a ser vistos como colaboradores dos viciados. Vimos, no Capítulo três, que nos EUA o Harrison Act levou a uma longa batalha judicial entre autoridades policiais e classe médica, porque as primeiras passaram a perseguir as segundas. Dentro da visão mais ortodoxa do proibicionismo as terapias de manutenção eram percebidas como formas de desvio das normativas legais. Musto (1999, p.121-150) apresenta uma longa descrição daquilo que ele denominou de "O assalto federal as clínicas de manutenção". Essa, entretanto, não foi a regra em todos os países.

$\mathrm{Na}$ Inglaterra, por exemplo, as autoridades policiais também tentaram impedir a prescrição de drogas para usuários habituais, fato que levou a criação do Departamental Committee on Morphine and Heroin Addiction para avaliar a questão. Ao contrário dos EUA, os médicos tinham grande influência sobre o poder político. As atuações policiais dos estadunidenses foram apresentadas como um grande abuso e uma forma de interferência indevida na autonomia médica. Entre os médicos que defenderam a competência da sua classe para prescrever opiáceos esteve Sir. Humphrey Rolleston, nome até hoje referenciado entre os críticos ao modelo proibicionista. Preservou-se entre os usuários da classe média a possibilidade de utilizarem-se drogas que em outras classes eram vistas como sinais de degeneração (BERRIDGE, 2013, p.130-132).

Em São Paulo, as autoridades policiais desde cedo procuraram restringir a autonomia dos médicos em prescrever entorpecentes. Como as receitas ficam retidas nas farmácias, a atenção da fiscalização

\footnotetext{
"é atraída para receitas de tóxicos repetidas com demasiada frequência ou contendo doses exageradamente altas de entorpecentes, ou ainda apresente qualquer particularidade que autorize a pensar se destinem elas a alimentação do vício" (RODRIGUES, 1931, p.63).
}

Nesses casos a Inspetoria chama o médico para obter os esclarecimentos. A punição não é aplicada no primeiro momento, pois se apela "para os seus sentimentos 
de dignidade profissional, processo altamente elogioso e que tem mostrado a sua eficácia já por várias vezes" (RODRIGUES, 1931, p.63). Sem conseguir nada por esse meio, o médico é punido. Não foram encontradas referências a clinicas que forneçam entorpecentes.

No Rio de Janeiro, Silva (2015, p.254) aponta a existência de algumas notícias criticando o fato das farmácias alimentarem livremente o vício daquelas pessoas que possuíam receita médica. Augusto Mendes, por sua vez, manifestou sua opinião na Gazeta de Notícias, em 1930, contra aquilo que era denominado de "método decrescente" para tratamento dos toxicômanos. Em sua opinião, compartilhada por esse jornal, esse método servia de pretexto para transformar as casas de saúde em verdadeiros paraísos artificiais (SILVA, 2015, p.268-269). Percebe-se nessas passagens que o uso terapêutico de entorpecentes se tornava crescentemente alvo de suspeição por parte das autoridades policiais.

Essas considerações sobre os conflitos entre a classe médica e as autoridades policiais servem para mostrar que também no Brasil as restrições ao consumo de fármacos geravam esse tipo embate - embora as fontes apresentadas ainda ofereçam poucas informações a esse respeito. As pretensões monopolistas da classe médica levaram à restrição geral do consumo de opiáceos e ao fortalecimento da opiofobia que será tão característica da segunda metade do século XX. Os casos do Rio de Janeiro e de São Paulo, que possuem algumas diferenças entre si, não devem ser tomados como nacionais. Vimos, no final da última secção, a polêmica entre Nina Rodrigues e Azevedo Sodré sobre a natureza da jurisdição da DGSP. Conforme se entra e se avança no século XX, cresce a percepção de que existia um descompasso entre aquilo que se realizava no Rio de Janeiro e o abandono do interior - que alimentará o movimento sanitarista descrito anteriormente.

Para não se restringir apenas aos estados mais ricos da federação, e para poder criar um contraponto, optou-se por trazer também o exemplo do Rio Grande do Sul. O PRR, que deu sustentação ao novo regime político, teve que enfrentar a maioria liberal que tinha enorme tradição nesse estado. Esse fato levou a curiosa aliança entre republicanos e conservadores. A sua base social reduzida era superada pela organização e disciplina de seus componentes. Prevendo derrotas eleitorais, o PRR outorgou uma constituição altamente centralizadora em 1891. O alijamento do poder levou os liberais a se radicalizarem, desembocando na guerra civil conhecida como Revolução Federalista (1892-1895). A vitória sobre esse conflito, que contou com apoio do 
exército nacional, possibilitou a construção de um aparato burocrático e militar capaz de perpetuar os quadros do PRR no poder durante toda a primeira república. Nessa estrutura de poder, a polícia tinha uma autonomia extraordinária e o Chefe de Polícia tornava-se um dos cargos de maior prestígio e importância (TORCATO, 2011, p.21-23).

O PRR extraiu de Augusto Comte e do positivismo a crença na forma republicana e ditatorial de governar, inspirada nos preceitos da ciência. "Nesse contexto, a perspectiva fundada na ciência estabelecia a completa separação dos poderes temporal e espiritual, assegurando, a partir daí, a liberdade de religião, de profissão e de indústria" (WEBER, 1999, p.42). Cabia ao governo eliminar "quaisquer privilégios nobiliárquicos, teológicos ou acadêmicos" (WEBER, 1999, p.42). A saúde pública, nesse arcabouço teórico, era pensada sempre dentro dos limites da liberdade individual e de consciência. Tendo com base esses critérios, e possibilitados pelo federalismo, o governo gaúcho organizou o serviço sanitário permitindo que práticos também pudessem exercer a medicina - desde que cadastrados nos órgãos do serviço sanitário. O Rio Grande do Sul tornava-se, na visão dos médicos acadêmicos, o pior exemplo de política sanitária do país (WEBER, 1992, p.42-45).

Os médicos que atuavam no Rio Grande do Sul criticavam muito a situação sanitária desse estado, acusando as autoridades de negligentes. Muitos dos seus quadros tinham forte influência liberal, porém estavam excluídos da política formal por causa da configuração peculiar das instituições políticas gaúchas. A exclusão da oposição da política formal perdurou até a guerra civil de 1923, que acabou com um acordo que ficou conhecido como Pacto de Pedras Altas. A classe médica, nesse contexto, procurou associar a defesa de melhorias gerais aos seus interesses. "A proteção à infância e à família, a prostituição, o alcoolismo e as toxicomanias, e a saúde pública em geral aparecem vinculados ao fim da liberdade Professional, que acabou se tornando uma 'obra de patriotismo"” (KUMMER, 2002, p.101).

Essa situação bastante peculiar levou a inércia do poder público em relação à defesa do monopólio médico no comércio de drogas. Somente no final dos anos de 1920 que o PRR, principalmente depois que Getúlio Vargas assume a presidência do Estado, irá efetivamente fazer cumprir os decretos de 1921. O símbolo da aproximação entre essas duas partes foi a nomeação de Belisário Penna para a coordenação do serviço sanitário do Rio Grande do Sul em 1928. Junto com Arthur Neiva, ele coordenou as expedições para o interior do Brasil que trouxeram para o debate público a questão do abandono do sertão ao longo da década de 1910. Ele era uma figura destacada do 
movimento sanitarista brasileiro, incansável militante da causa antialcoólica. Essa mudança tem impactos diretos na repressão aos entorpecentes, fato perceptível tanto nos discursos médicos, quanto nas fontes policiais.

Os ARGM, principal periódico médico gaúcho, passou a dar destaque à questão dos entorpecentes. Em 1928, o editorial intitulado "Toxicomanias", de autoria de Argymiro Galvão (1929, p.11-16), é um exemplo do novo momento vivido pela higiene pública no Rio Grande do Sul a partir daquele ano. Ele inicia o texto apontando os efeitos negativos que as drogas trazem sobre "a economia orgânica", sobre "a família e por consequência sobre a sociedade". Quatro são as substâncias que precisavam ser controladas: a cocaína, verdadeiro "veneno universal"; o álcool, que gera uma "influência nefasta que ninguém ignora" por ser responsável "pela a crescente porcentagem de tarados mentais"; a morfina, que atua em três fatores - "a dor, o pesar, a voluptuosidade" - escravizando "os desfrutadores de toda a espécie, mundanos, artistas, nervosos, etc., todos em buscas de sensações novas e intensas"; o éter, "veneno de tão larga extensão [...] também conduz o homem ao termo final da degeneração orgânica e moral". Todas essas substâncias gerariam um "espetáculo Dantesco" causado pelas degenerações físicas e pela incapacidade de "conduzirem uma raça a caminho da vitória". Através dessas substâncias "a infecundidade das uniões concorrendo para a baixa do expoente da população; o adultério, a prostituição, a degradação do sentido genésico, o roubo, o suicídio, o crime, enfim tudo quanto é mau se reúne". Sem as regulações públicas necessárias o "Rio Grande preparava-se para a derrocada da sua tradicional nobreza", problema que se agravava por causa do contrabando de tóxicos da fronteira. Era preciso, na opinião desse médico, comemorar as recentes ações do Estado, embora muito ainda tenha que ser feito por causa do "tempo em que permaneceu abandonada" a higiene pública. Seria preciso maior rigor na legislação, pois os criminosos têm se livrado "pela impotência de textos rígidos". Portanto, "é mister armar mais eficazmente as autoridades incumbidas de defender a sociedade contra tais celerados"

Nesse texto destacado acima, portanto, é possível verificar as concepções já visualizadas das drogas como elemento de degeneração da raça, assim como um elogio sutil ao novo momento político simbolizado com ações do governo contra esse comércio. Curioso notar que existem críticas aos textos legais por permitirem a impunidade daqueles que promovem o comércio ilícito. A análise dos processos-crimes trazem elementos que ajudam a entender essa crítica. 
A pesquisa no Arquivo Público do Estado do Rio Grande do Sul localizou vinte e sete processos-crimes envolvendo o tráfico de entorpecentes em Porto Alegre. Destes, vinte e dois foram instaurados entre 1929 e 1930 e coordenados pelo delegado Argymiro Indio Brazileiro Cidade da $1^{a}$ Delegacia Auxiliar. Essa repartição policial foi criada em 1929, resultado da reorganização da polícia que transferiu da Intendência Municipal para o governo do Estado a tarefa do policiamento. Depois do Pacto de Pedras Altas, que colocou fim à guerra civil, os opositores do governo passaram a se sentir mais seguros para criticá-lo, e a polícia foi um alvo privilegiado. Desde então se iniciou a campanha pela estadualização do policiamento (MAUCH, 2011, p.86-87). A reforma policial foi promovida por Getúlio Vargas com objetivo de combater a partidarização da mesma (MONTEIRO, 1991, p.46-47). Uma delegacia especializada no tráfico de entorpecentes servia, tanto para dar uma face científica ao policiamento, quanto para dar uma satisfação à classe médica - conforme vimos.

A análise do conjunto desses processos-crimes revelam algumas características da campanha repressiva gaúcha. As principais ações ocorriam nas regiões identificadas com as classes populares e com as atividades ligadas ao meretrício, como a Rua Três de Novembro, a Travessa Dois de Fevereiro e a Rua São João. Sobre o perfil social dos réus, a grande maioria fazia parte das classes populares, embora alguns farmacêuticos também tenham sido alvos. Sobre os resultados do tribunal do júri, de um total de trinta e nove pessoas processadas apenas cinco foram condenadas culpadas, o que significa algo em torno de $12 \%$ do total. Esses números dão sentido à crítica de Argymiro Galvão solicitando armas mais eficazes as autoridades imbuídas de reprimir esse comércio. Também mostra que o fenômeno de absolvição dos presos pelo tribunal popular não era apenas uma característica de São Paulo, fato que teria motivado naquele estado a adoção de uma lei para retirar dessa instituição a competência de julgar esse tipo de crime. Esse tipo de situação também denota a impopularidade das medidas restritivas.

As descrições das primeiras experiências proibicionistas no Brasil, realizadas dentro do formato institucional do federalismo, pretenderam mostrar que essas políticas foram parte integrante do contexto político, social e cultural da sociedade brasileira. Elas se inseriram dentro das lutas de um movimento mais amplo que criticava a herança da tradição, dos privilégios de um restrito grupo de aristocratas proprietários de terras e da erudição dos bacharéis alheios à realidade nacional. A classe médica teve um papel importante nessa luta, porém não parece correto a redução do movimento político que 
deu sustentação ao proibicionismo somente a essa classe. Os conflitos internacionais que o comércio de entorpecentes suscitou despertavam interesse e serviam como ponto de referência em alguns casos, porém igualmente não é possível reduzir o controle da ebriedade brasileiro a mero reflexo de normativas externas.

\subsection{O proibicionismo centralista (1932-1964)}

A partir da década de 1930, mais especificamente a partir de 1932, inicia uma nova fase nas políticas que tratam do uso de substâncias 'entorpecentes'. O Decreto $\mathrm{n}^{\circ}$ 20.930, de 11 de janeiro de 1932, é um marco na reorganização da política de drogas no Brasil, acompanhando as mudanças que ocorriam no Estado brasileiro como um todo. Para Carvalho (2007, p.12), essa lei cria uma nova disciplina da matéria, tornando mais densas as penas e complexificando as condutas reprimidas. A troca do conceito de 'venenoso' para 'entorpecente' e a submissão de licenças ao Departamento de Nacional de Saúde Pública (DNSP) teriam criado um novo modelo de gestão repressiva.

A exposição realizada na secção anterior mostra, entretanto, que alguns estados da federação já vinham se organizando, tanto no âmbito normativo, quanto no âmbito institucional, no sentido de dar efetividade à repressão ao comércio de entorpecentes. Esse decreto acima destacado, mais do que uma novidade no campo normativo, representava apenas "alguns adendos" - para usar a expressão de Adauto Botelho e Pernambuco Filho destacada anteriormente - realizados para dar mais efetividade à campanha que já vinha ocorrendo. A comparação entre essa normativa e a anterior pode elucidar esse ponto: a expressão substância de "qualidade entorpecente" foi substituída por "substância entorpecente", porém com a ampliação da lista de substâncias proibidas - como a Cannabis; em relação à punitividade, em 1921 era previsto detenção de um a quatro anos (artigo 1) e em 1932 ela podia chegar até dez anos no caso de médico ou dentista infrator (artigo 25); em relação ao abuso, em 1921 era punido com internação aquelas pessoas que causavam desordem ou se embriagavam por hábito (denotando o conceito de livre arbítrio), já em 1932 a toxicomania se torna uma doença de notificação compulsória (artigo 45); aumenta a discricionariedade médica, pois em 1921 o tempo de internação era previsto em lei (três meses até um ano) e em 1932 ele não era previamente definido, variando de acordo com a opinião do especialista (podia até ser perpétuo). 
O que se percebe com essa comparação de artigos é que, de fato, aumentou a punitividade do sistema. Verifica-se uma maior influência da Escola Positiva em relação à Escola Clássica, conforme o debate apresentado por Silva (2015, p.185-213). Mas isso é suficiente para aceitarmos a existência de um novo modelo repressivo? A principal mudança, a meu ver, não está na ampliação da punitividade ou na crise dos valores liberais e ascensão do positivismo em matéria penal, pois isso não altera a essência da repressão e do controle que já vinha sendo feitos: o reconhecimento do monopólio médico da prescrição de entorpecentes e a defesa desse controle através da ameaça do uso da força.

Existe, portanto, uma continuidade com o período anterior. Porém, apesar disso, defendo que a Lei de 1932 seja considerada o marco de uma nova configuração política e institucional, porque ela indicará o início de uma tendência que se ampliará a partir de normativas que serão publicadas sobre o assunto até 1946: a centralização. Entre 1932 e 1946, o poder executivo federal terá tomado para si a tarefa de coordenação de uma política nacional, com órgãos capazes de sistematizar informações sobre a circulação das substâncias entorpecentes no país. Carvalho (2013, p.87-132), reconhecerá o período entre 1936 e 1946 como aquele onde o Estado brasileiro construiu uma nova racionalidade em torno da temática das drogas, tomando como marco inicial o Decreto $n^{\circ} 780$, de 28 de abril de 1936 - que prevê a criação da CNFE. Acredito, entretanto, que a tendência centralizadora já é perceptível em 1932, pois o DNSP passará a receber várias atribuições: atualização da lista das substâncias proibidas (artigo 1); competência para reconhecer profissionais e estabelecimentos aptos a receitar e vender (artigo 2); fixar qual é a dose terapêutica adequada e a quantidade máxima de estoque permitido (artigo 26); entre outros.

$\mathrm{O}$ aumento da punitividade também não deve ser tomado como característica fundamental desse novo arranjo institucional por outro motivo. O órgão centralizador da política de drogas, a CNFE, estava subordinado ao MRE cuja principal preocupação era estabelecer o controle sobre a entrada e saída de substâncias entorpecentes no país, elaborar estatísticas de consumo, sugerir leis para evitar o desvio desses produtos das funções lícitas para as ilícitas, etc. A principal preocupação do órgão é regular o comércio e não restringir o uso em si a partir da punitividade. Outro órgão importante, a partir de então, na condução da política de drogas no país será a DNSP, subordinada ao Ministério da Educação e Saúde (MES). A ação fiscalizadora, que poderia levar ao estabelecimento das penalidades previstas, ficou ao encargo do Serviço Nacional de 
Fiscalização da Medicina (SNFM) diretamente subordinado ao DNSP. Segundo Carvalho (2013, p.95-97), desde 1932, o SNFM mandava ofícios ao MRE reclamando da falta de estrutura para fiscalizar as normativas existentes. Independente da efetividade ou não da fiscalização, importante salientar agora é que ênfase do esforço normativo é sobre a atividade terapêutica e o acesso aos fármacos e não a repressão ao consumo em si.

Na primeira metade da década de 1940 será consolidado o arcabouço legal e institucional desenhado acima. Segundo a hipótese do continuísmo e da ascensão punitivista "somente a partir da década de 40 é que se pode verificar o surgimento de política proibicionista sistematizada" ${ }^{99}$ (CARVALHO, 2007, p.12), pois no Código Penal de 1940 se percebe a tentativa

\footnotetext{
“de preservar a hipótese de criminalização junto às regras gerais de interpretação e aplicação da lei codificada. No entanto, a partir do DecretoLei 4.720/42 (que dispõe sobre o cultivo), e com a publicação da Lei 4.451/64 (que introduz ao artigo 281 a ação de plantar), se inicia na legislação pátria - não apenas no que diz respeito às drogas, mas aos entorpecentes de maneira muito especial -, amplo processo de descodificação, cujas consequências serão drásticas para o (des)controle da sistematicidade da matéria criminal (dogmática jurídico-penal)" (CARVALHO, 2007, p.13-14).
}

Essa interpretação do arcabouço legal parece equivocada. O controle sobre o plantio existe desde o Decreto-lei n ${ }^{\circ}$ 891, de 25 de novembro de 1938, quando são proibidas no território nacional as culturas do Papaver somniferum, Erytroxylum Coca e da Cannabis Sativa (Artigo 2). Se analisarmos o Decreto-lei $\mathrm{n}^{\circ} 4.720$, de 21 de setembro de 1942, citado por Carvalho (2007) acima, ele fixa "normas gerais para o cultivo de plantas entorpecentes e para a extração, transformação e purificação dos seus princípios ativo-terapêuticos". Ele prevê a possibilidade da união conceder concessões a firmas particulares "para a cultura de plantas entorpecentes e para extração e exploração de seus princípios ativos" (Artigo $1^{\circ}$ ). Mais uma vez se percebe que a motivação última não é a criminalização, mas a regulamentação da produção de substâncias terapêuticas.

Mesmo não concordando com a interpretação do continuísmo e da ascensão punitivista, percebe-se que a primeira metade da década de 1940 é importante para a afirmação dessa orientação centralizadora da política de drogas. Gostaria de destacar

${ }^{69}$ Itálico no original. 
duas leis: Código Penal de 1940 que consolida as mudanças legislativas e institucionais realizadas na década anterior; o Decreto $\mathrm{n}^{\mathrm{o}}$ 20.397, de 14 de janeiro de 1946, que regulamenta a indústria farmacêutica no Brasil, definindo regras para a produção de produtos entorpecentes, "por via sintética ou extrativa" (artigo 19), e obrigando a colocação de rótulos indicando tratar-se de uma substância entorpecentes e a quantidade e a dose indicada para o consumo (artigo 84), entre outras regras.

As mudanças em matéria de legislação que ocorreram entre 1932 e 1946 serão o fundamento legal do proibicionismo até 1964, quando começará uma reordenação da política de drogas - conforme veremos na próxima seção. Muito ainda precisa ser estudado a respeito dessas mudanças legislativas. O único trabalho que existe é o de Carvalho (2013), porém ele ainda se restringe aos documentos da CNFE e do MRE. A análise dos projetos de lei, dos debates parlamentares e o maior entendimento sobre os agentes sociais envolvidos certamente trarão novos esclarecimentos sobre esse complexo processo descrito suscintamente acima.

As mudanças legislativas não podem ser entendidas se não a relacionarmos com as mudanças sociais e econômicas mais amplas que ocorriam simultaneamente. O período que vai da década de 1930 até a década de 1950 é marcado por uma mudança importante no perfil da indústria farmacêutica, tanto nacional, quanto internacional. Transformação que servirá para alimentar a retórica triunfalista da medicina tantas vezes criticada ao longo dessa Tese.

O desenvolvimento industrial do Brasil usualmente é pensado através da burguesia cafeeira e dos grandes importadores como precursores em diversos ramos. As iniciativas de substituição de importações foram importantes na formação e na consolidação de um mercado de cervejas no Brasil (MARQUES, 2014). A história da indústria farmacêutica, entretanto, destoa um pouco desse enredo, pois ela tem como característica específica a necessidade de mão de obra qualificada. Os estados do Rio de Janeiro e de São Paulo, especificamente, produziram esse tipo de profissional nas diversas instituições de pesquisa - como o Instituto Bacteriológico (depois Adolfo Lutz), o Vacinogênico, o Butantã, Manguinhos, etc - fundadas ao final do século XIX como meio de enfrentar o problema das epidemias.

"Um contingente expressivo de egressos de instituições públicas de pesquisa transformou-se em empresários, investindo o conhecimento científico e escassos recursos financeiros, muitas vezes, obtidos junto a sócio ou por 
meio de empréstimos para a instalação de empresas de pequeno e de médio porte" (RIBEIRO, 2007, p.164).

No começo do século XX, a formação de uma empresa farmacêutica era viável com pequenos investimentos, pois o mais importante era a mão de obra qualificada. A Primeira Guerra se constituiu em um grande estímulo para o setor, com a multiplicação dos laboratórios "que passaram a processar matérias-primas básicas antes importadas" (STUCKER et al, 2007, p.55). As empresas brasileiras se tornaram referências na produção de soros e vacinas e também passaram a ter a capacidade de processar e produzir produtos que antigamente eram comprados prontos, porém ainda dependente da importação de matéria prima e máquinas.

Nos anos de 1930, acompanhando a centralização e a burocratização dos governos de Getúlio Vargas, também as empresas farmacêuticas foram obrigadas a se sindicalizar ampliando assim sua organização e articulação com o Estado. A política de substituições de importações, nesse cenário, tornava-se uma questão patriótica (STUCKER et al, 2007, p.72). Até o final da Segunda Guerra poucos eram os laboratórios estrangeiros que fabricavam produtos no país e, por isso, a concorrência centrava-se na disputa de mercado entre os representantes das grandes companhias estrangeiras, importadores, e as empresas nacionais. O setor farmacêutico nacional era constituído por pequenas empresas - somente oito fábricas $(5,7 \%)$ possuíam mais do que cinquenta funcionários em 1945 (RIBEIRO, 2006, p.52-53).

Quando iniciou a Segunda Guerra Mundial o cenário se tornou bastante ambíguo. Por um lado, existia o perigo iminente de faltarem medicamentos porque os principais fornecedores eram europeus. Por outro lado, era uma oportunidade de desenvolvimento da indústria nacional - fenômeno que já tinha ocorrido durante a Primeira Guerra. De fato, o setor farmacêutico aumentou 38\% em valor estimado durante o período. As substituições de importação ocorriam tanto no nível das especialidades, quanto no nível da matéria prima - com diversificação dos produtos e ampliação das redes de distribuição. Pela primeira vez, o país se tornava exportador de alguns fármacos, principalmente cafeína, teobromina, mental, emetina.

"A indústria passou então a fabricar, além dos produtos já citados, estricnina, cumarina, atropina, hiosciamina e escopalamina, ópio, eucaliptol, curcumina, pilocarpina, digitalina, extratos glandulares, hormônios e outros" (STUCKER et al, 2007, p.86). 
O crescimento foi tão grande que não havia mão de obra especializada suficiente para trabalhar no setor (STUCKER et al, 2007, p.82-86). É dentro desse contexto que o Decreto-lei $\mathrm{n}^{\mathrm{o}} 4.720$, de 21 de setembro de 1942, regulamentando a plantação de matéria prima para produtos entorpecentes, deve ser considerado. A trajetória desse setor mostra como a indústria farmacêutica nacional alcançou alto padrão na produção de produtos biológicos combinando ciência, pesquisa e produção - ganhando liderança no mercado mundial de soros. Mostra também que elas "não eram apenas pequenas e insignificantes firmas de manipulação de produtos oficinais" (RIBEIRO, 2007, p.186).

O término da Segunda Guerra, entretanto, gerou uma crise sem precedentes no setor farmacêutico nacional levando a "um dos processos mais radicais de desnacionalização da indústria que se tem conhecimento na história econômica brasileira" (RIBEIRO, 2007, p.187). A indústria farmacêutica estrangeira representava 2,1\% do setor em 1900 e 7,3\% em 1920 (STUCKER et al, 2007, p.33); Em 1930, a parcela de faturamento das empresas estrangeiras pulava de 7,3\% para 13,6\%, embora acompanhasse o crescimento da indústria nacional (STUCKER et al, 2007, p.63); Em 1940, no auge da indústria nacional, a participação dos estrangeiros no mercado chegava a 33,5\% (STUCKER et al, 2007, p.81). Até o estourar da Segunda Guerra, 70\% dos químicos e farmacêuticos que o Brasil importava provinham da Alemanha (STUCKER et al, 2007, p.86).

Esses dados apresentados acima mostram dois pontos: $1^{\circ}$. Desde o início do século XX a participação das indústrias estrangeiras no mercado brasileiro esteve em crescimento; $2^{\circ}$. A Alemanha era o principal parceiro comercial do país durante todo o período. A primeira Guerra Mundial serviu de estímulo à indústria nacional sem, entretanto, interromper o crescimento da presença da indústria estrangeira no país. A partir do fim da segunda Guerra Mundial, entretanto, ocorreu uma radical mudança no perfil de desenvolvimento do setor que inviabilizou o modelo de substituição de importações.

A explicação para esse fenômeno, por parte da historiografia triunfalista, é baseada no discurso evolucionista do aperfeiçoamento das técnicas. Os novos produtos farmacêuticos descobertos nos anos de 1940 teriam levado

"a uma mudança que alterou significativamente as condições da prática da medicina e do mercado farmacêutico nacional e internacional, criando aos 
poucos um desnível tecnológico e industrial que se aprofundou nos anos de 1950 e 1960" (STUCKER et al, 2007, p.100).

Os medicamentos de síntese química (década de 1930) e os antibióticos (década de 1940) produzidos nos "centros de pesquisa estrangeiros implicaram numa radical transformação tecnológica" (STUCKER et al, 2007, p.100) exercendo uma "pressão competitiva" (STUCKER et al, 2007, p.100) que levou as firmas nacionais a enfrentar "uma súbita obsolescência da maioria dos seus produtos" (STUCKER et al, 2007, p.100). Nesse cenário, a indústria farmacêutica estadunidense teria sido a mais vigorosa e a mais beneficiada desse novo estágio de desenvolvimento, pois teria se aproveitado da "quase total paralização das firmas europeias" (STUCKER et al, 2007, p.105) durante a guerra. Ela teria se beneficiado, também, de fortes investimentos estatais em pesquisas por causa do interesse militar em desenvolver medicamentos, levando para dentro das empresas - e saindo das universidades - os centros de pesquisa (STUCKER et al, 2007, p.104-108). Os estadunidenses, graças aos investimentos e a aposta da inovação, teriam ocupado

\footnotetext{
“o lugar deixado vago pelas importações originárias da Europa, investindo política e economicamente na América Latina, por meio de várias agências, para promover o interesse de sua indústria farmacêutica" (STUCKER et al, 2007, p.86).
}

Esse discurso triunfalista opõe, portanto, o químico (sinônimo de inovação e investimento em pesquisa por parte das empresas e do governo estadunidense) e o biológico (sinônimo de atraso e falta de interesse do governo brasileiro em investir no setor). Esse discurso pressupõe a existência de um "campo da farmacologia de base química, que admite ser a ação do medicamento função da estrutura da molécula química" (ALMEIDA, 2011, p.47). Nós já vimos, no segundo Capítulo, que é impossível separarmos a estrutura molecular e seus efeitos dos aspectos antropológicos. Agora vamos tentar compreender as diferenças entre o natural, o químico e o biológico e as relações entre eles.

No segundo Capítulo foi apresentado de forma resumida o surgimento da ciência dos alcaloides. As plantas contêm uma complexa e variável mistura de químicos, que mudam de acordo com a espécie, estação do ano, forma de colheita, etc. O caminho simplista para minimizar esse risco é isolar os componentes que produzem determinadas 
respostas fisiológicas. A filosofia do alambique é a racionalidade por trás dessa ciência. A indústria brasileira, que era especialista no mercado de soros, também tinha a capacidade técnica para extrair os princípios ativos dessas plantas - embora fosse dependente da importação de matéria prima e maquinário. O alcaloide, portanto, é um medicamento fitoquímico. Do ópio, analgésico natural mais conhecido, foi extraído o primeiro alcaloide - a morfina. Muitos outros vieram na sequência ao longo do século XIX.

Vimos também, no quarto Capítulo, que rapidamente esses fitoquímicos passaram a sofrer a concorrência de análogos sintéticos. Em 1868, numa clássica investigação feita por Alexander Crum Brown, se descobriu a existência da relação entre a estrutura química e a atividade biológica. Não é por coincidência que apenas um ano mais tarde, depois de experiências realizadas com a morfina, era descoberta a apomorfina. Embora não tivesse o efeito analgésico, descobriu-se depois que ela era um poderoso emético e acabou, assim, sendo colocada no mercado em 1902. Coube também aos derivados do ópio o privilégio de serem as primeiras substâncias obtidas por alteração da estrutura química molecular. À morfina, se seguiram a cocaína, quinina, tebaína, etc. Entre as substâncias obtidas com esse tipo de procedimento está a heroína (SNEADER, 2005, p.115-116). Esse tipo de fármaco é denominado de medicamento análogo.

Existem também, quanto a sua origem, os medicamentos químicos propriamente ditos. A indústria de corantes se revolucionou quando William Perkin, em 1856, descobriu por engano a mauveína - que foi a primeira vez na história que se prescindiu de produtos naturais para criar corantes. Longe de aposentar os fitoquímicos e os seus análogos, essa descoberta abriu caminho para desenvolvimento de novos fármacos. Entre eles é possível destacar o hidrato de cloral, descoberto em 1868, e tornado um sucesso comercial, apesar dos efeitos colaterais. Sete anos mais tarde foi a vez do salicilato de sódio, seguido de outros. Desde o final do século XIX, as indústrias farmacêuticas alemãs financiavam pesquisas com esses produtos em departamentos separados das universidades, visando à produção de fármacos para o mercado (SNEADER, 2005, p.04). A Aspirina ${ }^{\circledR}$ é um exemplo de medicamento químico.

O que é possível perceber é que, no início do século XX, já existia um grande desenvolvimento dos processos para obter análogos a partir de moléculas, pois a química orgânica tinha se desenvolvida o suficiente para produzir um ilimitado número de novas drogas sintetizadas. Depois das plantas, serviram como protótipos as 
substâncias provenientes dos organismos vivos, hormônios, glândulas e vitaminas. A grande revolução da segunda metade do século XX foi obtida através da obtenção de substâncias provenientes de micro-organismos e, posteriormente, de análogos dessas substâncias através da alteração molecular (SNEADER, 2005, p.06).

As drogas sintéticas, químicas propriamente ditas, são conhecidas desde o século XIX. Uma das primeiras substâncias utilizadas na fabricação de químicos foi o fenol, que era um indesejável subproduto da iluminação pública por gás comum na Inglaterra - o alcatrão de carvão aparentemente sem valor. A partir dele se desenvolveram bálsamos, desinfetantes e outros produtos. O mais importante dos seus derivados foi a Aspirina ${ }^{\circledR}$. Outros produtos químicos usados na terapêutica eram os hipnóticos, primeiro o cloral e depois os barbitúricos. Corantes e outras substâncias inusitadas foram usadas na obtenção de medicamentos químicos desde fins da primeira metade do século XIX (SNEADER, 2005, p.355-445).

Essa exposição sobre a natureza e origem dos fármacos é importante para começarmos a relativizar esse discurso que atribui, unicamente, à superioridade técnica estadunidense a ruina das formas medicamentosas anteriores. As bases da farmacologia moderna foram lançadas e consolidadas pelos alemães na segunda metade do século XIX. A quimioterapia, que será a marca da superioridade técnica estadunidense, não se refere à qualidade química de dado medicamento. Se fosse esse o caso, o uso de cloral ou barbitúricos seria também parte integrante desse tipo de tratamento. Se não se refere a uma qualidade do fármaco, ao que se refere à quimioterapia?

A história triunfalista da medicina é feita com heróis e, também nesse caso, existe um: o alemão Paul Ehrlich (1854-1915). Ele foi responsável por descrever o princípio da ação seletiva das drogas, ou seja, ao entrar no organismo ela agiria de maneira seletiva sobre o agente causador da moléstia infeciosa sem causar (ou causando o menos possível) males ao indivíduo infectado. Ele desenvolveu com suas pesquisas o Salvarsan 606 contra a sífilis, que se mostrou ativo contra a bactéria e muito tóxico aos doentes. Melhoramentos foram realizados até chegar ao Salvarsan 914 ou Nelsalvarsan. Mesmo sendo muito tóxicos, eles foram usados a partir de 1914, sendo somente aposentados pelos antibióticos nos anos de 1940 (STUCKER et al, 2007, p.116-118). Segundo Sneader (2005, p.06), Paul Ehrlich foi o responsável pela primeira grande quebra da confiança nos produtos naturais como provedores de novas drogas. Esses remédios também foram vendidos no Brasil. 

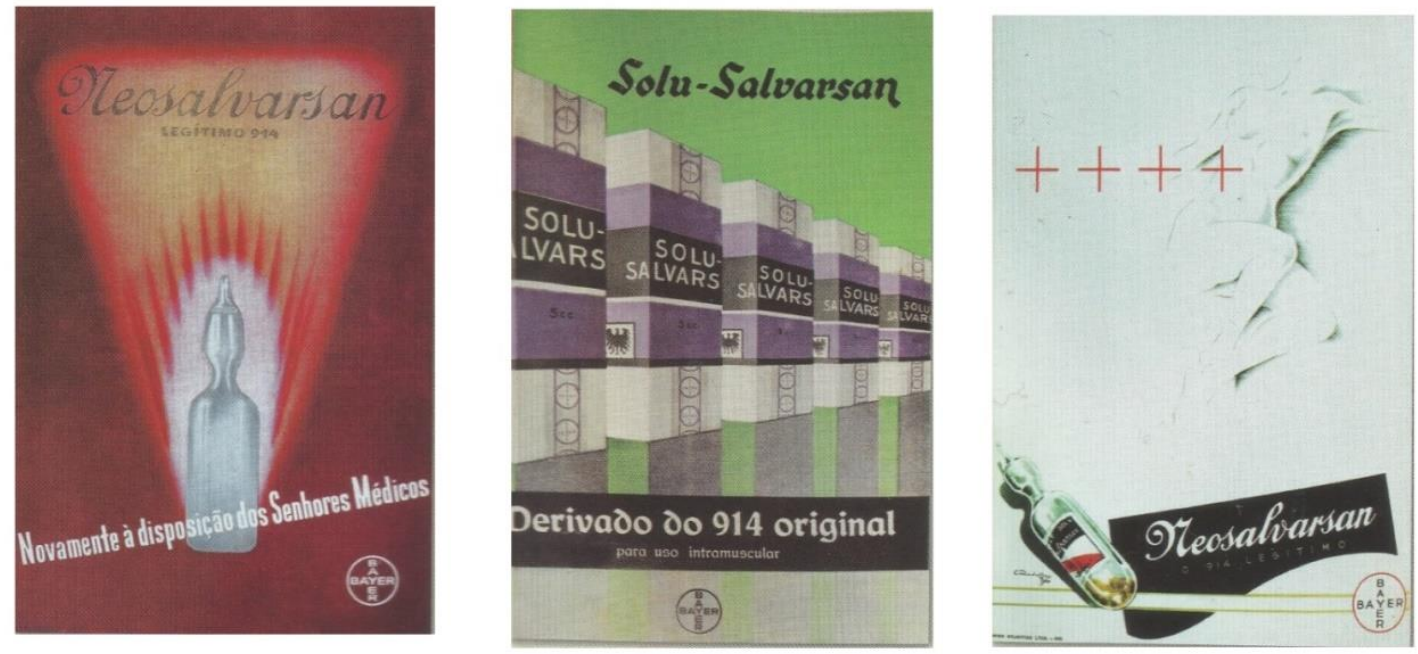

Figura 10 - Os primeiros quimioterápicos

FONTE: STUCKER et al, 2007, p.117

Paul Ehrlich foi responsável por lançar o conceito de "pílulas mágicas", que se baseia na ideia de que o medicamento poderia e deveria agir diretamente sobre o agente patogênico. Na prática, os resultados do Salvarsan foram desapontadores por causa da toxicidade, porém isso somente ficou aparente depois que ele foi usado de forma massiva na Primeira Guerra. A pesquisa em torno de fármacos que seguiam esse princípio da luta contra o agente patogênico específico foi estimulada pelo governo estadunidense a partir dos anos de 1920, resultando na produção de antitoxinas, vacinas e, mais tarde, no isolamento e síntese de diversas vitaminas. A verdadeira "boleta mágica”, entretanto, somente seria produzida em 1931, quando foi desenvolvido o primeiro antibiótico. Mesmo depois dessa descoberta, ainda foi preciso desenvolver meios de produzi-lo em escala industrial - algo que só seria realizado no final da Segunda Guerra (HEALY, 1997, p.20-21). Embora o Salvarsan, efetivamente, tenha sido desenvolvido a partir de químicos, a verdadeira boleta mágica é derivada de um micro-organismo presente na natureza.

Essa revisão sobre a origem das drogas é útil para corrigirmos alguns exageros triunfalistas. De uma maneira ou de outra, igual como ocorria no passado, a "luxuriante indústria farmacêutica permanece curiosamente sujeitada aos arbustos, florestas e plantações. Ela ainda não cortou essa ligação de dependência” (DAGOGNET, 2012, p.22). O maior exemplo desse vínculo com o naturalismo provém do "remédio maior do nosso tempo, a penicilina" (DAGOGNET, 2012, p.77), pois ele foi criado a partir da "secreção antagonista de um cogumelo" (DAGOGNET, 2012, p.77). Ressaltar essa 
ligação com o protótipo natural não se faz no sentido de exaltar um naturalismo ingênuo, na medida em que cada vez menos os remédios são resultados daquilo que se planta. A penicilina é o exemplo máximo disso, porque mesmo depois de descobertos os seus efeitos foi necessário criar os meios para a produção em massa. "Quando a natureza possui o tesouro curativo e substancial, ela com frequência não contêm dele senão traços, não poderia, portanto, alimentar o consumo. Disso decorre a urgência do artificialismo" (DAGOGNET, 2012, p.78). O ponto inicial geralmente é o naturalismo e a seleção das espécies, porém são as alterações sobre as moléculas descobertas que “inauguram a emancipação que não deixará de prosseguir” (DAGOGNET, 2012, p.78). A natureza dá os primeiros passos aos farmacólogos (DAGOGNET, 2012, p.76-78).

Existe um vínculo intrínseco entre as 'descobertas' farmacológicas e os compostos isolados de plantas, animais e micro-organismos. A maioria das drogas até hoje usadas são resultados de pequeníssimas alterações nas moléculas já existentes e com efeitos conhecidos - porém suficientes para acionar o direito as patentes. A partir de Segunda Guerra o direito de explorar as patentes será o ponto central de tensão entre indústria farmacêutica internacional e governo brasileiro, resolvido somente no final da década de 1990. Por ora, apenas gostaria de destacar que desde o início do século XX as empresas farmacêuticas estrangeiras ampliavam a presença no país, muito em função do conhecimento sobre química que era alheio à indústria nacional. Não se trata, portanto, de uma mudança do biológico para o químico ou de um abismo tecnológico que surgiu em uma década.

Procurarei mostrar aqui que se trata, antes, de uma estratégia comercial agressiva que atuava em várias frentes. Nenhuma inovação do período retirou a importância dos analgésicos leves de uso seguro como são a Aspirina ${ }^{\circledR}$ e seus análogos e genéricos. Contra esses remédios, que são químicos, tratou-se de uma disputa comercial clássica. Quintaneiro (2002), utilizando como fontes os documentos produzidos pelo U.S. Departamento $f$ State, mostrou a articulação de agências do governo e das empresas estadunidenses na produção de informações, nas articulações diplomáticas e nas iniciativas econômicas visando destituir as indústrias alemãs do mercado sul-americano durante a Segunda Guerra Mundial. Analisando os casos da Aspirina ${ }^{\circledR}$ e da Atebrina ${ }^{\circledR}$ (usada contra a malária), ela mostrou as dificuldades encontradas pelas novas empresas em desbancar as marcas alemãs consolidadas no mercado, principalmente a Bayer.

Ao lado de disputas comerciais com produtos equivalentes, também eram alvos da diplomacia estadunidense as iniciativa do Brasil em se tornar autossuficiente em 
matéria prima para produção de medicamentos da farmacopeia clássica. O conflito, por si só, já representou um desafio aos países periféricos. Os esforços de guerra e a destruição da estrutura econômica dos países beligerantes, principalmente a Alemanha e a Turquia, traziam problemas para o abastecimento de medicamentos ao mercado brasileiro. Segundo Carvalho (2013, p.109-112), a incapacidade da Alemanha e da Roche S/A, com sede na Suíça, de prover as necessidades mínimas levou o MRE apresentar o projeto Kabay - da Hungria. A ideia era tornar o Brasil um produtor de dormideira, com instalação de fábricas que pudessem extrair os princípios ativos do ópio.

\begin{abstract}
A proposta parecia tentadora, o governo brasileiro não teria quaisquer ônus com a instalação da fábrica, a empresa seria uma sociedade anônima cujas ações em sua totalidade pertenceriam ao Estado, o presidente e a diretoria seriam nomeados pelo governo, que cederia três cargos para serem ocupados por representantes do grupo proponente. Como contrapartida pelos investimentos na construção, instalação, operação e funcionamento da fábrica, o grupo exigia uma participação de $50 \%$ nos lucros líquidos por cinquenta anos (CARVALHO, 2013, p.112).
\end{abstract}

O Decreto-lei $\mathrm{n}^{\mathrm{o}}$ 4.720, de 21 de setembro de 1942, que regulamentava a produção de matéria prima para produção de medicamentos, fazia desse projeto uma alternativa para dar autossuficiência à indústria nacional com previsão de transferência de tecnologia. Porém, ela foi rejeitada depois dos esforços da diplomacia estadunidense. Optou-se por atrelar esse campo econômico ao capital internacional. Aproveitando o impasse do suprimento e a aproximação com o governo brasileiro - que se estreitava com o conflito mundial - os EUA ofereceram facilidades para aquisição dos novos fármacos sintéticos. Olhando hoje, retrospectivamente, essa opção parece uma mera iniciativa entreguista totalmente em desacordo com o modelo econômico de substituição de importações - que era o centro do projeto varguista em voga durante o Estado Novo. Como explicar, então, essa opção econômica?

A desnacionalização radical da indústria brasileira pós-1945 e a presença hegemônica do capital estrangeiro nesse campo econômico, principalmente estadunidense, se explicam por outros fatores. Os EUA, inegavelmente, tornaram-se líderes em tecnologia química, lançando uma linha de remédios capazes de transformar enfermidades crônicas milenares em doenças tratáveis, como foi o caso da tuberculose, da sífilis e da hanseníase; os primeiros tratamentos efetivos contra o câncer; os 
primeiros anti-histamínicos eficazes permitiram o maior controle das alergias; e assim por diante. Em nenhum momento se trata de negar, aqui, os avanços técnicos que a indústria estadunidense apresentava. Mas, antes, mostrar que os efeitos simbólicos desses recursos muito vão além da cura das doenças que eles se propunham.

Essas novas possibilidades de tratamento foram saudadas como um dos "maiores avanços da história da medicina" (TEIXEIRA et al, 2012, p.83). Esses avanços faziam os contemporâneos creem "na possibilidade de controle ou erradicação das doenças transmissíveis" (TEIXEIRA et al, 2012, p.149) criando o período que foi denominado de "otimismo sanitário". Além da cura de determinadas doenças, portanto, esses remédios também foram essenciais para o reforço na ideologia do progresso e da superioridade absoluta do novo sobre o antigo, do químico sobre o fitoquímico. A substituição dos 'entorpecentes' pelos novos produtos da indústria farmacêutica significaria, na visão daqueles que viviam a cura das doenças milenares, uma medida científica - no imaginário dessa época o sintético era superior ao natural pelo simples fato de ser sintético - e humanitária - milhões de pessoas deixariam de serem escravas do vício. Veremos logo abaixo que esses novos produtos ficaram amplamente disponíveis nas farmácias, reiterando os velhos problemas de abuso e intoxicações.

Ao lado do otimismo no progresso gerado pelas "boletas mágicas" se somou um novo e importante fator que incidiu para a mudança no perfil dos serviços de saúde: a incorporação de uma série de novos, e caríssimos, equipamentos que passaram a ser a base de determinadas especialidades. O hospital centralizou os novos serviços e se constituiu em um local de oferta de serviços especializados, tanto em diagnóstico, quanto em terapêutica. Em torno desse complexo industrial se constitui uma "elite médica de proprietários de clínicas e hospitais" (TEIXEIRA et al, 2012, p.83) capazes de alta concentração de capital. A experiência da doença como uma enfermidade, vivida em geral em casa com o apoio do círculo pessoal mais próximo e do médico de família, transforma-se em objeto de intervenção sobre a doença por especialistas. Isso implica em uma nova forma de perceber e de intervir sobre a doença, estritamente vinculada à aplicação de capital de empresas e indústrias subsidiárias, "em particular as de medicamentos e de equipamentos" (LAMPERT, 2009, p.55). A multiplicação e expansão das especialidades criam novos campos de atuação, altamente remunerados, para pessoas treinadas.

Foge do objetivo desse Capítulo abordar a transformação dos meios de produção do trabalho médico em todos os seus aspectos. Seguindo uma temática já abordada ao 
longo dessa Tese, vou mostrar através do exemplo da anestesiologia como a combinação de treinamento, organização classista e articulação política foram capazes de criar uma nova classe de médicos especialistas. Não se trata apenas da história da construção de uma especialidade, mas de uma organização classista que defende o monopólio de sua técnica sobre todas as outras, não apenas sobre a sociedade em geral, mas inclusive no interior da classe médica.

Vimos, no quarto Capítulo, que alguns médicos no Brasil aplicaram a técnica de raquianestesia com cocaína no início do século XX. Essa técnica, entretanto, somente foi se difundir após os anos de 1930 - existindo grande polêmica, na historiografia triunfalista, sobre quem foi o pioneiro. Achille Mario Dogliotti, italiano, é considerado o precursor e principal difusor da técnica de localização do espaço epidural. Ele foi escolhido duas vezes relator do Congresso Internacional de Anestesia e eleito vicepresidente honorário da principal Sociedade deste campo (DOGLIOTTI, 1943, p.15). Existe também a reivindicação dos espanhóis aos pioneiros trabalhos de Fidel Pagés Miravé (ROMAN, 2005). Essa luta entre italianos e espanhóis pelo mito de origem da técnica moderna desse tipo de anestesia esconde o mais importante: o papel preponderante dos estadunidenses na formação dessa especialidade.

\footnotetext{
"A criação da figura do anestesista moderno, que estuda essencialmente os problemas da fisiopatologia da dor, que deve ser um perfeito anatomista para bem aplicar as anestesias regionais pléxicas e tronculares, possuir conhecimentos precisos de química fisiológica, estar familiarizado com os mais complexos aparelhos empregados nos diversos métodos de anestesia geral e também ter, por necessidade, uma educação cirúrgica completa para conhecer as exigências do operador e os problemas que mais diretamente envolvem as resistências do operando, constituem uma autêntica conquista dos nossos tempos: conquista de origem anglo-saxônica e essencialmente norte-americana" (DOGLIOTTI, 1943, p.01).
}

A nova especialidade desenvolvida pelos estadunidenses entusiasmava, desde o início dos anos de 1940, alguns médicos brasileiros que atuavam na Casa de Saúde Dr. Pedro Ernesto no Rio de Janeiro. A esses médicos, somaram-se outros que foram enviados para a Segunda Guerra Mundial para fazer estágio Corpo de Saúde do V Exército das Forças Aliadas. O retorno desses profissionais e a divulgação das técnicas aprendidas durante o conflito levou ao crescente interesse pelo campo e, em 1948, os 
interessados na consolidação dessa especialidade fundam Sociedade Brasileira de Anestesiologia. Essa instituição foi responsável pela difusão desse novo campo do conhecimento médico em todo o território nacional, mobilizando a criação de sociedades estaduais e a organização de congressos e eventos científicos usados para difundir as novas técnicas (MANICA, 2004, p.32-63).

Criava-se o profissional, dentro do campo médico, especialista na anestesia e na analgesia - que em breve se tornaria o único responsável pelo controle dos fármacos destinados a essa finalidade. A cocaína e seus análogos lançados no começo do século faziam parte das técnicas de anestesia por infiltração - aplicadas diretamente no local da dor visando a insensibilização. A anestesiologia como campo específico provocará uma sofisticação do método de anestesia local, retirando do local da dor a aplicação do anestésico. Serão disseminadas as anestesias regionais e espinhais em substituição à anestesia por infiltração, vista a partir de então como pré-história pela retórica triunfalista.

Dagognet (2012, p.241-250), sobre esse processo, considera a anestesia uma das técnicas mais heroicas e revolucionárias da farmacologia. Desde o início os experimentadores e cirurgiões "se dedicaram a precisar minuciosamente a zona mediana" (DAGOGNET, 2012, p.242) que impedisse os efeitos ruins de uma toxicose ou de uma dose insuficiente. Como nenhum remédio tem seus efeitos puramente definidos por moléculas, os anestésicos não deixarão de "despertar consequências maléficas" (DAGOGNET, 2012, p.243), ou seja, provocar intoxicação e efeitos indesejados. A anestesiologia conseguiu reverter esses problemas de três formas: na busca por fármacos capazes de reduzir a dose e a toxicidade; na fragmentação da anestesia a partir da preparação do organismo para a perda das funções; na utilização de outros fármacos não anestésicos para evitar os inconvenientes gerados pela anestesia. $\mathrm{O}$ resultado foi uma polifarmácia complexa que cerca o anestésico de corretivos. Essa tendência à polifarmácia contemporânea já era verificada desde o início do século XX com a crescente popularização da combinação de novocaína e adrenalina, conforme discutido no Capítulo quatro.

Não restam dúvidas sobre a excelência técnica que o campo da anestesiologia constituiu. O problema é que a consolidação de especialidades está ligada à formação de um complexo industrial que altera as formas de acesso aos meios de produção do trabalho médico, transformando os agentes do processo curativo (as classes terapêuticas, as instituições de ensino médico e os serviços de saúde) em instrumentos comerciais 
que visam à acumulação de capital. Porém, para que a mercantilização da saúde se complete é preciso que as práticas populares de administração das enfermidades sejam reduzidas a uma questão técnica da alçada do profissional habilitado.

Um exemplo do impacto da consolidação da anestesiologia como especialidade sobre as práticas tradicionais de cuidado sobre o corpo está na transferência do parto da casa para o hospital - destacando que o parto não é uma enfermidade, embora seja um momento que envolva dor e perigo à vida da gestante. Vimos, no Capítulo quatro, como as técnicas anestésicas eram usadas durante o parto - em geral pelo médico de família e pressupondo a dor como parte integrante do processo. Segundo Carneiro (2015, p.5052), nas classes menos favorecidas ainda prevalecia a ação das parteiras portadoras de práticas criticadas pela Igreja, por vincular ao processo de parto crenças não oficiais, e pela classe médica, pela adoção de práticas não higiênicas. A anestesiologia permitiu ao hospital se colocar como local apto a exercer o parto com meios higiênicos e sem dor, graças à combinação de anestesia peridural ou raquidiana e a cesariana. Ao longo da segunda metade do século XX esse se tornará o padrão para todas as classes, transferindo o conhecimento do parto das parteiras, geralmente de origem popular, para uma classe de especialistas com formação biomédica - de origem elitista.

Conforme dito acima, não tenho a pretensão de abordar a transformação dos meios de produção do trabalho médico em todos os seus aspectos - ainda é preciso construir uma agenda de pesquisa capaz de elucidar esse processo em toda a sua extensão. Por ora, gostaria de salientar que o período pós-1945 foi fundamental para a consolidação de uma noção de terapêutica que pressupõe: a percepção de doença como um desvio biológico; uma prática médica que tem como foco de ação o hospital; a competência como sinônimo de domínio técnico; o médico especialista como centro do ato terapêutico. As vitórias sobre algumas doenças milenares e os maiores recursos técnicos escondem, portanto, a construção de uma concepção de saúde mercantilizada que se tornará hegemônica a partir de então. Isso terá consequências funestas sobre a saúde e a cultura farmacológica da população como um todo.

Os avanços no campo da terapêutica obtidos com os antibióticos ou as máquinas que permitem o diagnóstico mais preciso não modificaram em nada algumas das funções que os fármacos clássicos exerciam na sociedade. As pessoas ainda precisavam de recursos capazes de fazer dormir, acalmar a dor e relaxar o organismo; ou ampliar a vivacidade, a atenção e a vigília. O Decreto no 20.397, de 14 de janeiro de 1946, além de colocar o infame rótulo de "narcótico" nos fármacos clássicos, ainda ampliava o 
controle com a diversificação da burocracia destinada a verificar o fluxo legal e legítimo de uso. Por outro lado, mantinha livre o uso dos substitutos oferecidos pela indústria estrangeira.

Um desses produtos oferecidos eram os "psicoestimulantes, como a anfetamina" (STUCKER et al, 2007, p.134), que "passaram a ser utilizados no tratamento da depressão nos últimos anos da década de 1930. Efeitos semelhantes eram causados pela cocaína, na época ainda utilizada legalmente na terapêutica" (STUCKER et al, 2007, p.134). Em termos estritamente farmacológicos as anfetaminas são mais potentes que a cocaína. Ao invés dos hipnóticos opiáceos, começaram a serem oferecidos livremente os barbitúricos - que são muito mais tóxicos, com menor taxa de segurança (distância da dose ideal da dose letal) e maior poder de criar dependência - e depois pelos ansiolíticos - que trataremos na próxima seção. Embalados pelo imaginário da superioridade técnica do químico e por ser vendido livremente como medicamentos seguros (não entorpecentes), o público passava a ter uma alternativa lícita aos antigos fármacos - que gradualmente caiam em desuso terapêutico, realimentando a ideologia (retórica) do progresso técnico.

Entre os anos de 1930 e o começo dos anos de 1950, essa política de controle pareceu resolver o problema do uso ilícito de entorpecentes. Foram fatores que contribuíram para essa percepção: a Segunda Guerra mundial e a desarticulação da indústria farmacêutica legal que alimentava o comércio de produtos entorpecentes intervenção sobre a oferta; a disponibilização de substitutivos legais, e mais potentes, sem restrição de acesso - intervenção sobre demanda. Um discurso otimista se consolidava entre os órgãos do governo responsáveis pelo controle de entorpecentes a partir dos anos de 1930 - o tema "se dissipa no que diz respeito às drogas" (SILVA, 2015, p.297), entrando como agravante de temas mais gerais, como a subversão e a vadiagem.

O Delegado paulista Guido Fonseca, que escreveu um livro sobre a atuação da polícia contra as drogas com fontes exclusivas e inacessíveis, aponta dois fatores que levaram ao fim do problema com os tóxicos: a escassez dos produtos pela guerra e o regime autoritário que facilitava a ação policial. Nos relatórios policiais as toxicomanias passam para um plano secundário. Entre 1941 e 1942, a Delegacia de Costumes de São Paulo logra em afirmar que não existem casos de toxicomania naquela praça (FONSECA, 1994, p.139-140). 
A CNFE, que é o órgão responsável pela política de drogas, tinha uma estrutura precária, porém conseguia instaurar uma série de novos controles em parceria com a SNFM (CARVALHO, 2013, p.121-127). Foram criadas Comissões Estaduais, visando difundir e divulgar os princípios da política proibicionista (CARVALHO, 2013, p.116120). Em 1938, quando o governo argentino começava a debater as mudanças legislativas no campo da toxicomania, a CNFE foi convidada a participar do seminário e expor a experiência brasileira (CARVALHO, 2013, p.114-115). O Brasil se tornaria um exemplo de adequação legislativa às normativas sugeridas pelos órgãos internacionais.

Esse otimismo pode ser verificado no artigo intitulado As toxicomanias no apósguerra, quando Roberval Cordeiro de Farias - diretor da CNFE - comentou a preparação do Brasil para enfrentar a onda de toxicomania que acompanha o fim de conflitos. Ele garantia que o país só importava entorpecentes para fins médicos e científicos, em níveis inferiores a outros países latino-americanos. A heroína tinha sido banida. A morfina estava sendo substituída pela "codeína e dionina, muito menos nocivas, graças à campanha educativa exercida junto às classes médicas e farmacêuticas do nosso país" (FARIAS, 1958, p.150). A cocaína também estava sendo substituída por “outros anestésicos que não estabelecem vício" (FARIAS, 1958, p.150). Sem sombra de dúvidas, o Brasil estaria dotado de uma legislação "que pode ser considerada, sem exagero, como uma das mais completas e eficientes que existem atualmente" (FARIAS, 1958, p.150).

Esse cenário de aparente sucesso começa a mudar ao longo da década de 1950 por dois motivos. Primeiro, pelo retorno do velho problema dos desvios dos remédios da farmacopeia lícita para usos não controlados pelos médicos. Guido Fonseca (1994) ao analisar as políticas do período Vargas apontará com certa amargura a ausência de instrumentos legais capazes de conter o consumo das "bolinhas".

\footnotetext{
“Além das chamadas drogas clássicas, maconha, cocaína, ópio e heroina, começaram a proliferar entre os viciados as chamadas 'bolinhas' ou substâncias fármaco sintéticas (sedativos e estimulantes) adquiridas livremente nas farmácias. Por longos anos a Polícia ficou sem os instrumentos legais necessários para uma ação repressiva e isso deve ter estimulado o seu consumo e a sua venda" (FONSECA, 1994, p.149).
} 
Outro relato policial, realizado em 1961, corrobora com a imagem trazida por Guido Fonseca. Segundo o Delegado José Dirceu C. Leal de Oliveira, Titular da Delegacia Especializada na Fiscalização sobre os Costumes, existe

\footnotetext{
“essa falha clamorosa da nossa legislação sanitária. Bastaria, como exemplo da gravidade dessa questão, citar-se os malefícios, de todos tão conhecidos, que o PERVITIN vem causando à Sociedade. [...] As chamadas 'bolinhas' estão a exigir dos poderes públicos responsáveis maiores cuidados" (OLIVEIRA, José Dirceu C. Leal de apud TELLES, 1961, p.22).
}

A falta de controle sobre a farmacopeia legal, desde meados da década de 1950, vinha preocupando os diretores da CNFE, Benoni Laurindo Ribas e Nelson Lobo Vianna. Em artigo publicado na revista Medicina - Cirurgia - Farmácia eles alertavam que, apesar das novas drogas terem um menor "poder toxicomanógeno" (RIBAS et al, 1956, p.313), elas não eram "totalmente isentas de perigos na aplicação de doses altas e repetidas, podendo levar aos desastrosos resultados da toxicomania" (RIBAS et al, 1956, p.313). Era preciso relativizar as virtudes fartamente proclamadas pelos anunciantes, nas propagandas 'éticas', que alegavam que "a medicação sintética possuía maior poder analgésico, menor toxidez e ação mais duradoura do que a morfina, o que, parece, ao menos em parte, não traduz com exatidão a realidade" (RIBAS et al, 1956, p.313). Cabia, portanto, aos médicos se instruírem para fazer uma "utilização cautelosa e com indicação precisa" (RIBAS et al, 1956, p.313), pois "se os produtos sintéticos realizam trabalho hipnógeno e sedante idêntico ao do ópio e seus derivados, não são eles, contudo, destituídos de efeitos secundários lamentáveis” (RIBAS et al, 1956, p.314).

Essas fontes, mesmo que preliminarmente, evidenciam que o velho problema do desvio de fármacos restritos às atividades terapêuticas para outras finalidades não desaparecera - apenas tomava uma nova roupagem. Escohotado (2008, p.785-788) chama atenção que esse fenômeno era verificado nos vários países que aplicaram o repertório estadunidense de controle das drogas. A "sociedade limpa", característica do pós Segunda Grande Guerra, dispõem de inúmeros recursos clínicos para obter tranquilidade, sono e estimulação. A difusão dos remédios sintéticos, com suas propagandas 'éticas' pouco informativas e restritas aos especialistas, levou a multiplicação dos dependentes de origem iatrogênica. A tentativa de proteger os adultos de si mesmos através da troca de uma farmacopeia por outra, tendo como critério a 
preferência o sintético ao natural e o patenteado ao não patenteado, não resolveu o problema do consumo abusivo em uma sociedade de massas.

O segundo motivo que modificou esse cenário de tranquilidade e confiança na política de drogas foi a ascensão do comércio ilícito da farmacopeia clássica. Depois de desarticulada a indústria legal, foi lento e gradativo o desenvolvimento da produção e das redes do comércio ilegal. A primeira dessas substâncias a consolidar um mercado nacional ilícito foi a Cannabis, apesar da tentativa dos órgãos oficiais em minimizar o problema em um primeiro momento. Em $1^{\circ}$ de abril de 1952, em conferência na Sociedade Brasileira de Higiene, Roberval Cordeiro de Farias fez outro balanço sobre as ações da CNFE, porém o tom já era outro em relação aquele feito no pós-guerra. Ele apontava que o país estava plenamente adaptado às diretrizes internacionais de controle há bastante tempo. Se algum problema ainda persistia era por causa da falta de informação; também criticava aqueles que defendiam a prisão ao invés de internação dos toxicômanos. "O viciado é um doente, e como doente é que deve ser tratado" (A Gazeta da Farmácia, maio de 1952). O maior apelo ao recrudescimento da pena era fomentado pela presença cada vez mais insinuante da Cannabis nos centros urbanos. Ao contrário do que de fato aconteceu, Roberval garantiu na ocasião que

"o problema da maconha ou diamba, como é conhecido no Brasil a 'cannabis
índica' - 'hashish' dos árabes ou marihuana da América Central e dos
Estados Unidos, está perfeitamente equacionado e em vias de solução"
(FARIAS, Roberval Cordeiro de Apud A Gazeta da Farmácia, maio de 1952)

A Cannabis, apesar de central no debate atual, ainda é pouco estudada. A única pesquisa sobre esse tema, na década de 1950, é a Dissertação de Jorge Souza (2012) que trata da repressão ao consumo na cidade de Salvador. Apesar de importante, pouco contribui para a compreensão do processo de nacionalização do consumo. Em geral, ainda prevalece a ideia de que o consumo se expandiu por causa da influência do movimento hippie estadunidense nos anos de 1960 - quando o complexo da marijuana ganha força e se globaliza. Essa hipótese aparece de forma exemplar no livro de França (2015).

A "juventude desorientada" dos anos de 1960 e 1970 não promoveria uma redescoberta do outrora popular hábito do diambismo [...]. Os canabistas ou maconheiros de então - não mais diambistas - tinham descoberto o hábito no 
estrangeiro e atribuíam a ele outros significados. Pelas mãos de jovens universitários, artistas e intelectuais popularizava-se agora no Brasil - como de resto, um pouco por todo o mundo ocidental - aquela tradição estranha aos brasileiros cultos do século XIX, mas tão cara a certos intelectuais do Ocidente, como aqueles pertencentes ao Clube dos Haxixeiros de Paris (FRANÇA, 2015, p.71).

Embora ainda tenha que ser pauta de uma pesquisa de fôlego, parece certo que o hábito de fumar Cannabis se nacionalizou antes da influência hippie. O trabalho do Delegado Guido Fonseca, apesar do pouco profissionalismo, ainda é de inegável valor por causa das fontes que apresenta. Enquanto a pesquisa histórica não se desenvolve ele serve como incitação a pesquisa. Fonseca (1994, p.146-149) aponta que, entre 1956 e 1957, a polícia de São Paulo teria prendido 1.381 indivíduos e instaurado 44 inquéritos policiais somente em relação à Cannabis. $\mathrm{O}$ perfil social dos presos mostrava que a maioria deles não tinha profissão, ou seja, 'vagabundos' na visão desse delegado. Em 1961, a 'maconha' já superava todas as outras drogas em termos de apreensão.

Essa situação não parece se restringir ao sudeste. Mesmo em Porto Alegre, a capital estadual mais distante do epicentro nordestino, é possível verificar uma mudança na forma como o assunto é abordado. Entre 1940 e 1941, a presença de consumidores de Cannabis foi motivo de surpresa e curiosidade. Tratou-se tal evento como um fato isolado, resolvido depois que os envolvidos em tal incidente "foram enviados para o Norte, donde procediam, sem haver divulgado o canabismo" (CIULLA, 1958, p.381). A legislação vigente era elogiada. Foi

\footnotetext{
"um sucesso curioso o registro de alguns casos de canabismo, de dezembro de 1940 a fevereiro de 1941, pois, até então, entre os toxicômanos que temos tratados no Hospital São Pedro, era desconhecido o cânhamo indiano. O álcool, em virtude de seu fácil acesso, ocupa lugar de destacado, enquanto a morfina com seus sucedâneos e a cocaína vêm seu consumo reduzido, consequência da repressão rigorosa que hoje se estabelece" (CIULLA, 1958, p. 377).
}

Esse clima descontraído e curioso parece bem distinto do tom alarmista usado pela imprensa diária gaúcha no final dos anos 1950. Uma notícia publicada no jornal Correio do Povo, sob o título Quatro maconheiros presos pela polícia, indica que "A Delegacia de Costumes está movendo tenaz campanha contra os traficantes de maconha e seus viciados, detendo-os e instaurando contra eles o competente processo" (Correio 
do Povo, 08/01/1959, p.05). Em uma operação realizada "em plena Praça da Alfandega, ponto de reunião de malandros que exploram aquele vício" (Correio do Povo, 08/01/1959, p.05) foram presos vários “contraventores" (Correio do Povo, 08/01/1959, p.05). Antes dos hippies, portanto, o hábito de fumar já tinha chegado na distante Porto Alegre.

O tema dos entorpecentes, que tinha deixado de aparecer no cinema, volta a despertar o interesse da população. Depois do filme Vício e Perversidade (1932) o tema das drogas desapareceu de cena. Só retornou com o lançamento do polêmico Cais do Vício (1953), que narra a história de um motorista que se vê acidentalmente envolvido com um traficante de maconha e com o assassinato de um fazendeiro, porém é auxiliado por uma repórter policial.

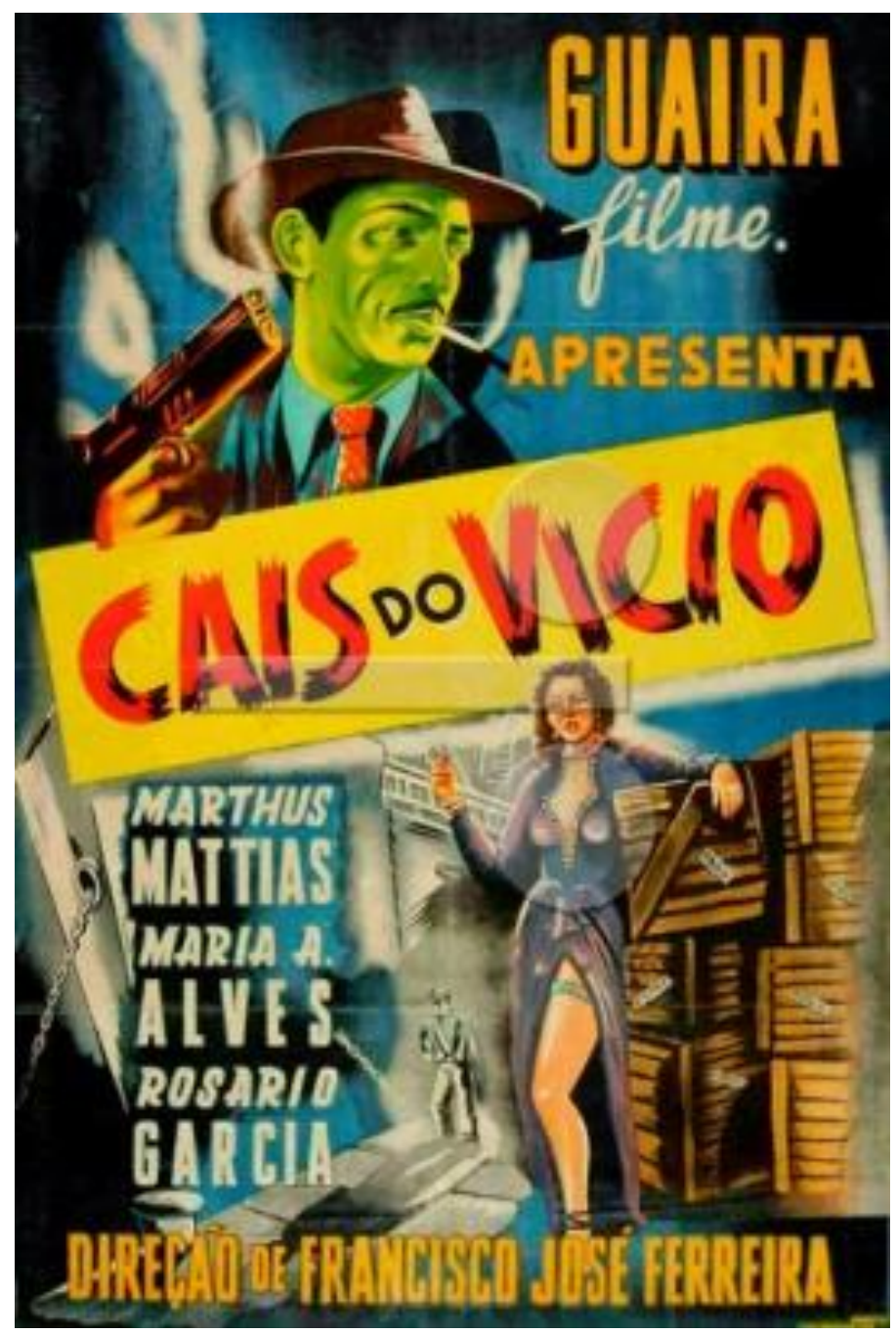

Figura 11 - Cartaz de divulgação do filme "Cais do Vício" FONTE: Cinemateca Brasileira 
Vimos, acima, como os agentes responsáveis pela segurança criticavam a legislação que não lhes davam meios de conter os usos não legítimos derivados da farmacopeia lícita. O discurso condenando a legislação vigente receberá um reforço da sensação de impunidade gerada nos casos de repressão aos ilícitos, principalmente a distinção tênue entre usuário e traficante. A Carta Prefácio escrita por Ítalo Galli, Juiz de Direito da $17^{\text {a }}$ Vara Criminal da Comarca de São Paulo, ao livro do Delegado de Polícia Celso Telles ${ }^{70}$, em 1961, intitulado Comércio Clandestino de Entorpecentes é um exemplo desse tipo de crítica. O citado juiz apontava os erros da doutrina derivada da decisão do Juiz do Supremo Tribunal Federal, Nelson Hungria, no julgamento de Habeas-corpus $n^{\circ} 36.007$, que entendia ser doença e não crime o uso de drogas.

\begin{abstract}
Inegavelmente, um dos tropeços que vêm dificultando as atividades repressivas da Polícia, no setor em apreço, reside no entendimento, agora bafejado por recentes julgados do Supremo Tribunal Federal, segundo o qual não pode ser responsabilizado criminalmente o detentor do entorpecente, desde que o possua, não para comércio, mas para uso próprio, sob o pretexto de que o viciado, real ou potencial, é um doente, que deve sofrer tratamento adequado e não castigo. Essa orientação, 'data venia', tem contra si a letra da lei, o seu elemento histórico e o próprio interesse social. Além disso, representa, em última análise, uma inovação 'sui generis', na disciplina de responsabilidade criminal seguida pelo Código (GALLI, Ítalo apud TELLES, Celso, 1961, p.111).
\end{abstract}

O tema da Cannabis esteve na pauta do Supremo Tribunal Federal antes dos hippies estadunidenses. Embora sejam apresentados apenas alguns indícios, incitando novas pesquisas, eles parecem suficientes para rechaçarmos a ideia de que o uso de Cannabis no Brasil tenha se reduzido ao reflexo da pauta contracultural estadunidense. O sistema de controle alarmado como tão eficiente logo depois da Segunda Guerra se mostrou, no médio prazo, ineficaz para lidar com as novas pautas culturais de consumo criadas pela ilicitude que os próprios dispositivos criaram.

Em linhas gerais foram essas as principais características da centralização da política de drogas ocorrida entre 1932-1964: uma mudança no perfil da indústria farmacêutica e a criação de um complexo industrial altamente rentável; a substituição da

${ }^{70}$ Celso Telles era Chefe da Polícia de São Paulo na ocasião da morte do ex-delegado Sérgio Paranhos Fleury. Ele proibiu a necropsia do corpo, fato que alimentou inúmeras teorias sobre as causas de sua morte. Esses eventos foram revelados poucos anos antes de sua morte (1999) pelo jornalista Percival de Souza autor do livro Autópsia do medo - vida e morte do delegado Sérgio Paranhos Fleury. 
farmacopeia tradicional por novos e potentes fármacos, com a repetição do velho problema da intoxicação iatrogênica; o crescimento do tráfico ilícito, principalmente de Cannabis. É importante ressaltar esses fatores para não creditarmos unicamente à Single Convention on Narcotics Drugs, de 1961, ou a pauta de uso da contracultura a alteração da política de drogas no Brasil.

O projeto que resultou na Lei $n^{\circ} 4.451$, de 4 de novembro de 1964, marco inicial do novo modelo proibicionista que seria instaurado como resposta a essa crise, foi apresentado em 1959 ao Congresso. Seu idealizador, o comunista pernambucano Coutinho Cavalcante (PTB), justifica assim a necessidade de aprová-lo:

\footnotetext{
"a criminalidade, ligada ao setor de entorpecente, não se exaure na conceituação das figuras delituosas previstas no artigo 281 do Diploma Penal vigente. Um ponto básico foi olvidado: a plantação de substâncias entorpecentes, que, por exemplo, no caso da chamada 'maconha' [cânhamo cannabis sativa e variedade índica] assume importância relevante" (Diário do Congresso Nacional [seção I], 01 de agosto de 1959, p.4748).
}

Portanto, embora o marco do novo regime proibitivo seja a Lei ${ }^{\circ} 4.451$, de 4 de novembro de 1964, os problemas que levaram a alteração da política são anteriores inclusive ao novo ordenamento internacional de 1961.

\subsection{O proibicionismo punitivista (1964-1999).}

Os acontecimentos políticos relevantes, como aqueles que levam a uma mudança no regime político, exercem sedução como marcos de delimitação nos estudos históricos. Entretanto, “a verdadeira exatidão consiste em se adequar, a cada vez, à natureza do fenômeno considerado" (BLOCH, 2001, p.150). O caso dessa pesquisa é um daqueles exemplos em que há coincidência entre a mudança no regime político e as políticas que abordam a questão das drogas.

Em termos mais gerais, a crise que levou a mudança de regime político também esteve vinculada aos problemas gerados pelo modelo de política de saúde adotado no período anterior. Em 1961, durante o governo Jânio, "eclodiu um escândalo bem divulgado pela imprensa: o abusivo preço de importação dos insumos farmacêuticos pelas indústrias de capital estrangeiro" (BUENO, 2008, p.110) que resultou na “instalação de uma Comissão Parlamentar de Inquérito (CPI), criada para investigar, 
também, a crescente desnacionalização da indústria farmacêutica no país" (BUENO, 2008, p.111). Os resultados, divulgados no governo Jango, mostraram que a desnacionalização da indústria tinha chegado aos impressionantes $95 \%$.

Para tentar conter a evasão de dinheiro, o governo passou a defender a regulamentação da Lei de Remessa de Lucros e, paralelamente, criou alguns órgãos como o Grupo Executivo da Indústria Farmacêutica - para discutir os rumos do setor e propor medidas com objetivo de controlar os preços das importações. As empresas multinacionais passaram a usar seu sindicato, que funcionava como órgão consultivo para o setor desde 1947, como meio de pressionar o governo a permitir a livre circulação de capitais e autonomia para a definição de preço dos produtos. O governo federal ignorou essas pressões e aprovou o Decreto $\mathrm{n}^{\circ} 53.584$, de 21 de fevereiro de 1964

\footnotetext{
"que determinava a uniformização dos preços dos produtos farmacêuticos em todo o território nacional, obrigava os laboratórios a estampá-los nas embalagens e forçava a indústria farmacêuticas a revelar suas planilhas de custos" (BUENO, 2008, p.112).
}

Essa lei foi objeto de debates acalorados entre o representante brasileiro do Ministério da Saúde e o enviado estadunidense na Assembleia da OMS pouco depois de sua promulgação. Uma das primeiras medidas adotadas pela ditadura civil-militar que assumiu depois da queda de Jango foi revogar essa lei. Por causa desses acontecimentos, não é possível dizer que a questão do lucro da indústria farmacêutica estrangeira não tinha ligação com a mudança do regime político.

Se os EUA tinham uma enorme influência na condução das políticas econômicas no setor antes do golpe de 1964, esse fator somente aumentou depois da derrubada do governo eleito. Ainda serão precisos estudos específicos para avaliar o grau de ingerência dos EUA nas políticas farmacêuticas, mas é fato que ocorreu uma modificação nos currículos médicos no sentido de moldar a formação de profissionais às demandas criadas pelo nascente mercado de medicamentos e de máquinas hospitalares. Segundo Lampert (2009, p.64-65), a Lei $\mathrm{n}^{\circ} 5.540$, de 28 de novembro de 1968, adequou oficialmente as escolas médicas brasileiras ao modelo estadunidense, substituindo as cátedras por departamentos contendo disciplinas e dividindo o ensino em dois ciclos - o básico e o especializado. Essas mudanças consagraram uma estrutura "individualista, biologicista, hospitalocêntrica e com ênfase nas especializações" 
(LAMPERT, 2009, p.65). A década de 1960 marcará “o deslocamento definitivo do modelo liberal" (SCHRAIBER, 1993, p.113) a partir da adoção do modelo de medicina tecnológica e empresarial. Estabelecer-se-ão empresas do tipo capitalista, as chamadas medicinas de grupo, com auxilio do governo - ao contrário de outros países onde esse tipo de organização dos serviços médicos foi uma iniciativa da sociedade civil (SCHRAIBER, 1993, p.133-134)

O ano de 1964 é um marco também porque foi nele que se aprovou a Lei $n^{\circ}$ 4.451, de 4 de novembro - ela foi enviada ao Congresso motivada pelos problemas gerados na legislação que dava inteligibilidade ao proibicionismo centralista descrito na seção anterior. Seguiu a essa o Decreto-Lei $n^{\mathbf{0}}$ 159, de 10 de Fevereiro de 1967, equiparando

\footnotetext{
"as substâncias capazes de determinar dependência física ou psíquica aos entorpecentes para os fins penais e de fiscalização e controle. Nesta matéria, o Brasil foi o segundo país do mundo a enfrentar o problema, considerando tão nocivo quanto o uso de entorpecentes, o uso, por exemplo, dos anfetamínicos, ou dos alucinógenos" (GREGO FILHO, 1972, p.34)
}

Se a lei de 1964 acabava de vez com a legitimidade do uso de entorpecentes para fins médicos, a lei de 1967 foi responsável por equiparar os medicamentos legais às substâncias ilegais quando usados para 'fins não legítimos'. Em 1968, foi promulgado o Decreto-lei $\mathrm{n}^{\mathrm{o}} 385$, de 26 de dezembro, dando nova redação ao artigo do Código Penal que tratava dos entorpecentes. Segundo Carvalho (2007, p.18), o "legislador brasileiro optou pela medida drástica de identificar, na mesma categoria, todos os envolvidos com tóxicos, independentemente do grau de sua participação". Todas essas tendências culminam na Lei $n^{\circ} 6.368$, de 21 de outubro de 1976, que será a normativa que orientará a política de drogas ilícitas até 2006.

A política de drogas e a política de medicamentos estão intrinsicamente ligadas, por isso não é coincidência que quase simultaneamente a lei de drogas é promulgada a Lei $\mathrm{n}^{\mathrm{a}}$ 6.360, de 23 de setembro de 1976, definindo a obrigatoriedade de tarjas (vermelha e preta) para indicar a periculosidade dos medicamentos e as formas de acesso - garantindo o monopólio médico da prescrição sobre todos os medicamentos e não mais somente sobre os entorpecentes. Era preciso regulamentar o comércio de fármacos legais como meio de evitar os usos 'não legítimos' e as intoxicações que eram tão comuns. Assim como no caso da construção do ordenamento jurídico do 
proibicionismo centralista, também neste caso ainda será preciso novos estudos que analisem os documentos que fundamentam as alterações, os agentes envolvidos e as dinâmicas sociais e econômicas que levaram a adoção desse modelo punitivista.

A mudança na lei de drogas não se referia somente as demandas internas, também nos outros países os problemas enfrentados pelo Brasil eram percebidos. Entre as décadas de 1960 e 1980, várias conferências e eventos internacionais foram realizados para debater o assunto, elaborar critérios para definição da periculosidade das substâncias oferecidas no mercado lícito e as substâncias que deviam ser banidas da face da terra (em geral plantas ou fitoquímicos ligados a tradições milenares de uso). Os mais importantes eventos internacionais foram: Single Convention on Narcotics Drugs (1961); Convention on Psychotropic Substances (1971); United Nation Convention Against Illicit Traffic in Narcotic Drugs and Psychotropic Substances (1988). Desde os anos de 1950, os EUA passaram por uma verticalização e centralização das instituições responsáveis pela repressão ao tráfico e o uso de drogas culminando na formação da Drug Enforcement Administration (DEA) em 1973 (ESCOHOTADO, 2008, p.8851061; MUSTO, 1999, p. 245-300; RODRIGUES, 2004, p.70-91; DELMANTO, 2013, p.39-63).

A verticalização e centralização das políticas repressivas sobre o uso de entorpecentes também foi verificada no Brasil, denotando a inspiração do modelo institucional estadunidense. O Decreto $\mathrm{n}^{\circ}$ 85.110, de 2 de setembro de 1980, retirou da CNFE a gerência sobre a política de drogas no Brasil e passou para o Conselho Federal de Entorpecentes (CFE), composto por membros de vários ministérios e coordenado pelo Ministério da Justiça. Com essa mudança institucional o proibicionismo punitivista finalizou sua fase de configuração, porém ainda é preciso destacar uma última lei que foi promulgada depois e que, embora não alterasse os fundamentos do sistema, teve enorme impacto social: a Lei $\mathrm{n}^{\circ} 8.072$, de 25 de julho de 1990, conhecida como a Lei dos Crimes Hediondos. Ela foi responsável por restringir o direito de presunção de inocência e dificultar a progressão de regime das pessoas presas pelo tráfico de drogas. Ela foi uma das principais responsáveis por multiplicar a população carcerária do país, que combinado com os baixos investimentos no setor levaram à superlotação dos presídios, à ampliação da violência em torno dos condenados (e seus familiares) e ao fortalecimento do crime organizado.

Essas foram, basicamente, as principais normativas que resultaram na modificação da política de drogas. Antes de entrar na discussão a respeito das 
consequências dessa legislação sobre o tráfico de substâncias ilícitas, gostaria de discutir outro mito da historiografia triunfalista da medicina. Segundo essa corrente, nos anos de 1950 e 1960

\footnotetext{
"a Medicina passou por outra importante transformação que ficou conhecida como a Revolução Farmacológica da Psiquiatria, quando foram introduzidas drogas psicoterapêuticas capazes de melhorar o estado de pacientes portadores dos chamados distúrbios de comportamento e das funções psicológicas, denominados psicoses" (STUCKER et al, 2007, p.131).
}

Graças a esses avanços, proporcionados pela pesquisa da indústria farmacêutica, os hospitais psiquiátricos não precisariam mais internar os doentes por toda a vida, permitindo que sua ação ocorresse no nível ambulatorial, graças à "introdução de drogas antipsicóticas, neurolépticas ou antiesquizofrênicas" (STUCKER et al, 2007, p.131). No início dos anos de 1960, foram introduzidos os primeiros benzodiazepínicos - que representaram outra revolução nos já propagados ansiolíticos. Em altas doses, eles têm função hipnótica e puderam substituir os perigosos barbitúricos (STUCKER et al, 2007, p.134-137).

Essa retórica 'revolucionária' é um exemplo emblemático de como a quimioterapia, que proporcionou avanços terapêuticos de enorme significância, habitualmente costuma "atropelar os fatos e criar os mitos" (ALMEIDA, 2011, p.47). É inegável a utilidade de alguns desses fármacos para lidar com a esquizofrenia ou como antipsicóticos, porém isso não pode ser estendido para todo o campo da psiquiatria sem uma reflexão sobre os aspectos sociais, políticos e econômicos envolvidos. Essas 'revoluções' só foram possíveis depois de mudanças ocorridas nas políticas de medicamentos. A indústria farmacêutica nacional faliu, conforme vimos, tornando-se instrumento de transferência de recursos para o exterior. Mudanças importantes ocorriam no centro dinâmico dessa indústria (EUA), com consequências para a situação brasileira. Atentemos a elas.

Um dos argumentos que venho apresentando ao longo dessa Tese é a impossibilidade de separarmos a política econômica da indústria farmacêutica e o proibicionismo às drogas. Nesse sentido, ao lado da centralização das agências repressivas que resultou na formação da DEA - que foi bem relatado pela historiografia das drogas - também ocorreu o crescimento do controle sobre a venda de fármacos através da Food and Drug Administration (FDA). Existia, entretanto, uma forte 
resistência, tanto em relação à monopolização da prescrição na classe médica, quanto uma crítica à propaganda 'ética' por ser uma forma de disseminação de novos fármacos e de provocar uma mudança no perfil do consumo de medicamentos. Se as drogas não são seguras, mesmo as 'boletas mágicas' podem gerar intoxicações, é preciso que os médicos as prescrevam com responsabilidade e as pessoas as usem com moderação. No passado os clínicos podiam ser distinguidos dos 'charlatões' pela sua tendência em prescrever pouca medicação, pois tinham a crença de que o pouco poderia ser bem efetivo. Depois da guerra e do fortalecimento da indústria farmacêutica ocorreu uma mudança cultural com o incremento do nível de prescrições. A propaganda 'ética' fazia parte dessa mudança (HEALY, 1997, p.24-25).

No meio dessa disputa, em 1957, ocorrem os primeiros eventos com a talidomida, com ampla divulgação das imagens de má formação fetais em todo o mundo. Nos EUA, essa questão serviu para mobilizar a opinião pública em torno da aprovação do Food and Drug Cosmetic Act, em 1962, dando amplos poderes ao FDA e quebrando as resistências à centralização tão desejada pelas grandes empresas farmacêuticas. Foram consequências dessa política: uma revisão de todos os produtos que circulavam nos EUA, algo em torno de meio milhão, apontando que três quartos não funcionavam; a vitória sobre o lobby antiprescrição e a monopolização das receitas pela classe médica; a consolidação do critério do aleatório, controle placebo o triagem duplo-cego como meio apropriado de verificar a eficiência de um remédio - que podem ser úteis na verificação da ação de algumas drogas, porém questionáveis como parâmetro para outras, como as drogas psiquiátricas (HEALY, 1997, p.25-27).

Para o argumento que apresento nesse momento, a mais importante consequência dessa política foi a transformação da FDA em um órgão de licenciamento de novas drogas através do parecer de especialistas que chegavam a um acordo para definir quais os compostos eram válidos para combater as doenças (disease/biomédica). A grande maioria das drogas até então presentes no mercado, que foram apontadas como ineficientes, eram destinadas ao mau hálito, ao esgotamento, à fadiga nervosa e outros problemas desse tipo. Os consumidores iam as farmácias buscarem meios para administrar seus sofrimentos (illnesses/enfermidade). Aplicou-se em todas as drogas o critério bacteriológico e biomédico (HEALY, 1997, p.27-28).

Verificando esses acontecimentos fica mais claro que, por trás dos 'avanços técnicos' que levaram à 'Revolução Farmacológica da Psiquiatria', existe uma opção política em retirar da população a autonomia sobre os recursos farmacológicos, 
principalmente os antálgicos. O resultado desses 'avanços' é o estímulo crescente da indústria farmacêutica, por meio da 'propaganda ética', para a medicina intervir em situação de vida e de trabalho que antigamente não pertenciam a sua alçada.

No Brasil, a adequação ao modelo estadunidense descrito acima encontrou problemas por causa da crise econômica e fiscal gerada pelo endividamento externo inconsequente realizado pela ditadura civil-militar. Em 1969, o governo brasileiro negou-se a reconhecer as patentes dos processos industriais, tornando legítima a fabricação de produtos similares - dando sobrevida à indústria nacional. O governo reagiu à desnacionalização criando a Central de Medicamentos para produzir e distribuir remédios, além de criar laboratórios em vários estados. Durante a década de 1980, em meio à crise inflacionária e cambial, o governo congelou o preço dos medicamentos levando a indústria estrangeira para a oposição (STUCKER et al, 2007, p.148-153).

No Brasil, portanto, não houve em um primeiro momento um órgão centralizador da política de medicamentos, como o FDA, que em articulação com a indústria de medicamentos levou a uma concentração de poderes nas mãos dos médicos. Aqui os principais atores responsáveis pela expropriação da saúde e, consequentemente, a sua mercantilização foi a classe médica que se associou com a indústria estrangeira. Temporão (1986), que estudou a história da propaganda de medicamentos no Brasil, aponta que o cerne da estratégia comercial das empresas estrangeiras, desde 1920, era a propaganda 'ética'. Essa política de aproximação com os médicos foi se fortalecendo ao longo dos anos, para ganhar status de atitude eticamente responsável e compromisso com o progresso depois de 1950.

\footnotetext{
"A conjuntura $[\ldots]$ fez convergir os interesses da categoria dos médicos e das indústrias estrangeiras, que passam a manter uma verdadeira cruzada contra a indústria nacional, pelo monopólio da prescrição. É um período de ruptura, de transformações profundas no modo de produzir e consumir medicamentos" (TEMPORÃO, 1986, p.30).
}

A classe médica, que passava a ser formada estritamente dentro dos padrões biomédicos depois da Lei $\mathrm{n}^{\mathrm{o}} 5.540$, de 28 de novembro de 1968, tornou-se o veículo de concentração de capital de empresas e indústrias subsidiárias localizadas no exterior. Segundo Almeida (2011, p.07), nessa parceria o médico transfere para a indústria à elaboração da diagnose, tornando-se a partir de então em um receptor das informações comerciais produzidas pelos grandes laboratórios. Longe de ser uma expropriação do 
ato médico, essa relação estabelece um consórcio com grandes retornos financeiros para ambas as partes.

Os resultados foram excelentes para a classe médica e a indústria farmacêutica, porém terríveis para a população. A propagação do uso de ansiolíticos, por exemplo, é prova dessa relação promíscua. Na década de 1980, a propaganda 'ética' apresentava esses fármacos "pelo sugestivo título de Urbanil, ou seja, o paliativo ideal para as tensões e dissabores advindos da vida nas grandes metrópoles" (TEMPORÃO, 1986, p.104). Eles claramente ocuparão um espaço antigamente destinado aos narcóticos. Escohotado (2008, p.1235-1237) aponta que: atualmente os ansiolíticos são quase a metade dos psicofármacos receitados no planeta; tais remédios são capazes de produzir síndrome de abstinência superior à heroína; organicamente produzem letargia, torpor e coma com facilidade; provoca problemas para as funções sexuais se utilizado em longos períodos.

Outro exemplo, perceptível desde os anos de 1980, foi a medicalização da infância e da juventude. Já naquela época era recomendado, pela propaganda 'ética', o “tratamento de escolares 'hiperdinâmicos' com anfetaminas e Ritalín, anteriormente tratados com disciplinas e castigos" (TEMPORÃO, 1986, p.105). Recentemente os usos pediátricos desses remédios alcançaram o grau de epidemia. O próprio Ministério da Saúde publicou, em $1^{\circ}$ de outubro de 2015, uma recomendação para que Estados e Municípios publiquem "protocolos de dispensação" com objetivo de frear o uso Concerta ${ }^{\circledR}$ e Ritalina ${ }^{\circledR}$. Segundo esse documento, o Brasil se tornou o segundo mercado mundial no consumo do metilfenidato - cerca de 2 milhões de caixas foram vendidas em 2010 - sofrendo um aumento de $775 \%$ do consumo nos últimos 10 anos (BRASIL - Ministério da Saúde, 2015).

Uma última consequência, possivelmente a mais dramática, precisa ser observada. A maioria das funções exercidas pelos antigos 'entorpecentes' teve substituto na nova farmacopeia lícita: a cocaína como estimulante, diminuidor do apetite e potencializador da atenção deu lugar às anfetaminas; como descongestionante nasal ela deu lugar a benzedrina e como anestésico local foi substituída pelos fármacos derivados das amino-amidas; o ópio deixou de ser usado como hipnótico para dar lugar aos barbitúricos e outras substâncias; como tranquilizante, ele foi substituído pelos ansiolíticos que provocam uma embriaguez passiva de enorme potencial conformista gerando uma preguiça indiferente, sem sono ou ampliação da capacidade de reflexão cujos efeitos são baseados na diminuição do oxigênio enviado ao cérebro. Essa se 
tornou a droga evasiva honrada da contemporaneidade e as demais, em geral, são mais tóxicas, perigosas (menor distância da dose ideal e dose letal) e com piores efeitos colaterais que os antigos entorpecentes. Se a historiografia triunfalista esconde esses problemas, o principal deles não é nem sequer citado: os 'entorpecentes' que não tiveram substitutos disponíveis.

A nova farmacopeia científica e 'ética' teve como mais dramática consequência a proibição da circulação de antálgicos opiados. Os sonhos dos missionários puritanos do início do século $\mathrm{XX}$ em proibir o ópio e seus derivados às pessoas em geral foi finalmente efetivado. A dor enobrece a alma! Em 1982, foi fundada a Sociedade Brasileira para Estudos da Dor por médicos anestesiologistas com objetivo de denunciar o estado da analgesia no país e a situação crítica que vive a maioria da população. O ponto fundamental de tal agremiação não é, obviamente, retomar a autonomia das pessoas. Para esses médicos a questão da dor na sociedade continua sendo uma questão de reserva de mercado, ou melhor, de ampliação dele a partir da defesa do alargamento do tema da analgesia na formação médica e da maior presença de profissionais desse tipo nos serviços de saúde em geral. A heteronomia sobre a dor é a principal e mais cruel consequência do proibicionismo contemporâneo. Para proteger uma minoria do vício iatrogênico em opiáceos se condenou toda a sociedade a viver e a conviver com a dor.

A transformação da população em objeto mercadológico por parte de agentes técnicos (classe terapêutica, principalmente os médicos) com objetivo de ampliar a concentração de capital do complexo industrial responsável pelos equipamentos e insumos teve como resultado o maior consumo de fármacos e a heteronomia sobre a dor. Ao longo dessa Tese foi mostrado que o consumo de drogas e os estados alterados de consciência não se reduzem aos aspectos terapêuticos - ao moldar a psique elas transformam as pessoas, possuindo assim enormes implicações antropológicas. Essa configuração do mercado criou, de fato, uma classe privilegiada - os médicos - e instrumentos para acumulação de capital, porém não foi capaz de reduzir as pessoas a meros objetos. Elas seguem sendo agentes e, por isso, não são poucas aquelas que passam às fileiras da dissidência farmacológica - alimentando, assim, o mercado ilícito.

Vimos, na seção anterior, que desde o final dos anos de 1940 a Cannabis se espalhava pelos centros urbanos do Brasil, deixando de ser uma cultura farmacológica regional (norte e nordeste) para se tornar nacional. A partir dos anos de 1960 veremos uma diversificação dos produtos oferecidos pelo mercado ilícito. Dentre eles, os que 
geraram maior pânico depois da Cannabis foram os fármacos visionários, principalmente o LSD. Não foram encontrados estudos contemporâneos sobre o uso de fármacos visionários no contexto brasileiro, mas nem por isso deixarei de fazer algumas observações sobre esse fenômeno - apontando possibilidades de pesquisas.

O primeiro fármaco desse tipo isolado pela ciência ocidental foi a mescalina, derivado do cacto peiote, por L. Lewin em 1888. Ele foi usado na forma de extrato em experiências voltadas a estimular a criatividade, a percepção e as emoções. Os experimentos com essa substância se reduziram a poucas pessoas, em geral intelectuais, artistas e boêmios, e não tardou que tais práticas fossem criticadas pelo British Medical Journal em 1897. Desde cedo é possível identificar a ideia de que tal psicoativo era capaz de abrir outras realidades e novas sensibilidades (ESCOHOTADO, 2008, p.484488).

Se a mescalina teve seu uso restrito, o mesmo não aconteceu com outra substância visionária que surgiu no final dos anos de 1930: o ácido lisérgico ou LSD. Isolado em fins dos anos 1930, foi utilizado nas duas décadas seguintes na psiquiatria e, mesmo, para o tratamento do alcoolismo (ESCOHOTADO, 2008, p.830-831). É uma trajetória que foi igual à de outros fármacos (Courtwright, 2001, p.69): inicia como uma nova medicina com potenciais terapêuticos, porém os usos começam a escapar do controle médico e estimular novas formas de consumo e de sociabilidade que acabam gerando alarde e intervenção pública.

No Brasil, uma das principais obras sobre o assunto foi escrita pelo juiz Geraldo Gomes intitulada Os alucinógenos e o direito (L.S.D.). Publicada em 1972, trouxe na íntegra o estudo realizado por esse magistrado para sustentar a primeira sentença de tráfico de LSD no Brasil. Percebe-se o grande esforço argumentativo para convencer os leitores das várias restrições que esse tipo de fármaco possui no interior da classe médica, como forma de criticar aqueles que a utilizam na terapêutica (GOMES, 1972, p.50-56). Essas considerações pareciam ser direcionadas especialmente para o Dr. Edmundo Maia, que supostamente faria uso terapêutico de LSD no Brasil - fato que precisa ser investigado.

O uso não médico do LSD, por sua vez, se populariza nos EUA ao longo dos anos de 1950 e 1960. Iniciou-se em alguns círculos cultos acompanhados de uma forte crítica à sociedade industrial e às concepções de mundo modernas baseadas no dualismo platônico e cartesiano, que deformariam a percepção de mundo e a própria ciência, conforme a filosofia vinha mostrando desde Heidegger. A tecnologia, ao invés de 
libertarem o homem, como previu Marx, eram responsáveis pela sua escravização. Essa era a base de uma crítica filosófica, sociológica e antropológica que ganhava espaço nas principais universidades estadunidenses (Califórnia, Princeton, Chicago, Yale e Harvard, entre outras), inspirando intelectuais como Herbert Marcuse, Norman Oliver Brown, Theodore Roszak, Timothy Leary e outros (ESCOHOTADO, 2008, p.821-824).

Seguindo uma concepção histórica mais tradicional, Courtwright (2001, p.88-90) credita a disseminação do LSD à Timothy Leary e a sua falta de ética na condução das pesquisas com esse fármaco. Foi, justamente, um Comitê de Ética em Pesquisa (CEP) que foi responsável por persegui-lo e expulsá-lo de Harvard (ESCOHOTADO, 2008, p. 838-842). Mais do que as ações de líderes inconsequentes ou efeito das travessuras populares, optou-se por tentar entender quais são os sentidos que essas substâncias possuem para aquelas pessoas que as consomem e, principalmente, de que forma elas interagem com os padrões sociais aceitos em dada sociedade.

Observamos, no primeiro Capítulo, como os cristãos perseguiam as práticas culturais que usavam substâncias do tipo visionário-alucinógenas. O LSD era uma substância praticamente sem custos e que popularizava a experiência xamânica/extática. Isso representava um risco enorme para as religiões tradicionais, uma vez que a experiência mística deixaria de ser privilégio daqueles iniciados em tortuosos cerimoniais que incluem rezas, jejuns, meditações e outros exercícios e práticas. $\mathrm{O}$ polêmico Aldous Huxley resume bem o desafio que essas substâncias representavam para as igrejas tradicionais.

Os futuros alteradores da mente, poderosos mas quase sem custo, vão mudar completamente tudo isto. Em vez de raras, as experiências pré-místicas e místicas vão-se tornar comuns. O que era antes o privilégio espiritual de poucos tornar-se-á acessível a muitos. Para os ministros das religiões organizadas do mundo, isto vai fazer surgir vários problemas sem precedentes. Para a maioria das pessoas, a religião sempre foi uma questão de símbolos tradicionais e sua própria reação emocional, intelectual e ética a esses símbolos. Para os homens e mulheres que tiverem uma experiência direta de autotranscendência para o Outro Mundo da mente de visão e união com a natureza das coisas, uma religião de meros símbolos não tem chance de ser muito satisfatória. A leitura atenta de uma página de um livro de culinária, mesmo que otimamente escrito, não substitui o jantar (HUXLEY, 1983, p.125). 
Os usos do LSD afetavam os valores religiosos em seu aspecto mais fundante, porém, além disso, carregavam consigo diferentes formas de sociabilidade, movidas pela música, pela arte, pelas trocas públicas de afeto que desafiavam os valores dominantes. De forma difusa várias bandeiras eram levantadas, como o retorno a vida rural, a crítica ao industrialismo, a defesa do meio ambiente, a construção de uma psiquiatria humana, entre outros. Escohotado (2008, p.879-880) caracteriza tal movimento como uma espécie de individualismo pagão que significava o abandono simultâneo de ideais burgueses e proletários, com especial atração sobre a juventude. $\mathrm{O}$ ápice desse movimento ocorreu no Woodstock Music \& Arg Fair em 1969. A vitória de Nixon e a famosa declaração de guerra às drogas, em 1971, se explicam pela reação da América branca, puritana e que se encontrava impotente frente ao avanço do movimento contracultural.

O movimento contracultural teve implicações importantes para as artes, particularmente a música (DINIZ, 2012, p.65-122), porém ainda não existem trabalhos que abordem especificamente o uso de drogas. A Dissertação de Delmanto (2013), que procura compreender como a contracultura e a questão das drogas eram percebidas entre os movimentos de esquerda, confirma a hipótese de Escohotado (2008, p.880-882) de que existia uma rejeição da esquerda tradicional aos seus princípios - aqueles e aquelas que se influenciavam pela contracultura eram taxados de desbundados e desbundadas. Sabe-se, pelo livro do magistrado Geraldo Gomes, que o tema do LSD era presente na imprensa brasileira, pois os

\footnotetext{
"meios de comunicação, - imprensa falada, escrita e televisionada - têm dado enorme ênfase ao problema dos tóxicos, e, de especial modo, à novidade do século, o LSD-25, ora no seu leal combate, mas, não raras vezes, na sua subtil, solerte e discreta apologia, que cala fundo nos espíritos menos críticos ou despreparados" (GOMES, 1972, p.59).
}

Esses apologistas seriam "na sua larga maioria elementos frustrados e que inclusive já se deram ao experimento" (GOMES, 1972, p.60) e, portanto, indignos para fazerem considerações sobre o tema. É relevante, entretanto, que apenas nos meses iniciais do ano de 1970 o magistrado tenha recolhido mais de uma dezena de reportagens sobre o LSD em diferentes jornais e revistas, incluindo Folha de São Paulo, Playboy, Ele e Ela, Manchete, O Estado de São Paulo e outros. Assim como a questão 
do uso médico, a presença do tema nos principais veículos culturais da época é um ponto que precisa de melhor investigação.

Os desafios filosóficos e morais colocados pelo LSD estão bem claros na obra do magistrado. Segundo ele, os usuários dessas substâncias relatam encontrar a "GRANDE VERDADE",71 (GOMES, 1972, p.56) que não passariam de "uma manifestação ilusória" (GOMES, 1972, p.56). Aqueles que consideram essas substâncias adequadas as "experiências de fundo filosófico, religioso, místico" (GOMES, 1972, p.56), como Aldous Huxley, apenas fazem "uma pertinaz e inconcebível apologia da droga" (GOMES, 1972, p.57). Para contrastar os apologistas, o magistrado recorria a Ivan Petrovich Pavlov, que ganhou o prêmio Nobel em 1904, cuja teoria

\footnotetext{
"dos processos mentais complexos tem sua ênfase na experiência objetiva, e não na subjetividade da psicologia tradicional e no dualismo corpo-alma, supostamente inerente a ela [...]. No entanto o conhecimento faz-se através de uma assimilação vital do sujeito cognoscente com o objeto conhecido, podendo ser sensitivo ou intelectual. Mas até hoje ainda não se conseguiu desmoralizar os velhos conceitos aristotélicos-tomistas do 'nihil est in intellectu quod prius non furir in sensu'. Nada está na inteligência do homem por primeiro não tenha passado pelos seus sentidos" (GOMES, 1972, p.57).
}

A predileção em matéria filosófica do autor não está em discussão, tão pouco se nega os avanços tecnológicos obtidos em razão das premissas epistemológicas da racionalidade aristotélica e kantiana. Importante destacar, entretanto, que a experiência com esse tipo de fármaco parece auxiliar na compreensão de outra epistemologia que tem como ponto de partida a experiência subjetiva de sujeitos concretos e não conceitos pré-definidos. O magistrado também não deixa de destacar que a disseminação do uso da Cannabis e do LSD entre os hippies é um

\footnotetext{
“exótico movimento [...], que infelizmente graça em certos 'meios artísticos' e inclusive com pomposas denominações, como 'FILOSOFIA hippie', onde se confundem conceitos, com erotismo com sexualismos e outros exotismos. Pelo diagnóstico acima reproduzido faz-se aberta campanha de corrupção dos costumes" (caixa alta no original) (GOMES, 1972, p.74).
}

${ }^{71}$ Caixa alta no original. 
Nas terapias desenvolvidas nas décadas de 1940 e 1950, o LSD não era associado a uma maior performance sexual, embora a psicologia o utilizasse "no tratamento da frigidez, da timidez, das inibições e nas relações sexuais pobres"72 (STAFFORD; GOLIGHTLY, 1967, p.146 Apud ESCOHOTADO, 2008, p.877). O discurso proibicionista, entretanto, passou a enfatizar que seus efeitos retiram a noção de realidade, servindo de pretexto para orgias. É preciso, entretanto, distinguir os efeitos dos fármacos das orientações da contracultura em matéria de sexualidade. Existia, nitidamente, uma postura pagã que não condenava os prazeres do corpo. Essa cultura específica, em matéria sexual, tinha como princípio básico o não estabelecimento de relações afetivas com alguém sem antes comprovar compatibilidade no contato sexual, costume que acabou se arraigando, posteriormente, na maior parte das sociedades ocidentais como modelo de racionalidade (ESCOHOTADO, 2008, p.877-879). Os anticoncepcionais deram a base material para essa nova atitude diante do sexo - para a tristeza de setores cristãos puritanos que pretendiam reduzir a mulher às funções domésticas e reprodutivas.

Ao lado da Cannabis e do LSD, drogas que podem ser caracterizadas como visionárias, também entraria na pauta do consumo ilícito novamente a cocaína - dessa vez desassociada dos usos terapêuticos. A indústria legal da cocaína, que encontrou obstáculos terríveis depois da Segunda Guerra, passou por um período de readaptação para se tornar uma vigorosa empresa ilícita. Embora sejam vários os exemplos de que pequeno comércio ilícito exista desde as primeiras proibições do século $\mathrm{XX}$ (GOOTEMBERG, 2008, p.247-261), é possível verificar que o fim da indústria legal fortaleceu grupos contrabandistas em vários países sul-americanos. No Brasil, o Rio de Janeiro e São Paulo se tornaram uma cena de consumo vigorosa a partir dos anos de 1960, consolidando o país como de trânsito aos mercados mais ricos dos EUA e da Europa. A cocaína poderia entrar pelo Rio Grande do Sul através da Argentina. Buenos Aires tinha uma longa tradição de consumo e algumas regiões, como Salta e Tucumán, são geograficamente e culturalmente ligados à Bolívia, possuindo comunidades tradicionais de consumo de coca (GOOTEMBERG, 2008, 268-272). Assim como a questão dos fármacos visionários, faltam estudos que abordem a consolidação do mercado ilícito da coca e seus derivados no Brasil.

\footnotetext{
72 "Los investigadores coincidían en pensar que si bien no eran afrodisíacos en sentido usual, podían ser de utilidad en el tratamiento de la frigidez, la timidez, las inhibiciones y las relaciones sexuales pobres" tradução sugerida.
} 
Vimos, no quarto Capítulo, que o comércio lícito da cocaína teve uma importante contribuição peruana, em fins do século XIX e início do XX, graças ao desenvolvimento da tecnologia da cocaína crua. Esse sulfato, para se transformar em cocaína pura, precisa ser lavado com uma série de substâncias altamente voláteis como éter e a acetona. Os controles crescentes instituídos sobre esses agentes químicos capazes de transformar a cocaína crua em pura, passaram a elevar custo da produção de cocaína e a motivar os fabricantes a elaborar outro produto que os dispensassem desse oneroso custo. Esse fator somado a adição de grandes quantidades de bicarbonato de sódio, que aumenta o peso do produto, levou ao lançamento do crack como uma nova droga recreativa pelo mercado ilícito. Ele é um produto impuro que não pode ser administrado por via intravenosa ou intramuscular, tampouco por via nasal ou digestiva, fazendo que seu uso seja restrito aos cigarros, às pipas e a outras formas de emprego pulmonar. (ESCOHOTADO, 2008, p.1010-1012). O crack, ao contrário de outras drogas ilícitas que foram inicialmente projetados como medicinas, nasceu diretamente do produtor ilícito como resultado da proibição.

A Cannabis, o LSD, a cocaína e o crack são os produtos que, de maneira geral, dominam o mercado ilícito até hoje, embora existam também o estasy, Nbome, e muitas outras. Mais do que contar a história particular de cada uma delas, parece mais importante salientar que também os fármacos ilícitos passaram a apresentar duas características verificadas acima nos medicamentos oferecidos pela indústria farmacêutica legal: a tendência em se constituírem em uma polifarmácia e o artificialismo. O termo cocaína, por exemplo, cada vez mais deixa de se referir a um fármaco para designar um conjunto de substâncias que somente a menor parte é a cocaína propriamente dita. Os produtos oferecidos pelo tráfico ilícito com essa denominação incluem vermicidas, anestésicos locais vendidos pela indústria legal, bicarbonato de sódio, cafeína, teobromina, entre outras substâncias. As técnicas de adulteração variam de acordo com o local, a remessa de produto e os vendedores. Embora ainda hoje se internem pessoas com o diagnóstico de cocainomania, pouquíssima quantidade dessa substância é encontrada no produto oferecido pelo mercado ilícito com essa denominação. O termo $L S D$ é outro exemplo de um termo que deixou de ser uma referência a um fármaco. Em geral, os produtos vendidos sob essa denominação são análogos produzidos em laboratórios caseiros incapazes de precisar o produto exato que é colocado no mercado. Vimos, na seção anterior, que pequenas alterações nas moléculas podem provocar grandes mudanças nos efeitos fisiológicos. Os 
produtos lançados no mercado ilícito, produzidos em laboratórios precários, não possuem estabilidade. Por isso é cada vez mais difícil falar em LSD em termos estritamente farmacológicos, e sim em drogas de desenho ou designer drugs. Graças a esse fenômeno teríamos entrado, a partir dos anos de 1980, na "Era do Sucedâneo" (ESCOHOTADO, 2008, p.1005-1033; SILVA, 2013, p.337-339).

Essas são as características do mercado ilícito de psicofármacos que crescerá durante o final do século XX e início do século XXI. O olhar retrospectivo mostra uma política e um padrão de consumo bastante distinto daquele do início do século por dois motivos: $1^{\circ}$. A medicina, que se colocava como elemento de racionalização do consumo com o discurso crítico ao livre arbítrio e a ganância das empresas, modificou seu papel ao se associar ao complexo industrial da saúde e se tornar instrumento de ampliação da dieta farmacológica; $2^{\circ}$. As mudanças normativas e institucionais que são baseadas na heteronomia em matéria de administração das enfermidades, do ânimo e da consciência criaram um contexto favorável ao desenvolvimento da economia ilícita movida pela dissidência farmacológica - que gerou enorme custo social pela violência associada e pela insegurança no consumo (intoxicações). Existem diferenças importantes que nos obrigam a falar de vários tipos de proibicionismo, de forma a delimitá-los e compreendê-los em suas historicidades e racionalidades. Esse vem sendo o objetivo principal desse Capítulo.

Antes de finalizar e propor uma nova hipótese interpretativa sobre as políticas sobre drogas no Brasil, gostaria de salientar algumas mudanças importantes recentes que vem transformando a atual política. Conforme no início desse Capítulo, mesmo antes do proibicionismo federalista existiam algumas formas de controle público - seja pela política de licenciamento da JCHP, seja pelas normativas das Câmaras Municipais. Isso mostra que não é o controle público que confere o caráter proibicionista de uma política, mas o pressuposto da heteronomia. Ao longo das décadas de 1980 e 1990 é possível perceber três fenômenos, independentes e interligados, que vêm forçando uma alteração na política proibicionista e reconduzindo a autonomia como princípio para a regulamentação.

O primeiro desses fenômenos se refere ao fim dos conflitos entre governo brasileiro, indústria farmacêutica nacional e a internacional e ao esgotamento tecnológico dos centros industriais. Vimos, anteriormente, que a ditadura civil-militar adotou uma política de enfrentamento com a indústria farmacêutica depois que a crise inflacionária e cambial alcançou seu auge na década de 1980. A política adotada se 
baseou em duas iniciativas: o congelamento dos preços e o não reconhecimento do direito de patente. Com o fim desse regime político, também foi lançada uma nova política para o setor com a permissão para que o preço dos medicamentos aumentasse e com o início da discussão das patentes (STUCKER et al, 2007, p.152-153): em 1991, foi protocolado no Congresso o projeto para regulamentar essa questão; em 1994, o Brasil adere ao acordo internacional de reconhecimento de patentes que é um dos fundamentos da Organização Mundial do Comércio - a partir de então se viabilizou a cobrança de royalties sobre os produtos patenteados (STUCKER et al, 2007, p.159161); em 1996, foi aprovada a Lei $n^{\circ} 9.279$, de 14 de maio, que reconhece o direito de patentes, entrando em vigor no ano seguinte.

Essa lei foi importante porque permitia ao Brasil a constituição de uma indústria nacional de produtos genéricos, viabilizada com a Lei $\mathrm{n}^{\circ}$ 9.787, de 10 de fevereiro de 1999. Essa lei atendia a uma solicitação dos movimentos sociais que viam nesse tipo de iniciativa uma forma de fortalecer a indústria nacional, trazendo soberania para esse setor. Em 2007, o mercado de medicamentos genéricos já correspondia algo em torno de $14 \%$ do total. Apesar da tendência de crescimento verificada, esse tipo de indústria ainda é extremamente dependente da importação de farmoquímicos - em 2007, entre oitenta e noventa por cento da matéria prima precisava ser importada da Índia ou da China. Esse tipo de regra que classifica os remédios em patenteados, genéricos e similares existe nos EUA desde a década de 1960 (STUCKER et al, 2007, p.159-161). Outra importante normativa para adequar o país ao modelo estadunidense foi Lei $\mathrm{n}^{\mathrm{o}}$ 9.782, de 26 de janeiro de 1999, criando a ANVISA. Ela foi planejada a partir de uma adaptação "do modelo internacional da Agência norte-americana FDA" (BUENO et al, 2008, p.143).

A superação das divergências entre governo, indústria nacional e internacional foi fundamental para o início de um novo momento de cooperação entre todas essas partes. Em 2002, foi fundada a Federação Brasileira da Indústria Farmacêutica que reúne as principais empresas do setor, responsáveis por $98 \%$ do faturamento total (STUCKER et al, 2007, p.182-183). Esse acordo permite o crescimento da participação da indústria nacional no mercado, pois existem grandes possibilidades abertas na produção de genéricos e similares, e garante os lucros pelos novos produtos inseridos pelas indústrias estrangeiras que são os polos de desenvolvimento do setor por causa da lei de patentes. 
A questão é que esse acordo pressupõe a existência de um fluxo de novas drogas para serem introduzidas, e isso não está mais ocorrendo. Nos últimos cinquenta anos percebe-se uma diminuição de novos compostos lançados no mercado, pois não existem mais protótipos a serem explorados como ocorria em meados do século XX. Vimos na seção anterior que é a natureza que inspira a farmacologia. Existe grande expectativa que o genoma humano, uma vez conhecido, possa dar novos modelos moleculares a serem explorados, porém os cientistas estão falhando no desenvolvimento de métodos capazes de realizar esse projeto (SNEADER, 2005, p.446-447).

É dessa dificuldade de criar novos produtos que a indústria legal procura entrar em um campo até então reservado ao comércio ilícito: as chamadas 'drogas cosméticas'. Elas são estimulantes desenvolvidos para ampliar a performance laborativa, memorativa ou atentiva. Remédios como Provigil@, Modiodal®, Alertec $\AA$ prometem ser mais efetivos que a Ritalina ${ }^{\circledR}$ ou os ilícitos, com menor potencial aditivo. Essas drogas se situam na fronteira entre a doenças (disease) e a enfermidade (illness). Esse tipo de medicamento tem gerado interesse dos exércitos em diferentes países, além de estar na mira dos esportes de alto rendimento. "Não são poucas as controvérsias a respeito de drogas que podem ser comparadas tanto à ilícita cocaína como a uma inofensiva taça de café ou um elixir milagroso" (CALIMAN, 2014, p.233). São remédios que estão localizados na fronteira do uso médico legítimo e a busca por otimização das funções com uso de estimulantes.

Outras drogas que se mostram promissoras são as derivadas da Cannabis. Courtwright (2001, p.192-193) aponta que, ao longo da história, a Cannabis não teve suporte industrial que defendesse esse fármaco das investidas de controle - por isso ela esteve mais vulnerável à restrição legal. Essa situação, entretanto, vem se modificando com o crescimento da indústria da Cannabis medicinal. Zuardi (2006, p.153-157), por sua vez, destaca que a Cannabis teve seu uso medicinal rejeitado em meados dos anos de 1930 pela dificuldade de obter amostra de seus princípios ativos. Essa situação levou essa droga a um ostracismo da ciência médica oficial até os anos de 1960 quando, finalmente, começa a identificação de seus princípios ativos. Gradativamente esses princípios são isolados e transformados em medicinas patenteadas segundo os critérios mercadológicos. Nos anos de 1990, esses estudos passaram a ter interesse renovado depois que foi reconhecido um sistema canabinóide endógeno no cérebro ativado por alguns de seus princípios ativos. 
Os usos e os controles sobre a Cannabis e seus derivados se tornaram temas importantes na agenda política atual. A permissão para a importação de canabidiol (CDB) ocorreu depois da comoção nacional gerado pelo caso da menina Anny - que foi transformado em documentário no final de 2014.

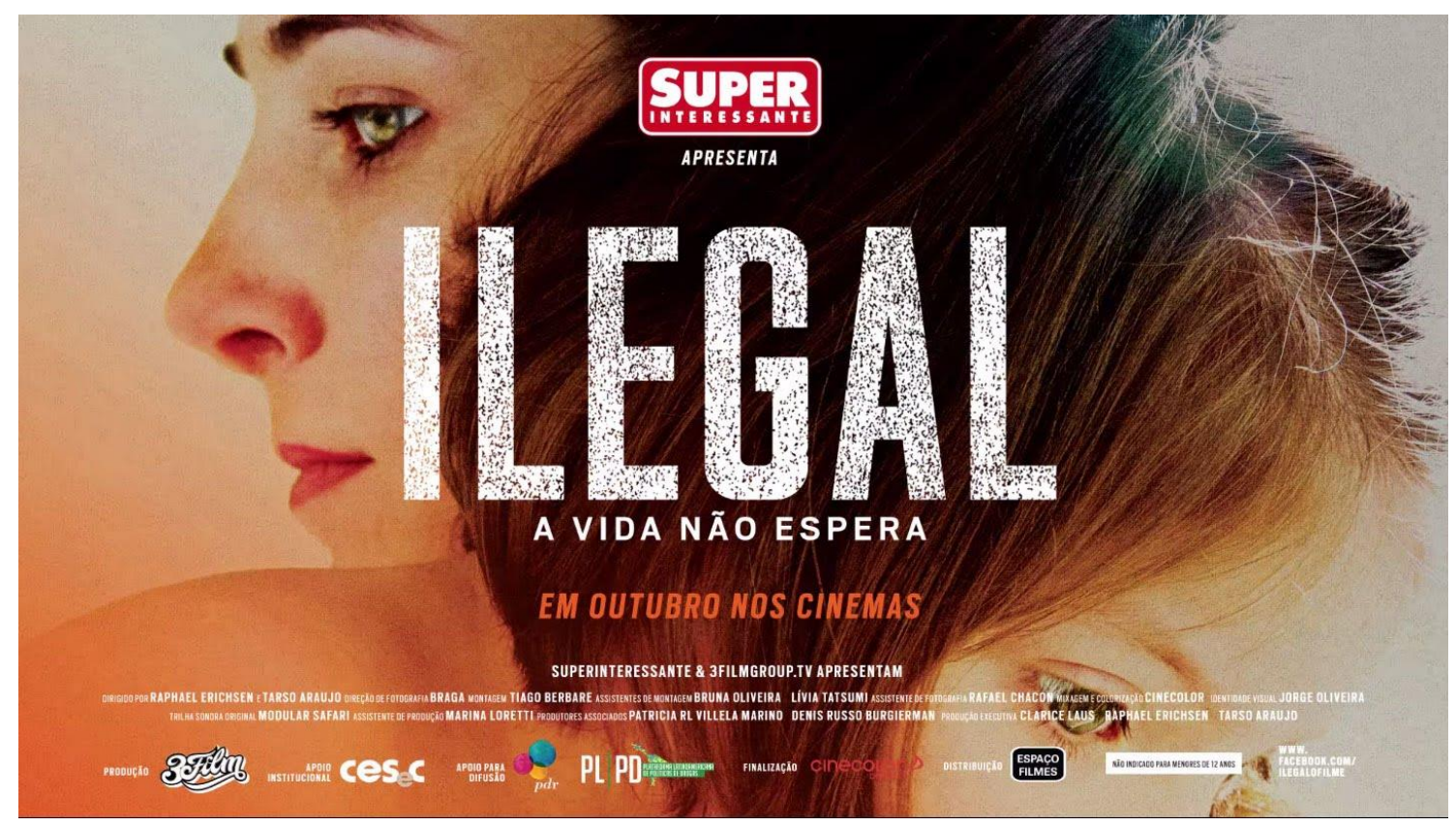

Figura 12 - Cartaz do documentário "Ilegal: a vida não espera" FONTE: Revista Superinteressante, 07 de Outubro de 2014.

Essas substâncias, que se situam na fronteira entre a doença (disease) e a enfermidade (illness) e são parecidas com aquelas oferecidas pelo mercado ilícito, parecem ser uma alternativa à indústria farmacêutica internacional para superar a dificuldade atual de criar novos fármacos rentáveis. Para ampliar a participação nesse mercado, cada vez mais será necessário prescindir da heteronomia e apostar na autonomia.

O segundo fenômeno relacionado à crise do paradigma proibicionista provém do interior da comunidade científica. A partir dos anos de 1950 o discurso triunfalista e a ideologia do progresso conseguiram impor uma regulamentação que privilegiava os produtos industriais, patenteados e difundidos com apoio da medicina de base biologicista em detrimento dos fitoquímicos, conforme vimos. Paralelamente a isso, entretanto, se desenvolvia o campo da saúde pública que, gradativamente, começava a apontar a relação entre determinados padrões de consumo de psicofármacos e o desenvolvimento de morbidades. 
Essas ideias foram aplicadas primeiramente ao tabaco. Vimos, no primeiro Capítulo, que o tabaco foi uma das grandes drogas que, pelo seu caráter altamente viciante, se disseminou pelo mundo inteiro no espaço de um século. Ele entrou na cultura geral e se massificou na sociedade industrial depois que passou a ser vendido na forma de cigarro - que tomou a forma de oligopólios no começo do século XX. No final da Segunda Guerra ele tinha se tornado onipresente, sendo possível fumar em praticamente qualquer ambiente. Faltam pesquisas que mostrem como ele se tornou um produto de massa no Brasil. O fato é que paralelamente a essa difusão também se confirmavam os estudos comprovando que o hábito do cigarro provoca câncer e outras dezenas de doenças, fato que levou parte da classe médica e dos movimentos sociais a questionarem a tolerância com esse hábito tão danoso. No Brasil, é possível perceber os movimentos que questionavam essa permissividade ganharam força na década de 1970, quando começaram os esforços para que o poder público ampliasse os impostos e restringisse o consumo (BRASIL, 2011). Gradativamente, o tabaco deixou de pertencer à cultura geral e novamente passou a ser compreendido como uma droga - voltando a se constituir em uma subcultura.

Esse movimento foi importante porque associou uma droga lícita aos parâmetros que passaram a ser considerados indesejados para a população em geral. A partir dos anos de 1970, a saúde pública e os cuidados primários tomaram um lugar de destaque na OMS. Esses desenvolvimentos foram possíveis por causa dos entrecruzamentos de várias epistemologias: a epidemiologia que tentava compreender os riscos gerados pelo consumo sobre a "população inteira"; a intersecção entre psiquiatria e epidemiologia; a crescente compreensão que o uso de substâncias estava relacionado com a saúde mental da população (BERRIDGE, 2011, p.189-190). Todos esses desenvolvimentos levaram a uma tentativa, no final dos anos de 1970, de unificar todas as substâncias através do conceito de dependência que, apesar de vinculado à noção biologicista, foi o precursor de uma mudança que marcaria o final do século XX: a percepção de que todas as drogas e mesmo os prazeres que as dispensam podem ser considerados comportamentos de risco. A linguagem científica que conseguiu criar um padrão universal para a leitura dos efeitos das drogas nasceu do maior diálogo entre a ciência do cérebro (neurologia) e a psicofarmacologia. Os equipamentos capazes de mostrar as mudanças cerebrais evidenciaram que alterações fisiológicas de um abusador de cocaína são similares aos de um adicto de nicotina ou de um jogador compulsivo. A psicologia e a psiquiatria 
finalmente se encontravam com a fisiologia e a anatomopatologia, modificando os parâmetros de entendimento das enfermidades psicológicas (BERRIDGE, 2011, p.195).

Berridge (2011, p.211-212), depois de descrever a construção dessa nova linguagem científica, procura chamar a atenção para não tomarmos essa nova leitura como plenamente objetiva. Como outras linguagens científicas, ela também é uma construção social que pode se relacionar com objetivos políticos e econômicos. Assim como ocorre com a leitura biologicista clássica, a leitura neurológica que emerge no final do século $\mathrm{XX}$ facilmente pode ignorar os aspectos antropológicos a partir da ênfase nas alterações do formato 'natural' do cérebro. No primeiro Capítulo foi mostrado como Courtwright (2001, p.91-92), ao apontar que o cérebro tem parcimônia com o prazer, procura defender uma percepção cristã que só aceita como legítimo o prazer ligado à reprodução ou à sobre vivência. Esse tipo de leitura que aponta o aspecto 'natural' do cérebro também pode ser percebido em livros de divulgação científica publicados no Brasil (HERCULANO-HOUZEL, 2003). Esse tipo de explicação advoga que o consumo de drogas é algo exógeno à natureza humana e, portanto, que precisa ser repelido a qualquer custo - tomando os problemas relacionados ao seu consumo como um desvio da norma biológica. Procurei mostrar ao longo dessa Tese, contrariamente, que o consumo dessas substâncias é parte integrante da sociedade e, por isso, as medidas relacionadas à sua racionalização precisam ser pensadas a partir dos aspectos sociais e antropológicos.

No Brasil, o campo da saúde pública tomou conotações particulares. Nos anos de 1950, ela tomou feições de um projeto preventivista que criticava a formação médica demasiadamente biológica e a centralidade do hospital na terapêutica. Com a consolidação do modelo mercadológico da medicina, que ampliava os custos e restringia o acesso, e o agravamento das desigualdades sociais por causa do modelo econômico adotado pela ditadura civil-militar, vemos se consolidar uma crítica à condução política na área. Consolidava-se um discurso com foco no direito à saúde, no papel do Estado na promoção desse direito e na ênfase na atenção primária como porta de entrada para o sistema de saúde. No auge da crise econômica dos anos de 1980, criava-se uma aliança social de base democrática que possuía como foco aglutinador das forças políticas as Conferências Nacionais de Saúde. A saúde coletiva é o termo brasileiro utilizado para delimitar esse campo de estudos que sustenta um projeto político de universalização da saúde. O Sistema Único de Saúde (SUS) foi resultado dessa luta (NUNES, 2014, p.20-24). As críticas à formação biomédica de profissionais 
unicamente voltadas para a formação de especialistas e as necessidades do mercado levou a necessidades de alterar a formação médica, promovendo a ascensão do paradigma da integralidade mais adaptado as necessidades básicas de saúde da população (LAMPERT, 2009).

Essas duas mudanças destacadas acima - uma epistemologia capaz de perceber o uso de drogas e os comportamentos compulsivos a partir de uma única linguagem; a percepção de que os problemas de saúde não se resumem a um desvio biológico e sim correspondem também ao contexto social - foram fundamentais para a emergência de uma nova forma de lidar com os usos abusivos de drogas na sociedade: a Redução de Danos (RD). Os antigos "dependentes", "adictos" ou "viciados" que eram enxergados como pessoas doentes que deviam ser excluídas do convívio social, através da internação ao da prisão, passam a ser definidos como usuários de drogas, portadores de direitos que precisam ser observados. Essa nova conceitualização substitui a ideia de uma pessoa passiva que recebe serviços de assistência por outra mais ativa com opção de escolha. Essa nova categoria passa a englobar tanto os consumidores de drogas ilícitas, que passam a ser entendidos como agentes, quanto os(as) consumidores(as) de tabaco, que deixam de gozar de plena inserção na cultura geral para serem entendidos como adeptos de uma prática que gera riscos. O importante é que em ambos os casos as táticas adequadas para lidar com os usos problemáticos sofrem uma sobreposição: é preciso adotar medidas para que o uso dessas substâncias acarrete o menos mal possível ao usuário e à sociedade; a RD se consolida como uma prática terapêutica adequada em uma sociedade que incorpora o diferente (BERRIDGE, 2008, p.203-204).

A RD, enquanto tecnologia de intervenção, se sustenta em duas estratégias ou respostas para a situação do uso abusivo de drogas: disponibilização de instrumentos (como as seringas, cachimbos, etc) e de alternativas farmacológicas (metadona como substituto da heroína, remédios para diminuir a vontade de fumar, etc). Essa estratégia ganhou notoriedade com o sucesso obtido na contenção da disseminação do vírus HIV. A previsão de emprego de novos psicofármacos em substituição aos mais danosos abre um campo de apoio na indústria farmacêutica que vê nesses tratamentos uma nova possibilidade de ganhos financeiros (BERRIDGE, 2013, p.208). Courtwright (2001, p.201-203), por sua vez, caracteriza a RD como um mero movimento de contestação ao proibicionismo. "É uma prática que salva vidas, porém é moralmente monstruosa" "73

\footnotetext{
73 "Harm reduction saves lifes, but it is also moral eyesore" - tradução sugerida.
} 
(COURTWRIGHT, 2001. p.202). A troca de seringas seria um péssimo exemplo para a juventude que aumentaria a exposição às drogas. Ela somente foi aceita nos países ocidentais pelo êxito que teve em conter o HIV. Os EUA, por serem mais engajados na guerra às drogas, seriam uma exceção - fato que levou os militantes de RD a fazer seus trabalhos na forma de uma guerrilha contra o status quo.

No Brasil, os primeiros experimentos com RD também tiveram que ser feitos com enorme resistência dos setores ligados às concepções tradicionais. Visando conter a propagação do vírus HIV e das hepatites B e C, foi desenvolvido na cidade de Santos, em 1989, o primeiro programa de RD do Brasil que consistia basicamente em fornecer seringas para evitar o seu compartilhamento entre usuários de drogas injetáveis. $\mathrm{O}$ Ministério Público do Estado de São Paulo, entretanto, não aceitou tal política por considerá-la apologia ao uso de drogas. Apesar de seu cancelamento, a experiência foi exitosa em seus objetivos e inspirou nova iniciativa na cidade de Salvador, com apoio da Escola de Medicina da Universidade Federal da Bahia, do governo do Estado e da prefeitura. O sucesso dessas iniciativas fez o Ministério da Saúde recomendar a implementação das iniciativas de RD e outras ações contra o vírus HIV em todo o Brasil. Segundo dados oficiais, em 10 anos o número de casos notificados de Aids entre usuários de drogas injetáveis maiores de 13 anos caiu de 29,5\%, em 1993, para 13\% em 2003. Ao contrário das alegações difundidas pelos proibicionistas contrários a esse tipo de política, não foram verificados aumento do consumo de drogas injetáveis (DUARTE et al, 2009, p.351).

A ascensão da RD como a melhor estratégia para enfrentar os problemas gerados pelo uso abusivo de drogas contrasta com o paradigma psiquiátrico clássico que entendia o dependente como um doente que precisava ser isolado do convívio social para não contaminar os demais. Ela também é diferente do que era defendido por Sir. Humphrey Rolleston na Inglaterra. Naquela ocasião, a luta era pela autonomia dos médicos em continuar a prescrever narcóticos de forma continuada; a RD, por sua vez, parte do pressuposto que as pessoas utilizam drogas por conta própria sem a anuência de um médico. Essa forma pragmática de lidar com os usos abusivos rompe com a heteronomia que caracteriza o proibicionismo como política.

O terceiro, e último, fenômeno que vem desafiando a política proibicionista provêm do campo religioso com a disseminação dos cultos ayahuasqueiros. No final do primeiro Capítulo, foi apresentada a atuação de curandeiros nos centros urbanos do norte com o chá de ayahuasca no movimento chamado de vegetalismo. Com o ciclo da 
borracha e a imigração nordestina ao norte, houve um intenso intercâmbio cultural entre indígenas e caboclos. Nesse cenário ocorreu o desenvolvimento do culto do Santo Daime em uma pequena comunidade, as margens do igarapé Mapiá (Amazonas), composta por cerca de 40 famílias caracterizadas por fortes laços consanguíneos. Entre 1930 e 1970, essa pequena comunidade manteve-se isolada e estável (ASSIS et al, 2014, p.13-14). O uso de bebida indígena e a temática da cura, algumas vezes buscada por elementos alheios a comunidade, despertavam um imaginário que gerava desconfiança em parte da população. Pela medicina oficial os líderes comunitários eram acusados de curandeirismo e charlatanismo. Também existia um discurso que associava tais práticas à macumba, apontando a presença do racismo - vale lembrar que afrodescendentes também integravam essas famílias (GOULART, 2008, p.257-262).

Esse cenário restrito começa a mudar a partir dos anos de 1970, favorecido por um contexto global de descentralização do religioso e de formação de novas organizações permeadas por forte sincretismo. É inserido nesse fenômeno geral que o Santo Daime passou a atrair um novo público em busca de experiências espirituais e possibilidades de cura. Conforme ia se inserindo nos centros urbanos, também passou a atrair

\footnotetext{
"o que poderíamos denominar uma certa esquerda mística. Por esse conceito designamos uma esquerda apolítica, ou seja, pessoas de caráter humanista, antimaterialista e filantrópico, distantes do espírito capitalista de acumulação" (ASSIS et al, 2014, p.18).
}

A expansão dessa religião para os centros urbanos também pode ser entendida como parte de um movimento geral de diáspora das religiões e expressões culturais brasileiras, como a renovação carismática, o espiritismo, a capoeira, as religiões afrobrasileiras e o neopentecostalismo. Nos anos de 1980, os cultos ayahuasqueiros começavam a cruzar as fronteiras nacionais e se estabelecer em diversos países enfrentando problemas legais com os setores encarregados do tráfico de drogas. Hoje, existem igrejas reconhecidas em 43 países e em todos os continentes, números que tendem a serem ainda maiores por causa da fluidez dos pontos de encontro e do caráter clandestino em algumas localidades (ASSIS et al, 2014, p.17-23).

Essa expansão das religiões ayahuasqueiras também foi responsável por uma mudança no perfil social dos seus seguidores. Elas passaram a atrair profissionais liberais, artistas e intelectuais, pessoas com o perfil diferente do original - provocando 
mudanças nas relações familiares e de gênero. Muitas pessoas de outras regiões do país e do mundo se interligaram via laços consanguíneos com as comunidades ayahuasqueiras tradicionais. Esse fluxo intenso de pessoas, de diversas regiões do mundo, transformou a região do Mapiá em uma espécie de 'Meca' daimista - um centro de peregrinação internacional, fato que gera movimento na economia local (ASSIS et al, 2014, p.25-29).

Paralelamente a esse crescimento, assistimos também a maior exposição dessa religiosidade pela grande imprensa e a regulamentação governamental. Proibida em 1985, voltou a ser permitida, em 1987, depois que uma comissão enviada pela CFE ao local a considerou uma expressão religiosa legítima. Em 1992, houve uma denúncia que tal comissão foi parcial e nova comitiva foi enviada para avaliar a questão - reiterando as conclusões da anterior. Em 2004, o governo lançou um Grupo de Trabalho para regulamentar o uso de ayahuasca - dessa vez além de especialistas estavam presentes também os principais grupos ayahuasqueiros. Em 2006, como reflexo dos problemas legais gerados em vários países, o International Narcotics Control Board lança comunicado afirmando que nem a bebida, nem as espécies vegetais que lhe dão origem são objeto de controle - embora o DMT, que é seu princípio ativo, esteja proscrito (ASSIS et al, 2014, p.23-25).

A expansão e a legalização dos cultos ayahuasqueiros colocam diversas questões que precisam ser exploradas, mesmo que brevemente. A primeira é referente à liberdade religiosa. Seriam esses cultos legalizados se eles não usassem a simbologia cristã? O processo de legalização da ayahuasca apresenta várias similaridades com o ocorrido nos EUA com o cacto do peiote. O mesmo tratamento valeria para outras formas de religiosidade? Outra questão importante levantada por esse fenômeno é referente ao uso de substâncias visionárias no tratamento de usos abusivos de drogas. O entendimento que o consumidor de drogas é um usuário com direitos pressupõe, também, agência na escolha da dieta farmacológica. Do ponto de vista cultural, relembrando, a abstinência sempre foi uma atitude ética minoritária nas sociedades em geral - a temperança como consumo moderado é a atitude dominante ao longo da história (CARNEIRO, 2010). Os tratamentos tradicionais sobre o uso abusivo de drogas, entretanto, colocam a abstinência como fundamento - fato que ignora a alteração da consciência como necessidade humana básica (WINKELMANN, 2001, p.340-341). Dentro desta perspectiva, as substâncias visionárias têm tido resultados surpreendentemente positivos na recuperação de pessoas que fazem usos abusivos de drogas, seja com a ayahuasca 
(LABATE et al, 2014, p.153-159), seja com a ibogaína ${ }^{74}$. Importante salientar, como bem alerta Gomes (2013, p.91-98), que embora essas substâncias possam ser relevantes aliadas na construção de um consumo integrado, o mais importante aspecto que leva ao abuso são os contextos sociais nos quais essas pessoas estão inseridas e não as drogas em si. Mesmo que ainda ligado aos símbolos e a ritualística cristã, os cultos ayahuasqueiros pressionam temas como a liberdade religiosa e de pensamento, quebrando o monopólio do vinho como único enteógeno legal.

Todos esses três fenômenos descritos acima - os desenvolvimentos recentes da indústria legal de psicofármacos; os novos paradigmas epistemológicos da saúde; a internacionalização dos cultos ayahuasqueiros - apontam para a necessidade de racionalização das políticas sobre o uso de drogas. Somado a essas questões, os custos sociais do tráfico ilícito e a demanda crescente por parte da população por maior autonomia, com o fortalecimento dos movimentos sociais e a consolidação das instituições democráticas depois de 1988, levaram a uma crise do sistema proibicionista. Fenômeno que também pode ser percebido em outros países ocidentais. No próximo item veremos brevemente os desdobramentos recentes dessa crise.

\subsection{A crise do proibicionismo (2006-hoje).}

Não poderia finalizar esse Capítulo sem um breve comentário sobre os desdobramentos atuais. Mostrei, ao longo dessa exposição, que as políticas sobre drogas devem ser lidas para além da ascensão punitivista, porque elas não são restritas a uma área do direito penal - possuem uma intrínseca relação com as formas como se concebem os sistemas de saúde e, principalmente, como são concebidas as formas de acesso aos medicamentos por parte da população. A ascensão punitivista é paralela à monopolização do ato terapêutico na classe médica - que se tornou uma categoria privilegiada no interior da classe terapêutica, sustentada por uma parceria realizada com o complexo industrial dos insumos e dos equipamentos hospitalares. A característica fundamental que une políticas tão diversas, ao longo de mais de um século, é a crescente heteronomia da população na gestão da dieta psicoativa - fato que resultou no enorme crescimento da dissidência farmacológica.

\footnotetext{
${ }^{74} \mathrm{O}$ fenômeno da utilização clínica de ibogaína foi abordado por Bruno Ramos Gomes em apresentação intitulada Fronteiras entre drogas, dependência e cura: uma etnografia clínica do uso de ibogaína para tratamento de dependência de drogas no IV Encontro Nacional Sobre a Sócio Antropologia do Uso de Psicoativos, ocorrido na Escola de Saúde Pública da Universidade de São Paulo entre 08 e 10 de setembro de 2015. Tema que também tem ganho espaço na grande mídia.
} 
No início do século XXI se percebe a ascensão dos movimentos sociais que lutam pela descriminalização do uso de drogas, principalmente da Cannabis que é a mais popular das drogas ilícitas. São hoje dezenas de coletivos e movimentos políticos espalhados por todos os Estados brasileiros e que tem na Marcha da Maconha, ocorrida todo o ano entre março e maio, seu ponto de encontro e de exposição máxima. Esse movimento nasceu timidamente, em São Paulo e no Rio de Janeiro no começo dos anos 2000, porém foi ganhando força com o passar dos anos até alcançar projeção nacional. Hoje, a maioria dos partidos identificados com a esquerda (PSOL, PCB e PSTU) se abriu para discutir a descriminalização. Graças à onda liberal que toma conta dos países do centro do capitalismo, também os grandes conglomerados de imprensa (Rede Globo, Folha de São Paulo, Estado de São Paulo, entre outros) têm se colocado em defesa da legalização. Essas iniciativas também contam com apoio de personalidades políticas, como o ex-presidente Fernando Henrique Cardoso. (DELMANTO, 2013, p.252-256).

Também no início do século XXI, mais precisamente no ano de 2001, assistimos a promulgação da Lei 10.216 de 6 de abril, que, embora não esteja diretamente vinculada à política de drogas, foi importante para a desarticulação das práticas terapêuticas tradicionais no campo da psiquiatria, proibindo os manicômios. Desde essa Lei, a saúde mental da população ficou vinculada às Unidades Básicas de Saúde, ao Programa de Saúde da Família e às novas instituições especializadas, como o Centro de Atenção Psicossocial (CAPS) e o CAPS-Álcool e Drogas (CAPS-AD). Essa nova normativa foi resultado das lutas do movimento pela reforma psiquiátrica, no sentido de questionar a instituição asilar e a reivindicar um tratamento mais humano para as pessoas que sofriam problemas dessa natureza desde os anos de 1970. Está, portanto, inserida no contexto mais amplo dos anseios sociais que levaram a formação do SUS.

Apesar dessa importante mudança de perspectiva frente ao problema do uso abusivo de drogas, que pressupõe uma perspectiva descentralizada e comunitária de enfrentamento dessa questão, optei por escolher o ano de 2006 como marco para sinalizar a crise do proibicionismo por causa da Lei $\mathrm{n}^{\circ} 11.343$, de 23 de agosto desse ano. Ela procurou apresentar algumas mudanças conceituais em relação ao que vinha se fazendo, pois os órgãos e as políticas deixaram de serem "Antidrogas" e se tornaram "Sobre Drogas" a partir de então. Pelo menos teoricamente, reconhecia-se que o consumo de psicofármacos não é algo externo a sociedade. Outra mudança importante que surgiu com essa nova normativa foi a substituição das penas de privação de 
liberdade por outras nos casos referentes ao consumo, sobretudo, devido ao colapso do sistema prisional.

Ao trazer todos esses fenômenos que levaram a um questionamento ao modelo punitivista desenhado institucionalmente a partir de 1964, conforme foi visto na seção anterior, não se pretende assinalar que o caminho para a superação das políticas proibicionistas seja um caminho inevitável. A lei de 2006, destacada acima, é um exemplo do arraigamento do proibicionismo em nossa sociedade. Boiteaux et al (2009) mostrou que a ausência de um critério objetivo que separe as figuras penais do traficante e do usuário levou à maior caracterização das prisões como tráfico - mantendo a tendência de alta das prisões por esse tipo de infração. Essa lei serviu apenas para reforçar o tratamento diferenciado, pois os jovens, brancos e das classes mais altas passaram a ser caracterizados como usuários com penas leves, enquanto os negros, pobres e de periferia continuaram a ser enviados para os presídios.

No que se refere à questão do tratamento, a Lei 10.216, de 6 de abril de 2001, não acabou com o prestígio que as práticas tradicionais de internação possuem no campo do tratamento de uso abusivo de drogas. Vimos, ao longo dessa Tese, que mudanças epistemológicas no campo da medicina não se traduzem imediatamente em uma mudança de práticas. É um longo e tortuoso caminho que envolve conflitos, negociações, avanços e retrocessos. Os espaços tradicionais de internação continuam fortes no campo das drogas - profissionais ligados às clínicas de desintoxicação estão organizados nacionalmente ${ }^{75}$ e ocupam generosos espaços na grande imprensa toda vez que o tema é abordado - situação que reforça a legitimidade desse complexo terapêutico muito rentável. Clínicas privadas de desintoxicação, algumas de alto padrão ${ }^{76}$, seguem como referência técnica para grande parcela da população. A Lei de 2001, citada acima, manteve a autoridade médica ( $\left.\operatorname{art}^{\circ} 8\right)$ e judiciária ( $\left.\operatorname{art}^{\circ} 9\right)$ na definição da internação mesmo contra a vontade das pessoas.

Mais do que uma mera concessão às clínicas privadas, as terapêuticas sobre uso abusivo de drogas que pressupõem a exclusão das pessoas do convívio social com imposição de abstinência, de acordo com o modelo tradicional, são reconhecida e financiada pelo poder público. O Decreto $\mathrm{n}^{\circ} 7.179$, de 20 de maio de 2010, prevê destinação de vultosas quantias para instituições dispostas a acolher usuários de drogas,

\footnotetext{
75 Associação Brasileira de Estudos do Álcool e outras Drogas. <http://www.abead.com.br/site/> último acesso: 03 de Novembro de 2015.

${ }^{76} \mathrm{Um}$ exemplo desse tipo de instituição é a Villa Janus.

<http://villajanus.com.br/> Último acesso: 01 de Novembro de 2015.
} 
principalmente do crack, nas denominadas "comunidades terapêuticas". 77 Ao invés de fortalecer o SUS, através dos CAPS e CAPS-AD, dinheiro público é utilizado para financiar as tais comunidades terapêuticas que, além de atentarem contra os princípios básicos que sustentam a luta antimanicomial, são usadas para fins de doutrinação religiosa $^{78}$ - em claro atentado contra o caráter laico do Estado.

O caráter ambíguo das políticas públicas nesse campo pode ser verificado nos limites encontrados para a consolidação da visão da saúde como um direito. O sistema de produção dos serviços médicos, que intermedia os recursos humanos e técnicos disponíveis e as necessidades e demandas da população, engloba estabelecimentos públicos, privados e sistemas de seguridade social. O SUS, que parte de uma perspectiva universalista e humana, é obrigado a coexistir com um sistema privado fundado na perspectiva biologicista e mercadológica - criando mais uma vez condições para o tratamento diferenciado segundo as classes sociais. O consumo de psicofármacos nesse sistema acaba subordinado à lógica do capital, pois a centralização do ato terapêutico na classe médica cria uma barreira que impede a formação de uma cultura farmacológica calcada na autonomia e na percepção da saúde como um direito.

Estamos vivendo um momento onde a dissidência farmacológica assumiu enormes proporções, colocando em crise as percepções heteronômicas que sustentam as políticas proibicionistas construídas desde fins do século XIX. Essa crise, entretanto, não significa a construção lógica de um sistema voltando à gestão dos usos. O Brasil, particularmente, tem uma tradição religiosa e conservadora muito grande - fato que tem criado fortes resistências às mudanças e nos aproximado dos países islâmicos e orientais mais rígidos com as normas sociais. Esse conservadorismo é ainda sustentado pelos interesses do complexo industrial que transforma o direito à saúde em mercadoria, ampliando as formas de expropriação da população. Por causa dessas poderosas forças políticas não parece evidente que estamos caminhando para a racionalização dos

\footnotetext{
77 São vários os problemas advindos dessa opção política. O primeiro e mais evidente é reiterar um modelo terapêutico incompatível com os preceitos antimanicomiais. Como era de se esperar, várias dessas instituições atentam contra os direitos humanos dos internos, conforme demostrado pelo Relatório de Inspeção em Comunidades Terapêuticas Financiadas pelo Governo do Estado do Rio de Janeiro (RIO DE JANEIRO, 2013).

${ }^{78}$ Ribeiro e Minayo (2015) discutem essa participação na região de Manguinhos na cidade do Rio de Janeiro. Reportagem do jornal O Globo, de 29 de Abril de 2013, mostra como parlamentares ligados à religião utilizavam esses recursos para construírem centros de doutrinação religiosa. $<$ http://oglobo.globo.com/brasil/comunidades-terapeuticas-mantidas-por-parlamentares-podem-ganharverba-federal-8237104> Último acesso: 01/11/2015.
} 
controles e construção de uma cultura farmacológica emancipatória, apesar da crise do modelo proibicionista de políticas de drogas.

\subsection{Conclusão}

Esse Capítulo procurou problematizar um dos principais limites das leituras atuais sobre o tema das drogas, a saber, aquilo que foi caracterizado como hipótese do continuísmo e da ascensão punitivista. Inegavelmente, ao longo de sua história, as normativas sobre o consumo de psicofármacos foram amplificando as penalidades à dissidência farmacológica e diversificando a tipologia dos comportamentos enquadrados como desvio da norma. Existe, portanto, uma ascensão punitivista se atentarmos unicamente à perspectiva do direito penal.

Essa hipótese acima destacada apresenta, entretanto, três limitações: $1^{\text {a }}$. Naturaliza uma visão de que a política de drogas é uma espécie de guerra às drogas, de uma luta do poder público contra o consumo de psicoativos; $2^{\mathrm{a}}$. Percebe as normativas promulgadas ao longo de mais de um século dentro de uma ordem coesa e coerente de aumento da punitividade que se contrapõem a liberdade individual em matéria de alteração da consciência; $3^{\text {a }}$. Ignora as diferenças existentes nas pautas culturais de uso e nas dinâmicas econômicas que dão inteligibilidade às normativas legais.

Foi para se contrapor a essa hipótese e, paralelamente, diferenciar as políticas públicas atuais daquelas que foram implantadas no começo do século XX que procurei desenvolver esse Capítulo. A política sobre as drogas em nenhum momento se colocou como uma guerra às drogas: em um primeiro momento, até a década de 1940, ela era voltada para garantir o monopólio médico sobre a prescrição como forma de racionalizar o consumo; em um segundo momento, depois da década de 1950, as leis passaram a privilegiar os medicamentos industriais e patenteados vendidos através do médico em detrimento das antigas drogas. Em nenhum momento se percebe uma política contra as drogas: ora ela era no sentido de racionalização do consumo, ora como forma de substituir um escopo farmacológico por outro.

No momento em que percebemos que os objetivos finais dessas políticas não estão relacionados com a não utilização de psicofármacos, mas sim com a forma como os utilizamos, nota-se mais claramente que não se trata de um aumento da interferência estatal na esfera da liberdade. Trata-se, antes, de duas estratégias distintas de regulação que se aproximam unicamente pela perspectiva da heteronomia em relação à definiçãa 
da dieta psicoativa. Por isso é correto falar em "proibicionismos" no plural, em políticas distintas pautadas pela mesma perspectiva. O resultado no longo prazo foi o crescimento da dissidência farmacológica e os círculos econômicos ilícitos que lhe dão sustentação.

A última consequência dos equívocos interpretativos que acarreta a hipótese do continuísmo e da ascensão punitivista é a percepção do uso de drogas como algo exógeno à sociedade e, por isso, sujeito à intervenção pública através dos tempos. Procurei mostrar ao longo de toda essa Tese que os psicofármacos são algo intrínseco a modernidade, com implicações fundamentais nas formas de administrar os limites corporais às exigências e pressões sociais. As pautas culturais de uso variaram de acordo com o cardápio psicoativo disponível - por isso conforme o acesso a determinados fármacos foram sendo restringindo, outros foram sendo disponibilizados. A ordem heteronômica construída em benefício da acumulação de capital se mostrou insustentável no longo prazo, criando variados tipos de dissidência que podem e devem ser conhecidas em suas particularidades e historicidades.

A hipótese dos ciclos proibitivos, conforme representação proposta no Gráfico 2 abaixo, pretende compreender o proibicionismo como uma política com base social e histórica capaz de auxiliar no entendimento das dinâmicas que lhe dão sentido. Ela é baseada na percepção dos próprios agentes públicos que entendiam como exitoso o esforço antinarcótico que começou a ser realizado a partir do começo do século XX.

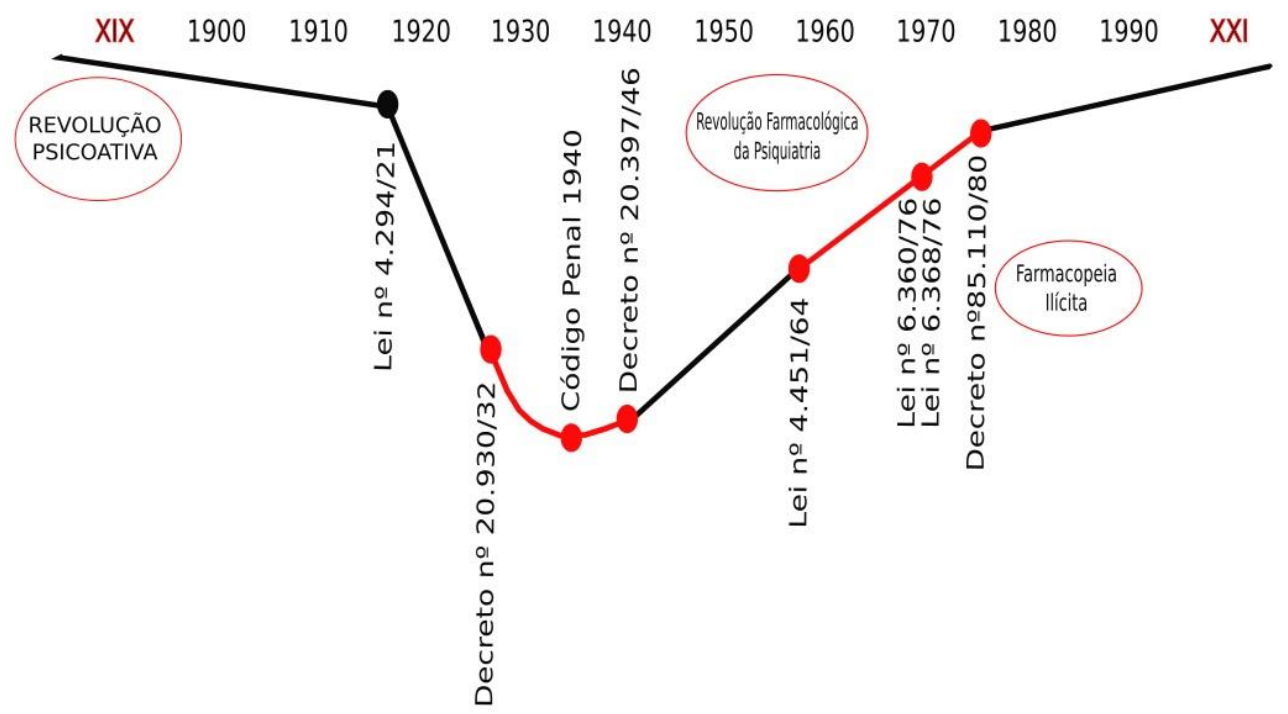

GRÁFICO 2 - Hipótese dos ciclos proibitivos 
Existe um momento inicial onde o consumo de psicofármacos é aberto, pois a forma de produção de remédios ocorria tanto através de receitas, quanto pelos medicamentos vendidos no comércio, conforme visto no segundo Capítulo. O acesso livre aos antálgicos e a capacidade ampliada de alterar a consciência das populações de todo o mundo são as características da revolução psicoativa descrita no primeiro Capítulo. Esse é o quadro que as normativas, primeiro dentro do federalismo (a partir da Lei 4.294/21) e depois em um projeto centralista (entre o Decreto 20.930/32 e o Decreto 20.397/46), têm sentido. A medicina, nesse contexto, entra como uma força que pretende a tutela sobre o consumo desses psicofármacos através da defesa do monopólio do uso médico. A desarticulação da indústria legal de 'entorpecentes' durante a Segunda Guerra Mundial gerou uma intervenção sobre a oferta, criando um cenário onde o monopólio do álcool e a tutela médica conseguiram se efetivar.

Esse cenário, entretanto, começa a mudar a partir da década de 1950 graças a um duplo fenômeno: o início da comercialização dos fármacos sintéticos e da conversão dos médicos em agentes da medicalização; o crescimento da dissidência farmacológica e do mercado ilícito que a sustenta. A diminuição dos usos legais de 'entorpecentes', obtida parcialmente através da expropriação dos remédios tradicionais, mostrou-se efêmera. Isso levou a um cenário de crise e a readequação das normativas entre 1964 e 1980. Essa política se mostrou extremamente eficaz no objetivo de acumular capitais para as partes envolvidas na venda de serviços de saúde (indústria farmacêutica e classe médica), para as pessoas que controlam os circuitos ilícitos e como justificativa para a manutenção de um aparato bélico para a segurança pública.

Porém, foi terrível para a população que se viu alijada dos recursos tradicionais para lidar com as demandas da sociedade moderna. Somada a essa situação, a dissidência farmacológica criou um contexto de colapso da segurança pública com enormes custos sociais, principalmente entre as classes e as pessoas mais vulneráveis. Atualmente estamos vivendo um período de crise sem precedentes, fato que leva a questão das drogas a ocupar o centro da pauta política. A hipótese dos ciclos proibitivos visa, sobretudo, contribuir na inteligibilidade das políticas proibicionistas implementadas através do século XX, dando historicidade à leitura das políticas públicas. Se elas são bastante diferentes em seus objetivos e nas práticas sociais que lhe dão sentido, ainda estão ligadas pelo princípio da heteronomia que passou a ser fortemente questionado no início do século XXI. 


\section{CONCLUSÃO}

O tema abordado por essa Tese é particularmente difícil no que se refere à isenção e ao distanciamento. Não se trata, obviamente, de reivindicar uma neutralidade para os argumentos que foram apresentados ao longo desse texto. A escolha dos conceitos, das fontes e da forma de abordagem do objeto de estudo faz parte do esforço analítico que está carregado com os valores e os projetos políticos do contexto onde o conhecimento é formado (BLOCH, 2001, p.125-130). Por isso o presente e o passado estão em constante diálogo (BLOCH, 2001, p.60-68). As drogas e suas interdições são particularmente sensíveis nesse quesito.

Acredito que ao longo dessa exposição algumas contribuições originais foram apresentadas ao atual conhecimento histórico desse tema. Não se tratou de buscar a origem do fenômeno da proibição das drogas. A principal tarefa realizada nesse trabalho foi intervir em modelos explicativos elaborados por outros campos do conhecimento, principalmente a biomedicina e sua retórica triunfalista, e experimentá-los em campos estranhos ao de sua elaboração. Com os argumentos apresentados buscou-se explicitar as ausências relativas às formalizações científicas atuais (CERTEAU, 2008, p.87-90).

Existem alguns discursos que são bastante redutores da complexidade que esse tema carrega, como aquele que procura dividir as abordagens sobre esse objeto entre os que são contra (antiliberais ou proibicionistas) e dos que são a favor (liberais ou antiproibicionistas) da descriminalização das drogas. O termo "proibicionismo" em geral é bem pouco explicativo, pois essa conceitualização esconde uma pluralidade de políticas de controles. Igualmente, "liberalismo" não significa ausência de regulação.

Outro discurso redutor, e que se pretende técnico, é aquele que atribui todo o consumo de drogas ao dano físico ou psicológico - partindo do pressuposto de uma inabilidade evolutiva do ser humano ao lidar com essas substâncias. Nessa lógica, se as pessoas são incapazes de lidar com os próprios prazeres, é preciso evitar toda e qualquer exposição a eles. Buscou-se mostrar, entretanto, que não é possível reduzir o prazer a mera função biológica ou neurológica, pois não somos apenas instintos ou um conglomerado de células ou órgãos. Antes de qualquer outro aspecto é preciso considerar que as pessoas estão inseridas em coletividades humanas dotadas de múltiplos códigos sociais que variam de acordo com a classe social, o gênero e a geração; enfim, vivemos em um mundo dividido por fronteiras e identidades culturais. 
Essa Tese percorreu, a passos largos, a história da humanidade como um todo para mostrar que o advento da sociedade moderna trouxe uma mudança quantitativa na capacidade das populações, em todo o mundo, de alterarem suas consciências com o uso de psicoativos. As drogas foram sendo incorporadas ao cotidiano das populações como medicinas, como meios de se conectar com o mundo espiritual, como entretenimento, como forma de obter ânimo ou mitigar as dores das jornadas de trabalho. O Brasil, apesar de estar na periferia do mercado mundial, participou da sua forma desse fenômeno denominado de revolução psicoativa.

No Brasil, como em outras partes do mundo, essa dieta farmacológica alimentada por uma cultura da automedicação foi obumbrada pela retórica triunfalista da medicina - que percebia qualquer uso fora da orientação oficial como ineficaz ou perigoso. Curiosamente, a historiografia (SAMPAIO, 2001) engajada na crítica dessa visão acabou por reforçá-la ao enfatizar a persistência e a efetividade das práticas tradicionais de cura - dotadas de efeitos sugestivos e crenças que faltavam à medicina oficial dos oitocentos. Mostrou-se, entretanto, que a arte de formular remédios e os recursos antálgicos não eram exclusividade das classes mais ricas - pertencendo ao repertório popular de cura. Essa dualidade entre científico e popular também esquece que falta ao medicamento científico uma objetividade que possa reduzi-lo a uma fórmula química.

O consumo de drogas, que se generalizou pelo mundo inteiro, teve na China e no ópio os símbolos maiores da ruina moral de um povo. Submetida militarmente pelas potências ocidentais, não sobrou outra alternativa aos seus governantes do que verem seu povo ser envenenado pela droga introduzida pelo imperialismo. A retórica da nação submetida pelo vício seria uma das bases de condenação dos opiáceos, bandeira que os estadunidenses teriam tomado para si quando iniciaram sua trajetória como potência imperial. O parâmetro do uso médico legítimo teria surgido da percepção compartilhada de degradação do povo chinês, e alçada à política ética e humanitária. A ascensão do proibicionismo nos EUA teria sido o principal fator para adoção, no mundo inteiro, de políticas restritivas no campo do comércio de entorpecentes - e no Brasil essa leitura não foi diferente.

Esse discurso, repetido a exaustão e até hoje com grande significado político, foi contrastado com os interesses econômicos e políticos existentes nas disputas imperialistas no Oriente. A democratização dos antálgicos, que em outros tempos eram privilégios da elite, criou um contexto de intenso mal estar. Antigas concepções 
religiosas foram travestidas de verdades científicas que associavam o uso de drogas por uma população inculta às práticas indesejadas, promotora do crime e da degeneração das raças. Esse é o contexto social e cultural que permitiu a ascensão de políticas proibitivas em vários países, voltadas a restringir o acesso a essas substâncias e viabilizando o monopólio médico.

No Brasil não foi diferente, apesar da tentativa dos discursos dominantes diplomático e médico-triunfalista - de diminuírem a todo o custo o papel dessas substâncias para a cultura terapêutica que persistiu durante boa parte da primeira metade do século XX. As leis sobre drogas teriam sido resultado de dinâmicas externas, resultados do papel subalterno e subserviente do país nos fóruns internacionais - como se as drogas não tivessem nenhuma utilidade terapêutica. Mostrou-se, entretanto, que elas eram largamente usadas nos mais diversos ramos da medicina. A proibição, nesse contexto, esteve vinculada ao mal estar gerado por uma percepção de degradação dos costumes e as críticas ao modelo federalista que reiterava o caráter tradicional e oligárquico da sociedade e da política brasileira.

Todo esse argumento resultou em uma crítica mais geral ao sentido da proibição das drogas no Brasil, que percebe as políticas nesse campo a partir de uma unidade de princípio (reduzir o consumo) e de método (aumentar a punitividade). Mostrou-se, entretanto, que as dinâmicas que levaram as primeiras normativas eram baseadas em uma perspectiva biopolítica que visava intervir na raça/população através da diminuição do acesso às drogas - fato que convinha a classe médica porque ela se tornaria a fiadora do uso através da prescrição. O breve êxito dessa política se rompe por causa do desenvolvimento da indústria farmacêutica, que transforma a classe médica em instrumento mercadológico privilegiado. A ideia de ciclos proibitivos é mais adequada para entender as particularidades de cada momento, embora em ambos seja possível identificar a heteronomia no consumo como princípio.

Os resultados desses processos, visíveis hoje, são catastróficos do ponto de vista social e humano. A farmacopeia clássica, que tem por base produtos fitoquímicos com raízes culturais em algumas regiões do mundo, não foi extinta. A partir dos antigos núcleos produtivos se desenvolveu uma poderosa indústria que alimenta uma sempre crescente dissidência farmacológica. Os custos sociais e humanos do tráfico ilícito alimentam a criminalidade urbana e a letalidade dos conflitos sociais, corrompendo as instituições legais e alimentando uma cultura do desrespeito à lei. Se os mortos dessa guerra se contam aos milhares, não menos dramática foi a criação da opiofobia e a 
consolidação de um sistema de acesso aos fármacos legais que consagra o princípio da heteronomia sobre a dor e a modulação do ânimo.

O acesso aos fármacos na sociedade contemporânea virou uma questão de mercado, alheio à racionalidade farmacológica e às demandas de saúde da população. $\mathrm{O}$ poder político, financiado pelos oligopólios do álcool e da indústria farmacêutica, é comprometido com interesses que impedem uma política social que fortaleça uma cultura farmacológica capaz de trazer soberania para o país e autonomia para os indivíduos. 


\section{REFERÊNCIAS}

\section{FONTES PRIMÁRIAS}

\subsection{Documentos legais}

BRASIL, Constituição Política do Império do Brasil, elaborada por um Conselho de Estado e outorgada pelo Imperador D. Pedro I, em 25.03.1824.

<http://www.planalto.gov.br/ccivil_03/Constituicao/Constituicao24.htm> Último acesso: 05 de junho de 2016.

BRASIL, Lei de 15 de outubro de 1827.

$<$ http://www2.camara.leg.br/legin/fed/lei_sn/1824-1899/lei-38396-15-outubro-1827-

566688-publicacaooriginal-90219-pl.html> Último acesso: 05 de junho de 2016.

BRASIL, Lei de $1^{\circ}$ de outubro de 1828.

<http://www2.camara.leg.br/legin/fed/lei_sn/1824-1899/lei-38281-1-outubro-1828-

566368-publicacaooriginal-89945-pl.html> Último acesso: 05 de junho de 2016.

BRASIL, Lei de 16 de dezembro de 1830. [Código Criminal do Império]

<http://www.planalto.gov.br/ccivil 03/leis/LIM/LIM-16-12-1830.htm> Último acesso: 05 de junho de 2016.

BRASIL, Decreto ${ }^{\circ}$ 9.554, de 3 de fevereiro de 1886.

<http://www2.camara.leg.br/legin/fed/decret/1824-1899/decreto-9554-3-fevereiro-

1886-543197-publicacaooriginal-53270-pe.html> Último acesso: 05 de junho de 2016.

BRASIL, Decreto no 847 , de 11 de outubro de 1890 [Código Penal].

$<$ http://www2.camara.leg.br/legin/fed/decret/1824-1899/decreto-847-11-outubro-1890-

503086-publicacaooriginal-1-pe.html> Último acesso: 05 de junho de 2016.

BRASIL, Decreto $n^{\circ} 2.449$, de $1^{\circ}$ de fevereiro de 1897.

<http://www2.camara.leg.br/legin/fed/decret/1824-1899/decreto-2449-1-fevereiro-

1897-539632-publicacaooriginal-38965-pe.html> Último acesso: 05 de junho de 2016.

BRASIL, Decreto $\mathrm{n}^{\circ} 1.151$, de 5 de janeiro de 1904.

$<$ http://www2.camara.leg.br/legin/fed/decret/1900-1909/decreto-1151-5-janeiro-1904583460-publicacaooriginal-106278-pl.html> Último acesso: 05 de junho de 2016.

BRASIL, Decreto $\mathrm{n}^{\circ}$ 5.156, de 8 de março de 1904.

$<$ http://www2.camara.leg.br/legin/fed/decret/1900-1909/decreto-5156-8-marco-1904517631-publicacaooriginal-1-pe.html> Último acesso: 05 de junho de 2016.

BRASIL, Decreto n ${ }^{\circ} 2.861$, de 8 de julho de 1914.

$<$ http://www2.camara.leg.br/legin/fed/decret/1910-1919/decreto-2861-8-julho-1914575437-publicacaooriginal-98630-pl.html> Último acesso: 05 de junho de 2016.

BRASIL, Decreto $\mathrm{n}^{\circ} 11.481$, de 10 de fevereiro de 1915.

<http://www2.camara.leg.br/legin/fed/decret/1910-1919/decreto-11481-10-fevereiro1915-574770-republicacao-98061-pe.html> Último acesso: 05 de junho de 2016. 
BRASIL, Decreto n ${ }^{\circ} 4.294$, de 6 de julho de 1921.

<http://www2.camara.leg.br/legin/fed/decret/1920-1929/decreto-4294-6-julho-1921569300-publicacaooriginal-92525-pl.html> Último acesso: 06 de junho de 2016.

BRASIL, Decreto ${ }^{\circ} 11.969$, de 3 de setembro de 1921.

$<$ http://www2.camara.leg.br/legin/fed/decret/1920-1929/decreto-11969-3-setembro1921-569340-publicacaooriginal-92577-pe.html> Último acesso: 06 de junho de 2016.

BRASIL, Decreto $\mathrm{n}^{\mathrm{o}} 20.930$, de 11 de janeiro de 1932.

<http://www2.camara.leg.br/legin/fed/decret/1930-1939/decreto-20930-11-janeiro1932-498374-publicacaooriginal-81616-pe.html> Último acesso: 07 de junho de 2016.

BRASIL, Decreto ${ }^{\circ} 780$, de 28 de abril de 1936.

<http://www2.camara.leg.br/legin/fed/decret/1930-1939/decreto-780-28-abril-1936472250-publicacaooriginal-1-pe.html> Último acesso: 07 de junho de 2016.

BRASIL, Decreto-lei no 891, de 25 de novembro de 1938.

<http://www2.camara.leg.br/legin/fed/declei/1930-1939/decreto-lei-891-25-novembro1938-349873-publicacaooriginal-1-pe.html> Último acesso: 07 de junho de 2016.

BRASIL, Decreto-lei no 2.848, de 7 de dezembro de 1940. [Código Penal] $<$ http://www2.camara.leg.br/legin/fed/declei/1940-1949/decreto-lei-2848-7-dezembro1940-412868-publicacaooriginal-1-pe.html> Último acesso: 07 de junho de 2016.

BRASIL, Decreto-lei no 4.720, de 21 de setembro de 1942

<http://www2.camara.leg.br/legin/fed/declei/1940-1949/decreto-lei-4720-21-setembro1942-414751-publicacaooriginal-1-pe.html> Último acesso: 07 de junho de 2016.

BRASIL, Decreto n 20.397 , de 14 de janeiro de 1946.

<http://www2.camara.leg.br/legin/fed/decret/1940-1949/decreto-20397-14-janeiro1946-327522-norma-pe.html> Último acesso: 07 de junho de 2016.

BRASIL, Lei ${ }^{\circ}$ 4.451, de 4 de novembro de 1964.

<http://www2.camara.leg.br/legin/fed/lei/1960-1969/lei-4451-4-novembro-1964-

376671-publicacaooriginal-1-pl.html > Último acesso: 07 de junho de 2016.

BRASIL, Decreto-lei no 385, de 26 de dezembro de 1968.

<http://www2.camara.leg.br/legin/fed/declei/1960-1969/decreto-lei-385-26-dezembro1968-378122-publicacaooriginal-1-pe.html> Último acesso: 07 de junho de 2016.

BRASIL, Lei ${ }^{\mathrm{a}}$ 6.360, de 23 de setembro de 1976.

<http://www2.camara.leg.br/legin/fed/lei/1970-1979/lei-6360-23-setembro-1976357079-publicacaooriginal-1-pl.html> Último acesso: 07 de junho de 2016.

BRASIL, Lei $\mathrm{n}^{\circ} 6.368$, de 21 de outubro de 1976.

<http://www2.camara.leg.br/legin/fed/lei/1970-1979/lei-6368-21-outubro-1976-357249publicacaooriginal-1-pl.html> Último acesso: 07 de junho de 2016.

BRASIL, Decreto no 85.110 , de 2 de setembro de 1980 
$<$ http://www2.camara.leg.br/legin/fed/decret/1980-1987/decreto-85110-2-setembro1980-434379-publicacaooriginal-1-pe.html> Último acesso: 07 de junho de 2016.

BRASIL, Lei no 8.072, de 25 de julho de 1990.

<http://www2.camara.leg.br/legin/fed/lei/1990/lei-8072-25-julho-1990-372192-

publicacaooriginal-1-pl.html> Último acesso: 07 de junho de 2016.

BRASIL, Lei $n^{\circ}$ 9.787, de 10 de fevereiro de 1999.

<http://www2.camara.leg.br/legin/fed/lei/1999/lei-9787-10-fevereiro-1999-351613-

publicacaooriginal-1-pl.html> Último acesso: 07 de junho de 2016.

BRASIL, Lei 10.216, de 6 de abril de 2001.

<http://www2.camara.leg.br/legin/fed/lei/2001/lei-10216-6-abril-2001-364458-

publicacaooriginal-1-pl.html > Último acesso: 07 de junho de 2016.

BRASIL, Lei $\mathrm{n}^{\circ} 11.343$, de 23 de agosto de 2006.

<http://www2.camara.leg.br/legin/fed/lei/2006/lei-11343-23-agosto-2006-545399-

publicacaooriginal-57861-pl.html> Último acesso: 07 de junho de 2016.

BRASIL, Decreto $\mathrm{n}^{\circ} 7.179$, de 20 de maio de 2010.

<http://www2.camara.leg.br/legin/fed/decret/2010/decreto-7179-20-maio-2010-606392publicacaooriginal-127199-pe.html> Último acesso: 07 de junho de 2016.

BRASIL, Ministério da Saúde; Instituto Nacional do Câncer; Organização PanAmericana de Saúde. Pesquisa Especial de Tabagismo - PETab - Relatório Brasil. Rio de Janeiro: INCA, 2011.

<http://www1.inca.gov.br/inca/Arquivos/comunicacao/pesquisa_especial_tabagismo.pdf >

Último acesso: 06 de junho de 2016.

BRASIL, Ministério da Saúde. Recomendações do Ministério da Saúde para adoção de práticas não medicalizantes e para publicação de protocolos municipais e estaduais de dispensação de metilfenidato para prevenir a excessiva medicalização de crianças e adolescentes, 2015.

<http://conselho.saude.gov.br/recomendacoes/2015/Reco019.pdf>

Último acesso: 06 de junho de 2016.

Diário do Congresso Nacional [seção I], 01 de agosto de 1959, p.4748.

RIO DE JANEIRO (Estado). Comitê de Prevenção e Combate à Tortura. Relatório de Inspeção em Comunidades Terapêuticas Financiadas pelo Governo do Estado do Rio de Janeiro, 2013.

<http://www.cressrj.org.br/download/arquivos/relatorio-ct-financiadas-pelo-gov-est-rjjunho-13.pdf> Último acesso: 06 de junho de 2016.

SÃO PAULO, Decreto $n^{\circ} 233$, de 2 de março de 1894.

<http://www.al.sp.gov.br/repositorio/legislacao/decreto/1894/decreto-233-

02.03.1894.html> Último acesso: 05 de junho de 2016.

SÃO PAULO, Decreto nº 2.918, de 9 de abril de 1918. 
<http://www.al.sp.gov.br/repositorio/legislacao/decreto/1918/decreto-2918-

09.04.1918.html > Último acesso: 05 de junho de 2016.

SÃO PAULO, Lei n ${ }^{\circ} 1.859$, de 30 de dezembro de 1921.

<http://www.al.sp.gov.br/repositorio/legislacao/lei/1921/lei-1859-30.12.1921.html>

Último acesso: 06 de junho de 2016.

SÃO PAULO, Lei no 2.034 , de 30 de dezembro de 1924.

<http://www.al.sp.gov.br/repositorio/legislacao/lei/1924/lei-2034-30.12.1924.html>

Último acesso: 06 de junho de 2016.

Ordenações Filipinas, vols. 1 a 5. Rio de Janeiro: Edição de Cândido Mendes de Almeida, 1870.

<http://www1.ci.uc.pt/ihti/proj/filipinas/ordenacoes.htm>

Último acesso: 06 de junho de 2016

\subsection{Teses, Livros e Artigos Médicos}

ASMCSP. Anesthesia geral pelo ether. Archivo da Sociedade de Medicina e Cirurgia de São Paulo Vol. III, n ${ }^{\circ}$ 11-12, p.214-215, 1912.

ASMCSP. A anesthesia geral pelo ether. Archivo da Sociedade de Medicina e Cirurgia de São Paulo Vol. IV, nº 1-2, p.247-248, 1913.

ASMCSP. Tratamento das pleurisias agudas, pelo dr. Hirtz. Archivo da Sociedade de Medicina e Cirurgia de São Paulo. Vol. III, nº 12-13, p.188-189, 1912.

AMB. Carta Dirigida á Redacção sobre a necessidade de se crear uma materia medica brasileira, e indicando o modo como se ha de entender na confeição della. Archivo Medico Brasileiro. Tomo II, $\mathrm{n}^{\mathrm{o}}$ 1, p.141, 1845.

AMB. Envenenamento pelo Acetato de Morphina combatido com proveito por uma dóse enorme de infusão de café. Archivo Medico Brasileiro. Tomo IV, $\mathrm{n}^{\mathbf{0}} 1$, p.43, 1847.

ARGM, A narcose pelo chlorureto de ehyia terá perigos? Arquivos Rio Grandenses de Medicina. Ano VII, nº10, p.18, 1928.

AVILA, Cesar. Mal sub-occipital. Arquivos Rio Grandenses de Medicina. Ano XIX, no 4, p.129-133, 1940.

BARRETO, Luiz Pereira. A cura radical das hemorrhoides por processo sem sangue, sem dor e sem chloroformio. A cirurgia de hontem e a cirurgia de hoje. Annaes Paulistas de Medicina e Cirurgia. Vol. V, ano III, nº 2-4, p.214-224, 1915.

BSMCSP. Café e opio. Boletim da Sociedade de Medicina e Cirurgia de São Paulo. $\mathrm{N}^{\circ} 18$, p.23, 1896.

BSMCSP. VARIAS - etherisação e chloroformização. Boletim da Sociedade de Medicina e Cirurgia de São Paulo. No 30, p.18-20, 1898. 
BORGES, Eugenio Augusto de Oliveira. Cocaina e seus usos. These. (Cadeira de Clinica Organica e Biologica / Faculdade de Medicina do Rio de Janeiro), 1888.

BOTELHO, Adauto; FILHO, Pernambuco. Vícios Sociaes Elegantes. (Cocaína, ether, diamba, ópio e seus derivados etc) - estudo clínico, médico-legal e prophylatico. Rio de Janeiro: Livraria Francisco Alves, 1924.

BOTELHO, Francisco de Andrade. Do valor anesthesico da cocaina na cirurgia em geral. These. (Cadeira de Anatomia Cirurgica, Medicina Operatoria e Apparelhos / Faculdade de Medicina do Rio de Janeiro), 1890.

CARNEIRO, Manoel Clementino de Barros. Acção physiologica e therapeutica dos alcoolicos. These. (Cadeira de Therapeutica e Materia Medica Especialmente Brazileira / Faculdade de Medicina do Rio de Janeiro), 1883.

CARVALHO, Oscar Pereira de. Analgesia cirurgica por meio das injecções subarachnoideanas lombares de cocaina. These. (Cadeira de Clinica Cirurgica / Faculdade de Medicina e de Pharmacia da Bahia), 1902.

CHAVES, Luiz Antonio. O Opio, de sua acção sobre a economia animal, e dos casos que reclamão seo uso, precedida de considerações geraes sobre o systema nervoso. These. (Faculdade de Medicina do Rio de Janeiro), 1839.

CLARK, Oscar. Alcool e Climas - Alcool e Epilepsia - Alcoolismo Chronico e Meningite Serosa. In: FIALHO, José Antonio de Abreu. Medicina publica e clinica geraes e especiaes. Rio de Janeiro: Jacintho Ribeiro dos Santos, 1917, p.365-385.

DOGLIOTTI, Achille Mario. Tratado de Anestesia: narcose, anestesia local, regional e espinhal. Rio de Janeiro: Scientifica, 1943.

FILHO, Álvaro Guimarães. Da hygiene mental e sua importância em nosso meio. These. (Cadeira de Hygiene / Faculdade de Medicina de São Paulo), 1926.

GALVÃO, Argymiro. Toxicomanias. Arquivos Rio Grandenses de Medicina. Ano VII, No 6, p.11-16, 1928.

GCSP. Interdicção da Heroina. Gazeta Clínica (SP). Vol. 22, p.94, 1924.

GMRJ. Tetano tratado com sucesso pelo alcool em alta dose. Gazeta Médica do Rio de Janeiro. N.6, 1862, p.70.

GOMES, Laudelino. Anestesia Local. Annaes Paulistas de Medicina e Cirurgia. Vol. XI, ano VIII, no 3, p.61-62, 1920.

LOPES, Euclides Silveira da Cunha. Da anesthesia local nas hernias inguinaes. These approvada com distincção. (Cadeira de Clinica Cirurgica / Faculdade de Medicina de Porto Alegre), 1912. 
LOUREIRO, Oswaldo Ayres. Anesthesia Obstetrica. These. (Cadeira de Clinica Medica / Faculdade de Medicina do Rio de Janeiro), 1913.

MASCARENHAS, Domingos Pinto de Figueiredo. Da anesthesia local em cirurgia operatoria. These. (Cadeira de Clinica Cirurgica ( $2^{\mathrm{a}}$ Cadeira) / Faculdade de Medicina do Rio de Janeiro), 1894.

MOREIRA, A. A. Santos. Formulario de Therapeutica Infantil: Revisto e Prefaciado pelo Prof ${ }^{\circ}$ Fernandes Figueira com a collaboração dos drs. Zopyro Goulart, Aleixo de Vasconcellos, Edilberto Campos e J. Marinho. Rio de Janeiro: Editores Besnard Freres, 1920.

PAUlinO, Augusto. Manual de Cirurgia. Rio de Janeiro: Mundo Médico, 1930.

PEREIRA, Clemente. Do emprego clínico do Chlorydrato de Heroína. Revista Médica de São Paulo. Vol. 2, p.304-306, 1899.

RANGEL, Mario. Medicamentos Novos na Clínica Diária. Rio de Janeiro: Irmão di Giorgio e Cia, 1950.

RENNOTTE, Maria. Do emprego do chloroformio quente. Archivo da Sociedade de Medicina e Cirurgia de São Paulo. Vol. I, nº I, p.27-31, 1910.

RIBAS, Benoni Laurindo; VIANNA, Nelson Lobo. O uso de entorpecentes no Brasil. Medicina - Cirurgia - Farmácia. N.243, p.308-315, 1956.

RMF. Observação de envenenamento pelo acetato de morphina, seguida de algumas reflexões, por Orfila, Professor da Escola de Medicina de Paris. Revista Medica Fluminense. $\mathrm{N}^{\mathrm{o}} .4,5^{\mathrm{o}}$ Anno, p.102-111, 1836.

RMF. Da Moléstia considerada em geral, segundo as diferentes doutrinas medicas. Revista Médica Fluminense. N ${ }^{\mathrm{o}} .2,5^{\circ}$ Anno, p.399-449, 1836.

RODRIGUES, Plinio Martins. Toxicomanias: meios para combatel-as. These. (Cadeira de Hygiene / Faculdade de Medicina de São Paulo), 1931.

SANTOS, José Fernandes da Costa. Anesthesicos. These. (Siencias Cirurgicas/Faculdade de Medicina do Rio de Janeiro), 1882.

SIGAUD, J. F. Sobre o acetato de Morphina. O Propagador das Sciencias Medicas. $1^{\circ}$ Anno - Tomo Primeiro - No 1. 1827, p.331-332.

SILVA, Peçanha da. Nota. Annaes Brasilienses de Medicina. Tomo XXV, n.11, p.438, 1874 .

URSAIA, Francisco. Dos derivados da morphina no apparelho respiratorio. These approvada com distincção. (Cadeira de Pharmacologia / Faculdade de Medicina do Rio de Janeiro), 1924. 
VAMPRÉ, Fabricio Carneiro Tupinambá. Anesthesicos. These. (Cadeira de Anatomia Topographica e Operações / Faculdade de Medicina do Rio de Janeiro), 1881.

\subsection{Prontuários Médicos}

Manuel Pereira da Silva, Pavilhão de Observações, Livro de Observações Clínicas n $^{\circ}$ 346, p.127-130.

José Torres, SPSP, Prontuário nº 240, 1931.

Carlos Araújo, SPSP, Prontuário nº 551, 1932.

\subsection{Bibliografia primária}

ANDRADE, Mario de. Amar, verbo intransitivo. São Paulo: Instituto Canal do Livro, 1927.

AVÉ-LALLEMANT, Orville. Sociologia do mate no Rio Grande do Sul e Paraná de 1858. In: CASCUDO Luís da Câmara (org). Antologia da Alimentação no Brasil. Rio de Janeiro/São Paulo: Livros Técnicos e Científicos, 1977, 170-172.

CIULLA, Luiz. Intoxicados pela maconha em Pôrto Alegre. In: Maconha: coletânea de trabalhos brasileiros. Rio de Janeiro: Serviço Nacional de Educação Sanitária, 1958, p.377-381.

DÓRIA, Rodrigues. Os fumadores de maconha: efeitos e males do vício. In: Maconha: coletânea de trabalhos brasileiros. Rio de Janeiro: Serviço Nacional de Educação Sanitária, 1958, p.01-14.

FARIAS, Roberval Cordeiro. As toxicomanias de após-guerra. In: Maconha: coletânea de trabalhos brasileiros. Rio de Janeiro: Serviço Nacional de Educação Sanitária, 1958, p.147-153.

GOMES, Geraldo. Os alucinógenos e o direito (L.S.D.). São Paulo: Editora Juriscrédi, 1972.

GRECO FILHO, Vicente. Tóxicos: prevenção e repressão - comentários à Lei 5.726: Tóxicos: prevenção e repressão - comentários à Lei 5.726. São Paulo: Saraiva, 1972.

MORAES, Evaristo de. Ensaios de patologia social: vagabundagem, alcoolismo, prostituição e lenocínio. Rio de Janeiro: Leite Ribeiro, 1921.

TELLES, Celso. Comercio Clandestino de Entorpecentes: Índice Confidencial - uso exclusivo das autoridades policiais. São Paulo: Serviço Gráfico da Secretaria de Segurança Pública, 1961.

\subsection{Jornais}

\subsubsection{Hemeroteca Digital Brasileira}

A Gazeta da Farmácia, maio de 1952. 
A Federação, 13 de maio de 1885.

A Noite, 04 de Janeiro de 1913.

A Noite, 06 de Janeiro de 1913.

A Noite, 11 de Abril de 1913.

Correio Paraense, 30 de Agosto 1893.

Diário da Bahia, 12 de novembro de 1889.

Diário do Rio de Janeiro, 13 de agosto de 1863.

Diário do Rio de Janeiro, 17 de setembro de 1867.

Diário do Rio de Janeiro, 20 de fevereiro de 1863.

Diário do Rio de Janeiro, 04 de janeiro de 1869.

Diário do Rio de Janeiro, 27 de março de 1869.

Gazeta da Bahia, 21 de dezembro de 1879.

O Jornal, 19 de agosto de 1920.

O Jornal, 19 de maio de 1921.

O Jornal, 20 de maio de 1921.

O Jornal, 11 de junho de 1921.

O Monitor, 11 de janeiro de 1881 .

O Paiz, 14 de agosto de 1878.

\subsubsection{Arquivo Histórico Moysés Vellinho}

Correio do Povo, 08/01/1959, p.05.

\subsubsection{Internet}

Revista Superinteressante, 07 de Outubro de 2014.

1.6 Documentos policiais e judiciais.

\subsubsection{Arquivo Histórico do Rio Grande do Sul}

AHRGS. Documentação Policial. Caixa 225, 1931.

1.6.2. Arquivo Público do Estado do Rio Grande do Sul

APERGS. Processo-Crime contra Arnaldo Koehln, nº 448, maço 262, ano 1939.

\subsubsection{Arquivo Nacional}

AN. Infração Sanitária de Júlio Cezar de Paula Freitas, 1913.

[BR AN RIO 72.0.IFS.16404].

AN. Infração Sanitária de Carlos Martins Vieira, 1913.

[BR AN RIO 70.0.IFS.16381].

AN. Infração Sanitária de Luiz de Mattos Pimenta, 1913.

[BR AN RIO 6Z.0.IFS.21993]. 


\section{BIBLIOGRAFIA}

ABREU, Jean Luiz Neves. O corpo, a doença e a saúde: O saber médico luso-brasileiro no século XVIII. Tese. (PPG - História / Universidade Federal de Minas Gerais), 2006.

A Colônia enferma e a saúde dos povos: a medicina das 'luzes' e as informações sobre enfermidade da América portuguesa. História, Ciências, Saúde Manguinhos. V.14, n.3, p.761-778, 2007a.

Ilustração, experimentalismo e mecanicismo: aspectos da transformação do saber médico em Portugal no século XVIII. Topoi. V.8, n.15, p.80-104, 2007 b.

ADIALA, Julio Cesar. A criminalização dos entorpecentes. Dissertação. (PPGSociologia / IUPERJ), 1996.

Drogas, Medicina e Civilização na Primeira República. Tese. (PPG em História das Ciências da Saúde / Fundação Oswaldo Cruz), 2011.

ALMEIDA, Eduardo. As razões da Terapêutica: Racionalismo e Empirismo na Medicina. Niterói: Editora da UFF/ART Intituto de Medicina Integral, 2011

ALVES, Mariana da Hora. Junta Central de Higiene Pública: ações, estigmas e conflitos sociais (1850-1889). XV Encontro Regional de História - Ofício do Historiador: Ensino e Pesquisa. Universidade Estadual do Rio de Janeiro (UERJ) - São Gonçalo (RJ). Anais. 2012. 01-10 p.

A reorganização dos serviços sanitários no Império em 1886: a questão dos vinhos falsificados e dos gêneros alimentício como um imperativo. XXVIII Simpósio Nacional de História - Lugares dos Historiadores: Velhos e Novos Desafios. Florianópolis - SC. Anais. 2015. 01-16 p.

ALVES, Olga Sofia Fabergé. Farmacêuticos Diplomados e algumas Estratégias de Institucionalização da Farmácia em São Paulo: (1892-1934). Dissertação. (Programa de Pós-Graduação em História Social / USP), 2011.

ANTUNES, Henrique Fernandes. Droga, religião e cultura: um mapeamento da controvérsia pública sobre o uso da ayahuasca no Brasil. Dissertação. (PPG em Antropologia Social / USP), 2012.

ANTUNES, José Leopoldo Ferreira. Medicina, leis e moral: pensamento médico e comportamento no Brasil (1870-1930). São Paulo: UNESP, 1999.

ARAVANIS, Evangelia. O corpo em evidência nas lutas do movimento operário: (1890-1917). Tese. (PPG - História / UFRGS), 2005.

ASSIS, Glauber Loures; LABATE, Beatriz Caiuby. Dos Igarapés da Amazônia para o outro lado do Atlântico: a expansão e internacionalização do Santo Daime no contexto religioso global. Religião \& Sociedade. V.34, n.2, p.11-35, 2014. 
ASTORGA, Luis. Cocaine in Mexico: a prelude to 'los Narcos'. In: GOOTENBERG Paul (org). Cocaine: global histories. New York: Routledged, 1999, p.183-191.

BEHR, Edward. Prohibition: Thirteen Years That Changed America. New York: Arcade Publishing, 2011.

BENCHIMOL, Jaime Larry. Dos micróbios aos mosquitos: febre amarela e revolução pasteuriana no Brasil. Rio de Janeiro: Fiocruz, 1999.

BERRIDGE, Virginia. Demons: Our changing attitudes to alcohol, tabacco, \& drugs. Oxford: Oxford University Press, 2013.

BERTUCCI, Liane Maria. Remédios, charlatanices ... e curandices: práticas de cura no período da gripe espanhola em São Paulo. In: CHALHOUB Sidney, et al. (orgs). Artes e Ofícios de Curar no Brasil: capítulos de história social. Campinas: UNICAMP, 2003, p.197-217.

BLOCH, Marc. Apologia da História ou o oficio do historiador. Rio de Janeiro: Jorge Zahar, 2001.

BRAUDEL, Fernand. Civilização Material e Capitalismo: séculos XV-XVIII. Lisboa/Rio de Janeiro: Edições Cosmos, 1970.

BRETON, David Le. Antropologia da dor. São Paulo: Unifesp, 2013a.

Antropologia do corpo e modernidade. Petrópolis: Vozes, 2013 b.

BRIGOLA, Higor Ferreira; ALBUQUERQUE, Edu Silvestre de. As principais diretrizes da agenda de segurança nacional brasileira no pós-guerra fria: as questões ambientais e o tráfico de ilícitos. Revista de Geopolítica. V.3, n.1, p.78-95, 2012.

BOGUSZEWSKI, José Humberto. Uma história cultural da erva-mate: o alimento e suas representações. Dissertação. (PPG - História / UFPR), 2007.

BOITEAUX, Luciana. A reforma da Política Internacional de Drogas virá de baixo para cima. Argumentum. V.7, n.1, p.17-20, 2015.

; CASTILHO, Ela Wircko Volkmer; VARGAS, Beatriz; BATISTA, Vanessa Oliveira; PRADO, Geraldo Luiz; JAPIASSU, Carlos Eduardo Adriano. Série Pensando o Direito: Tráfico de Drogas e Constituição. Rio de Janeiro/Brasilia: Resumo do Projeto de Pesquisa apresentado ao Ministério da Justiça/ PNUD, 2009.

BUENO, Eduardo; TAITELBAUM, Paula. Vendendo Saúde: história da propaganda de medicamentos no Brasil. Brasília: Agência Nacional de Vigilância Sanitária, 2008.

CALIMAN, Luciana. Drogas de Desempenho: a Ritalina e o transtorno do déficit de atenção/hiperatividade (TDAH). In: ALARCON Sergio (org). Álcool e outras drogas: diálogos sobre um mal-estar contemporâneo. Rio de Janeiro: Editora da Fiocruz, 2014, p.223-238. 
CANCELLI, Elizabeth. A cultura do crime e da lei: 1889-1930. Brasília: EDUNB, 2001.

CANGUILHEM, Georges. O normal e o patológico. Rio de Janeiro: Forense Universitária, 2009.

CAMARGO, Maria Thereza Lemos de Arruda. Garrafada na medicina popular: uma revisão historiográfica. Dominguezia. V.27, n.1, p.41-49, 2011.

As plantas medicinais e o sagrado: a Etnofarmacobotânica em uma revisão historiográfica da medicina popular no Brasil. São Paulo: Ícone, 2014.

CARNEIRO, Beatriz H. S. A vertigem dos venenos elegantes. Dissertação. (PPGHistória / PUCSP), 1993.

CARNEIRO, Henrique. Amores e sonhos da flora: afrodisíacos e alucinógenos na botânica e na farmácia. São Paulo: Xamã, 2002.

Autonomia ou heteronomia nos estados alterados da consciência. In: LABATE, Beatriz Caiuby et al (org). Drogas e Cultura: novas perspectivas. Salvador: EDUFBA, 2008, 65-87.

SENAC, 2010.

Bebida, Abstinência e Temperança: na história antiga e moderna. São Paulo:

. O corpo sedento. Bebidas na História do Brasil. In: PRIORE, Mary del; AMANTINO, Marcia (org). História do Corpo no Brasil. São Paulo: Editora da Unesp, 2011, p.131-156.

CARNEIRO, Rosamaria Giatti. Cenas de parto e políticas do corpo. Rio de Janeiro: Editora da Fiocruz, 2015.

CORRÊA, Mariza. As ilusões da liberdade: a escola Nina Rodrigues e a antropologia no Brasil. Rio de Janeiro: Editora da FIOCRUZ, 2013.

CARVALHO, Jonatas Carlos de. Regulamentação e criminalização das drogas no Brasil: A Comissão Nacional de Fiscalização de Entorpecentes. Rio de Janeiro: Multifoco, 2013.

CARVALHO, Salo de. A política criminal de drogas no Brasil: Estudo criminológico e dogmático. Rio de Janeiro: Lumen Juris, 2007.

CASCUDO, Luís da Câmara. História da Alimentação no Brasil. São Paulo: Global Editora, 2004.

CAULFIELD, Sueann. Em defesa da honra: moralidade, modernidade e nação no Rio de Janeiro (1918-1940). Campinas: EdUnicamp, 2000.

CERTEAU, Michael de. A escrita da história. Rio de Janeiro: Forense Universitária, 2008. 
CERVO, Amado Luiz. Prefácio. In: SILVA, Luiza Lopes da. A Questão das Drogas nas Relações Internacionais: Uma perspectiva brasileira. Brasília: Fundação Alexandre de Gusmão, 2013, p.37-44.

EDUnB, 2012.

; BUENO, Clodoaldo. História da política exterior do Brasil. Brasília:

CHANGSHENG, Shu. Imigrantes e a imigração chinesa no Rio de Janeiro (1910-1990).

Leituras da História. Ano II, p.44-53, 2009.

CHALHOUB, Sidney. Cidade Febril: cortiços e epidemias na corte imperial. São Paulo: Companhia das Letras, 1996.

CORDEIRO, Hesio. A indústria da saúde no Brasil. Rio de Janeiro: Graal, 1985.

COSTA, Jurandir Freire. Ordem Médica e Norma Familiar. Rio de Janeiro: Graal, 1979.

COSTA, Raul Max Lucas da. Tensões sociais no consumo de bebidas alcoólicas em Fortaleza (1915-1935): trabalhadores, boêmios, ébrios e alcoólatras. Dissertação. (PPG - História Social / UFC), 2009.

COURTWRIGHT, David T. Forces of Habit: Drugs and the Making of the Moderns World. Massachusetts/London: Harvard/Cambrindge, 2001.

CUNHA, Maria Clementina Pereira. O outro lado do espelho: Juqueri, a história de um asilo. Rio de Janeiro: Paz e Terra, 1986.

CZERESNIA, Dina. Constituição epidêmica: velho e novo nas teorias e práticas da epidemiologia. História, Ciência, Saúde - Manguinhos. V.VIII, n.2, p.341-56, 2001.

DAGOGNET, François. A Razão e os remédios. Rio de Janeiro: Forense, 2012.

DAVENPORT-HINES, Richard. The Pursuit of Oblivion: A Global History of Narcotics. Londres/ N. York: W.W. Norton \& Company, 2002.

DELAMARQUE, Elizabete Vianna. Junta Central de Higiene Pública: Vigilância e Política Sanitária (antecedentes e principais debates). Dissertação. (PPG em História das Ciências e da Saúde / FIOCRUZ), 2011.

DELMANTO, Júlio. Camaradas Caretas: Drogas e esquerda no Brasil após 1961. Dissertação. (PPG - História Social / USP), 2013.

DIAS, Laércio Fidelis. Usos e abusos de bebidas alcoólicas segundo os Povos Indígenas do Uaçá. In: LABATE, Beatriz Caiuby et al (org). Drogas e Cultura: novas perspectivas. Salvador: EDUFBA, 2008, 199-217.

DIKOTTER, Frank; LAAMANN, Lars; XUN, Zhou. Narcotic Culture: a history of drugs on China. Chicago: The University of Chicago Press, 2004. 
DINIZ, Sheyla Castro. "Nuvem Cigana": A trajetória do clube da esquina no campo da MPB. Dissertação. (PPG em Sociologia / UNICAMP), 2012.

DONNANGELO, Maria Cecília Ferro. Saúde e sociedade. São Paulo: Duas Cidades, 1979.

DONGHI, Tulio Halperin. História da América Latina. Rio de Janeiro: Paz e Terra, 2012.

DUARTE, Paulina do Carmo Arruda; BARROSO, Lúcia Pereira; STEMPLIUK, Vladimir de Andrade. Relatório Brasileiro sobre Drogas. Brasília: Secretaria Nacional de Políticas Sobre Drogas (SENAD), 2009.

EDLER, Flavio Coelho. O debate em torno da medicina experimental no segundo reinado. História, Ciência e Saúde - Manguinhos. V.3, n.2, p.284-299, 1996.

A medicina brasileira no século XIX: um balanço historiográfico. Asclepio. V.L, n.2, p.169-186, 1998.

De olho no Brasil: a geografia médica e a viagem de Alphonse Rendu. História, Ciências, Saúde - Manguinhos. V.7, n.(suplemento), p.925-943, 2001.

A escola tropicalista baiana: um mito de origem da medicina Tropical no Brasil. História, Ciência e Saude - Manguinhos. V.9, n.2, p.357-385, 2002.

A medicina no Brasil imperial: fundamentos da autoridade profissional e da legitimidade científica. Anuario de Estudios Americanos. V.LX, n.1, p.129-156, 2003.

O saber médico e o poder profissional. In: FIDÉLIS Carlos; FALLEIROS, Ialê (org). Na corda bamba de sombrinha: a saúde no fio da história. Rio de Janeiro: Fiocruz/COC; Fiocruz/EPSJV, 2010, p.25-48.

Pesquisa clínica e experimental no Brasil oitocentista: circulação e controle do conhecimento em helmintologia médica. História, Ciências, Saúde - Manguinhos. v.17, n.3, p.739-755, 2010.

A Medicina no Brasil Imperial: clima, parasitas e patologia tropical. Rio de Janeiro: FIOCRUZ, 2011.

Pesquisas em parasitologia médica e circulação do conhecimento no contexto da medicina colonial. In: BASTOS Cristiana; BARRETO, Renilda (org). Medicina, Redes e Impérios: Medicina, Redes e Impérios. Lisboa: Instituto de Ciências Sociais, 2011, p.173-199.

; FREITAS, Ricardo Cabral. O "imprescrutável vínculo" - corpo e alma na medicina lusitana setecentista. Varia História. V.29, n.50, p.435-452, 2009. 
; GUIMARÃES, Maria Regina Cotrim. Chernoviz e a medicina no Império. Insight Inteligência. V.23, p.128-146, 2003.

ESCOHOTADO, Antonio. Historia General de las Drogas: incluyendo el apéndice Fenomenologia de las Drogas. Madrid: Espasa Calpe, 2008.

FARE, Mónica de; MACHADO, Frederico Viana; CARVALHO, Isabel Cristina de Moura. Breve revisão sobre regulação da ética em pesquisa: subsídios para pensar a pesquisa em educação no Brasil. Práxis Educativa. V.9, n.1, p.247-283, 2014.

FAUSTO, Boris. Crime e cotidiano: a criminalidade em São Paulo (1880-1924). São Paulo: Brasiliense, 1984.

História Concisa do Brasil. São Paulo: USP, 2002.

FERNANDES, João Azevedo. Cauinagens e bebedeiras: os índios e o álcool na história do Brasil. Revista Anthropológicas. V.13, n.2, p.39-59, 2002.

FERREIRA, Luiz Otávio. Das doutrinas à experimentação: rumos e metamorfoses da medicina no século XIX. Revista da SBHC. N.10, p.43-52, 1993.

; MAIO, Marcos Chor; AZEVEDO, Nara. A Sociedade de Medicina e Cirurgia do Rio de Janeiro. História, Ciências, Saúde - Manguinhos. V.4, n.3, p.475-491, 1998.

. Os periódicos médicos e a invenção de uma agenda sanitária para o Brasil (1827-1843). História, Ciências, Saúde - Manguinhos. V.6, n.2, p.331-351, 1999.

Uma interpretação higienista do Brasil imperial. In: HEIZER Alda; VIDEIRA, Antonio Augusto Passos (org). Ciência, civilização e império nos trópicos. Rio de Janeiro: Access, 2001, p.207-225.

Medicina Impopular. Ciência médica e medicina popular nas páginas dos periódicos científicos (1830-1840). In: CHALHOUB Sidney, et al. (orgs). Artes e Ofícios de Curar no Brasil: capítulos de história social. Campinas: UNICAMP, 2003, p.101-122.

Negócio, política, ciência e vice-versa: uma história institucional do jornalismo médico brasileiro entre 1827 e 1843. História, Ciências, Saúde - Manguinhos. V.11, n.(suplemento 1), p.93-107, 2004.

FIGUEIREDO, Betânia Gonçalves. Barbeiros e cirurgiões: atuação dos práticos ao longo do século XIX. História, Ciências, Saúde - Manguinhos. V.6, n.2, p.277-291, 1999.

O arranjo das boticas e farmácias mineiras entre os séculos XVIII e XIX. In: VENÂNCIO Renato Pinto; CARNEIRO, Henrique (org). Álcool e drogas na história do Brasil. São Paulo/Belo Horizonte: Alameda/PUCMinas, 2005, p.141-150. 
Os manuais de medicina e a circulação do saber no século XIX no Brasil: mediação entre o saber acadêmico e o saber popular. Educar. N.25, p.59-73, 2005.

A Arte de Curar: Cirurgiões, médicos, boticários e curandeiros no século XIX em Minas Gerais. Belo Horizonte: Argymentvm, 2008.

; CASTRO, Evandro C. G. Os cuidados com a saúde dos escravos no Império Português: a aguardente para fins medicinais. In: BASTOS Cristiana; BARRETO, Renilda (org). A Circulação do Conhecimento: Medicina, Redes e Impérios. Lisboa: Instituto de Ciências Sociais, 2011, p.103-128.

FIORE, Maurício. A medicalização da questão do uso de drogas no Brasil: reflexos acerca de debates institucionais e jurídicos. In: VENÂNCIO, Renato Pinto; CARNEIRO, Henrique (org). Álcool e drogas na história do Brasil. São Paulo / Belo Horizonte: Alameda / Editora PUCMinas, 2005, 257-290.

FRANÇA, Jean Marcel de Carvalho. História da Maconha no Brasil. São Paulo: Três Estrelas, 2015.

FRENKEL, Jacob. Tecnologia e competição na indústria farmacêutica brasileira. Brasília: FINEP, 1978.

FONSECA, Guido. O submundo dos tóxicos em São Paulo: séculos XVIII, XIX e XX. São Paulo: Resenha Tributária, 1994.

FOUCAULT, Michael. Vigiar e Punir: nascimento da prisão. Petrópolis: Editora Vozes, 2004.

O Nascimento da Clínica. Rio de Janeiro: Forense Universitária, 2013.

GERTZ, René E. Médicos alemães no Rio Grande do Sul, na primeira metade do século XX: integração e conflito. História, Ciências, Saúde - Manguinhos. V.20, n.1, p.141157, 2013.

GIOVANNI, Geraldo. A questão dos remédios no Brasil: produção e consumo. São Paulo: Polis, 1980.

GOMES, Bruno Ramos. Ayahuasca e Recuperação de Pessoas em Situação de Rua. Saúde \& Transformação Social. V.4, n.2, p.91-98, 2013.

GoOtenberG, Paul. Andean Cocaine: The Making of a Global Drug. Chapel Hill: University of North Carolina Press, 2008.

GOULART, Sandra Lucia. Estigmas de grupos ayahuasqueiros. In: LABATE, Beatriz Caiuby et al (org). Drogas e cultura: novas perspectivas. Salvador: EDUFBA, 2008, 251-288.

GUIMARÃES, Maria Regina Cotrim. Civilizando as artes de curar: Chernoviz e os manuais de medicina popular no Império. Dissertação. (Programa de Pós-Graduação 
em História das Ciências da Saúde da Casa Oswaldo Cruz / Fundação Oswaldo Cruz), 2003.

Os manuais de medicina popular de Chernoviz na sociedade imperial. Cantareira. V.1, n.5, p.01-20, 2004.

. Chernoviz e os manuais de medicina popular no Império. História, Ciências, Saúde - Manguinhos. v.12, n.2, p.501-514, 2005.

HEALY, David. The antidepressant era. Cambridge: Harvard University Press, 1997.

HERCULANO-HOUZEL, Suzana. Sexo, Drogas, Rock'n'roll ... \& Chocolate: O cérebro e os prazeres da vida cotidiana. Rio de Janeiro: Vieira \& Lent Casa Editorial, 2003.

HOBSBAWM, Eric. A Era dos Impérios: (1875-1914). Rio de Janeiro: Paz e Terra, 1988.

HOCHMAN, GIlberto. A Era do Saneamento: As bases da política de Saúde Pública no Brasil. São Paulo: Hucitec, 2006.

HUTCHINSON, Harry William. Patterns of Marihuana Use in Brazil. In: RUBIN, Vera (org). Cannabis and Culture: World Anthropology. Haia: Mouton, 1975, p. 173-184.

HUXLEY, Aldous. Moksha: Textos sobre Psicodélicos e a Experiência Visionária (1931-1963). Rio de Janeiro: Globo, 1983.

ILLICH, Ivan. A expropriação da saúde: Nêmesis da medicina. Rio de Janeiro: Editora Nova Fronteira, 1975.

JESUS, Nauk Maria de. Aulas de cirurgia no centro da América do Sul (1808-16). História, Ciências, Saúde - Manguinhos. V.11, n.1, p.93-106, 2004.

KNEPPER, Paul. International Crime in the 20th Century: The League of Nations Era, 1919-1939. New York: Palgrave Macmillan, 2011.

KOERNER, Andrei. Judiciário e Cidadania na construção da República brasileira. São Paulo: HUCITEC, 1998.

KUMMER, Lizete Oliveira. A medicina social e a liberdade profissional: os médicos gaúchos na primeira república. Dissertação. (PPG - História / UFRGS), 2002.

LABATE, Beatriz C; SANTOS, Rafael Guimarães; STRASSMAN, Rick; ANDERSON, Mizumoto. Effect of Santo Daime Membership on Substance Dependence. In: LABATE, Beatriz C; CAVNAR, Clancy (org). The Therapeutic Use of Ayahuasca. Berlin/Heidelberg: Springer, 2014, 153-159.

LABBÉ, Marcos Fernández. Los usos de la taberna: renta fiscal, combate al alcoholismo y cacicazgo político en Chile, 1870-1930. Instituto de História. v.2, n.39, p.369-429, 2006. 
Drogas en Chile (1900-1970): Representación, mercado y consumo. Santiago: Ediciones Universidad Alberto Hurtado, 2011.

LAMPERT, Jadete Barbosa. Tendências e mudanças na formação médica no Brasil: tipologia das escolas. São Paulo: Hucitec, 2009.

LESSER, Jefrey. A negociação da identidade nacional: Imigrantes, minorias e a luta pela etnicidade no Brasil. São Paulo: UNESP, 2001.

LIMA, Oswaldo Gonçalves de. Pulque, Balchê e Pajauaru: Na etnobiologia das bebidas e dos alimentos fermentados. Recife: Universidade Federal de Pernambuco, 1974.

LIMA, Tania Andrade. Humores e odores: ordem corporal e ordem social no Rio de Janeiro, século XIX. História, Ciências, Saúde - Manguinhos. v.2, n.3, p.44-96, 1996.

LIMA, Rita de Cássia Cavalcante. Uma história das drogas e do seu proibicionismo transnacional: relações Brasil-Estados Unidos e os organismos internacionais. Tese. (Escola de Serviço Social / UFRJ), 2009.

LOVE, Joseph. A Locomotiva: São Paulo na Federação Brasileira (1889-1937). São Paulo: Paz e Terra, 1982.

LUSTIG, Robert. Fat Chance: the bitter truth about sugar. London: HarperCollins Publisher, 2013.

MACHADO, Roberto; LOUREIRO, Ângela; LUZ, Rogério; MURICY, Katia. Danação da Norma: a medicina social e constituição da psiquiatria no Brasil. Rio de Janeiro: Edições Graal, 1978.

MACHADO, Vanderlei. Entre Apolo e Dionísio: A imprensa e a divulgação de masculinidade urbana em Florianópolis (1889-1930). Tese. (PPG - História / UFRGS), 2007.

MACRAE, Edward. A elaboração das políticas públicas brasileiras em relação ao uso religioso da ayahuasca. In: LABATE, Beatriz Caiuby et al (org). Drogas e Cultura: novas perspectivas. Salvador: UFBA, 2008, 289-313.

MAIO, Marcos Chor. Raça, Doença e Saúde Pública no Brasil: um debate sobre o pensamento higienista do século XIX. In: MAIO Marcos Chor; SANTOS, Ricardo Ventura (org). Raça como questão: história, ciência e identidades no Brasil. Rio de Janeiro: Editora da FIOCRUZ, 2010, p.51-82.

MANICA, James. Anestesiologia: princípios e técnicas. Porto Alegre: Artmed, 2004.

MARQUES, Teresa Cristina de Novaes. A Cerveja e a Cidade do Rio de Janeiro: De 1888 ao início dos anos 1930. Brasília: EdUNB, 2014. 
MARQUES, Vera Regina Beltrão. Natureza em Boiões: medicinas, boticários no Brasil setecentista. Campinas: UNICAMP, 1999.

Medicinas secretas: magia e ciência no Brasil setecentista. In: CHALHOUB Sidney, et al (orgs). Artes e Ofícios de Curar no Brasil: capítulos de história social. Campinas: UNICAMP, 2003, p.163-196.

MAUCH, Claudia. Dizendo-se autoridade: polícia e policiais em Porto Alegre (18961929). Tese. (PPG - História / UFRGS), 2011.

MENZ, Maximiliano. Os escravos da feitoria do Linho Cânhamo: trabalho, conflito e negociação. Afro-Ásia. v.32, p.139-158, 2005.

MONTEIRO, Mário Ypiranga. Antropogeografia do guaraná. Manaus: Institutto Nacional de Pesquisas da Amazonas, 1965. 299, 1966.

Folclore da Maconha. Revista Brasileira de Folclore. Ano VI, n.16, p.285-

MONTEIRO, Rejane Penna. A nova polícia: a guarda civil em Porto Alegre (19291938). Dissertação. (PPG - História / PUCRS), 1991.

MONTFORT, Ricardo Pérez. Framentos de historia de las 'drogas' en México 18701920. In: MONTFORT Ricardo Pérez; CASTILLO, Alberto del; PICCATO, Pablo (org). Hábitos, Normas y Escándalo: Prensa, criminalidad y drogas durante el porfiriato tardío. Ciudad de México: Plaza y Valdez Ediciones, 1997, p.145-210.

MOTA, André. Quem é bom já nasce feito: sanitarismo e eugenia no Brasil. Rio de Janeiro: DP\&A, 2003.

Tropeços da Medicina Bandeirante: medicina paulista entre 1882-1920. São Paulo: EDUSP, 2005.

; SCHRAIBER, Lilia Blima. Medicina Católica e Eugenismo no Brasil 19301950. In: MOTA, André; MARINHO, Maria Gabriela da Silva Martins da Cunha (orgs). Eugenia e história: ciência, educação e regionalidades. São Paulo: USP/UFABC/CD.G Casa de Soluções e Editora, 2013, p.99-114.

MOTTA, Kátia Sausen da. Juiz de Paz e cultura política no início dos oitocentos: Província do Espírito Santo, 1827-1842. Dissertação. (PPG em História Social das Relações Políticas / Universidade Federal do Espírito Santo), 2013.

MOTT, Luiz. A maconha na história do Brasil. In: HENMAN Anthony Richard; JUNIOR, Osvaldo Pessoa (orgs). Diamba Sarabamba. São Paulo: Ground, 1986, p.117-136.

MUSTO, David F. The American disease: origins of narcotic control. New York: Oxford University Press, 1999. 
NOGUEIRA, André Luís Lima. Doenças de feitiço: as Minas setecentistas e o imaginário das doenças. Varia História. v.28, n.47, p.259-278, 2012.

Saberes terapêuticos nas Minas coloniais: diálogos entre a medicina oficial e as curas não licenciadas (séc. XVIII). História Unisinos. v.18, n.1, p.15-26, 2014.

NUNES, Everardo Duarte. Saúde Coletiva: uma história recente de um passado remoto. In: CAMPOS Gastão Wagner de Sousa; BONFIM, José Ruben de Alcântara; MINAYO, Maria Cecília de Souza; AKERMAN, Marco; JÚNIOR, Marcos Drumond; CARVALHO, Yara Maria de (orgs). Tratado de Saúde Coletiva. São Paulo: Hucitec, 2014, p.17-37.

PICCATO, Pablo. El discurso sobre la criminalidad y el alcoholismo hacia el fin del porfiriato. In: MONTFORT Ricardo Pérez; CASTILLO, Alberto del; PICCATO, Pablo (org). Hábitos, Normas y Escándalo: Prensa, criminalidad y drogas durante el porfiriato tardío. Ciudad de México: Plaza y Valdez Ediciones, 1997, p.77-142.

PIERCE, Gretchen Kristine. Sobering the revolution: Mexico's anti-alcohol campaigns and the process of state-building, 1910-1940. Dissertation. (Departament of History / University of Arizona), 2008.

; TOXQUI, Áurea (org). Alcohol in Latin America: A Social and Cultural History. Tucson: The University of Arizona Press, 2014.

PIGNARRE, Philippe. O que é medicamento? Um objeto estranho entre ciência, mercado e sociedade. São Paulo: Editora 34, 1999.

PIMENTA, Tânia Salgado. Terapeutas populares e instituições médicas na primeira metade do século XIX. In: CHALHOUB Sidney, et al (orgs). Artes e Ofícios de Curar no Brasil: capítulos de história social. Campinas: UNICAMP, 2003, 307-330.

REBOLLEDO, Mauricio Becerra. Ruina, degeneración y contagio: Toxicomania y peligrosidad social en Chile. Sociedad Hoy. v.25, p.145-162, 2013.

REIS JR, Almiro dos. Anestesia regional intravenosa primeiro centenário (1908-2008). Início, desenvolvimento e estado atual. Revista Brasileira de Anestesiologia. V.58, n.3, p.299-321, 2008.

Carlos Parsloe (1919-2009) - In Memoriam. Revista Brasileira de Anestesiologia. V.59, n.4, p.496-519, 2009.

Homenagem ao Dr. Zephirino Alves do Amaral, por Ocasião do Primeiro Centenário da Introdução da Anestesia Regional Intravenosa no Brasil (1911-2011). Revista Brasileira de Anestesiologia. V.61, n.2, p.268-271, 2011.

RESENDE, Beatriz. Cocaína: literatura e outros companheiros de ilusão. Rio de Janeiro: Casa da Palavra, 2006. 
RIBEIRO, Fernanda Mendes Lages; MINAYO, Maria Cecília de Souza. As Comunidades Terapêuticas religiosas na recuperação de dependentes de drogas: o caso de Manguinhos, RJ, Brasil. Interface (Botucatu). V.19, n.54, p.515-526, 2015.

RIBEIRO, Maria Alice Rosa. Saúde Pública e as empresas químico-farmacêuticas. História, Ciências, Saúde - Manguinhos. V.7, n.3, p.607-623, 2000. Indústria farmacêutica na era Vargas: São Paulo 1930-1945. Caderno de História da Ciência - Instituto Butantã. V.2, n.1, p.47-76, 2006. Empresas farmacêuticas na industrialização brasileira. América Latina en la Historia Económica. N.30, p.161-189, 2007.

RIBEIRO, Márcia Moisés. A ciência nos trópicos: a arte médica no Brasil do século XVIII. São Paulo: Hucitec, 1997.

Exorcistas e demônios: demonologia e exorcismo no mundo luso-brasileiro. Rio de Janeiro: Campus, 2003.

Nem nobre, nem mecânico: a trajetória social de um cirurgião na América portuguesa do século XVIII. Almanack Braziliense. N.2, p.64-75, 2005 a.

RIBEIRO, Ricardo Ferreira. Tortuosas raízes medicinais: as mágicas origens da farmacopéia popular brasileira e sua trajetória pelo mundo. In: VENÂNCIO Renato Pinto; CARNEIRO, Henrique (org). Álcool e drogas na história do Brasil. São Paulo/Belo Horizonte: Alameda/EdiPUC, 2005b, 155-184.

RIBEIRO, Tiago Magalhães; TORCATO, Carlos Eduardo Martins. Governamentalidades e usos de drogas no Brasil. Argumentum. V.7, n.1, p.39-54, 2015.

RODRIGUES, Thiago Moreira de Souza. Política e Drogas nas Américas. São Paulo: Educ/Fapesp, 2004.

ROMÁN, C. Cortés. Anestesia epidural lumbar 1931-1936. Revista Española de Anestesiología y Reanimación. V.52, p.159-168, 2005.

ROSA, Ana Lúcia Gonçalves. Passos Cambaleantes, Caminhos Tortuosos: Beber Cachaça, Prática Social e Masculinidade - Recife/PE (1920-1930). Dissertação. (PPG História / UFC), 2003.

RUBIN, Vera. Introduction. In: RUBIN, Vera (org). Cannabis and Culture: World Anthropology. Haia: Mouton, 1975, p.01-10.

SÁ, Dominichi Miranda. A ciência como profissão: médicos, bacharéis e cientistas no Brasil (1895-1935). Rio de Janeiro: FIOCRUZ, 2006.

SAAD, Luísa Gonçalves. "Fumo de Nego": A criminalização da maconha no Brasil (c.1890-1932). Dissertação. (PPG-História / Universidade Federal da Bahia), 2013. 
SALES, Eliana Vieira. Flagelo da Humanidade: Saberes e Práticas Acerca do Alcoolismo (Recife 1930-1939). Dissertação. (PPG - História / Universidade Federal de Pernambuco), 2011.

SAMPAIO, Gabriela dos Reis. Nas trincheiras da cura: As diferentes medicinas no Rio de Janeiro Imperial. Campinas: EdUNICAMP, 2001.

SANTOS, Fernando Sergio Dumas dos. Alcoolismo: Algumas Reflexões acerca do Imaginário de uma Doença. PHYSIS - Revista de Saúde Coletiva. V.3, n.2, p.75-95, 1993.

Alcoolismo: a invenção de uma doença. Dissertação. (PPG em História / UNICAMP), 1995.

Bêbados e Alcoólatras, Medicina e Cotidiano. In: NASCIMENTO Dilene Raimundo do [et.al.] (org). Uma história brasileira das doenças: [vol 2]. Rio de Janeiro: Mauad X, 2006, p.64-91.

; VERANI, Ana Carolina. Alcoolismo e medicina psiquiátrica no Brasil do início do século XX. História, Ciência, Saúde - Manguinhos. V.17, n.2, p.401-420, 2010.

SANTOS FILHO, Lycurgo de Castro. História geral da medicina brasileira: vol.1. São Paulo: Edusp, 1991a.

História geral da medicina brasileira: vol.2. São Paulo: Hucitec, 1991 b.

SANTOS, Luiz Antônio de Castro; FIGUEIREDO, Regina Érika Domingos de. Belisário Penna, combatente. In: HOCHMAN Gilberto; LIMA, Nísia Trindade (orgs). Médicos intérpretes do Brasil. São Paulo: Hucitec, 2015, p.74-99.

SARTI, Thamires Regina R. M. Classes viciosas, classes perigosas: a transformação do uso e da comercialização de entorpecentes em um problema social no Rio de Janeiro da década de 1920. Monografia. (Departamento de História / UNICAMP), 2012.

Maratonas e rambles: repressão aos tóxicos no início do século XX. Dissertação. (PPG - História Social / UNICAMP), 2015.

SAYD, Jane Dutra. Mediar, Medicar, Remediar: Aspectos da terapêutica na medicina ocidental. Rio de Janeiro: Editora da UERJ, 1998.

SCHIVELBUSCH, Wolfgang. Histoire des stimulants. Paris: Gallimard, 1991.

SCHRAIBER, Lilia Blima. O médico e seu trabalho: limites da liberdade. São Paulo: HUCITEC, 1993.

SCHWARCZ, Lílian Moritz. O espetáculo das raças: cientistas, instituições e questão racial no Brasil. São Paulo: Companhia das Letras, 1993. 
SCHWARTZ, Stuart B. Segredos Internos: engenhos e escravos na sociedade colonial, 1550-1835. São Paulo: Companhia das Letras, 1988.

Brasil colonial: plantaciones y periferias, 1580-1750. In: BETHELL, Leslie

(org). Historia de América Latina: 3. América Latina colonial - economía. 1990, p.191-259.

SHERRATT, Andrew. Alcohol and its alternatives: symbol and substance in preindustrial cultures. In: J. L. GOODMAN, PAUL E; SHERRATT, ANDREW (org). Consuming Habits: Drugs in History and Antropology. London/New York: Routledge, 1995, p.11-46.

SILVA, Luiza Lopes da. A Questão das Drogas nas Relações Internacionais: Uma perspectiva brasileira. Brasília: Fundação Alexandre de Gusmão, 2013.

SILVA, Marcos Virgílio. A Eugenia e o Ideário Antiurbano no Brasil. In: MOTA André; MARINHO, Maria Gabriela da Silva Martins da Cunha (orgs). Eugenia e história: ciência, educação e regionalidades. São Paulo: USP/UFABC/CD.G Casa de Soluções e Editora, 2013, p.115-131.

SILVA, Maria de Lourdes. Drogas no Rio de Janeiro da Bela Época: a construção da noção de crime e criminoso. Dissertação. (PPG - História/PUCRJ), 1998.

. Drogas - da medicina à repressão policial: a cidade do Rio de Janeiro entre 1921 e 1945. Tese. (PPG - História/UERJ), 2009.

Polícia de Costumes, Drogas e Educação na Capital Federal nos anos 1920-30. Revista Teias. V.11, n.23, p.3-22, 2010.

. Drogas: Da medicia à repressão policial - a cidade do Rio de Janeiro entre 1921 e 1945. Rio de Janeiro: Outras Letras, 2015.

SILVA, Selma Lima. As mulheres da Luz: uma etnografia dos usos e preservação no uso do crack. Tese. (Serviço de Saúde Pública / USP), 2000.

SIMÃO, André Luciano. Congressos Agrícolas de 1878: Um retrato do reformismo ao final do século XIX. Dissertação. (Departamento de Sociologia / UNICAMP), 2001.

SNEADER, Walter. Drug Discovery: A History. West Sussex: John Wiley and Sons, 2005.

SOARES, Márcio de Sousa. Médicos e mezinheiros na Corte Imperial: uma herança colonial. História, Ciências, Saúde - Manguinhos. V.8, n.2, p.407-438, 2001.

SOUZA, Jorge Emanuel Luz. Sonhos da diamba, controle do cotidiano: uma história da criminalização da maconha no Brasil republicano. Dissertação. (PPG-História / UFBA), 2012.

SOUZA, Laura de Mello e. O diabo e a Terra de Santa Cruz: feitiçaria e religiosidade popular no Brasil colonial. São Paulo: Companhia das Letras, 1986. 
SOUZA, Ricardo Luiz. O uso de drogas e tabaco em ritos religiosos e na sociedade brasileira: uma análise comparativa. Saeculum - Revista de História. n.11, p.85-102, 2004.

SPENCE, Jonathan D. Em busca da China moderna: quatro séculos de história. São Paulo: Companhia das Letras, 1996.

STÜCKER, Ananda; CYTRYNOWICZ, Monica Musatti. Origens e trajetória da indústria farmacêutica no Brasil. São Paulo: Narrativa Um, 2007.

SZTUTMAN, Renato. Caium, substância e efeito: sobre o consumo de bebidas fermentadas entre os ameríndios. In: LABATE, Beatriz Caiuby et al (org). Drogas e Cultura: novas perspectivas. Salvador: EDUFBA, 2008, 219-250.

TEIXEIRA, Luiz Antônio; EDLER, Flavio Coelho. História e cultura da medicina no Brasil. São Paulo: AORI Produções Culturais, 2012.

TELAROLli JUNIOR, Rodolpho. Poder e saúde: as epidemias e a formação dos serviços de saúde em São Paulo. São Paulo: Editora da UNESP, 1996.

TEMPORÃO, José Gomes. A propaganda de medicamentos e o mito da saúde. Rio de Janeiro: Edições Graal, 1986.

TOIT, Brian M. du. Dagga: The History and Etnographic Setting of Cannabis sativa in Southern Africa. In: RUBIN, Vera (org). Cannabis and Culture: World Anthropology. Haia: Mouton, 1975, 81-117.

TORCATO, Carlos Eduardo Martins. A repressão oficial ao jogo do bicho: uma história dos jogos de azar em Porto Alegre. Dissertação. (PPG - História / UFRGS), 2011.

A proibição das drogas ontem e hoje: (des)continuidades a partir de um diálogo com Michael Foucault. XXVIII Simpósio Nacional de História - Lugares dos Historiadores: Velhos e Novos Desafios. Florianópolis - SC. Anais. 27 a 31 de Julho de 2015 2015. 01-13 p.

USÓ, Juan Carlos. Drogas y cultura de masas: España 1855-1995. Madrid: Taurus, 1995.

VALDIVIA, Zinnia Verenice Capó. El rechazo simbólico, la tolerancia pragmatica y los sistemas institucionalizados de evasión: análisis del discurso oficial sobre el opio en Mexicali, 1900-1935. Tesis. (Instituto de Investigaciones Culturales / Universidad Autónoma de Baja California), 2014.

VELLASCO, Ivan de Andrade. O juiz de paz e o Código do Processo: vicissitudes da justiça imperial em uma comarca de Minas Gerais no século XIX. Justiça \& História. V.3, n.6, p.01-23, 2003.

As seduções da ordem: violência, criminalidade e administração da Justiça. Minas Gerais, século XIX. Bauru/SP: Edusc/Ampocs, 2004. 
VELLOSO, Verônica Pimente. Farmácia na Corte Imperial (1851-1887): práticas e saberes. Tese. (PPG em História das Ciências e da Saúde / FIOCRUZ), 2007.

VOLCOV, Katerina; VASCONCELLOS, Maria da Penha. "Crack, é possível vencer" ou é preciso compreender: observações a partir de campanhas publicitárias do governo federal. Saúde \& Transformação Social. v.4, n.2, p.99-106, 2013.

WALLERSTEIN, Immanuel. O sistema mundial moderno. Porto: Afrontamento, 1990.

WASSON, R Gordon; KRAMRISCH, Stella; OTT, Jonathan; RUCK, Carl A. P. La búsqueda de perséfone: Los enteógenos y los orígenes de la religión. Ciudad de México: Fondo de Cultura Económica, 1992.

WEBER, Beatriz Teixeira. As artes de curar: medicina, religião, magia e positivismo na república rio-grandense (1889-1928). Santa Maria / Bauru: UFSM / EDUSC, 1999.

WINKELMAN, Michael. Alternative and tradicional medicine approaches for substance abuse programs: a shamanic perspective. International Jornal of Drug Police. v.12, p.337-351, 2001.

WISSENBACH, Maria Cristina Cortez. Gomes Ferreira e os símplices da terra: experiências sociais dos cirurgiões no Brasil-Colônia. In: FURTADO, Júnia Ferreira (org). Erário Mineral: Publicado em 1735 em Lisboa Ocidental na oficina de Manuel Rodrigues dividido em 12 tratados. Belo Horizonte/Rio de Janeiro: Fundação João Pinheiro/Fundação Oswaldo Cruz, 2002, p.106-149.

Cirurgiões e mercadores nas dinâmicas do comércio atlântico de escravos (séculos XVIII e XIX). In: SOUZA Laura de Mello e; FURTADO, Júnia Ferreira; BICALHO, Maria Fernanda (org). O governo dos povos. São Paulo: Alameda, 2009, p.281-300.

XAVIER, Regina Célia Lima. Dos males e suas curas. In: In: CHALHOUB Sidney, et al (orgs). Artes e Ofícios de Curar no Brasil: capítulos de história social. Campinas: UNICAMP, 2003, 331-354.

ZHENG, Yangwen. The social life of opium in China. New York: Cambridge University Press, 2005.

ZUARDI, Antonio Waldo. History of Cannabis as a medicine: a review. Revista Brasileira de Psiquiatria. V.28, n.2, p.153-157, 2006. 